\author{
Szegedi Tudományegyetem \\ Gazdaságtudományi Kar \\ Gazdálkodástudományi Doktori Iskola \\ Gazdaságpszichológia Alprogram
}

\author{
DR. NAGY ÁGNES
}

\title{
A CSALÁDI NAPKÖZI TÁRSADALMI-GAZDASÁGI JELENTŐSÉGE, MUNKAHELYTEREMTŐ SZEREPE, ÉS MINDEZEK HATÁSA A NÖI FOGLALKOZTATÁSRA
}

Doktori Értekezés

Témavezető: Dr. Málovics Éva

SZTE Gazdaságtudományi Kar

Szeged, 2013 


\section{Tartalom}

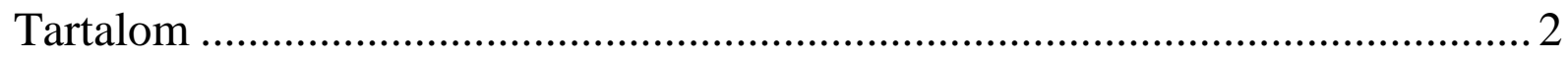

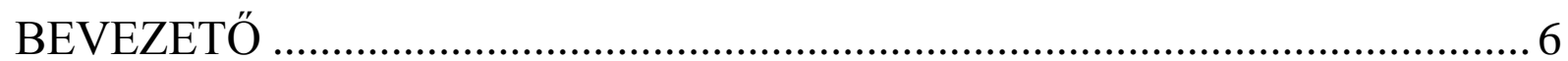

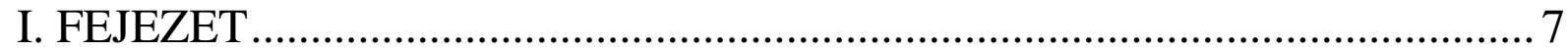

PROBLÉMAFELVETÉS, A TÉMAVÁLASZTÁS INDOKLÁSA, ELMÉLETI MODELL, KUTATÁSI KÉRDÉSEK, HIPOTÉZISEK ….................................... 7

1.1 Alacsony népesedés, alacsony női foglalkoztatottság .............................. 8

1.1.1 Speciális hazai anyai attitüdök, speciális hazai munkaerö-piaci helyzet. 8

1.1.2 Napközbeni kisgyermekellátás megoldatlansága.................................... 10

1.2 Elméleti kutatási modell ............................................................................ 13

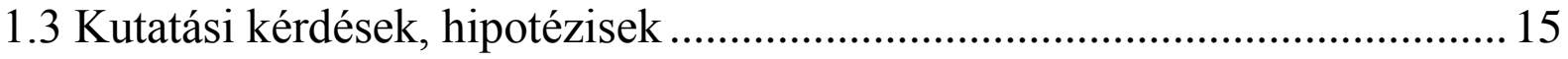

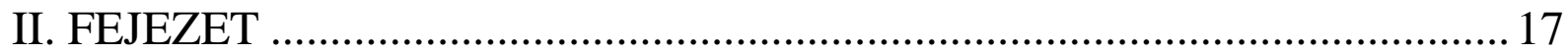

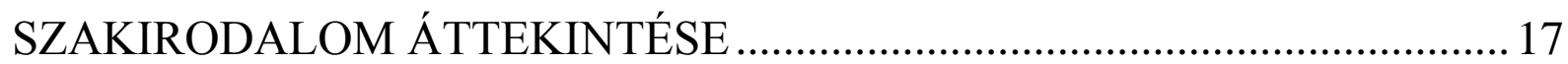

2.1 Nők és a munka világa - „,család vagy karrier?” ........................................... 18

2.1.1 A dolgozó nő - a női foglalkoztatottság .............................................. 18

2.1.2 A női munkavállalás és a népesedés, demográfia kapcsolata ................22

2.1.3 Gyermeknevelési támogatások, családtámogatások ................................32

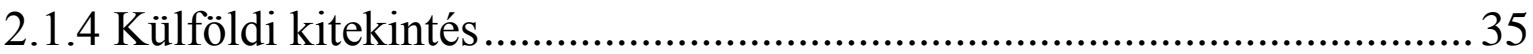

2.2 Anyai munkavállalás és a gyermekfejlődés összefüggései...........................37

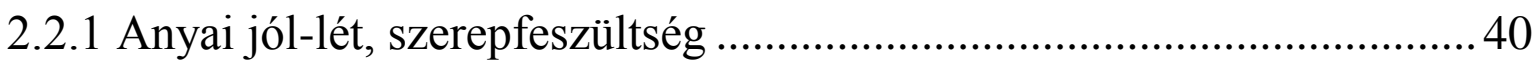

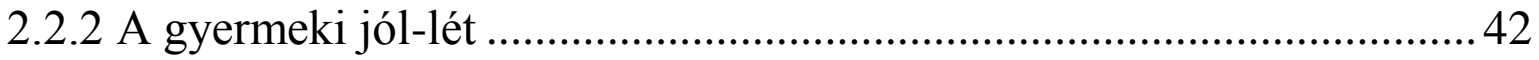

2.2.3 A gyermekfelügyelet módja és minősége ............................................. 44

2.1.4 Hitek és tévhitek az anyai munkavállalás hatásairól (összefoglalás) ....45

2.3 Szocializációs és esélyegyenlőségi szempontok (kitekintés)........................49

2.3.1 A család és a lakókörnyezet hatása - elsődleges szocializáció...............49

2.3.2 A napközbeni kisgyermek ellátóhely szerepe - másodlagos szocializáció

2.3.3 A gazdasági szocializáció és a tanult tehetetlenség ...............................55

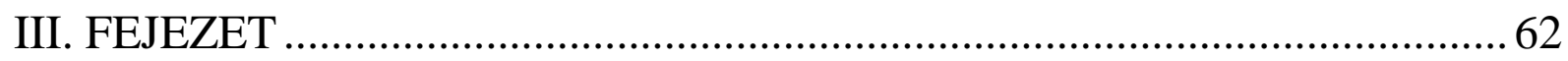

NEMZETKÖZI ÉS HAZAI NAPKÖZBENI KISGYERMEK ELLÁTÁS

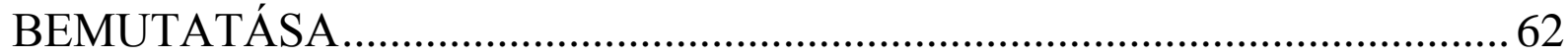

3.1 Napközbeni kisgyermek ellátás definíciója, célja.......................................... 64

3.2 Kitekintés - máshol hogyan oldják meg? ................................................66

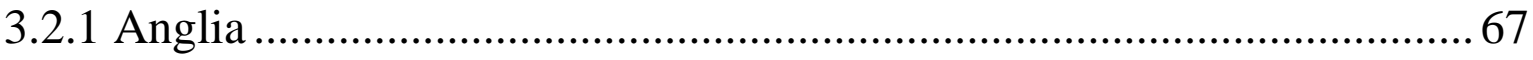




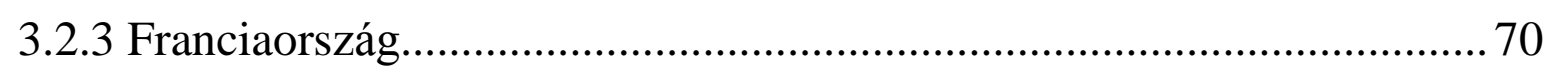

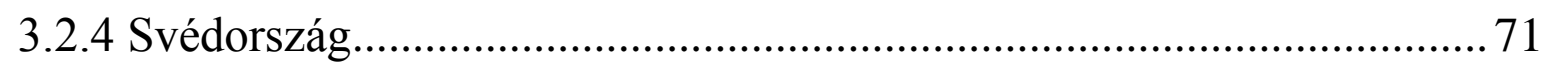

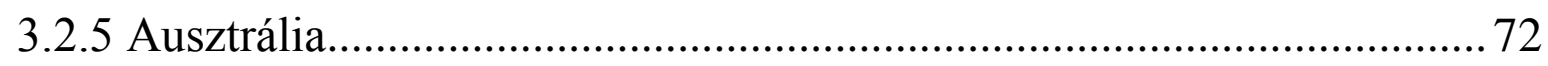

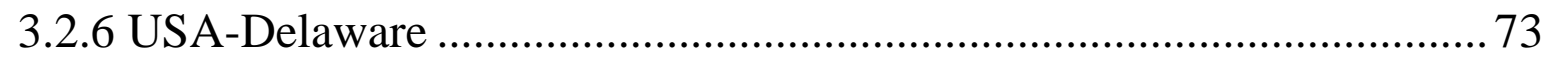

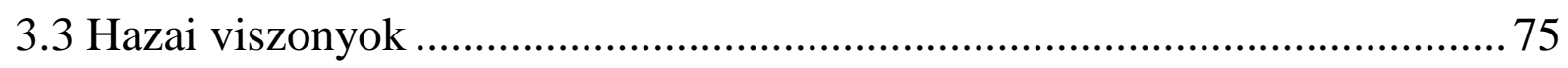

3.3.1 Jogszabályi háttér (családi napközi).................................................... 75

3.3.2 Bölcsődék, óvodák és családi napközik áttekintése............................... 81

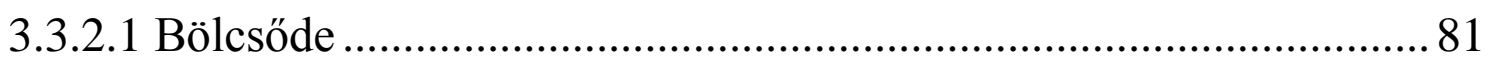

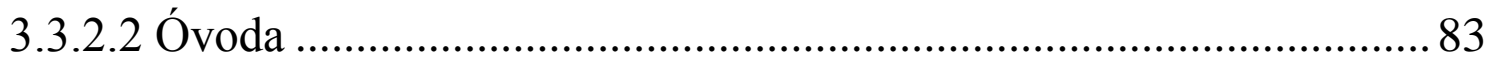

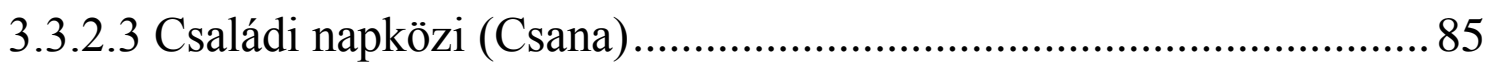

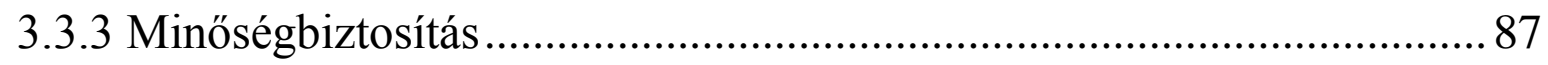

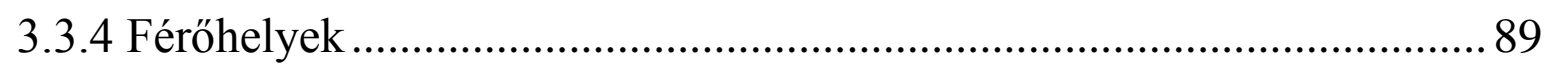

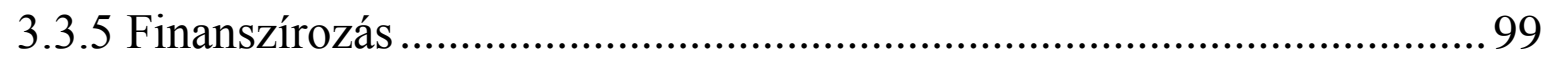

3.3.5.1 Müködési önköltség és a térítési díj kapcsolata .............................. 99

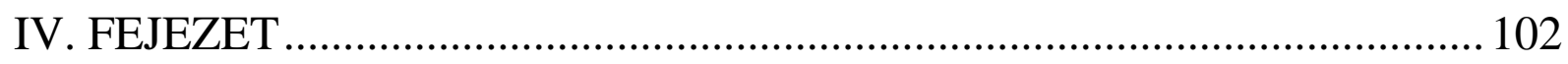

SAJÁT KUTATÁSOK BEMUTATÁSA ..................................................... 102

4.1 Kutatás módszerei, választott módszerek relevanciájának bizonyítása ...... 103

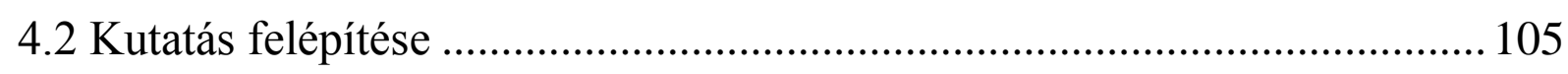

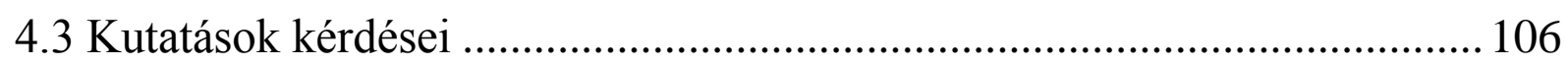

4.3.1 Kik látják el a családi napközikbe járó gyermekeket? ......................... 106

4.3.2 A bölcsőde és a családi napközi munkahelyteremtő szerepe................ 108

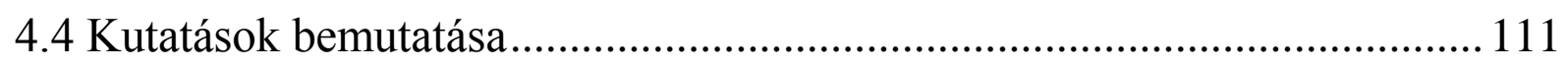

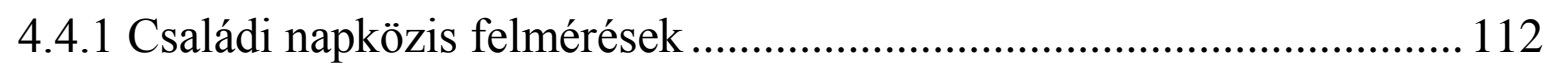

4.4.1 1 Csana tanfolyami hallgatók közti felmérések $(2009,2012)$......... 112

4.4.1.2 Családi napközisek közötti kérdöíves felmérések $(2009,2012)$ 116

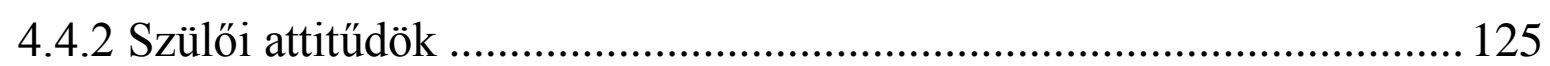

4.4.2.1 A 0-3 éves korú gyermeket nevelők közötti felmérés (2009)....... 125

4.4.2.2 Céges gyermekfelügyelet munkavállalói oldalról (2012)............. 130

4.4.2.3 Összehasonlítás .................................................................... 132

4.4.3 Napközbeni kisgyermekellátás a munkáltató szemszögéből ................ 133

4.4.3.1 Munkáltatói kérdőíves felmérés (2013) ....................................... 133 


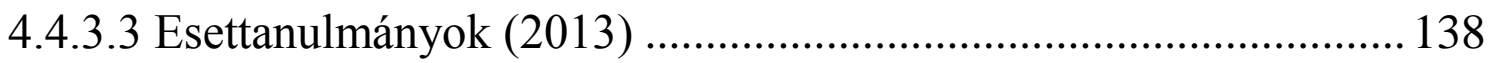

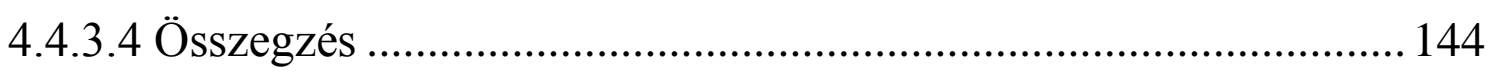

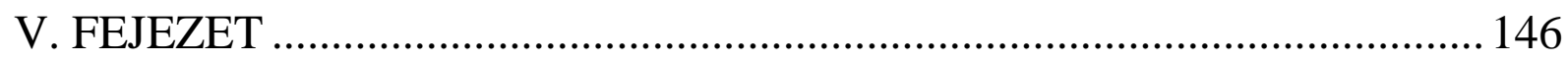

HIPOTÉZISEK BIZONYÍTÁSA, KÖVETKEZTETÉSEK, AJÁNLÁSOK ... 146

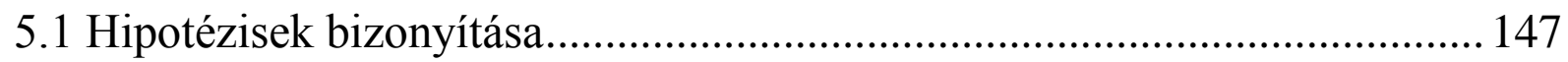

5.2 Céges családi napközi ajánlott modellje …................................................. 149

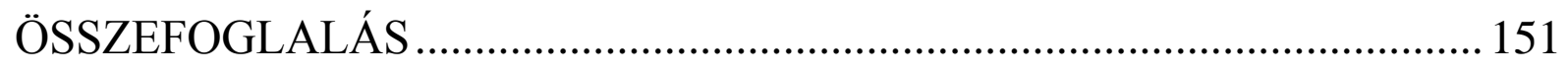

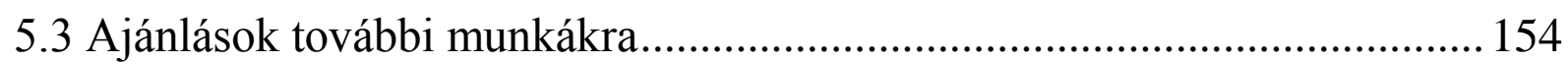

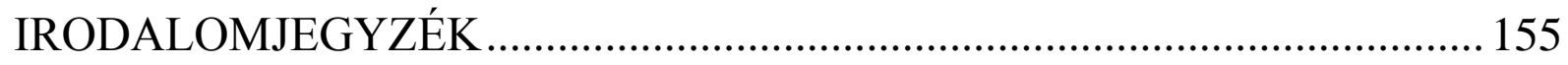

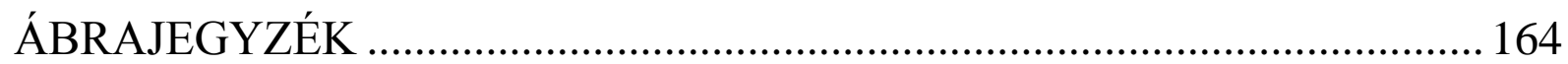

MELLÉKLETEK (KÉRDÖÍVEK), FÜGGELÉKEK (RÉSZKUTATÁSOK) 166

1. melléklet - Családi napközi vezetők közötti kérdőív 2009, 2012 ......... 167

2. melléklet - 0-3 éves korú gyermeket nevelők közötti felmérés............. 172

3. melléklet - Céges gyermekfelügyelet munkavállalói oldalról............... 177

4. melléklet - Napközbeni kisgyermekellátás a munkáltató szemszögéböl 180

1. függelék - A családi napközi létrehozását és müködtetését befolyásoló

fontosabb jogszabályok (felsorolás, kivonatolás)

1997. évi XXXI. törvény a gyermekek védelméről és a gyámügyi igazgatásról

15/1998. (IV. 30.) NM rendelet a személyes gondoskodást nyújtó gyermekjóléti, gyermekvédelmi intézmények, valamint személyek szakmai feladatairól és müködésük feltételeiről

259/2002. (XII. 18.) Korm. rendelet a gyermekjóléti és gyermekvédelmi szolgáltatótevékenység engedélyezéséről, valamint a gyermekjóléti és gyermekvédelmi vállalkozói engedélyröl

226/2006. (XI. 20.) Korm. rendelet a szociális, gyermekjóléti és gyermekvédelmi szolgáltatók, intézmények ágazati azonosítójáról és országos nyilvántartásáról

213/2009. (IX. 29.) Korm. rendelet az egyházi és nem állami fenntartású szociális, gyermekjóléti és gyermekvédelmi szolgáltatók normatív állami támogatásáról.

328/2011. (XII. 29.) Korm. rendelet a személyes gondoskodást nyújtó gyermekjóléti alapellátások és gyermekvédelmi szakellátások térítési díjáról és az igénylésükhöz felhasználható bizonyítékokról. 
2. függelék - Céges Csana Kerekasztal összefoglaló................................286

3. függelék - NAV állásfoglalás ...................................................................293 


\section{BEVEZETÖ}

Doktori értekezésemben a családi napközi gazdasági, társadalmi jelentőségét, ezen belül a foglalkoztatásra, kiemelten a női foglalkoztatásra gyakorolt szerepét mutatom be. Teszem ezt azért, mert dolgozni akaró szülöként jómagam is érintetté váltam a napközbeni kisgyermekellátás és a közoktatási rendszer hiányosságai által felmerülő napi nehézségekben, megoldandó, a társadalom és az állam által nem (vagy csak részben, esetleg látszólag, szavak szintjén) támogatott feladatokban. Felelős kutatóként megoldást kínálok a tudomány és a döntéshozók számára - remélve, hogy eredményeim a köz javát szolgálják.

A dolgozat első fejezetében körüljárom a problémát, bemutatom az elméleti modellemet, mely alapján felteszem azokat a kutatási kérdéseimet, melyek a hipotézisem felállításában játszottak szerepet. A második fejezetben bemutatom a téma szakirodalmi áttekintését. A harmadik fejezetben a hazai és nemzetközi kisgyermek-ellátásra tekintek ki. A negyedik fejezetben bemutatom azt a 4 évet átölelő kutatás-sorozatot, amely alapján az ötödik fejezetben a hipotéziseimet bizonyítom, illetve ajánlásokat teszek további munkákra. Külön mellékletekben mutatom be a kutatáshoz használt kérdőíveket. A függelékekben a részeredményeket, háttéranyagokat prezentálom.

Ezúton mondok hálás köszönetet családomnak a türelmes támogatásáért, tanáraimnak a töretlen bizalmukért és lankadatlan segítségükért, kiemelten férjemnek - Imrének, fiamnak Décsének, Hámori Balázs Professzor Úrnak, Málovics Éva Tanárnőnek. Köszönöm opponenseim (Dr. Veres Pál és Dr. Prónay Szabolcs) támogató, elörevivő bírálatát. Köszönöm kollégáim, kutató társaim segítségét, valamint mindenkinek a támogatását, akik az elmúlt években részesei voltak munkámnak. 
I. FEJEZET

\section{PROBLÉMAFELVETÉS, A TÉMAVÁLASZTÁS INDOKLÁSA, ELMÉLETI MODELL, KUTATÁSI KÉRDÉSEK, HIPOTÉZISEK}

„A népmesékben mindig a harmadik királyfi vagy királylány menti meg az öreg királyt, az országot. A mai demográfiai helyzetben nagy

szükség volna arra, hogy megszülethessenek a kívánt, tervezett gyerekek. Míg a nyolc általánost vagy kevesebbet végzett fiatalok tervezett gyermekei megszületnek, az érettségizett vagy magasabb végzettségü fiatalok körében sokkal kevesebb születik, mint ahányat szeretnének. Felmérésünk szerint a mai fiatalok 20 százaléka három, 60 százaléka két gyereket szeretne, és csak három százalékuk mondja azt, hogy egyet sem. De a magasabb végzettségü nök nagyon súlyos hátrányba kerülnek a velük azonos végzettségü gyermektelen nökkel vagy férfiakkal összehasonlítva, ha gyereket vállalnak. Természetes, hogy szeretnének idöt szakitani a nevelésre, ugyanakkor nem akarják veszni hagyni a hivatásukba fektetett energiáikat, ami egyébként az

ország számára is nagy veszteség lenne. A mi mozgalmunk célja a tervezett gyermekek vállalásának segitése, és annak biztositása, hogy az iskolázott nöknek ne kelljen szükségszerüen választaniuk a gyermekvállalás és hivatásuk gyakorlása között."

(dr. Kopp Mária,

Három Királyfi, Három Királylány Mozgalom alapítója) 


\subsection{Alacsony népesedés, alacsony női foglalkoztatottság}

Magyarországon a párok által tervezett gyermekszám 2 - 2,2 körül mozog, míg a teljes termékenységi arány csak 1,2 - 1,3 körül ingadozik ${ }^{1}$, ami Európában a legalacsonyabb mutatók közé tartozik. Ennek egyik fő oka, hogy a magasabb végzettségü (érettségizett, ill. felsőfokú végzettségü) nők ma igen súlyos hátrányba kerülnek a velük azonos korú gyermektelenekkel szemben, hiszen arra kényszerülnek, hogy válasszanak pályájuk és a gyermekvállalás között (Kopp és társai, 2008; Kopp-Skrabski, 2006). Ez a nemzetgazdaság számára is igen súlyos veszteség, hiszen így elvész a képzésbe fektetett energia jelentős hányada is.

Európában a születésszám drasztikusan csökkent a hagyományos családi mintát követő, a kisgyermekek intézményi ellátására keveset költő országokban, míg a születésszám viszonylag kedvezően alakult azokban az országokban, amelyek nagy gondot fordítanak, és sokat költenek a kisgyermekes szülők családi és munkahelyi kötelezettségének összehangolására. Ott magasak a születési ráták, ahol jelentős a női foglalkoztatottság (NGM, 2012), különös tekintettel az atipikus női foglalkoztatás (Pongrácz, 2011; Szalai, 2012). Ez alapján a „Népesedési Kerekasztal véleménye szerint Magyarországon a tervezett gyermekek megszületésének egyik alapvetö akadálya, hogy hiányoznak az elérhetö atipikus foglalkoztatási formák, és a kisgyermek elhelyezési intézményi féröhelyek. A magasabb végzettségü nök számára súlyos hátrányt jelent, ha gyermeket vállalnak, mert ebben az esetben évekre kiesnek választott munkaterületükböl."’2

\subsubsection{Speciális hazai anyai attitüdök, speciális hazai munkaerö-piaci helyzet $^{3}$}

A nemzetközi és a hazai szakirodalom áttekintése kapcsán nyilvánvaló vált, hogy mást ért a nyugat-európai, amerikai szakirodalom korai munkavállalás alatt, mint amit a magyar anyák: míg előbbi esetekben az első életévben megkezdett munka hatását vizsgálják, addig nálunk az első 3 életév szinte tabunak számít munkavállalási szempontból: a KSH adatai szerint a magyar anyák átlag 4,7 évig maradnak otthon (Cseres-Gergely, 2008). Hazai

\footnotetext{
${ }^{1}$ Forrás: www.ksh.hu (letöltés ideje: 2011.07.10)

2 Forrás: Kopp és tsai: Napközbeni kisgyermek ellátási megoldások, Munkacsoport anyag, Népesedési Kerekasztal, 2010

${ }^{3}$ Forrás: Cseres-Gergely Zs. Foglalkoztatottság Magyarországon: a GYES/GYED és a nyugdíjrendszer hatása,

Termelékenység és gazdasági növekedés, munka-erőpiaci kihívások, MNB-PM Konferencia, 2008
} 
kutatások azt mutatják, hogy a gyermek 6 (és nem is 3) éves koráig gondolják az anyák, hogy otthon kellene maradniuk (Cseres-Gergely, 2008; Blaskó, 2008; Blaskó, 2011). Ennek a problémának véleményem szerint több tényezője van: egyrészről egy erősen konzervatív szerep-felfogás (a nő dolga, hogy otthon legyen, illetve a gyermeknek csak és kizárólag az édesanyára van szüksége az első 3 évben - ennek a jelenségnek a vélhető hátteréről igen részletesen olvashatunk Blaskó 2011-es mélyinterjús tanulmányában) - amit nem árnyal még az sem, hogy ha a család fenntartásához szükség van a két szülö jövedelmére. Ezt erősíti a pénzbeli anyasági támogatás léte - amely nagyon sok esetben szinte az egyetlen, de legalábbis az egyik stabil jövedelemnek számít a család bevételei közt. Másrészről valós probléma az, hogy annak, aki dolgozni szeretne a gyermekvállalás után, sokszor valóban választania kell: család VAGY karrier. Elégtelen számú, túlzsúfolt, rugalmatlan, az államnak igen sokba kerülő, bár a szülő számára viszonylag nem drága állami ellátórendszerrel ${ }^{4}$, vagy egy, az állam által nem (vagy alig) finanszírozott, így a szülő számára sokszor jelentős többletköltségként jelentkező kiscsoportos, rugalmas (magán)ellátással szembesül, aki napközbeni ellátóhelyet keres gyermekének. E mellett nem terjedt el a részmunkaidő, a távmunka, az osztott munkakör sem - nem ismert, így nem is preferált atipikus foglalkoztatási formák ezek, melyek épp a kisgyermekes munkavállalónak jelenthetnének valós megoldást. Ám ezen megoldások mellett is szükséges épp a rugalmas kisgyermekellátást lehetővé tevő ellátórendszer (Kocsisné, 2013)

Lehet, hogy csak kisebbség, de mindenképp létező kisebbség, aki kisgyermek mellett dolgozna, de ezzel a társadalmi hozzáállással jelentős szerepfeszültség lép fel náluk (Ross, 1983). Ám a kisgyermekes nők nagy része ma is dolgozik - csak épp a szürke-, vagy még inkább a feketegazdaságban (nem számlaképesen, nem bejelentett munkát végeznek). Ez is egy olyan társadalmi - gazdasági probléma, melyről beszélnünk kell - jelentős adóbevétel elmaradást okoz ugyanis hazánk számára. Sokszor ők maguk sem tudják, hogy az általuk végzett tevékenység illegális (korrepetálás, gyermekfelügyelet, fordító munka, nyelvlecke, takarítás, családi vállalkozásban számlázás, stb.) - ezek az anyák a saját preferencia rendszerüknek megfelelően „otthon vannak a gyermekükkel, csak mellette keresnek egy kis pénzt” (Blaskó, 2011). A munkáltatónak is „megéri” nem hivatalosan visszavenni a GYEDen, GYES-en lévő kolleganőt, hiszen így mentesül a járulékfizetés alól. KSH (2012) adatok

\footnotetext{
${ }^{4}$ Figyelembe vettem, hogy 2012. január 1-től „fizetős” a bölcsődei rendszer (azaz a szülők számára a fenntartó térítési díjat állapíthat meg) - de a bölcsődék és óvodák állami finanszírozása összességében fajlagosan még így is $\mathrm{kb} 4 \mathrm{x}$-ese, mint a családi napközinek.
} 
szerint a nők negyede dolgozna, ha lenne kire hagyni a gyermekét, vagy lenne munkája, ezt erősíti meg Blaskó (2009, 2011): a nők nagy része (kb. 40\%) „feketén” dolgozik GYED/GYES alatt most is.

\subsubsection{Napközbeni kisgyermekellátás megoldatlansága}

Nemzetközi és hazai kutatások egyértelművé tették, hogy a gyermekvállalással kapcsolatos anyasági családtámogatások támogatások szerkezetének átalakítása hozzájárulhatna a női foglalkoztatottság növeléséhez, és ezen keresztül a magyar gazdaság versenyképességének javításához. Az átalakítás lényege az lenne, hogy az otthoni gyermekellátás pénzbeli támogatásának egy részét átcsoportosítanák az anyák munkavállalását támogató napközbeni gyermekellátás finanszírozásába (Reszkető és tsai, 2011). Véleményem szerint az átcsoportosítást mindkét rendszer rugalmasabbá tételével kellene fokozni (és talán kezdeni): az atipikus foglalkoztatási formák erőteljes preferációja mellett egy többszereplős, a jelenleginél lényegesen rugalmasabb (és olcsóbb) kisgyermekellátásra van szükség (kisebb csoportok, rugalmas nyitva tartás, a család igényeihez igazodó ellátás).

A magyar anyák nagy része erős ellenállást mutat a napközbeni kisgyermekellátó helyekkel szemben (Blaskó, 2011). Sokan azért választják a hosszú otthonmaradást, mert nem szeretnék a gyermeket „bölcsibe” adni. A bölcsődékkel ${ }^{5}$ szembeni ellenérzések többsége a fizikai ellátás minőségére, a túlzsúfoltságra, a nem megfelelőnek tartott gyermek-gondozó arányra vonatkozik. E mellett már a 0-3 éves korosztály ellátási igényeinél megjelenik a differenciálódás - különböző szülök különböző szolgáltatásokat tartanak megfelelőnek és kívánatosnak gyermeküknek (Blaskó, 2011).

A másik hivatalos alternatíva a 0-3 éves (igazából a 0-14 éves) korosztály számára családi napközi ${ }^{6}$. Ez a (nálunk) közel 20 éves ellátási forma csak hazánkban (és a környező poszt-szocialista országokban) számít unikumnak, Európa, Amerika és Ausztrália legtöbb pontján zömében ily módon oldják meg a gyermekek ellátását (Reszkető, Váradi, 2009). Előnye, hogy a kis ellátotti létszám miatt rugalmasan, könnyen és olcsón létrehozható, hivatalos munkahelyet teremt a benne dolgozóknak, és rugalmasan tud alkalmazkodni az igénybe vevők szükségleteihez (Reszkető és tsai, 2011). Mivel hazánkban a napközbeni

\footnotetext{
5 és sokszor ugyanez az ellenérzés figyelhető meg az óvodákkal szemben is (szerző megjegyzése a 2014-töl 3 éves kortól kötelező óvodáztatással kapcsolatban)

${ }^{6}$ A Gyermekvédelmi Törvény a 0-3 éves korú gyermekek napközbeni ellátását bölcsődében, családi napköziben vagy családi gyermekfelügyeletben definiálja.
} 
ellátások kialakításakor egyedüli módként a bölcsőde terjedt el, a családi napközi feltételrendszerének kialakításakor pedig sajnos nem igazán sikerült elrugaszkodni az intézményi keretektől ${ }^{7}$, így érthető, ha a szülők számára a családi napközi (alulfinanszírozottsága okán) „méregdrága magánbölcsi” kategóriaként jelent meg.

A fentiekből következik az a feltevés, hogy ha az ellátóhely fenti negatívumait kiküszöböljük (túlzsúfoltság megszüntetésével a meglévő állami intézményekben, illetve a nem állami ellátóhelyek hozzáférésének javításával a finanszírozás átalakításával) az talán javíthat az anyák negatív attitüdjén, mellyel a napközbeni kisgyermekellátásokhoz viszonyulnak. Azért fontos ez a kérdés, mert lehet, hogy az anya szívesen dolgozna a gyermeke mellett (lehet, hogy alkalomszerüen, nem hivatalosan dolgozik is), de kisebb rossznak tartja az otthonmaradást, mint hogy ,, beadja” a gyermeket bölcsödébe. Ha ezek az édesanyák úgy mennek vissza dolgozni, hogy ez a vélekedésük nem változik (azaz rossz döntésnek tartják a gyermek felügyeletének ilyen irányú megoldását), akkor ezeknél az anyáknál is fellép a szerepkonfliktus (Ross, 1983), ami újabb pszichés károkat okoz mind a szülőnek, mind a gyermeknek. Az ellátórendszer javításával, és ennek a ténynek az intenzív kommunikálásával vélhetően elejét lehet venni a fenti probléma tovább gyürüzésének.

Azonban nem szünik meg a probléma a gyermek óvodás korba lépésével. Igaz, hogy hazánkban viszonylag jól kiépített óvodai rendszer áll a családok rendelkezésére, de az elosztás egyenetlensége együtt jár egy nagyfokú túlzsúfoltsággal, így sok helyen nem kisebb gond az óvodai, mint a bölcsődei férőhely-hiány. A 2014-től életbe lépő Köznevelési Törvény 3 éves kortól kötelezi óvodáztatásra a szülőket. A témára külön visszatérek az ellátórendszer bemutatásakor.

Bár kiemelt fontosságú területnek tartom, de dolgozatomban nem kívánom külön kezelni a hátrányos helyzetű gyermekek integrációjának kérdését. Túl összetett a probléma, és a dolgozatnak nem elsődleges célja a marginalizált csoportok felzárkóztatására iránymutatást találni - ellenben úgy vélem, hogy az általam vázolt lehetőségek egyszerü megoldást jelenthetnek erre a problémakörre is. Nem kívánom külön kezelni a témát, mert ugyanolyan fontosnak tartom a leszakadó csoportok segítését, mint a többi társadalmi réteg nehézségeinek a megoldását. Viszont utalok rá, hogy a versenyképesség növelésében hol látok kitörési pontot, bemutatok követendő (és hazai viszonyokra könnyen átfordítható) külföldi példát. Számomra minden család, minden gyermek egyformán fontos - a társadalom sokszínűségét

\footnotetext{
${ }^{7}$ ami érthető, hiszen a rendszer kialakításában kizárólag bölcsődei szakemberek vettek részt
} 
épp a családok sokszínűsége adja, mely sokszínüséget nem egybemosni, hanem megőrizni szükséges, úgy, hogy közben mindenkinek azt a segítséget nyújtsuk, amire szüksége van.

Itt a témafelvetésnél nagyon fontosnak tartom leszögezni: semmilyen körülmények között sem célom annak bebizonyítása, hogy a kisgyermek melletti munkavállalás mindenkinek egységesen jó. Hiszem, hogy vannak édesanyák, akik kiteljesedve az anyaságban tudnak és akarnak hosszú éveken keresztül napi 24 órában tevékenyen foglalkozni a gyermekeikkel, gondozni, nevelni őket. Vannak, akik képesek ebben megújulni, úgy, hogy mindeközben a családjuk maximálisan az előnyeit élvezi az édesanya hasznos és elengedhetetlen háttértevékenységének. Hiszem, hogy vannak családok, akik így müködnek megfelelően. Azt gondolom, ha a családnak ez a valódi tudatos választása, ezeket a családokat ebben kell erősíteni, az ő más jellegủ problémáikra más megoldásokat kell találni.

Azonban vannak olyan családok, élethelyzetek, kényszerek vagy motivációk, amikor mindez nem elég, szükség van az édesanya munkavégzésére is. Én ezt a problémát vizsgálom, tiszteletben tartva az ettől eltérő családmodellt. Azoknak a családoknak keresem a megoldást, ahol a szülők együttesen kívánják a családi és a munkahelyi kötelezettségeket összehangolni úgy, hogy ez minden szereplőnek jó legyen: a gyermekeknek, a szülőknek, a munkáltatóknak és az államnak egyaránt. 


\subsection{Elméleti kutatási modell}

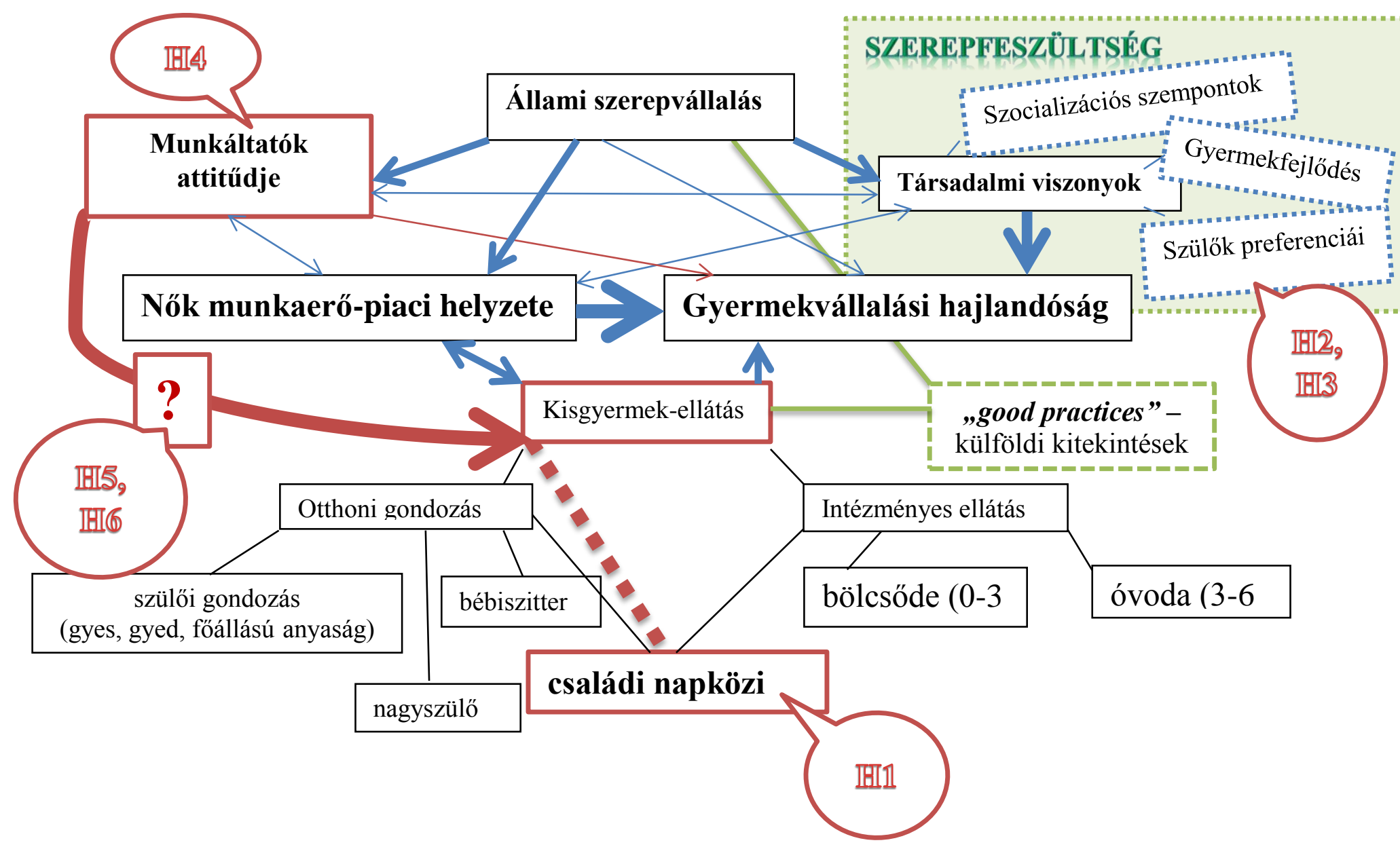


Elméleti kutatásom modelljét az alábbi gondolatok mentén építettem fel:

1. A gyermekvállalási hajlandóságot befolyásolja a nők munkaerő-piaci helyzete, valamint a meglévő társadalmi viszonyok. A társadalmi viszonyok vizsgálatakor a szocializációs szempontok, az anyai munkavállalás és a gyermekfejlődés összefüggései, valamint a szülői preferenciák bemutatására törekedtem. Fenti kérdéseket a szerepfeszültség (Ross, 1983) viszonyában vizsgáltam, ugyanis ha egy édesanya szerepzavart él át a gyermekvállalása, illetve a gyermeke elhelyezése kapcsán, abban az esetben kevésbé fog realizálódni a vágyott gyermekek megszületése. Nem választható szét az anyai és a gyermeki jól-lét, ha ugyanis a gyermek ellátása nem megnyugtató, az anya vagy nem fog munkába állni, vagy a munkavállalása közben szerepzavart él át. Dolgozatomban azzal a társadalmi csoporttal foglalkozom, ahol az édesanya a gyermekvállalás után vissza kíván térni a munkaerő-piacra. A szakirodalmi hátteret a dolgozat második fejezetében tekintem át. A második és a harmadik hipotézisem a gyermek napközbeni ellátásával kapcsolatos szülöi preferenciákat vizsgálja.

2. A nők munkaerő-piaci helyzetét befolyásolja a munkáltatók családos munkavállalóhoz füződő attitűdje (foglalkoztatja-e a kisgyermekes szülőt, támogatja-e ezen szülő gyermekének az ellátását). A munkáltatói attitüdre és a női munkavállalásra erősen hat a mindenkori állami szerepvállalás: ha az állam a szülői otthonmaradást támogatja, abban az esetben mind a család, mind a munkáltató ellenérdekelt a foglalkoztatásban. A dolgozatom második fejezetében mutatom be a szakirodalmi hátteret, valamint külföldi jó gyakorlatokat. A külföldi gyakorlatok bemutatásával a célom az esetleges ,good practices” szemléltetése, nem pedig a hazai rendszerrel való összevetés. Az ötödik és a hatodik hipotézis a kutatási kérdésben feltett alapkérdést vizsgálja.

3. A napközbeni kisgyermek ellátás bemutatásával a jelenlegi realitásokat szemléltetem. A külföldi jó gyakorlatok szintén gondolatébresztő, és semmiképp sem összehasonlító céllal kerülnek bemutatásra. Az első hipotézissel a családi napköziben ellátást nyújtókat vizsgálom.

4. Az állami szerepvállalás kulcskérdés, így bemutatom a jelenlegi szabályozást mind a családtámogatások, mind a napközbeni kisgyermek-ellátás területén. Jó gyakorlatként bemutatok néhány külföldi példát.

A kutatási kérdésemben arra keresem a választ, hogy vajon a családi napközik rendszerszintű fejlesztésével növelhető-e a női foglalkoztatás? A modell alapján felállított 
hipotézisem szerint az állami szerepvállalással befolyásolható a munkáltatói attitűd, mely kihatással van a női foglalkoztatásra. Amennyiben a munkáltatók támogatják a munkavállaló szülők gyermekeinek a megnyugtató ellátását, azzal egyrészt csökkenthető a dolgozni akarók anyák szerepfeszültsége, másrészt ezáltal növelhető a női foglalkoztatás direkt és indirekt módon: a gyermekellátó helyeken munkát vállaló nők látják el a dolgozó anyák gyermekeit. Bemutatom, hogy a meglévő ellátási formák közül miért javaslom a családi napközik fejlesztését: gyermekfejlődés szempontjából, anyai szerepzavar szempontjából, gazdasági (létrehozás, fenntartás) szempontok alapján egyaránt vizsgálom a kérdést.

\subsection{Kutatási kérdések, hipotézisek}

Mivel szándékomban áll megalapozni egy, a családi napközik minőségbiztosításához szükséges kutatást, jelen kutatásban vizsgálom a családi napközik szakmai hátterét (ott dolgozók végzettsége, indíttatása, motivációi), mivel a leggyakoribb „szakmai vád” a családi napközikkel szemben az intézményekhez viszonyított szakmaiatlanság. Egyet értek azzal, hogy mind az állam, mind a családok, mind a bevonni kívánt munkáltatók joggal várják el a legmagasabb szintü, professzionális ellátást. Ehhez azonban meg kell határozni a minimum-és az optimum személyi-és tárgyi feltételeket, szakmai sztenderdeket. Nem feladata jelen dolgozatnak ezen mutatók kidolgozása, de a dolgozat mindenképp megalapoz egy későbbi ilyen irányú munkát.

Mivel a hozzáférhetőség javításának egyik feltételeként érzékelem a munkáltatók bevonását a dolgozóik gyermekeinek a napközbeni ellátásába, ezért külön vizsgálom a munkáltatók attitűdjeit, jelenlegi és vágyott megoldási lehetőségeit. Célom felmérni, hogy valós igény-e a munkáltatók részéről a családos, gyermekes munkavállalók támogatása, a kisgyermekes dolgozók gyermekének megnyugtató ellátásában való részvétel. Javaslatokat kívánok tenni a mindenkori Kormányzatnak a téma megoldásában egy optimálisnak vélt finanszírozási modell megalkotásával.

Feltételezem, hogy a jelenlegi szabályozás mellett a probléma leggyorsabb, legköltséghatékonyabb és legrugalmasabb megoldása családi napközik létrehozása. Ez tehermentesíti a jelenleg igen túlzsúfolt ellátórendszert, direkt munkahelyeket teremt a létrejövő családi napközikben dolgozó szakembereknek, és indirekt munkahelyeket teremt azoknak a szülőknek (zömében édesanyáknak), akik a jelenlegi szabályozók mellett nem tudnak legálisan visszatérni a munkaerőpiacra úgy, hogy a családi és a munkahelyi kötelezettségeiknek egyaránt eleget tudjanak tenni. Mivel az Európai Uniós források szabadon 
használhatóak fel az ellátórendszer bővítésére, így meggondolandó a költséghatékonyság szempontjából a családi napközik létrehozásának sürgetése.

\section{Első hipotézis (H1)}

A családi napközi vezetők többségében magasabb végzettségủek, mint a törvény által előírt 40 órás tanfolyamhoz szükséges és elégséges feltételként megszabott 8 osztályos végzettség. A családi napközit vezetők, müködtetők között vannak szakképzett pedagógusok.

\section{Második hipotézis (H2)}

A szülők által képviselt preferencia-rendszer által a szülők meghatározzák, hogy mikor, milyen feltételek teljesülése esetén érkezik el a munkába való visszatérés ideje, és ez alapján döntik el azt is, milyen helyet tartanak megfelelőnek a gyermeküknek.

\section{Harmadik hipotézis (H3)}

A szülöknek a gyermekük elhelyezésekor fontosabb a relatív szubjektív gyermeki jól-lét, mint az ellátóhelyet jellemző dokumentálható, technikai tényezők (tárgyi feltételek, környezet, müködési engedély, gondozó végzettsége, stb).

\section{Negyedik hipotézis (H4)}

A munkáltatók megfelelö ösztönzők és állami támogatás megléte esetén hajlandóságot mutatnak a munkavállaló gyermekének az elhelyezésében.

\section{Ötödik hipotézis (H5)}

A családi napközik számának növelésével elsősorban a női foglalkoztatási mutatók nőhetnek (direkt és indirekt munkahelyek).

\section{Hatodik hipotézis (H6)}

A családi napközi, mint rugalmas kisgyermek-ellátási forma hozzájárul az atipikus foglalkoztatás elterjedéséhez, ami növeli a női foglalkoztatottságot (indirekt munkahelyek). 
II. FEJEZET

SZAKIRODALOM ÁTTEKINTÉSE 


\subsection{Nők és a munka világa - „család vagy karrier?”}

Ki mondja meg, vajon meddig lehet, hogy minden nap, mindenhol erös legyek? A csönd volna jó. Kicsit könnyebb napok. Ne kérdezz semmit, ha látod, hogy fáradt vagyok. (Balázs Fecó)

A kisgyermekes nők számára a mindennapos feladat-összeegyeztetési nehézségeknek önmagukon túlmutató, a gyermekfejlődést is befolyásoló következményei lehetnek. Ez ma Magyarországon egyénileg megoldandó, kívülről alig támogatott feladat (Blaskó, 2008). A hozzáállás a társadalom részéről álságos: megkövetelik az anyától a teljes idejü otthonmaradást szülés után, akár indokolatlanul hosszú ideig (KSH adatok alapján a magyar nők 4,7 évig maradnak otthon gyermekük születése után), majd teljes (napi 8-10 órás) állásba kell visszamenniük (hiszen alig elterjedt a részmunkaidő, távmunka (NGM, 2012). A napközbeni kisgyermekellátó-rendszer túlzsúfolt, és ez magával vonja az állandó betegségeket, táppénzt. Még mindig gyakori a diszkrimináció a munkavégzés során. Elmondható, hogy jellemző hazánkban a házimunka egyenlőtlen megosztása (alacsony gépesítettségi fokkal párosulva), általános a nők túlterheltsége, valamint a gyes-szokások rögzülése. (Blaskó, 2008; Pongrácz, 2011; Kocsisné, 2013).

\subsubsection{A dolgozó nő - a női foglalkoztatottság}

Jelen fejezetben bemutatom, hogy a női munkavállalás hogyan alakult az utóbbi évtizedekben, és ez az átalakulás milyen hatással van a termékenységre. Feltárom azokat az összefüggéseket, melyek az alacsony női foglalkoztatottság, az alacsony születésszám, a napközbeni kisgyermekellátó-rendszer hiányosságai, a pazarlónak mondható családtámogatás, és a szocializációs hátrányok, szegénység között fellelhetőek.

Nem célom teljes történeti áttekintést adni sem a demográfiai trendekről, sem a női munkavállalás ipari kor - rendszerváltás kora - tudástársadalmi kor (jelen) előtti szakaszairól. Mivel jelenleg is egy átalakuló társadalomban élünk, így az elfogadott társadalmi értékek is folyamatos változást mutatnak (Spéder, 2006). Ezért elegendőnek tartottam (és a dolgozat terjedelme sem tette a bővebb kifejtést lehetővé) az ún. második ipari kortól a napjainkban fellelhető információs társadalom demográfiai és munkaerő-piaci helyzetét bemutatni mindezeket is kizárólag a női munkavállalás szemszögéből. Ezen kívül nem szándékozom részletesen kitérni sem a különféle társadalmi aktivitásokra, sem a gender kérdésre, sem a 
férfi és női esélyegyenlőségre, sem a kultúrák közti különbségekre. Ennek oka egyrészt terjedelmi korlát, másrészt véleményem szerint szorosan nem befolyásolja a téma tárgyalását a fenti aspektus beemelése.

A nők mindig is aktívan részt vettek a család életében. Az otthoni munka (háztartási munka) mellett gyakran segítették férjük munkáját, főként iparosoknál, kereskedőknél, orvosoknál, ügyvédeknél, mezőgazdasági termelő egységeknél volt ez általános (Drjenovszky, 2009). A nők munkaerőpiacon való tömeges megjelenésében komoly szerepet játszott az, hogy egyre iskolázottabbá válhattak, egyre fejlettebbé vált a technika, különféle társadalmi mozgalmak egyre nagyobb szerepet követeltek a nőknek a munkaerőpiacon - és nem utolsó sorban a növekvő létfenntartási költségek is megkövetelték a két jövedelmet a családban. Ez a folyamat azonban magával vonta a feszültséget, mely fellépett a nőknél az otthoni és a munkahelyi kötelezettségek összehangolásának nehézségei miatt. (Drjenovszky, 2009). A rendszerváltást követően a nők nagy része munkanélkülivé vált, és sokuk számára az inaktivitás ${ }^{8}$ (föállású anyaszerep) jelentette a megoldást az anyagi bevételek növelésére (Spéder, 2003).

A gyermekvállalás és a kereső tevékenység összeegyeztetését megkönnyíti a háztartási munkák egalitáriánus megosztása. Bowly (1958) kötődéselméleti tanulmányában is kimutatta, hogy a családok összetartását növeli, ha a dolgozó feleség férje is részt vesz a házimunkában. A háztartási munkamegosztás gyakorlatát négy európai ország adatain keresztül vizsgálva meg állapítható, hogy bár a nők leterheltsége a férfiak szerepvállalásának mértékétől függően országonként eltérő képet mutat, de általában mégis igaz az, hogy az otthoni feladatok túlnyomó többsége a nőkre hárul. Az országok közötti azonosságok és különbségek alapvetően az egyes társadalmak értékrendjének hasonlóságaira, illetve eltéréseire vezethetők vissza. A magyar társadalom erőteljesen tradicionális beállítottságával magyarázható a magyar nök nagyarányú otthoni leterheltsége a férfiak csekély szerepvállalása mellett (Pongrácz, 2011, Kocsisné, 2013).

Kutatók (Pongrácz, 2009, 2013; Spéder, 2003, 2006; Blaskó, 2009) szerint úgy kellene hatni a munkáltatókra, hogy ne kerüljön veszélybe annak az állása, aki gyereket vállal - olyan modellt kellene népszerüsíteni, ahol az anyának a szakmai és a szülői karrier egyidejü megvalósitására van lehetősége. A család és a munka összeegyeztethetőségének nehézségei

\footnotetext{
${ }^{8}$ A munkaerőpiac szempontjából inaktívak: tanulók, nyugdíjasok, gyermeknevelési támogatást igénybe vevők és egyéb inaktívak. A továbbtanulást és a gyermekkel való otthonmaradást a társadalom nagy része kívánatos inaktivitásként definiálja (Laky, 2003)
} 
Blaskó szerint (2009) az alábbiak: családi és munkahelyi körülmények, egyén személyisége, elvégzett munka mennyisége, munkaidő rugalmassága, családméret, gyermekek száma és kora, anyának a munka iránti elkötelezettsége, foglalkozás presztízse, partner támogatása. Véleményem szerint fontos lenne a fenti tényezőket komplex módon kutatni.

Miért gazdasági probléma a népességfogyás? Demográfusok szerint három gyermek vállalása lenne az ideális a népességfogyás megállításához. Az aggodalmak szerint, ha a csökkenő tendencia így folytatódik, az komoly veszélybe sodorhatja a szociális rendszert, egyebek között a nyugdíjakat: nem lesz ugyanis, aki dolgozzon, és megtermelje a szociális ellátáshoz szükséges járulékokat.

Összehasonlítva a női foglalkoztatottság arányát az EU átlaggal, 2003-ra már 5,1\%-kal elmarad attól (ez főként annak tükrében figyelemfelkeltő, hogy 1990-ben még 18\%-kal felülmúlta azt) (Frey, 2005). Az Európai Bizottság egyik célkitüzése a férfiak és nők azonos mértékü gazdasági függetlenségének megteremtése, illetve biztosítása ${ }^{9}$. Az EU szinten 2010re tervezett foglalkoztatási célkitűzéseket Magyarország nem teljesítette ${ }^{10}$. Az alacsony magyar foglalkoztatási mutatók szorosan összefüggnek a részmunkaidő szükös elterjedtségével (Szalai, 2012). A foglalkoztatási rendszerben a nők az átlagosnál rosszabb helyet foglalnak el, s ebből következően mind keresetük, mind az ebből származtatott szociális jövedelmük a férfiakénál alacsonyabb szinten mozog. Ugyanezen irányelvhez kapcsolódik a gazdasági döntéshozatalban való esélyegyenlőség kérdése. Az iskolázottsági arányok változása ellenére a gazdasági élet vezetésében a nők részvétele - Európa-szerte csak kis mértékben növekedett. A lehetséges magyarázatok közül kiemelendő a „labirintusmetafora”, amely arra utal, hogy az elörejutás útvesztőjében haladó nők az előítélet, az ellenállás, a vezetési stílus, illetve a magánélet és a munka összeegyeztethetőségének akadályába ütköznek.

A 0-3 éves korú gyermeket nevelő foglalkoztatott anyák aránya tekintetében Magyarországnál csak Olaszországon és Máltán alacsonyabb az arány. A részmunkaidőben foglalkoztatottak aránya tekintetében szintén csak 2 ország kullog mögöttünk: Szlovákia és Bulgária. 2011-ben hazánkban a női foglalkoztatási ráta 7,9\%-kal volt alacsonyabb, mint az

\footnotetext{
${ }^{9}$ Forrás: Nagy I. - Pongrácz T.: Szerepváltozások - 2011, Tárki, Budapest, 2011

10 A közösségi politikák között az 1997. évi Amszterdami Szerződés rögzítette az Európai Foglalkoztatási Stratégiát, mely többek közt a foglalkoztatottság bővítésére és a munkanélküliség visszaszorítására vonatkozó iránymutatásokat tartalmazza az Európai Unióban. A 2010-es cél - EU átlagban - a teljes foglalkoztatottság, amely a 15-64 éves népességre vonatkozóan a 70\%-os foglalkoztatottságot jelent, amelyen belül a nök foglalkoztatottsági rátája legalább $60 \%$. A nők és a férfiak munkaerő-piaci egyenlőségének megteremtése érdekében csökkenteni kívánják a nemek közti különbségeket a foglalkoztatási ráta, a munkanélküliségi ráta és a keresetek tekintetében. (Frey, 2008)
} 
unió 27 országának átlaga. Nálunk a 15-64 éves korú nők 50,6\%-a foglalkoztatott, míg az EUban 58,5\%. Ez a hiány legföképp a 25 év alattiak, az 55 év felettiek, az alacsony iskolázottságúak és a 6 év alatti gyermeket nevelők szegmenseiben kimutatható. A 40-49 évesek, a diplomások és a 12 évesnél idősebb gyermeket nevelők körében a női foglalkoztatási ráta $75 \%$ közeli, több helyen meghaladva ezzel az uniós átlagot ${ }^{11}$. (Szalai, 2012)

\section{Női foglalkoztatási ráta (Szalai, 2012)}

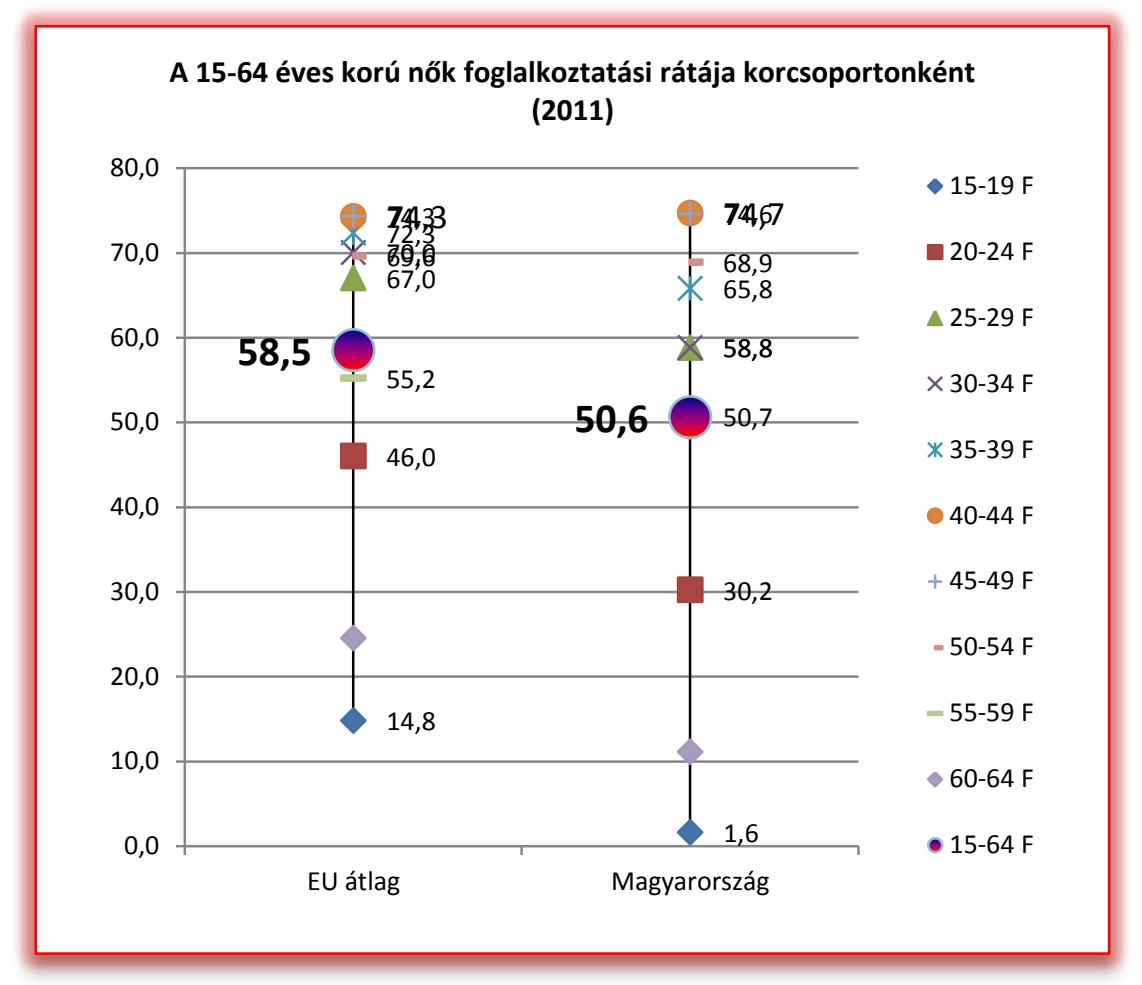

1. ábra, Női foglalkoztatási ráta (Szalai, 2012)

11 Hiányterületek:

- a 25 év alattiak - 20-24 éves nők foglalkoztatási rátája 30,2\% (EU_27 átlaga: 46\%)

- az 55 év felettiek - 55-59 éves nők foglalkoztatási rátája 50,7\% (EU_27 átlaga: 55,2\%)

- az alacsony iskolai végzettségüek - 15-64 éves nem érettségizett nők foglalkoztatási rátája $22,5 \%$ (EU_27 átlaga: 36,9\%)

- a kisgyermekes anyák, akiknek a legfiatalabb gyermeke kisebb, mint 6 éves foglalkoztatási rátája 34\% (EU_27 átlaga: 58,9\%);

illetve azok a legalább 3 gyermeket nevelők, akiknek a legfiatalabb gyermeke 6-11 éves foglalkoztatási rátája 44,9\% (EU_27 átlaga: 61,7\%)

Erősségek - a legjobb foglalkoztatási mutatójú csoportok:

- 40-49 évesek - foglalkoztatási rátája 74,6\% (EU_27 átlaga: 74,3\%)

- diplomások - foglalkoztatási rátája 74,4\% (EU_27 átlaga: 78,7\%)

- azon anyák, akiknek a legfiatalabb gyermeke idősebb, mint 12 éves foglalkoztatási rátája 75,1\% (EU_27 átlaga: 71,6\%) (Forrás: Szalai, 2012) 
Magyarországon a teljes munkaidős női foglalkoztatottak 15-64 éves korosztálybeli aránya $46,1 \%$, az EU-ban $40 \%$, s a statisztikai értelemben vett részmunkaidős, tehát heti 35 órát nem meghaladó idejü foglalkoztatottak a korosztály 4,5\%-a, az EU-ban 18,5\% (Szalai, 2012). 
Női foglalkoztatása ráta2 (Szalai, 2012)

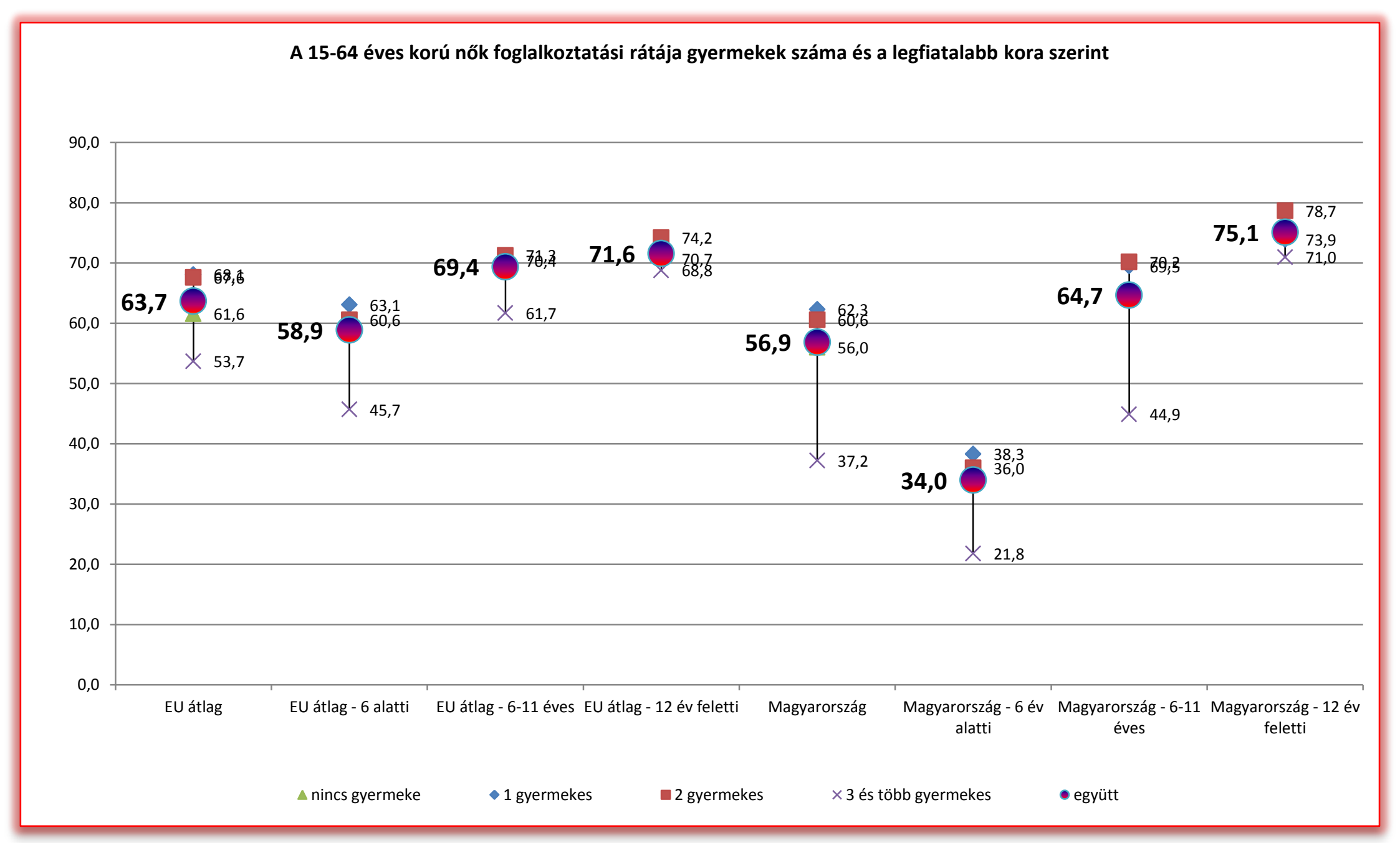

2. ábra, Női foglalkoztatása ráta2 (Szalai, 2012) 
Mind az EU-ban, mind nálunk azok a nők, akik 6 év alatti gyermeket (is) nevelnek, a foglalkoztatási rátája kisebb az átlagnál. Az EU-ban ez a lemaradás 4,8\%, míg nálunk 23\%. Ha a családban 3 vagy több gyermek van, akkor amíg a legfiatalabb gyermek nem éri el a 12 éves kort, az anya foglalkoztatási rátája kisebb az átlagnál. Az EU-ban 2\%-kal, nálunk 12\%kal (Szalai, 2012). Ez az érték különösen alacsony a 3 évesnél fiatalabb gyermeket nevelöknél. Ez összefüggést mutat a rugalmatlan és elégtelen napközbeni kisgyermek-ellátási lehetőségekkel és az atipikus foglalkoztatási módok elégtelen voltával (Scharle, 2008).

A részmunkaidős és a távmunkában való foglalkoztatás feltételei hazánkban kevésbé adottak, mint Európa számos más országában. Sem a munkahelyi, sem a társadalmi kultúrája nem alakult ki, e mellett igen erőteljes a láthatatlan munkavégzés nőkre háruló aránya (háztartási munka, idősápolás, gyermeknevelés, stb.) (Pongrácz, 2011, Kocsisné, 2013). A jelenleginél lényegesen markánsabb kormányzati ösztönzőkkel lehetne azt elérni, hogy a munkáltatóknak is megérje egy munkakört több munkavállalóval ellátni, vagy a hazaadható munkák egy részét legalább távmunka formájába kiszervezni (adókedvezmények, mintaprojektek). A munkavállalók oldaláról sem mindegy, hogy a részmunka mit jelent: ha pl. minden nap be kell mennie a munkahelyére 4 órahosszát dolgozni, a munkába járás direkt és indirekt költségei felemészthetik a munkabérrel megszerezhető anyagi előnyt (NagyPongrácz, 2011). 


\section{Női foglalkoztatási ráta3 (Szalai,2012)}

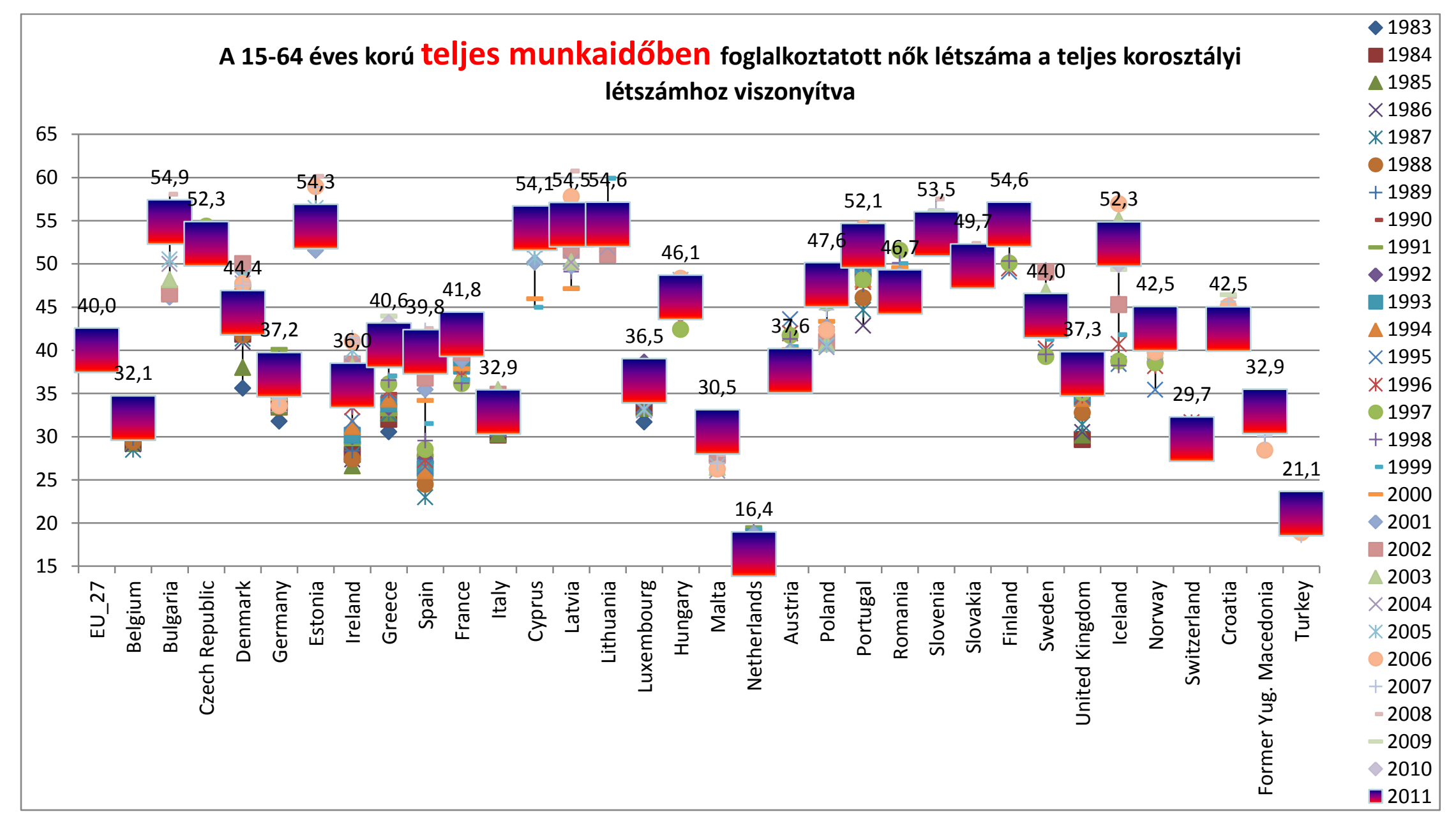

3. ábra, Női foglalkoztatási ráta3 (Szalai,2012) 
Részmunkaidős fogl. (Szalai,2012)

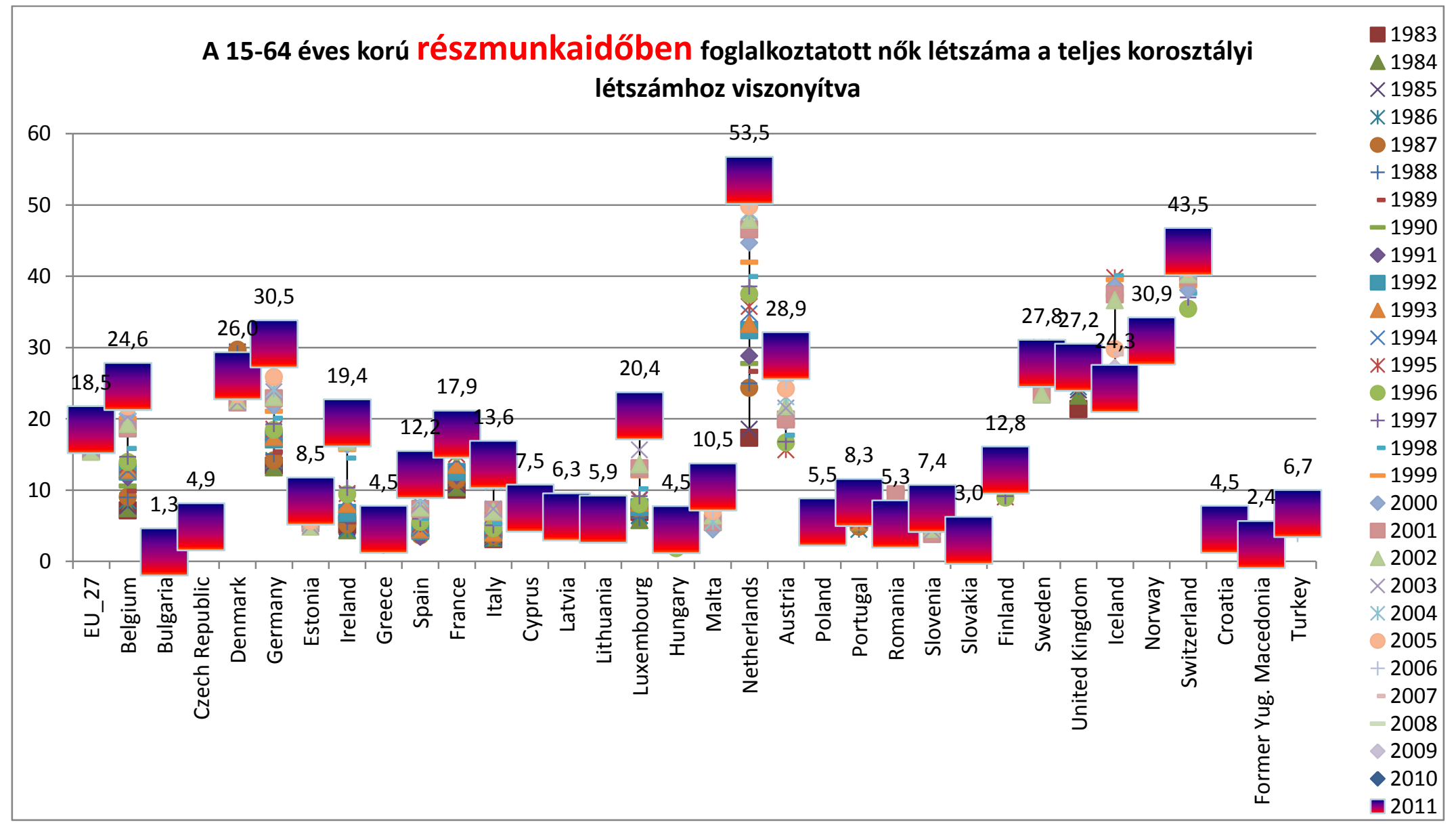

4. ábra, Részmunkaidős fogl. (Szalai,2012) 


\subsubsection{A női munkavállalás és a népesedés, demográfia kapcsolata}

„Gyermekszeretö, de gyermektelen társadalomban élünk”

Farkas Péter, NCSSZI

Komoly kérdés ma az egész világon, de Magyarországon talán még inkább: meddig maradjon otthon az anya gyermekvállalás után? A kérdésre elmúlt évek hazai, és a téma alapjait adó külföldi szakirodalom áttekintése sem biztos, hogy egyértelmü választ ad. Az azonban biztosnak tünik, hogy változásnak kell következnie.

A nők munkaerö-piaci részvételét döntően befolyásolja a gyermeknevelés. A 3 (több kutató és a saját véleményem szerint a 6, de akár 10) éven aluli gyermekek napközbeni ellátása keretében nyújtott szolgáltatások egyrészt segítik a család és a munkahely feladatainak összehangolását, segítik a nők fokozottabb munkaerö-piaci részvételét, ami ahogy európai példák is bizonyítják - növeli a gyermekvállalási hajlandóságot és javítja a demográfiai mutatókat. A magyar lakosság értékrendje és tényleges demográfiai magatartása ${ }^{12}$ között jelentős eltérés van. Míg a lakosság véleménynyilvánítás szintjén a tradicionális családmodell mellett érvel (kenyérkereső férj - családot gondozó feleség), addig mindez a tényleges magatartásban (házasodás, gyermekvállalás, stb.) nem, vagy csak alig jelenik meg (Pongrácz, 2011). Az ezredfordulót követő évtized során mára társadalmi konszenzus alakult ki abban, hogy az ún. materiális életcélok (pl. jövedelem, lakás) és a posztmateriális életcélok (pl. hobbi, egyéni célok, munkasiker, barátok) bővülő kínálatából szinte kizárólag csak a gyermekszám mérséklése árán lehet válogatni. És ez az ár a társadalom részéről elfogadott - noha a tradicionális családfelfogására büszke a megkérdezett polgárok többsége (S. Molnár, 2011). A feszültséget Blaskó szerint (2011) az oldhatná, ha a családpolitika részéről határozott törekvés mutatkozna a munka és a család összehangolásának elősegítésére. Több kutató (Pongrácz, 2011; Blaskó, 2008; Blaskó, 2011; Szalai, 2012; Kocsisné, 2013) egybehangzó véleménye, hogy a családtámogatási rendszer bővítése vagy akár a jelenlegi szinten tartása sem bír egyértelmüen kimutatható pozitív hatásokkal. Véleményem szerint a fentieknél sokkal fontosabb lenne a munkavállalási rugalmasság és a munkavállalást lehetővé tevő, rugalmas és gyermekközpontú ellátóhelyek hozzáférhetőségének bővítése.

\footnotetext{
${ }^{12}$ demográfiai magatartás: a kívánt gyermekek realizálása (azaz megszületése)
} 
A gyermekvállalás kitolódásában központi szerepet játszik a párkapcsolatok átalakulása, a hagyományos családmodell megbomlása. Visszaesett a házasodási kedv, az első házasságkötések ideje kitolódott (Kamarás, 2002; Temesváry, 2013). A statisztikai adatokat vizsgálva megállapítható, hogy a házasságkötések száma együtt mozog a gyermekszületésekkel - azaz bátrabban vállalnak gyermeket a házasságban élők (KoppSkrabski, 2006; Temesváry, 2013). A válások száma nem változott, viszont a házasságok száma csökkent - azaz a házasságok sokkal nagyobb arányban végződnek válással, mint évtizedekkel ezelött (NGM, 2012). A házasságkötési és születési mozgalom rendszerint érzékenyen reagál a társadalmi és gazdasági életben bekövetkezett változásokra.

Magyarországon a házasodási kedv folyamatos csökkenése, alábbhagyása figyelhető meg. Leginkább a 25 évesnél fiatalabb nők és férfiak házasságkötéseinek száma marad el a korábbitól, ugyanakkor mérsékelt emelkedést mutat a 30-as éveikben járó nők és férfiak házasságkötési aránya. A fiatalon meg nem kötött házasságokat az idősebb korosztályok növekvő házasodási hajlandósága messze nem képes ellensúlyozni, így a házasságkötések száma csökken. Kitolódott a házasságkötés-kori átlagos életkor: férfiaknál 28 esztendőről (1960) 30,1-re (2007); nőknél ez a változás még nagyobb: 24 évről 27,5 évre.

A házasságkötések számának csökkenése elsősorban a tanulmányi idő kitolódásának és az egzisztencia megalapozásának igényből adódik. A házasságkötések kitolódásának következménye lehet a későbbi első gyermek vállalása is, aminek egyenes következménye összességében a kevesebb gyermek vállalása (hiszen idősebb korban már nem vállalnak annyi gyermeket a nök, mint ha fiatalabb korban szülnének) (NGM, 2012; Temesváry, 2013).

Kamarás (2000) szerint a termékenység csökkenése mindig is kíváncsisággal vegyes érdeklődést, nemritkán aggodalmat váltott ki a társadalom jövője iránt felelősséget érző emberekből. Rámutat, hogy a tartós csökkenés kezdeti jelei már a múlt század utolsó évtizedében jelentkeznek, a századfordulót követő évtizedekben pedig felgyorsultak. A születésszám-csökkenés minden várakozás és előrejelzés ellenére folyamatos ${ }^{13}$. Az 1990-es évek elején készült népesség-elöreszámítás valamennyi változata az 1995-1999 közötti időszakra éves átlagban magasabb születésszámot prognosztizált, mint az 1990-1994 közötti évekre. Tette ezt abból kiindulva, hogy a „Ratkó-gyermekek" gyermekei ekkor lépnek húszas éveikbe, szülőképes koruk legtermékenyebb időszakába. Jóllehet nem volt várható egy - a

\footnotetext{
${ }^{13}$ Forrás: http://nepesedes.hu/drupal/node/308
} 
húsz évvel ezelőttihez hasonló - születési hullám kialakulása, arra számítani lehetett, hogy a csökkenő termékenységet némileg ellensúlyozza a szülőképes korba lépő generációk nagyobb létszáma, és ez, ha időlegesen is, születésszám-emelkedéssel jár együtt. A várakozásoknak azonban pont az ellenkezője történt, felgyorsult a csökkenés mértéke a fiatalok gyermekvállalási kedvének drasztikus visszaesése miatt. A „Ratkó-gyermekek" unokái nem születtek meg.

A KSH felmérése szerint (2008) a családalapítási szokásokat napjainkig hosszú időszakon keresztül a fiatalkori házasságkötés és a fiatalon vállalt anyaság jellemezte. Nem volt jellemző az akaratlagos gyermektelenség, mindenki kívánt legalább egy gyermeket, általánossá vált a kétgyermekes családmodell. Ritka volt a 30 vagy 35 év feletti gyermekvállalás, alacsony volt a házasságon kívüli születések aránya. E termékenységi minta változásának első jelei már az 1980-as évek elején megjelentek, az 1990-es években pedig egyre határozottabbá váltak. Ez a korábbiaktól eltérő gyermekvállalási szokások kialakulásához vezetett, ami főleg a szülő nők korösszetételében okozott jelentős változásokat. Erősen visszaesett a fiatalok - föleg a 25 éven aluliak - gyermekvállalási kedve, így a nők jóval kisebb arányban szülték meg az első és a második gyermeküket nők 20, illetve 25 éves korukig, mint korábban. Az 1990-es években a 20 év alatti nők termékenysége 38\%kal csökkent, a legtermékenyebb korú 20-24 éveseké pedig a felére zuhant. Ennek eredményeként hetven év óta ismét a 25-29 éves nök körében lett a leggyakoribb a gyermekvállalás a 20-24 éves életkor helyett. A 30 év feletti nők gyermekvállalási kedve viszont némileg emelkedett az utóbbi években, és még mindig magasabb, mint tíz vagy húsz évvel ezelött volt. Századunk folyamán elöször figyelhető meg tartósan az a jelenség, hogy a termékenység csökkenése az anyák „öregedésével" jár együtt. Emelkedik az anyák átlagos életkora gyermekük világra hozatalánál. A későbbi házasságkötés és gyermekvállalás miatt 1990 óta 1,7 évvel emelkedett és 25 évet ért el a házas nők átlagos életkora első gyermekük megszülése. 


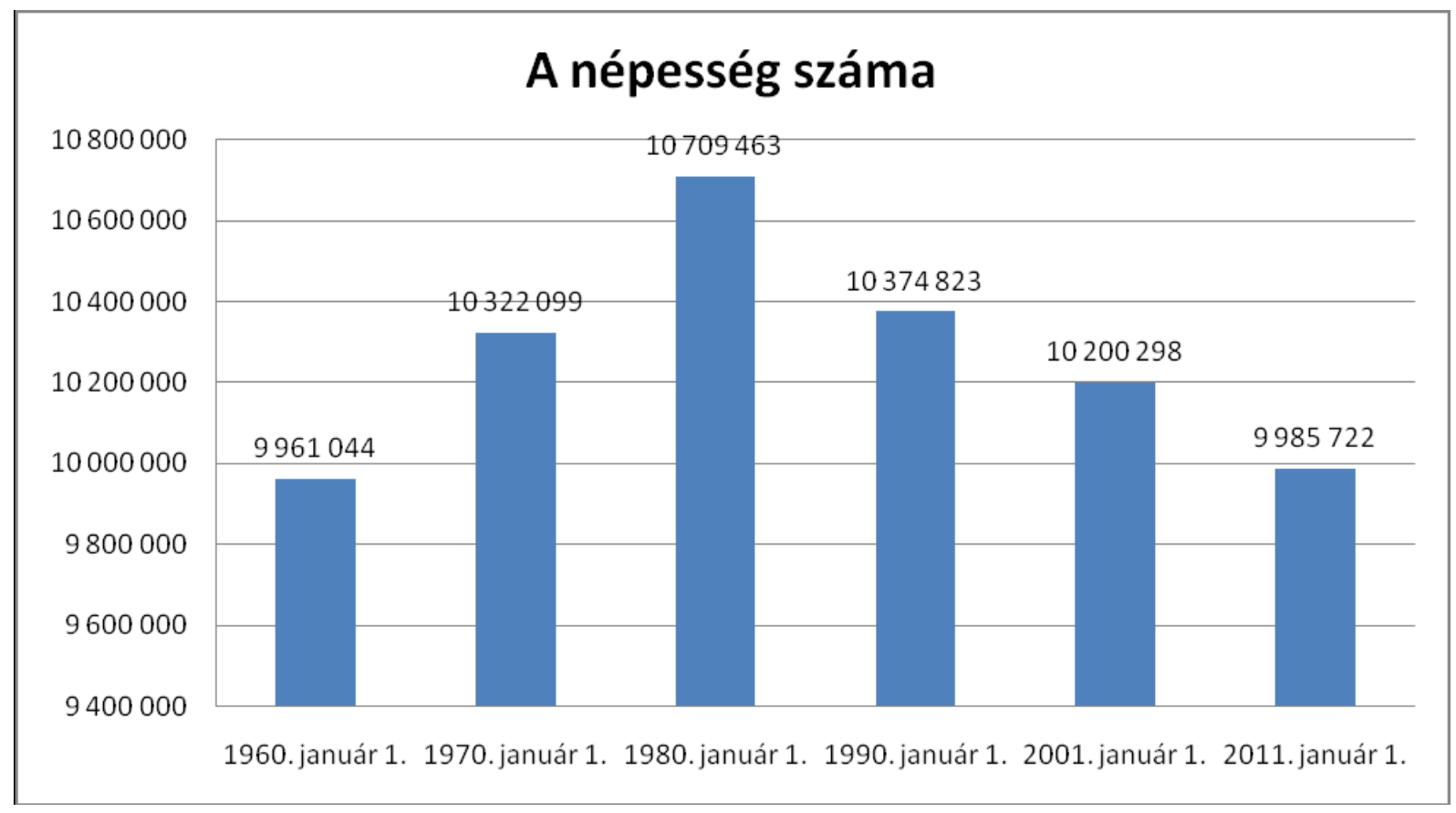

5. ábra, A népesség száma (KSH,2012)

A tartós népességcsökkenés számos aggodalmat vált ki. A csökkenés és öregedés párhuzamos folyamatok, amelyek egy idő után kölcsönösen erösítik és gyorsítják egymást. Egy ilyen társadalomnak csökken a versenyképessége, kevésbé rugalmas és befogadó a társadalmi és gazdasági újdonságokra, csökken az emberi erőforrások és a társadalom egészének megújulásra való képessége (Pongrácz-Spéder 2002). 


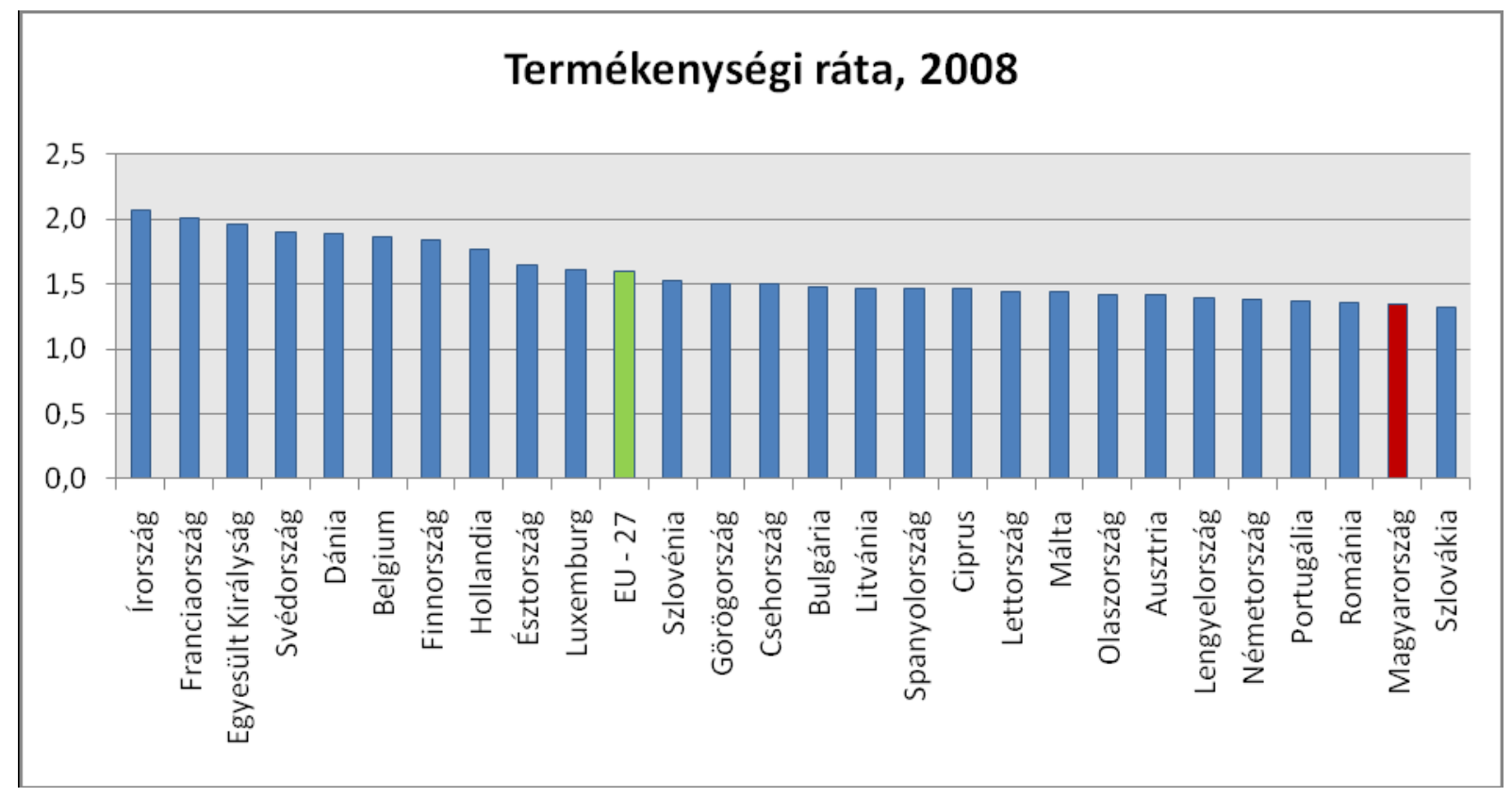

6. ábra, Termékenységi ráta (Eurostat) ${ }^{14}$

Magyarországon a párok által tervezett gyermekszám 2-2,2 körül mozog, míg a teljes termékenységi arány csak 1,2 - 1,3 körül ingadozik, azaz a népességpótlási szint alatt van, ami azt jelenti, hogy 100 nő 120 - 130 gyermeket szül élete során. (A népesség egyszerü reprodukciójához 100 nőre 210 gyereknek kellene jutni.) A termékenység tehát tartósan legalább egyharmaddal alacsonyabb annál a szintnél, amely a népesség természetes újratermelődéséhez szükséges. A születésszám alacsony szinten való állandósulásában jelentős szerepe van a későbbi önállósulásnak (a fiatalok tovább maradnak a szülői háznál), az együttélési formák megváltozásának (az élettársi kapcsolatok és a "szingliség" elterjedése), a tanulási idő meghosszabbodásának és ezekkel összefüggésben a szülések időbeli kitolódásának. Az első szülés elhalasztása sokszor a későbbi szülések elmaradását eredményezi. (NGM, 2012; Pongrácz, 2011). Az alacsonyabb termékenység másik lehetséges oka, hogy a magasabb végzettségü (érettségizett, ill. felsőfokú végzettségü) nők ma igen súlyos hátrányba kerülnek a velük azonos korú gyermektelenekkel szemben, hiszen arra kényszerülnek, hogy válasszanak pályájuk és a gyermekvállalás között. Ezt támasztja alá, hogy hazánkban a gyermek 3 éves kora előtt a nők csupán elenyésző része $(15 \%$ alatt $)$ tér vissza a foglalkoztatottak közé, szemben az OECD átlaggal (45\% felett). Ez a nemzetgazdaság számára is igen súlyos veszteség (NGM, 2012). Temesváryék (2013)

\footnotetext{
${ }^{14}$ Átvéve innen: NGM, 2012, 32. old.
} 
kutatása visszaigazolja az előzetes várakozásokat: a 100 ezer Ft alatti nettó jövedelemmel rendelkező családos (házas) faiatalok több gyermeket terveznek és realizálnak, mint a 200 ezer Ft nettó jövedelem fölött keresők. A gyermekválallás elmaradásának oka tehát épp hogy nem a pénztelenség, hanem a jövedelem elvesztésétől való félelem, hiszen az alacsony jövedelműeknek reálisan nem változik a jövedelmi viszonya az érvényben lévő családtámogatás mellett. Ha viszont figyelembe vesszük azokat a szociológiai kutatásokat, melyek szerint a gyermek várhatóan továbbviszi a szülői (elsősorban anyai) mintát, megfontolandó lenne figyelembe venni a magasabban kvalifikált családok jelzését. Ök ugyanis nem a családtámogatáshoz, hanem a család és munka összeegyeztetéséhez kötik a gyermekvállalást. Mivel a nőkre háruló kettős teher a jövőben várhatóan nem csökkenni, hanem növekedni fog, így a nők reprodukciós funkciójának teljesítése fontos nemzetgazdasági kérdéssé válik a szociális-, nyugdíjrendszer müködtetése miatt (Pongrácz, 2011).

\subsubsection{Gyermeknevelési támogatások, családtámogatások}

Ebben a fejezetben arra világítok rá, hogy a jelenlegi magyar családtámogatási rendszer hol segíti, és hol akadályozza a kisgyermekes nőket a családtámogatás, és a munkába való visszatérés terén. Nem célom jelen fejezetben részletesen bemutatni és összehasonlítani a magyar és külföldi családtámogatási rendszereket, viszont „good practice"-ként kitekintek néhány jó gyakorlatra.

Állandó témaként merül fel társadalmi - gazdasági konzultációkban: ,a gyermek a jövőnk”. De mit is értünk ez alatt? Gábos (2000) szerint a családtámogatásokat az alábbi módokon segíthetik az emberi tőke-felhalmozást:

- növelik a gyermekek, tehát a jövendő adó-és járulékfizető generációhoz tartozók számát (ők jelentik a gazdaság munkaerő-utánpótlását)

- a gyermeknevelés és a munkavállalás összeegyeztetésével csökkentik az anya emberitőke-veszteségét (a gyermeknevelésre fordított idő erodálja a munkaerőpiacon is hasznosítható tudást és készségeket)

- egy különösen fontos időszakban hatnak a gyermekek kognitív és érzelmi fejlődésére, és ezen keresztül felnőttkori teljesítményükre

- segíthetik a gyermekek emberitőke-felhalmozását azokban a családokban, amelyek erre nem, vagy csak korlátozottan képesek (akár a felhalmozáshoz szükséges 
anyagi források, akár a szülők ehhez szükséges emberi, kulturális vagy társadalmi tőkéjének a hiánya miatt).

A gyermekgondozási szabadsággal kapcsolatos elvi és gyakorlati kérdések is igen időszerủek. Bár léteznek minimum kívánalmak az Unió egészére nézve az anyasági és a szülési szabadságra vonatkozóan, de azok nem eredményezték a rendszer uniformizálódását. Egyes országok a hosszú szabadság és az alacsony összegü juttatás gyakorlatát választották, míg más kormányok a kieső bért viszonylag magas szinten, de rövidebb ideig kompenzálják. Hazánkban a kisgyermekes anyák foglalkoztatási aránya igen kicsi (OECD: utolsó $^{15}$ ), míg a gyermekellátó intézményrendszer ezzel összhangban fejletlen, az anyasági ellátásokra költött pénz relatív nagysága pedig a legnagyobb (Scharle, 2009, Cseres-Gergely Zs, 2008). Nemzetközi tapasztalatok arra utalnak, hogy azokban az országokban jobb a gazdasági helyzet, és egyben kedvezőbbek a gyermekvállalási mutatók, amelyekben a szülőket, mindenekelőtt a nőket a munkahelyre történő korai visszatérésre ösztönzik, és e célkitüzés figyelembevételével alakítják ki a gyermekgondozási szabadságok és a kapcsolódó intézményes ellátások rendszerét (Blaskó és tsai, 2009). Fontos különbség hazánk és az EU-ben a témában nálunk jobban teljesítők között az elérhető atipikus foglalkoztatás és rugalmas kisgyermek ellátóhelyek megléte.

A magyar gyermektámogatási rendszer 1967-ben a munkától való hosszas inaktív távollétet támogató rendszerként indult (Gyes bevezetése). Azonban az évek során egyre több olyan igénybe vevő jelent meg, aki nem a munkából munkába átmenet támogatásaként kapja a juttatást, hanem jövedelem helyett - lévén a szülést megelőzően sem volt semmilyen munkatapasztalata. A magyar anyák kevesebb mint 5\%-a tért vissza a munkába a gyermek egyéves kora előtt (ugyanez az arány az USA-ban közel $40 \%$ - ezért is aggályosak a nemzetközi összehasonlítások), és alig 8\% a gyermek kétéves kora előtt (KSH, 2011).

Ennek némileg ellentmondanak azok a KSH felmérések (Blaskó 2009), melyek ugyenezen korú gyermekeket nevelő nők között a munkavállást 40\% körülinek mérték. Valószínűleg az informális (szürke és/vagy fekete) gazdaságban dolgoznak a kisgyermekes nők - azonban ez felveti a napközbeni kisgyermek ellátás megoldásának az ugyancsak informális módjait: család (nagyszülő, nem dolgozó felnőtt rokon), illetve a működési engedéllyel nem rendelkező gyermekfelügyeletek, bébiszitterek létét. Ez 2 ponton ad okot aggodalomra: egyrészről az ellenőrzési lehetőségek teljes hiánya (szakmai, közegészségügyi), másrészről az

\footnotetext{
${ }^{15}$ Forrás: http://www.oecd.org/document/4/0,3746,en_2649 $34819 \quad 37836996$ 1_1_1_1,00.html (letöltés dátuma: 2012.02.01)
} 
adó-és járulékfizetési kötelezettség elmulasztása mind az igénybe vevő (legtöbbször „feketén” dolgozó), mind a szolgáltatást (szintúgy „feketén”) nyújtó részéről.

A munkaerőpiac és családtámogatási rendszer, a gyermekvállalási szándékok realizálását társadalmi rétegenként és családtípusonként szelektíven befolyásolja. Az alacsony jövedelmü nők az átlagnál nagyobb arányban realizálják gyermekvállalási terveiket. A közepes pozícióban lévő nők gyermekvállalási kedve azonban a támogatási rendszer és a munkaeröpiaci folyamatok együttes hatásának következtében a legalacsonyabb, míg a magas jövedelmúeknél a hatás differenciáltan jelentkezik. Körükben nő a gyermektelenek és a többgyermekesek aránya, miközben csökken az egy gyermeket vállalóké (Kopp, 2010; Temesváry, 2013). Bass és társai (2007) azt vizsgálták, hogy vajon hogyan lehetséges, hogy az átlagjövedelmekhez képest kimagaslóan magas gyermektámogatási rendszer sem képes növelni sem a termékenységet, sem a kisgyermekes anyák foglalkoztatottságát? Úgy találták, hogy

„a szülés utáni visszatérés kapcsán a munkakihagyás optimális hosszát a munka és az otthonlét értékének viszonya mozgatja. Az elöbbi (munka) függ a bértöl, a munkavállalás és a gyermekelhelyezés fix költségeitöl, valamint az ellátóhely minőségétöl (a szülök által megitélt hatás a gyermek kognitiv és értelmi fejlödésére). Az utóbbi (otthonlét) függ a gyermektámogatás mértékétöl, a háztartási termelés értékétöl, a megnövekedett szabadidö hasznától, valamint az otthoni, anyai gondoskodáshoz társitott hasznosságtól. A napközbeni elhelyezés költsége a gyermek növekedésével eröteljesen csökken, ... , valamint az idö elörehaladtával a az intézményes és az anyai felügyeletnek a gyermek fejlödésére gyakorolt hatásai is jelentösen módosulnak az intézményes nevelés javára. Ez többnyire már elegendö ahhoz, hogy elérkezzen egy pont, ahol a munkába való visszatérés nettó haszna már pozitív. Ha azonban a várható bér szintje nagyon gyorsan csökken a kihagyás hosszával, ha a munkába járás és a napközbeni gyermekelhelyezés költségei nagyon magasak, a háztartási termelés hozamai jelentékenyek, vagy a gyermekintézmények minösége nagyon rossz, akkor egy ilyen pont csak nagyon késön, vagy soha nem jön el. A készpénzes segélyek változtatása befolyásolja ugyan az otthonlét értékét, de nem feltétlenül fordítja meg a munkavállaláshoz, illetve az otthonléthez kapcsolt hasznosságok viszonyát. ... A leirtakból adódó fontos következtetés, hogy egy olyan rendszer, amelyik szélsőséges mértékben torzitott a készpénzes támogatások javára, nem feltétlenül képes segíteni a munka és a gyermeknevelés összeegyeztetését. Ám arra sincs biztositék, hogy jól szolgálja a magas termékenységet és a hagyományos családmodell fennmaradását. A készpénzes támogatások szintjének és igénybevételi feltételeinek változtatgatása hatástalan maradhat, ha egyidejüleg nem történik eröfeszittés a gyermekvállalás melletti munkavégzés költségeinek csökkentésére, beleértve a napközbeni gyermekfelügyelet elérhetöségének és színvonalának a javitását ${ }^{16}$."

\footnotetext{
${ }^{16}$ kiemelés tőlem (szerző)
} 
Bass és társai 2007-es tanulmányuk függelékében megjegyzik, hogy a folyamatosan negyedmillió embert segélyező magyar gyermektámogatási rendszerről 1972 óta nem készült olyan adatfelvétel, mely a rendszer munkapiaci hatásait pontosan felmérhetné. A magyarországi elemzések zöme KSH adatokon nyugszik, mely korántsem tekinthető korlátlanul alkalmasnak egy támogatási rendszer meghozásához. A kisgyermekes anyákkal kapcsolatos eseti kiegészítő felvételek a munkavállalási szándékokról és a munkapiaci várakozásokról adnak képet (Frey, 2001, 2002). Ezek a felmérések bár igen alaposak, de nem pótolják a tényleges állapotok megismerésére törekvő kutatást. Fontos megállapítás, hogy a magas jövedelmüek nem a családtámogatási lehetőségekhez, hanem a család-és munka összeegyeztethetőségének lehetőségéhez kapcsolják a gyermekvállalási tervik realizálást. Az alacsony jövedelmüeknek ugyanis nem jelent jelentős anyagi hátrányt a jövedelem helyetti családtámogatás, a magasabb jövedelmủeknek azonban a karrier kettétörése anyagi ellehetetlenülést okoz (Temesváry, 2012).

\subsubsection{Külföldi kitekintés ${ }^{17}$}

A nők munkavállalásának a népesedére gyakorolt hatását felismerve a legtöbb európai ország erőfeszítéseket tesz a gyermekvállalás és a gyermeknevelés megkönnyítése, valamint a család és a munka összeegyeztetésének lehetősége terén. Ezen erőfeszítések korántsem csak anyagi juttatások nyújtására terjednek ki, hanem a munkaügyi, családjogi szabályozást, gyakorlatot teszik képessé arra, hogy a fenti szerepek a családoknak egymással összeegyeztethetőek legyenek (Pongrácz, 2011).

Elkészült egy 41 országra kiterjedő, 74 adatsorból álló adatbázis, mely az $\boldsymbol{O E C D}$ Family Database legfrissebb, vonatkozó (elsősorban a 0-3 éves korosztályhoz kapcsoló problematikákra fókuszáló) adatain alapul. Az adatokat a következőképpen csoportosították:

Család- és gyermektámogatások politikái kérdéskörben az alábbi kategóriákat állították fel: Finanszírozás, 0-3 éves gyermekek napközbeni ellátása, A családok munkaerö-piaci pozíciója, Családbarát munkáltató, Női munkavállalás körülményei (a gyermek 3 éves koráig). A fent említett adatbázisból egy 29 európai országra kiterjedő rangsor készült, 21 tényező figyelembevételével. A fenti szempontok szerint egyenként, illetve egy összesített családtámogatás-hatékonysági rangsor készült.

\footnotetext{
${ }^{17}$ Jelen fejezetben erősen támaszkodom a Nemzetgazdasági Minisztérium 2012-es tanulmányára (NGM, 2012)
} 


\section{Családtámogatások (NGM,2012)}

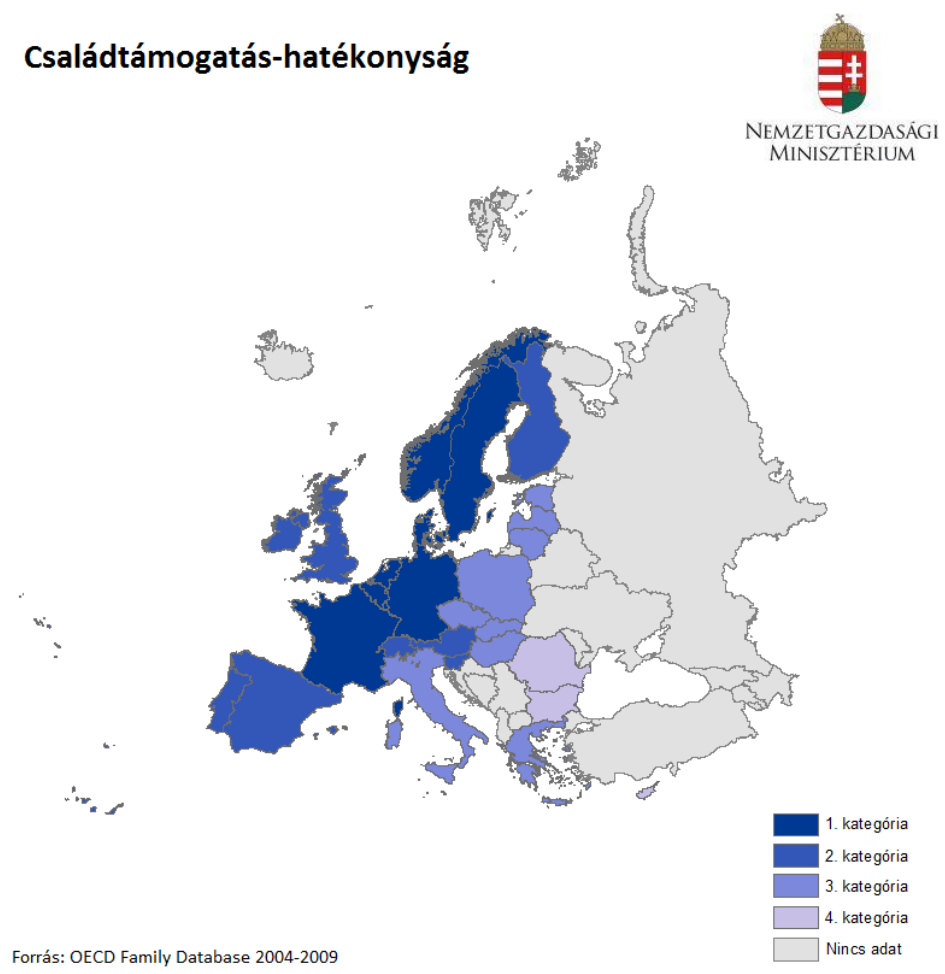

7. ábra, Családtámogatások (NGM,2012)

Ezeket 4 kategóriába csoportosítva megállapíthatjuk, hogy a vizsgált időszakban, az összesített rangsor alapján leghatékonyabbnak ígérkező (1. kategória) országok jellemzően a Skandináv országok (Svédország, Dánia), Franciaország, Németország illetve Belgium, második kategóriába Szlovénia, Ausztria, Svájc, Spanyolország és az Egyesült Királyság tartozik. Kelet-Európa (ideértve Magyarországot), Olaszország és Görögország a harmadik ilyen szempontból, míg végül a negyedik csoportot Románia, Bulgária, Ciprus és Málta alkotja.

A konzervatív társadalmak megnehezítik a nők kettős ambícióinak a megvalósulását. Teszik ezt egyrészt társadalmi szinten (nehezen elérhető, elégtelen, rugalmatlan kisgyermekellátási lehetőségek), valamint családi szinten (férfiak családi funkcióinak a „kenyérkereső” opcióval való egyenlővé tétele, valamint a nők „családi tüzhely őrzője” egyedüli funkcióval).

A skandináv államokban és egyre több nyugat-európai országban ezzel szemben igyekeznek megteremteni az összhangot a két szerep (munkavállalás és családanya) 
között, és alapvetően ez az összhang magyarázza az átlagosnál magasabb születési arányszámokat ezen országokban (Pongrácz, 2011) ${ }^{18}$.

\title{
2.2 Anyai munkavállalás és a gyermekfejlődés összefüggései
}

\author{
Mióta csak megszülettem, elfoglaltam és lefogtam egy másik \\ embernek, az anyámnak az egész életét. Mikor még kicsiny voltam, \\ maga öltöztetett, ö fürdetett meg este és míg el nem aludtam, ruhástul \\ mellém dölve a kis ágyamba suttogott, mesélt és dalolt nekem. (...) Azt \\ hittem, hogy ö egészen és csupán ennyi, - nincs rajtam kívül más élete, \\ vagy vágya vagy joga. Énnekem nem maradt adósom soha egy jó \\ szóval, egy karácsonyi aranydióval sem; azt hittem, követelhetem, \\ hogy az én kedvemért ne élje az önmaga életét.
}

(Kaffka Margit)

Jelen fejezet a dolgozat gazdaságpszichológiai hátterét mutatja be, az alábbi tényezők mentén:

1. anyai szerepfeszültség (ha dolgozna, de nem tud, vagy ha otthon maradna, de dolgozni kényszerül), kiemelten az anyai és a gyermeki jóllét függvényében,

2. szocializációs szempontok, különösen az elsődleges (család) és másodlagos (gyermek-közösség) szocializáció szerepe, valamint a gazdasági szocializáció témája

A nemzetközi irodalom hazaival történő összevetése során egyértelmüvé vált, hogy mivel sem a társadalmi-gazdasági helyzet, sem a gyermekellátóhelyek, sem a pénzbeli családtámogatások nem összehasonlíthatóak, így a kutatások eredményei (melyek maguk is egymásnak ellentmondóak több helyen) nem, vagy csak komoly kompromisszumokkal adaptálhatóak a magyar környezetbe. Áttekintésemben erősen támaszkodom Blaskó Zsuzsa 2008-as, Demográfiában megjelent szakirodalmi áttekintésére, valamint egyéb írásaira (2008, 2011). Külön problémát okozott az irodalom áttekintése során, hogy szinte elenyésző azon kutatások száma ${ }^{19}$, melyek az anya munkavállalásán, illetve annak hiányán keresztül a családok, a családtagok jól-létét, kapcsolatuk minőségét, illetve a gyermek fejlődését

\footnotetext{
${ }_{18}^{18}$ Kutatás a témában: PPA (Public Policy Acceptance) 2000-2009

${ }_{19}$ Magyar adatokkal gyakorlatilag nem is találtam, talán csak Benedek Dóra 2007-es tanulmánya, és Bass Lászlóék szintén 2007-es kutatása, bár utóbbi inkább a Biztos Kezdet Program kapcsán a mélyszegénységben élő hátrányos helyzetű gyermekek marginalizációját vizsgálja. Jelen dolgozatomban egyedülálló volta miatt többször is utalok rá.
} 
vizsgálná. Blaskó (2008) véleménye szerint ennek oka, hogy ehhez longitudinális vizsgálatokra lenne szükség. A kutatások túlnyomó része az Egyesület Államokban készült, ahol a 20. század második felében drámaian megemelkedett a nők, ezen belül az anyák foglalkoztatása. Remélem, dolgozatom megalapozza a téma további hazai vizsgálatát.

Az anyai munkavállalással kapcsolatos aggodalmak valószínüleg Bowlby kötődéselmélete alapján (Bowly, 1958) öltöttek testet. E szerint a gyermeknél az első életévekben alakul ki a biztonságos kötődés. Az elmélet szerint ahhoz, hogy a korai kötődés kialakulhasson, megfelelő válaszokat adó, érzékeny gondozószemélyre, lehetőleg az édesanyára van szükség ${ }^{20}$. Ez a korai kötődés teszi majd ugyanis lehetővé, hogy a gyermek a későbbiekben kellően magabiztossá váljon, és személyes kapcsolatait biztonságosan tudja kezelni. Azt ugyanakkor nem sikerült egyértelmüen kimutatni, hogy ez a fajta pozitív kötődés feltétlenül sérül-e akkor, ha az anya munkát vállal a gyermek 1-3 éves kora előtt.

Valószínüsíthetően ezt a kötődéselméletet „lovagolták meg” (egy kis aktuális ideológiával megerősítve) a hazai vezető gyerekpszichológusok az otthon gondozás mindenekelőttiségét preferálva (Blaskó, 2011). Ennek a (sokszor negatív) hatása ma is igen erősen érezhető a kisgyermekes édesanyák között - táptalajul szolgálva annak a kognitív disszonancia feloldásnak, mely az otthonmaradás esetleges feszültségeit hivatott kezelni. Ez a hozzáállás, ha lassan is, de enyhülni látszik ${ }^{21}$, kimondható, hogy önmagában az édesanya munkába lépése nem ártalmas a gyermek viselkedésének alakulására. Talán elérkezünk addig a vélhetően egészséges középpontig, ahol kimondódik, hogy annak jó otthon maradni, aki ezt örömmel teszi - és annak a gyermeknek jó és hasznos ez, akinek az édesanyja nem él át az ő gondozása közben szerepzavart (Ross, 1983). Harvey (1999) több hasonló témájú kutatás áttekintése kapcsán arra jutott, hogy sem az anya munkaerőpiaci státusza, sem munkavállalásának időzítése, sem pedig a munkavégzés folytonossága nem alakítja egyértelműen a gyermek fejlődését. A fentiek alapján az anya munkavállalásának a gyermek fejlődésére gyakorolt hatásával kapcsolatban alábbi domináns körülményeket lehet azonosítani: a gyermek életkora az anya szülés utáni munkába állásakor, a napközbeni

\footnotetext{
${ }^{20}$ Megjegyzem, Bowly a tanulmánykötetében az anyával és/vagy az elsődleges gondozóval való kötődést vizsgálta. Ebben a kötetben már axiómaként kezelte a kötődés tényét, a vizsgálatokban (Idegen Helyzet Teszt Strange Situation Test) a kötődésekben megjelenő egyéni eltéréseket vizsgálta, azt figyelte meg, hogy a kötődés mennyire biztonságos. Az így kialakított fö kategóriák: biztonságos, bizonytalan/rezisztens, bizonytalan/elkerülö. Ezeket az 1978-ban kiadott második kötetében (Separation) a szeparációra adott szervezett, koherens viselkedési stratégiának tekintette.

${ }^{21}$ „Korábban úgy vélték, hogy a gyereknek az a legjobb, ha hároméves koráig otthon van vele az anyja. Manapság ezt két-két és fél éves korra teszik, de csak akkor, ha az anya nem érzi magát bezárva. Az ugyanis a legrosszabb a gyereknek.” (Blaskó, 2011)
} 
gyermekellátási mód jellege és minősége, az anya munkája, valamit ezen 3 fő körülmény mellett megjelenik 2 másik is, melyek azonban összefüggést mutatnak az előző hárommal: a családi társadalmi-gazdasági státusza, valamint az anyai gondozás minősége. Felvethető még az apa jelenléte és a gyermekeire fordított idő mennyisége és minősége is ${ }^{22}$ (Blaskó, 2008).

A témára vonatkozó említett kutatások jellemzően az egy éves kor elötti, az 1-3 éves kor közötti, és a 3 éves kor feletti munkavállalási mintákat vizsgálják. Kevés a követéses vizsgálat, amely a gyermek eredményeinek hosszú távú kimenetét vizsgálja (Nomaguchi, 2006; Belsky, 1988). Howes (1990) azt találta, hogy a gyenge minőségü gyermekgondozás és annak korai (1 éves kor előtti) igénybe vétele már jelentős mértékben növelhetik az iskolás kor előtti években megjelenő problémás viselkedés valószínűségét. Ám több másik tanulmány úgy találta, hogy ezek a különbségek nem léteznek, illetve a nyolcadik osztály végére megszünhetnek. Bass (2007) úgy találja, hogy a magatartászavarok és a későbbi deviáns viselkedésformák előfordulása jóval gyakoribb az egy éves korukban bölcsődébe járók között. A kutatás nem tér ki a bölcsőde körülményeire és az igénybe vevők státuszára (iskolai végzettség, jövedelemviszonyok, családi helyzet).

Bár a kutatások eredményei nem vágnak egybe, Blaskó (2008) mégis megpróbált néhány általános érvényünek mondható következtetést levonni:

- Minél korábban történik (a gyermek első életévében) a munkába állás, annál számosabbak lehetnek a káros következmények.

- Lényeges következtetés, hogy a viselkedési következmények egy része esetleg csak több évvel az anya munkába állását követően jelentkezik - ezeket azonban csak longitudinális vizsgálatokkal lehetne kimutatni.

Kevés hazai vizsgálat létezik az egy éves kor utáni ellátási formák gyermekegészségre gyakorolt hatásával kapcsolatban ${ }^{23}$. Bassék úgy találták, hogy a korán bölcsődébe került

\footnotetext{
${ }^{22}$ Számomra igen meglepö, hogy a kutatások nem a családokat, hanem csak az anya-gyermek kapcsolatot vizsgálják - mintha az anya és/vagy a gyermek elkülöníthető lenne a családtól és az apától. Az apa hiánya és/vagy gyakori, hosszú idejü távolléte véleményem szerint külön vizsgálandó tényezö, nem pedig egy kontrollfeladat.

23 Bass (2007) megállapítása, miszerint a bölcsődében több betegséget kapnak el a gyermekek, mint otthon, több újabb kutatás alapjait veti föl: Vajon későbbi közösségbe kerüléssel megerősödik-e az immunrendszer annyira, hogy csökkenjen a fertőzéses betegségek kockázata? Az elkapott betegségek gyakorisága és lefolyása mennyire függ össze azzal, hogy az anya nyugodt szívvel, vagy szorongva hagyta ott a gyermekét a bölcsődében? Az elkapott betegségek lefolyása könnyebb, gyorsabb-e, mint az otthon megbetegedett gyermekeknél? Van-e összefüggés a gondozóhely minősége (egy gondozóra jutó gyermekszám, egy gyermekre jutó játszófelület, csoportméret, napi levegőztetés, élelmezés minősége, stb.) és a betegségek
} 
gyermekek gyakrabban betegek, mint bölcsődébe nem járó társaik ${ }^{24}$. Bass kutatásaival ellentétesen Krämer (1999) azt találta, hogy a korai gyermekközösség csökkenti a későbbi allergiás hajlamot. Ez az ellentmondás is felveti a gyermekközösség módja és minősége közötti lehetséges eltéréseket, valamint a családi háttér befolyásoló tényezői voltát.

\subsubsection{Anyai jól-lét, szerepfeszültség}

Legkülönfélébb kutatási hagyományok érvelnek a mellett, hogy az anya munkavégzéssel kapcsolatos objektív és szubjektív körülményei az anya attitüdjein, jólétén, hangulatán vagy éppen kognitív állapotán keresztül kihatással lehetnek (vannak) a gyermek jólétére (Blaskó, 2009). Kulcsfontosságú, hogy milyen hatással van a munkavégzés az anya saját jól-létére, mert ez kihat a gyermekével szemben gyakorolt viselkedésére, és ez kihat a gyermek fejlődésére. Kijelenthető, hogy a gyermeki jól-lét tulajdonképpen az anyai jól-lét függvénye (C. Molnár, 1996).

Kihagyhatatlan tényező a téma tárgyalásakor a szerepfeszültség jelensége (Ross, 1983), mely szerint ha az anyának szándékai, preferenciái ellenére kell dolgoznia, miközben erős meggyőződése, hogy emiatt anyai feladatait nem tudja megfelelően ellátni, feszültséghez vezet, mely stresszorként jelentkezik, ez pedig depresszióhoz vezethet. Ugyanígy szerepkonfliktust él át az az anya, aki szeretne visszamenni dolgozni, de nem tud, mert nem talál munkát, vagy nem tudja megnyugtató helyre vinni a gyermekét. A munkavállalás kisebb megterheléssel jár akkor, ha összhangban van a személyes preferenciákkal.

Ross kutatásaiban feleségeket vizsgálva 4 fajta „nőtípust” különböztet meg:

1. nem dolgozik - nem is akar

2. dolgozik - nem akarna

3. nem dolgozik - dolgozna (legmagasabb szintű kimerültséget itt mérték)

4. dolgozik - akar is (legalacsonyabb szintű kimerültséget itt mérték)

Azoknál, akiknél szerepkonfliktus lép fel, a gyermekei éretlenebbek, kevésbé figyelmesek (Ross, 1983). Fontos hozadéka a kutatásnak, hogy nagyobb kárt okoz a társadalom azoknak a nőknek, akik dolgoznának, de nem tudnak, mint azoknak, akik preferenciáik

\footnotetext{
száma, súlyossága és lefolyása között? A külföldi kutatásokkal való összevethetőség érdekében mindenképp definiálni kell a gyermekközösséget, gyermekintézményt magát.

${ }^{24}$ Érdekes lenne megvizsgálni a bölcsőde minőségét (csoportlétszám, gondozónők száma és minősége), valamint az anya munkájának komplexitását, a munkában való motiváltságát, és a család háttéradatait (gazdasági és kulturális szocializáció).
} 
ellenében kell dolgozzanak. A szerepzavar negatívan befolyásolja az anya hangulatát, mivel könnyen kialakul a gyes-neurózis.(C. Molnár, 1996; Blaskó, 2008).

A munkavállalásnak az egyén jól-létére gyakorolt hatása jellemzően pozitív (Csíkszentmihályi, 1991). A saját kereset kedvező hatással van az önértékelésre, és azon keresztül a jól-létre. Ám a dolgozó nők kondíciói nemcsak munkavégzésük objektív körülményeiből eredendően különböznek (pl. munkaidő hossza és rugalmassága, munka fizikai környezete, komplexitása, stb.), hanem abból is, ahogyan saját munkájukat és önnön helyzetüket szubjektíve észlelik (Blaskó, 2009).

Feltételezték (Blaskó, 2009), hogy minél hosszabb időt van távol az anya a gyermekétől, a kontaktus hiánya miatt a gyermek ezt annál jobban megsínyli. Ám ezt senkinek sem sikerült bizonyítania, így ha óvatosan is, de talán kijelenthető, hogy ellentétben a várakozásokkal - önmagában annak sincsen káros hatása a gyermek fejlődésére, ha az anya dolgozik, vagy akár kifejezetten sokat dolgozik. A problémák csak akkor jelentkeznek, ha az intenzív munkavállalás nagyon korán kezdődik ${ }^{25}$, illetve ha egyéb kockázati tényezők is jelen vannak (Blaskó, 2009). A legnagyobb kockázati tényezők: $a$ végzett munka alacsony komplexitása, és a nem megfelelö minöségü napközbeni kisgyermek ellátóhely. Hogy az anya munkavégzése milyen módon hat gyermekére, az összefügg azzal, hogy mennyi szellemi ösztönzést nyújt számára az elvégzett munka, és mekkora stresszel jár annak a munkának a végzése. (Blaskó, 2009). Az alacsony iskolázottság magában hordozza az elvégezhető munkák közül a legkevésbé komplexek választásának lehetőségét - ez vélhetően a marginalizált csoportok további leszakadásának egyik oka.

Ha fokozatosan lassan csökkenö arányban is, de mindenképp jelen van a nők munkahelyi szegregációja: az üvegplafon jelenség, illetve az a tény, hogy ugyanazon munkakör betöltésekor a férfiakénál alacsonyabb bérben részesülnek (Drjenovszky, 2009). A „Családbarát munkahely” programmal talán javítani lehet valamit - de igazi áttörést a részmunkaidő, az osztott munkakör, a távmunka elterjedése, valamint a munkahelyi gyermekellátó egységek létrehozása jelenthet (Nagy, 2013, 2014). A női munkaerőpiac rugalmatlanságát jellemzi - melyben jelentősen eltér a hazai gyakorlat a nyugat-európai mintától -, hogy az atipikus foglalkoztatási módok (részmunkaidő, távmunka, osztott munka, stb.) jelenléte igen alacsony (Blaskó, 2006, Frey, 2005). A teljes munkaidős foglalkoztatás

\footnotetext{
${ }^{25}$ Megjegyzem, a kultúrközi különbségek kapcsán a „nagyon korán” az USA-ban a gyermek 6-8 hetes korában kezdett teljes állású munkavégzés, míg nálunk az 1 éves kor alatti munkavégzés már „nagyon korán”-nak minősül.
} 
pedig nagyon sok esetben valóban összeegyeztethetetlen a családi kötelezettségekkel (ellátóhelyek nyitva tartásának rugalmatlansága is fokozza ezt a helyzetet). Ezen tényezők jelenlétének hiánya (atipikus foglalkoztatás, rugalmas gyermekellátó-rendszer) komoly gátja lehet a nők gyermekvállalás utáni újbóli munkába állásának.

\subsubsection{A gyermeki jól-lét}

Mára már egyértelmü, hogy a csecsemő legfőbb (és optimális esetben egyetlen) tápláléka élete első hat hónapjában az anyatej, ennek táplálási módja a szoptatás ${ }^{26}$ - jó, ha a gyermek két éves koráig az édesanya szoptatja a gyermekét. A kora-gyermekkori halandóság összefüggéseit vizsgálva azt találták, hogy ha az édesanya fizetett anyasági szabadságon volt, akkor csökkent csak a csecsemőhalandóság (Ruhm, 2000). Fontos megjegyeznem, hogy ez az említett szülési szabadság a szülés utáni 3 hónapos támogatott otthonlétet jelenti, azaz nem összevethető a hazai viszonyokkal, amikor a gyermek fél - , de inkább egy éves kora előtt szinte fel sem merül az anya munkába állása.

A gyermek egy éves kora előtti munkavállalás csak akkor tekinthető elfogadhatónak, ha a gyermek természetes táplálása megoldható. Ha a gyermeket ellátó hely eléggé közel van az édesanya munkahelyéhez (akár azon belül, Workplace daycare, on-site ${ }^{27}$ ), és a munkaszervezés figyelembe veszi a gyermek és a szülő természetes igényeit, akkor ez kényelmesen megoldható a legtöbb munkakörben. Azaz kellő körültekintéssel ez a probléma kiküszöbölhető lehet.

Vannak olyan szituációk, amikor az anya önfoglalkoztató (pl. vállalkozó, saját ügyfélkörrel: fodrász, kozmetikus, ügyvéd, könyvelő) vagy olyan kisvállalkozást vezet, amely nem tudja az ügyvezetést nélkülözni (bérek, járulékok utalása, a napi ügymenet vitele miatt), illetve nagyobb cégnél olyan pozícióban lévő közép-vagy felsővezető, akinek nem nélkülözhető a tudása, kapcsolatrendszere. Kutatásom szerint ezen esetekben igen rugalmasan megoldják a gyermekellátás és a munka összeegyeztetését (munkahelyhez közeli gyermekelhelyezés, segítő személy bevonásával), megoldott a szoptatás, az „üresjáratokban” a gyermekkel való törődés. A probléma ebben az esetben jogi természetü: ha ez az anya legálisan akarna dolgozni, akkor a családi pótlék kivételével semmilyen családtámogatásra nem lenne jogosult, így ezek a szülök illegálisan dolgoznak. Ez minden szektorban és minden

\footnotetext{
${ }^{26} \mathrm{http}: / /$ www.medlist.com/HIPPOCRATES/II/6/397.htm

${ }^{27}$ http://www.childcare.net/workplace-daycare.shtml
} 
vállalatnagyságnál meglévő valós gond. Nem mellesleg jelentősen torzul a statisztika, hiszen ezek a szülök úgy jelennek meg, mint a gyermeküket otthon gondozók.

Blaskó felmérésében (2011) azt találta, hogy viszonylag jelentéktelen kisebbség jelölte meg az egy év előtti időszakot kívánatosnak a munkába való visszatérésre, a legtöbben a 2 , illetve a 3 évet határozták meg kívánatosnak. 20\% még ennél is későbbre (akár 6 évre) tették ezt az időpontot. A hazai családtámogatás szorosan összefügg ezen dátumokkal (2 éves GYED, 3 éves GYES, illetve 6-7 éves korig tartó óvoda). Az ellátórendszer rugalmatlansága alapvetően nem kedvez a munkavégzésnek (nagy csoportos ellátás, így gyakori fertőzéses betegségek, és a szülők számára sokszor nem megnyugtató „tömeges” ellátás, valamint megoldhatatlan mennyiségü szünet - tavaszi, téli, őszi és nyári). Atipikus munkavégzésre alig van mód, így sokaknak talán nem az otthonmaradás az igazi vágy, hanem nem lévén alternatíva, ez a választható realitás. Sehol sem találtam az irodalmi feldolgozásban erre konkrét felmérést, Blaskó (2011) és Pongrácz utalásain (2011) kívül.

A gyermek értelmi fejlődését vizsgálva szülőktől hallható gyakori panasz: ,, Szeret a közösségben lenni, a többi gyermek között, de visszafejlödik, mert túl sokan vannak, és nem jut rá elég figyelem. A problémás gyerekek lekötik az egyébként nagyon kedves gondozók energiáit” (saját kutatás, 30 éves diplomás anya, 2,5 éves bölcsődés kislány). Más így nyilatkozik: „Nagyon jó neki a közösségben, én már nem tudok neki annyit nyújtani itthon, mint amit a gyermek pajtások között megél." (saját kutatás, 32 éves anya, 2 éves családi napközis fiúgyermek). Vajon általánosítható a negatív vagy a pozitív hatás?

Bass (2007) a gyermekközösségeket vizsgálva az alábbi pozitív hatásokat találta: az intellektuális fejlődés, ill. az iskolai teljesítmények tekintetében a bölcsődékben, ill. a nagyszülőknél elhelyezett gyermekek jelentősen jobb eredményeket produkálnak, mint azok, akiket édesanyjuk nevelt 1 éves korukban. Ami pozitív hatást találtak, abból sok az első életév utáni munkavállaláshoz köthető: 3-4 évesen jobb a szókincsük, 7-8 éves korukban jobb a szövegértésük. Egyes külföldi irodalmak beszámolnak negatív hatásokról, de csak fehér gyermekeknél $^{28}$. Úgy találták, hogy minél nagyobb óraszámban dolgozik az anya, annál erősebb a tendencia a szövegértés és a matematika terén. Úgy találták, hogy a hatás függ: gyermekelhelyezés módjától, család jövedelmi viszonyaitól (szegényeknél erősebb a hatás).

Felmerültek bennem kérdések a talált irodalmak tükrében: Mi volt a fenti kutatásoknál a munkába állás oka? Kényszer vagy önálló döntés? Milyen munkakörben, milyen munkarendben dolgoztak az anyák? Milyen közösségben volt a gyermek? (létszám,

\footnotetext{
${ }^{28}$ Ld. Blaskó kézirat
} 
hely, stb.). Az ott dolgozóknak mennyi idejük, erejük, kapacitásuk jutott a gyermekkel való kognitív foglalkozásra? Ezen kérdésekre kapott válaszok nélkül nehezen értelmezhetőek a különböző, sokszor egymásnak is ellentmondó kutatási eredmények. Érdekes, hogy a kutatások nem térnek ki minden említett komponensre, így az összehasonlíthatóságuk kérdéses. Sok kutatás ellentétes eredményeket hozott a témában, így nem vettem figyelembe az ellentmondásos eredményeket.

\subsubsection{A gyermekfelügyelet módja és minősége}

A fentiek alapján kijelenhető, hogy az anya szerepét helyettesítő gyermekfelügyelet módja és minősége alapvetően kihat a gyermek fejlődésére. 2 fajta gyermekfelügyeleti formát különböztet meg a szakirodalom: formális (amikor a gyermek ellátása az otthonától távol zajlik, jellemzően intézményi keretek között), és informális (a gyermek otthonában történő felügyelet családtag vagy bébiszitter által). Mindkettőnek lehetnek és vannak előnyei és hátrányai a gyermekre és a családra nézve. Belsky $(1988,1990)$ úgy találta, hogy az informális ellátásban erősebb lehet a kötődés (ami pozitív hatás), de ingerszegényebb lehet a környezet (ami negatív hatás lehet), a formálisban stimulálóbb a fizikai környezet, amely több interakciót tesz lehetővé, fóként a kortársakkal (ami pozitív hatás), viszont megoszlik a gondozó figyelme (ami negatív hatás lehet). A minöségi ellátás döntő szempontjaiként a következőket nevezte meg: csoportnagyság, gondozó-gyermek arány és a gondozók szakképzettsége. Belsky ugyanezen kutatásában (1990) kiemelkedően jó minőségü, egyetemi központokban működő bölcsődék vizsgálata kapcsán kijelentette: „ha kivételesen jó feltételeket biztositó bölcsödébe kerül egy gyermek, az biztosan nem tesz benne kárt."29. Mivel Blaskó a saját tanulmányaiban $(2008,2011)$ is ezt a minősítő rendszert említi, és másikat az általam vizsgált szakirodalom nem említ, így elfogadtam alapkritériumnak ezen szempontokat.

Sajnos nincsenek felmérések (sem nemzetközi, sem hazai) az irányba, hogy milyen különbségeket tudnak nyújtani a különböző ellátóhelyek:

- informális otthoni ellátás családtaggal (nagyszülő, nem dolgozó felnőtt családtag)

- informális otthoni ellátás idegennel („,bébiszitter”)

- formális, de otthonközeli kiscsoportos ellátás (családi napközi saját otthonban)

\footnotetext{
${ }^{29}$ Idézve: Blaskó, 2008a
} 
- formális, nem otthonközeli, de kiscsoportos ellátás (családi napközi más, e célra kialkított helyiségben)

- formális, intézményi, nagycsoportos ellátás (bölcsőde, óvoda)

A rossz minőségü kisgyermekellátás káros, ez kijelenthető. A magas színvonalú gyermekellátó helynek azonban léteznek pozitív hatásai. Ezért is lenne célszerü a részmunkaidő elterjedésének az elősegítése, illetve a munkahelyhez közeli ellátóhelyek preferálása (utazási időt a szülőjével tölti a gyermek).

Minőségi ellátóhely (Nagy,2013)

\begin{tabular}{|c|c|c|c|}
\hline & Ismérv & Miért fontos? & Hogyan lehet elérni? \\
\hline 1. & $\begin{array}{l}\text { megfelelő gondozó - gyermek } \\
\text { kontaktus }\end{array}$ & $\begin{array}{l}\text { megfelelő kötődési minta } \\
\text { kialakulása miatt }\end{array}$ & \multirow{4}{*}{ 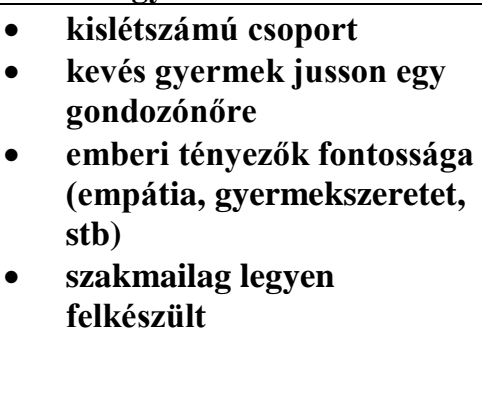 } \\
\hline 2. & alacsony gyermek/gondozó arány & $\begin{array}{l}\text { hogy megfelelö lehesen a } \\
\text { gondozó-gyermek }\end{array}$ & \\
\hline 3. & gondozó személy stabilitása & $\begin{array}{l}\text { megfelelő kötődési minta } \\
\text { kialakulása miatt }\end{array}$ & \\
\hline 4. & $\begin{array}{l}\text { gondozó személy megfelelő } \\
\text { képzettsége, szupervíziója. }\end{array}$ & $\begin{array}{l}\text { professzionális ellátás miatt } \\
\text { (szakmai elvárásoknak való } \\
\text { megfelelés) }\end{array}$ & \\
\hline
\end{tabular}

8. ábra, Minőségi ellátóhely (Nagy,2013) ${ }^{30}$

\subsubsection{Hitek és tévhitek az anyai munkavállalás hatásairól (összefoglalás)}

Külföldi és hazai kutatások összehasonlításával Blaskó (2008) a következő megállapításokra jutott:

Az anya munkavállalása önmagában nincs negatív hatással a gyermek fejlődésére, ám vannak meghatározó kulcstényezők:

- gyermek életkora az anya munkába állásakor (1 éves kor alatt, 3 éves kor alatt, 3 éves kor fölött)

- anya munkavállalásának körülményei (motiváció, komplexitás, szerepfeszültség)

- gyermekgondozási forma minősége

\section{Az 1 éves kor előtti munkavállalás káros hatásai lehetnek:}

- problémás viselkedés iskoláskor előtti időszakban gyakoribb

\footnotetext{
${ }^{30}$ Forrás: Blaskó Zs. (kézirat). Meddig maradjon otthon az anya? - a gyermekfejlődés szempontjai. Kutatási tapasztalatok és társadalompolitikai következtetések
} 
- 10 évesen alacsony mért értékek különféle érzelmi és társas viselkedések terén

- 7-8 évesen externalizálási problémák jelentkezhetnek

- Gyakoribb a csökkent frusztráció tolerancia

- Jellemzően nem rövid időn belül az anya munkába állása után, hanem késleltetve, több év után jelennek meg a problémák.

Mivel a fenti negatív hatások megfelelő minőségü napközbeni ellátóhellyel bizonyos határig kompenzálhatóak, ezért meggondolandó lehet a családtámogatási formák bővítése helyett az ellátóhelyek minőségének és az ellátóhelyhez való hozzáférésnek a javítása. Ez nem igényelne külső forrást, csak belső átcsoportosítást.

A szakirodalmi áttekintés alapján egy saját szerkesztésü táblázatban igyekszem összefoglalni a gyermekvállalással kapcsolatos hiteket és tévhiteket, melyek Magyarországon széles körben elterjedtek, ám legalábbis megkérdőjelezhetőek (és nem mellesleg ellentétes előjelü bizonyítékok állnak rendelkezésünkre). 
Hitek, tévhitek (Nagy,2013)

\begin{tabular}{|c|c|}
\hline HIEDELEM & KUTATÁSI TÉNY \\
\hline $\begin{array}{l}\text { Hosszú anyai otthonlét, konzervatív } \\
\text { családmodell biztosítja a magas termékenységet }\end{array}$ & $\begin{array}{l}\text { A termékenység és a nöi foglalkoztatás közötti } \\
\text { viszony, az OECD-ben mára szignifikánsan pozitívvá } \\
\text { vált. }\end{array}$ \\
\hline $\begin{array}{l}\text { A gyermek kognitív fejlödése, érzelmi } \\
\text { biztonsága és kötődése szempontjából } \\
\text { elengedhetetlen az anyával való folyamatos } \\
\text { együttlét legalább } 3 \text { éves, de inkább } 6 \text { éves } \\
\text { korig. }\end{array}$ & $\begin{array}{l}\text { - A nemzetközi szakirodalom ezt az állítást nem } \\
\text { erősíti meg. nagyon sok ezzel ellentétes } \\
\text { eredmény látott viszont napvilágot (kevesebb } \\
\text { betegség, jobb szociális készség, jobb kognitív } \\
\text { funkciók). } \\
\text { - Átfogó hazai kutatás az ellátórendszer } \\
\text { fölmérésével, a hazai társadalmi viszonyok } \\
\text { figyelembe vételével nem készült. } \\
\text { - Fontos, hogy a szülöt helyettesítő ellátó helynek } \\
\text { elég jónak }{ }^{31} \text { kell lennie ahhoz, hogy } \\
\text { elkerülhetőek legyenek a rossz ellátásból fakadó } \\
\text { negatív hatások, és a pozitív hatások } \\
\text { érvényesülni tudjanak. }\end{array}$ \\
\hline $\begin{array}{l}\text { Rossz munkaerőpiaci helyzetben lévő anyák } \\
\text { gyes, gyed és gyet útján történő segélyezése } \\
\text { olyan szociálpolitikai eszköz, mely a méltóság } \\
\text { sérelme nélkül támogatja a „munkalehetőség } \\
\text { hiányában” mindenképp ,állásnélküliségre } \\
\text { ítélt” nőket }{ }^{32}\end{array}$ & $\begin{array}{l}\text { - „Egy semmilyen álláskeresési követelményt nem } \\
\text { támasztó, bevallottan munkanélküli-segélyezési } \\
\text { funkciókat betöltő készpénzes támogatás, } \\
\text { amelyhez a regisztráció hiányában eleve nem is } \\
\text { társulhatnak a piacképességet fokozó } \\
\text { szolgáltatások, semmiképpen sem tekinthető } \\
\text { ideális formának a munkaerö-piaci beilleszkedés } \\
\text { támogatására”33. } \\
\text { A jelenlegi rendszer a munkaerőpiachoz erősen } \\
\text { kötődő nőket hosszú távollétre ösztönzi, illetve } \\
\text { kényszeríti - a rossz munkapiaci helyzetben } \\
\text { lévőket pedig nem segíti abban, hogy } \\
\text { visszatérhessenek a munkába, vagy } \\
\text { beléphessenek a munkaerő piacra. }\end{array}$ \\
\hline $\begin{array}{l}\text { Az anyának is egyértelmüen „pozitív juttatás” } \\
\text { (ti. a pénzbeli bevételen túl) az otthonmaradás } \\
\text { lehetősége (,,elfogadott vélekedés, hogy az } \\
\text { „elég jó anya" legalább 3, de inkább } 6 \text { évig } \\
\text { otthon van a gyermekével - és ez } \\
\text { mindkettejüknek jó) - anyai jól-lét kérdése. } \\
\text { „Ne hisztizz, örülj hogy otthon lehetsz!” }\end{array}$ & $\begin{array}{l}\text { - A munka komplexitása és a fellépő stressz erős } \\
\text { összefüggést mutatnak az anya hangulatával és } \\
\text { gyermekével szembeni viselkedésével. } \\
\text { Emellett igen lényeges a potenciális } \\
\text { szerepfeszültség is: azok az anyák, akiknek a } \\
\text { munkára és a gyermeknevelésre vonatkozó } \\
\text { preferenciái nincsenek összhangban tényleges } \\
\text { lehetőségeikkel, olyan lelki megterhelést } \\
\text { szenvednek el, mely kihathat gyermeknevelési } \\
\text { módjukra, ezen keresztül gyermekük } \\
\text { személyiségfejlődésére is }{ }^{34} \text {. }\end{array}$ \\
\hline
\end{tabular}

9. ábra, Hitek, tévhitek (Nagy,2013)

31 A minőségi gyermekellátóhely ismérvei az alábbiak: megfelelő gondozó - gyermek kontaktus, alacsony gyermek/gondozó arány, gondozó személy stabilitása, gondozó személy megfelelő képzettsége, szupervíziója. (Blaskó, 2008)

${ }^{32}$ Forrás: Bass és társai, 2007

${ }^{33}$ Forrás: Bass és társai, 2007

${ }^{34}$ Forrás: Blaskó, 2008 
Összességében, a szakirodalom áttekintése után kijelenthetőnek és elfogadhatónak érzem Blaskó Zsuzsa következtetéseit:

„, Az anya munkába állásának káros hatásai elvileg kompenzálhatóak lennének magas színvonalú gyermekgondozó intézmények révén, vagy úgy, hogy a dolgozó anya a rendelkezésére álló idöben kiemelt figyelmet fordit gyermekére, és a számára leginkább megfelelö gondozást nyújtja neki. Sajnos azonban a helyettesitésnek ezek a módozatai csak korlátozottan müködtethetök. A valóságban a felsorolt kockázati tényezök gyakran összekapcsolódnak, és a jelzett kiutak éppen azok számára járhatóak a legkevésbé, akiknek a legnagyobb szükségük lenne rájuk. A rosszul fizetett munka rendszerint alacsony komplexitású, és az érintettek sokszor komoly stresszt élnek át. Ugyanakkor az alacsony jövedelmü családok számára a kellö színvonalú gyermekgondozó intézmények nem igazán elérhetőek és/vagy megfizethetöek. ... Ráadásul éppen az alacsony jövedelmü, jellemzően alacsony iskolázottságú anyák azok, akiktől nem mindig várható el, hogy szabadidejükben megfelelö színvonalon foglalkozzanak gyermekükkel. (Blaskó, 2009)"” 


\subsection{Szocializációs és esélyegyenlőségi szempontok (kitekintés)}

\subsubsection{A család és a lakókörnyezet hatása - elsődleges szocializáció}

A családok a gyermekvállalásnál a materiális és a post-materiális szempontokat is egyaránt figyelembe veszik (Pongrácz, 2011). A családok egy részénél (főleg a középosztálynál, és a legalább középfokú végzettségüeknél) a nehezebb anyagi helyzet miatt elhalasztódik a várt, kívánt gyermek realizálása, míg a kevésbé iskolázott, alsóbb rétegeknél épp a családtámogatás miatt realizálják a gyermekvállalást (munkanélküliség helyetti alternatív bevétel) (Kopp, 2008, 2009). Kérdés, hogy a pénzbeli családtámogatási rendszer hogyan képes kezelni a szegénység önmagát újratermelö mechanizmusait, és hogy vajon egy hozzáférhető, magas minőségű napközbeni ellátórendszer nyújtana-e megoldást a problémára. Dolgozatomban kitérek néhány olyan fogalom tárgyalására, melyek a későbbi kutatások szempontjából elengedhetetlenek.

Ruth Turley (2002) rámutat arra, hogy még nem tisztázott, hogy a relatív szegénységnek -azaz annak a jelenségnek, ha valakinek kevesebb anyagi eröforrása van, mint másoknak a környezetében- milyen hatása van a gyermekek késöbbi eredményeire. Annak az árát, hogy kevesebb relatív erőforrásunk van, és annak az előnyét, hogy a környezetünknek több van, bonyolult súlyozni, mivel a családok elvileg választhatnak, hogy hol éljenek. Ez azért is problémás, mert ugyanazok a családi karakterisztikák, amik befolyásolják a gyermekek eredményeit, hatással vannak azokra a családi döntésekre is, amelyekkel lakóhelyet választanak. A cikk írója szerint emiatt nehéz elkülöníteni azokat a hatásokat, amelyek a gyermekek családi karakterisztikájából származnak, azoktól, amik a gyermekek lakóhelyéből fakadnak. Ezért Turley a testvér adatok elemzését javasolja. Technikája arra a tényre épül, hogy az olyan testvéreknek, akik között nagy a korkülönbség, nagyban eltér a családi jövedelemre és forrásokra alapuló életrajza, valamint ugyancsak nagy az eltérés a lakóhelyre vonatkozó életrajz tekintetében (az amerikai családok ugyanis gyakran, a magyar családoknál sokkal gyakrabban költöznek).

Stouffer (1949) és munkatársai cikkükben egy új fogalmat alkottak: a relatív deprivációt (relatív hiány elmélete). Tanulmányuk amerikai katonákról szólt. Azt találták, hogy a Katonai Rendőrségnél (MP) többen voltak elégedettek az előléptetési lehetőségekkel, mint a Repülő Hadtestnél (AC), noha a Katonai Rendőrségnek tulajdonképpen feleannyi előléptetési lehetősége volt, mint a Repülő Hadtestnek. Arra jutottak, hogy az elégedettség több szubjektív, mint amennyi objektív tényezőtől függ. A személynek muszáj 1. látni, hogy másvalaki birtokolja a kívánt tárgyat/dolgot, 2. akarnia kell azt, 3. feljogosítva érezni magát rá, 4. azt kell gondolnia, hogy megvalósítható a megszerzése, 5. ne magát okolja, hogy neki nincs. 
A relatív depriváció modellje azóta tovább fejlődött. Magyarországon többek között Ferge Zsuzsa ${ }^{35}$ használta fel a szegénységkutatásai során (1985). Azt írja, hogy bár számos társadalmi problémáról léteznek statisztikai érvényü ismeretek, túl keveset tudunk arról, hogy különböző rossz helyzetek (rossz munka, alacsony iskolázottság, rossz lakás devianciák stb.) hogyan függnek össze, azaz, hogy milyen módon és mértékben kapcsolódnak össze társadalmi hátrányok, hogyan és mennyire halmozódnak társadalmi egyenlőtlenségek. Azt sem tudjuk eléggé, hogy rossz helyzetek mindenkori újratermelődése mennyire kapcsolódik nehezen mozdítható szubkultúrákhoz, s hogy a "deprivációs ciklus", a rossz helyzet családon belüli "szükségszerü" újratermelődése mennyire létező jelenség, vagy hogy mi a rossztársadalmi helyzetek oka, következménye. Az okok és okozatok megkülönböztetése, szétválasztása számos társadalmi jelenségnél nehéz, sőt megoldhatatlan feladat. „Ki tudja biztonsággal megmondani, hogy egy alagsori szükséglakás oka-e az itt felnövö gyermekek rossz iskolai eredményeinek, majd rossz munkaeröpiaci helyzetének, esetleg tartós betegségének, illetve agresszív magatartásának, vagy következménye a szülök alacsony iskolázottságának, alacsony keresetének, esetleg annak, hogy nem voltak képesek a tanácsnál önmaguk érdekeiért harcolni, 3-4 gyermek esetén papíron létezö jogukat érvényesiteni?" A továbbiakban szétválasztja egyfelől azokat a jelenségeket, amelyekben a hátrányok kifejeződnek: ezt nevezi Peter Townsend magyarul nem jól hangzó, de legalább egyértelmü kifejezésével objektív relatív deprivációnak. (Townsend, 1979) Másfelöl külön vizsgálja a depriváció okait, amelyek között az alábbiakban megkülönböztet föként természeti, fóként társadalmi, egyszerre egyéni és társadalmi és végül föként egyéni okokat. A depriváció szó eredeti latin, bár a latinban csak a "privatio" létezik, ami valami rossztól való szabadulást jelent. A szociológusok az angolszász szociológiában meghonosodó értelemben kezdik használni a kifejezést, amikor a depriváció valami jótól való megfosztottságra utal. Townsend a szegénység és egyenlőtlenség problematikájának összekapcsolása során dolgozta ki az "objektív relatív depriváció” fogalmát. Ennek tartalma a következő: "Egyénekről, családokról és a népesség egyes csoportjairól akkor mondhatjuk, hogy szegényesen élnek (azaz, hogy az objektív relativ depriváció helyzetében vannak), ha nem rendelkeznek elegendö forrással ahhoz, hogy úgy táplálkozzanak, olyan tevékenységekben vegyenek részt és olyan életfeltételekhez és javakhoz jussanak, amelyek társadalmunkban szokásosak, vagy legalább

\footnotetext{
${ }^{35}$ Ferge a relatív depriváció kifejezést használja, amit a relatív szegénységgel azonosít. Természetesen a nomenklatúráját tiszteletben tartva használom dolgozatomban a munkáit, így meghagyom ezen kifejezéseket az őáltala használt formában. Én továbbra is a relatív hiány kifejezést részesítem előnyben a saját kutatásomban.
} 
széles körben elfogadottak és helyeslésre találnak. Az átlagos egyénhez vagy családhoz képest annyival szükösebbek a rendelkezésükre álló források, hogy ténylegesen kirekesztödnek az általánosan elterjedt életmódokból, szokásokból, tevékenységekböl” A lényeg, ha úgy tetszik, a súlyosan halmozott hátrány: az egyén vagy család helyzete nem egy-két szempontból rosszabb, mint a többsége, hanem sok lényeges vonatkozásban. A depriváció objektív meghatározása természetesen nem zárja ki olyan közelítések létjogosultságát, amelyek azt kutatják, hogy az emberek hogyan érzékelik, hogyan értelmezik, hogyan élik meg saját helyzetüket.

Gyakran felcserélhetően használják a "szegénység” és “depriváció" fogalmait. A részletes meghatározások azonban világossá teszik, hogy tudományos helyzetelemzésnél miért célszerü Ferge szerint a tradicionális fogalmat változtatni. Lényegében azért, mert a “szegénység” fogalma hagyományosan tapad az anyagi szükösséghez, vagy épp az alacsony jövedelmekhez. Említ néhány olyan példát, amelyek - úgy véli - a mi körülményeink között is érzékeltetik a szoros értelemben vett jövedelmi szükösség és a tágabban értelmezett depriváltság közötti különbséget. Így pl. nem elég, hogy az emberek munkából származó jövedelme legyen. Az is szükséges, hogy ezt a mai társadalom emberéhez méltó módon szerezze meg - azaz ne egészségét károsító, képességeit visszaszorító munkával, vagy olyan fáradsággal, önkizsákmányolással, ami lehetetlenné teszi, hogy másfajta tevékenységekbe is bekapcsolódjon. (Ezt pl. soha nem veszik figyelembe azok, akik a kőműves segédmunkásnál vagy a mezőgazdaságban dolgozónál csak azt látják, hogy a hétvégéken és szabadsága alatt rengeteget keres, de azt nem, hogy ennek következtében nincs egyetlen szabad hétvégéje sem, és soha nem jut el nyaralni.) ${ }^{36}$. Ferge az "objektív relatív depriváció” kategóriáját megfelelő átértelmezésekkel, kiegészítésekkel, s - ha sikerülne - a kifejezés magyarra átültetésével nálunk is használhatónak tartja. Ez a kategória volna hivatva leírni, hogy milyen területeken és milyen mértékben nyilvánulnak meg ún. hátrányok. Megfelelő adatbázis alapján azután megállapítható lenne, hogy az objektív relatív depriváció előfordulása milyen mértékig jellemző a társadalom különböző csoportjainál.

A gazdasági átalakulást követően Magyarországon a jövedelmi egyenlőtlenségek nem csupán megnőttek, de az egyenlőtlenségi viszonyrendszer is átstrukturálódott. Az új játékszabályokat a többség nem ismerte fel, illetve a korábbi szocializációs mechanizmusok

\footnotetext{
${ }^{36}$ Itt meg kell jegyeznem, hogy vajon biztos, hogy az említett segédmunkás időhiány miatt nem megy nyaralni? Hiszen pénze lenne rá, és nem minden hétvégéjét dolgozza végig. Lehet, hogy a szocializációs hátránya az ("minek, az, az olyan úri passzió"), ami miatt valódi igénye sem támad a nyaralásra.
} 
eredményeképpen illegitimnek értékelte. Az átlagember azt látta, hogy miközben a többség életszínvonala csökkent, néhányan nagyon rövid idő alatt kiugró jövedelemre tettek szert. Mivel az egyének saját pozitív önképüket minden körülmények között fenn akarják tartani (Festinger 1957), Magyarországon a többség arra a következtetésre jutott a rendszerváltást közvetlenül követő időszakban, hogy ha a személyes teljesítmény nem befolyásolja az anyagi boldogulást, akkor saját egyéni teljesítménye és általában pozitív énképe degradálása nélkül, sőt, szinte ennek védelmében lehetnek elégedetlenek az emberek jövedelmi helyzetükkel és életszínvonalukkal (Kopp-Skrabski, 1995).

A befektetések és megtérülések racionális kalkulációjának megközelítésmódja szerint az egyének bizonyos célokat tüznek ki maguk elé, számba veszik azokat a mechanizmusokat, szabályokat és eszközöket, amelyeket a céljuk eléréséhez fel tudnak, illetve fel kívánnak használni, figyelembe veszik a külső kényszereket is, mint a társadalmi környezet, az általuk utilizálható eszközök korlátozott volta, valamint bizonyos szempontból maga a müködési mechanizmus. Ezek után racionálisan kalkulálnak, hogy adott cél eléréséhez adott „,befektetés" milyen mértékben térül meg, illetve nem térül meg. A kutatók arra is felhívják a figyelmet, hogy az átlagember nem feltétlenül a közgazdászok tiszta racionális kalkulációját alkalmazza. Ugyanazon cél elérése ugyanolyan „költségek" kalkulációja esetén az egyik társadalmi csoportnak még megéri, míg a másiknak nem, mivel a külső szemlélő szempontjából megítélt ,,azonos cél", illetve ,azonos költség" nem feltétlenül bír azonos jelentéssel a különböző társadalmi csoportok tagjai számára. Gambetta (1987) például arra hívja fel a figyelmet, hogy egy adott iskolai végzettség elérése azonos objektíve mérhető anyagi és nem anyagi költségek esetén nem jelenti ugyanazt a költséget egy alacsonyabb, illetve egy magasabb kulturális háttérrel rendelkező gyerek számára. Ez azért lehet így, mivel a gyerek által megtett társadalmi távolság alacsonyabb kulturális háttér esetén lényegesen nagyobb, mint szerencsésebb társa esetében. A jövedelmi stabilitás egy olyan cél, amelyet csak akkor érhetnek el az egyének, ha kedvező relatív jövedelmi helyzetük nem változik. A relatív jövedelmi helyzetet pedig nem csupán az objektíve mért faktorok, de a társadalom jövedelmi viszonyairól alkotott globális kép, s ezen észlelt egyenlőtlenségi viszonyrendszerben az egyén észlelt társadalmi pozíciója is befolyásolja. Így a költségek kalkulációja során, az észlelt relatív jövedelmi pozíció függvényében ugyanarról a jövedelemről egyesek úgy vélhetik, hogy arányban áll a befektetett idővel, energiával, egyéni teljesítménnyel, míg mások úgy vélhetik, hogy befektetett erőfeszítéseik nem térültek meg kellőképpen. Vizsgálataik szerint a magyarok leginkább a barátok, közelebbi ismerősök életszínvonalát (51,4\%), a lakókörnyezetükben élők helyzetét (48\%), saját régebbi 
életszínvonalukat (49\%) és a magyarországi átlagemberek életszínvonalát (43\%) veszik figyelembe akkor, amikor saját anyagi-jövedelmi helyzetüket értékelik. A kérdezettek egyharmada testvérei, kortárs rokonai anyagi helyzetét is fontos referenciának tekinti. Általában elmondható, hogy a többség nem viszonyítja saját jövedelmi helyzetét a nála magasabb anyagi-társadalmi pozícióban levő személyekhez.

Nincs egyetértés azon kérdésben, hogy a lakókörnyezetnek milyen hatása van a gyerekek későbbi eredményeire. Ezért figyelembe kell venni egyéb külső körülményeket is, például azt a folyamatot, ahogyan a családok kiválasztják a lakóhelyüket. Továbbá lehetséges, hogy a relatív szegénységnek lehetnek párhuzamosan elönyös és hátrányos hatásai a gyermekekre. Fontos meghatározni és mérni ezeket az ellentétes erőket. Turley (2002) több kutatásra alkalmas, izgalmas kérdést vet föl dolgozatában: Milyen árat fizetnek a gyermekek a relatív szegénységért? Milyen hatása van a relatív szegénységnek a gyermekek kognitív és viselkedésbeli eredményeire? A relatív hiány ára egyben a relatív előny haszna is?

A fenti kérdésekre ad választ Temesváryék 2012-es kutatása, mely Kopp eredményei alapján feltette a kérdést: a magasan kvalifikált és a kevésbé iskolázott szülők körében mennyi a tervezett gyermekek száma, és mindez hogyan realizálódik - azaz melyik társadalmi rétegben születnek meg a kívánt, tervezett gyermekek? (Kopp, 2010, Temesváry, 2012). A kutatás igazolta Kopp eredményeit: az alacsony végzettségü, alacsony jövedelmü családok realizálják az egyébként is magasabbra tervezett gyermekszámot, amely realizálást a családtámogatásoktól tesznek függővé. Ez érthető, hiszen a gyermek születésével nem változik jelentősen a család egyébként is alacsony bevétele - viszont ez nem függ a munkaerőpiac bizonytalanságától, hanem állandó a gyermek egy bizonyos koráig. A magasabb képzettségü, magasabb jövedelmű családokban kevesebb gyermeket terveznek, és sajnos még ez a kevesebb gyermek sem születik meg, ezek a családok ugyanis a család és a munka összeegyeztetésétől teszik függővé a gyermekvállalást., Az ő esetükben a bizonytalan munkaerőpiacon egy már elért karrierszintről való lecsúszás a család teljes létbizonytalanságát eredményezheti. Ez relatív nagyobb kockázat, mint az előző populációé. Ezért is komoly feladat a családpolitikusok számára az a döntés, hogy mit támogatunk: a nők otthonmaradását (mely esetben föként az alacsonyabb végzettségű családokban fog realizálódni a gyermekszületés), vagy a család és munka összeegyeztetését (ez esetben a kvalifikált, magasan képzett családok vállalnak több gyermeket). Ha figyelembe vesszük a szegénységkutatások eredményeit, amelyek szerint a szegénység újratermeli önmagát, a magasan kvalifikált környezet viszont képes lenne felemeli a marginalizált rétegeket, komoly aggodalomra ad okot az elmúlt évtizedek családpolitikája, mely sajnos ma is töretlenül 
folytatódik, figyelmen kívül hagyva a kutatási eredményeket és a nemzetközi és hazai trendeket.

\subsubsection{A napközbeni kisgyermek ellátóhely szerepe - másodlagos szocializáció}

2010-re teljesíteni kellett volna azokat az EU-s irányelveket, miszerint a korosztály 30\%-ának jut majd bölcsődei férőhely. Több, Ferge Zsuzsa vezetésével készített tanulmány a gyermekszegénységröl $^{37}$ alapvetően fontosnak mutatta a kora gyermekkori nevelést a marginalizálódott, illetve mélyszegény családok társadalmi reintegrációjában. A bölcsőde, családi napközi az a hely, ahol a gyerek elsajátítja a társas együttélés alapjait, és egy fajta társadalmi tudást, hogy ne mondjuk „müveltséget” is, ezáltal később könnyebben illeszkedik be az óvodába és az iskolába.

\section{Bölcsődések száma (KSH,2012)}

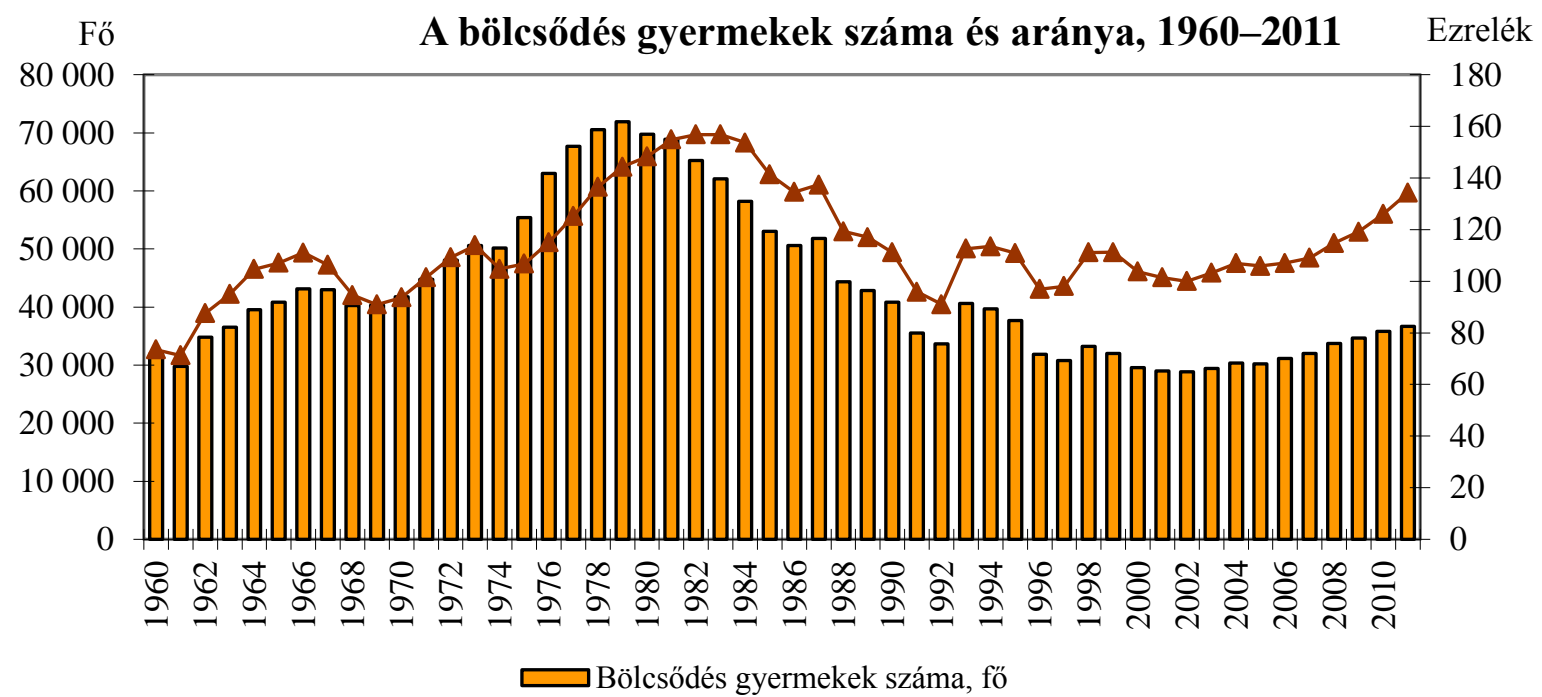

10. ábra, Bölcsődések száma (KSH,2012)

Azonban nem csak a legszegényebb rétegeknek van szüksége bölcsődékre (illetve a gyermekének napközbeni ellátó helyre), hanem annak a fiatal, középosztálybeli csoportnak is, akik nem engedhetik meg maguknak, hogy évekre kiessenek a munkából, ugyanakkor nem, vagy alig tudnak egy magánbölcsődét vagy egyéb alternatív gyermekmegőrző szolgáltatást

\footnotetext{
${ }^{37}$ Forrás: http://www.gyerekszegenyseg.hu/ (letöltés: 2012.04.20)
} 
megfizetni. Ök azok, akik azért nem térnek vissza a munkába, mert nem tudják megoldani kisgyermekük felügyeletét.

A munkahelymegszünések okozta munkanélküliséget papíron csökkentette, ha a nők gyesre-gyedre mentek. Ma már amilyen elképzelhetetlen a nők nagy többsége számára, hogy 8-10 hónapos gyermekük mellől visszamenjenek dolgozni (Blaskó, 2009), olyan lehetetlen is - csak éppen esetleg a két éves mellől is, amikor már a GYED is megszünt. A kétkeresős modell így aztán a magyar háztartások háromnegyedében ugyan ma is irányadó, csak nem mindig megvalósítható. Szinte minden bölcsődében 100\% feletti a féröhely kihasználtság, és a túltöltöttség miatt az azonos évre jelentkezőket többnyire nem tudják fogadni, csak várólistára teszik, és egy esetleges üresedéskor kerülhet bölcsődébe a gyermek. A bizonytalanság azonban tovább nehezíti a nők munkakeresését-munkavállalását. A gyermekgondozási ellátások célja a kimondott családtámogatáson túl a női munkanélküliség visszaszorítása. Ám pillanatnyilag talán olcsóbb az államnak a hosszan gyesen, gyeden levő anya, mint a munkakereső, esetleg munkanélküli anya - de vajon hosszabb távon is ésszerü-e ez a magatartás? Hiszen a hosszú távú hatások közé tartozik az is, hogy az éveket otthon töltő nő tudása elavul, munkakeresési hajlandósága lanyhul, tapasztalatai megkopnak, munkahelye megszünik. Gyermekei pedig nem kerülnek be az intézményes nevelésbe, így a hátrányos helyzetüek még inkább lemaradhatnak kortársaiktól, és az ő későbbi integrációjuk, sikertelenebb életpályájuk nagyon sokba kerülhet az államnak.

Nem csak a munkaerő-szabályozás áll a nők otthontartása mögött - a bölcsődei, óvodai férőhely költségei igen magasak. Erre jelentene alternatívát a családi napközi intézménye. És még egy fontos tényező: a ,fekete gyermekfelügyelet” (a legkisebb falutól a fővárosig mindenhol létező ellátás: működési engedély nélkül, nem bejelentett jogviszonyban történő gyermekfelügyelet). Ennek a legalapvetőbb nemzetgazdasági vesztesége könnyen kiszámítható: elmaradt adók-és járulékfizetés mind a „feketén” dolgozó szülő, mind az ő gyermekére „feketén” vigyázó gondozó részéről.

\subsubsection{A gazdasági szocializáció és a tanult tehetetlenség}

A gazdasági szocializáció definíciója Kőrössy és Lisznyai ${ }^{38}$ szerint (Hunyadi 2003): megmutatja, milyen mechanizmusok révén, milyen fázisokon át válik a gyermek a gazdasági

\footnotetext{
${ }^{38}$ Hunyadi és Székely által szerkesztett könyv 9. fejezetének szerzői: Kőerössy Judit és Lisznyai Sándor. A fejezet címe: A pénz pszichológiája és a gazdasági szocializáció (Hunyadi, Székely, 2003)
} 
folyamat részesévé és alkotójává. Mivel a dolgozatom szorosan vett témája nem a szocializáció, így az érintőlegesség okán megelégszem egy elfogadott definíció átemelésével.

Mivel mindannyian a gazdasági folyamatok részesei vagyunk (a háztartásunknak bevételei és kiadási vannak), ezért megkerülhetetlennek érzem a témát az esélyegyenlőség vizsgálatakor: mit tanul otthon és/vagy a napközbeni ellátóhelyen a gyermek a gazdasági folyamatokról? Vajon mekkora az esélye egy olyan gyermeknek, aki élete első 3-6 évét a munka nélkül otthon lévő szüleivel töltötte arra, hogy ő majd versenyképes munkaerö-piaci szereplő lehessen? Milyen pénzügyi mintákat tanul a gyermek? Van-e összefüggés a szülők pénzügyi kultúrája, pénzkeresési, költekezési, megtakarítási szokásai és a gyermek felnőttkori gazdasági viselkedése között? Olyan kérdések ezek, melynek sem a teljes szakirodalmi áttekintésére, sem a kutatására ezen dolgozatban nem vállalkozom, de érintőlegesen igen fontosnak tartom - épp az esélyegyenlőség, versenyképesség tárgyalása kapcsán. Hiszen a napközbeni ellátó helyeket zömében azok a szülők veszik igénybe, akik gyermekvállalás után visszalépnek (vagy belépnek) a munka világába.

Kopp Mária cikkében (2003) rámutat, hogy milyen összefüggések vannak a vegetatív eltérések, a depresszió, a kardiovaszkuláris halálozás és a tanult tehetetlenség között. Egy másik fogalommal, a tanult sikerességgel is összefüggésbe hozza a problémát, illetve lehetséges megoldásként felveti ennek alkalmazását. Leírja, hogy a tanult tehetetlenség állapota akkor alakul ki, ha egy állatot -vagy embert- negatív ingerek érnek úgy, hogy nincs lehetősége a menekülésre, például folyamatosan áramütések érik, vagy jeges vízben kell úsznia. Egy ideig mindent megtesz, hogy elmenekülhessen, azonban egy idő múlva feladja, a „holttá tettetési reflexnek" megfelelően passzívvá válik. Amennyiben az állat többször éli át ezt az élményt, már a veszélyhelyzet előjeleire is tehetetlenséggel, passzivitással reagál. Az ember esetében hasonló szerepe lehet egy tartósan rossz, megoldhatatlannak érzett kapcsolatnak, fenyegető munkanélküliségnek, munkahelyi rossz légkörnek. Kiemeli a krónikus stressz és depresszió közötti párhuzamot. Megemlíti, hogy a depresszió kialakulásában a gyermekkori, családi háttér, az egyén megbirkózási, coping képességei, szociális kompetenciája és az életesemények meghatározó szerepet játszanak. Mivel véleménye szerint- az önértékelés attól függ, hogy az ember milyen célokat tüz ki maga elé, mikor érzi magát sikeresnek, úgy véli, hogy az énideál, a célok, értékek szerepe a depresszió megelőzése szempontjából alapvető. Itt említi meg, hogy a tanult tehetetlenség mellett egy másik fogalom az ún. tanult sikeresség, eredményesség vált a mai, pozitív pszichológia egyik központi fogalmává. Ennek a készségnek az elsajátítása szintén a nevelés, az önnevelés 
eredménye, de az orvos hatékonyságának egyik legfontosabb mutatója lehet, ha a betegeiben a krónikus betegséggel kapcsolatos „tanult sikerességet" alakítja ki.

Az anya és a gyermek jólléte erősen függ attól, hogy az édesanya hogyan éli meg az otthonlétet vagy épp a munkavégzését. Ha attitüdjei ellenére kell tennie szerepfeszültséget él át. A pozitív pszichológia nemzetközileg elismert képviselője a Chicagói Egyetem professzora, Csíkszentmihályi Mihály (1997), akinek Flow címü magyarul is megjelent könyve gyakorlati eszközöket nyújt a tanult sikeresség, eredményesség eléréséhez.

"Fölfedezésem" az volt, hogy a boldogság nem olyasvalami, ami csak úgy megtörténik velünk, és nem kapcsolatos a szerencsével vagy a véletlennel sem. Nem vásárolható meg pénzzel, nem szerezhetö meg hatalommal. Nem a külső eseményektöl függ, inkább attól, hogyan értelmezzük azokat mi magunk. A boldogság valójában olyan állapot, amelyre fel kell készülni, és mindenkinek magában kell ápolnia és óvnia. Azok az emberek, akik megtanulják, hogyan kell irányitásuk alatt tartani belsö élményeiket, képesek arra, hogy életük minöségét is meghatározzák - ennél közelebb egyikünk sem kerülhet a boldogsághoz.” - írja Csíkszentmihályi (1997, 20. old). Tehát azt állítja, hogy rajtunk múlik, hogyan érezzük magunkat a bőrünkben, miben leljük örömünket, illetve ha keressük, megtalálhatjuk az örömöt abban, amit épp csinálunk. Tehát a kérdés az, hogy hogyan állunk az élethez: nekünk félig üres-e vagy félig tele van-e a pohár? A kutatásai alapján állítja, hogy a flow állapotába leggyakrabban akkor kerülünk, amikor valami olyan tevékenységet végzünk, amiben a teljesítményért keményen meg kell dolgoznunk. Az ilyen élmények nem feltétlenül kellemesek akkor, amikor átéljük őket ${ }^{39}$.

Az Egyesült Államokban Seligman (1975, 1990, 1993, 1996, 2002) magas depressziós kockázattal rendelkező 10-12 éves gyerekeket tanulmányozott (akiknél már megjelentek a depresszió első halvány jelei vagy rendszeresen veszekedtek a szüleik). A szülők közötti veszekedést jelentős rizikófaktornak találták a kezdeti gyerekkori depresszió kialakulásánál. Ezeknek a gyerekeknek a szüleit tanárai megtanították olyan technikákra, amelyekkel tudatosították magukban, hogy a hangulatuk nem közvetlenül azoktól a rossz dolgoktól függ, amelyek velük történnek, hanem attól, hogyan észlelik ezeket az eseményeket. A gyerekeknek megtanították, hogy keressenek bizonyítékokat, amelyek segítségével megerősíthetik vagy

\footnotetext{
39 „Lehet, hogy az úszó izmai fájtak legemlékezetesebb versenye közben, úgy érezte, szétrobban a tüdeje és szédült a fáradságtól - ám mégis ezek voltak élete legszebb percei. Soha nem könnyü úrra lenni életünk felett, néha pedig határozottan fájdalmas is lehet. Hosszú távon azonban a tökéletes élmények összeadódnak, és egyre inkább az lesz az érzésünk, hogy teljesen uraljuk életünket, sőt tevékenyen részt veszünk irányításában is. Ez az érzés pedig olyan közel áll ahhoz, amit az emberek általában boldogságnak neveznek, hogy jobban talán nem is tudjuk szavakba önteni." (Csíkszentmihályi, 1997. 22. old.)
} 
elvethetik a feltevéseiket. Megtanították őket alternatívák keresésére, hogy a pesszimisták ne higgyék el az első nagyon rossz gondolatot, ami eszükbe jut. Megtanították őket, hogy ideiglenes külső okokat keressenek az őket ért csapásokra, az állandó belső magyarázatok helyett. A vizsgálatok azt az eredményt hozták, hogy azok közt a gyerekek közt, akiket megtanítottak ezekre a képességekre, fele annyian váltak komolyan depresszióssá, mint azok közt a gyerekek közt, akiket nem védtek ilyen technikákkal. Két évvel később azok a gyerekek, akik megtanulták a 'dolgok megkérdőjelezésének' ilyenfajta a technikáit, még jobbnak bizonyultak bennük. Egyre kevésbé és kevésbé voltak lehangoltak, míg a gyerekeknek az a csoportja, amelyik nem tanult ilyen technikákat, egyre lehangoltabbakká, depressziósabbá váltak, ahogy a serdülőkoron keresztülmentek. Seligman szerint fiataljaik leginkább abban reménykedhetnek, hogy a társadalom a depresszió megelőzését tűzi ki elsődleges céljául, és inkább az erősségek fejlesztésére törekszik, mint arra, hogy a gyengeségeket megjavítsa. Ahhoz, hogy ez lehetséges legyen, az alapvető emberi erényekhez kell visszanyúlnunk - a bátorsághoz, az optimizmushoz, a kitartáshoz, a belső emberi értékekhez, arra törekedve, hogy fejlesszük, neveljük, ezeket az erősségeket. Bölcs kezdet lenne, véli, ha a jelenlegi oktatási és nevelési gyakorlatban kezdenénk a változásokat.

Csíkszentmihályi (1997) úgy véli, hogy az egyénnek, hogy képes legyen felülemelkedni hétköznapi aggodalmain és félelmein, függetlenné kell válnia társadalmi környezetétől legalább olyan mértékig, hogy ne kizárólag ennek a környezetnek a jutalmai és büntetései irányítsák az életét. Ehhez azonban meg kell tanulnia jutalmaznia saját magát, meg kell tanulnia célokat kitüznie saját magának. A célok elérése azonban nem minden: az oda vezető utat is meg kell tanulnia élvezni. Ez a képesség egyrészről könnyü, mivel ezek mindenkiben benne rejlő dolgok (a szerző véleménye szerint), ám olyan önfegyelmet és kitartást igényelnek, ami már lehet, hogy (szerintem) nincs meg mindenkiben (legalábbis a saját tapasztalataim szerint, bár ez csak laikus empíria jelen pillanatban). A szerző úgy véli, hogy a legfontosabb lépés a társadalmi ellenőrzésről való leválásban, hogy képesek legyünk megtalálni minden egyes perc jutalmát. „, Amíg egy színpompás reklám hatására kicsordul a nyálunk a reklámozott holmi után, vagy a fönök zord arckifejezése képes tönkretenni a napunkat, addig nem vagyunk képesek meghatározni élményeink tartalmát." (Csíkszentmihályi, 1997, 44. old.). A kutatásai eredménye alapján úgy találja, hogy az áramlat-élmény után az Én felépítése összetettebb lesz, mint előtte volt. A komplexitás növekedésével egyező mértékben fejlődik az Én is. A személyiség differenciálódik (melynek eredményeként az ember egyedivé, másoktól különbözővé válik), és egyben integrálódik (azaz az Énen kívüli eszmékkel, emberekkel és dolgokkal egyesül). Így az az ember, aki 
gyakran él át flow-t, egyre különlegesebbé, megismerhetetlenebbé válik, mások szerint ritka képességek birtokosává lesz. Az integrálódás miatt összeszedettebbnek érzi magát, mint azelőtt, nemcsak belsőleg, hanem az emberekkel, és általában a világgal kapcsolatban is. Ha valaki megtalálja az áramlatot a munkájában és az emberekkel való kapcsolataiban, akkor egész élete kedvezőbb irányt vehet. Csíkszentmihályi (1997) úgy találja, hogy igaz, hogy dolgozni nehezebb, mint semmit sem csinálni, de rengeteg olyan esetet tálal, amikor az emberek a munkát olyan örömteli eseményként élik meg, ami az életük legélvezetesebb része. ${ }^{40}$. Mindez tanítható is, oly módon, hogy az embereket megtanítjuk, hogyan ismerjék fel a cselekvési lehetőségeket, hogyan fejlesszék képességeiket, és hogyan tüzzenek ki elérhető célokat. Az anyaság is lehet egy ilyen cél, vagy akár az anyaság és a munkavállalás összeegyeztetése.

Müller Péter (2007) katarzisnak hívja azt, amikor valaki a nehézségek súlya alatt nem megroppan, hanem újjászületik ${ }^{41}$. Úgy véli, hogy mindannyian rendelkezünk az „önvarázslás

\footnotetext{
${ }^{40}$ Miért is hajtunk?

„A halász hazatér fatörzsből vájt csónakján és találkozik egy külföldi piackutató szakemberrel, aki ebben a fejlődő országban dolgozik. A piackutató megkérdezi a halásztól, hogy miért jött haza olyan korán. A halász azt feleli, hogy tovább is maradhatott volna, de elég halat fogott ahhoz, hogy gondoskodjon a családjáról.

- ...és egyébként mivel tölti az idejét? - kérdezi a szakember.

- Hát, például halászgatok. Játszom a gyerekeimmel. Amikor nagy a forróság, lepihenünk. Este együtt vacsorázunk. Összejövünk a barátainkkal és zenélünk egy kicsit - feleli a halász.

A piackutató itt közbevág:

- Nézze, nekem egyetemi diplomám van, és tanultam ezekről a dolgokról. Segíteni akarok magának. Hosszabb ideig kellene halásznia. Akkor több pénzt keresne, és hamarosan egy nagyobb csónakot tudna vásárolni ennél a kis kivájt fatörzsnél. Nagyobb csónakkal még több pénzt tudna keresni, és nem kellene hozzá sok idő, máris szert tudna tenni egy több csónakból álló vonóhálós flottára.

- És azután? - kérdezi a halász.

- Azután ahelyett, hogy viszonteladón keresztül árulná a halait,közvetlenül a gyárnak tudná eladni, amit fogott, vagy beindíthatna egy saját halfeldolgozó üzemet. Akkor el tudna menni ebből a porfészekből Cotonouba, Párizsba vagy New Yorkba, és onnan irányíthatná a vállalkozást. Még azt is fontolóra vehetné, hogy bevezesse a tőzsdére az üzletet, és akkor már milliókat kereshetne.

- Mennyi idő alatt tudnám ezt elérni? - érdeklődik a halász.

- Úgy 15-20 év alatt - válaszolja a piackutató.

- És azután? - folytatja a kérdezősködést a halász.

- Ekkor kezd érdekessé válni az élet - magyarázza a szakember. Nyugdíjba vonulhatna. Otthagyhatná a városi rohanó életformát, és egy távol eső faluba költözhetne.

- És azután mi lenne? - kérdezi a halász.

- Akkor volna ideje halászgatni, játszani a gyermekeivel, a nagy forróság idején lepihenni, együtt vacsorázni a családjával és összejönni a barátaival zenélgetni kicsit...” (Ismeretlen forrás)

41 „...De a katarzisban minden tövestül kiszakad. Olyan gyökerestül, hogy innen kezdve már teljesen mások leszünk, mint akik voltunk. Más lények, akik csak annyira hasonlítanak régi énünkre, mint a pillangó a hernyóra. Az ilyen ember meghalt a múltja számára, és ha találkozol vele, az a gondolatod támad, hogy ez már nem ugyanaz, akit ismertél. Mi manapság inkább szenvedünk, mint hogy katarzist éljünk át. És akármilyen pokoli és elviselhetetlen a szenvedésünk, mégis van valami, amit a markunkból nem engedünk kitépni. Az énünket szorítjuk, görcsösen. Ezért van az, hogy a mai ember rendszerint benne marad a bajában, akár élete végéig is, és nem képes a lényét megváltani. ... A megoldásképtelenség lett az általános tapasztalatunk. Átírhatatlan programok müködtetnek bennünket.” Müller, 2007, 92-93. old.
} 
képességével”. Azt írja, mindenkiben lakik egy Mágus. „Ha valaki úgy dönt, hogy „,igen!”, akkor beindul a varázslás folyamata. ... És akkor már nincs megállás. Ha azonban a Mágus úgy dönt, hogy „,nem!", akkor ... nem történik semmi ${ }^{42}$,.

Komoly társadalmi felelőssége van a médiának, az opinion leadereknek, ismert pszichológusoknak abban, hogy hogyan kommunikáljuk a család és a munka kapcsolatát. Ha a pozitív hatásokat hangsúlyozzuk, megerősítjük azokat a családokat, akik lehet, hogy kényszerből, lehet, hogy bizonytalanul, de mindketten dolgoznának a gyermekvállalás mellett. Ezt egyszer sikerült ellentétes irányba elrontani, ha most az otthonmaradás értékét elismerve egy támogató kommunikációval megerősítenénk a dolgozó szülőket, sokat javulna a hazai családok lelkiállapota.

Sokan sokféleképpen definiálják a versenyképességet. Sok ember szemében a versenyképesség csupán a nyereség/veszteség szituációjáról szól, ahol egy nemzet, egy vállalat vagy egy egyén teljesítményben felülmúlja a másikat. Helyesebb lenne azonban azt mondani, hogy a versengő személy, vállalat, ország komparatív, viszonylagos előny megszerzésére törekszik valamilyen területen, ahol másokat felül tud múlni. A magas fokú versenyképesség minden egyes területen nagy valószínüséggel lehetetlen. A viszonylagos, komparatív előnynek köszönhetően azonban valamely terület gyengesége kompenzálható bármely más terület előnyével. Ugyanakkor a komparatív előnyök kihasználása, a specializáció mindenkinek előnyére válhat, hiszen ez nem zéró végeredményü üzlet: az egyik fél nem annyit nyer, amennyit a másik veszít, hanem kölcsönös előnyökkel jár. Ez a specializáció manapság az outsourcing, illetve az off-shoring tevékenységekben ragadható meg igazán. A munkáltató versenyképességét fokozhatja a családbarát léte: a betanított, képzett, megbízható munkavállaló szempontjából versenyelőnyt jelent egy olyan munkahely, amely a családos munkavállalónak stabilitást kínál. A motivált, elégedett munkavállaló pedig bizonyíthatóan jobban teljesít.

Fülöp (2007) cikkében úgy véli, a versenyképesség egyik fontos feltétele, hogy az egyén a versenyhez, versengéshez szükséges motivációkkal és személyiségjegyekkel

\footnotetext{
42 , Titkot mondok, és ez nemcsak a szerelemre, hanem az életünk sok más eseményére is vonatkozik: döntés nélkül ritkán történik velünk valami. ... De mivel nem figyeljük önmagunkat, ez a döntés rendszerint tudattalanul történik. És nagyon rövid időnk van hozzá. Ha elmulasztjuk, később azt hisszük, hogy az érzés kívülröl szakadt ránk, s mi tehetetlenek vagyunk. Ez nem igaz. Mindazt, ami velünk történik, igenis akarjuk; néha csak úgy, hogy hagyjuk megtörténni. Öntudatlan okból. ... De egy ilyen ,igen” vagy „nem” minden döntésünket megelőzi. ... Aki azonban az önismeretében eljutott odáig, hogy tud a Mágusáról, döntéseit még idejében fölismeri, és bármikor végre is tudja hajtani. ... Aki az uraltság állapotában él, annak nincs mit elfojtania, mert a lélek belső döntése nélkül el sem indulhat semmi. És tisztában van azzal, hogy kívülről csakis olyasmi jöhet, amit belül megidézett. Az uraltság azt is jelenti, hogy az ember átlátja, az élete nem „megtörténik” vele, hanem ö csinálja.” (Müller, 2007. 259-261. old. Kiemelés tőlem)
} 
rendelkezzen. Iskolákban vizsgálták a verseny, versengés, globalizáció, üzleti siker fogalmak megjelenését és értelmezését. Megemlíti, hogy létezik „pozitív és negatív sikerfelfogás”, ami a kutatás eredményei szerint összefüggésben állhat a nemzetre jellemző szocializációs mintával (különböző országok diákjai között tettek összehasonlítást). Kulturális összehasonlításukban a győzelem mellett a versengés másik törvényszerü motívumát, a vesztést is figyelték. Meglepő módon a magyar válaszadók 46\%-a valamilyen negatív érzelmet is kapcsolt a győzelemhez. (versus: Japán 5\%, Kanada 10\% negatív érzelem előfordulása a győzelem említése kapcsán). Mivel azt az eredményt kapták, hogy a magyar fiatalok sok negatív érzelmet kapcsolnak a győzelemhez, és inkább deaktiválódnak vesztés esetén, ezért ezt az összefüggést külön is vizsgálták. ${ }^{43}$

A versenyképesség vizsgálatánál a humán erőforrás szempontjából megkerülhetetlen terület a közoktatás és a napközben kisgyermekellátás. Az itt eltöltött időnek és az ellátás minőségének statisztikailag szignifikáns pozitív hatása van a gazdasági teljesítményre (Z. Karvalics-Kollányi, 2006). Épp ezért a marginalizáció megállításának kikerülhetetlen módja a napközbeni kisgyermekellátás és a közoktatás minőségének radikális újragondolása, és az átalakítás azonnali racionalizálása. Gyermekvállalás után az édesanya tudása megfelelő intézményrendszer és folyamatos szakmai interakciók híján gyorsan elavul elengedhetetlen a magas minőségü napközbeni gyermekellátóhelyek hozzáférésének a javítása az édesanya tudásmegőrzésének érdekében is (Z. Karvalics-Kollányi, 2006).

\footnotetext{
43 „Lehet valaki nagyon okos, rendelkezhet kiváló tudással, számítógépes ismeretekkel, beszélhet öt nyelven, de ha nem tud talpra állni egy sikertelenség után, akkor a tudása feleslegessé válhat. Tehát a sikertelenségekkel, a vesztéssel való megküzdés a versenyképes személyiségnek fontos része.” -idézet a cikkből (Fülöp, 2007)
} 
Ha a szülö üzleti befektetésnek tekinti a gyereknevelést, a legnagyobb mértékben pórul jár. Ha úgy gondolja, hogy minél több gyereket nevel, mint a malacnevelésböl, meglesz idövel az a haszna, hogy mikorra eröi elmúlnak s maga szorul eltartásra, akkor a gyermekek...

Vagy pláne, hogy a gyermekei erötartalékát akarja a maga céljaira felhasználni, ha majd megnönek? Vagy csak az is, ha bármiképpen, nemcsak üzletileg, tehát nem pénzben kifejezhető módon, de érzelmileg akar hasznot, például ideái tovább plántálásában, vágyálmainak kiélésében - akkor is a legnagyobb mértékben pórul jár. (...) A gyerek mindennap kifizeti saját magát. A szülö egy fökönyvi lapot tart a gyermeke számára: egyik oldalon beírja, amit ráköltött $s$ amit rápazarolt, a másik oldalon felrója, mit vár ezért viszonzásul. Az én tanácsom az, sén amennyire emberileg lehetséges, ezt végre is hajtottam: a szülö mindennap zárja le a számadást, írja be egyenlegül, hogy: van gyermeke. Ez az öröm mindent ki kell, hogy fizessen.

(Móricz Zsigmond)

\section{FEJEZET}

\section{NEMZETKÖZI ÉS HAZAI NAPKÖZBENI KISGYERMEK ELLÁTÁS BEMUTATÁSA}

A fejlett országokban alapvető fontosságú, hogy a munkavállaló szülőknek lehetőségük legyen munkaidőjük alatt gyermeküket megfelelö, az állam által szabott feltételek szerint müködő intézmények, személyek gondozására bízni. Ez egyrészt megkönnyíti a női munkavállalást (ami csökkenti a családok elszegényedést), másrészt hozzájárul a TB - és nyugdíjrendszer fenntartásához (a munkavállalók adó-és járulékfizetése által), harmadrészt pozitívan hat a gyermekvállalásra (a munka és család összeegyeztethetősége által). (Blaskó, 2009). Nem mindegy az sem, hogy ezen ellátóhelyek mennyire alkalmazkodnak a családok valós igényeihez. A túl sok szünet megoldhatatlan kényszerszabadságra kényszeríti a családokat, a túl nagy csoportlétszám indokolatlanul sok betegséget, így áttételes táppénzes állomány eredményez. Ezen két tényező nem segíti, nem támogatja a nők, édesanyák munkavállalását, hiszen a gyermek gondozása többnyire rájuk hárul. Ha a szülő nem bízik az ellátó helyben, nem nyugodt, akkor nem dolgozik megfelelően, gondolatai kicsaponganak, teljesítménye csökkenhet (Nagy, 2013).

Sajnos a 3 év alatti gyermekek esetében napközbeni kisgyermekellátást igénybe vevők között nemzetközi összehasonlításaiban is egyértelmüen a sor végén kullogunk. 


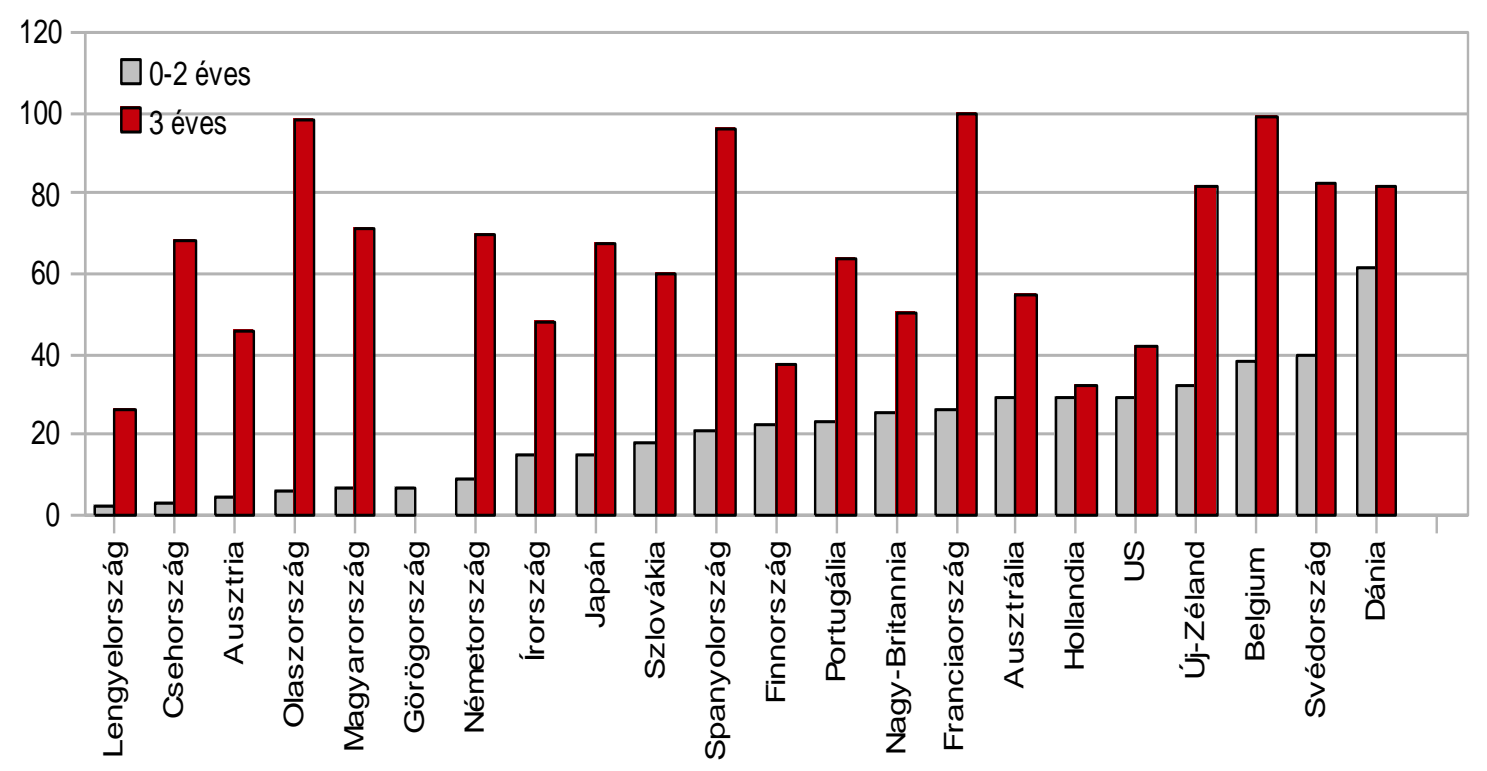

11. ábra, Napközbeni ellátás (OECD-Scharle,2009)

A tanulmányok összehasonlításában, konklúziók leszürésében nehézséget okozott, hogy a fellelhető tudományos cikkek nem a hatályos jogszabályoknak megfelelő nómenklatúrát használják az „intézmény” és az „alternatív napközbeni gyermekfelügyelet" említésekor ${ }^{44}$. Ez a jogszabálytól következetesen eltérő szóhasználat félreértésekre adhat (és sokszor ad is) okot. A szerzők mentségéül hozom fel, az ő szóhasználatuk logikus (és a társadalom szóhasználatával koherens), csak sajnos a jogalkotók más logikai rendszer mentén használják a fentieket. Nehézség volt a nemzetközi irodalom értékelésénél, hogy szinte az összes máshol jelen lévő sokféle napközbeni ellátási formát egységesen „bölcsőde"-ként említi a hazai irodalom, holott sokszor egyáltalán nem bölcsődéről, hanem 0-3 éves korú (azaz bölcsődés korú) gyermekek ellátásáról van a tanulmányokban szó. Ez is komoly aggályokat vet föl. Ennek hátterében az évtizedekig intézményi, azaz bölcsődei rendszer egyeduralkodása lelhető fel - szemben a külföldi sokszínűséggel. A társadalomban is gyakorlatilag minden koragyermekkori kisgyermek ellátóhelyet „bölcsi”-ként (vagy „ovi”-ként) aposztrofálnak - attól függetlenül, hogy az hivatalosan lehet, hogy nem az. Ez megint csak nem a tudományos írók, és főként nem a

\footnotetext{
${ }^{44}$ Ezt a problémát a jogszabályok bemutatásakor részletesen kifejtem , de a lényeg: a hatályos jogszabályok szerint a családi napközi nem intézmény, és nem alternatív ellátási forma.
} 
társadalom hibája, hanem egy tény, melyet a jogalkotásban és a tudományos irodalomban figyelembe kellene venni.

\subsection{Napközbeni kisgyermek ellátás definíciója, célja}

Felmerülhet a kérdés: miért kell költeni napközbeni alapellátásra? Mi is az a napközbeni kisgyermek alapellátás? A napközbeni kisgyermek ellátás definíciója a Gyermek védelméről és a gyámügyi igazgatásról szóló 1997. évi XXXI. törvény 41. § (1) szerint „, a gyermekek napközbeni ellátásaként a családban élö gyermekek életkorának megfelelö nappali felügyeletét, gondozását, nevelését, foglalkoztatását és étkeztetését kell megszervezni azon gyermekek számára, akiknek szülei, nevelöi, gondozói munkavégzésük, munkaerőpiaci részvételt elösegitő programban, képzésben való részvételük, betegségük vagy egyéb ok miatt napközbeni ellátásukról nem tudnak gondoskodni. A napközbeni ellátás keretében biztositott szolgáltatások időtartama lehetőleg a szülö munkarendjéhez igazodik" ${ }^{45}$. Saját definícióm szerint a gyermekek napközbeni ellátása az a tevékenység, amely során a szülő helyettesítése történik az idő alatt, ameddig ő nem tud a gyermekével lenni. Ez a tevékenység magában foglalja a gyermek életkori és egyéni igényeinek megfelelő gondozást, nevelést, foglalkozást, étkezést, mely tevékenységek nem lehetnek alacsonyabb színvonalúak, vagy merőben más elveken, értékeken alapulóak, mint amelyet a szülö maga nyújtana a gyermekének. A jogszabályi hátteret a következőkben részletesen bemutatom, most a téma közgazdaságtant és a szociológiát érintő hátteréről essék szó.

Gál-Gábos (2007) a gyermeknevelés költségeit feltáró tanulmányukban a gyermeknevelés céljából végzett tevékenységnek 3 típusát különböztetik meg:

1. közvetlenül a gyermeknevelés céljából végzett tevékenység

2. a gyermekneveléshez közvetetten kapcsolódó tevékenységek

3. azok a tevékenységek, melyek során a szülők egyúttal gyermekük felügyeletét is ellátják.

Közvetlenül gyermeknevelési céllal végzett tevékenységeknek tekintették azokat, melyek az időmérleg-naplóban kifejezetten a gyermek gondozásaként, képzéseként jelennek meg. Ilyen a csecsemőgondozás, a három év alatti, továbbá az idősebb gyermekek gondozása, ápolása, felügyelete, a mesélés, a gyermekkel való játék, valamint a tanulás, az

\footnotetext{
${ }^{45}$ Részletes jogszabályi kivonat található az 1. függelékben
} 
iskolai feladatok ellenőrzése ${ }^{46}$. Ugyancsak a közvetlen gyermeknevelési tevékenységek közé sorolták a gyermekruha vásárlására, a gyermekneveléssel kapcsolatos ügyintézésre, továbbá a gyermekgondozással-neveléssel összefüggő közlekedéssel töltött időt.

Azok a háztartási munkák, melyek eredményeként létrejött javakból és szolgáltatásokból a háztartás minden tagja, így a gyermekek is részesülnek, szintén részét képezik a gyermeknevelésnek.

A szülők nyilvánvalóan több időt töltenek együtt gyermekeikkel, mint amennyit nevelésükre vagy a fenti definíciók szerint közvetlenül vagy közvetve fordítanak. Így a szórakozás céljából végzett tevékenységek időtartama alatt passzívan jelen lévő gyermekre felügyelhetnek, sőt adott esetben nevelhetik is. A gyermekfelügyeleti tevékenységek beszámításakor is figyelembe vették a harmadik szereplö elvét ${ }^{47}$, hiszen a felügyeletet magát harmadik személy is el tudná látni.

A családtámogatási formák (többek között a megfelelő minőségü napközbeni ellátás) hozzájárulhatnak a szegénység generációs átörökítésének megtöréséhez (Gábos, 2000). Az anya munkavállalása növeli a háztartás rendelkezésre álló jövedelmét, mellyel csökkenti a család szegénységi kockázatát. Ezzel több módon is pozitív hatással lehet a gyermekek fejlődésére. Viszont a hatások iskolázottság szerint heterogének lehetnek. Amennyiben növekszik az iskolázatlan anyák munkaerő-piaci részvétele, az összességében pozitív hatással lehet a gyermek emberi-tőke akkumulációjára, mert a pozitív jövedelemhatás felülírhatja a szülő involváltságát a gyermeknevelésben. A másik oldalról nézve viszont az iskolázottabbak esetében a szülő jelenlétét csak magas színvonalú háztartáson kívüli gondozás ellensúlyozhatja. Nehéz megalkotni az „elég jó” ellátás definícióját - hiszen a családok igényei merőben különbözőek lehetnek.

Hazánkban a lassan változó tradicionális családmodell (Spéder, 2006; Pongrácz, 2011) miatt elfogadott a gyermek édesanya általi otthon gondozása, legalább 3 éves korig. A társadalom a pénzügyi szükségből munkát vállaló anyát jobban elfogadja, mint a munkáját szerető, abban örömet lelőt (Blaskó, 2011). A poszt-szocialista rendszer egyeduralkodó

\footnotetext{
${ }^{46}$ Komoly és mindennapos probléma a napközbeni kisgyermekellátás szociális, míg a tanuláshoz, neveléshez kapcsolódó tevékenység közoktatási besorolása. Így elvileg egy szociális ellátást nyújtó családi napköziben egy pedagógus végzettségü gondozónak sem lehet foglalkozást tartani (holott pl. a gyermek életkori sajátossága miatt ez indokolt lehet), vagy egy iskolás gyermekkel a pedagógus végzettségü gondozó hivatalosan nem ellenőrizheti a leckét, nem tanulhat. Ez a szabályozási anomália is megoldható egy korszerü és professzionális minőségbiztosítási rendszerrel.

47 „Ha gyermekünk mellé bébiszittert vagy nevelöt fogadnánk, akkor az a gyermekfelügyelettel, illetve a gyermekneveléssel összefüggő minden tevékenységet képes lenne ellátni. Nem kérhetünk ugyanakkor meg senkit arra, hogy megnézzen helyettünk egy tévémüsort, vagy kocogjon reggelente helyettünk" (Gál-Gábos 2007)
} 
bölcsődei struktúrája miatt sokszor valódi alternatívája sincs a munkát vállalni kényszerülő vagy akaró nőnek, hiszen az intézményrendszer rugalmatlansága nem kedvez a mai kor elvárásainak (nyitva tartás, szünetek, nagy létszám miatti gyakori betegségek, stb). Pedig kimutatható az összefüggés a napközbeni kisgyermekellátás, a női foglalkoztatottság (különösen a részmunkaidős női foglalkoztatottság - ld. Szalai, 2012) és a gyermekvállalási hajlandóság között. A KSH adatai $(\mathrm{KSH}, 2012)$ is rámutatnak erre. Ha a bölcsődébe beíratott gyermekek számához hozzáadjuk a családi napközibe beíratott gyermekek számát, akkor is elmarad a dolgozó (hivatalosan, bejelentetten dolgozó) nők számától. Ez a gyermekek informális ellátásának nagyságára hívja fel a figyelmet (Blaskó, 2008).

\section{Bölcsőde-női foglalkoztatás (KSH,2012)}

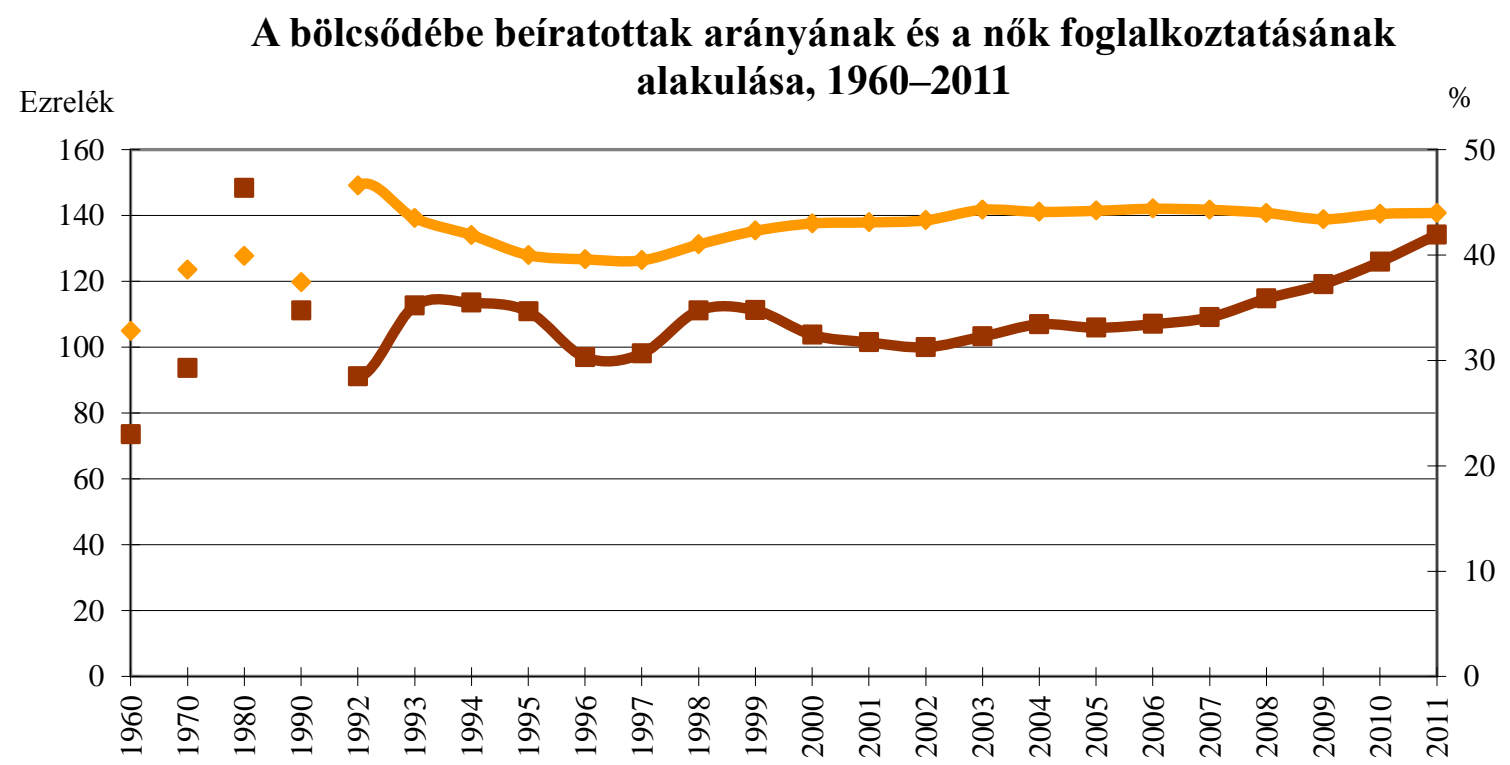

\footnotetext{
—Ezer 3 éven aluli kisgyermekre jutó bölcsődébe beíratottak száma, ezrelék — Nők foglalkoztatási rátája*, \% * 1960-1990 között aktív keresők aránya.
}

12. ábra, Bölcsőde-női foglalkoztatás (KSH,2012)

\subsection{Kitekintés - máshol hogyan oldják meg? ${ }^{48}$}

Jelen fejezettel célom annak a sokszínüségnek a bemutatása, amely jellemzi ezt a területet - példát mutatva a változtatás irányaira. Célom teret adni a témával kapcsolatos

\footnotetext{
48 Jelen fejezetben erősen támaszkodtam a Nemzetgazdasági Minisztérium 2012-es munkaanyagára (NGM, 2012), valamint Blaskó Zs., Cseres-Gergely ZS., Reszkető P., Scharle Á., Váradi B. Az 1-3 éves gyermekek napközbeni ellátásának bővítése: költségvetési ráfordítás és várható társadalmi hatások, Budapest Institute, Budapest, 2009-es tanulmányára.
} 
későbbi kutatásokhoz, összehasonlításokhoz. Mivel a téma szervesen illeszkedik a dolgozat logikájába, így fontosnak tartottam a bemutatást itt szerepeltetni.

Az európai, ausztrál és amerikai gyakorlatban jellemzően 3 féle nappali ellátást biztosító intézménytípus müködik (NGM, 2012):

1. Központi létesítésü napközi

2. Családi napközi (Family Day Care, FDC)

3. Iskola elötti ún. „korai oktatás programok”

\section{Központi létesítésű napközi}

- Jellemzően 4 éves kor alatt teljes vagy részidős ellátás. 4-5 éves kor felett gyakran belépnek a gyermekek a közoktatási rendszerbe.

- A finanszírozás ország-függő, a legtöbb európai országban a családok fizetik, amit azután az állam kompenzál adójóváírások, gyermektámogatások stb. formájában. Ez a modell jelentősen eltér a poszt-szocialista államok közfinanszírozott modelljétől, aggodalomra adna okot egy estleges átgondolatlan adaptáció. A skandináv modell az állami finanszírozást preferálja, azonban ott a családtámogatás (otthonmaradás támogatása) és a gyermekellátás finanszírozása szorosan összefügg, azaz vagylagos.

- A felelős szerv változó:

○ Oktatási Minisztérium: Hollandia, Portugália, Svédország

○ Társadalmi Ügyek Minisztériuma: Dánia, Finnország, Franciaország

- Számos európai országra egyre jellemzőbb a családok privát rendszerü gyermekmegőrzése (Írország, Hollandia, Svájc, Egyesül Királyság) illetve a családok összefogásával fenntartott napközi.

2. Családi napközi (FDC $\left.{ }^{49}\right)$

- A családnál, vagy a gyermeket őrző személy otthonában kerül megőrzésre a gyermek

- Jellemző, ha kevés az intézményi férőhelyek száma, vagy a család az „otthoni” környezetet szeretné biztosítani a gyermek számára

\section{Iskola előtti ún. „korai oktatás programok”}

- Oktatással egybekötött, elsősorban idősebb gyerekek számára fenntartott programok (néhol csatornázzák csak be az óvoda programjába)

\subsubsection{Anglia}

\footnotetext{
${ }^{49}$ Family Day Care
} 
A különböző okokból (bevándorló, munkanélküli, fiatalkorú, mélyszegény) veszélyeztetett vagy hátrányos helyzetü gyermekes családok segítése, és a gyermekszegénység leküzdése az Egyesült Királyságban is komoly közpolitikai cél. Az ezt orvosolni hivatott brit Sure Start (Biztos Kezdet) program ${ }^{50}$ célja a tartósan szegény, felzárkóztatásra szoruló vagy más szempontból hátrányos helyzetű családok segítése, bevonása és felzárkóztatása oly módon, hogy az ne járjon társadalmi megbélyegzettséggel.

Azokon a jellemzően kistelepüléseken és leszakadt településrészeken, ahol a bőkezübben finanszírozott 'nagy' Sure Start-tal megcélzott több száz gyermeket nem lehetett elérni, de kb. 150 négy évnél kisebbet igen, a meglévő gyermekellátó önkormányzati intézményekre, programokra építő, 'mini’ Sure Start programokat indítottak be. E programok keretében 2-3, részben részmunkaidős, vagy máshonnan ideiglenesen átigazolt szociális munkásból, pedagógusból, egészségügyi dolgozóból álló csapat, a szülők és a gyermekellátással, gyermekegészségüggyel, kulturális szolgáltatásokkal helyben foglalkozók bevonásával olyan, a stigmák elkerülése végett minden család számára nyitva álló szolgáltatásokat igyekeztek nyújtani, amelyek a helyi igényeknek a legjobban megfeleltek. Ezek egészségügyi szolgáltatásokat (diagnosztika, fejlesztés: pl. logopédia, babamasszázs, babaúszás), gyermekellátási lehetőségeket (bölcsőde előtti-utáni gyermekmegőrzés, játszótérlétesítés, játék-tékák es játszóbuszok müködtetése), és a szülőknek nyújtott szolgáltatásokat (pl. személyiségfejlesztés, a többségi nyelv tanítása, álláskeresésben adott támogatás) egyaránt tartalmazhattak. A programban részt vevő gyermekek mérhetően, kimutathatóan jobban fejlödtek, nagyobb önállóságot mutattak, miközben jobban alkalmazkodtak, mint hasonló helyi/családi körülményekkel rendelkező, programon kívüli társaik. A programok csökkentették a szülői háttér okán adódó negatív kockázatokat (deviáns viselkedés), és a családok általában véve együttmüködőbbnek mutatkoztak más, gyermekjóléti szolgáltatások igénybe vétele során. (Blaskó és tsai, 2009).

Hazánkban az egyik fó oka a 3 éves gyerekek kötelező óvodáztatásának a marginalizált csoportok felzárkóztatása volt. Talán érdemesebb lett volna a már működő Biztos Kezdet programot tovább bővíteni - így elkerülhető lett volna a mindenki által ismert óvodai férőhelyhiány és az ebből fakadó túlzsúfoltság fokozása.

\footnotetext{
${ }^{50}$ A Biztos Kezdet program hazánkban is megvalósult a TÁMOP 5.2.1 program keretében. Ún. Gyerekházak jöttek létre, ahol a szülők együtt játszhatnak a gyermekekkel, közben tanulhatnak, és igénybe vehetnek különféle szolgáltatásokat. Mellékletként csatoltam a program kiírását. A program weboldala: http://www.biztoskezdet.hu/
} 


\subsubsection{Dánia}

Dániában a 0-6 éves korú gyermekek ellátásaért az 1999-es Szociális Szolgáltatások törvény alapján a Szociális Minisztérium a felelős. A minisztérium irányelveket adott ki a napközbeni ellátásra az ENSZ Gyermekjogi Konvenciója elveivel összhangban. Alapvetően Dániában minden olyan gyereknek tudnak helyet biztosítani, akinek a szülei ezt szeretnék. A három év alatti gyerekes anyák 70\%-a dolgozik. Leegyszerüsítve azt lehet mondani, hogy a kora gyermekkori nevelés és gondozási szolgáltatások Dániában a gyermek 6 hónapos korától 7 éves koráig tartanak.

A helyi hatóságok a napközbeni ellátás 70\%-át biztosítják (kommunale daginstitutioner), független vagy magán nappali intézmények (selvejende daginstitutioner) pedig a többit. Az egyes helyi önkormányzatok maguk határozzák meg a napközbeni ellátás szerkezetét a helyi igényeknek megfelelően. Ebbe beletartozik a korosztályos csoportok meghatározása, a különböző napközbeni ellátás kombinációja, valamint a nyitvatartási idő. Néhány helyi önkormányzat éjszakai bölcsödét és óvodát is létrehozott, ahol a gyerekek éjszakára is bent maradhatnak. A részidős formákra többféle változat van: a félnapos ellátás (a gyermek vagy délelőtt, vagy délután van bent), illetve egész napos ellátás (a gyermek minden második nap, vagy kétszer egy héten van bent egész nap).

A magán napközbeni gondozóhelyeket is a helyi hatósággal kötött szerződések határozzák meg. A helyi hatóságnak joga van megszabni hány ilyen létesülhet. A helyi hatóságok a szerződésben meghatározott gyermekenkénti támogatást adnak az intézménynek.

A napközbeni szolgáltatásokra a helyi hatóságok a következő típusú intézményeket hozták létre (0-3 éves gyermekek számára):

- Bölcsőde - 6 hónapos kortól 2 éves korig

- Családi napközi - 6 hónapos kortól 3 éves korig

Emellett a helyi hatóságok támogatják a magán napközbeni gondozó intézményeket, vállalati létesítményeket, speciális napközbeni gondozókat és nyitott oktatási létesítményeket illetve játszóközpontokat.

A napközbeni és év közbeni nyitvatartási idő szolgáltatás-típusonként változó:

- 0-1 év között a szülői gondoskodás a jellemző, de hathónapos kortól már be lehet íratni a gyerekeket napközbeni ellátásra. A fekete foglalkoztatás nem elterjedt. A családok elvihetik gyermekeiket játszóházba, amelyeket az önkormányzat müködtet.

- 1-2 év közöttiek: 83\%-uk be van íratva napközbeni ellátásra (legnagyobb arány Európában). A leginkább kedvelt a családi napközi (45\%), amely elsősorban vidéki 
területeken elterjedt, míg máshol az integrált létesítmények, illetve a bölcsődék az a gyakoribbak (38\%).

Vidéken jellemzőbb forma a családi napközi, mivel ott sem integrált típusú intézmény, sem bölcsőde nincs. A gyermekgondozókat a helyi hatóság alkalmazza, amely jóváhagyja a lakást illetve az ellátás egyéb helyszíneit, valamint vizsgálják a gondozó személyiségét is. Ha a gondozó távol marad betegség, szabadság vagy egyéb ok miatt, a helyi hatóságnak kell gondoskodnia helyettesről. A 0-6 évesek ellátásának minősége nagymértékben függ az egy gondozóra eső gyerekek számától. Ez a legfiatalabb gyerekeknél a legnagyobb, majd csökken. A szülők maguk választhatják meg, hogy milyen típusú ellátást szeretnének gyermekeiknek, és támogatást kapnak ahhoz is, hogy szabadon választott, az önkormányzat által elfogadott gyermekfelügyelőt alkalmazzanak, de nem adnak támogatást, ha a szülő maga neveli gyermekét. A szülők (mind az anya, mind az apa) gyermekgondozási szabadság révén kapnak támogatást. Törvény alapján a helyi hatóságoknak jóvá kell hagyni minden szerződést, amit a gyerekfelügyeletre kötöttek és személyt, akit a szülők kiválasztottak gyerekük mellé.

A finanszírozás alapelve, hogy a helyi hatóságok fizetik a regisztrált napközik müködési költségeit. A magánintézményeknek nyújtott támogatások egyetlen feltétele, hogy bizonyíthatóan a napközbeni ellátásra kell fordítani és a magánmüködtető nem profitálhat a központból. A finanszírozás a helyi adókból, blokktámogatásokból és szülői hozzájárulásból ered. A blokktámogatások általában nem célzottak, a helyi hatóságok kapják a központi kormányzattól. Ez kb. 66 \%-a a teljes költségeknek. A szülők költségei 30-33\%-on vannak maximálva, 6 éves kortól ingyenes az ellátás. (NGM, 2012)

\subsubsection{Franciaország}

Franciaországban a kora gyermekkori nevelés és gondozás két fő vonalon fut: csoportos gondozás és az egyéni gondozás formájában.

- A csoportos ellátásnál a 3 év alattiak bölcsődébe járhatnak, míg a három év felettiek óvodába.

- Az egyéni ellátás keretében megkülönböztetünk családi napköziket (assistante maternelle) illetve otthoni gyerekfelügyeletet.

A bölcsődei férőhelyek száma ugyan fokozatosan nő, mégsem tudják kielégíteni a keresletet. A bölcsőde iránti kereslet jelentősen meghaladja a kínálatot. Néhány család engedély nélküli, nem regisztrált gyermekgondozási lehetőséget vesz igénybe, ami illegális. A bölcsőde a férőhelyek csekély száma miatt a 3 év alattiak mindössze 10\%-át fogadja be és a 2 éves gyerekek 34,7\%-a már óvodába jár. Általában a bölcsődei férőhelyeket a dolgozó szülők 
gyermekeinek vagy speciális oktatási vagy társadalmi szükséglettel bíró gyermekeknek tartják fent. A bölcsődék 64\%-a helyi önkormányzat müködteti, 29\%-át különböző szervezetek, beleértve szülöi csoportosulásokat is. Van néhány vállalati bölcsőde is, általában egészségügyi intézményekben. Nagyon kevés a magán létesítmény. A bölcsődék átlagosan napi 11 órát tartanak nyitva évi 235 napon át.

Azoknak, akik csak alkalmanként igénylik hat év alatti gyermekük ellátását, használhatják az ún. haltegarderie-kat. Ide általában olyan szülők hozzák gyereküket, akik részmunkaidőben, illetve rendszertelen az időbeosztással dolgoznak, vagy továbbképzésen vannak.

Az egyéni megoldások közül a legelterjedtebb a családi napközi (Assistante Maternelle), ahol a hat év (de inkább 3 év) alatti gyerekeket gondozzák a szolgáltatásnyújtó otthonában. Ez a tevékenység engedélyhez kötött. A gondozók fizetését törvény rögzíti. 10 óra túlóra engedélyezett. A családok közvetlenül a gondozóval beszélik meg az étkezést, a vakáció idejét és az eljárást, ha a gyerek hiányzik. A gondozók speciális adóhelyzetet is élveznek. A családi gondozók 90\%-át a szülök közvetlenül alkalmazzák és ezért speciális állami támogatásban ésadókedvezményben részesülnek a költségeik csökkentése céljából.

A maradék 10\% az ún. családi bölcsődékbe szerveződik, amely átmenet a bölcsőde és a családi napközi között. Ebben az esetben a gondozó egy csecsemőápoló vagy orvos irányítása alatt dolgozik. Az igazgató toborozza a gondozókat és gondoskodik a továbbképzésükről is. A családi napközit üzemeltető gondozók hálózatát is létrehozták, amely segíti a szülőket információval és oldja a gondozók elszigeteltségét.

Az otthoni gyerekfelügyelet is alternatíva. Ebben az esetben a gyermek otthonába jön a gondozó. Ezeket a dolgozókat a szülök közvetlenül fizetik, és nem szükséges, hogy legyen engedélyük. Az állam erre a formára is ad támogatást és speciális adócsökkentést. (NGM, 2012; Makay, 2008)

\subsubsection{Svédország}

Svédországban a gyereknevelés- és gondozás mar évtizedek óta a kormányzati prioritások között szerepel a családpolitika kiemelt részterületeként. Már a '70-es évek végén markáns állami szerepvállalást tükröző szakpolitikai koncepciók születtek, melyek fö hangsúlyai a gyermekellátások teljes lefedettségének, a szolgáltatások magasabb minőségének, és az állami (központi es helyi önkormányzati) hozzájárulás jelentős mértékének biztosítása voltak. (Blaskó-Cseres-Reszkető-Scharle-Váradi, 2009) 
A juttatásokat az állam fizeti a Svéd Társadalombiztosítási Kasszán keresztül. A redisztribúció során felhasznált pénzösszeg kétharmad arányban a munkáltatóktól, egyharmad arányban az állampolgárok adóiból áll össze. Az állam a legtöbb esetben 80 százalékos helyettesítési rátával kompenzálja a szabadság során kimaradó béreket. Ez az első 390 napra vonatkozik azok esetében, akik legalább 240 nap munkaviszonnyal rendelkeznek Svédországban. Az ő esetükben ez a juttatás akkor jár, ha jövedelmük egy bizonyos határt nem ér el. A szabályzás szerint nem vállalhatnak teljes munkaidőben munkát azok, akik éppen részesülnek a juttatásokból, számukra csak a részmunka engedélyezett. A támogatást lehet kérni egész napra, fél napra, de még egy-nyolcad napra is. Akkor is jár állami kompenzáció, ha a szülőnek beteg gyermekét kell ápolnia - ez a lehetőség a gyermek 12 éves koráig vehető igénybe, bizonyos esetekben akár 16 éves korig is. (NGM, 2012)

\subsubsection{Ausztrália ${ }^{5152}$}

Ausztráliában a központi kormányzat felel a gyermekmegőrzés ügyeiért, és a tartományok feladata az óvodai oktatásról való gondoskodás. Az utóbbi szinte univerzális, félnapos a négyéves,- és egész napos az ötéves gyermekek számára.

A születés után egy éves, fizetés nélküli szabadságon osztozhatnak a szülők, de államilag előírt vagy fizetett szabadság nem jár. A fő közpolitikai kihívás Ausztráliában a szülők munkába állását megkönnyítő gyermekmegőrzési lehetőségek kiépítése. Valószínűleg legalább részben a fizetett szabadság teljes hiánya miatt Ausztráliában a háromévesnél kisebb gyermekek édesanyjainak a magyarországit csaknem kétszeresen meghaladó hányada, 56,7\%a dolgozik (OECD 2006, 2000-es adat). Ezt a központi kormányzat szektor-semlegesen, a keresleti oldal felöl igyekezett megoldani, hiszen az egyes tartományokban és községekben erősen különböző megoldásokat preferálnak a helyi közösségek.

Ez magyarázhatja, hogy az ausztrál kormányzat a közösségi kisgyermek-ellátó intézmények közvetlen támogatásáról áttért az adókedvezmények itt nem tárgyalt mechanizmusara, és egy ún. kereslet-oldali támogatási rendszerre. A központi költségvetés tehát továbbra is hozzájárul az országban élö családok gyermekfelügyeleti költségeihez. A támogatás (Child Care Benefit) olyan kisgyermekes családoknak jár,

\footnotetext{
51 http://www.censusdata.abs.gov.au/ABSNavigation/prenav/ViewData?method=Place\%20of\%20Usual\%20Resi dence $\&$ subaction $=1 \&$ producttype $=$ QuickStats $\&$ areacode $=0 \&$ action $=401 \&$ collection $=$ Census $\&$ textversion $=$ false \&breadcrumb=PL\&period=2006\&javascript=true\&navmapdisplayed=true\&\#Income (letöltés ideje: 2012.02 .01 ) 52 http://www.familyassist.gov.au/Internet/FAO/fao1.nsf/content/publications-factsheets-ccb.htm (letöltés ideje: 2012.02.01)
} 
- melyek gyermeke(i) részesült(ek) a különböző oltásokban,

- melyek jövedelme nem halad meg egy bizonyos határt,

- es melyek gyermeke(i) hatósági minőségi jóváhagyással rendelkező gyermekfelügyeleti intézményt ('approved care'), vagy regisztrált szolgáltató ('registered care' - ez lehet dadus, nagyszülö, rokon is) szolgáltatásait veszik igenybe, és azért fizetniük kell ${ }^{53}$.

Az utalványrendszert kiegészíti egy igazságosság-elvű maximális jövedelmi határ, mely alatt egy gyermek eseten családonként évi 127 ezer ausztrál dollár jár. Nagyobb gyerekszám mellett a küszöb progresszíven nő. A fenti kritériumoknak megfelelő minden család gyermekenként heti 24 órányi szolgáltatás után igényelheti a támogatást, de ha mindkét szülő dolgozik, tanul vagy munkát keres, heti ötven óra után jár ugyanez. Sőt, ha mindkét szülö igazolja, hogy heti ötven óránál többet dolgozik, az ötven óránál többre is igényelhető a juttatás. A támogatási összeg függ a gyermekről való gondoskodás típusától. Regisztrált, ám nem intézményi jellegü megoldás esetén jóval kevesebb jár. Az intézményi jellegü megoldás esetén a támogatás vagy a szülő által fizetett szolgáltatási díj csökkentése formájában jelentkezik, és azt az intézménynek utalja a központi költségvetés, vagy a család úgy is dönthet, hogy azt a pénzügyi év vége után egy összegben igényli. Nem intézményi megoldás esetén csak a számlák benyújtásával járó utólagos igénylési csatorna áll nyitva (NGM, 2012).

\subsubsection{USA-Delaware ${ }^{54}$}

Az Amerikai Egyesült Államokban több szervezet foglalkozik kisgyerek-ellátó intézmények minősítésével. A Nemzeti Gyermekgondozó Intézmények Információs Központjának honlapja ${ }^{55}$ kilenc országos akkreditáló testületet sorol fel, köztük Montessori-, keresztény- és családi napközi jellegü intézményekre koncentráló szervezeteket is. A minősítések kiadása folyamán részletes kérdőívet töltetnek ki a jelentkezőkkel, igazolásokat kérnek be, maguk is vizsgálódnak, interjúznak a helyszínen. Söt, a folytatólagos akkreditációhoz szúrópróba-szerü vizsgálatokat is tarthatnak. A legmagasabb presztízsü akkreditáló testület a Nemzeti Kisgyermek-oktatási Egyesület (National Association for the

\footnotetext{
${ }^{53}$ Szerző megjegyzése: egy remek megoldás a nem hivatalos („fekete”) gyermekfelügyelet visszaszorítására - de ehhez elengedhetetlen látni, hogy más juttatást a család nem kap, csak ezt a támogatást. Ameddig megkapja egy család a pénzbeli támogatást is, és finanszírozza az állam a napközbeni gyermekellátást is, addig (az államon kívül) egyik szereplőnek sem érdeke a meglévő gyakorlaton változtatni.

${ }_{55}^{54}$ Minőségbiztosítás, minősítési rendszer bemutatása a célja az alfejezetnek

${ }^{55}$ http://www.hhs.gov/ (letöltés ideje: 2012.02.01)
} 
Education of Young Children ${ }^{56}$ ). Ez tíz dimenzióban fogalmazza meg elvárások hosszú sorát a magukat akkreditáltatni kívánó intézményekkel szemben. Ezek:

- viselkedés (gyermekkel) es kapcsolattartás (pl. pedagógus és a család között)

- fejlesztési curriculum

- foglalkozások, tanulás

- a gyermek fejlődésének felmérése (saját tervek, a megfelelő monitoring-eszköz kiválasztása, individualizált fejlesztés)

- egészség (táplálkozás, környezet, fertőzések elkerülése, kezelése)

- pedagógusok, gondozók

- családok (megismerésük, információ - áramlás feléjük)

- kapcsolatok a tágabb közösséggel

- fizikai feltételek

- menedzsment, vezetés

Delaware állam elindította egy sor nonprofit szakmai- es szülőszervezettel (pl. Children and Families First) közösen a „Delaware-i csillagok a korai sikerért” programját. A program végcélja, hogy minden delaware-i gyermeknek a születéstől a beiskolázásig minőségi gyermekellátási lehetőségek álljanak rendelkezésére. Az intézmények regisztrációja viszonylag egyszerü: a magyar családi napköziknek megfelelő intezmény engedélyeztetéséhez szükséges rendelet a (legfeljebb hat gyermekre vigyázó) felnőttől egy 12 órás tanfolyam elvégzését, büntetlenséget, ha szükséges, helyettesítésről való gondoskodást, megfelelö, kisgyerekeknek biztonságos helységeket, elemi közegészségügyi, elsősegélynyújtási felkészültséget vár el. A rendszer egy egyszerü, egytől öt csillagig terjedő értékeléssel támogatja az intézményválasztási es finanszírozási döntéseiben a szülőket, illetve az államot. Az egy csillag az intézmények engedélyezéséhez szükséges minimális feltételek egy évre való meglétét igazolja, az öt pedig a teljes NEAYC-akkreditációnak felel meg. A minősítési rendszer egyik dimenziója pl. a gondozók szakirányú végzettsége, folyamatos továbbképzése. Az állam jól kezelhető honlapon is bemutatja és hirdeti a minőségbiztosítási rendszert $^{57}$, ugyanitt megtalálható a résztvevő ellátóhelyek tételes listája is, az adott intézmények korábban kapott minősítéseivel együtt.

\footnotetext{
${ }^{56}$ http://www.naeyc.org/ (letöltés ideje: 2012.02.01)

${ }^{57}:$ http://kids.delaware.gov/pdfs/occl_reqs_fcch.pdf
} 


\subsection{7 Értékelés}

A külföldi példák szemléltetik a lehetőségek sokszínüségét. Fontos nemzetgazdasági feladat egy olyan több éves, akár több évtizedes koncepció, amely azt eldönti, hogy milyen módon támogatja az otthonmaradást, és milyen módon támogatja a gyermeknevelés melletti munkavállalást. Fontos annak meghatározása, hogy melyik társadalmi csoporton hogyan tudunk a leghatékonyabban segíteni: amelyik támogatási forma (pl. pénzbeli anyasági támogatás) segíti a gyermekvállalási kedvet az egyik csoportban, az nem segíti ugyanezt a másikban (Temesváry, 2013). A marginalizáció megállítására szolgáló jó gyakorlatként átemelésre került pl. az angliai Biztos Kezdet Program - sajnos a finanszírozás akadozása gátját képezi a fenntarthatóságnak. A családtámogatási rendszernek része a napközbeni kisgyermek ellátás finanszírozása - a két terület összehangolása érdemi előnyökkel járhat mind a demográfiai, mind a foglalkoztatási mutatók javulása terén.

\subsection{Hazai viszonyok}

\subsubsection{Jogszabályi háttér (családi napközi) ${ }^{58}$}

Hazánkban a gyermekek napközbeni ellátását a Gyermekvédelmi Törvény (Gyvt) szabályozza. Ez alapján az önkormányzatok kötelező feladat a 0-14 éves korú gyermekek napközbeni ellátásának biztosítása, különösen a szülő munkába állása esetén. Ezt az önkormányzat megszervezheti bölcsődében (0-3 éves kor), óvodai napköziben (3-6 éves kor, a közoktatási célú délelőtti óvodai foglalatosság után, és a közoktatási szünetekben), iskolai napköziben, családi napköziben. 10.000 fő fölött köteles az önkormányzat bölcsődét létrehozni, ez alatt maga dönthet az ellátás formájáról. Az ellátást az önkormányzat feladatellátási szerződés keretében kiszervezheti nem állami fenntartónak (KSH, 2012).

A családi napközit több jogszabály is szabályozza. Az 1. számú mellékletben felsoroltam a leggyakoribb családi napközit érintő jogszabályokat. A 2. számú mellékletben kivonatoltam a legfontosabb családi napközis jogszabályokat. Kivettem belöle azokat a részeket, melyek egyáltalán nem vonatkoznak a családi napközire. Feketével benne hagytam, amely vonatkozik rá, pirossal kiemeltem, ami kifejezetten családi napközis vonatkozással bír,

\footnotetext{
${ }^{58}$ A fejezet a 2012. január 31-i jogi állapotot tükrözi, csak a lényeges változásokat emeltem ki ezt követően
} 
illetve nagyon fontos a családi napközi müködtetése szempontjából is. A melléklet tartalmazza a kötelezően vezetendő nyomtatványokat is ${ }^{59}$. (Nagy, 2010).

A fentiek közül bemutatom a legfontosabb jogszabályokat, azok rövid lényegi tartalmát, melyek a családi napközik mindennapjára erős kihatással bírnak (Nagy, 2010):

- 1997. évi XXXI. törvény a gyermekek védelméről és a gyámügyi igazgatásról

○ A Gyermekvédelmi Törvény (Gyvt) definiálja a gyermekvédelem rendszerét, ezen belül a gyermekjóléti szolgáltatásokat, ezen belül a napközbeni kisgyermekellátást. A napközbeni kisgyermekellátást 2 fö csoportra osztja: állandó és alternatív ellátások csoportja. Az állandó napközbeni ellátásokhoz tartozik többek között a bölcsőde és a családi napközi, az alternatívok közé pl. a játszóházak, táborok. A bölcsődét az intézmények, a családi napközit a gyermekjóléti szolgáltatások csoportjába sorolja.

○ A Gyvt kimondja, hogy a gyermekvédelem rendszerének (ezen belül a napközbeni kisgyermekellátásnak) a megszervezése kötelező önkormányzati feladat. Ehhez a feladathoz rendelt, a mindenkori költségvetési törvényben meghatározott ún. feladatnormatíván (bölcsődei, családi napközis, óvodai, stb) felül lakosságszám -és összetétel szerinti kiegészítő normatívát rendel, amelynek mértékét és összegét szintén a mindenkori költségvetési törvényben határozza meg.

○ A Gyvt kimondja, hogy a fenti kötelezö önkormányzati feladatot elláthatja más, ún. egyházi vagy nem állami fenntartó. Az állami és a nem állami, egyházi fenntartóknak ugyanazon feltételeket kell (elvileg) teljesítenie. A finanszírozást tekintve sajnos ez a szektorsemlegesség nem áll fenn: az elvileg minden fenntartót megillető ${ }^{60}$ feladatnormatíván felül az önkormányzati fenntartású családi napközi részesülhet az önkormányzatnak juttatott kiegészítő normatívából, az egyházi fenntartó egy ehhez hasonló mértékü ún. egyházi kiegészítő normatívát kap. A nem állami fenntartó pedig csak akkor kapja meg a feladatnormatíva 100\%-át, ha nonprofit -

\footnotetext{
${ }^{59}$ A melléklet a 2012-es jogállapotot tükrözi

${ }^{60}$ azon egyházi, és nem állami fenntartók, akiknek a müködési engedélye 2011. december 31 után született, nem részesülhetnek normatív támogatásban - illetve egy befogadási procedúrán kell átessenek, azonban annak a kimenete egyértelmü, ugyanis miniszteri levélben tudatták a fenntartókkal, hogy senki sem részesülhet befogadásban 2012. január 1 után. www.nrszh.hu (letöltés ideje: 2012.01.20)
} 
azaz a fenntartó vagy civil szervezet (alapítvány, egyház), vagy nonprofit gazdasági társaság. Ha nem nonprofit, abban az esetben csak a normatíva 30\%-át kapja meg. Ha 2012. január 1 után jön létre, akkor pedig még azt sem. A normatíva összege (100\%) 2012-ben: 268.200.- Ft, azokra az ellátási napokra, amelyeken a gyermek a családi napköziben tartózkodott (ez évi 252 ellátási nappal számolva 1.064,- Ft/gyermek/nap). Az önkormányzatnak joga van ellátási szerződést kötni nem állami fenntartóval, ezzel biztosítva az ellátást ${ }^{61}$.

○ A Gyvt ezen felül meghatározza, hogy milyen adattartamú nyilvántartásokat kell vezessen a fenntartó. Ezt több, külön fejezetben lehet megtalálni. Ezek meglétét, szabályosságát folyamatosan ellenőrzik az alábbi szervek: Kormányhivatal („gyámügy”), NCSSZI Családi Napközi Módszertani Igazgatóság ${ }^{62}$, normatíva igénybevétele esetén a Magyar Államkincstár. A működést ellenőrzi elen felül a Kormányhivatal tisztiorvosi része (régi nevén: ÁNTSZ), valamint a NAV, a munkavédlmi ellenőrök, a katasztrófavédelem. Civil fenntartó esetén az ügyészség is.

\section{- 15/1998. (IV. 30.) NM rendelet a személyes gondoskodást nyújtó} gyermekjóléti, gyermekvédelmi intézmények, valamint személyek szakmai feladatairól és müködésük feltételeiről

○ Ez a végrehajtási rendelet szabályozza a személyi és tárgyi feltételeket.

- Ezek szerint egy családi napköziben maximum 5 gyermek gondozható. Ha a gondozónak van állandó segítője, abban az esetben plusz 2 gyermeket felvehet.

- Egy ingatlanban létrehozható több családi napközi is. Ebben az esetben családi napközinként kell teljesíteni a személyi és tárgyi feltételeket.

\footnotetext{
${ }^{61}$ Sajnos csak joga van ellátási szerződést kötni, és nem kötelessége - ahogy a kiegészítő normítívát sem köteles az adott feladatra költeni, sem átadni nem köteles nem állami fenntartónak,akkor sem, ha az a nem állami fenntartó látja el az önkormányzat helyett a feladatot.

62 http://www.ncsszi.hu/modszertani-epitkezes-1_22/munkacsoportok-2_56/gyermekvedelmi-4_231 (letöltés ideje: 2012.02.01)
} 
- A családi napközit bárhol létre lehet hozni, ahol ki lehet alakítani a MÚ-ban leírt feltételeket ${ }^{63}$.

- A családi napközit „bárki” müködtetheti, aki egy külön jogszabályban meghatározott, aki legalább 8 általános iskolai végezttséggel bír, és egy külön jogszabályban ${ }^{64}$ meghatározott 40 órás tanfolyamot elvégez. Mivel a tárgyi feltételek kritikája mellett ez a másik fő támadáspont a családi napközi ellen (és feltételezésem szerint az elterjedésének egyik gátja, hiszen a finanszírozási többletet épp azokhoz a vélt magasabb szakmai szempontokhoz rendelik a bölcsőde, óvoda esetbében, melyeknél könnyen lehet, hogy adott családi napközi többet teljesít (pl. magasabb felszereltség, magasabb iskolai végzettség), ezért erről kutatásom empirikus részében külön szót ejtek. Mindezek mellett megjegyzem, hogy magánszemély nem lehet a fenntartója családi napközinek, tehát vállalkozóvá kell válni ahhoz, hogy valaki családi napközit nyithasson, így önfoglalkoztató lesz - vagy munkavállalóként fog tudni megjelenni a munkaerőpiacon, mint családi napközi gondozó.

- Ezen jogszabály mellékleteként használja a szakma az ún. Módszertani Útmutatót, melyet dolgozatomhoz 3. számú mellékletként csatoltam, A MÚ tartalmazza azokat a közegészségügyi, építésügyi és szakmai minimumokat, melyeket a családi napközinek be kell tartania (Kovácsné, 2013).

- 259/2002. (XII. 18.) Korm. rendelet a gyermekjóléti és gyermekvédelmi szolgáltatótevékenység engedélyezéséről, valamint a gyermekjóléti és gyermekvédelmi vállalkozói engedélyről

○ Ez a jogszabály szabályozza a müködési engedély kiadásának, változtatásának és megszüntetésének menetét, módját. Összefoglaltam, mit kell a fenntartónak beadnia az engedélyezéshez:

\footnotetext{
${ }^{63}$ Ez az egyik neuralgikus pontja a jogalkotásnak. Ha a jó szándékot fel is tételezzük, amellyel ez a pont megszületett, mivel nem lett elhatárolva a magas ellátotti létszám miatt intézményi feltételeket teljesíteni köteles bölcsődétől. Így ez egy támadási felület maradt: bár az ellátás minőségén nem feltétlenül javít az orvosi elkülönítö, a könyvtárszoba, a mosoda és a HACCP-s konyha (amelyeknek a kis létszámú ellátásnál jogosan nincs létjogosultsága), de ezek hiánya miatt alacsonyabb tárgyi színvonallal támadják a családi napközit.

${ }^{64} 29 / 2003$ (V.20) ESzCsM rendelet a helyettes szülők, a nevelőszülök, a családi napközit müködtetők képzésének szakmai és vizsgakövetelményeiről, valamint az örökbefogadás előtti tanácsadásról és felkészítő tanfolyamról
} 
Csana engedélyeztetés (saját szerk)

\begin{tabular}{|c|c|c|c|}
\hline BEADANDÓ & $\begin{array}{c}\text { ÁLLAMI } \\
\text { FENNTARTÓ }\end{array}$ & $\begin{array}{l}\text { NEM ÁLLAMI } \\
\text { FENNTARTÓ }\end{array}$ & $\begin{array}{l}\text { EGYHÁZI } \\
\text { FENNTARTÓ }\end{array}$ \\
\hline $\begin{array}{l}\text { Szolgáltatást nyújtó (csana vezető) és a } \\
\text { helyettesének csana tanúsítvány másolata }\end{array}$ & $\mathrm{X}$ & $\mathrm{X}$ & $\mathrm{X}$ \\
\hline $\begin{array}{l}\text { Szolgáltatást nyújtó (csana vezető) és a } \\
\text { helyettesének erkölcsi bizonyítványa }\end{array}$ & $\mathrm{X}$ & $\mathrm{X}$ & $\mathrm{X}$ \\
\hline $\begin{array}{l}\text { csana vezető és helyettes Gyvt } 15 \S \\
\text { nyilatkozata }\end{array}$ & $\mathrm{X}$ & $\mathrm{X}$ & $\mathrm{X}$ \\
\hline $\begin{array}{l}\text { csana vezetó és helyettes Egészségügyi } \\
\text { nyilatkozata, illetve háziorvosi igazolása }\end{array}$ & $\mathrm{X}$ & $\mathrm{X}$ & $\mathrm{X}$ \\
\hline Szakmai program & $\mathrm{X}$ & $\mathrm{X}$ & $\mathrm{X}$ \\
\hline $\begin{array}{l}\text { Épület(rész) használati jogcímét bizonyító } \\
\text { okirat másolta }\end{array}$ & $\mathrm{X}$ & $\mathrm{X}$ & $\mathrm{X}$ \\
\hline Előzetes szakhatósági hozzájárulás & $\mathrm{X}$ & $\mathrm{X}$ & $\mathrm{X}$ \\
\hline $\begin{array}{l}\text { Fenntartó és a szolgáltató adószámát } \\
\text { igazoló okirat másolatát }\end{array}$ & $\mathrm{X}$ & & \\
\hline Alapító okirat másolat & $\mathrm{X}$ & & \\
\hline Társulási szerződés másolat & $\mathrm{x}$ & & \\
\hline Normatíva nyilatkozat & $\mathrm{X}$ & & \\
\hline Felelősség-biztosítás másolat & & $\mathrm{x}$ & $\mathrm{x}$ \\
\hline Ellátási szerződés & & $\mathrm{x}$ & $\mathrm{X}$ \\
\hline Köztartozás mentes adózói igazolás & & $\mathrm{X}$ & $\mathrm{x}$ \\
\hline Egyéni vállalkozói igazolvány & & $\mathrm{x}(\mathrm{EV})$ & \\
\hline Cégkivonat & & $\mathrm{x}(\mathrm{CÉ} G)$ & \\
\hline Bírósági kivonat & & c (CIVIL) & \\
\hline Bírósági kivonat & & & $\mathrm{X}$ \\
\hline Fenntartói nyilatkozat & & & $\mathrm{x}$ \\
\hline Adószám-igazolás & & $\mathrm{X}$ & $\mathrm{x}$ \\
\hline Normatíva nyilatkozat & & $\mathrm{X}$ & $\mathrm{X}$ \\
\hline $\begin{array}{l}\text { NRSZH befogadás, Ellátási szerződés } \\
\text { vagy pályázati igazolás }\end{array}$ & & $\mathrm{X}$ & $\mathrm{X}$ \\
\hline
\end{tabular}

13. ábra, Csana engedélyeztetés (saját szerk)

○ Mielőtt ezeket az iratokat beadná, létre kell jöjjön a cég (aki a fenntartó lesz), meg kell írjon egy szakmai programot (amit a Szociális-és Gyermekvédelmi Főigazgatóság Módszertani Főosztályának ${ }^{65}$ szakértői jóvá kell hagyjanak). Ezen felül ezen jogszabály „A” mellékletét is ki kell töltse. Így egyben tudja beadni a müködési engedélyezési kérelmet. A szakhatósági díjak önmagukban kb. 150.000 - 500.000.- Ft-ig terjednek (szakhatóságonként változó, hogy mit kérnek, és mit fogadnak el -

\footnotetext{
${ }^{65}$ http://www.szgyf.gov.hu/ (letöltés ideje: 2013.01 .10 )
} 
köszönhetően az elnagyolt szabályozásnak, és az egyedi hazai jogértelmezési gyakorlatnak ${ }^{66}$ ).

- 226/2006. (XI. 20.) Korm. rendelet a szociális, gyermekjóléti és gyermekvédelmi szolgáltatók, intézmények ágazati azonosítójáról és országos nyilvántartásáról

- 213/2009. (IX. 29.) Korm. rendelet az egyházi és nem állami fenntartású szociális, gyermekjóléti és gyermekvédelmi szolgáltatók normatív állami támogatásáról

- 328/2011. (XII. 29.) Korm. rendelet a személyes gondoskodást nyújtó gyermekjóléti alapellátások és gyermekvédelmi szakellátások térítési díjáról és az igénylésükhöz felhasználható bizonyítékokról

○ Ez a jogszabály szabályozza a térítési díjat, annak mértékét, valamint a kötelezően vezetendő nyomtatványokat.

\footnotetext{
${ }^{66}$ Sajnos ezen sorok írója is számtalanszor elszenvedője volt ennek a sajátosan magyar hatalmi hozzáállásnak, amikor is a hatóság képviselője önhatalmúan kér a jogszabályban elöírtakon felüli megfeleléseket. Remélem, hogy dolgozatomnak hozadéka lesz az ilyen és hasonló eljárások gyakoriságának csökkenése is.
} 


\subsubsection{Bölcsődék, óvodák és családi napközik áttekintése}

Nem célom jelen fejezetben a bölcsődék és óvodák történeti áttekintéséről, müködéséröl részletes képet adni. A családi napközikre fókuszálok, azonban az ellátóhelyek egymás mellettisége okán vonok párhuzamot többször is közöttük. Átgondolandó közelíteni az ellátási formákat - egy megfelelö minőségbiztositási protokollal ez viszonylag könnyedén megtehetö lenne.

\subsubsection{Bölcsőde}

A bölcsőde hazánkban a Gyermekvédelmi Törvény által szabályozott napközbeni kisgyermek alapellátás része. Európában az első bölcsődék létrejötte a gyári nagyipar kialakulásához köthető, elsősorban a női munkásokat foglalkoztató iparágak üzemeinek létesítése támasztotta az igényeket. Gondozási lehetőség hiányában a dolgozó szülők a munkavégzés idejére gyermekeiket vagy bezárták - sokszor egészségtelen - lakásaikba, vagy magukkal vitték, kitéve ezzel a kicsiket a munkahelyi ártalmaknak. Bölcsőde először 1844ben Franciaországban, majd nem sokkal később Angliában, Dániában, Olaszországban, Németországban és Ausztriában nyitotta meg kapuit.

Magyarországon az első bölcsőde 1852-ben egy Kalap utcai lakásban kezdte meg müködését, fő funkciója már akkor is a napközbeni ellátás volt. Létrejöttét az Első Pesti Bölcsődei Egylet segítette elő, gyüjtések segítségével teremtették elő a szükséges forrásokat. Az akkori rövid szülési szabadság okán már két hetes koruktól gondoztak csecsemőket négy éves korig. Kötelező volt az édesanyák számára, hogy csecsemőiket délben, ebédszünet alatt megszoptassák. A nyitva tartás igazodott a munkarendhez, reggel 5 órától este 7-ig biztosították az ellátást. Az első, kimondottan bölcsődének épített intézmény 1877-ben nyitotta meg kapuit Józsefvárosban. Ybl Miklós tervei alapján készült, és a mai napig bölcsődeként funkcionál. (Vokony, 2002). Az első hivatalos statisztikai adat a bölcsődékről 1938-ból származik. A Magyar statisztikai évkönyv szerint abban az évben 37 bölcsődében 1.070 kisdedet gondoztak.

A második világháború után a bölcsődék fejlesztése állami irányítás alá került, a nők munkához való jogának törvénybe iktatásával együtt biztosítani kellett a dolgozó nők gyermekeinek napközbeni ellátását. Üzemek, tanácsok kezdtek bölcsődét kialakítani lakásokból és más rendeltetésủ intézményekből, például kórházakból. Az intézmények számának alakulása egészen a nyolcvanas évekig növekedö tendenciát mutatott. Az üzemi bölcsődék száma a 60-as években volt a legmagasabb (9 év alatt több mint duplájára nőtt), de 
arányuk az összes bölcsődén belül ekkor már csökkent, az újonnan épült bölcsődék önkormányzati fenntartásúak voltak (akkori megnevezésük: területi bölcsőde). A hatvanas évek második felében kezdődött lakótelep-építések is hozzájárultak a bölcsődék számának növekedéséhez, a legtöbb lakótelep komplex gyermekellátást is biztosított: bölcsődékkel, óvodákkal, iskolákkal együtt tervezték, építették meg őket. Az 1979. év volt a bölcsődék eddigi történetének a csúcspontja, mind az intézmény és férőhelyszámok tekintetében, mind az igénybe vevők számának alakulása alapján. Rá tíz évre az üzembezárások nyomán közel 300 intézmény szünt meg, közülük 200 üzemi bölcsődeként müködött korábban. Az intézményfenntartók között 1990-ben már csak 8,5 százalékos arányban voltak jelen az üzemek, a következő évtized elejére pedig ki is koptak a rendszerből. A rendszerváltozás a bölcsődei fenntartók körét „,színesebbé tette”, de a folyamat nagyon lassan indult. 2000-2005 között az intézmények alig 5 százalékát müködtette nonprofit szervezet, egyház vagy társas vállalkozás (KSH, 2012).

Mivel az 1967-ben bevezetett gyes elsősorban az alacsonyabb iskolai végzettséggel és kereseti lehetőségekkel rendelkezők körében tudott elsősorban hatékony családpolitikai eszközzé válni (Blaskó, 2008, Pongrácz, 2011), a termékenység növelése érdekében a magasabb végzettséggel és keresettel rendelkezők gyermekvállalási feltételeit próbálták a gyed 1985. évi bevezetésével javítani. Hatására 1986-1987-ben a bölcsődét igénybe vevő gyermekek száma és aránya is enyhén nőtt. A munkavállalás mellett gyermeket vállaló nők részére - bevezetésekor - a gyed a gyermek egy, majd másfél, később 2 éves koráig folyósított ellátás volt, az igénybevétel végeztével visszatérve a munkaerőpiacra, ismét nagyobb arányban támasztottak igényt napközbeni ellátás biztosítására.

A bölcsődék helyzetének nem kedvezett a rendszerváltozás, hatására rengeteg üzemi bölcsődét zártak be, így a rendelkezésre álló férőhelyek száma drasztikusan, a felére apadt. A csökkenő foglalkoztatottság és a növekvő munkanélküliség - a születésszám visszaesése mellett - a napközbeni ellátást nyújtó intézmények iránti keresletet is visszavetette. A kilencvenes évek közepétől a családtámogatási rendszer többszöri módosításához, a nők munkaerő-piaci helyzetének és az ellátás iránti igények változásához az intézményrendszer nem tudott megfelelően alkalmazkodni. (KSH, 2012)

A rendszerváltást követően csökkenő női foglalkoztatás és a müködő bölcsődei férőhelyek számának további visszaesése azt eredményezte, hogy a 3 éven aluli gyermekek közül kisebb arányban részesültek napközbeni ellátásban. A gyed 1996 és 1999 közötti megszüntetése, a gyed helyett az alanyi jogon járó, jövedelemvizsgálathoz kötött és értéknövelt gyes igénybevételi lehetősége a nők egy részét visszaterelte a munkaerőpiacra, 
ami együtt járt a nők foglalkoztatási rátájának növekedésével, így újra emelkedett a bölcsődék iránti igény is. Ebben a tendenciában csak a gyed 2000. évi újbóli bevezetése okozott átmeneti törést, amikortól a gyermekek aránya az intézményekben átmenetileg csökkent. Ehhez az is hozzájárult, hogy a bölcsődei férőhelyek száma a 2003-2004-es években volt a mindenkori legalacsonyabb szinten, nem érte el a 24 ezret. A következő években a női foglalkoztatás növekedésével, a családtámogatások igénybevétele melletti munkavégzés lehetőségének biztosításával, valamint a bölcsődei ellátástípusok színesítésével az elmúlt 8 évben fokozatosan emelkedett a bölcsődében gondozott gyermekek száma. Míg 2000-ben ezer 3 éven aluli gyermekböl alig 100-nak, 2011-ben már több mint 134 gyermeknek jutott a bölcsődékben féröhely és gondoskodás.

2011-ben hazánkban 689 bölcsőde müködött. A 35450 féröhelyen $36 \quad 685$ kisgyermeket láttak el. A gyermekek 66 százaléka a május 31-i referencianapon még nem töltötte be 3. életévét, a többiek jellemzően még abban az évben óvodai nevelésbe távoztak. A bölcsődék kihasználtsága még a 2010-ben végrehajtott 20 százalékos férőhelybővítés ellenére is több mint 100 százalékos. A területi különbségekre a legjellemzőbb példa, hogy minden 4. intézmény Budapesten található. Minden harmadik pedig Közép-Magyarország régiójában. A települések népességnagysága alapján megállapítható, hogy a bölcsődék kétharmada a 10000 főnél népesebb településeken müködött, ami összefügg a gyermekvédelmi törvény előírásaival, illetve kifejezi az intézmény létrehozás- és fenntartás anyagi és egyéb nehézségeit is, vagyis ahol nem kötelező a bölcsődei ellátás megszervezése, ott csak nagyon csekély számú szolgáltató vállalkozik ilyen ellátás biztosítására. (KSH, 2012).

\subsubsection{2 Óvoda}

A mai értelemben vett óvodák hosszú történelmi fejlődés eredményei. Az ipari fejlődés útjára lépő nyugat-európai országokban már viszonylag hamar felmerült az egészen fiatal gyermekek valamiféle intézményes gondozásának-nevelésének igénye. Ennek oka elsősorban szegénysorban élő nők tömeges kényszer-munkavállalásában keresendő. $\mathrm{Az}$ óvodarendszer társadalmi funkciói összetettek: napközbeni alapellátást nyújtanak (kisgyermekek felügyelete, gondozása, szülőhelyettesítő szolgáltatásként), szociálpolitikai juttatás (a térítési díj a közterhekből kerül kiegyenlítésre, így a szülőknek „kvázi ingyenes”), munkaerö-politika fontos eszközei (lehetővé válik mindkét szülő munkavállalása), iskola előkészítő szerepük miatt a közoktatási, köznevelési rendszer részei (Szalai, 1998).

\section{Óvodatörténet}


- 1828. június 1. Budán a Miklós utcában megnyitott közép Európában elsőként a Magyarországi kisdedóvó intézet, Brunszvik Terézia megalapításával. Az angol kisgyermekiskolákról szóló német nyelvre lefordított Wildespin címü könyv mintájára. Bizonyos fokig a kisdedóvók az iskolahelyettesítő funkciót is töltöttek be. A két intézmény közötti különbségre Brunszvik Terézia az Utasítás a Tanító uraknak címü írásában hívja fel a figyelmet, miszerint: „A morális és triviális iskolák pusztán oktató intézmények, ami ott fődolog az itt mellékes és fordítva. Az erkölcsiség érdekében alakultak ezek az intézmények; ez itt a cél, nem pedig a tudás." (Vág, 1994)

- 1891. évi XV. törvény, az első óvodai törvény: Elöírta a kisdedóvodás céljára szolgáló intézményt. Az intézmények fenntartói az állam, egyház. Felügyeletet valamennyi kisdedóvó felett az állam gyakorolja. Az óvoda feladata: óvó védő funkció, magyar nyelv tanítása. Egyértelmủen elöírja, hogy tanításnak az intézményben helye nincs! (Vág, 1994, Aczél, 2012)

- 1919 Tanácsköztársaság idején az óvoda szociális- pedagógiai funkcióját erősítve JÁTÉKISKOLÁK jöttek létre. (Vág, 1994).

- 1936: Belügyminisztérium hatáskörébe kerül át a kisdedóvodás igazgatása. Az óvoda szociálpolitikai intézménnyé válik. Felerősödik szemléletében és tartalmi anyagban is a nemzeti szellem és a militarista szemlélet. A zsúfoltság rendszeres nevelőmunkára alig ad lehetőséget. (Vág, 1994, Szalai, 1998)

- 1945 után erősödő ellátó funkció, általánossá váltak a magas létszámú csoportok. (Aczél, 2012)

- 1949: Az óvodák ismét visszakerülnek a Vallás-és Közoktatásügyi Minisztérium felügyelete alá. A korábban a bölcsődékkel együtt kezelt óvodák ügye különválik, a bölcsődék a Népjóléti, majd Egsészségügyi Minisztériumhoz kerülnek. (Aczél, 2012)

- 1953. évi III. törvény (Kisdedóvásról szóló törvény), Módszertani levél és az 1957-es kézikönyv segíti a tervszerüséget. Az állam átvállalja a gyermekek gondozását, nevelését. A kézikönyv, állást foglal amellett, hogy az óvoda elsősorban nevelő intézmény. Elveiben és szemléletmódjában hangsúlyozza az oktatás eszközjellegét. Tisztázza a foglakozási ágak és módszerek fogalmát és viszonyát.

- 1971: Országos Nevelési Program jelenik meg. Az iskolára való előkészítés közoktatás politikai feladattá vált. Érvénybe lép az iskolára való előkészítés az óvodába nem járó gyermekeknek. ONAP továbbfejlesztésének igénye hamar jelentkezett. 
- 1989 TONEP koncepciójába beépítették az európai tapasztalatokat, gondolatokat. Öt éves kortól óvodakötelezettség. Funkciók: ellátó, gondozó, nevelő, iskola előkészítő.

- 1993. évi LXXIX. törvény a közoktatásról kimondja, hogy minden gyermek 6. életévének betöltésétől iskolaköteles, melyet megelőző tanévben iskola-előkészítő foglalkozáson kell részt vennie. Azaz bár tévesen így terjedt el a köztudatban, de nem a nagycsoportot teszi kötelezővé a tövény, hanem az iskolaelőkészítő foglalkozást, mely a szülö kötelezettsége.

- 1996: Országos Óvodai Nevelési Program ${ }^{67}$. A program szintén három funkciót jelölt meg. 1. Óvó védő, 2. szociális, 3. nevelő személyiségfejlesztő (Spengler, 1995)

- Az Óvodai nevelés országos alapprogramjáról szóló 363/2012. (XII. 17.) Korm. rendelet

- 2011. évi CXC. törvény a köznevelésről kimondja, hogy minden harmadik életévét betöltött gyermek köteles részt venni óvodai nevelésben. A jogszabály eredeti tervezetében benne volt az a kiegészítés, hogy a családi napköziben is teljesíthető a kötelező óvodáztatás, ha a családi napközi óvodapedagógust alkalmaz. Ezt azonban kikerült a jogszabályból, jelenleg szakmai és társadalmi vita folyik a témában. A jelenleg érvényben lévő, 2012-es ONAP így rendelkezik: „A hároméves kortól kötelező óvodába járás ideje alatt az óvodai nevelési folyamat célja, feladata a gyermeki személyiség harmonikus testi és szociális fejlődésének elősegítése ${ }^{68}$. Nehezen védhető szakmailag, hogy a fenti tényezők miért csak óvodában teljesülnek, akkor, ha egy más típusú ellátóhely képes az óvoda személyi és tárgyi feltételeit biztosítani, valamint a szakmai programja megfelel az adott korosztály szükségleteinek.

\subsubsection{Családi napközi (Csana)}

Az első családi napköziket hazánkban 1993-ban nyitották Kiskunhalason, egy modellkísérlet keretében ${ }^{69}$ (Pro Excellentia Alapítvány, Fehér Kereszt Alapítvány, Rockefeller Brothers Found). A szakmai hátteret a Bölcsődék Országos Módszertani Intézete nyújtotta. A jó szándék vitathatatlan: létrehozni egy olyan rugalmas ellátási formát, amely képes a meglévő rigid bölcsődei, óvodai, iskolai napközi rendszer hiányosságait pótolni. Ám

\footnotetext{
${ }^{67}$ érvényben: Az Óvodai nevelés országos alapprogramjáról szóló 363/2012. (XII. 17.) Korm. rendelet

${ }^{68}$ forrás: http://www.ovi-suli.hu/pdf/20092013Alapprogramtablazata.pdf (letöltés ideje: 2013.02.10)

${ }^{69} \mathrm{http}: / /$ www.proexcellentia.hu/A\%20csal\%E1di\%20napk\%F6zi_tartalom.htm (letöltés ideje: 2013.02.10)
} 
sajnos valószínűleg nem készültek olyan releváns megvalósíthatósági tanulmányok, amelyek a tényleges elterjedésben segítettek volna, így a finanszírozási rendszerbe csak későn, 2004ben emelték be, akkor is a bölcsődei normatívánál lényegesen kisebb mértékben. Az elterjedésnek komoly gátat vet a hazai kisgyermek-ellátás egységes minőségbiztosításának a hiánya, amely egyrészt átjárhatóvá tenné az ellátási formákat, másrészt racionalizálná a normatív támogatások és családtámogatások jelenlegi pazarló rendszerét. Az elterjedés lassúságát egyértelműen mutatja, hogy a Pro Excelentia Alapítvány 2001-es beszámolójában még „kb. 30-40” müködő családi napközi említ. Ez a szám a a KSH adatai szerint 2009-ben mutatott először szignifikáns növekedést, majd 2010-től a növekedés dinamikus volt. Ezt a növekedést a szülöi igények valós léte indokolta, azonban a növekedésnek gátat szabott a 2012. január 1-én életbe lépett normatíva befogadási moratórium, hiszen a hozzáférhetőségnek alapvető eszköze a megfizethetőség.

A jogszabály szerint a családi napközi létrehozható az ellátást nyújtó saját otthonában, vagy más, e célra kialakított helyiségben. Így akár egy munkahelyen is - a kis létszám és az ebből adódó alacsony beruházási költség mindenképp a családi napközik elterjesztésének kedvez. Azaz kedvezne, ha az állam figyelembe venné a vállalatok ez irányú igényét: adókedvezménnyel, költségeloszlással kellene segíteni a folyamatot.

A családi napközikben gondozott gyermekek zöme bölcsődés korú a KSH adatai szerint, a többiek megoszlanak az óvodás és az iskolás korcsoportok között.

\section{Csanában gondozott gyermekek (KSH,2012)}

Családi napköziben gondozott gyermekek korcsoportos megoszlása, 2008-2011

\begin{tabular}{|c|r|r|r|r|r|r|r|}
\hline Év & $\begin{array}{c}4-11 \\
\text { hónapos }\end{array}$ & $\begin{array}{c}12-23 \\
\text { hónapos }\end{array}$ & $\begin{array}{c}24-35 \\
\text { hónapos }\end{array}$ & 3-4 éves & 5-6 éves & 7-10 éves & 11-14 éves \\
\hline 2008 & 1,3 & 15,4 & 45,6 & 21,6 & 4,2 & 8,0 & 3,9 \\
\hline 2009 & 0,5 & 14,3 & 45,0 & 20,3 & 3,9 & 9,6 & 6,4 \\
\hline 2010 & 0,5 & 12,2 & 45,7 & 20,5 & 3,7 & 9,8 & 7,7 \\
\hline 2011 & 0,5 & 11,6 & 43,1 & 24,2 & 5,3 & 8,3 & 7,0 \\
\hline
\end{tabular}

14. ábra, Csanában gondozott gyermekek (KSH,2012)

Jól jellemzi a minisztérium álságosnak mondható hozzáállását a Szociális-és Munkaügyi Minisztérium 2009-es anyaga, mely meg sem említi a családi napközit mint ellátási formát:

„Az iskoláskor előtti korosztály napközbeni, intézményes ellátása hazánkban a kezdetektől fogva - dominánsan - két intézménytípusra, a bölcsődékre és az óvodákra hárul. Sajnos egyéb alternatív ellátási forma nem terjedt el, ez leginkább történeti okokra (szocialista ideológia) 
vezethetö vissza. Annak ellenére, hogy mindkét intézmény a kisgyermekek nevelését hivatott betölteni, a bölcsöde és az óvoda két különbözö minisztériumhoz tartozik, valamint nem egyenlök a feltételek a képzést és a képzettséget illetően sem. Ezért a közös intézmény pedagógiai elveit és az azokhoz kapcsolódó gyakorlatát különösen fontos egymáshoz illeszteni. Az eltérö minisztériumok eltérö preferenciákkal járnak együtt, melyek leginkább megragadható elemei, hogy a bölcsödék inkább gondozási-nevelési feladatokat látnak el, (ugyanakkor szigorú közegészségügyi szabályokat is be kell tartani), ezzel szemben az óvodák az oktatási rendszer legelsö állomását képezik, noha a gondozási-nevelési teendök ott sem elhanyagolandók. Ez azonban - a tények ellenére - leegyszerüsitett, pusztán a jelenség szintjén megfogalmazott álláspont, hiszen a létezö, a gyermekek életkori eltéréseiböl szükségszerüen következö eltérések ellenére, mindkét intézmény elsösorban nevel. Noha az érvényben lévő képzések nem egyformák, hierarchiát teremteni a végzettség szerint kisgyermekgondozók és az óvodapedagógusok között nem pusztán etikátlan, hanem a pedagógiai egységesség ellen valló megkülönböztetés lenne.

A két intézményrendszer nevelési elveinek, szemléletének, valamint az erre épülö gyakorlatnak, a gyermekkép, a gyermekröl vallott azonos gondolkodás miatt szükséges egységesen müködnie. Cél, hogy a bölcsödébe járó kisgyermek, ha átlép az óvodába, ne vegyen észre - a személyiségét befolyásoló tényezők között (elsősorban a vele kapcsolatos attitüdök és bánásmód terén) - alapvetö változásokat. A másik épület, (vagy csak másik csoportszoba) más tárgyi körülmények, más gyerekek, és más felnőttek élménye természetes módon illeszkedjen addigi életébe, a változásokat érdekesnek, kedvezönek élje meg. E kontinuitás élményét a szülök számára is biztositani kell. Mindez akkor lehetséges, ha a két intézmény pedagógiai programja egymásra épül. (A pedagógiai koherencia kedvéért indokolt megemliteni, hogy az egységes gyermekkép és a hasonló bánásmód - kívánatos esetben - nem fejezödik be az óvodáskor végére, hanem folytatódik az általános iskola alsó tagozatában, és lehetöség szerint még azután is.) ",70.

\subsubsection{Minőségbiztosítás}

A rossz minőségü kisgyermekellátás káros, ez kijelenthető. A magas színvonalú gyermekellátó helynek azonban léteznek pozitív hatásai (Nagy, 2013). De mitől JÓ egy ellátóhely? Objektív egységes mérési rendszer hiányában kihagyhatatlanok a szubjektív

\footnotetext{
${ }^{70}$ forrás: www.szmm.gov.hu/download.php?ctag=download\&docID=20707
} 
tényezők: láthatóan jól érzi magát a gyermek, szépen fejlődik, szereti a gondozókat, a pedagógusokat. Ahhoz, hogy egy egységes mérési rendszert ki lehessen dolgozni, közelíteni kell egymáshoz a különböző ellátási formák standardjait. Ez, ismerve a több évtizedes rossz beágyazódást, szinte lehetetlen feladatnak tünik. A bölcsődéket a BOMI (Bölcsődék Országos Módszertani Intézete) által kiadott, olykor a szakmát is megosztó korszerü és kevésbé korszerü szakmai anyagok alapján müködtetik a fenntartók. Az óvodákat a Közoktatási, illetve a Köznevelési Törvény végrehajtási rendeleteiben szabályozott ONAP (Országos Óvodai Nevelési Alapprogram) alapján megírt saját helyi nevelési alapprogramok jellemzik - ezek sajnos jellemzően sablonos és általános elveket foglalnak magukba, ritka a valódi egyedi szín. A családi napköziket a Módszertani Útmutató alapján megírt szakmai program szerint kell működtetni - melyet a módszertan akkor sem fogad el pedagógiai programnak, ha pedagógusok végzik a tevékenységet. Ezt „színesíti” az egységes óvodabölcsőde, ami a gyakorlatban (kevés üdítő kivételtől eltekintve) az óvoda egyik szobája integrált „minicsoportot” jelent, gyakran valódi megfelelő személyi és tárgyi feltételek nélkül.

Ahhoz, hogy egy egységes standard elkészülhessen, alapjaiban kellene újragondolni a kisgyermekellátást. Mindegy, hogy hogyan hívják az adott helyet, az is mindegy, hol van (akár egy vállalaton belül), ha egy korosztályra szabott alapfeltételnek képes megfelelni. Mik ezek a minősítő szempontok?

1. Gondozók végzettsége, szupervíziója (folyamatos továbbképzése)

2. Egy gondozóra jutó gyermeklétszám (ténylegesen, nem az ölelkező müszakkal számolva)

3. Gondozó személy stabilitása, állandósága (kötődés kialakulása miatt fontos)

4. Csoportlétszám (fertőzéses, főként felsőlégúti betegségek miatt elengedhetetlen figyelembe venni a korosztályos sajátosságokat)

5. Nyitva tartás folytonossága, rugalmassága (minimális leállás maximum évi 2 hét, napközbeni nyitva tartás hossza alkalmazkodjon a munkaidőhöz).

Ehhez a jelenlegi ellátást szabályozó szakemberek között el kell induljon egy diskurzus, ahol sikerül olyan szabályozást megalkotni, mely végig szem előtt tartja azt a tényt, miszerint nem a társadalom van az ellátórendszerért, hanem az ellátórendszer azért létezik, hogy szolgálja, kiszolgálja a társadalom valós, mindenkori igényeit. Azét a társadalomét, amely ezt a rendszert finanszírozza, müködteti. Egy család ugyanis akkor vállal gyermeket, ha biztosítottnak látja a megélhetést, a gyermek felnevelését. Ehhez a jelenlegi társadalomban mindkét fél keresetére szükség van. Egy szülő azonban csak akkor produktív és megbízható munkavállaló, ha jó helyen tudja a gyermekét addig, ameddig dolgozik. Ehhez olyan 
ellátóhelyre van szükség, amely alkalmazkodik a család valós igényeihez (kiszolgálja azokat), megfelelő a gyermeknek (fizikai és lelki síkon egyaránt), könnyen elérhető és hozzáférhető. A 24. órában vagyunk mind népesedési, mind morális szinten. A kérdés nem az, hogy egy családi napköziben dolgozó óvónő képes-e megfelelően ellátni egy óvodáskorú gyermeket, hanem az, hogy az elérhető szolgáltatásokat képes-e az aktuálpolitika úgy alakítani a valós társadalmi igényekhez, hogy ennek a szándéknak a „szakma” nem sértődött gátlója, hanem konstruktív kidolgozója lesz.

\subsubsection{Férőhelyek}

Mivel az irodalmi áttekintés során többféle adattal találkoztam a bölcsődék, családi napközik, férőhelyek számát illetően, így megpróbáltam én magam is megtudni, hogy pontosan hány bölcsőde, családi napközi müködik hazánkban, hány férőhelyet tudnak biztosítani, ezeken a férőhelyeken hány gyermeket látnak el, és hányan is dolgoznak bölcsődében, illetve családi napköziben.

A Nemzetgazdasági Minisztérium 2012-es anyagában talált adatok vagy a KHS-tól származnak, vagy az általam is ismert és idézett szerzők tanulmányaiból. Néhány szemléletes ábrát mellékelek az anyagból. 
0-4 éves lakosok (NGM,2012)

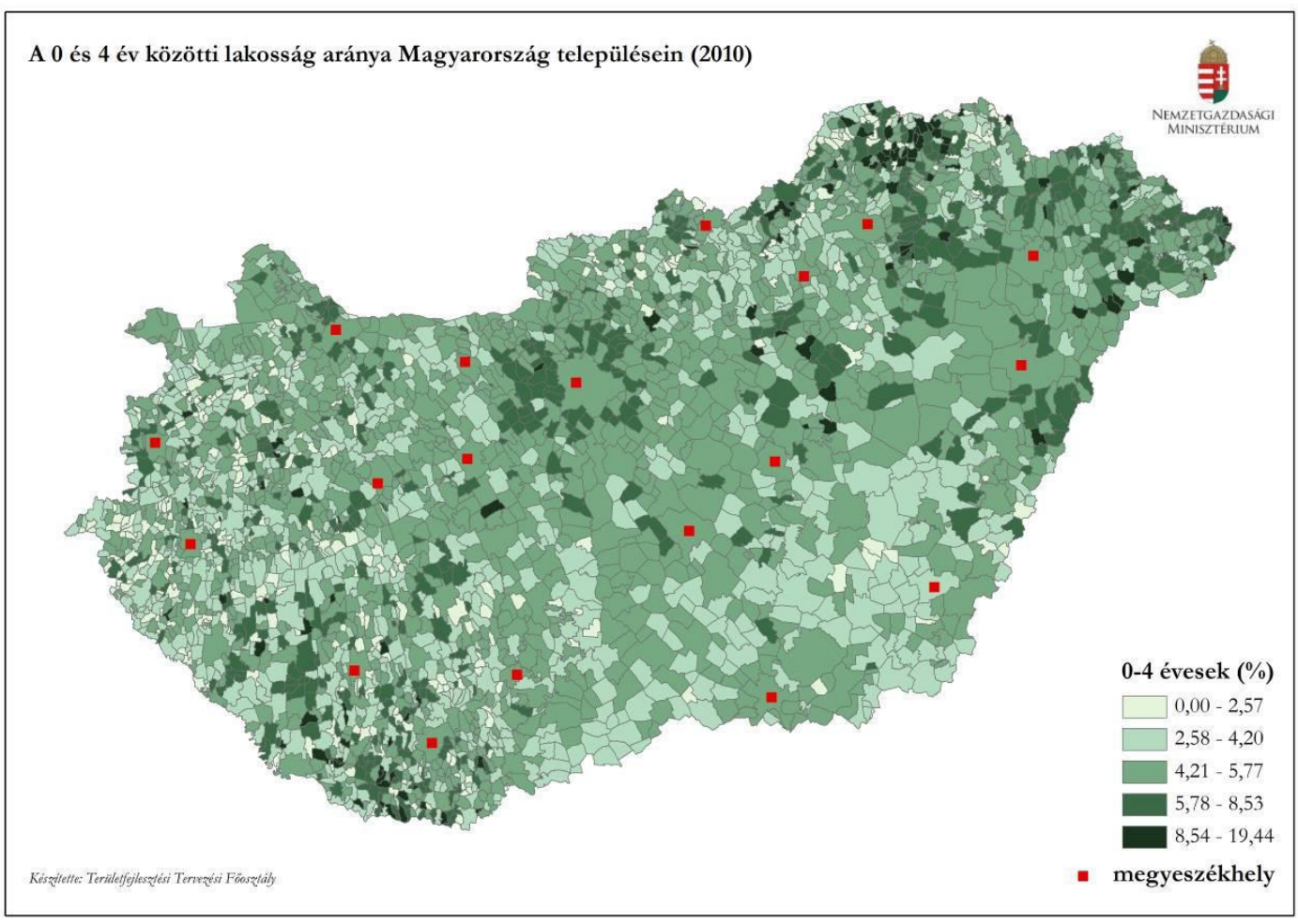

15. ábra, 0-4 éves lakosok (NGM,2012)

Bölcsődei férőhelyek (NGM,2012)

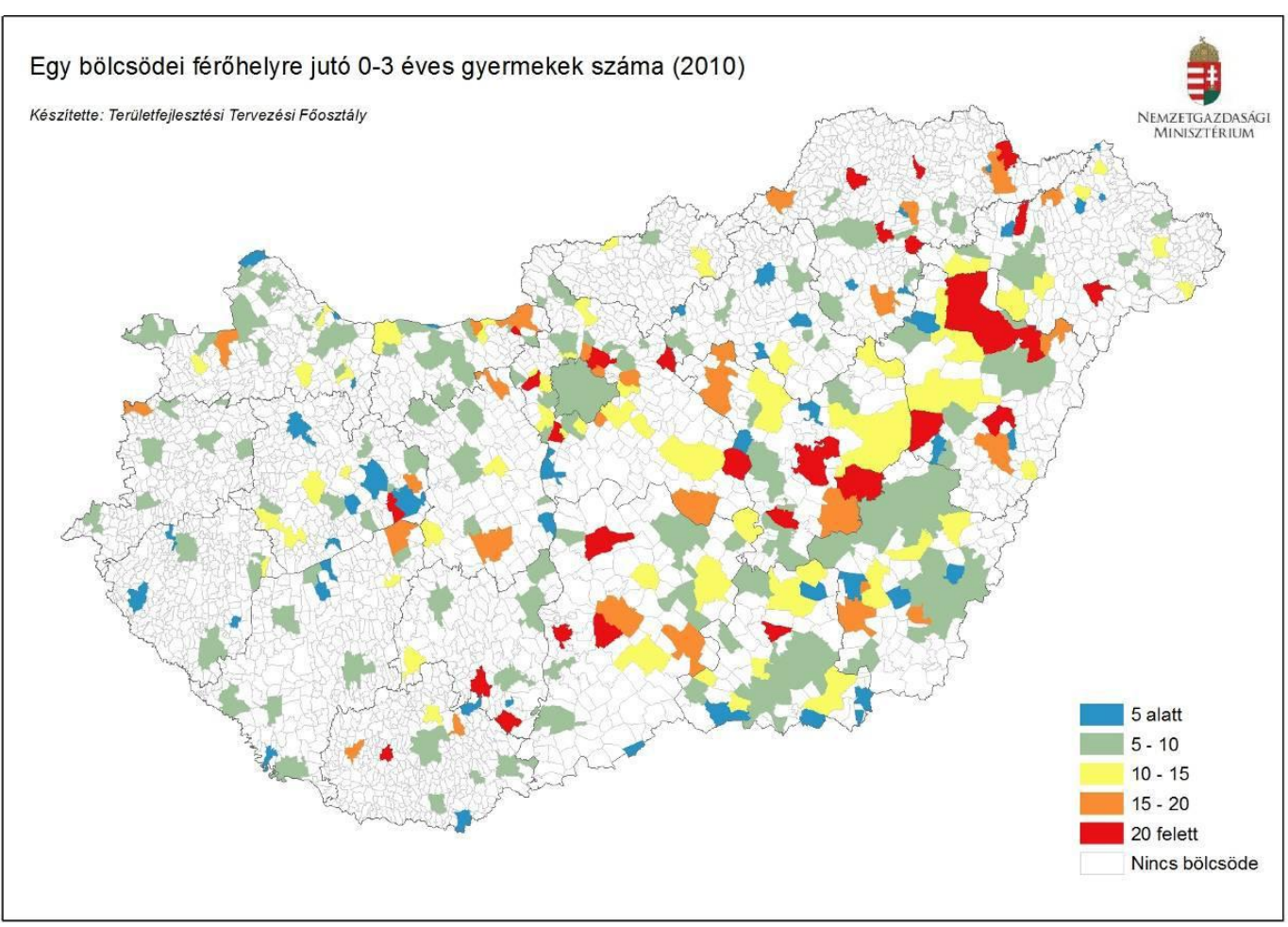

16. ábra, Bölcsődei férőhelyek (NGM,2012) 
Bölcsődés, csanás gyermekek (NGM,2012)

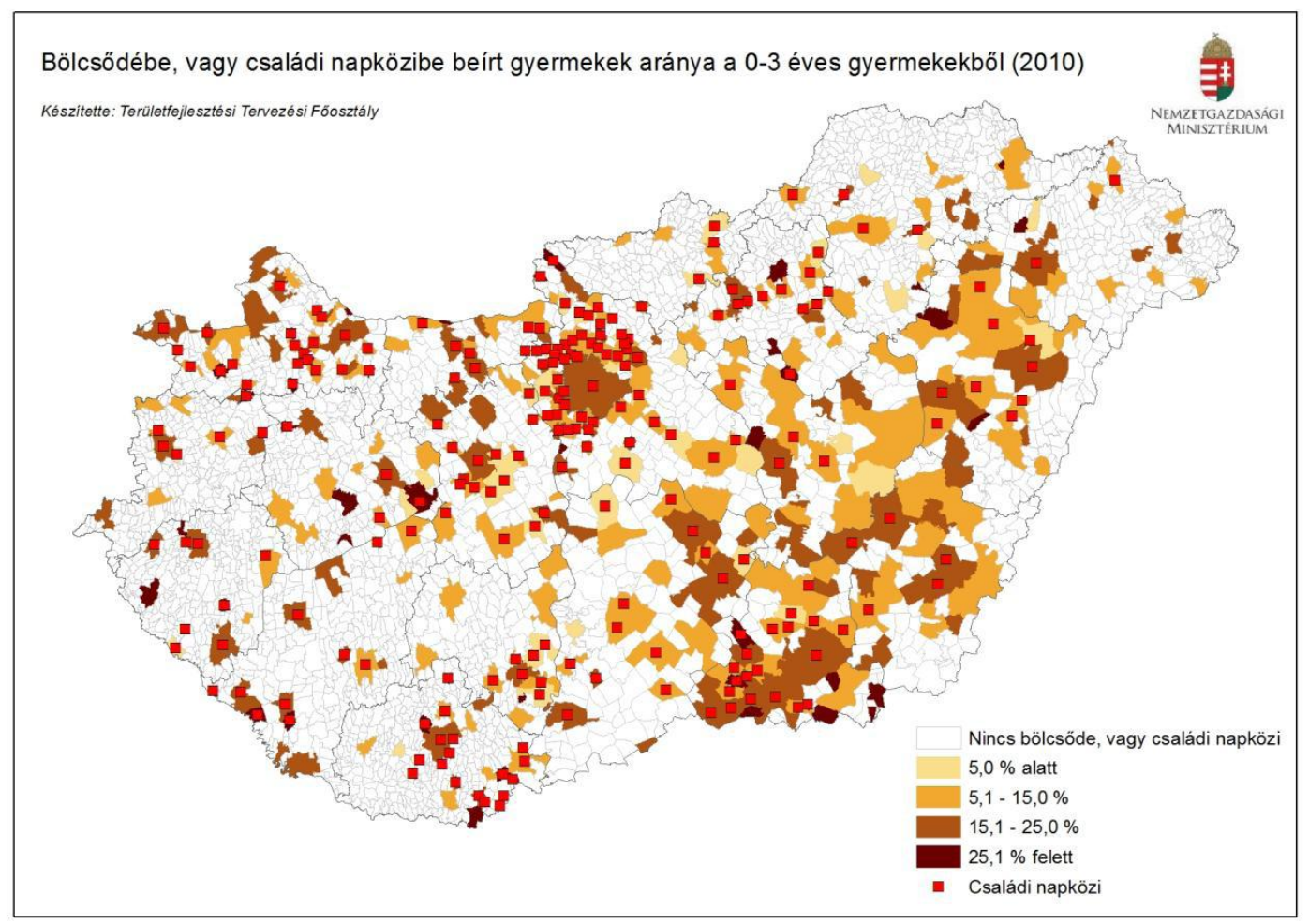

17. ábra, Bölcsődés, csanás gyermekek (NGM,2012)

Míg 1995-ben 31.020 bölcsődei féröhely volt, addig 2011-ben 35.450. A férőhelyszám nem jelent igazi számottevő bővítést, hanem a felvehető gyermekek számát növelték meg. Eredetileg ugyanis egy bölcsődei csoportban 10 gyermek volt gondozható. Ez ma 12 fö, ha minden gyermek betöltötte a 2. életévét, akkor 14 fö. Megjegyzem, ezen gyermeklétszám ellátása továbbra is 2 állandó, ölelkező müszakú gondozónő bevonásával történik, azaz bár statisztikailag 5-6 gyermek jut egy gondozóra, ez a valóságban napi több órán át egy gondozó egyedüli jelenlétét jelenti - a csoport teljes létszámát tekintve. KSH adatok (2012) szerint a következőképpen alakult a bölcsődék és a családi napközik férőhelyszámának változása: 


\section{Bölcsődei, csanás férőhelyek (KSH,2012)}

Bölcsődei és családi napközis férőhelyek számának alakulása, 19952011

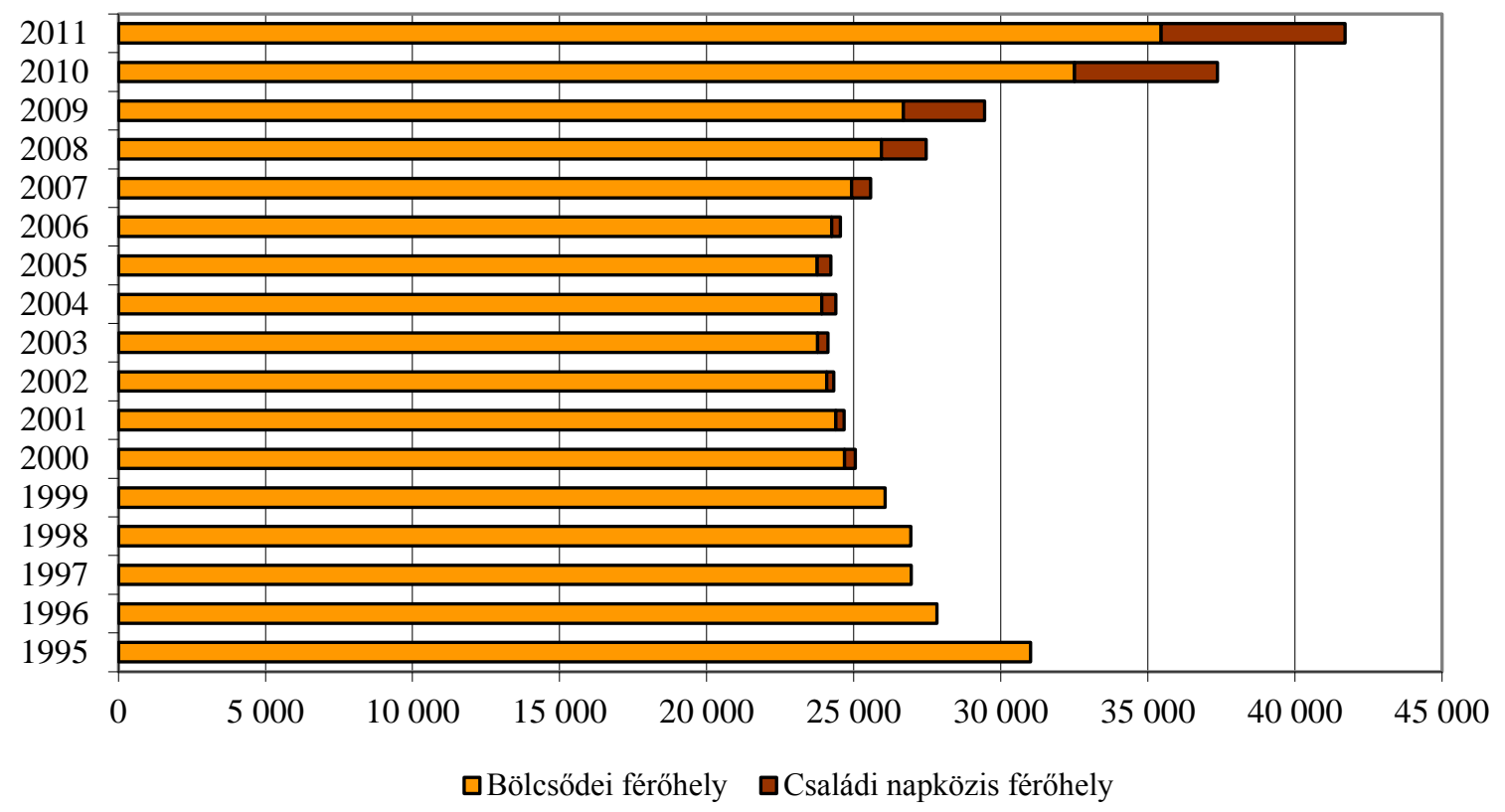

18. ábra, Bölcsődei, csanás férőhelyek (KSH,2012)

Elkészítettem a családi napközikre vonatkozóan egy adattáblát, melyből az látható, hogy 2010-ben 694 családi napközinek volt müködési engedélye, 4.861 férőhellyel. 7.200 ellátott gyermeket látunk az adatok között, ám ha összesítjük az adatokat (korcsoportokat), akkor csak 3.134 gyermeket kapunk. Ha a tényleges ellátási napokat elosztjuk 251-el (ellátási napok száma), akkor 2.902 gyermekröl szólna az adattábla, ha minden féröhelyen csak egy gyermek lett volna beíratva, és az a gyermek minden nap jelen lett volna. A fentiek alapján megállapítható, hogy a 3.134 ellátotti létszám reálisnak tünik. Viszont a 64\%-os kihasználtság már kevésbé reális, feltételezve, hogy ahol müködik a családi napközi, ott legtöbbször szinte teltházzal (vagy akár várólistával) müködik (különben nem fenntartható). A nem kellően kihasznált családi napközik bezárnak. Valószínüsíthető, hogy a fenti adatok között nem szerepelnek a bezárt családi napközik, csak a müködési engedélyt kapottak. Ehhez tudni kellene a pontos módszertant: a családi napközik és a családi napközis féröhelyek számánál a müködési engedélyek számát, vagy a visszaérkezett kérdőíveket veszik-e figyelembe? Ez azért is érdekes, mert egy családi napközi féröhelyeinek száma vagy 5, vagy 7 - és itt ha a férőhelyeket elosztjuk a csanák számával, 7-et kapunk (ami azt feltételezi, hogy nincs 5 férőhelyes családi napközi, ami egészen egyszerüen nem igaz, a szerző is ismer 5 férőhelyes 
családi napközit). Ez alapján azt feltételezem, hogy az adatoknál a müködési engedélyek számát veszik figyelembe. 


\section{Bölcsődék, csanák adatai (KSH,2012)}

\begin{tabular}{|c|c|c|c|c|c|c|c|c|c|c|c|}
\hline \multicolumn{12}{|c|}{ 2.4.10. Bölcsőde, családi napközi (2000-) } \\
\hline Év & $\begin{array}{l}\text { Müködő } \\
\text { bölcsődék } \\
\text { száma }\end{array}$ & $\begin{array}{c}\text { Müködő } \\
\text { bölcsődei } \\
\text { férőhelyek } \\
\text { száma }\end{array}$ & $\begin{array}{c}\text { Ebből: } \\
\text { önkormányzati } \\
\text { bölcsődék } \\
\text { férőhelyei }\end{array}$ & $\begin{array}{c}\text { Beíratott } \\
\text { gyermekek } \\
\text { száma }\end{array}$ & $\begin{array}{c}\text { Gondozónők } \\
\text { száma }\end{array}$ & $\begin{array}{c}\text { Ebböl: } \\
\text { szakképzett } \\
\text { gondozónők } \\
\text { aránya }\end{array}$ & $\begin{array}{l}\text { Családi } \\
\text { napközik } \\
\text { száma }\end{array}$ & $\begin{array}{c}\text { Családi } \\
\text { napköziben } \\
\text { engedélyezett } \\
\text { férőhelyek } \\
\text { száma }\end{array}$ & $\begin{array}{c}\text { Családi } \\
\text { napköziben } \\
\text { elhelyezett } \\
\text { gyermekek } \\
\text { száma }\end{array}$ & $\begin{array}{c}\text { Beíratott } \\
\text { gyermekek } \\
\text { száma }\end{array}$ & $\begin{array}{l}\text { Ebből } \\
\text { bölcsődés } \\
\text { korúak } \\
\text { száma }\end{array}$ \\
\hline 2000 & 532 & 24965 & 24089 & 29561 & 5335 & 90,9 & .. & .. & 852 & .. & . \\
\hline 2001 & 532 & 24394 & 23564 & 28981 & 5300 & 89,8 & .. & .. & 3306 & .. & . \\
\hline 2002 & 523 & 24078 & 23300 & 28847 & 5394 & 88,9 & .. & .. & 1362 & .. & . \\
\hline 2003 & 515 & 23771 & 22959 & 29422 & 5413 & 90,1 & .. & .. & 1093 & .. & . \\
\hline 2004 & 527 & 23911 & 23024 & 30333 & 5418 & 90,5 & .. & .. & 798 & .. & . \\
\hline 2005 & 530 & 23766 & 22909 & 30230 & 5416 & 90,1 & .. & .. & 706 & .. & . \\
\hline 2006 & 543 & 24255 & 23344 & 31153 & 5514 & 90,6 & 60 & .. & 1198 & .. & . \\
\hline 2007 & 556 & 24934 & 23868 & 32010 & 5576 & 89,5 & 101 & 638 & 1448 & .. & . \\
\hline 2008 & 594 & 25937 & 24243 & 33726 & 5788 & 88,0 & 223 & 1526 & 2621 & 1403 & 1099 \\
\hline 2009 & 625 & 26687 & 24767 & 34694 & 6026 & 89,6 & 413 & 2762 & 4760 & 2315 & 1828 \\
\hline 2010 & 668 & 32516 & 31070 & 35782 & 6346 & 92,9 & 694 & 4861 & 7200 & 3920 & 3134 \\
\hline 2011 & 689 & 35450 & 33805 & 36685 & 6628 & 94,4 & 857 & 6253 & 13032 & 4992 & 2744 \\
\hline
\end{tabular}

19. ábra, Bölcsődék, csanák adatai (KSH,2012)

\footnotetext{
${ }^{71}$ http://www.ksh.hu/docs/hun/xstadat/xstadat_eves/i_fsg005a.html (letöltés dátuma: 2013.02.01)
} 
Családi napközik adatai (KSH,2012)

\begin{tabular}{|c|c|c|c|c|c|c|c|}
\hline \multicolumn{8}{|c|}{ A családi napközik fontosabb adatai területi egységek szerint, 2011} \\
\hline Területi egység & $\begin{array}{l}\text { A családi napközik } \\
\text { száma }\end{array}$ & $\begin{array}{c}\text { Engedélyezett } \\
\text { féröhelyek száma }\end{array}$ & $\begin{array}{l}\text { A beíratott gyermekek } \\
\text { száma (V. 31-én) }\end{array}$ & $\begin{array}{l}\text { Ebböl: } 3 \text { évesnél fiatalabb } \\
\text { gyermekek száma }\end{array}$ & $\begin{array}{l}\text { Az összes beíratottból: } \\
\text { fogyatékkal élö }\end{array}$ & $\begin{array}{l}\text { A családi napközit igénybe vevő } \\
\text { gyermekek száma az év folyamán összesen }\end{array}$ & $\begin{array}{l}\text { A foglalkoztatottak } \\
\text { száma összesen }\end{array}$ \\
\hline Budapest & 144 & 1211 & 820 & 518 & - & 5594 & 273 \\
\hline Pest & 197 & 1425 & 1183 & 715 & 6 & 1953 & 378 \\
\hline Közép-Magyarország & 341 & 2636 & 2003 & 1233 & 6 & 7547 & 651 \\
\hline Fejér & 27 & 209 & 205 & 167 & - & 341 & 54 \\
\hline Komárom-Esztergom & 16 & 104 & 112 & 53 & - & 221 & 28 \\
\hline Veszprém & 11 & 115 & 74 & 53 & - & 156 & 25 \\
\hline Közép-Dunántúl & 54 & 428 & 391 & 273 & - & 718 & 107 \\
\hline Győr-Moson-Sopron & 35 & 239 & 226 & 112 & 7 & 386 & 64 \\
\hline Vas & 9 & 64 & 49 & 25 & 2 & 57 & 16 \\
\hline Zala & 19 & 134 & 109 & 52 & - & 170 & 30 \\
\hline Nyugat-Dunántúl & 63 & 437 & 384 & 189 & 9 & 613 & 110 \\
\hline Baranya & 60 & 387 & 326 & 114 & - & 516 & 101 \\
\hline Somogy & 27 & 180 & 154 & 72 & - & 252 & 47 \\
\hline Tolna & 36 & 250 & 189 & 62 & - & 496 & 66 \\
\hline Dél-Dunántúl & 123 & 817 & 669 & 248 & - & 1264 & 214 \\
\hline Dunántúl & 240 & 1682 & 1444 & 710 & 9 & 2595 & 431 \\
\hline Borsod-Abaúj-Zemplén & 17 & 115 & 82 & 33 & - & 178 & 30 \\
\hline Heves & 27 & 193 & 153 & 108 & - & 324 & 44 \\
\hline Nógrád & 22 & 161 & 88 & 55 & - & 223 & 33 \\
\hline Észak-Magyarország & 66 & 469 & 323 & 196 & - & 725 & 107 \\
\hline Hajdú-Bihar & 29 & 213 & 128 & 91 & - & 304 & 54 \\
\hline Jász-Nagykun-Szolnok & 13 & 89 & 81 & 54 & - & 154 & 23 \\
\hline Szabolcs-Szatmár-Bereg & 19 & 133 & 68 & 33 & - & 145 & 36 \\
\hline Észak-Alföld & 61 & 435 & 277 & 178 & - & 603 & 113 \\
\hline Bács-Kiskun & 65 & 445 & 364 & 165 & - & 614 & 97 \\
\hline Békés & 18 & 133 & 100 & 52 & 7 & 211 & 32 \\
\hline Csongrád & 66 & 453 & 481 & 210 & - & 737 & 114 \\
\hline Dél-Alföld & 149 & 1031 & 945 & 427 & 7 & 1562 & 243 \\
\hline Alföld és Észak & 276 & 1935 & 1545 & 801 & 7 & 2890 & 463 \\
\hline Ország összesen & 857 & 6253 & 4992 & 2744 & 22 & 13032 & 1545 \\
\hline
\end{tabular}


Mivel 2012. január 1-től életbe lépett a Nemzeti Rehabilitációs és Szociális Hivatal egységes nyilvántartása (ahol napi jelentést kell adjon az ellátottakról minden szociális szolgáltató és intézmény, aki normatív támogatást vesz igénybe), és a jogszabályok szerint az adattartalom nyilvános, így megpróbáltam az NRSZH honlapjáról megtudni a keresett adatokat $^{72}$.

Az országos nyilvántartás ${ }^{73}$ alapján az alábbi érdekes adatokat kaptam: 2011. április 30-án 1776 bölcsőde van Magyarországon, 73.089 férőhellyel. Ugyanezen napon 211 családi napközi müködik, 1.436 féröhellyel.

Az adatok tanulmányozása során felfigyeltem arra, hogy ugyanazon bölcsőde többször (akár több tízszer) is szerepel az adatbázisban. Az elsőfokú határozat száma alapján ${ }^{74}$ tisztítottam a táblázatot, aminek következtében az alábbi adatok születtek: a regiszter tisztított adatai szerint 306 bölcsődében 12.462 féröhelyen látnak el gyermekeket, valamint 211 családi napközinek van 1.436 féröhelye. A családi napközik között duplikációt nem találtam, így azok az adatok változatlanok.

Ugyanezen lekérdezést megismételtem 2012.12.04-én. A családi napközik száma 3.648 (!) lett, ahol is $10-14$, sőt 28 férőhelyes családi napközikben (sic!) ${ }^{75}$ látnak el összesen 49.296 férőhelyen gyermekeket. Tisztítás után 548 családi napközi „maradt”, ahol 6.253 férőhelyen gondoznak gyermekeket. A bölcsődékkel is érdekes dolog történt: 929 bölcsődét és 62.672 bölcsődei férőhelyet tartalmazott a lekérdezés, amely tisztítás után lecsökkent 181 bölcsődére és 14.564 bölcsődei férőhelyre.

Bölcsőde-csana számok (saját szerk)

\begin{tabular}{|c|r|r|r|r|}
\hline & $\begin{array}{c}\text { Bölcsődék } \\
\text { száma }\end{array}$ & \multicolumn{1}{c|}{$\begin{array}{c}\text { Bölcsődei } \\
\text { féröhelyek } \\
\text { száma }\end{array}$} & $\begin{array}{c}\text { Családi } \\
\text { napközik } \\
\text { száma }\end{array}$ & $\begin{array}{c}\text { Családi napközi } \\
\text { féröhelyek száma }\end{array}$ \\
\hline NRSZH 2012.04.30 & 1776 & 73089 & 211 & 1436 \\
\hline NRSZH 2012.04.30 tisztított & 306 & 12462 & 211 & 1436 \\
\hline NRSZH 2012.12.04 & 929 & 62672 & 3348 & 49296 \\
\hline NRSZH 2012.12.04 tisztított & 181 & 14564 & 548 & 7714 \\
\hline KSH 2011! & 689 & 3545 & 857 & 6253 \\
\hline
\end{tabular}

21. ábra, Bölcsőde-csana számok (saját szerk)

\footnotetext{
72 írásban feltett kérdéseimre nem kaptam választ az NRSZH-tól

73 226/2006. (XI. 20.) Korm. rendelet a szociális, gyermekjóléti és gyermekvédelmi szolgáltatók, intézmények ágazati azonosítójáról és országos nyilvántartásáról: 15. § (1) A 2012. január 1-jén működési engedéllyel rendelkező fenntartók e-képviselöje 2012. január 31-éig köteles kérni - szükség esetén ügyfélkapuregisztrációt követöen - a 13/C. $§(4)$ bekezdése szerinti nyilvántartásba vételt.

${ }_{74}$ Mivel egy müködési engedélyhez csak egy engedélyszám tartozhat, így ez tünt a legkézenfekvőbb megoldásnak.

${ }^{75}$ egy családi napköziben engedélyezhető maximális féröhelyszám: 7
} 
Az adatgyüjtés során egyértelművé váltak módszertani problémák:

- 2 fö adatforrást vizsgáltam, és az eredmények aggályosnak mondhatóak. A KSH és az NRSZH az adatait a hivatalos szervektől (müködési engedélyeket kiállító hatóság) nyeri. Ugyanezen szervnek kellett feltöltenie az adatokat (illetve ugyanezen szerv által szolgáltatott adatokat töltötték fel) az NRSZH rendszerébe. A müködési engedélyekért 2011. július 1-ig a települési jegyzők voltak felelősek, amikor is átkerült a Kormányhivatalok jogkörébe mindez (engedélyek kiadása, módosítása, visszavonása). A Minisztériumok és a kutatók érthető okokból a KSH adatait vizsgálják - amely azonban nagyon is eltér az NRSZH adataitól (bár az adatokat mindkettőnek ugyanazon szervek szolgáltatják). Az NRSZH adataiban sem magyarázhatóak a többszöröződések. Azt tudjuk, hogy a rendszer 2012. július 1-ig tesztidőszak alatt van - de ekkora eltérések semmivel sem magyarázhatóak (sem a duplikációk, sem a sehol sem található szolgáltatók). A fentiek alapján sajnos kijelenthető, hogy nem tudjuk, hogy pontosan hány bölcsőde és hány családi napközi van ma Magyarországon.

- Az is probléma, hogy ha helyre is áll az NRSZH rendszere, akkor sem lesz teljes a kép, ugyanis jelentési kötelezettsége csak annak a szolgáltatónak van, aki normatív támogatást vesz igénybe. Azaz azok a bölcsődék, családi napközik, akik nem kapnak normatívát, nem is fognak megjelenni ebben a rendszerben (azaz pl. a 2012 január 1 után létrejött nem állami szolgáltatók közül gyakorlatilag senki).

- A beíratott gyermekek száma sem egyértelmü, épp a két ellátási forma különbségeiből adódóan.

○ A bölcsődébe csak úgy lehet fölvenni gyermeket, ha minden nap szeretné vinni őt a szülője. Viszont a bölcsőde fölvehet több gyermeket, mint az engedélyezett férőhelyszáma (amit a családi napközi nem tehet meg). Így lehetséges, hogy a bölcsőde kihasználtsága 100\% fölött van, még a hiányzásokkal is. Nincs adat a bölcsődei játszócsoportokról sem (azok a csoportok, ahol fizetős gyermekfelügyeletet vállal a bölcsőde ${ }^{76}$ ).

○ A családi napközi lehetővé tesz egy rugalmas ellátást, és sokan élnek is ezzel: épp azok, akik atipikus munkarendben, projektmunkában, vagy épp váltott müszakban dolgoznak, vagy a gyermekfelügyeletben részt vesznek egy-egy nap a nagyszülők is. Ez a gyakorlat föleg Budapesten elterjedt, ahol lehetősége

\footnotetext{
${ }^{76}$ Mészáros Z.: A bölcsődei gondozási díj hatása és a bölcsődék gazdálkodása, NCSSZI Konferencia, 2013 (még nem publikált kutatás)
} 
van a munkavállaló szülönek a fenti foglakoztatási modelleket kihasználni, illetve a fizetőképesség magasabb volta miatt a térítési díjak is magasabbak tudnak lenni, így könnyebben engedik a müködtetők is ezt a fajta igénybe vételt. Így lehetséges az, hogy 1 „féröhelyen” akár 2-3 gyermek is osztozik: a szabály az, hogy egy nap egyszerre nem lehet több gyermek a családi napköziben, mint amennyi az engedélyezett férőhelyszám. Nincs adat a családi napközik által müködtetett ún ,játszóházakról” sem (azok a gyerekek, akik nem fértek be a létszámba, de megoldották a felvételét - a bölcsődei játszócsoport mintájára).

- Az összehasonlítást az is nehezíti, hogy a bölcsőde csak 0-3 éves gyermeket láthat el, míg a családi napközi 0-14 éveseket. A családi napköziben ellátott gyermekek jelentős része nem bölcsődés korú: így könnyen megoldható a szülőnek, hogy a testvéreket ugyanoda viszi, vagy pl. az iskolás testvér odamegy az iskola után tanulni, ahol a bölcsis korú a napját tölti. Ez a gyakorlat pedig inkább vidéken lelhető fel.

A fentiekből következik, hogy véleményem szerint a bölcsődékkel, családi napközikkel kapcsolatos adatok nem pontosak, azaz nem tudjuk pontosan, hogy hány bölcsőde és hány családi napközi van ma Magyarországon, így azt sem tudjuk, hogy mennyi férőhelyen láthatnak el gyermeket. Az ellátott gyermekek pontos számát sem tudjuk. Ahogy azt sem tudjuk, hogy a meglévő ellátóhelyek mekkora kihasználtsággal müködnek. És így azt sem tudjuk, hogy hány alkalmazottat foglalkoztatnak.

Azt viszont tudjuk, hogy a gyermekek igen nagy része informális, illegális ellátásban részesül (Blaskó, 2009), ami gyermekvédelmi szempontból igen aggályosnak mondható. 


\subsubsection{Finanszírozás}

Az elmúlt évtizedben számos országban alakították át és egyesítették a gyermekneveléshez- és gondozáshoz tartozó különböző kormányzati feladatokat és hatásköröket. A kormányzati integráció sikerfeltételeiként összehasonlító elemzések az alábbiakat jelölik meg:

- politikai agenda: a gyermekügyi kérdések kormányzati fontosságának erősödése,

- politikai elkötelezettség: vezető döntéshozók (területért felelős miniszter) kiállása,

- konszenzus és támogatottság: jelentősebb kormányzati és/vagy szakmai érdekcsoportok részéről felmerülő ellenállás hiánya, (Blaskó-Cseres-ReszketőScharle, 2009)

Ám az ellátórendszer átalakításának szerves (és talán leginkább neuralgikus) része a finanszírozás átalakítása.

\subsubsection{Müködési önköltség és a térítési díj kapcsolata}

Mielőtt a finanszírozási rendszert bemutatom, egyértelművé kívánom tenni, hogy mit is jelent maga a fogalom - ugyanis sajnálatos módon a családi napközit igényes tudományos írások is drága ellátási formának nevezik (ellentétben az kvázi ingyenes bölcsődével).

Az ellátóhely finanszírozásának lényege, hogy a müködtetés során felmerült müködési önköltséget valakinek ki kell fizetnie. Ha a családi napköziben csak 5 gyermeket gondoz a müködtető, akkor az lényegesen gazdaságosabb, mint a 7 gyermek gondozása (hiszen a felvett hatodik gyermektől már be kell jelentenie egy legalább 6 órás segítőt, viszont a létszámot nem töltheti 7 fölé). A müködési költségekkel úgy tud még játszani, hogy ha egy ingatlanon belül több családi napközit hoz létre (amire a törvény lehetőséget is ad).

Viszont egyértelmüen látszik, hogy ha a legolcsóbb megoldást is választja a müködésre (azaz a saját nappalijában indítja el a vállalkozását), és csak 5 gyermeket fogad (azaz csak a saját minimálbérét + közterheit kell kigazdálkodnia), abban az esetben is (teljes feltöltöttséggel számolva) legalább 60 ezer Ft-ba kerül egy gyermek ellátása. Azaz kell legyen 5 olyan gyermek, aki minden nap jelen van, és fejenként 60 ezer Ft-ot fizetnek értük. Ha már egy-egy gyermek hiányzik, akkor rohamosan nő a fajlagos díj. És ekkor a gondozó a saját lakásában müködteti a családi napközit, a jövedelme pedig minimálbér.

Azt a díjat, amibe egy ellátott gyermek kerül, intézményi térítési díjnak nevezzük. Ha normatívát vesz igénybe a müködéshez a fenntartó, akkor az intézményi térítési díj a müködési önköltség normatívával csökkentett összege (bővebben: Gyvt). Az az összeg, amit 
egy - egy gyermek ellátásáért a szülö fizet, a személyi térítési díj. Ez gyakorlatilag bármennyi lehet, egy szabály van: a személyi térítési díj nem lehet több, mint az intézményi térítési díj (azaz a vállalkozás nem termelhet nyereséget, csak a müködési költségeket lehet ráterhelni a szülőre).

Abban az esetben, ha a müködési költségekbe „beszáll” az állam (normatíva), az önkormányzat (kiegészítő normatívából ad át), a munkáltató (béren kívüli juttatás), a szülőnek már csak egy töredékrészt kell(ene) kifizetnie. Erre a modellre tesz javaslatot Scharle $(2009)^{77}$ :

Finanszírozási modell (Scharle,2009)

\begin{tabular}{|c|c|c|c|}
\hline $\begin{array}{l}\text { Jelenlegi } \\
\text { szabályozás (A) }\end{array}$ & normativa & önkormányzat & szülö \\
\hline $\begin{array}{l}\text { Jelenlegi } \\
\text { szabályozás (B) }\end{array}$ & \multicolumn{2}{|l|}{$\begin{array}{l}\text { önkormány } \\
\text { zat }\end{array}$} & szülő \\
\hline Javasolt & \multirow[t]{2}{*}{ normativa } & önkormányzat & \multirow[t]{2}{*}{ szülö } \\
\hline szabályozás (C) & & munkáltató & \\
\hline
\end{tabular}

22. ábra, Finanszírozási modell (Scharle,2009)

- Ebben a modellben a jelenlegi szabályozást A-val jelöli, amit hívjunk bölcsődei modellnek, amikor is a bölcsőde finanszírozásának egy részét a feladatnormatíva ( $\mathrm{kb}$. 30-40\%), másik részét a kiegészítő önkormányzati normatíva (50-60\%) teszi ki. A maradék 5-15\%-ot térítik a szülők (mint étkezési díj. Megjegyzem, hogy a modell elkészülte óta bevezetésre került a bölcsődei térítési díj (2012. január 1-től), de a modell elve nem változott. Ez a modell csak az önkormányzati fenntartású ellátóhelyekre vonatkozik, illetve azokra a nem állami fenntartásúakra, amelyekkel az önormányzat ellátási szerződést kötött.

- A B változat gyakorlatilag a normatívát kapó családi napközi modellje, azzal a megjegyzéssel, hogy a normatívát nem az önkormányzat, hanem az állam (Államkincstár) adja. De az arány valós: a családi napközis normatíva kb. a müködési költségek 20\%-ára elegendő, a maradék kb. 80\%-ot a szülőnek kell fizetnie.

\footnotetext{
77 Megjegyzem, hogy a modell a bölcsődei finanszírozást veszi alapul, de mivel meggyőződésem szerint a finanszírozás átalakításában az elveket egységesíteni kell, így a modellt adaptálhatónak tartom a családi napközi finanszírozásának bemutatására
} 
- A C változat az általam is javasolt modell: a költségeket osszuk meg az állam, az önkormányzat, a munkáltató és a szülő között. Ez a modell nem igényel az állam részéről plusz forrást. Amennyiben a munkáltató béren kívüli Cafeteria elemként (vagy egyéb legális, de mindenképp adómentes formában) tudja adni, abban az esetben a jövedelmek kifehérítésében is jelentős szerepet játszik. A szülői hozzájárulás csökkentése pedig egyértelműen javítja a hozzáférhetőséget.

A finanszírozási anomáliák miatt jelenleg a drága bölcsődei és óvodai ellátást az önkormányzatok finanszírozzák, a költségvetési adóforrásokból (maguk a bölcsődék és óvodák jórészt Európai Uniós forrásokból épülnek fel). A lényegesen gazdaságosabb, ám nagy horderejü uniós beruházást nem feltétlenül igénylő családi napközik (melynek a finanszírozásából az állam igyekszik kimaradni) inkább a nem-állami szektorban jönnek létre:

\section{Bölcsőde, csana fenntartók (KSH,2012)}

\begin{tabular}{|c|c|c|c|c|c|}
\hline \multicolumn{6}{|c|}{\begin{tabular}{|c|} 
Bölcsődék és családi napközik müködő férőhelyeinek megoszlása a fenntartó típusa \\
szerint, 2007-2011
\end{tabular}} \\
\hline \multirow[t]{2}{*}{ Fenntartó típusa } & 2007 & 2008 & 2009 & 2010 & 2011 \\
\hline & \multicolumn{5}{|c|}{ Bölcsődék } \\
\hline Települési önkormányzat & 94,6 & 91,4 & 88,7 & 88,3 & 88,9 \\
\hline Önkormányzati intézményfenntartó társulás & 1,1 & 2,0 & 4,1 & 4,5 & 3,4 \\
\hline Többcélú kistérségi társulás & 0,9 & 2,3 & 2,6 & 2,8 & 3,1 \\
\hline Egyház, egyházi intézmény & 0,1 & 0,2 & 0,4 & 0,5 & 0,6 \\
\hline Nonprofit gazdasági társaság, közhasznú társaság & 0,8 & 0,8 & 1,0 & 0,9 & 1,1 \\
\hline Alapítvány, közalapítvány, egyesület & 1,8 & 2,3 & 2,5 & 2,3 & 2,2 \\
\hline \multirow[t]{2}{*}{ Egyéni vagy társas vállalkozás } & 0,2 & 0,2 & 0,2 & 0,4 & 0,3 \\
\hline & \multicolumn{5}{|c|}{ Családi napközik } \\
\hline Települési önkormányzat & 11,9 & 22,6 & 16,6 & 13,2 & 10,7 \\
\hline Önkormányzati intézményfenntartó társulás & 2,4 & 1,3 & 1,0 & 1,3 & 1,2 \\
\hline Többcélú kistérségi társulás & 2,4 & 5,0 & 5,0 & 5,8 & 5,6 \\
\hline Egyház, egyházi intézmény & 0,0 & 0,0 & 1,2 & 4,4 & 8,7 \\
\hline Nonprofit gazdasági társaság, közhasznú társaság & 1,9 & 3,5 & 11,4 & 17,7 & 21,8 \\
\hline Alapítvány, közalapítvány, egyesület & 36,2 & 43,3 & 47,0 & 43,8 & 40,5 \\
\hline Egyéni vagy társas vállalkozás & 45,3 & 24,2 & 17,7 & 13,8 & 11,6 \\
\hline
\end{tabular}

23. ábra, Bölcsőde, csana fenntartók (KSH,2012)

Azonban ez a finanszírozási anomália igen nagy mértékben rontja hozzáférhetőséget, hiszen a családi napközi önköltségét nem tudja ráterhelni a szülőkre - akik, hozzászokva az elmúlt évtizedek alatt a kvázi-,,ingyenes” ellátáshoz, a számukra lényegesen olcsóbb, bár az adóforintokból pazarlóan finanszírozott, túlzsúfolt, rugalmatlan, így valójában igen drága bölcsődei ellátáshoz hasonlítják a térítési díjat. Így alakult ki az a téves elképzelés, hogy az állami ingyenes, ami nem állami, azért pedig azért kell fizetni, mert nem állami, hanem magán (nem azért, mert nem finanszírozza az állam). 
IV. FEJEZET

SAJÁT KUTATÁSOK BEMUTATÁSA 


\subsection{Kutatás módszerei}

Mivel a kutatásomban a napközbeni kisgyermek ellátás több szereplőjével kapcsolatban fogalmaztam meg hipotézist, így a szereplöket külön-külön is kutatásnak vetettem alá. A kutatásban az előzetesen felállított modell és a szakirodalmi áttekintés alapján az alábbi vizsgálandó célcsoportokat határoztam meg:

1. célcsoport: családi napköziben dolgozók

2. célcsoport: munkavállaló szülők

3. célcsoport: munkáltatók

4. célcsoport: állam

A téma komplexitása miatt többfajta módszert használtam. A kvantitatív módszerek azon alapulnak, hogy az emberi hozzáállás, magatartás is mérhető, tehát számszerüsíthető, továbbá az így nyert adatok statisztikai módszerekkel elemezhetők. A fenti megközelítésből adódóan a kvantitatív eljárást megfelelő elemszámú mintán elvégezve, az eredmények megbízhatósága és pontossága meghatározható. A kvantitatív eljárásoknál a mérhetőség követelményének megfelelő standardizált kérdőív alkalmazása szükséges. Azokban az esetekben, amikor nagyobb számú mintából nyert adatokat általánosítani szerettem volna, meglévő adatok kvantitatív elemzését és kérdőíves technikát alkalmaztam. A kvalitatív módszerek általában mélyebb, árnyaltabb ismeretek megszerzésére irányulnak és viszonylag kis elemszámú mintán történik az adatfelvétel. A kapott eredmények nem számszerüsíthetők, nem mérhetők. A kvalitatív vizsgálatok abban az esetben alkalmazhatók sikeresen, amikor a különböző viselkedésformák, magatartásbeli sajátosságok mozgatórugóit igyekeznek feltárni. A kutatás zárásaként elvégzett fókuszcsoport, majd az itt nyert tapasztalatok alapján felvett mélyinterjúk ezt a célt szolgálták: a munkáltatói attitüdökre kerestem ezen módszerekkel a válaszokat.

Kutatásom 2009-es, 2012-es és 2013-as mérföldkövekre bontható. Az alábbi kutatásokat végzetem fent megjelölt időpontokban:

2009

- Családi napközi tanfolyamot végzettek közti kutatás (kvantitatív elemzés)

- Családi napközi vezetők közti felmérés (kérdőív)

- 0-3 éves gyermeket nevelők közötti felmérés (kérdőív)

2012

- Családi napközi tanfolyamot végzettek közti kutatás (kvantitatív elemzés) 
- Családi napközi vezetők közti felmérés (kérdöív)

- Céges gyermekfelügyelet munkavállalói oldalról (kérdőív)

- Jogszabály-kivonatok elkészítése mi a különbség a kérdőív és a kvantitatív elemzés között?

2013

- Céges családi napközi kerekasztal (fókuszcsoport)

- Munkáltatói esettanulmányok (mélyinterjú)

A 2009-es és a 2012-es KVANTITATÍV ADATELEMZÉSEK egy akkreditált felnőttképző családi napközi tanfolyamra jelentkező hallgatók jelentkezési lapjainak kiértékelését jelenti. Ezen adatelemzés szolgált az első és az ötödik hipotézis bizonyítékául. A felnőttképző intézmény az egész ország területére kiterjedően tart tanfolyamokat, így a minta országosnak tekinthető. Mivel az országban több hasonló felnőttképző is működik, az ő adataik ismerete szükséges lenne a reprezentativitáshoz, azonban ilyen adatok nem álltak a szerző rendelkezésére. A témáért felelős Minisztérium és a KSH sem rendelkezik a családi napköziben dolgozókra vonatkozó pontos végzettségbeli adatokkal. A fentiek alapján az adatelemzéssel nyert adatok nem biztos, hogy reprezentatívak, de az biztos, hogy országosak, és a témában jelen pillanatban egyedülállóak.

\section{A 2009-es és 2012-es KÉRDŐÍVES FELMÉRÉSEK a családi napközi vezetők}

között online módon valósultak meg. A kérdőívvel megkerestük az országos publikus családi napközis adatbázisban szereplő összes családi napközi vezetőt. A kérdőívet weboldalakon, Facebook oldalakon is terjesztettük. Az online kérdöív előnye a könnyü terjesztés, kitöltés, hátránya épp a könnyü hozzáférhetőség miatti „dömping”, azaz el kellett érjük, hogy komolyan vegyék a kérdőív kitöltését. A kérdőívet kitöltők zöme családi napközi müködtető, így a kapott adatok nem pontosak a dolgozókra nézve, hiszen sok olyan müködtető van, aki több napköziben több alkalmazottat is foglalkoztat, akik nem biztos (sőt inkább valószínüleg nem), hogy kitöltötték a kérdőívet. Ám az adatok a fenti feltételezés alapján bármerre szórhatnak, hiszen lehet, hogy szakemberekkel dolgozik az adott müködtető (fenntartó), és lehet, hogy nem. Ezen adatelemzés szolgált az első és az ötödik hipotézis bizonyítékául. A kérdőívek kiértékelése SPSS-es módszerrel történt. A 2009-es és a 2012-es szülői felméréssel a szülői attitüdökre kérdeztünk rá. Azt szerettük volna megtudni, mit tartanak a kisgyermeket nevelő szülök fontosnak akkor, ha a gyermeküknek ellátóhelyet keresnek. A kérdőív online, önkitöltős volt. A kérdőíveket kismamás weboldalakon, baba-mama fórumokon, Facebook csoportokban tettük közzé. A kérdőívek a második és a harmadik hipotézisek igazolását 
szolgálták. A kérdőívek elemzése SPSS módszerrel történt. A 2012-es munkáltatói felmérés szintén online kérdőív volt. Ebben a munkáltatók attitüdjére voltunk kíváncsiak, arra, hogyan viszonyulnak a kisgyermekes dolgozók gyermek-elhelyezési nehézségeihez. A kérdőívek elemzése SPSS módszerrel történt. A kapott eredmények rangsorolásánál kétféle tesztet végeztem, attól függően, hogy metrikus vagy nem metrikus a skála. Ahol nem metrikus skálákról és két független mintáról van szó, ott Mann-Whitney-féle U-próbát végeztem. Azokban az esetekben, amikor a skálák metrikusak, és átlagok közötti eltérést kellett vizsgálni, független mintás t-próbát végeztem.

A kérdőív megalapozta a 2013-as FÓKUSZ-CSOPORTOS munkát (Céges Családi Napközi Kerekasztal). Ezen fókuszcsoporton a kérdöívben fellelt kérdéseket, problémákat boncoltuk tovább. A munkamódszer az alábbi volt: egy rövid bevezető előadás után (melyet külsős moderátorral tartottunk) egy közös brain storming keretében megfogalmaztunk olyan közös problémákat, melyeket külön-külön munkacsoportok dolgoztak fel. Ezen munkacsoportok eredményeit a végén egy záró fórumon bemutatták a többi résztvevőnek.

A fókuszcsoport eredményeit felhasználva 2013-ban MÉLYINTERJÚKat készítettem ${ }^{78}$, melyek célja a valódi problémák és nehézségek feltárása volt. A mélyinterjúkat külön fejezetben (4.4.3.3) mutatom be dolgozatomban. Ezen 3 munkáltatói kutatás (kérdőív, fókuszcsoport és mélyinterjúk) adták a harmadik és az ötödik hipotézis igazolását.

Az állami szerepvállalás bemutatása érdekében JOGSZABÁLY KIVONATokat készítettem, melyeket az 1. számú mellékletben mutatok be.

\subsection{Kutatás felépítése}

Kutatásom 2009 és 2013 között zajlott. Több aspektusból jártam körül a témát:

- megvizsgáltam, kik azok, akik elvégzik a családi napközis tanfolyamot (2009, 2012),

- kérdöíves felmérést végeztem családi napközit müködtetők között $(2009,2012)$,

- felmértem a szülői attitüdöket a gyermekek elhelyezését illetően $(2009,2012)$,

- megvizsgáltam a családi napközikre vonatkozó jogszabályi hátteret (2012),

- fókuszcsoport kutatást ${ }^{79}$ végeztem munkáltatók, döntéshozók, szülők, civil szervezetek és családi napközi működtetők bevonásával (2013)

\footnotetext{
${ }^{78}$ köszönet segítőimnek: Trubjanszky Csillának (Csodacsalád Egyesület Céges Csana Koordinátor) és Beck Györgynek (Beckground Kft) az áldozatos munkájukért

${ }^{79}$ Céges Csana Kerekasztal
} 
- mélyinterjúkkal kapott eredmények: esettanulmányokat készítettem nagyvállalatoknál (2013)

\subsection{Kutatások kérdései}

\subsubsection{Kik látják el a családi napközikbe járó gyermekeket?}

A kutatásom során elsőként arra kerestem a választ, hogy kik vállalkoznak családi napközi müködtetésre, kik szeretnének családi napközben dolgozni.

A kezdetektől fogva támadási pont a társszakmák (bölcsőde, közoktatás) részéről: a családi napközi szolgáltatást egy 40 órás tanfolyammal bárki nyújthatja, akinek megvan a 40 órás tanfolyamhoz szükséges 8 általános osztályos végzettsége.

A bölcsődében és a családi napköziben dolgozók minimum szakmai elvárásait egyaránt a 15/1998. (IV. 30.) NM rendelet II. számú melléklete szabályozza. E szerint a bölcsődében létesítendő kisgyermeknevelő munkakört az alábbi végzettségekkel láthatják el:

csecsemö- és kisgyermeknevelö (BA), bölcsődei szakgondozó (OKJ), csecsemö- és kisgyermekgondozó (OKJ), csecsemö- és kisgyermeknevelö-gondozó (OKJ), csecsemöés gyermeknevelö-gondozó (OKJ), kisgyermekgondozó, -nevelö (OKJ), csecsemö- és gyermekgondozó $(O K J)$.

A KSH adatai alapján a bölcsődékben dolgozó gondozók jelentős része szakképzett. Főiskolai végzettséggel viszont csak 7\%-uk bír, a többiek középfokú végzettséggel (érettségi) + OKJ-s bizonyítvánnyal rendelkeznek. 
Bölcsődei gondozók (KSH,2012)

Gondozók megoszlása szakképzettség, iskolai végzettség szerint, 2008-2011

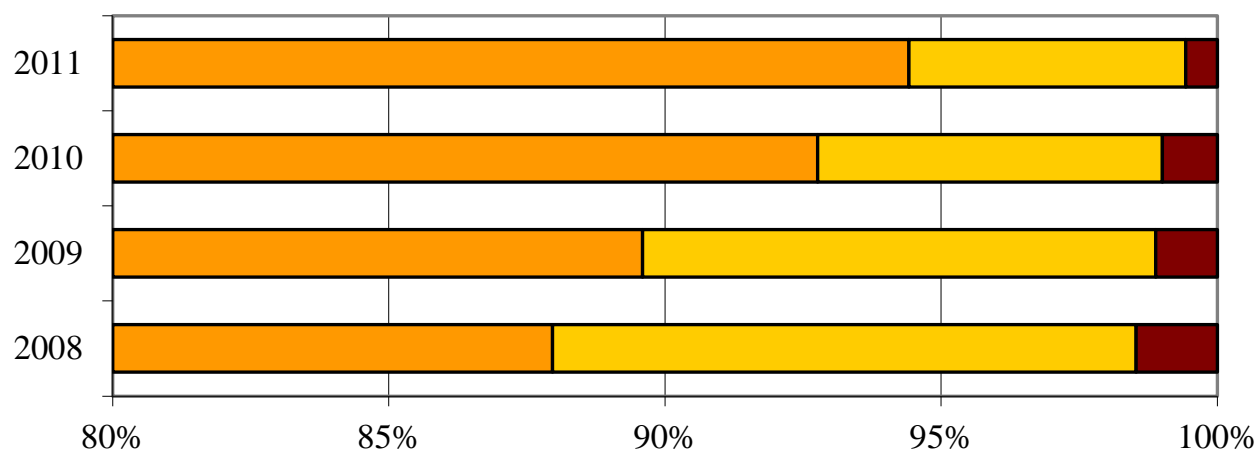

$\square$ Szakképzett $\quad \square$ Nem szakképzett, de érettségizett $\quad \square$ Nem szakképzett, nincs érettségije

24. ábra, Bölcsődei gondozók (KSH,2012)

Bölcsődei gondozók2 (KSH,2012)

A gondozónők megoszlása egyéb jellemzőik szerint, 2008-2011

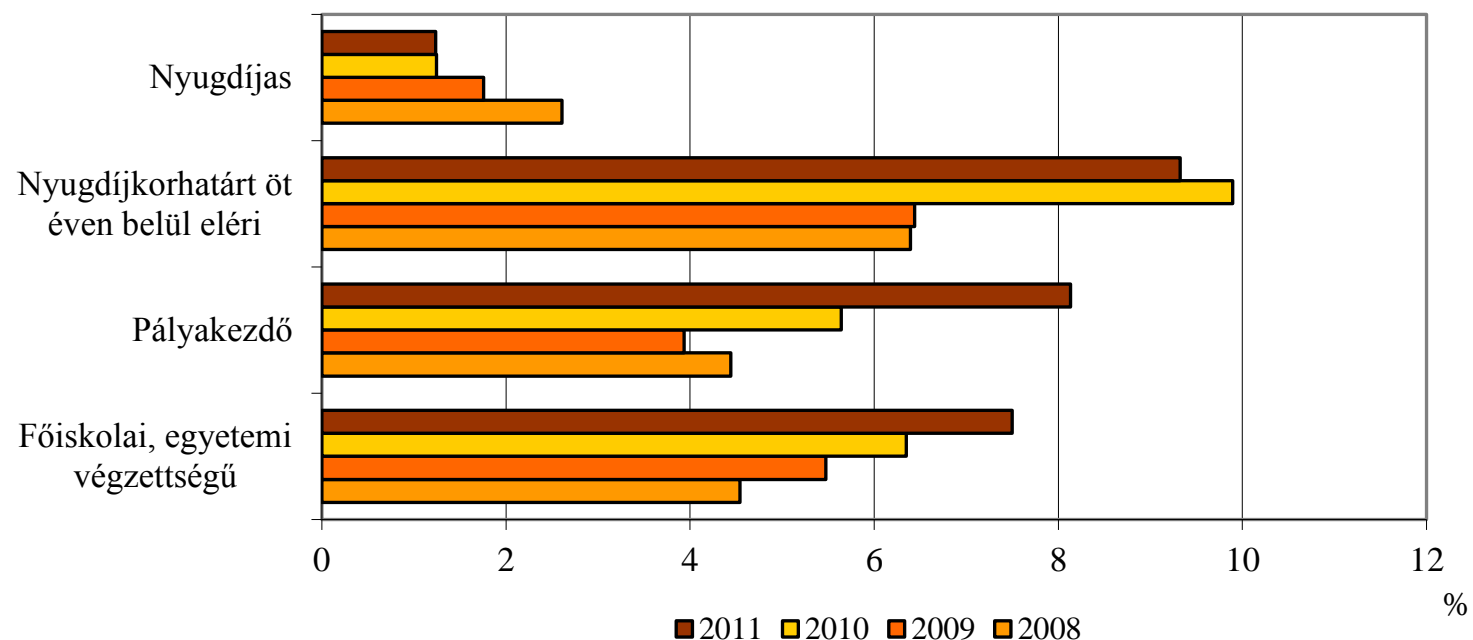

25. ábra, Bölcsődei gondozók2 (KSH,2012)

A családi napköziben ugyanezen jogszabály „szükséges és elégséges” feltételként definiálja a külön jogszabályban meghatározott 40 órás tanfolyamon megszerzett tanúsítványt.

„A családi napközi szolgáltatást nyújtó személy

a) családi napközit müködtetők felkészitö tanfolyamával rendelkezö személy 
b) vagy a családi napközit müködtetök felkészitő tanfolyamán túl egyéb szakképesitéssel rendelkezö, a fenntartó döntése alapján egyéb munkakörben foglalkoztatott nevelö, vagy kisgyermeknevelö vagy segédgondozó nevelö kisgyermeknevelö személy lehet."

Tehát a jogszabály a KJT besoroláshoz határoz meg végzettségeket.

Mivel a családi napközik zöme nem állami fenntartású, így a családi napközit müködtetők élnek azon jogukkal, hogy az általuk alkalmazott személyt nem sorolják be a végzettségük szerinti munkakörbe. Tehát a családi napközikben dolgozók végzettsége és a munkakörbe sorolás között gyakorlatilag - az állami fenntartók kivételével - semmilyen összefüggés nincs. A részmunkaidőben foglalkoztatottak a segítők. A KSH ennél részletesebb kimutatást nem készít a családi napközikben dolgozókról. Tudomásom szerint ilyen irányú felmérés sem készült még az országban.

A KSH adatok összevetése a fentiek miatt aggályos, hiszen míg a bölcsődei dolgozók szakképzettségét regisztrálják, addig a családi napköziben dolgozókról ugyanilyen adatfelvétel nem készül.

\subsubsection{A bölcsőde és a családi napközi munkahelyteremtő szerepe}

Csana dolgozók (KSH,2012)

\begin{tabular}{|r|c|c|c|}
\hline \multicolumn{4}{|c|}{ Családi napköziben foglalkoztatottak } \\
\hline & Foglalkoztatottak összesen & Szakmai munkakörben & Részmunkaidöben \\
\hline $\mathbf{2 0 0 8}$ & 170 & 143 & 44 \\
\hline $\mathbf{2 0 0 9}$ & 388 & 297 & 123 \\
\hline $\mathbf{2 0 1 0}$ & 729 & 586 & 232 \\
\hline $\mathbf{2 0 1 1}$ & 1096 & 890 & 346 \\
\hline
\end{tabular}

26. ábra, Csana dolgozók (KSH,2012)

A KSH 2011-es adataira támaszkodva az alábbi összefüggés mutatható ki (2011 év adatok alapján, saját szerkesztés):

Bölcsőde-csana számok (saját szerk) ${ }^{80}$

\begin{tabular}{|l|c|c|}
\hline & Bölcsőde & Családi napközi \\
\hline db & 689 & 857 \\
\hline féröhely & 35450 & 6253 \\
\hline
\end{tabular}

${ }^{80}$ forrás: KSH, 2012 


\begin{tabular}{|l|c|c|}
\hline ellátott gyermekek száma & 36685 & 4992 \\
\hline kihasználtság & & $1714^{81}$ \\
\hline összes álláshely & 9736 & 1096 \\
\hline összes foglalkoztatott & 9686 & $1096^{82}$ \\
\hline összes foglalkoztatottból gondozó & 6147 & 4,55 \\
\hline egy gondozóra jutó gyermekek száma & 5,97 & \\
\hline
\end{tabular}

27. ábra, Bölcsőde-csana számok (saját szerk)

A fenti adatok alapján egy bölcsődében átlagosan 15 fö dolgozik. Ez a 15 fó lát el bölcsődénként átlag 53 gyermeket. Az NFÜ weboldalán ${ }^{84}$ a bölcsőde beruházási adatokat összehasonlítva megállapítható, hogy egy bölcsőde átlagos bekerülési költsége 200 millió $\mathrm{Ft}^{85}$. Ez alapján egy bölcsődei férőhely ára 3,8 millió $\mathbf{F t}$ (ennyibe kerül egy indirekt munkahely a szülőnek), egy bölcsődei állás bekerülési költsége 13,3 millió Ft (ennyibe kerül egy direkt munkahely létrehozása). Mivel a bölcsődei beruházások szinte csak és kizárólag EU-s projektekből valósulnak meg, így ezen összegek valósnak vehetőek.

Mivel kifejezetten családi napközis EU-s projekt eddig 1 volt ${ }^{86}$, így csak azt vettem figyelembe. Itt két családi napközire és egy játszóházra 50 millió Ft-ot lehetett pályázni. Ez 6 munkahelyet ( 2 családi napközi vezető +2 segítő +1 helyettes +1 játszóház vezető) és 24 (2x7 csana +10 játszóház) férőhelyet jelent. Ebben az esetben 1 direkt munkahely bekerülési költsége 8,3 millió Ft, egy indirekt munkahely (férőhely) ára pedig 2,1 millió Ft. Figyelemmel arra, hogy a családi napközik létrehozása jellemzően nem EU-s beruházásból valósul meg, így reálisabb a valós költségekkel számolni. Egy családi napközi kialakítása átlagosan 2 millió $\mathrm{Ft}^{87}$. Ez 3 munkahelyet (1 családi napközi vezető, 1 segítő, 1 helyettes) és 7 férőhelyet jelent. Ebben az esetben egy munkahely bekerülési költsége 0,7 millió Ft, egy férőhelyé pedig 0,3 millió $\mathbf{F t}$. Ez nagyságrendileg annyival alacsonyabb költség, hogy erősen megfontolandó a nem állami szektor komoly beruházási hajlandóságát kihasználni.

\footnotetext{
${ }^{81}$ Becsült szám. A minimum jogszabályi elöírás: 5 férőhelyig 1 fö, 6-7 férőhely esetén 2 fő. Mivel a családi napközik zöme 7 féröhelyes, így becsültük a számot.

82 nem számoltuk a családi napközi hálózatok koordinátori munkakörét. Mivel a családi napközi hálózatok száma elenyésző, így ez hibahatáron belül lévő eltérést eredményezhet

${ }^{83}$ gondozók és ellátott gyermekek száma alapján

${ }^{84}$ www.nfu.hu (letöltés: 2012.01.20)

85 becsült szám, a fellelhető bölcsőde-fejlesztési projektek adatainak vizsgálata alapján

${ }^{86}$ TÁMOP 2.4.5/12

${ }^{87}$ ez az összeg akkor érvényes, ha nincs szükség extra átépítésre. Mivel a jogszabályi megfeleléshez nem kellenek különleges beruházások, így ha a helyiség, konyha, fürdőszoba adott, abban az esetben ezek valós összegek
} 
Munkahely-férőhely ára (saját szerk)

\begin{tabular}{|lccc|}
\hline \multicolumn{3}{|c|}{ Munkahelyek és férőhelyek fajlagos bekerülési költsége } \\
\hline \multirow{2}{*}{$\begin{array}{c}\text { bekerülési költség } \\
(\text { millió } \mathrm{Ft})\end{array}$} & Bölcsőde (EU) & Csana (EU) & Csana (privát) \\
\cline { 2 - 4 } & & & \\
\hline 1 fö munkahely & 13,3 & 8,3 & 0,7 \\
\hline 1 fö féröhely & 3,8 & 2,1 & 0,3 \\
\hline
\end{tabular}




\subsection{Kutatások bemutatása}

Családi napközis kutatásom több részből tevődik össze. 2009-ben és 2012-ben egyaránt elvégeztem a Csodacsalád Egyesület családi napközi tanfolyamára jelentkezett hallgatók adatainak az elemzését, majd mindkét évben egy (ugyanolyan) kérdőívet tölttettem ki családi napközi vezetőkkel. Az 2009-es és 2012-es adatokat összevetettem. A kérdőívet online módon, a publikus adatbázisokat felhasználva küldtem ki, önkitöltős válaszadással. A kiértékelést SPSS módszerrel végeztem.

2009-ben a Csodacsalád Egyesület által tartott családi napközis tanfolyamok adatait kiértékeltem. 267 fó adatait dolgoztam fel (2009-es év hallgatói).

- A kiértékelés során kapott fö változók mentén összeállítottam egy kérdőívet, melyet e-mailen továbbítottam a fellelhető családi napközi vezetőknek, valamint a tanfolyamot végzetteknek. Ehhez az alábbi elérhetőségeket vettem alapul: Csodacsalád Egyesület családi napközis tanfolyamán végzetteknek e-mail küldése, Magyarországi Családi Napközik Egyesületének tagságának e-mail küldése, nyilvános szociális regiszter adatbázisából e-mail címek kinyerése, majd ezekre is e-mail küldése. Ezen kutatás eredményeinek publikálása nem történt meg, csak egy konferencia-előadáson mutattam be. A 2009-es kérdőív tartalmazott egy módosított Beck-kérdőívet és egy tanfolyami visszajelző kérdéssort is, ám mivel a kutatásban végül nem használtam ezeket az eredményeket, így ezek a 2012-es kérdőívbe már nem kerültek bele, így dolgozatomban sem mutatom be.

- 2012-ben megismételtem a Csodacsalád Egyesület hallgatóinak az adatainak a kiértékelését, majd újra kiküldtem a kérdőíveket. A címzetteket ugyanúgy a hivatalos szociális regiszter címlistája ${ }^{88}$, a Csodacsalád Egyesület hallgatóinak a címlistája, valamint a Magyarországi Családi Napközik Egyesülete tagjainak a címlistája alkotta. Ezen felül a kérdőívet elérhetővé tettem a Csodacsalád Egyesület weboldalán ${ }^{89}$, valamint a Csodacsalád Egyesület Facebook oldalán ${ }^{90}$ is. Mivel a hallgatói adatok kiértékelésében nem találtam jelentős változásokat, ezért a 2009-es kérdőíven csak minimális változtatásokat hajtottam végre. Így a két kutatás eredménye is összevethető maradt.

\footnotetext{
${ }^{88} \mathrm{https://pubregiszter.nrszh.hu/} \mathrm{(letöltés:} \mathrm{2012.01.10)}$

${ }^{89} \mathrm{http://www.csodacsalad.hu/oldal/kerdoivek-szuloknek-csana-vezetoknek} \mathrm{(letöltés:} \mathrm{2012.05.01)}$

${ }^{90}$ www.facebook.com/pages/Csodacsalad-Egyesulet (letöltés: 2013.01.10)
} 
Kutatásaimban az alábbi 4 kérdéskört jártam körül:

1. családi napköziben dolgozók - a 4.4.1 fejezet mutatja be az eredményeket

2. szülői attitűdök - a 4.4.2 fejezetben olvashatóak az ide vonatkozó felmérések eredményei

3. munkáltatói szempontok - a 4.43 fejezet foglalkozik az ide vágó kutatások eredményeivel

4. állami szerepvállalás - a vonatkozó jogszabályok bemutatásával (1. függelék).

\subsubsection{Családi napközis felmérések}

\subsubsection{Csana tanfolyami hallgatók közti felmérések $(2009,2012)$}

A családi napközikkel szemben állandó vád a szakmaiatlanság: a jogszabály szükséges és elégséges feltételként egy külön jogszabályban meghatározott, mindössze 40 órás tanfolyamot $^{91}$ ír elő követelményként, mely tanfolyam befejezett 8 általános osztályhoz kötött.

A családi napközis tanfolyamok nyilvántartása a Nemzeti Család-és Szociálpolitikai Intézetben (NCSSZI) történik. Az NCSSZI nyilvántartása szerint 2012. júliusában 46 regisztrált családi napközis képző tevékenykedett az országban, ebből körülbelül 30 aktívan tartott tanfolyamokat (ez a szám 2011-ben 16 volt, azaz egy év alatt megduplázódott a képzők száma). 2009-ben 2.359 tanfolyamot végzett személyt tartottak nyilván, míg 2011-ben már 5.020-at (kezdetektől görgetett adatok). A tanfolyamok müködtetői nem kötelesek megszerezni a FAT akkreditációt. A tanfolyamok ellenőrzése nem megoldott, gyakorlatilag kontroll nélkül zajlanak a képzések.

A Csodacsalád Egyesület FAT akkreditált felnőttképző intézmény ${ }^{92} .2012$ júliusáig 681 hallgatót jelentettek le a képzők, ebböl a Csodacsalád Egyesület 191-et, ez az összes tanfolyamot végzett hallgatók $28 \%$-a. A tanfolyam ára $(44.000-55.000$ - Ft $)$ közép árfekvésű, a vizsgált időszakban 35 ezer Ft és 70 ezer Ft között volt elérhető hasonló tanfolyam az országban. Az akkreditáció megléte, az országos képzési lefedettség és a magas

91 29/2003 (V.20) ESzCsM rendelet a helyettes szülők, a nevelőszülők, a családi napközit működtetők képzésének szakmai és vizsgakövetelményeiröl, valamint az örökbefogadás előtti tanácsadásról és felkészítő tanfolyamról (letöltés: 2012.01.10)

${ }^{92}$ Felnöttképzési nyilvántartási szám: 00674-2008, Családi napközi tanfolyam nyilvántartási szám: 03-CSN/131, Akkreditációs lajstromszám: PL-4055, AL-2236, PL-5158 
képzési arány miatt döntöttem ezen képző adatainak tanulmányozása mellett. Az adott képző hallgatóinak családi napközi tanfolyami jelentkezési lapját vizsgáltam. A jelentkezési lapon azon adatok kitöltése kötelező, amelyek a tanúsítvány kiadásához szükségesek, így a többi adat némely dimenzióban hiányos.

A Csodacsalád Egyesület 2009 januárja és 2012 júliusa között 152 regisztrált „,családi napközi müködtetője” tanfolyamot tartott, az ország 16 településén. Zárójelben a megtartott tanfolyamok és az azokon résztvevő hallgató száma: Baja (3, 31), Budapest (55, 644), Debrecen (18, 198), Dunakeszi (2, 20), Eger (7, 61), Előszállás (1, 11), Erdőbénye (1, 10), Kecskemét (7, 81), Kisszállás (9, 73), Mindszent (3, 34), Miskolc (2, 22), Szarvas $(6,39)$, Szeged (1, 13), Szendrő (7, 81), Tatabánya $(6,55)$, Zirc $(3,26)$.

A vizsgált időszak alatt 1.349 hallgatót képeztek, ebből 1.269 nő és 80 férfi. A lakóhelyet tekintve 167 fö nevezett meg falut, 558 várost, 238 megyeszékhelyet és 369 Budapestet lakóhelyül.

Megvizsgáltam, hogy a tanfolyamot végzettek milyen végzettségről nyilatkoztak a jelentkezési lapon (zárójelben az összes hallgatókhoz viszonyított százalékos arány). A hallgatók közül 45 fő alapfokú (3,3\%), 456 fö középfokú (33,8\%), 820 fő (60,7\%) felsőfokú végzettségről nyilatkozott, és ennek meglétét igazolta bizonyítványmásolattal. 


\section{Családi napközi tanfolyami hallatók végzettségbeli megoszlása,}

Csodacsalád Egyesület, 2009-2012 (saját szerk)

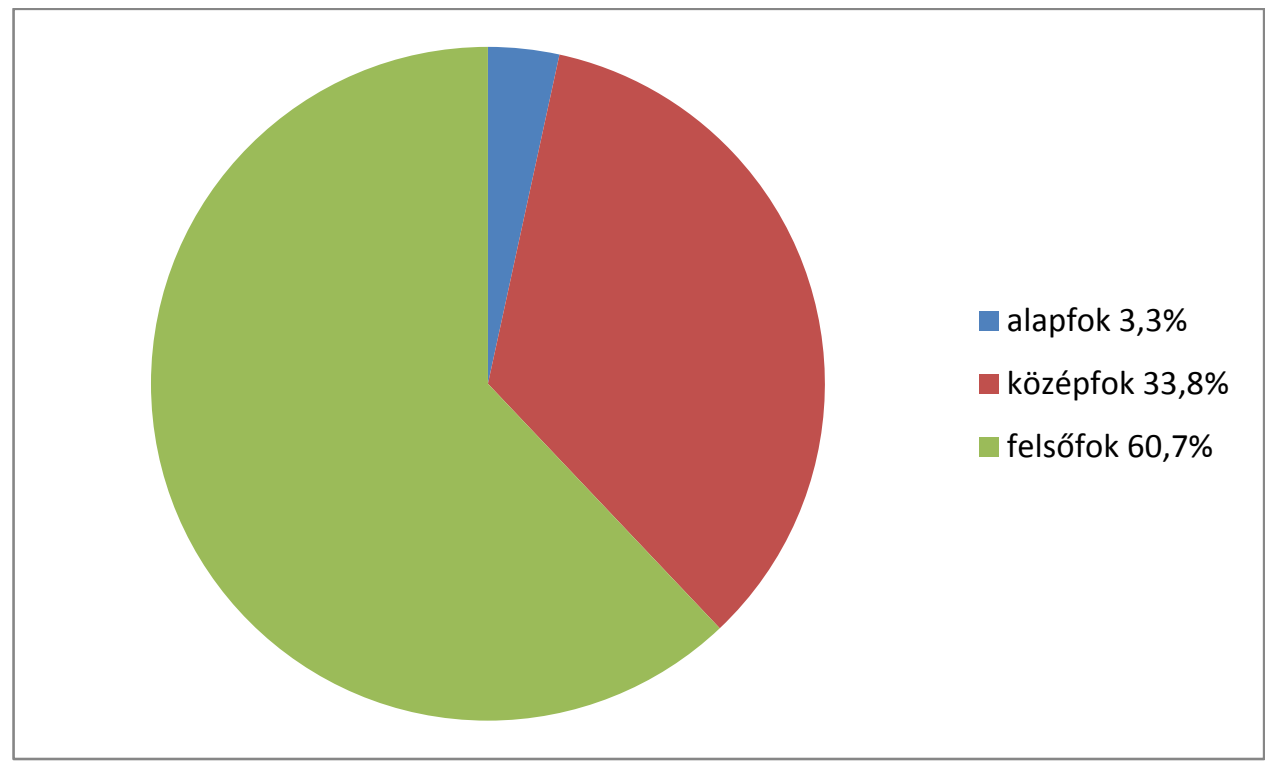

29. ábra, Családi napközi tanfolyami hallatók végzettségbeli megoszlása

Az alapfokú végzettségü hallgatók közül csak kizárólag 8 általánost végzett hallgató 4 fö volt $(0,29 \%), 1$ fö nyilatkozott 10 osztály befejezéséről. A többi hallgatónak (mindösszesen 45 fö, 3,3\%) érettségit nem igénylő szakmája volt (varrónő, fodrász, hentes, szakács, nevelőszülő, üvegcsiszoló, stb.). Ök mindannyian úgy nyilatkoztak, hogy családi napköziben kívánnak segítő munkakört betölteni (tehát egyikük sem családi napközi nyitási szándékkal érkezett a tanfolyamra). Ezek alapján feltételezhető, hogy a családi napköziket müködtetők nagy része valószínüleg nem a végzettség nélküli, 8 általános iskolát végzettek köréből kerül ki.

Megvizsgáltam, hogy a tanfolyamot végzettek között milyen arányban találhatóak a pedagógus alapvégzettségủek. Pedagógusnak tekintettem minden olyan szakmát, amely valamilyen módon kapcsolódik a kisgyermekellátáshoz: dajka, bölcsődei gondozó, óvodapedagógus, tanító, tanár, gyógypedagógus, fejlesztőpedagógus, stb. A felmérésem szerint a vizsgált 1.349 hallgató közül 864 fó pedagógus a fenti definíció alapján, azaz valamilyen gyermekellátó végzettséggel bír. Ez az összes hallgatók 64\%-a.

A nem-pedagógus végzettségű családi napközi hallgatók egyéb végzettségéről egy érdekes, nem teljes áttekintés:

- alapfok: varrónő, fodrász, hentes, szakács, nevelőszülö, üvegcsiszoló

- középfok: technikus, csecsemőápoló, könyvelő, szülésznő, rendezvényszervező, szociális asszisztens, kereskedő, szociális gondozó, 
munkaügyi felügyelő, fényképész, bútorasztalos, gazdasági informatikus, vegyész, ápolónő, kozmetikus, szoftverüzemeltető, postás, gyors-és gépíró, élelmezésvezető, nyomdász, idegenforgalmi szakmenedzser, cukrász, vízimentő, kertész, grafológus, bőrdíszműves, gyógymasszőr, fazekas, tolmács

- felsőfok: igazgatásszervező, közgazdász, mérnők, lelkész, szociális munkás, védőnő, katasztrófavédelmi szakértő, jogász, müvelődésszervező, fogorvos, építész, filmrendező, eu-s szakértő, sportszervező menedzser, személyügyi szervező, pszichológus

Érdekesnek találtam, hogy milyen motiváció miatt jöttek a tanfolyamra. A jelentkezési lapon lehetőség volt nyilatkozni erről. Többen több választ is adtak, iletve voltak, akik nem nyilatkoztak.

- 3 fö azt vallotta, hogy kutatási céllal végzi el a tanfolyamot. 1 fö óvodapedagógus hallgató a TDK munkájához, az ÁNTSZ vezető védőnője a családi gyermekfelügyeleti rendszer kidolgozásához, egy óvónő - szociálpedagógus a céges családi napközi kutatásaihoz gyüjtött anyagot.

- 75 fö (főként pedagógusok) továbbképzési céllal jöttek a tanfolyamra.

- 607 fö nyilatkozott arról, hogy családi napközi vállalkozást szeretne elindítani.

• 659 fő munkavállalási célból szeretne újabb végzettséget szerezni.

Családi napközi tanfolyami hallatók tanfolyam elvégzési motivációs megoszlása, Csodacsalád Egyesület, 2009-2012 (saját szerk)

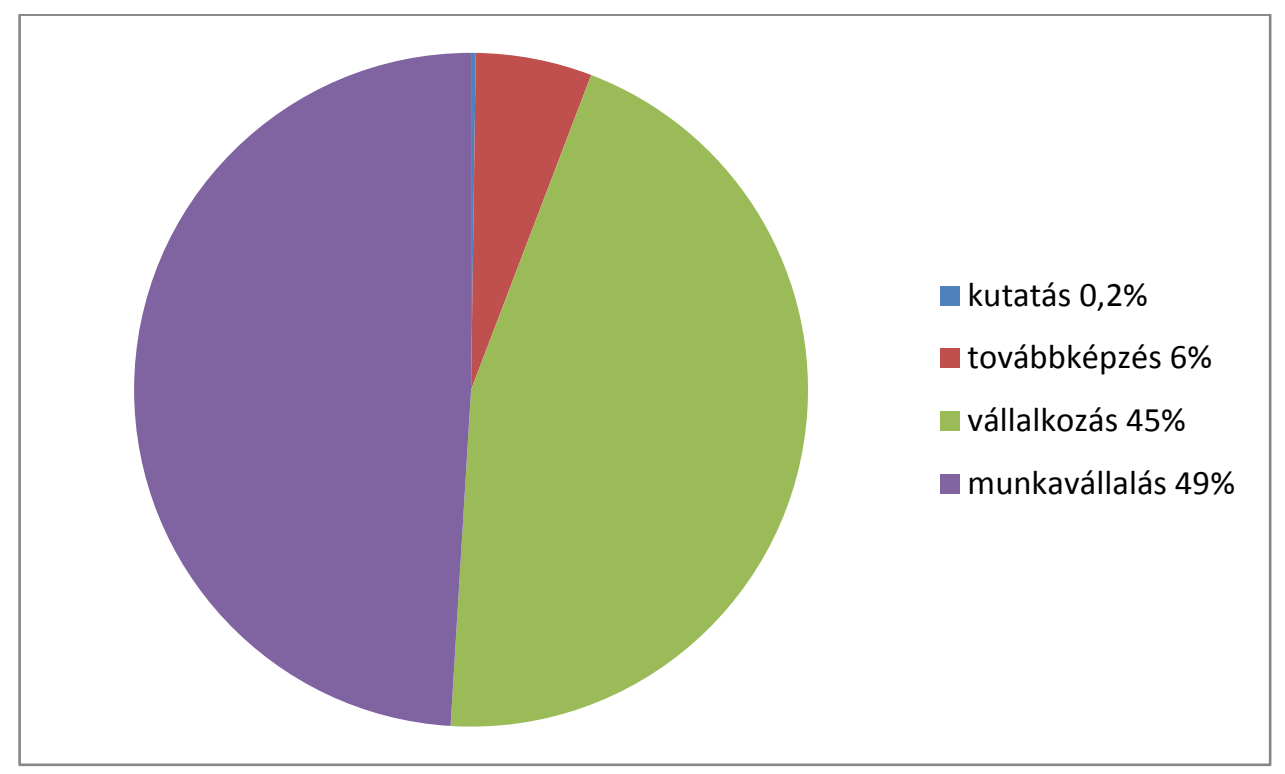

30. ábra, Családi napközi tanfolyami hallatók tanfolyam elvégzési motivációs megoszlása 


\subsubsection{Családi napközisek közötti kérdőíves felmérések $(2009,2012)$}

A tanfolyami hallgatók adatainak kvantitatív elemzése után kérdőíves felméréssel vizsgáltam a családi napköziben dolgozókat. 2 felmérést végeztem, 2009-ben, majd 2012-ben. Mindkét kérdőívet online juttattam el a kitöltőkhöz. A kitöltés önkéntes és anonim volt. A kitöltők köre bizonyosan nem egyezik teljesen, nem ismert az átfedés mértéke.

A kérdőívet 2009-ben kitöltők száma 121 fö (114 nő, 7 férfi). Kitöltők életkora: 22-66 év között, átlag 38,56 év. Lakóhelyet tekintve a kitöltők hatoda budapesti, majd 60\%-a egyéb városokból jön, a többiek községből. Végzettség tekintetében a legnagyobb csoport az óvodapedagógusok (22 fö), majd tanárok és gazdasági végzettségűek (15-15 fö). 23 válaszadónak nincs gyermeke, a többiek esetében az átlagos gyerekszám 2,15. A válaszadók 93,4\%-a kapcsolatban él, a többiek egyedülállóak.

A kérdőívet 2012-ben kitöltők száma 90 fő (83 nő, 6 férfi, 1 n.a.). A kitöltők életkora: 22-68 év között, átlag 41,2 év. Lakóhely: a kitöltők 22,5\%-a budapesti, 60,7\%-a egyéb városokból jön, a többiek községböl. Végzettség tekintetében a legnagyobb csoport a pedagógus végzettségüek: óvodapedagógusok (13 fö), majd tanárok (12 fö)és tanítók (10fö). 9 válaszadónak nincs gyermeke, a többiek esetében az átlagos gyerekszám 2,38. A válaszadók 91\%-a kapcsolatban él, a többiek egyedülállóak.

A legtöbben azért végezték el a családi napközi tanfolyamot, mert családi napközit szerettek volna nyitni, ez 2009-ben és 2012-ben egyaránt így volt. Ez későbbi munkahelyteremtési szempontból fontos tény, hiszen látható a családi napközi nyitási szándék a társadalom részéröl. Már 2009-ben a válaszadók többségének (57\%-nak) teljesültek a tanfolyammal kapcsolatos vágyai, sikerült csanát létesítenie vagy munkavállalóként csatlakoznia egyhez. 2012-ben ez az arány tovább tudod növekedni 66\%-ra. Az egyéb válaszlehetőségek között elsősorban arról írtak a válaszadók, hogy már folyamatban van vagy a tervek között szerepel csana létrehozása. 
Miért ment el a tanfolyamra?

\section{Miért ment el csana tanfolyamra?}

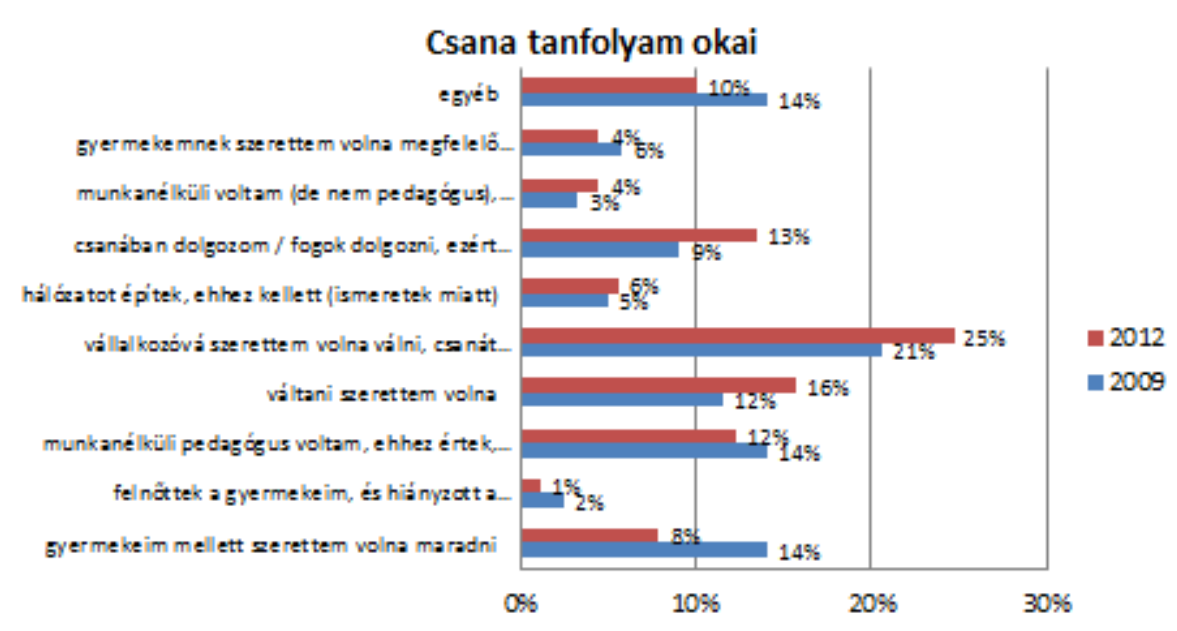

31. ábra, Miért ment el a tanfolyamra?

Szerettem volna megtudni, hogy mennyire volt szükségük külső segítségre a müködlsi engedély megszerzése során. A válaszok többsége (2009-ben 85\%, 2012-ben 84\%) beszámol valamilyen segítségkérésről, az elsődleges forrás a korábbi képzőhely volt, ennek a szerepe az évek folyamán növekedett. Ez a tény mindenképp a képzőhelyek felelősségére hívja fel a figyelmet. Egyéb válaszlehetőségekben arról számoltak be, hogy más csana vezetőktől kértek segítséget illetve mivel még csak tervezik a nyitást, senkitől. 2009-ben A válaszadók közel 70\%-a megfelelőnek érezte a segítségadást onnan, ahonnan kért, 2012-ben ez az arány 75,3\%ra növekedett. 


\section{Honnan kért segítséget?}

\section{Honnan, kitől kért segítséget az engedélyeztetés során?}

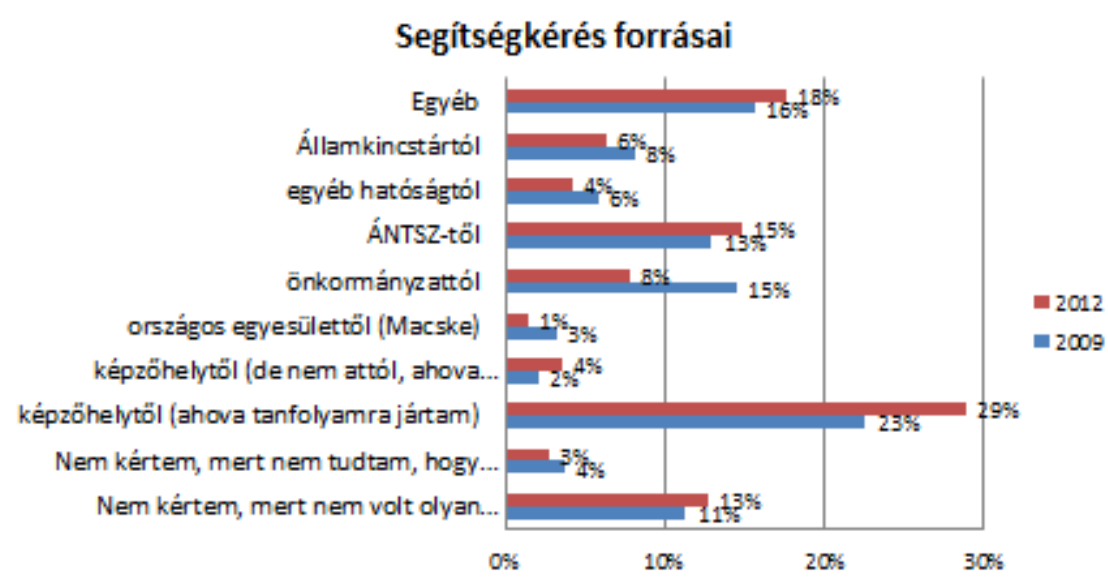

32. ábra, Honnan kért segítséget?

A hatóságok hozzáállása is fontos kérdés volt, ezért megkérdeztem, melyik szereplö hogyan viselkedett az engedélyezés során. A válaszadók segítségnyújtásban 2009-ben és 2012-ben is a legpozitívabban a tüzoltóságot értékelték, ettől alig marad el az ÁNTSZ és az önkormányzat. 2009-ben az építésügy megítélése kicsit rosszabb, de a hozzáállásuk korrektnek tekinthető. 2012-ben vizsgálta a kutatás a kormányhivatal és az országos csana módszertan megítélését, ezek átlag felettinek tekinthetőek ${ }^{93}$. 2009-ben a válaszadók negyede, 2012-ben a 18\%-a nem nyitott csanát, ezért nem volt tapasztalata ezekkel a szervezetekkel. Az önkormányzati segítségkérés növekedése 10\%-on szignifikáns. A 2009-es és a 2012-es év összehasonlításánál metrikus skáláról van szó és átlagokat hasonlítunk össze, így független mintás t-próbát végeztem. Az önkormányzat és a tüzoltóság esetében a null hipotézist, mely szerint az átlagok a két minta esetében egyenlők, elutasítjuk, míg az ÁNTSZ esetében ez nem

\footnotetext{
${ }^{93} 2011$. július 31 elött a müködési engedélyt a területileg illetékes jegyzö, ezt követően a Kormányhivatal adja ki. Amennyiben 1 ingatlanban csak 1 családi napközi kerül kialakításra, csak az ÁNTSZ szerepel szakhatóságként. Több ingatlan esetében a tüzoltóság (katasztrófavédelem) is. 2012. január 1 után létrejövő családi napköziknek befogadást kell kérniük a NRSZH rendszerébe (amit azonban sajnos nem kapnak meg, mert nincs befogadható kapacitás, így normatív támogatásban sem részesülhetnek). 2011. július 31 óta az országos Módszertani Intézet bírálja el a szakmai programokat. 2011-2012-ben 1 fö vezető és 5 fö területi szakértő látta el ezt a feladatot, 2013. január 1-től 1 fő alkotja az országos Módszertani Intézetet. Ezáltal sajnos mind a szakmai programok ellenőrzése, mind a területi szakmai munka támogatása sérül.
} 
vethető el. Azaz az első kettő változása 5\%-on szignifikáns. Megjegyzem, az értékelés 5-ös skálán történt, így a 3 körüli átlagok nem nevezhetőek pozitívnak, azaz közel annyian számoltak be negatív tapasztalatról, mint amennyien pozitívról.

\section{Hatóságok hozzállása (csana nyitás)}

\section{$2009-2012$}

Csana nyitásnál a közremũködő hatóság segítőkészsége, hozzáállása:

\begin{tabular}{|l|c|c|}
\hline \multicolumn{1}{|c|}{ Hatóság neve } & Átlagos értékelés 2009 & Átlagos értékelés $\mathbf{2 0 1 2}$ \\
\hline Önkormányzat & 3,05 & 3,00 \\
\hline ÁNTSz & 3,10 & 2,93 \\
\hline Tũzoltóság & 3,16 & 3,38 \\
\hline Építésügy & 2,72 & - \\
\hline $\begin{array}{l}\text { Kormányhivatal } \\
\text { ("gyámügy") }\end{array}$ & - & 3,35 \\
\hline $\begin{array}{l}\text { Országoscsana módszertan } \\
\text { (szakmai program) }\end{array}$ & - & 3,11 \\
\hline
\end{tabular}

$1-5$ skála, $5=$ =legjobb

33. ábra, Hatóságok hozzállása (csana nyitás)

Szerettem volna megtudni, hogy az, aki nem nyitott családi napközit, miért döntött így. A nem nyitás indokai között 2009-ben és 2012-ben is a leggyakoribb indok a váratlan anyagi vagy eljárásbeli nehézségekkel való szembesülés. Az egyéb válaszlehetőségek között leggyakrabban azt említették a válaszadók, hogy a csana nyitás folyamatban van.

Arra a kérdésre, hogy „Most mivel fogalalkozik?”, az alábbi válaszokat kaptam: 2009-ben a válaszadók 40\%-a a saját családi napközijében dolgozik, 14\% pedig alkalmazott egy csanában, valamint $3 \%$ válaszadó csanát vezet. Azok közül, akik nem csanában dolgoznak (48 fö), a többség (38 fö) szeretne valamilyen formában csanában dolgozni. 2012ben a csanában dolgozók aránya már 45\%, az alkalmazottak száma (26\%) és a hálózatvezetők (7\%) aránya is növekedett. Ez azt mutatja, hogy a kitöltők zöme az a vállalkozó, aki a családi napközit üzemelteti. 


\section{Most mivel foglalkozik?}

\section{Most mivel foglalkozik?}

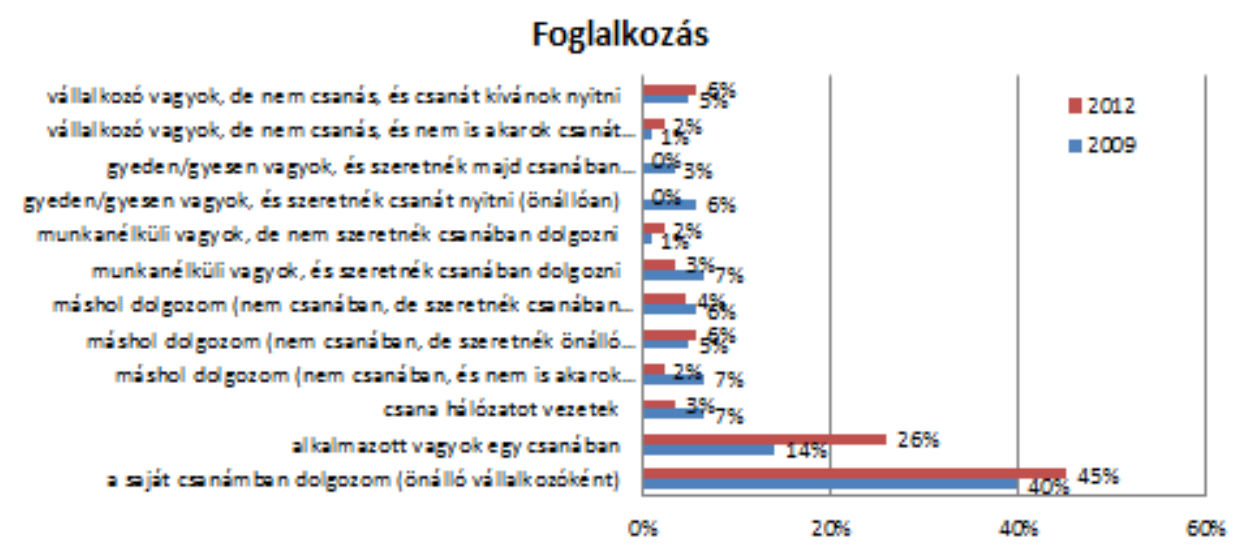

34. ábra, Most mivel foglalkozik?

Fontosnak tartottam megkérdezni, hogy a településen, ahol a családi napközi müködik, milyen más kisgyermek-ellátási lehetőséget találunk. 2009-ben a települések gyermekellátó lehetőségeit tekintve a legtöbb helyen alsó tagozatos napközi és óvoda van, de nagy ezekben a túlzsúfoltság. A bölcsődék tekintetében a legtöbb helyen várólista van. A felső tagozatos napközi tekintetében elmondható, hogy kevés a lehetöség, de megoszlik hogy kevés-e a gyerek vagy túlzsúfoltság van-e. A családi napközik, játszóházak és más gyermekellátó helyek száma kisebb, és általában kevés gyerek van ezeken a helyeken. 2012-ben számottevően nem változott az ellátottság. A települések gyermekellátó lehetőségeit tekintve a továbbra is a legtöbb helyen előfordul az alsó tagozatos napközi és óvoda, a zsúfoltság továbbra is nagy. Változást a bölcsődék és a családi napközik számának növekedésében láthatunk. A csanák korábban a települések 54\%-ában voltak megtalálhatóak, míg ez az arány most már 71\%. Egyre több családi napközi nyílik, azonban kapacitáskihasználtságuk még alacsony. Sajnos a kormányhivatalokból származó nem hivatalos adatok szerint ez a növekvő tendencia megtorpant 2012. január 1 után. Ennek oka vélhetően az, hogy az újonnan létrejövő családi napközik nem kapnak normatív támogatást, így a teljes müködési költséget rá kellene terhelniük a szülőkre. Ezt elkerülendő inkább meg sem nyitják a családi napköziket. 
Feltételezésem szerint egy részük müködési engedély nélkül fogadja a gyermekeket, egy részük pedig más típusú vállalkozásba kezd, illetve munkát vállal.

\section{Egyéb ellátóhelyek, 2009}

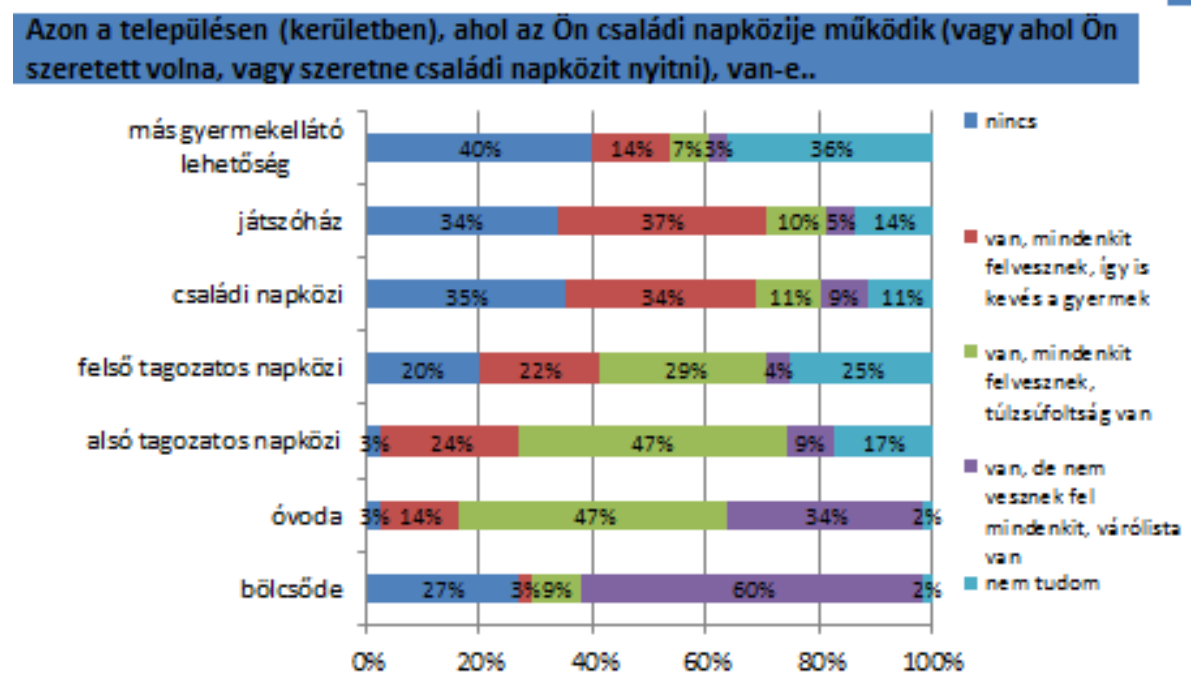

$n=121$

35. ábra, Egyéb ellátóhelyek, 2009

Egyéb ellátóhelyek, 2012

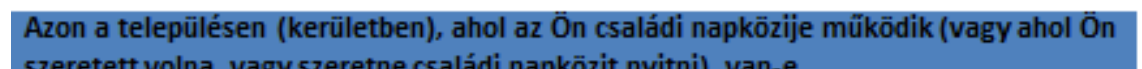
szeretett volna, vagy szeretne családi napközit nyitni), van-e..

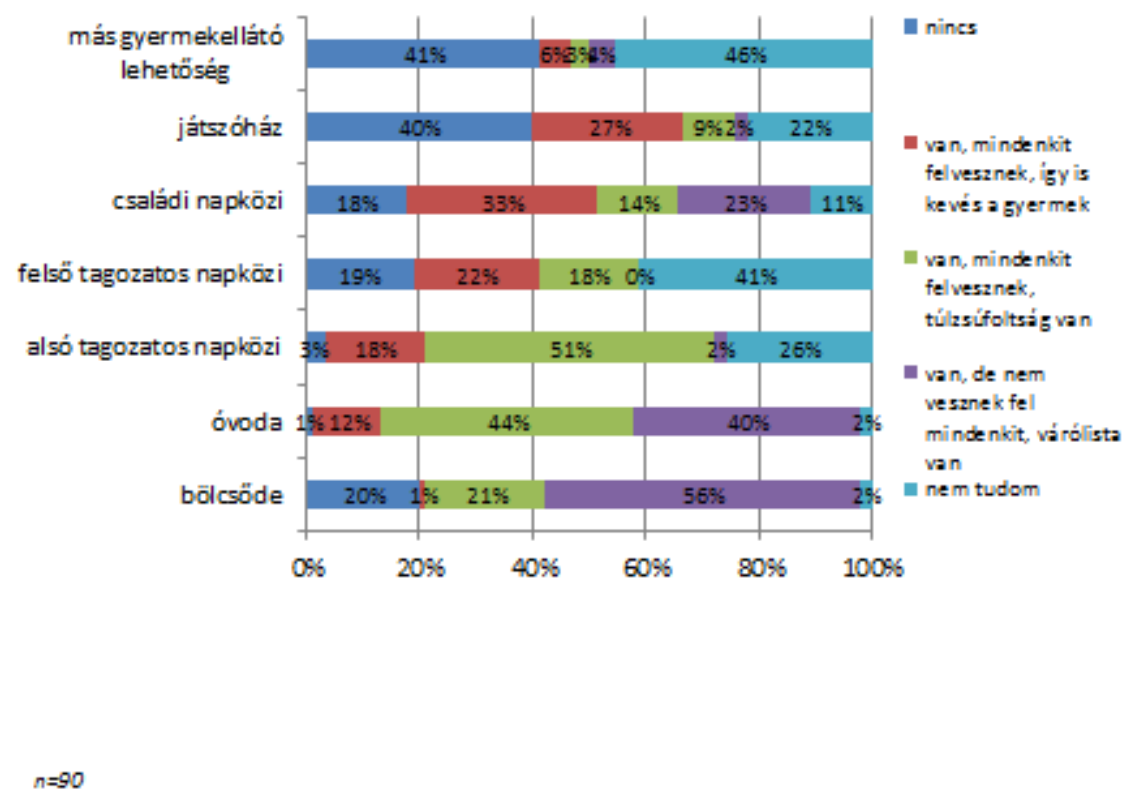

36. ábra, Egyéb ellátóhelyek, 2012 
A kitöltők között 2009-ről 2012-re 5\%-kal nőtt az önkormányzatokkal való ellátási szerződések aránya, bár ez az arány még így is igen alacsonynak mondható. 2009-ről 2012-re növekedést láthatunk az önkormányzat által támogatott családi napközik számában: 7\%-ról 12\%-ra nőtt az arányuk. Az egyéb támogatás tekintetében szintén növekedett az arány, 17-ről 20\%-ra. A válaszadók többsége a Magyar Államkincstártól kap egyéb támogatást. A kérdésfeltevés nem volt valószínüleg egyértelmü, itt a munkáltatók által nyújtott támogatásra, vagy egyéb (nem állami) szponzorációra szerettem volna választ kapni.

\section{Ellátási szerződések}
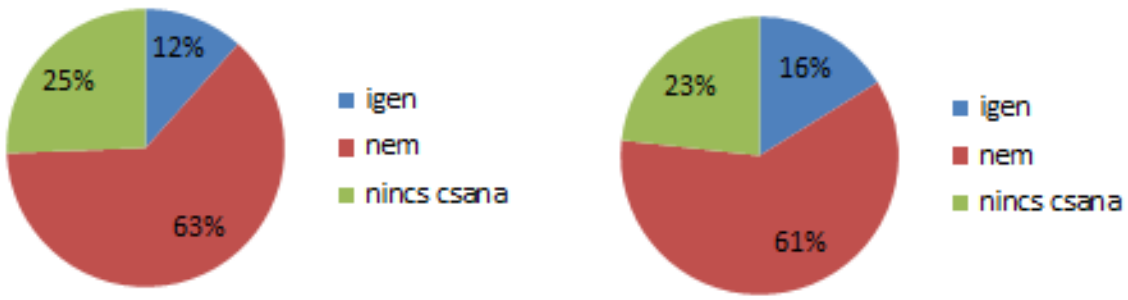

$n=121$

37. ábra, Ellátási szerződések 


\section{Önkormányzati támogatás}

Kap-e támogatást az önkormányzattól az ellátott gyermekek után?

2009

2012

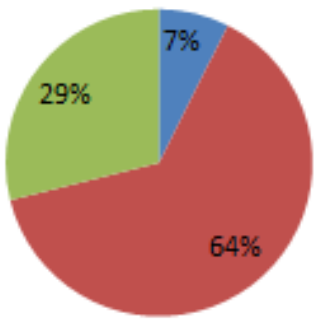

- igen

nem

nincs csana

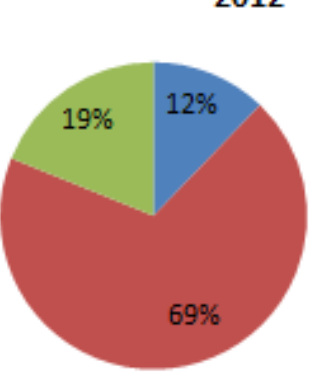

" igen

nem

nincs csana

$n=121$

38. ábra, Önkormányzati támogatás

\section{Egyéb támogatás}

2009

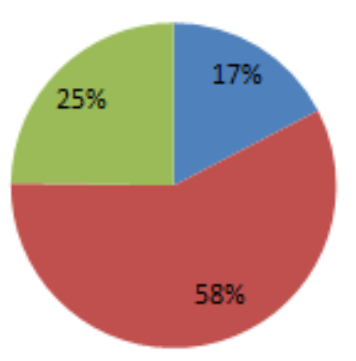

2012

$$
\text { migen }
$$

nem

nincs csana

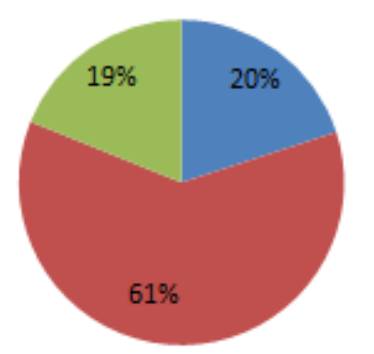

a igen

nem

nincs csana

39. ábra, Egyéb támogatás 
Az átlagos havi gondozási díj 2009-ben 29.368 Ft, 2012-ben 25.361 Ft. Az átlag változására szintén két független mintás t-próbát végeztem, melynek eredménye alapján az átlagos gondozási díj változása (csökkenése) 5\%-on szignifikáns. Ez talán köszönhető lehet annak, hogy csökkent a fizetőképessége a családoknak, illetve az újonnan belépő családi napközik elindíthattak egy árversenyt. Mivel a müködési önköltség idő közben nem csökkent, hanem nőtt, így ez a folyamat közép-és hosszútávon a családi napközik fenntarthatóságának a csökkenését eredményezheti.

\section{Havi gondozási díj}

\section{$2009-2012$}

\section{Mennyi az egész havi gondozási díj, étkezés nékül?}

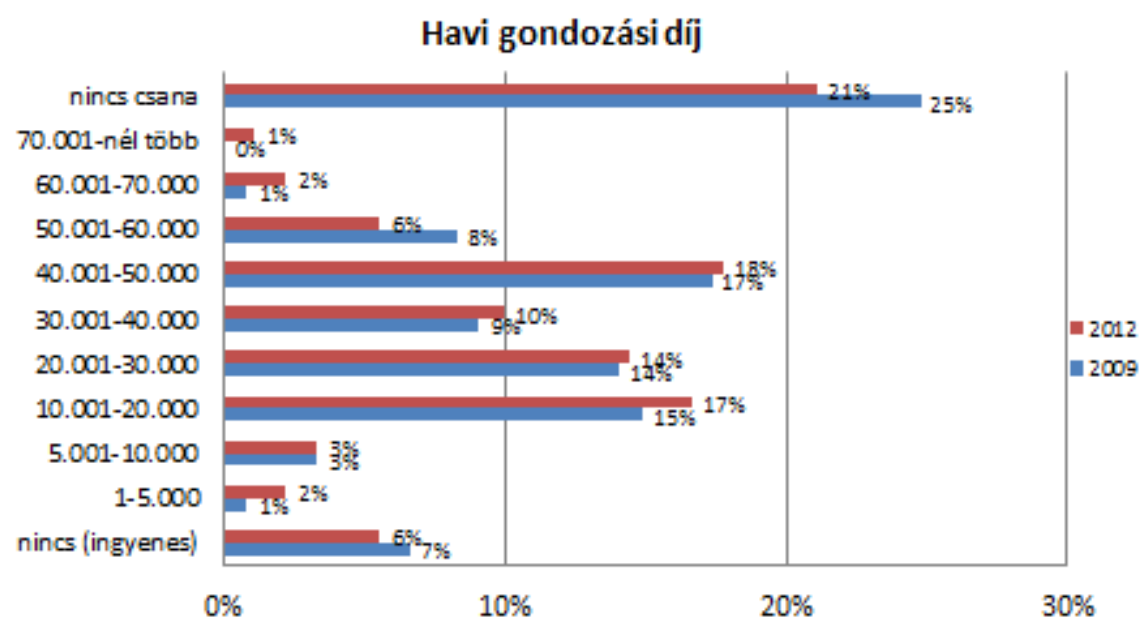

40. ábra, Havi gondozási díj

Fenti adatok elemzése során megállapítottam, hogy a családi napközis képzésre jelentkezők és a családi napközi vezetők adatai nagyban hasonlítanak (bár a családi napközi vezetők nem mind a vizsgált képző hallgatói közül kerültek ki, erre egyrészt az internetes mintavétel volt garancia, másrészt erre vonatkozó konkrét utalások is olvashatóak az anyagban). A kérdőívet kitöltő családi napközi vezetők zöme nő (93\%), és többségük pedagógus (53\%). Mivel egy családi napköziben többen is dolgoznak, a kérdöívben azonban a kollégák végzettségére nem kérdeztünk rá, így arról nincs pontos adatunk, hogy a családi napköziben dolgozók hány százaléka pedagógus. Feltételezhető, de nem bizonyított, hogy ennél magasabb arányt kapunk egy megkérdezésnél. 


\subsubsection{Szülői attitüdök}

2 felmérést végeztem szülők között, melyek célja az volt, hogy megismerjem a szülők gyermekellátással kapcsolatos attitüdjeit. Az elsőt 2009-ben végeztem, 0-3 éves korú gyermeket nevelő szülők között, a másodikat 2012-ben, ebben már kifejezetten a munkahelyi kisgyermekellátásra mint lehetőségre kérdeztem rá. Mindkét kérdőív önkitöltős volt, mindkettőt online terjesztettem (Facebook, kismama portálok, kismama csoportok).

\subsubsection{A 0-3 éves korú gyermeket nevelők közötti felmérés (2009)}

A 2009-es felmérés a 0-3 éves korú gyermeket nevelők között történt. A kitöltők száma 166 fő (150 nő, 16 férfi). Életkori átlaguk 33,64 év (19-65 év között). A kitöltők több mint negyede budapesti. Végzettség tekintetében a válaszadók több mint a fele (84 fö) felsőfokú, 53 fő középfokú, 29 fő egyéb végzettségü. Nyolc válaszadónak nincs gyermeke, a többiek esetében az átlagos gyerekszám 1,97. A foglalkozás tekintetében a legtöbben az oktatás / tudomány területén dolgoznak (37 fö), ezt követi az egészségügyi / szociális ellátás (20 fö) és a kereskedelem (17 fö). A válaszadók 92,8\%-ának volt munkája a szülés előtt.

Arra a kérdésre, hogy „A gyermekének az elhelyezése megoldott volt akkor, amikor Ön vissza szeretett volna térni dolgozni?", a következő válaszokat kaptam:

- A válaszadók közel harmada (30,7\%) vissza tudott menni dolgozni, mert gyermeke elhelyezése biztosított volt (elsősorban bölcsődében vagy családi napköziben)

- A válaszadók 9\%-a szintén vissza tudott volna menni dolgozni, azonban különböző okok miatt (pl. nem tudta biztosítani a gyermekének a felügyeletét)

- A válaszadók közel 40\%-a (39,6\%) nem ment vagy nem akart visszamenni dolgozni, ennek személyes és anyagi okai voltak. 9\%-ban neveztek meg anyagi okokat, 8,4\%ban pedig a pozíciója megszünését

- 13,9\% egyéb választ jelölt meg, itt olyan válaszok jelentek meg, mint a második gyerek érkezése, részmunkaidő, vagy a gyermek még csak pár hónapos, ezért nem aktuális a kérdés

A válaszadók legnagyobb csoportja (22\%) magánjellegü családi napközit keres gyermekének, a második legnépszerübb az állami bölcsőde (19\%), majd ezt követi az az opció, hogy nem keresnek ellátóhelyet, mert a szülő akar vele lenni (17\%). Az egyéb válaszok között az óvodát említették leggyakrabban. 
Szülői attitüdök, 2009 (ellátóhely)

\section{Milyen ellátóhelyet keres gyermekének?}
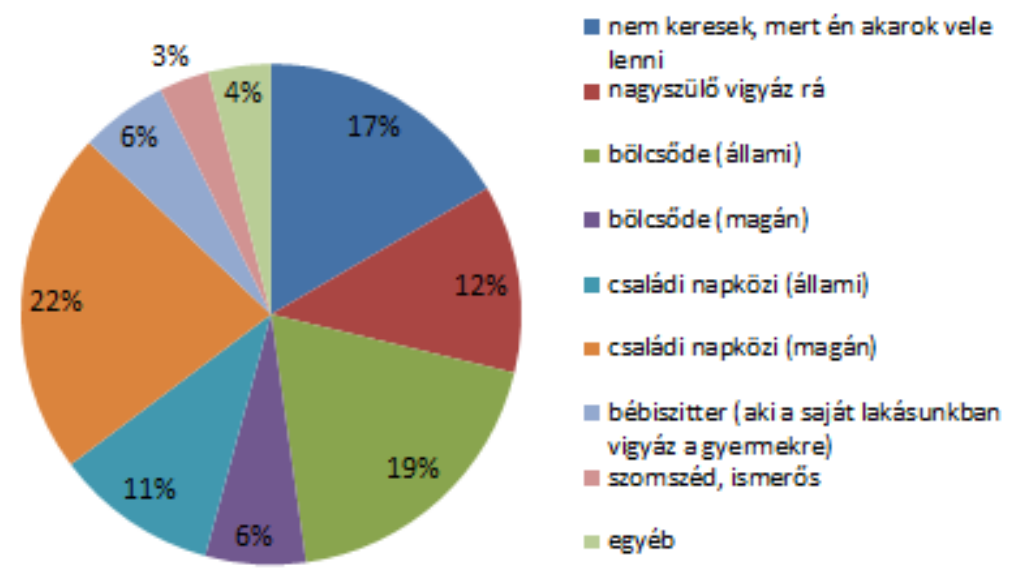

Tóbb vólosz lehetséges, $n=166$

41. ábra, Szülői attitüdök, 2009 (ellátóhely)

Kértem, hogy sorolják fel a különböző ellátóhelyek előnyeit-hátrányait. A válaszokból látható, hogy a szülői preferencia eldönti, hogy egy-egy tulajdonságot előnyként vagy hátrányként jelöl meg, azaz ha anyagi vagy mentális okokból fontosnak tartja a szülö a munkavállalást, abban az esetben hátrány a szocializáció hiánya, vagy épp ellenkezőleg, ha a gyermekével szeretne maradni, abban az esetben előny a szoros kötődés lehetősége. 


\section{Előnyök-hátrányok, bölcsőde}

\section{Elốnyök/hátrányok - Bölcsốde}
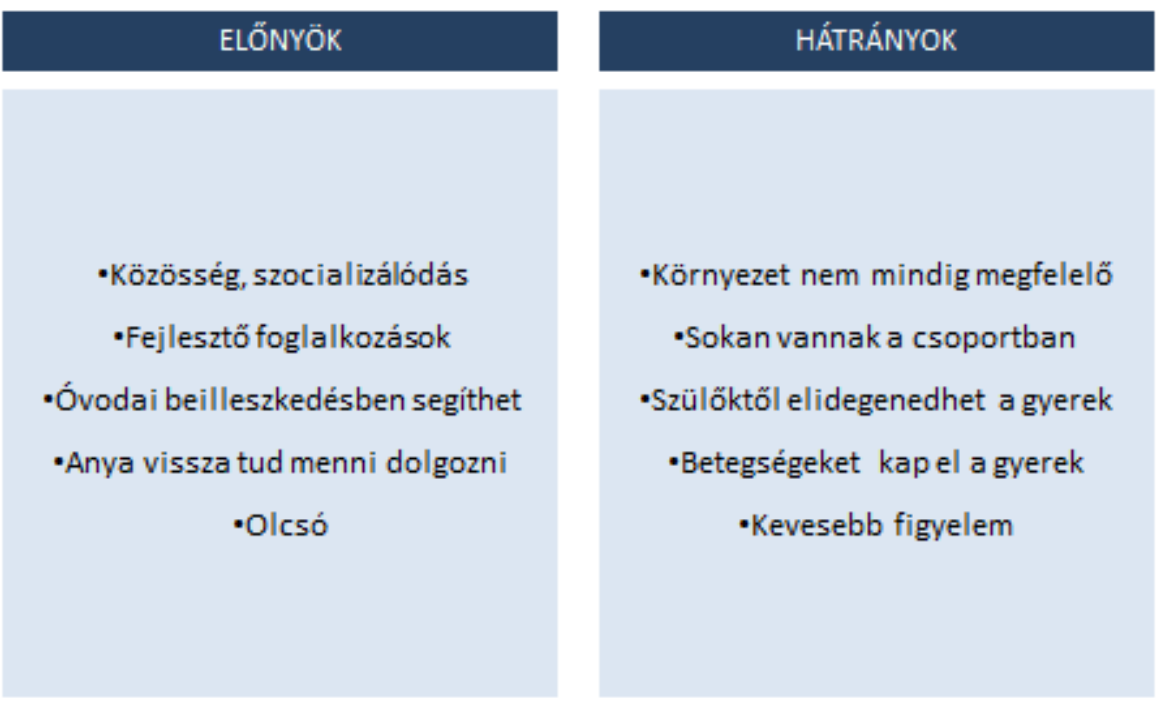

42. ábra, Előnyök-hátrányok, bölcsőde

Elő́nyök-hátrányok, csana

\section{Elốnyök/hátrányok - Családi napközi}

\section{ELŐNNYÖK}

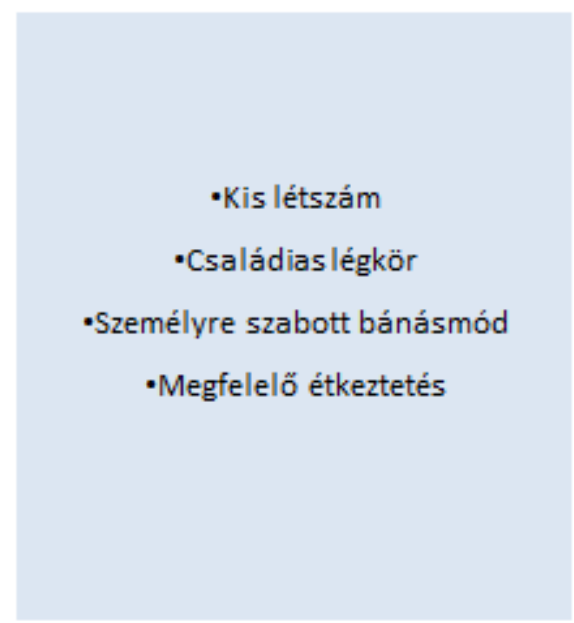

HÁTRÁNYOK

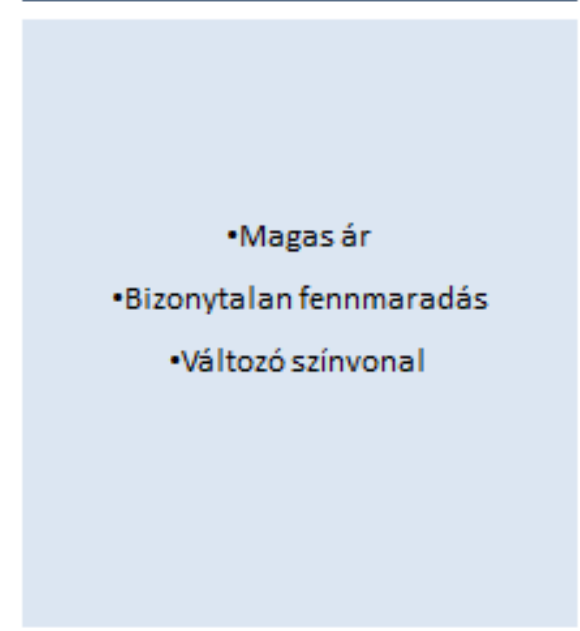




\section{Előnyök-hátrányok, bébiszitter}

\section{Elônyök/hátrányok - Bébiszitter}

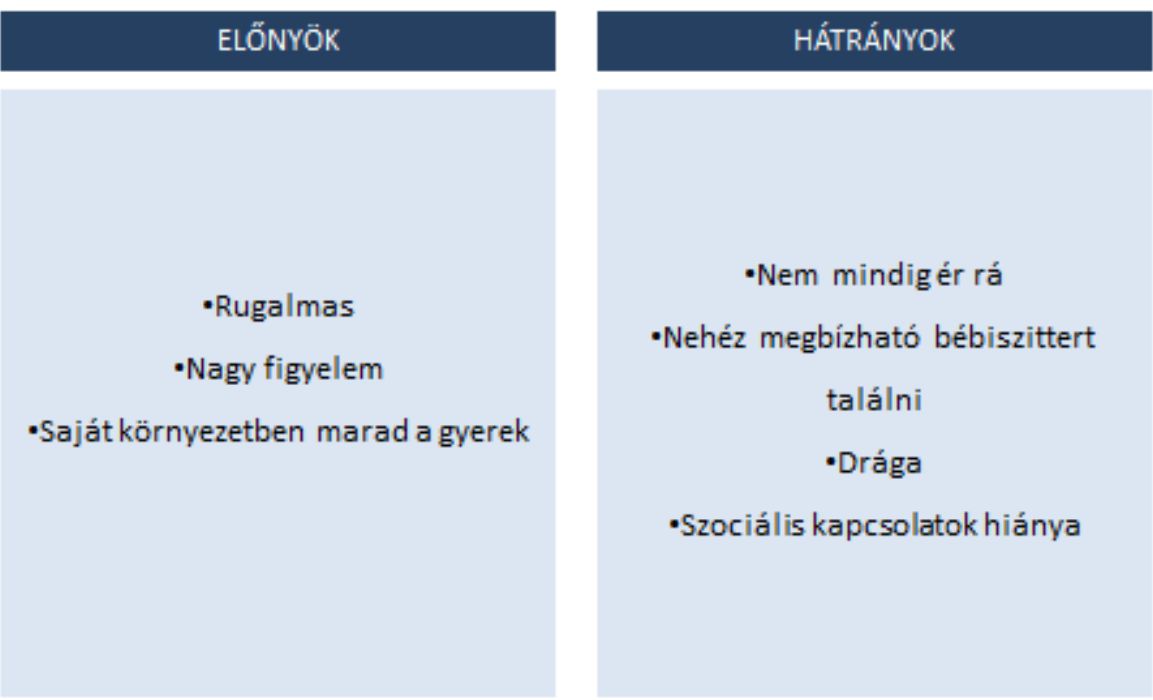

44. ábra, Előnyök-hátrányok, bébiszitter

\section{Előnyök-hátrányok, szülő}

\section{Elổnyök/hátrányok - Ha csak a szülỗ van a gyerekkel}

\section{ELŐNNYöK}

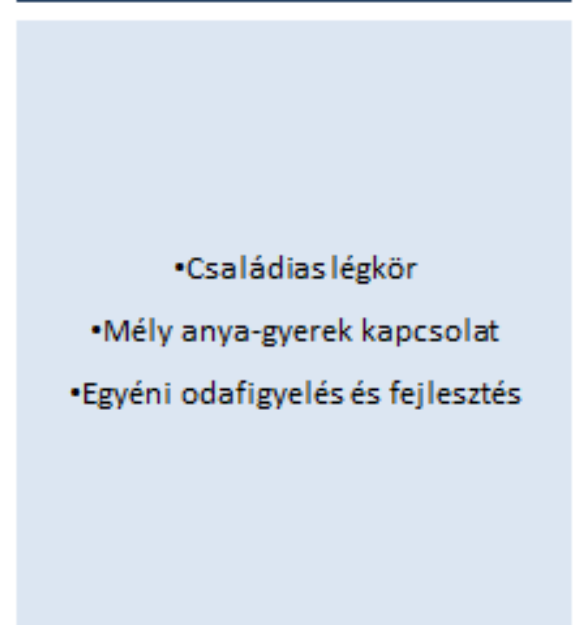

\section{HÁTRÁNYOK}

\section{•Szocial izáció hiánya}

•Egyik szülố kiesik a munkaerổpiacról, ami anyagilag és lelkileg is teher lehet

-Gyerek elszigetelődik

45. ábra, Előnyök-hátrányok, szülő 


\section{Előnyök-hátrányok, nagyszülő}

\section{Elổnyök/hátrányok - Nagyszülő vigyáz rá}
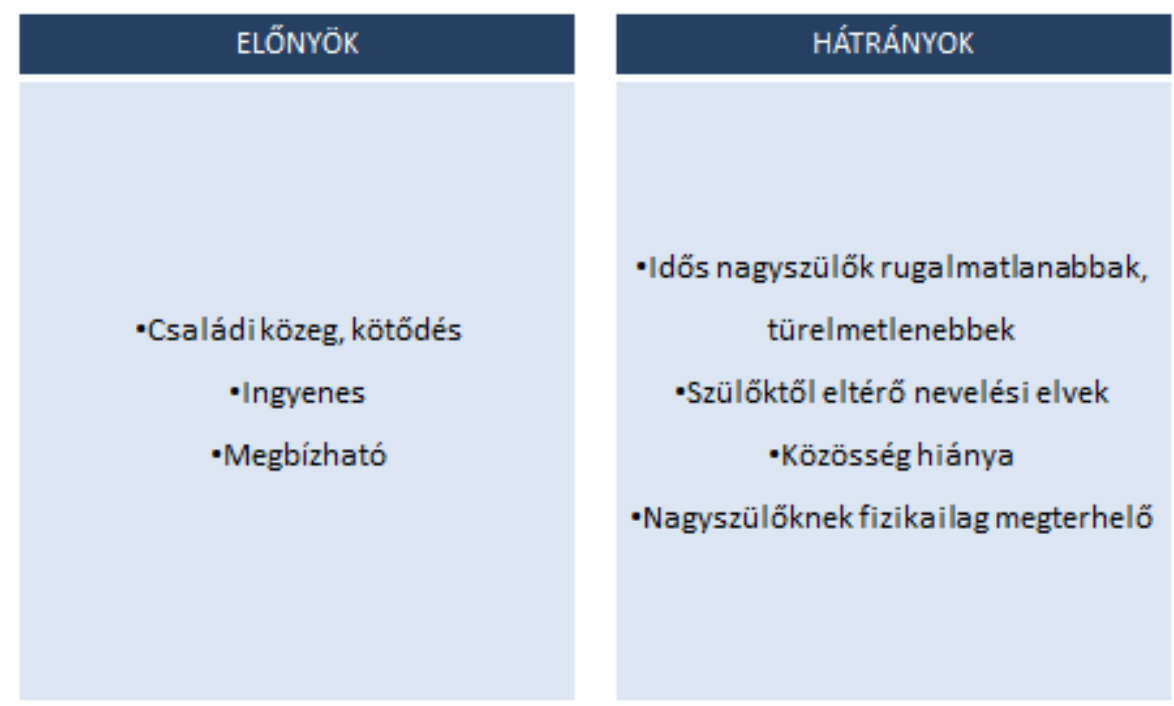

46. ábra, Előnyök-hátrányok, nagyszülö

Szabad szavas megfogalmazásban az alábbi TOP3 válaszokat adták arra a kérdésre, hogy „Mitől jó az ellátóhely?”:

- A leggyakrabban előforduló fogalom a gyerekközpontúság.

- „, Gyermekközpontú. Az Ö érdekei legyenek az elsök.

- A második leggyakrabban említett fogalom a családiasság. Kiemelném, hogy ez sok esetben önmagában, egyetlen szóként jelenik meg.

- A válaszadók nagy aránya fogalmazott meg elvárásokat a nevelők szakmai hozzáállásával kapcsolatban is.

- „Ha szakképzett emberek, egyedi igények alapján tudják gondozni a gyermekemet."

- Hasonlóan magas említéssel bír a szeretet kinyilvánítása is.

- „Nagyon fontos, hogy aki vigyáz a gyerekre, szeresse öt.”

- Ezeket követi a megbízhatóság, bizalom fogalma.

- „Megbizható, mégiscsak a legnagyobb értékem bizom rá."

- A válaszadók egy csoportja számára az a legfontosabb, hogy a gyerek jól érezze magát.

- A személyre szabottságot és a fejlődést a válaszadók 6-7\%-a említette. 
- Néhányan a rugalmasságra és a környezetre illetően is fogalmaztak meg elvárásokat. Egyéb szolgáltatások körében a legnépszerübb a zene és a sport (17-16\%) valamint a szülőkkel közös foglalkozás (15\%). Ezen kívül nagy igény lenne nyelvi oktatásra $(12 \%)$, valamint játszóházra (11\%) is. A sóbarlang igénye a válaszok tizedénél jelenik meg.

\section{Preferált egyéb szolgáltatások}

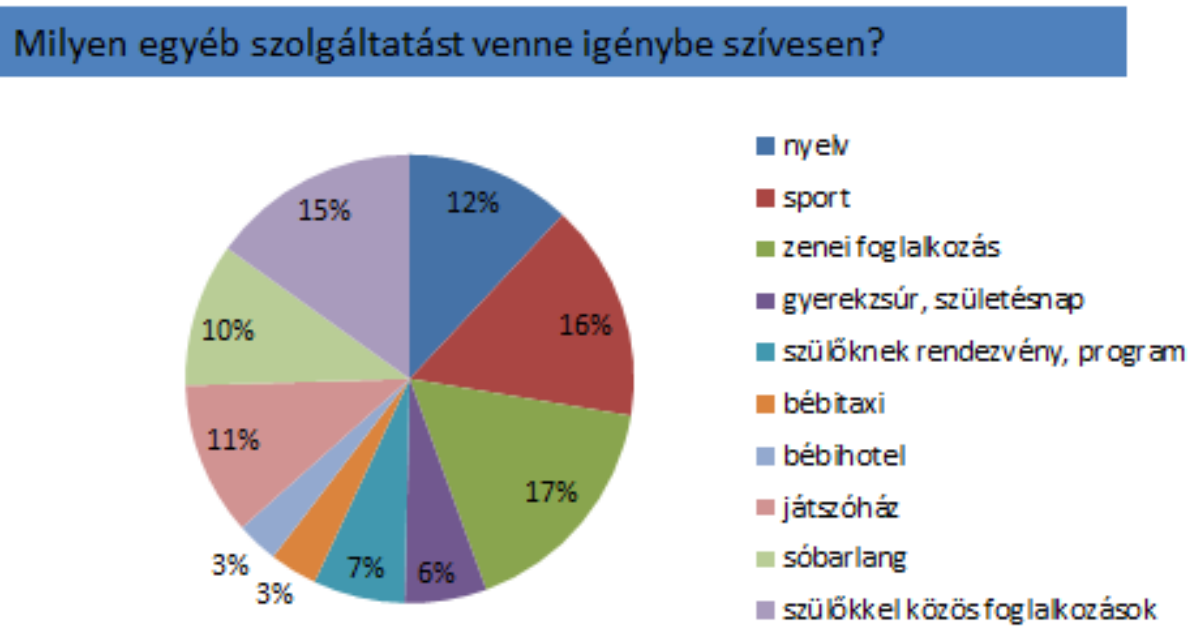

Tobb vólosz lehetsóges, $n=166$

47. ábra, Preferált egyéb szolgáltatások

\subsubsection{Céges gyermekfelügyelet munkavállalói oldalról (2012)}

2012-ben egy újabb internetes kérdőívvel kérdeztem rá a szülői attitűdökre, de most kifejezetten arra voltam kíváncsi, vajon a munkavállaló szülők hogyan vélekednek a munkahely által biztosított gyermekfelügyeletről. A kérdőívet kitöltők száma 40 fö (38 nő, 2 férfi). Kitöltők életkora: 24-52 év között, átlag 35,88 év. Lakóhely: a kitöltők majdnem fele, 19 fö budapesti. Végzettség tekintetében 31 fő felsőfokú, 6 fő középfokú, 3 fő egyéb végzettségü. Egy válaszadónak nincs gyermeke, a többiek esetében az átlagos gyerekszám 2.

Szerettem volna megtudni, mit tartanak fontosnak a szülők az ellátóhely esetén. Ezzel az „elég jó ellátóhely” fogalmára kerestem a választ. 5-ös skálán kellett értékeljék a szempontokat. A szakirodalmi adatokkal összhangban a válaszoló szülők első három helyen 
az alábbi szempontokat jelölték meg: minden nap szabad játék, mozgás $(4,46)$, gondozókkal személyes kapcsolat $(4,34)$, egészséges ételek biztosítása $(4,28)$. Csak ezt követte a müködési engedély megléte és a gondozók szakképzettsége.

Szerettem volna megtudni, jelenleg milyen megoldásokat alkalmaznak a dolgozó szülők a kisgyermekük ellátásra. A válaszadók körében legnépszerübb az állami bölcsőde, óvoda és iskolai napközi (36\%), ezt követi a magán családi napközi 20\%-kal. Ezen kívül sokan maradnak otthon (10\%) vagy kérik a nagyszülök segítségét (12\%). A családi napközit állami formában és a céges gyermekfelügyeletet azonban egyik válaszadó sem veszi igénybe - talán mert nincs, illetve nem is tudnak sokan arról, hogy létezik ilyen lehetőség.

\section{Hogyan oldja meg?}

\section{Hogyan oldja meg gyermeke felügyeletét, amíg Ön dolgozik?}
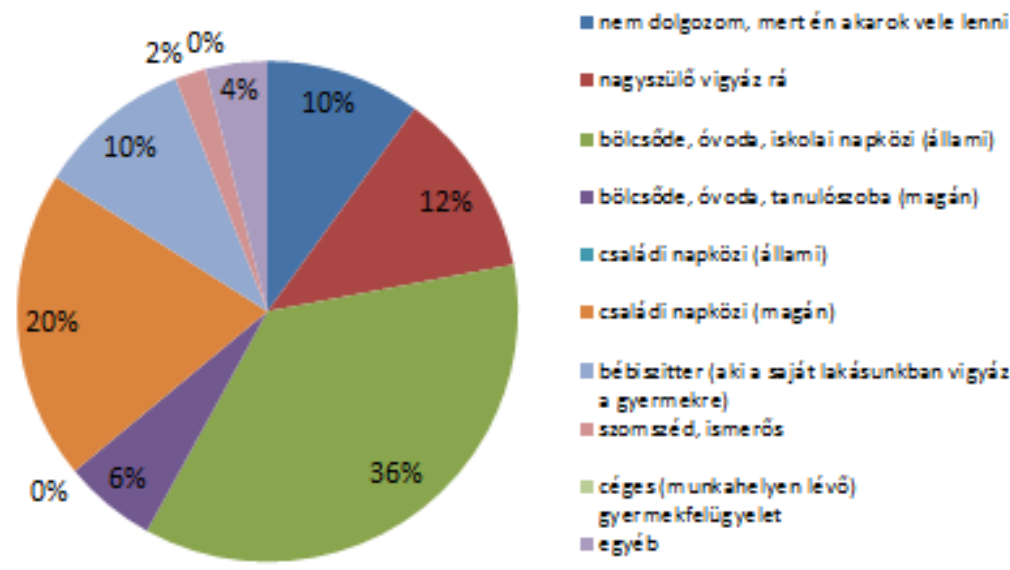

Tobb vólosz lehetséges, n=40

48. ábra, Hogyan oldja meg?

A vágyott szolgáltatások körében a legnépszerübb a sport és zene (17-17\%) valamint a nyelvi foglalkozás (16\%). Ezen kívül nagy igény lenne a játszóházra (14\%), a szülőkkel közös foglalkozásokra (12\%), valamint a szülöknek szóló rendezvényekre és programokra $(10 \%)$ is. 


\section{Vágyott szolgáltatások}

\section{Milyen egyéb szolgáltatást venne igénybe szívesen?}

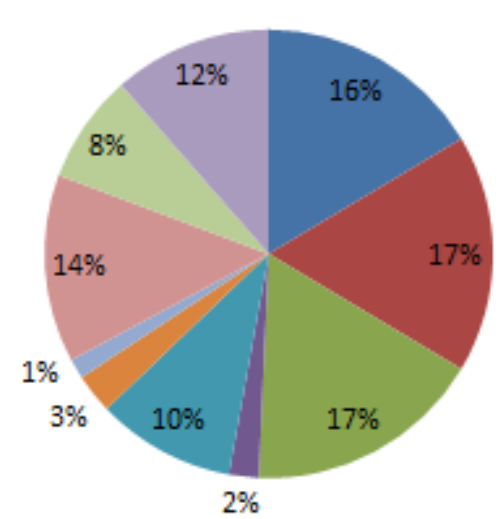

$2 \%$ nyel

aport

- zenei foglakozás

- gyerekzsúr, születésnap

口züloóknek rendezvény, program

bébitaxi

bébhotel

- játşóház

n sóbarlang

ธzülôkkel közös foglakozások

Tobb vólosz lehetséges, $n=40$

49. ábra, Vágyott szolgáltatások

\subsubsection{3 Összehasonlítás}

Összehasonlítottam a 2009-es és 2012-es szülői felmérések adatait. Bár a kérdőívek nem egyeztek meg, és jelentős eltérés volt a kitöltők száma között, mégis érdekes adatokat kaptam, melyeket fontosnak tartok megemlíteni.

\section{Hogyan oldja meg a gyermeke ellátását?}

2009-ben a munkavállalók körében készített felmérésben az állami bölcsőde és óvoda volt a legnépszerübb, ezt követi a magánjellegü családi napközi majd a nagyszülők segítsége. A 2012-es kérdőív esetében, ahol arról volt szó, hogy milyen ellátóhelyet keresnek, a magánjellegű családi napközi volt a legnépszerübb, csak ezután jön a bölcsőde. A harmadik helyen az a válaszlehetőség végzett, hogy a szülő ő maga szeretne otthon maradni a gyerekkel. A családi napközi népszerüsége 20\%-ról 22\%-ra nőtt. A bölcsőde 36\%-ról 19\%-ra csökkent. Az otthon maradás pedig 10\%-ról 17\%-ra növekedett. Szignifikáns változás ezek közül (5\%-os szinten) az állami bölcsőde és az állami családi napközi változása. A saját felügyelet majdnem 10\%-on szignifikáns, a kis minta miatt az lehet egy kutatói döntés, hogy elfogadjuk ezt is szignifikánsnak. 


\section{Elvárások a gyermekellátóhellyel szemben}

Az elvárások tekintetében 2009-ben a legfontosabb a szakmai hozzáállás, az odafigyelés és a gyerekközpontúság voltak. 2012-ben némi változás következett be, a legfontosabbá a gyerekközpontúság és a családiasság volt, a szakmai hozzáállás csak a harmadik leggyakrabban említett érték. Megjegyzem, mivel ez szöveges tartalomelemzés volt, nem lehet szignifikanciát mérni.

\section{Egyéb szolgáltatások népszerüsége}

2009-ben a legnépszerübb a zene és a sport volt, ezt követték a zenei foglalkozások. 2012-ben a zene és a sport népszerüsége töretlen, harmadik helyen pedig a szülőkkel közös foglalkozás jelenik meg.

\subsubsection{Napközbeni kisgyermekellátás a munkáltató szemszögéből}

\subsubsection{Munkáltatói kérdőíves felmérés (2013)}

A kutatásom egyik fő kérdése, hogy bevonhatóak-e a munkáltatók a munkavállalóik gyermekeinek az ellátásába. Ezért első lépéskent egy kérdőívet töltettem ki munkáltatókkal. A kérdőívet online terjesztettem, emailes megkereséssel, Facebook és Linkedin oldalakon, valamint hólabda módszerrel. 29 kitöltő volt (23 nő, 6 férfi). A kitöltők életkori átlaga 39,8 év (28-63 év között). A munkavállalók személyes ügyeit a cégek 58\%ánál az ügyvezető intézni. Mivel a válaszadók többsége kisvállalatot vezet, ez nem meglepő. A munkahelyek helyszíne 34,5\%-ban budapesti. A kitöltők háromnegyede ügyvezető vagy cégvezető, a többi esetben egyéb vezető pozícióban levőket kérdeztek meg. A munkahely méretének tekintetében 24 kisvállalatot (50 fö alatti), 1 középvállalatot (50-250 fö között) és 4 nagyvállalatot kérdeztünk meg. A szektor tekintetében a válaszadó cégek harmada családi napközit müködtet, de vannak válaszadók a szolgáltató szektorból, az oktatásból és kereskedelemből is, valamint állami vezetők is. A válaszolók zöménél az alkalmazottaknak van 14 év alatti gyermeke.

A munkavállalók harmada 1-2 év között tér vissza a munkába, összességében $62,1 \%$ tér vissza két év múlva. A gyors, 1 év alatt visszatérés sehol sem jelent meg, 10\% várja ki a GYES-t is vagy vállal több gyermeket. 


\section{Munkába való visszatérés ideje}

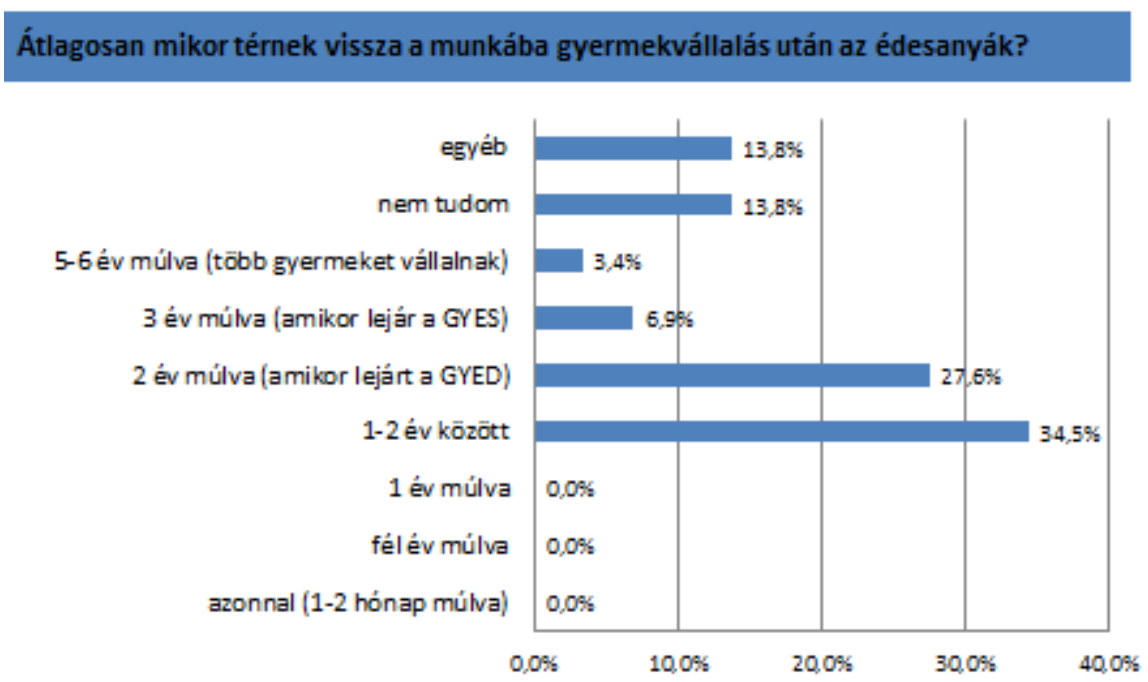

50. ábra, Munkába való visszatérés ideje

Szerettem volna megtudni, hogy hogyan viszonyulnak ahhoz a hírhez, hogy a munkavállaló gyermeket vár. A válaszadók sok esetben rugalmasan állnak a kérdéshez és közös egyeztetés van a távolmaradás idejéről, feltételeiről.

„A munkavállaló bejelenti, hogy várandós, eddig és eddig tud dolgozni, és kiván ennyi és ennyi idő után visszatérni. Az ügyvezetök korrekten tudnak számolni azzal, hogy mennyi idöre kell kiegészitö munkatársat felvenni az illetö helyére."

Néhány esetben megjelenik azonban a kommunikáció félrecsúszása, a kismamák hibáztatása is.

„A munkavállaló hallgat, ameddig nem látszik, utána elmegy táppénzre, mert az neki jár. Én felveszek helyette valakit, mert nem akar gyorsan visszajönni, mert a GYED neki jár. Legtöbbször a GYES alatt is otthon marad. Utána visszajönne, de a gyereke állandóan beteg, mert 36-an vannak az óvodában. Hiába kinálok megoldást, ameddig azért kap pénzt, hogy otthon maradjon, és ne dolgozzon... én ezzel nem tudok versenyezni."

A vállalat 59,4\%-ban nem segíti a munkavállalót a gyermekelhelyezés megoldásában, a nem segítés legfőbb indoka a pénzhiány. A válaszok 18,9\%-ában támogatják 
az elhelyezést, főként vállalati gyermekellátás formájában. A munkáltatók úgy gondolják, hogy az alábbi szempontok a legfontosabbak a kisgyermekes munkavállaló foglalkoztatása szempontjából: legyen rugalmas és átjárható a családtámogatás (GYED, GYES, családi pótlék), a normatív támogatás és a béren kívüli juttatások rendszere (igazodjon a család és a munkáltató igényeihez), valamint lehessen adó-és járulékmentesen adni a napközbeni kisgyermekellátás díját (magánbölcsőde, magánóvoda, családi napközi, tábor, stb.).

\section{Vállalat segítsége gyermekelhelyezésben}

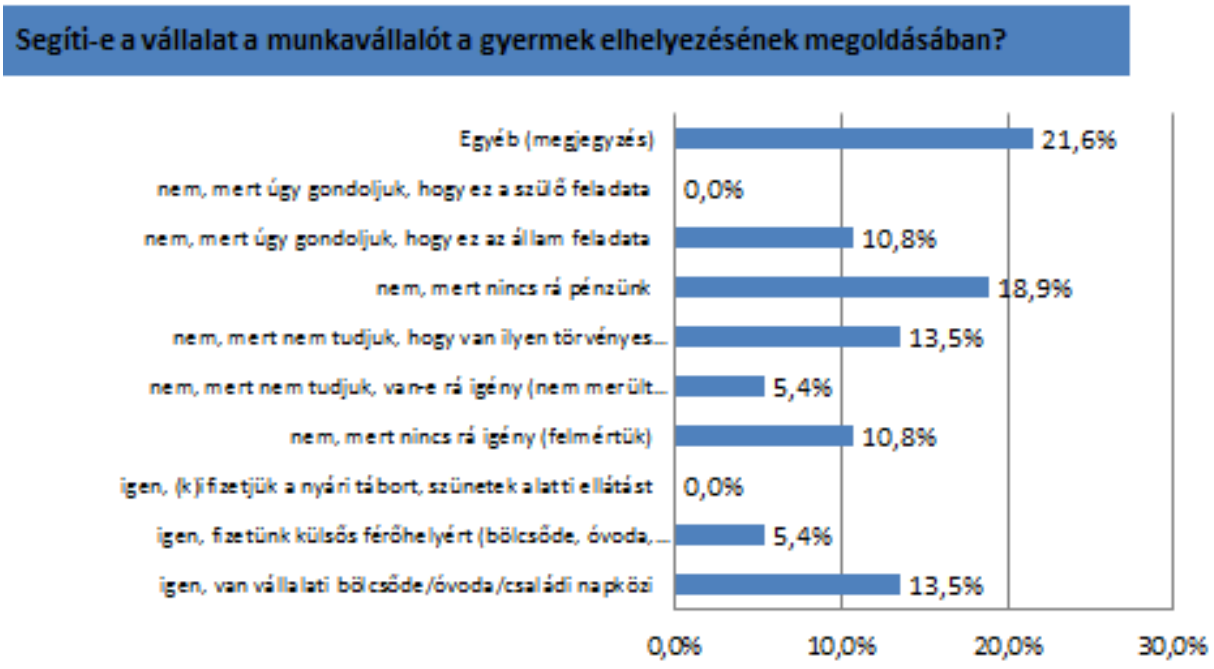

51. ábra, Vállalat segítsége gyermekelhelyezésben 


\section{Vágyott támogatási szempontok}

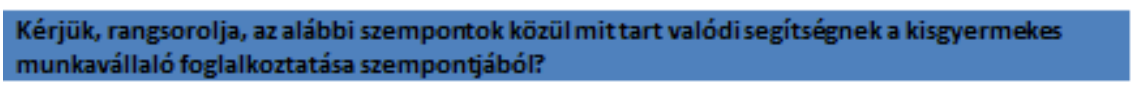

\begin{tabular}{l|c|}
\hline Állítás & Átlagos fontosság \\
\hline $\begin{array}{l}\text { lehessen egy éves kor elött hivatalosan, akár a } \\
\text { GYED/GYES mellett dolgozni }\end{array}$ & 2,62 \\
\hline $\begin{array}{l}\text { legyen rugalmas és átjárható a családtámogatás } \\
\text { (GYED, GYES, családi pótlék), a nomatív }\end{array}$ & 2,93 \\
támogatás és a béren kívüli juttatások \\
$\begin{array}{l}\text { rendszere (igazodjon a család és a munkáltató } \\
\text { igényeihez) }\end{array}$
\end{tabular}

52. ábra, Vágyott támogatási szempontok

Meg szerettem volna tudni, hogy a válaszoló pályázott-e a TÁMOP 2.4.5 pályázaton 2012-ben. A pályázaton a válaszadók ötöde pályázott, 6,9\% nyert is. A válaszadók többsége $(55,2 \%)$ azonban nem pályázott, főként azért, mert nem tartották elég vonzónak a konstrukciót.

Arra a kérdésre, hogy hozna-e létre vállalati kisgyermek-ellátóhelyet, a válaszadók kétharmada pozitívan áll a kérdéshez, az állami támogatás mindenképpen szükséges lenne. Akik nemet mondtak, ott főleg azzal indokolták, hogy a munkavállalók száma miatt ez nem lenne kifizetődő.

Szerettem volna arra választ kapni, hogy mit gondolnak arról, miért nincsenek ma munkahelyi gyermekellátóhelyek. A leggyakoribb válaszok a következőek voltak:

- A legfőbb oknak a pénzhiányt tartják, ezt a válaszadók fele nevezi meg. „, Sokba kerül a munkáltatónak. Így is nagy terhet jelent a munkabérek kigazdálkodása."

- Ezt követi az érdektelenség a munkáltató részéről, amit a válaszadók negyede nevez meg

„, Munkaerö "többlet" miatt nincs rákényszeritve a munkáltató, hogy pluszt adjon a dolgozójának." 
- Páran hivatkoznak az ismerethiányra és a megszokásra is.

„ Úgy gondolom, nem ismerik a munkáltatók magát a lehetöséget. Megszoktuk, hogy ez a dolog, ez a bölcsőde, óvoda, ez a szülö dolga, és ezt az állam fizeti.”

Azzal a kérdéssel, hogy megéri-e támogatni a munkavállaló gyermekének az elhelyezését, a válaszadók többsége egyetért, egy esetben volt csak konkrét elutasítás, de több kérdés is felmerült. Azért tudják támogatni az ötletet, mert ha a szülők nagyobb biztonságban tudják a gyermeküket, hatékonyabban dolgoznak. A válaszadók azonban szeretnének erről az állításról valamilyen bizonyítékot, kutatási eredményt látni.

Szerettem volna megtudni, hogy esetleges állami támogatás esetén hajlandóak lennének-e beruházni a dolgozók gyermekeinek ellátóhelybe. A válaszok ebben a kérdésben is többségében pozitívak, kérdések, kételyek itt is felmerülnek. Kérdés hogy a jelenlegi helyzetben az állam mennyi támogatást tud adni és hajlandóak-e a munkáltatók élni ezzel a lehetőséggel.

- Arra is kíváncsi voltam, hogy saját maguk vállalnák-e a fenntartást, vagy a kiszervezett formát tartják jobbnak. A válaszadók 65\%-a a kiszervezett formát támogatja.

„, Kiszervezett forma. A létrehozásnak nincs költsége, a vállalatot a fenntartás sem terheli, csak a valós igény/kihasználtság arányában vannak költségei”

- $14 \%$ a munkahely által létrehozott formát.

„A munkahely által létrehozottat azért támogatom jobban, mert amit maga a munkahely hoz létre, azt úgy hozza létre, (remélhetöleg) hogy elözetes felméréseket végez, mi a legjobb az adott célcsoportnak, a szülö pedig nyugodtabb, mert azt látja, hogy a munkaadónak is érdeke a minöségi oktatás."

- Szintén $14 \%$ mindkét lehetőségben lát potenciált.

\subsubsection{Céges Családi Napközi Kerekasztal (2013)}

Kutatásom következő kérdése az volt, hogy megtudjam, bevonhatóak-e a munkáltatók a dolgozó szülők gyermekeinek az ellátásába. Meg kívántam tudni, hogy ha igen, akkor milyen feltételekkel, és ha nem, akkor miért nem. Arra is kíváncsi voltam, hogy az államigazgatás mit gondol a témáról, hogyan reagál a felmerülő kérdésekre, mik a 
szándékai. Ezért összehívtam a kollégáimmal egy kerekasztal megbeszélést, ahol az államigazgatás, a munkáltatók, civil szervezetek, kisgyermekes szülök és családi napközit müködtető vállalkozók egyaránt szerepeltek. A kerekasztal résztvevőinek a listája és a született eredmények leírása a függelékben található.

A munkaértekezlet eredményeként a következő eredmények születtek:

1. Van valós igény a munkáltatók részéről egy béren kívül adható munkavállalói támogatásra, mellyel a munkavállaló gyermekek számára megnyugtató, a munkáltató és a munkavállaló igényeihez egyaránt alkalmazkodó, rugalmas, magas színvonalú ellátás biztosítható. Ezt egy olyan béren kívüli juttatásként tartják a munkáltatók megvalósíthatónak, mely kívül esik a jelenlegi cafeteria rendszeren („,bébi cafeteria”). A kivitelezéshez információra van szükség (létrehozás, müködtetés költségei, megvalósítás részletei). A fenntartói feladatok elől a munkáltatók elzárkóznak, külső müködtetők bevonása célszerü. A gyermekek napközbeni ellátását azonban a munkáltatók határozottan állami feladatnak látják, melynek teljes költségét és felelösségét átvállalni nem kívánják, azonban hozzájárulnak, amennyiben az állam részéröl ehhez ösztönzést kapnak.

2. Van szándék az államigazgatás részéről a családok ez irányú támogatására. A résztvevők üdvözlik a munkáltatók családbarát törekvéseit. A cafeteria rendszerbe való beemeléshez konkrét javaslatokat várnak.

3. Van létező kapacitás a családi napközi müködtetők között a rendszer kiépítésére, működtetésére. Ehhez állami és munkáltatói forrásokat várnak. A TÁMOP 2.4.5 pályázat hatalmas túlpályázása mutatja a valós igényeket. Sajnos a pályázati rendszer nem képes kezelni a probléma akutságát: legalább egy-másfél év egy ilyen pályázat elbírálása. Mivel a probléma most áll fenn, így azonnali megoldást kérnek a szereplők.

A munkacsoport létrehozott egy zárt google levelező csoportot, melyen aktív munka folyik a régi és új résztvevők bevonásával.

\subsubsection{Mélyinterjú elemzések (2013)}

A kérdőíves lekérdezéssel párhuzamosan, a fókusz-csoportos „Céges csana kerekasztal” után mélyinterjúkat készítettem ${ }^{94}$ néhány arra nyitott nagyvállalat HR vezetőjével. A célom az

\footnotetext{
${ }^{94}$ köszönöm kollégáim aktív és fáradhatatlan közremüködését: Beck György (Beckground Kft) és Trubjanszky Csilla (Csodacsalád Egyesület)
} 
volt, hogy válaszokat kapjak arra a kérdésre: ha adott a cég részéről a nyitottság, sőt, sokszor már érdemi lépéseket is tettek a munkavállalók gyermekeinek az elhelyezésének a segítésében, akkor hol és miért akad el mégis a munkahelyi gyermekfelügyelet létrehozása, vagy ha megvalósult bármi, az mindek köszönhető? Az interjúkon való részvétel önkéntes volt, a résztvevők beleegyeztek a kutatásban való részvételbe, de anonimitást kértek. Ezt tiszteletben tartva foglalom össze a mélyinterjúk tartalmát.

\section{Mélyinterjú}

Vállalat: 130 országban jelenlévő, 23.000 munkavállalót foglalkoztató német székhelyü multinacionális cég. Hazánkban a budapesti központi irodaház mellett területi képviselőkkel is dolgoznak, egy nagy cégcsoport tagjaként.

Eset bemutatás: az irodaházban dolgozó kb. 50 kisgyermekes munkavállaló gyermekeinek az elhelyezéséhez keresnek megoldást. Már régóta érlelődik bennük a gondolat, de a „hogyan kezdjünk bele” gondolatnál tovább most jutottak először. Nem mérték még fel a pontos igényeket, azaz hogy pontosan hány gyermeknek kellene ellátást biztosítani, körülbelül 30 fö 0-14 éves gyerek lehet érintett. Céljuk a tevékenységgel: a ,work life balance javítása”. Elmondásuk szerint jelenleg nem okoz a gyerekek ellátása problémát, de ez azért van így, mert „a szülők megoldják valahogy” nagyszülők, bébiszitter bevonásával a gyerekbetegséget és a szüneteket. Viszont ez feszültségeket szül, ezért keresnek megoldást a házon belüli gyerekellátásra.

Arra a kérdésre, hogy miért nem történt még eddig konkrét lépés, a válasz ez volt: „ötletnek nagyon jó, de túl sok a „de” és a kérdöjel”. Kérdésként merült fel: milyen beruházási és működési költségei vannak egy ilyen munkahelyi gyermekfelügyeletnek? Ki lehet a fenntartója, müködtetője? Mennyi egy gyermek ellátásának havi összege? Mennyit és hogyan támogatja ezt az állam?

Konklúzió: kérésükre összeállítottunk egy kérdőívet, melyet ígéretük szerint a HR-es kolleganő kiküld a dolgozóknak. Ehhez a vezetőség beleegyezése szükséges. A kérdőív célja az igények felmérése. Elkészítettünk egy olyan anyagot, amelyben bemutatjuk egy vállalati, munkahelyi gyermekfelügyelet (céges családi napközi) létrehozásának tervét, a szükséges lépéseket, azok idő-és költségigényét. Ezt az anyagot a kérdőívvel együtt a HR-es kolleganő rendelkezésére bocsájtottuk. Jelenleg a visszajelzést várjuk a megküldött anyagokkal kapcsolatosan.

\section{Mélyinterjú}


Vállalat: 17 országban jelen lévő osztrák székhelyü multinacionális cég, 60.000 alkalmazottal. Hazánkban 2 budapesti központi irodaházban, 1 vidéki központban és országos hálózatban müködő fióktelepekkel müködnek.

Eset bemutatása: néhány éve foglalkoztatja a HR-seket a téma. Elmondásuk szerint a válságig nem foglalkoztak különösebben a kismamákkal - beleszoktak a magyar rendszerbe, miszerint szülés után 3 évig otthon marad az anyuka, vagy ha több gyermeke születik, ez akár 5, vagy még ennél is több év lehet. Amikor jelezte a visszatérést, ,,valahol mindig találtunk neki pozíciót”. Nem alakult ki kultúrája annak sem a vállalat, sem a munkavállaló részéröl, hogy tervezett legyen a várandós kismama szülési távolléte. Nem volt gyakori a 3 évnél hamarabbi visszatérés, és ez alapvetően a cégnek is kényelmes volt: „,nem kellett foglalkozni vele, felvettünk valakit a helyére, és kész”. Azonban a válság hatására a humánerőforrással való gazdálkodás is szükségessé vált, azaz nem biztos, hogy a szülési szabadságról visszatérő kismamának tudnak helyet biztosítani. Megemelkedtek az elvárások a dolgozókkal szemben: a 8 órás munkaidő gyakran 9-10 óra, és nem hagyhatóak figyelmen kívül a beteg gyerekkel táppénzen lévő szülők által generált plusz költségek sem: „a táppénz költsége mellett a helyettesités és a kollégák túlórája is rontja a kisgyerekes szülö költséghatékonyságát”. Tudják, hogy az anyacégnél és konkurens cégek anyacégeinél is bevált gyakorlat a munkahelyen lévő gyermekfelügyelet, így merült fel az ötlet a hazai adaptációja.

Arra a kérdésre, hogy miért nem történt még eddig konkrét lépés, a válasz ez volt: „,macerás a létrehozás, a papírmunka, az elszámolás, az üzemeltetés, az egész, úgy, ahogy van.” Kérdésként merült fel a hozzáférés elve: vajon szociális alapon adott juttatásként kaphassák meg a dolgozók, vagy a teljesítmény-értékelési rendszer részeként mint motivációs faktor jöjjön szóba?

Konklúzió: Több lehetőség is szóba jön, de mindegyik egyelőre csak elvi szinten. Az egyik a vidéki központban létrehozandó családi napköziket jelenti, erre folyamatban van egy elbírálás alatt lévő TÁMOP-os Eu-s pályázat. A másik az egyik budapesti központban létrehozandó családi napközi lehetősége, de erre csak 2014-ben nyílik lehetőség. A harmadik az egész országos hálózat dolgozóinak elérhető kvázi „férőhelyvásárlás” olyan helyi, rugalmas családi napközikben, amely a cég vidéki dolgozóinak is megoldást nyújt. Ehhez itt is rendelkezésre bocsájtottunk egy igényfelmérő kérdőívet, valamint a mrá előbb említett megvalósíthatósági tanulmányt.

\section{Mélyinterjú}


Vállalat: a világ több mint 20 országában jelen lévő, 32.000 alkalmazottat foglalkoztató magyar székhelyü multinacionális vállalat.

Eset bemutatása: Több éve foglalkoztatja a vezetőséget a munkahelyi gyermekfelügyelet témája. Úgy gondolják, a székhelyen és a telephelyeken nem tudják megoldani az ellátás kialakítását, „nyugodtabbak lennének, ha nem lennének házon belül gyerekek”. Azt gondolják, a szülőknek is jobb, ha nem kell utaztatni a gyerekeket, így a lakóhelyhez közel lenne praktikus olyan „féröhelyeket vásárolni”, amelyek kellően rugalmasak, azaz képesek alkalmazkodni a szülők munkarendjéhez (kevesebb szünet, hosszabb nyitva tartás). Ök nem szeretnének munkahelyi gyermekfelügyeletet létrehozni, hanem e helyett támogatás formájában adnák az ellátás díját. Hónapok óta kutatják ennek a legális és költséghatékony lehetőségét. Úgy látják, hogy az állami férőhelyekkel azért nem tudnak mit kezdeni, mert ha az önkormányzatot támogatják, hogy a dolgozóik gyerekeinek legyen biztos helye, akkor más helyi lakosoktól veszik el esetleg a helyet. Tudják, hogy egy másik hazai egy bizonyos pénzügyi tranzakcióval hogyan oldja meg az összeg lefedését, de a jogászaik szerint „ez kockázatos”. Úgy találták, hogy jelenleg nem lehet legálisan adni a térítési díjat, csak mint személyi juttatást, az azonban „,nagyon drága az adók és a járulékok miatt” - ez nem éri meg már sem a dolgozónak, sem a cégnek. Épp ezért állásfoglalást kértek a NAV-tól a témában ${ }^{95}$, mely állásfoglalás sajnos 1 napig volt elérhető a NAV hivatalos weboldalán. E szerint adómentesen (költségként) elszámolható a bölcsődei, családi napközis térítési díj. Ez egy egyszerü, rugalmas lehetőség, ők maguk sem értik, mi az oka annak, hogy nem engedi az állam (főleg, hogy a NAV szekértői egyszer levezették, hogy miért legális mindez). Ök annak is örülnének, ha a Cafeteria elemek között megjelenne, egy 0 százalékos (vagy a töbinél is alacsonyabb kulcsú) közteherrel. Fontosnak tartják, hogy a többi vállalat is mozgolódjon, kérjen állásfoglalást. Nem értik, hogy „,miért nem tartja a Kormány fontosnak akkor, amikor nincs elég férőhely, szeretnék, hogy a nők dolgozzanak, és a cégektöl is van hajlandóság

\footnotetext{
${ }^{95} \mathrm{Az}$ állásfoglalást a függelék végén bemutatom. Május 16-án az alábbi választ kaptuk a kérdésünkre, melyben megkérdeztük, miért került le 1 nap után a weboldalról az állásfoglalás:

,,Tisztelt Ügyfelünk!

Adó Foigazgatóságunkhoz e-mailben érkezett levelére az alábbi tájékoztatást adom.

Tájékoztatjuk, hogy a ?Nem pénzben juttatott bölcsodei szolgáltatás, családi napközi ellátás adómentessége? cí mu tájékoztatás jelenleg egyeztetés alatt van a Nemzetgazdasági Minisztériummal, ezért a honlapon nem elérhet $o$.

Az egyeztetést követoen az állásfoglalás ismét megtekintheto lesz. Kérjük, továbbra is kísérje figyelemmel honlap unkat.

Tisztelettel:

Nemzeti Adó- és Vámhivatal

Közép-magyarországi Regionális Adó Foigazgatósága

Tájékoztatási Foosztály”
} 
támogatni mindezt.”. Arra a kérdésünkre, hogy milyen módon tartják elképzelhetőnek a müködtetést, mindenképp a „,kiszervezős modell” választ adták, azaz külsős fenntartókkal tartják kivitelezhetőnek. Fontosnak tartják, hogy a hely ellenőrzött, működési engedéllyel bíró legyen. Kidolgozott szabályozó rendszert kérnek számon a döntéshozóktól - hiszen ők mint fizető fél szeretnék tudni, hogy mennyire megbízható a hely, ahol szolgáltatást vásárolnak. Ezt jelenleg nem látják biztosítottnak. Elegendőnek érzik, hogy ha a szülő szerződik az ellátóhellyel, és hoz egy számlát, akkor ők azt befogadják - de tudniuk, kell, hogy pl. a számla megfelelő helyről van (akkreditáció, minőségbiztosítás). Kihangsúlyozták, hogy ha nem lesz adókedvezmény, akkor nem fogják sem támogatni, sem igénybe venni a lehetőséget.

Konklúzió: elengedhetetlennek tartanak egy egységes minősítő rendszert. Az igénybe vétel, rendszer kialakítás feltétele részükről az állami támogatás (adómentesség, vagy kedvezményes adózás) léte.

\section{Mélyinterjú}

Vállalat: Angliai székhelyü, nemzetközi cégcsoport hazai leányvállalata. Hazánkban országszerte 120 kirendeltségen 4.000 alkalmazottal dolgoznak országszerte.

Eset bemutatása: a HR-esek között hangsúlyt kapott a diverzitás, így külön felelöse van a GYES-GYEd-en lévő, a kisgyermekes szülő és a megváltozott munkaképességü dolgozóknak. Elkészítettek egy „Kismama kézikönyv”-et. Pilot projektként a budapesti központban dolgozóknak hoznának létre egy munkahelyi gyermekfelügyeletet (céges családi napközit). Kérdésként bennük is a létrehozás, müködtetés jogi és pénzügyi háttere merült fel. Nem értik, miért ilyen bonyolult a szabályozása.

Konklúzió: megvalósíthatósági tanulmányt kértek, vezetőséggel egyeztetik a hallottakat. Csak abban az esetben jöhet szóba a létrehozás, ha kedvezményes adókulccsal tudják elszámolni (költségként, alapítványi támogatásként vagy külön cafeteria elemként).

\section{Mélyinterjú}

Vállalat: Németországi központú nemzetközi cégcsoport hazai leányvállalata. Hazánkban 7.500 munkavállalót foglalkoztatnak.

Eset bemutatása: a cég évek óta segíti a kisgyermekes dolgozókat azzal, hogy számukra az általuk kiválasztott ellátási helyen (családi napközi, magánbölcsőe, magánóvoda) részben vagy egészben megfizeti a térítési díjat, illetve a nyári szünetek idején a táborok díját. A székhelyen berendeztek egy gyerekbarát munkaszobát, ahova magával hozhatja a dolgozó szülő a gyermekét, bár a felügyeletéről magának kell gondoskodnia. Régóta szeretnének 
továbblépni, akár saját családi napközik létrehozásával. de mindig megakadtak a gondolat szintjén. Úgy érzik, több rétü a probléma. Az egyik ok a negatív gazdasági helyzet: a cég leépítésekre kényszerül, így sajnos nem érvényesül egy fejlesztő, beruházó, pozitív személet, és a kutatásokat is csökkentik, nem pedig emelik. Az a kérdés, hogy ami még megmaradt juttatás, azt hogyan lehet személyessé tenni, hogy „ne a kukába menjen a pénz”? Sajnos sokszor „pont a női, gyerekes vezetők kegyetlenebbek”, mint pl. a férfiak vagy a gyermektelenek.

Konklúzió: „Amíg állami szinten nincs kinyilvánítva, hogy kellenek a „,kis magyarok”, addig mi cégszinten ellenérdekeltek vagyunk a szülök és a leendő szülők támogatásában.”

\section{Mélyinterjú}

Vállalat: 170 országban jelen lévő, angol székhelyü vállalat. Hazánkban 2 helyen (Budapesten és egy vidéki városban) van telephelyük.

Eset bemutatása: Évek óta gondolkodnak munkahelyi gyermekfelügyelet elindításában. Egy TÁMOP-os EU-s pályázat elbírálására várnak, amelyben a vidéki telephelyük dolgozóinak alakítanak ki gyermekfelügyeletet (családi napközit). A budapesti telephelyen beruházni is hajlandóak lennének, de nem látják biztosítva a fenntarthatóságot abban az esetben, ha a müködési költségek elszámolásához nem kapnak adó-és járulékkedvezményt. Készítettek számításokat arra nézve, hogy mekkora költséget jelent a dolgozó szülő gyermekfelügyeletének megoldása. Egyértelműen költséghatékonyabbnak találták a gyermekfelügyeletben való segítséget, mint az új dolgozó képzésébe, munkába állításába, majd a régi dolgozó reintegrációjába fektetett pénzt és munkát. Elmondásuk szerint a náluk dolgozó szülök legkésőbb a gyermek 1-1,5 éves korában visszamennek dolgozni - viszont nem megoldás számukra a bölcsőde - vagy mert nincs a közelben, vagy ha van, annyira zsúfolt, hogy sokat beteg a gyermek, illetve a nyitva tartás is rugalmatlan.

Konklúzió: másfél éve várják az Eu-s pályázat elbírálását - már ez év júniusától tervezték belőle a családi napközi igénybe vételét. Ök is kértek NAV állásfoglalást a térítési díj elszámolhatóságának ügyében.

\section{Mélyinterjú}

Vállalat: Belga székhelyű multinacionális vállalat hazai leányvállalata, 140 dolgozóval.

Eset bemutatása: a cég egy Eu-s pályázaton rugalmas kisgyermekellátási lehetőség létrehozására pályázott és nyert el összeget. Ebből kívánta megvalósítani egy munkahelyi családi napközi létrejöttét. Az irodaházban dolgozó szülők gyermekeinek az ellátását célozták 
meg, elsősorban a bölcsődés korosztályú gyerekeknek hozzák létre a családi napközit, de segítséget remélnek a nagyobb gyerekek közoktatási szüneteiben is. A vezetőség támogatta a tervet, azonban a kialakítás hónapokat csúszott az irodaház tulajdonosának az aggályai miatt. Alapvető problémát jeleztek, miszerint véleményük szerint „, a biznisz-környezetbe nem valók a gyerekek, mit fognak szólni az üzleti partnerek ${ }^{96, " . ~ T o ̈ b b ~ h o ́ n a p o s ~ e g y e z t e t e ́ s ~ e ́ s ~ e g y ~ t e l j e s ~}$ újratervezés után jelen pillanatban folyamatban van az engedélyeztetés.

Konklúzió: ha akad olyan vállalat, aki vállalja a fenntartást és a müködtetést, abban az esetben sem könnyü a létrehozás. Ez a projekt is külsős szakértők bevonásával valósul meg (engedélyeztetés, dolgozók kiválasztása és képzése, audit).

\subsubsection{4 Összegzés}

7 vállalatnál készítettünk mélyinterjúkat, melyek kapcsán az alábbi következtetéseket tettem:

- A munkahelyi gyermekfelügyelet iránt érdeklődő vállalatok mindegyike foglalkoztat külön „kismamaügyekért felelős” HR munkatársat. Arra nézve nincs pontos, naprakész adatuk, hogy hány kismama hány gyermekével érintett, és hány venne részt a programban. Mindegyikük örömmel fogadna egy átfogó auditot, mellyel a téma feltárható lenne.

- A lehetséges alternatívákat nem ismerik, bonyolultnak tartják a szabályozást. Nem tudják, mi a különbség a vállalati bölcsőde, óvoda és családi napközi között. Nem értik, mit takar a „fenntartó” és a „müködtető” fogalma. Nem látják át, miből adódik a müködési költség. Nem tudják, milyen folyamat maga az engedélyeztetés, majd utána milyen adminisztratív és pénzügyi feladatok következnek.

- Valamennyi interjú során felmerült az alábbi szempontok fontossága:

○ minőségbiztosítás, akkreditáció szükségessége (jelenleg nincs)

○ elszámolhatóság (törvényesen adható módjai a térítési díjnak)

○ kiszervezhetőség (külsős fenntartó, müködtető)

○ állami hozzájárulás (adómentes, vagy kedvezményes adókulcs)

- A „Társadalmi felelősségvállalás” mint fontos érték jelenik meg minden cég online és nyomtatott PR kommunikációjában. Amikor arra rákérdeztünk, hogy ezt a

\footnotetext{
96 megjegyzés: az irodaház tulajdonosát képviselő felsővezető is gyermekes nő. Visszaköszön az ötödik esettanulmányban tapasztalt ,, a gyerekes női vezetők kegyetlenek” észrevétel
} 
tevékenységet ${ }^{97}$ a társadalmi felelősségvállalás részének tarják-e, mindehol bizonytalan választ kaptunk.

${ }^{97}$ ti. a dolgozó szülők gyermekeinek az ellátásában való segítséget 
V. FEJEZET

HIPOTÉZISEK BIZONYÍTÁSA, KÖVETKEZTETÉSEK, AJÁNLÁSOK 


\subsection{Hipotézisek bizonyítása}

\section{Első hipotézis (H1)}

- A családi napközi vezetők többségében magasabb végzettségüek, mint a törvény által elöírt 40 órás tanfolyamhoz szükséges és elégséges feltételként megszabott 8 osztályos végzettség. A családi napközit vezetők, müködtetők között vannak szakképzett pedagógusok.

\section{Igazolás:}

Olyan előzetes kutatásról nem tudok (és a saját kutatásaim sem tértek ki rá), hogy a családi napköziben foglalkoztatottak milyen végzettséggel bírnak. A Minisztérium és a KSH sem gyüjtött ez irányú adatokat. A tanfolyami hallgatók adatait vizsgálva megállapítottam, hogy a családi napközis tanfolyamot végzettek 3,3\%-a alapfokú, 33,8\%-a középfokú, 60,7\%-a végzettséggel bír. A tanfolyami hallgatók 64\%-a pedagógus végzettségü. A 2009-es és a 2012-es kérdőívet kitöltők 53\%-a pedagógus.

\section{Második hipotézis (H2), Harmadik hipotézis (H3)}

- A szülők által képviselt preferencia-rendszer által a szülők meghatározzák, hogy mikor, milyen feltételek teljesülése esetén érkezik el a munkába való visszatérés ideje, és ez alapján döntik el azt is, milyen helyet tartanak megfelelőnek a gyermeküknek. Abban az esetben, ha ezek a szempontok sérülnek, a szülő szerepfeszültséget él át. Azzal, ha segítjük a családot abban, hogy a saját preferencia-rendszerének megfelelő ellátóhelyet válasszon abban az esetben, ha bármilyen okból vissza kell térjen a munkába, csökkenthető ez a szerepfeszültség.

- A szülőknek a gyermekük elhelyezésekor fontosabb a relatív szubjektív gyermeki jóllét, mint az ellátóhelyet jellemző objektív tényezők (működési engedély, gondozó végzettséges, $\mathrm{stb})$.

\section{Igazolás:}

A szülők között végzett kérdőíves felmérések alapján sorrendbe tettem azokat a szempontokat, amelyek a szülők számára fontosak a gyermekük ellátóhelyének a kiválasztásánál. Szerettem volna azt megtudni, mitől eléggé jó egy ellátóhely, mit tart a szülö annak. A válaszok szerint a gyermek jól-léte az, amely a szülő számára a legfontosabb (szabad játék, gondozóhoz való kötődés, egészséges ételek), ennél lényegesen kevésbé tartották fontosnak a lokalizációt: valószínüleg azok, akiknek van segítségük a gyermek 
hazavitelében, a lakáshoz való közelséget preferálják, akiknek ez egyénileg megoldandó feladata, azok a munkahelyi közelséget). Illetve akik autóval járnak, azoknak indifferens a tömegközlekedési lehetőség, és fordítva, akik tömegközlekedést használnak, azoknak mellékes, hogy könnyü-e ott parkolni. A legkevésbé fontosnak az intézményi jelleget jelölték meg, bár nem sokkal volt fontosabb a családiasság.

\section{Negyedik hipotézis (H4)}

- A munkáltatók megfelelő ösztönzők és állami támogatás megléte esetén hajlandóságot mutatnak a munkavállaló gyermekének az elhelyezésében.

\section{Igazolás:}

A munkáltatókkal közösen tartott fókuszcsoport megbeszélés, a körükben végzett kérdőíves vizsgálat és az esettanulmányok egybehangzóan azt a szándékot mutatják, miszerint a munkáltató hajlandó támogatni a munkavállalójának a gyermekelhelyezését, ha számára ennek a költsége kisebb, mint a munkavállaló elvesztésének, pótlásának, illetve bármilyen típusú helyettesítésének járulékos költsége. Ez csak úgy érhető el, ha állami ösztönzőkkel támogatjuk a munkáltatókat. Ebben az esetben az állam cserébe direkt és indirekt munkahelyeket, illetve gyermekellátó férőhelyeket kap a nem állami fenntartó működése által.

\section{Ötödik hipotézis (H5)}

- A családi napköziben dolgozók zöme nő, így a családi napközik számának növelésével elsősorban a női foglalkoztatási mutatók nőhetnek (direkt munkahelyek).

\section{Igazolás:}

A családi napközi tanfolyamot végzettek 94\%-a, a családi napközis kérdöíveket kitöltők 93\%-a nő.

\section{Hatodik hipotézis (H6)}

- A családi napközi, mint rugalmas kisgyermek-ellátási forma hozzájárul az atipikus foglalkoztatás elterjedéséhez, ami növeli a női foglalkoztatottságot.

\section{Igazolás:}

A hazai konzervatív családmodell miatt a nőkre több otthoni feladat hárul, mint a férfiakra. Ezt fokozza a GYES- szokások rögzülése (Pongrácz, 2011; Blaskó, 2008). Az atipikus foglalkoztatási formák elterjedése fokozza a női foglalkoztatást (NGM, 2012; Szalai, 2013). Ahhoz, hogy a nök vissza tudjanak térni dolgozni, szükség van olyan megnyugtató 
kisgyermek-ellátó helyekre, ahol nyugodtan hagyhatják a gyermekeiket. A szülőkkel folytatott kérdőíves megkérdezésekből ez egyértelmüen kiderül. Azonban a munkáltatói attitüdöknek is változniuk kell a kisgyermekes munkavállaló foglalkoztatása kapcsán. Erre van készség a munkáltatók irányából, a fókuszcsoportos munkán és a mélyinterjúk során egyaránt kinyilvánították szándékukat a gyermekellátás segítésére. Ehhez feltételül szabják az állami szerepvállalás változását (növekedését).

\subsection{Céges családi napközi ajánlott modellje}

A disszertációmban a kutatási modell alapján feltett kutatási kérdésekre válaszul, a primer kutatások eredményeit felhasználva, az alábbi modellt alkottam meg: feltételezem, hogy amennyiben rendszerszinten fejlesztjük a családi napköziket, azzal segítjük a női foglalkoztatást. Ehhez a fejlesztéshez a munkáltatók bevonása szükséges, hiszen ők azok, akik a kisgyermekes nök foglalkoztatásában segíteni tudnak. A modell lényege, hogy a munkáltatók bevonásával munkahelyi (azaz „céges”) családi napközik létrehozásával támogathatóak a munkavállaló szülők.

A rendszerszintü fejlesztés elemei a következőek:

1. Szabályozási eszközök: kiszámítható jogszabályi háttér, egyértelmü módszertani segítség.

2. Gazdasági, pénzügyi eszközök: pozitív ösztönzők (adójóváírás, adókedvezmények) és korlátozó eszközök (pl. pályázatból való kizárás).

3. Önkéntes, nem kényszerítő eszközök: minőségbiztosítási rendszerek felállítása (amelyhez hozzárendelhető az extra finanszírozás), közszféra-versenyszféra közti megállapodások (amennyiben hiányzó állami, önkormányzati férőhelyeket pótol, kapjon az állami finanszírozásból).

Az ajánlott modell munkahelyteremtő szerepe a következő: a munkahelyeken, akár külső fenntartók által müködtetett családi napközik képesek új munkahelyeket teremteni (gondozó pedagógusok), valamint segítik az atipikus női foglalkoztatás elterjedését rugalmas nyitva tartás, rugalmas létrehozás, racionális müködtetetés által. 


\section{Céges csana modell}

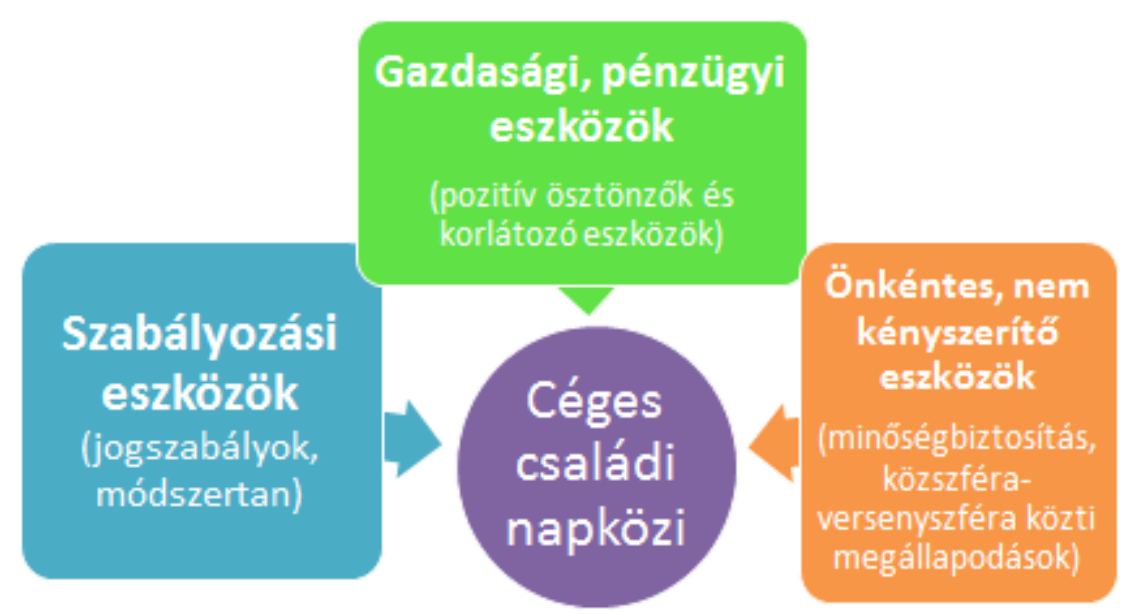

\section{Magyarázat:}

- Céges családi napközi: minden olyan rugalmas kisgyermek-ellátási forma, melynek a létrehozásában és/vagy a müködtetésében tevékenyen részt vesz a munkáltató, akinek a munkavállalójának a gyermeke igénybe veszi az ellátást. A fenntartó lehet a cég vagy külsős nem állami vagy állami fenntartó.

- Szabályozási eszközök: olyan koherens és átlátható jogszabályok, sztenderdek, módszertani útmutatók, amelyek alapján egyértelmü a létrehozás és a működtetés minden aspektusa.

- Gazdasági pénzügyi eszközök: olyan pozitív ösztönzők és korlátozó eszközök, amelyek támogatják a céges családi napközik elterjedését.

○ Pozitív ösztönzők: adókedvezmény létrehozáskor és működtetéskor, normatív finanszírozás

○ Korlátozó eszközök: egyes pályázatokból való kizárás (pl. családbarát munkahely pályázat egyik kötelező feltétele legyen valamilyen kisgyermekellátási lehetőség megléte)

- Önkéntes, nem kényszerítő eszközök: minőségbiztosítási rendszerek rendelkezésre bocsájtása (alkalmazása esetén további gazdasági ösztönzés), közszférával való megállapodás lehetősége (önkormányzat tehermentesítése esetén helyi iparüzési adó kedvezmény). 


\section{ÖSSZEFOGLALÁS}

A dolgozat logikai ívét az alap, fentebb már felvetett kutatási kérdésre füztem fel: vajon a családi napközik rendszerszintü fejlesztése hozzájárul a női foglalkoztatottság növeléséhez? A kutatási kérdéseket az alábbi gondolatmenet mentén tárgyalom:

$\mathrm{Az}$ alacsony női foglalkoztatottság együtt jár az alacsony népesedési mutatókkal. Ennek több komponense van, ilyenek a speciális hazai anyasággal kapcsolatos attitüdök, a konzervatív családmodellből fakadó viselkedési sztereotípiák. Ehhez társul a munkaerőpiac rugalmatlansága: nem terjedtek el az atipikus foglalkoztatási formák, melyek képesek lennének a fenti tényezőkön segíteni. A kialakult helyzet szerepfeszültséget okoz az édesanyákban: vannak, akik dolgoznának, de nem megoldott a gyermekük napközbeni ellátása, így ezért vagy nem tudnak megfelelő munkát vállalni, vagy otthon maradásra kényszerülnek. És vannak, akik szívesen otthon maradnának a gyermekükkel, de kényszerből (legtöbbször anyagi kényszerből) visszatérnek dolgozni, viszont a gyermekükről vélekedésük szerint így nem megfelelően tudnak gondoskodni - ők ezért élnek át szerepkonfliktust.

A kisgyermek melletti munkavégzés szándéka (függetlenül a motivációtól) egy valós társadalmi, gazdasági kérdés, amely kérdést igyekszem a fenti tényezők mentén szakirodalmi áttekintésnek alávetni. A téma tárgyalásánál nem megkerülhető a dolgozó szülö gyermekének napközbeni ellátásának megoldatlansága, hiszen a fenti felsorolt tényezők (konzervatív szerepek rögzülése, atipikus munkavállalás hiánya) mellett ez a legnagyobb gátja a női foglalkoztatottság növekedésnek. A meglévő ellátórendszer (bölcsőde, óvoda, iskolai napközi, illetve a tárgyalt családi napközi) csak részben képes a valós igényekre reagálni. A férőhelyek eloszlása nem egyenletes (van, ahol nincs is bölcsődei férőhely), ahol van, ott igen gyakori a túlzsúfoltság, és a várólista. Az óvodai rendszer tekintetében jobb a lefedettség, de a túlzsúfoltság olyan általánossá vált, hogy paradox módon már normálisnak tekintett. Pedig az ebből (ti. túlzsúfoltság) adódó gyakori betegségek miatti gyakori táppénzes helyzetek rontják az anya munkaerő-piaci helyzetét, nem beszélve a későbbi gyakori szövődményekröl (allergia, asztma, stb.), amely szintén rövid-és hosszú távú extra kiadást, illetve bevétel-kiesést jelent a nemzetgazdaságnak. Az ellátórendszer rugalmatlansága (rövid nyitva tartás, már szinte megoldhatatlan mennyiségü szünet) szintén nem kedvez annak, hogy az édesanya (akire legtöbbször a gyermek nevelése hárul) megbízható munkavállaló lehessen. A fenti problémák szintén fokozzák a már említett szülöi szerepfeszültséget. 
A fentiek tárgyalásakor felmerül a kérdése: ha a napközbeni ellátórendszer egyik létezö, de jelenleg marginalizált szereplőjét - a családi napközit - fejlesztenénk, abban az esetben sikerülne-e vajon a női foglakoztatást növelni?Az alábbi dimenziók mentén kerestem válaszokat a fenti kérdésre:

1. Családi napközik szakmai háttere

2. Szülői attitüdök

3. Munkáltatói szempontok

4. Direkt és indirekt munkahelyteremtés

A szakirodalmi áttekintést 3 téma köré csoportosítottam:

1. Nők és a munka világa. Itt az alábbi kérdéseket jártam körbe: a dolgozó nő - a női foglalkoztatottság kérdése; a női munkavállalás és a demográfia kapcsolata; gyermeknevelési támogatások, családtámogatások rendszere; külföldi kitekintés a családtámogatás rendszerére.

2. Anyai munkavállalás és a gyermekfejlődés összefüggései. Ez a fejezet a dolgozat gazdaságpszichológiai erőssége, hiszen azokat a tényezőket mutatom be, amelyek megalapozzák azt a döntést, hogy egy édesanya visszatér-e, és ha igen, mikor és hogyan, a munkaerö-piacra. Ebben a fejezetben mutatom be a már említett szerepfeszültség szakirodalmi hátterét. Kitérek a gyermeki és az anyai jóllét kapcsolatára. Bemutatom, hogy milyen összefüggés van a gyermek ellátóhely minősége és a gyermekfejlődés között. Végül ismertetem azokat a társadalmi hiteket és tévhiteket, amelyek az anyai munkavállalás és a gyermekfejlődés összefüggésében elterjedtek.

3. Ebben a fejezetben kapott helyet az a kitekintés, amelyben az elsődleges, a másodlagos és a gazdasági szocializáció hatását mutatom be. Mivel az anyai szerepfeszültség egyik fő oka a gyermek fejlődése miatti aggodalom, így ezen, a gyermek fejlődése szempontjából megkerülhetetlen témákra véleményem szerint a dolgozat fő vonalában kellett kitérnem. Mivel a gyermek későbbi kimenete szempontjából is lényeges a szocializációs közeg, így a témát nem emeltem ki a dolgozatból.

A szakirodalmi áttekintés mellett, ám külön fejezetben, de még nem a saját kutatás bemutatásaként térek ki a napközbeni kisgyermek-ellátás tárgyalására. Itt egy nemzetközi kitekintéssel külföldi példákat mutatok be. Nem célom ezen kitekintéssel a külföldi és a hazai ellátórendszer összehasonlítása, egyszerüen a külföldi minták sokszínűségét kívántam bemutatni - irányt mutatva esetleges későbbi jó gyakorlatok átemelésére. Bemutatom a hazai 
viszonyokat, érintve a családi napközi jogszabályi hátterét, valamint az érintett korosztály ellátására alkalmas egyéb helyek történeti áttekintését. Kitérek a minőségbiztosítás, a férőhelyek és a finanszírozás kérdéseire. Ezek fontosak a későbbi saját modell felállításában. Ezek után mutatom be a saját kutatásokat. 


\subsection{Ajánlások további munkákra}

Dolgozatomban bemutattam az összefüggéseket a népesedési mutatók, a napközbeni kisgyermek-ellátás és a női foglalkoztatottság között. Kitértem arra, hogy milyen hatással bír az anyai munkavállalás az anya és a gyermek jól-létére. Kitekintettem a téma szociológia, szocializációs, esélyegyenlőséget és versenyképességet érintő aspektusaira. Bemutattam külföldi példákat, jó gyakorlatokat, majd ismertettem a hazai helyzetet a női foglalkoztatottság és a kisgyermekellátás területén. Felállítottam hipotéziseket, melyeket 4 éven át tartó kutatási projekt eredményekkel bizonyítottam.

További kutatást javaslok az alábbi témákban:

- napközbeni kisgyermekellátás minőségbiztosításának kidolgozása, 0-14 éves korú gyermekekre vonatkozóan, korcsoportos bontásban

- fenti rendszer finanszírozásának kidolgozása, a minőségbiztosítási paraméterek figyelembe vételével. 


\section{IRODALOMJEGYZÉK}

- Aczél Zs. (2012): Üzemi óvodák 1945 és 1975 között, Iskolakultúra, Budapest

- Bálint M., Köllő J.(2007): Gyermeknevelési támogatások, in: Fazekas K, CseresGergely Zs és Scharle Á. (szerk): Munkaerőpiaci tükör, MTA-KTI, Budapest

- Bass L. - Darvas Á. - Szomor É. (szerk) (2007): Gyermeknevelési szabadságok és gyerekintézmények. Mi a jó a gyerekeknek, mit szeretnének a szülők? Biztos Kezdet Program, Budapest

- Baumeister, R.F., Smart, L., \& Boden, J.M. (1996): Relation of threatened egotism to violence and aggression: The dark side of high self-esteem. Psychological Review, $103,5-33$.

- Belsky J. (1988): The „effects” of infant day care reconsidered. Early Childhood Research Quarterly, 3. 235-272

- Belsky J. (1990): Parental and Nonparental Child Care and Children's Sotioemotional Development: A Decade in Review. Journal in Marriage and the Family, 52. 4. 885903

- Benedek D. (2007): A szülés utáni munkába állás hatása a gyerek fejlődésére. In: Fazekas K. - Kézdi G. (szerk): Munkaerőpiaci Tükör

- Blaskó Zs., Cseres-Gergely ZS., Reszkető P., Scharle Á., Váradi B. (2009): Az 1-3 éves gyermekek napközbeni ellátásának bővítése: költségvetési ráfordítás és várható társadalmi hatások, Budapest Institute, Budapest

- Blaskó Zs. (2008): Does early maternal employment affect non-cognitive children outcomes? - A literature review, Budapest Working Papers On The Labour Market, BWP - 2008/5, Institute of Economics, Hungarian Academy of Sciences, Department of Human Resources, Corvinus University of Budapest

- Blaskó Zs (2008): Az anya korai munkavállalásának hatásai a gyermek pszichés fejlődésére. Szakirodalmi áttekintés, in: Demográfia 2008, 51. évf. 2-3. szám, 259-281

- Blaskó Zs. (2011): „Hároméves kor alatt mindenképpen megsínyli?” Interjús kutatás kisgyermekes anyák körében. In: Nagy I. - Pongrácz T. (szerk): Szerepváltozások, TÁRKI, Budapest, 2011, 156-170. old.

- Bowly, J. (1958): The nature of the child's tie to his mother. Internationale Jurnal of Psycho-Analysis, 39, 350-373 
- Burlin S. (1976): The relationship of parental education and maternal work and occupational status to Occupational Aspiration in adolescent females, Journal of Vocational Behavior, Volume 9, Issue 1, August 1976, Pages 99-104

- Carr, A.J., Gibson, B., Robinson, P.G. (2001) Is quality of life determined by expectations or experience? British Medical Journal 2001; 322: 1240-1243

- C. Molnár E. (1996): Az anyaság pszichológiája, Akadémia Kiadó, Budapest

- Conelly R. - DeGraff S. D. - Willi A. R. (2004): Kids at work. The Value of Employer-Sponsored On-Site Child Care Centers, W.E. Upjohn Institue for Employment Research, Kalamazoo, Michigan

- Cseres-Gergely Zs. (2008): Foglalkoztatottság Magyarországon: a GYES/GYED és a nyugdíjrendszer hatása, Termelékenység és gazdasági növekedés, munkaerőpiaci kihívások, MNB-PM Konferencia

- Cseres-Gergely Zs., Reszkető P., Scharle Á. (2010): Háttér indikátorok a napközbeni gyermekellátások férőhely szükségletének meghatározásához, Budapest Intézet, Budapest

- Csíkszentmihályi M. (1997): Flow. Az áramlat. A tökéletes élmény pszichológiája. Akadémiai Kiadó, Budapest, 1997 (Mihaly Csikszentmihalyi: Flow. The Psychology of Optimal Experience, Harper Perennial, 1991)

- Csíkszentmihályi M. (2007): A fejlődés útjai. A harmadik évezred pszichológiája. Nyitott Könyvmühely, Budapest, 2007 (Csikszentmhalyi M: The evolving self. A Psychology for the Third Millenium. 1997)

- Drjenovszky Zs. (2009): A nők távolmaradása a munkaerőpiacról a gyermekvállalást követően, PhD értekezés, Budapesti Corvinus Egyetem, Budapest, 2009

- Dunifon R., Kalil A., Danzinger S. K. (2003): Maternal Work Behavior under Welfare Reform: How does the Transition from Welfare to Work Affect Child Development?, Children and Youth Services Review, Volume 25, Issues 1-2, January-February 2003, Pages 55-82

- Emlen, A., Koren P. (1984): Hard To Find and Difficult To Manage: The Effects of Child Care on the Workplace, A Report to Employers distributed at a forum on Child Care and Employee Productivity: The Workforce Partnership (Portland, OR, March 1, 1984).

- Ferge Zs. (1985): Szegénység, szegénységpolitika, Valóság, 1985.

- Festinger,L. (1957): A Theory of Cognitive Dissonance, Stanford University, 
Stanford, CA

- Frey M. (2001): A nők munkapiaci helyzete, KSH, Budapest

- Frey M. (2002): A gyermeknevelési támogatásokat igénybe vevő és a családi okból inaktív személyek foglalkoztatásának lehetőségei és akadályai. Összefoglaló a HO9918-13 Phare Program keretében végzett statisztikai kutatás záró tanulmányából, Budapest

- Frey M. (2005): A jogszabályi és intézményi környezet változásai. In: Fazekas K. Kaoltay J. (szerk): Munkaerőpiaci Tükör 2005. MTA Közgazdaságtudományi Intézet, OFA, Budapest

- Frey M. (2008): Nemzeti akcióprogram a növekedésért és foglalkoztatásért, Kézirat, Budapest

- Fülöp M. (2007): Az egyén versenyképességének lehetőségei. In: Új Pedagógiai Szemle 2007/1

- Gábos A. (2000): Családtámogatási rendszer és a családok helyzete, in: Kolosi T., Tóth I., Vukovich Gy. (szerk.): Társadalmi riport 2000., Tárki, Budapest

- Galinsky E., Hooks W. (1979): The New Extended Family: Day Care That Works, Teachers College Record Volume 80 Number 4

- Gál R., Gábos A., Keller T. (2007): A gyermeknevelés költsége és a társadalmi kompenzáció, Tárki, Budapest

- Gambetta, D. (1987): Were they push [pushed] or did they jump? Cambridge, Cambridge UP.

- Goslin, D., (1975): Áttekintés a szocializációról. In: Somlai P. (szerk.), Álláspontok a szocializációról. Budapest: Szociológiai füzetek 9.

- Harvey E. (1999): Short-term and long-term effects of parental employment on children of the National Longitudinal Survey of the Youth. Developmental Psychology, 35. 445-459

- Havasi V. (2011): A nők a munkaerőpiacon és a családban - a tények és értékek összefüggései, Budapest, Társadalomkutatás 29

- Herczog M. (2007): A koragyermekkori nevelés. Oktatási és Gyermekesély Kerekasztal, Budapest

- Hidas Gy. (szerk) (1997): A megtermékenyítéstől a társadalomig Dinasztia Kiadó, Budapest 
- Hoffman, L.W. - Nye, F.I. (szerk) (1974): Working mothers, Jossey-Bass, San Francisco

- Hoóz I. (1994): A nők gazdasági aktivitása és a gyermeknevelés, Statisztikai Szemle, 11. szám, 833-849

- Howes C. (1990): Can the age of entry and the quality of infant child care predict adjustment in kindergarten? Developmental Psychology, 26. 292-303

- Hunyadi Gy., Székely M. (szerk) (2003): Gazdaságpszichológia. Osiris Kiadó, Budapest

- Kai L., Poirier D. J. (2003): Relationship Between Maternal Behavior During Pregnancy, Birth Outcome, and Early Childhood Development: An Exploratory Study, Statistic is Medicine

- Kamarás F. (2000): A termékenység alakulása és befolyásoló tényezői

- Kamarás F. (2002): Családtervek és gyermekszám preferenciák az „Életünk fordulópontkai” c. vizsgálat tükrében, Demográfia, 45. évf., 4. szám

- Kocsisné P.H. (szerk) (2013): Nők a nemzetgazdaságban. Látható és láthatatlan munka. ERGO, Budapest

- Koltai L. - Vucskó B. (szerk) (2007): A munka - magánélet összeegyezetését segítő és gátló tényezők Magyarországon, Fővárosi Esélyegyenlőség Módszertani Iroda, Budapest

- Kontos S. (1994): Children's cognitive and social competence in child-care centers and family day-care homes, Journal of Applied Developmental Psychology

- Kontos S. (1994): The ecology of family day care, Early Childhood Research Quarterly

- Kopp M. (2003): A stressz szerepe az egészségromlásban, in Hippocrates

- Kopp M., Pikó B. (2001): A kultúra és az életminőség kapcsolata. In: Civilizáció és egészség, MTA Stratégiai Kutatások sorozat

- Kopp M., Skrabski Á. (1995): Magyar lelkiállapot. Végeken Kiadó, Budapest

- Kopp M., Győrffy Zs., Ádám Sz, (2008): Az iskolázott nők hátrányos megkülönböztetése, az esélyerősítés lehetőségei., Magyar lelkiállapot, Budapest

- Kopp M. (szerk) (2008): Esélyerősítés és életminőség a mai magyar társadalomban, Semmelweis Kiadó, Budapest 
- Kopp M., Skrabski Á. (2006): Gyermekvállalás és életminőség, In: Kopp M, Kovács M (szerk), A Magyar népesség életminősége az ezredfordulón, Semmelweis Kiadó, Budapest, 253-262. old

- Kopp Mária (Népesedési Kerekasztal), Bánkuty Tamás (NGM), Fürész Tünde (NEFMI), Dr. Nagy Ágnes (Csodacsalád Egyesület) (2010): Napközbeni kisgyermek ellátási megoldások, Munkacsoport anyag, Budapest

- Korintus M., Villányi Gy., Mátay K., Badics T. (2004): Gyermekeink gondozása, nevelése. Magyarországi háttértanulmány az OECD „A kisgyermekkori nevelés és gondozás szakmapolitikájának tematikus vizsgálata” című programjához. Corvinus Kiadó, Budapest

- Kosonen, T. (2011): To Work or Not to Work? The Effect of Child-Care Subsidies on the Labour Supply of Parents, University of Helsinki - Department of Political and Economic Studies, Government Institute for Economic Research Working Paper No. 23

- Kovácsné B.I. (szerk.) (2013): A családi napközi müködésének követelményei. Módszertani Útmutató, Emberi Erőforrások Minisztériuma, Szociális Füzetek, Budapest

- Központi Statisztikai Hivatal (2008): Magyarország 2007, Budapest, ISSN: 1416-2768

- Központi Statisztikai Hivatal (2012): Kisgyermekek napközbeni ellátása, Budapest

- Központi Statisztikai Hivatal (2011): Család változóban, Budapest

- Központi Statisztikai Hivatal (1996), Demográfia, Budapest

- Központi Statisztikai Hivatal (2004), Demográfia, Budapest

- Központi Statisztikai Hivatal (2008), Demográfia, Budapest

- Krämer, U. (1999): Airway diseases and allergies in East and West German children during the first 5 years after reunification: time trends and the impact of sulphur dioxide and total suspended particles, International Journal of Epidemiology

- Kuper, A. - Kuper, J. (szerk.) (1995): The Social Science Encyclopedia. London: Routledge

- Laky T. (2003): Munkaerőpiac Magyarországon 2002-ben. In: Fazekas K. (szerk): Munkaerőpiaci Tükör 2003. MTA Közgazdaságtudományi Kutatóközpont, OFA, Budapest

- Léderer P. (1992): Teher alatt nő a pálma..., Esély, Budapest 
- Le Vine, R., (1975): Kultúra, személyiség és szocializáció. In: Somlai P. (szerk.), Álláspontok a szocializációról. Budapest: Szociológiai füzetek 9.

- Lindbeck, A. (1998): The Insider-Outsider Theory of Employment and Unemployment, MIT Press

- Makay Zs. (2008): Ki vigyáz a munkavállaló anya gyermekére? Az egy éven aluli gyermekek napközbeni ellátása Franciaországban. in: Demográfia, 51. évf. 2-3. szám, $217-243$

- Müller P. (2007): Örömkönyv, Alexandra Kiadó, Budapest

- Nagy, Á. (szerk) (2010): Kézikönyv családi napközit müködtetőknek, Csodacsalád Egyesület, Budapest

- Nagy, Á. (szerk) (2011): Professzionális kisgyermek ellátás a gyakorlatban, Csodacsalád Egyesület, Budapest

- Nagy Á. (2013): Az anyai munkavállalás és a gyermekfejlődés összefüggései, Kapocs Folyóirat, Nemzeti Család-és Szociálpolitikai Intézet, Budapest

- Nagy I. - Pongrácz T. (2011): Szerepváltozások - 2011, Tárki, Budapest

- NGM (2012): Új baby boom. A középosztály gyermekvállalási forradalma, Nemzetgazdasági Minisztérium, Családbarát Magyarországért Munkacsoport

- Öri I. (2001): A nők munkavállalásának alakulása és főbb demográfiai jellemzői 19801996, Demográfia, 44. évfolyam, 1-2. szám, 74-104

- Nomaguchi K. (2006): Maternal Employment, Nonparental Care, Mother-Child Interactions, and Child Outcomes During Preschool Years. Journal of Marrieage and Family, 68. 5. 1341-1369

- Pavlov, I. P. (1927): Conditioned Reflexes: An Investigation of the Physiological Activity of the Cerebral Cortex. Translated and Edited by G. V. Anrep. London: Oxford University Press.

- Pongrácz T. (2007): A család és a munka szerepe a nők életében, Szerepváltozások, TÁRKI, Budapest

- Pongrácz T. - Spéder Zs. (szerk.) (2002): Népesség - értékek - vélemények. Budapest, KSH NKI , Kutatási jelentéseik 73.,

- Pongrácz T. (2011): A családi értékek és a demográfiai magatartás változásai Népességtudományi Kutatóintézet, Budapest

- Rathunde, K. (1988): Optimal experience and the family context. In M. Csikszentmihalyi - I.S Csikszentmihalyi, eds., Optimal experience: Psychological 
studies of flow in consciousness (342-363). New York, Cambridge University Press

- Reszkető P., Váradi B. (2009): A regionális operatív programok keretében kírásra került szociális alapszolgáltatások és gyermekjóléti alapellátások infrastrukturális fejlesztését, bölcsődék önálló fejlesztését, valamint az akadálymentesítést érintő pályázatok előrehaladásának összegzése, Budapest Intézet, Budapest

- Reszkető P. - Scharle Á. - Váradi B. (2011): A kisgyermekek napközbeni ellátásának bővítése: célok, eszköztár és várható társadalmi hatások, In: Nagy I. - Pongrácz T. (szerk): Szerepváltozások, 2011, TÁRKI, Budapest, 171-191. old.

- Ridge, T. M. (2007): It's a Family Affair: Low-Income Children's Perspectives on Maternal Work, Journal of Social Policy

- Ross, C. E., Mirowsky, J, Huber.J. (1983): "Dividing work, sharing work, and inbetween: Marriage patterns and depression." American Sociological Review 48: 809823.

- Rubinstein C. (1981): Survey report on money. Psychology Today, 5, 24-44.

- Ruhm J Ch. (2000): Parental leave and child health, Journal of health Economics

- Scharle Á. (2008): A jóléti rendszer: mennyit, mire és hogyan költsünk? Demos, Budapest

- Scharle Á. (2008): Foglalkoztatás, intézményrendszer és foglalkoztatáspolitika, Társadalmi Riport, Tárki, Budapest

- Scharle Á (szerk). (2009): Manka goes to work. Public childcare in the Visegrad countries 1989-2009, Budapest Intézet, Budapest

- Seligman, M. E. P. (1975): Helplessness: On depression, development, and death. San Francisco: Freeman

- Seligman, M. E.P. (1990): Learned optimism. New York: Alfred A. Knopf

- Seligman, M.E.P. (1993): What You Can Change and What You Can't: The Complete Guide to Successful Self-Improvement. New York: Knopf.

- Seligman, M.E.P. (1996): The Optimistic Child: Proven Program to Safeguard Children from Depression \& Build Lifelong Resilience. New York: Houghton Mifflin.

- Seligman, M.E.P. (2002): Authentic Happiness: Using the New Positive Psychology to Realize Your Potential for Lasting Fulfillment. New York: Free Press

- Selye, J. (1956): The stress of life. Rev. Ed. New York, McGraw-Hill.

- Singer, J.L. (1966): Daydreaming: An introduction to the experimental study of inner experiences, New York, Random House 
- Singer, J.L. (1973): The child's world of make-believe, New York, Academic Press

- Singer, J.L. (1981): Daydreaming and fantasy, Oxford, Oxford University Press

- Singer, J.L., Switzer, E. (1980): Mind play: The creative uses of fantasy, Engkewood Clifs, N. J.: Prenice - Hall

- S. Molnár E. (2011): A közvélemény gyermekszám-preferenciáinak alakulása Magyarországon az elmúlt évtizedekben. In: A családi értékek és a demográfiai magatartás változásai (szerk.: Pongrácz T.), KSH, Budapest

- Somlai P., (1977): Szocializáció. Budapest: Corvina.

- Spéder Zs. - Kapitány B. (2006): Szülővé válás az ezredforduló után: a strukturális körülmények és a tudtai tényezők szerepe az első gyermek vállalásakor. In: Kolosi T. - Tóth I.Gy. - Vukovich Gy. (szerk): Társadalmi Riport 2006, Tárki, Budapest

- Spéder Zs. (2003): Gyermeket vállalni - új strukturális körülmények között. In: Spéder Zs. (szerk): Család és népesség - itthon és Európában. Századvég Kiadó, Budapest

- Spéder Zs. (2006): Mintaváltás közben. A gyermekvállalás időzítése az életútban, különös tekintettel a szülő nők iskolai végzettségére és párkapcsolati státuszára. Demográfia, 49. évf. 2-3. szám, Budapest

- Spengler Gy (1991): Az óvoda helye a közoktatás rendszerében, Óvodai nevelés, 5 szám, Budapest

- Szalai, P. (2012): Segítsük elő a nők foglalkoztatásának bővülését! NGM, Budapest

- Stouffer, S., A. Lumsdaine, M. Lumsdaine, R. Williams, et al. (1949): The American Soldier. Princeton, NJ: Princeton University Press

- Statisztikai Tükör (2010), IV. év. 6. szám, KSH, Budapest

- Surányi É, Danis I. (szerk) (2009): Családpolitika más szemmel. Eltérő nézőpontok, változó gyakorlatok. MTA Közgazdaságtudományi Intézet, Budapest

- Szalai Júlia (1985): Mire kell az óvoda és kinek? (p. 196-212.) In: Nők és férfiak. Hiedelmek, tények. [Szerk.]: Koncz Katalin. Bp., MNOT - Kossuth Kvk., 284, [8] p., Budapest

- Száraz, K. (2005): A Lisszaboni Stratégia és a társadalmi kirekesztődés elleni harc, Társadalom és Gazdaság, Akadémiai Kiadó, Budapest, p. 271-285

- Termékenységi adattár (1996), 1970-1994. KSH, Budapest

- Townsend, P. (1979): Poverty in the United Kingdom: A Survey of Household Resources and Standards of Living, London: Penguin Books 
- Turley, Ruth N. López (2002): "Is Relative Deprivation Beneficial? The Effects of Richer and Poorer Neighbors on Children's Outcomes." Journal of Community Psychology, 30(6):671-686.

- Scharle Á. (2007): The effect of Welfare Provisions on Female Labour Supply in Central and Eastern Europe, Journal of Comparative Policy Analysis, Vol. 9, No. 2, 157-174, Budapest

- Smith, E. R., Mackie, D. M. (2001) Szociálpszichológia. Osiris, Budapest

- Temesváry Zs. (2013): Magasan képzett fiatalok gyermekvállaláshoz és házasságkötéshez kapcsolódó attitüdjei, Kapocs, XI. évfolyam 3. szám p. 8-20, Budapest

- Vág O. (1994): Az óvodai nevelés története Magyarországon. I. rész. Az első óvodától a Terjesztő Egyesület magalapításáig (1828-1936). Magyar Óvodapedagógiai Egyesület, Miskolc

- Váradi L. (szerk) (2006): Visszatérés a munkaerőpiacra a gyermekvállalás után, KSH, Budapest

- Vokony É (2002): Kis magyar bölcsődetörténet, Kapocs, NCSSZI, Budapest

- Wosinka, W., Cialdini, R.B., Barrett, D.W., Reykowski, J. (2001) The practice of social influence in multiple cultures. Lawrence Erlbaum Associates, Publishers

- Z. Kavalics - Kollányi (2006): Humán tőke és versenyképesség, www.magyarorszag2015.hu/tanulmanyok, http://www.socio.mta.hu/dynamic/Feher_konyv.pdf (letöltés ideje: 2013.02.10) 


\section{ÁBRAJEGYZÉK}

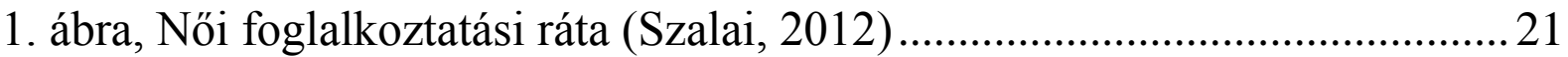

2. ábra, Női foglalkoztatása ráta2 (Szalai, 2012) …….......................................23

3. ábra, Női foglalkoztatási ráta3 (Szalai,2012) ……….....................................25

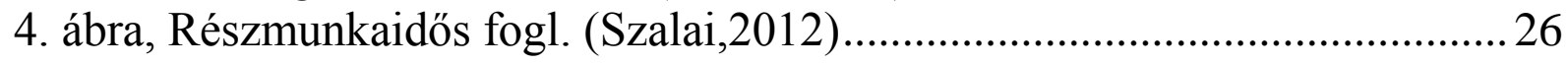

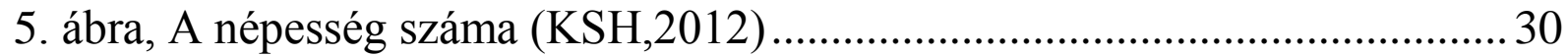

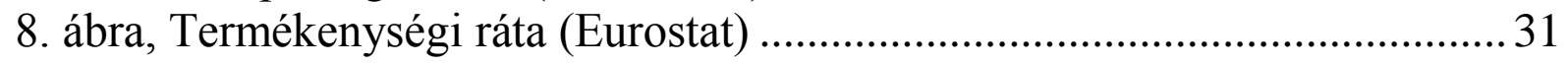

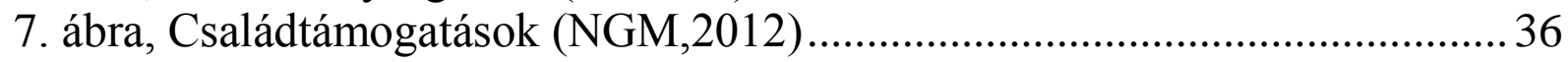

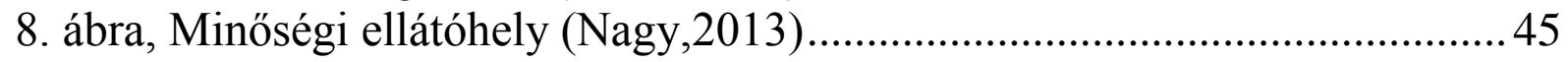

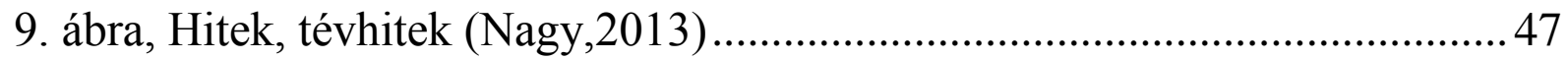

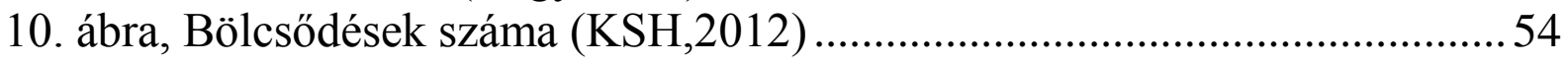

11. ábra, Napközbeni ellátás (OECD-Scharle,2009) …………..........................63

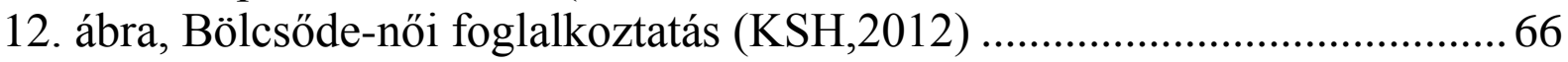

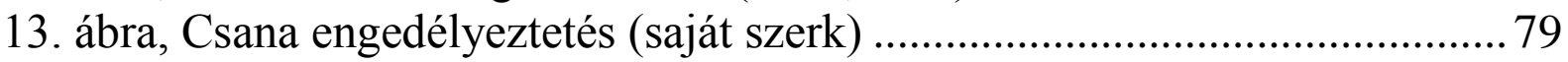

14. ábra, Csanában gondozott gyermekek (KSH,2012) ...................................... 86

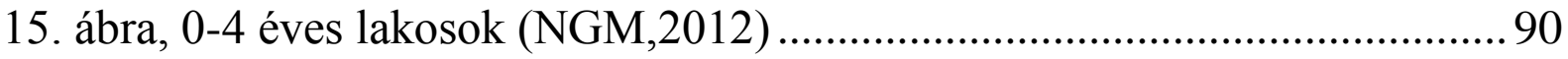

16. ábra, Bölcsődei férőhelyek (NGM,2012) ............................................... 90

17. ábra, Bölcsődés, csanás gyermekek (NGM,2012) .....................................91

18. ábra, Bölcsődei, csanás férőhelyek (KSH,2012) ......................................92

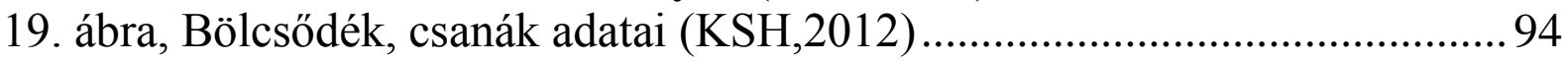

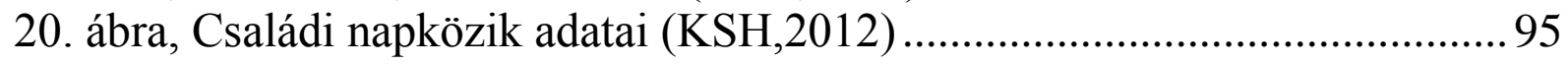

23. ábra, Bölcsőde-csana számok (saját szerk) …………………………...........96

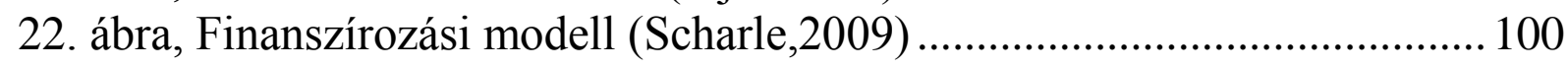

23. ábra, Bölcsőde, csana fenntartók (KSH,2012) ............................................ 101

24. ábra, Bölcsődei gondozók (KSH,2012) .................................................... 107

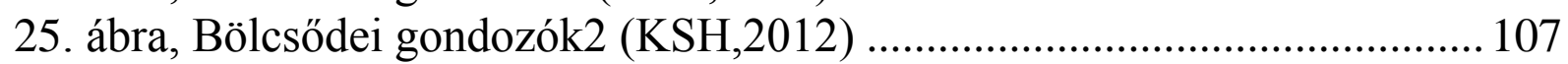

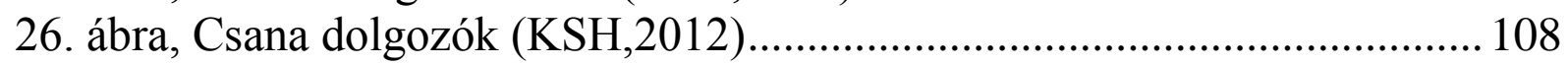

27. ábra, Bölcsőde-csana számok (saját szerk) ............................................. 109

28. ábra, Munkahely-férőhely ára (saját szerk) ............................................... 110

29. ábra, Családi napközi tanfolyami hallatók végzettségbeli megoszlása ...... 114 30. ábra, Családi napközi tanfolyami hallatók tanfolyam elvégzési motivációs

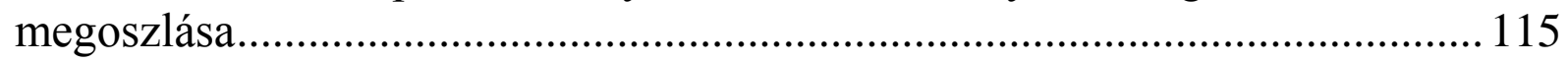

31. ábra, Miért ment el a tanfolyamra? ……….............................................. 117

32. ábra, Honnan kért segítséget?.................................................................... 118

33. ábra, Hatóságok hozzállása (csana nyitás) ………........................................ 119

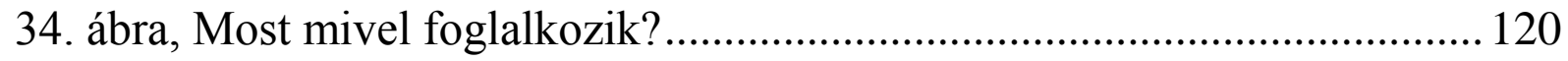

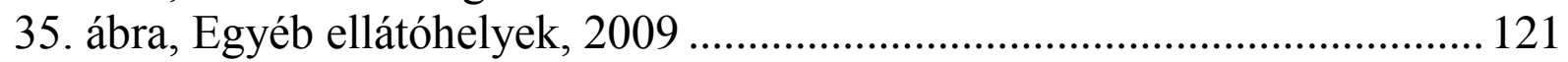

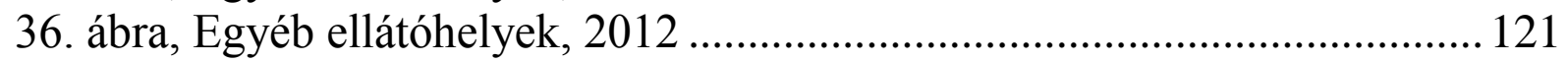

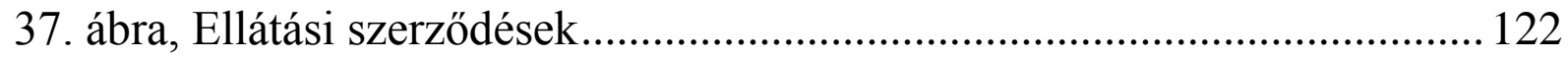

38. ábra, Önkormányzati támogatás ............................................................. 123

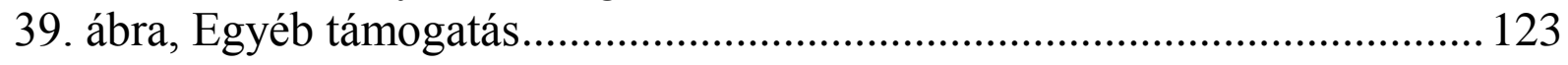

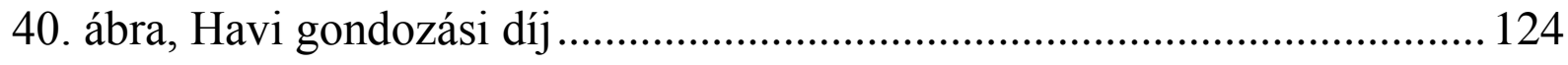




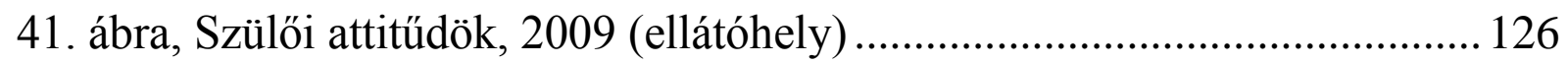

42. ábra, Előnyök-hátrányok, bölcsőde ............................................................ 127

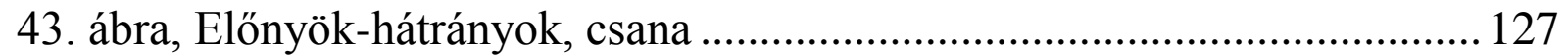

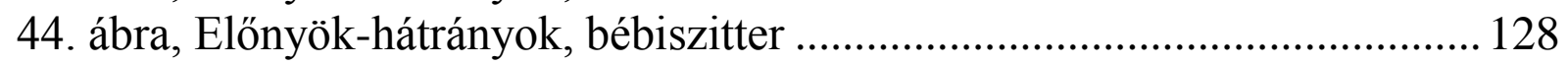

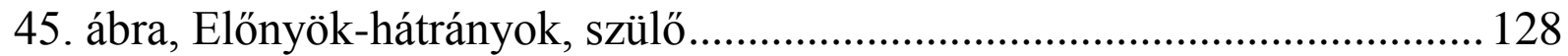

46. ábra, Elönyök-hátrányok, nagyszülö ......................................................... 129

47. ábra, Preferált egyéb szolgáltatások ………............................................... 130

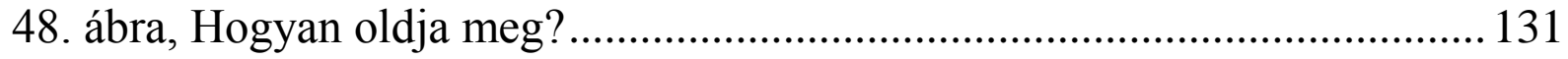

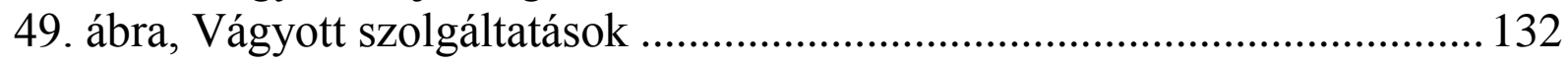

50. ábra, Munkába való visszatérés ideje ........................................................ 134

51. ábra, Vállalat segítsége gyermekelhelyezésben .......................................... 135

52. ábra, Vágyott támogatási szempontok ..................................................... 136 
MELLÉKLETEK (KÉRDÖÍVEK), FÜGGELÉKEK (RÉSZKUTATÁSOK) 


\section{1. melléklet - Családi napközi vezetők közötti kérdőív 2009, 2012}

\section{Családi napközi felmérés}

Ez a felmérés a Csodacsalád Egyesület kutatása a Csana MIÉRT-jeiröl: miért ment el családi napközis tanfolyamra, miért nyitott csanát, vagy épp miért nem nyitott csanát? A kutatás eredményeivel segíteni kívánunk a családi napközi müködtetöknek - tesszük ezt azért, mert mi magunk is családi napköziket müködtetünk, és úgy találjuk, hogy ez nem könnyü mesterség. És nagyon szeretnénk, ha könnyebb lenne. Ha Ön is ezt szeretné, akkor kérjük, segítse munkánkat. Hogy mi is segíthessünk - ahogy tettük ezt eddig is. Fontos - kérjük, hogy a családi napközi hálózatok esetében a hálózat vezetője IS, és a fenntartásában müködő családi napközik önállóan IS töltsék ki a kérdőívet. Köszönjük!

A kérdőív kitöltése $\mathrm{kb}$. 10-15 percet vesz igénybe.

A kérdőív kitöltése önkéntes, és anonym. KÖSZÖNJÜK!

Információk a kitöltőkröl:

Nem

Életkor

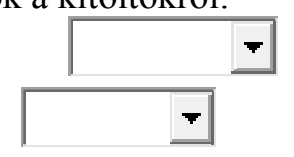

\section{Lakóhely}

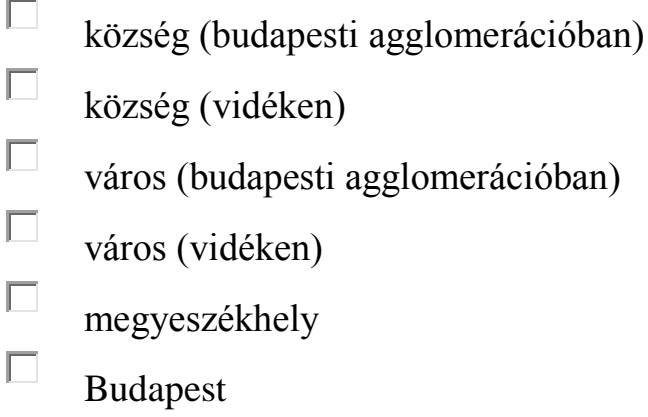

\section{Családi állapot}

kapcsolatban

「 egyedülálló

\section{Gyermekei száma}

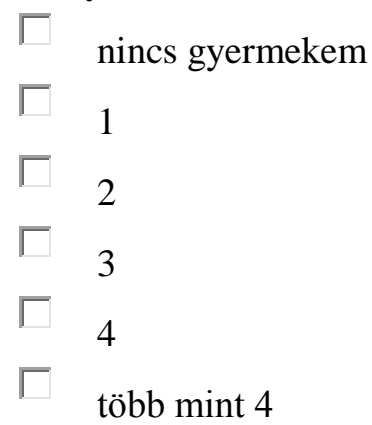

4. Végzettsége (ha több van, ami a legmagasabb szintü, illetve amelyiket naponta a munkájához leginkább használja)

\footnotetext{
Г csecsemőgondozó

rajka
} 
óvodapedagógus

tanító

tanár (általános és/vagy középiskolai)

egyéb pedagógus

szociális végzettség

egészségügyi végzettség

gazdasági végzettség

Egyéb

\section{Miért ment el csana tanfolyamra?}

gyermekeim mellett szerettem volna maradni

ᄃ felnőttek a gyermekeim, és hiányzott a gyermekzsivaly

$\square$ munkanélküli pedagógus voltam, ehhez értek, ezért gondoltam erre

$\ulcorner\quad$ váltani szerettem volna

$\Gamma \quad$ vállalkozóvá szerettem volna válni, csanát akartam nyitni, ehhez kellett

$\ulcorner$ hálózatot építek, ehhez kellett (ismeretek miatt)

$\ulcorner$ csanában dolgozom / fogok dolgozni, ezért kellett (papír miatt)

$\ulcorner$ munkanélküli voltam (de nem pedagógus), munkalehetőséget láttam benne

$\ulcorner$ gyermekemnek szerettem volna megfelelő ellátást

Egyéb

\section{Teljesültek-e a vágyai (amiért a tanfolyamra ment)?}

igen, önálló csanát nyitottam, és otthon maradtam a gyermekeimmel / újra lettek gyermekek a házban, és munkám is lett (vállalkozó lettem)

$\Gamma \quad$ igen, egy hálózathoz csatlakozva csanát nyitottam, otthon maradtam a gyermekeimmel / újra lettek gyermekek a házban, és így munkám is lett (alkalmazottként)

$\Gamma \quad$ igen, egy hálózathoz csatlakozva csanát nyitottam, otthon maradtam a gyermekeimmel / újra lettek gyermekek a házban, és így munkám is lett (alvállalkozóként)

$\ulcorner\quad$ igen, csanát nyitottam, de nem otthon, hanem bérelek hozzá helyet (önálló vállalkozó vagyok)

$\Gamma \quad$ igen, hálózatom lett

$\Gamma \quad$ igen, alkalmaztak egy csanában (nem az otthonomban), munkám lett

$\ulcorner$ nem, nem nyitottam csanát, mert nem látom belőle a megélhetést

$\lceil$ nem, nem nyitottam csanát, mert elakadtam az engedélyeztetés nehézségeiben

$\ulcorner$ nem, mert nem találtam munkát ezzel a papírral

「részben: bár nyitottam csanát, de már be is zártam, anyagi okok miatt (veszteséges volt)

$\lceil$ részben: bár nyitottam csanát, de már be is zártam, anyagi okok miatt (nem volt rá igény)

$\lceil$ részben: bár nyitottam csanát, de már be is zártam, családi okok miatt 
részben: bár nyitottam csanát, de már be is zártam, egészségügyi okok miatt

Egyéb

7. Honnan, kitől kért segítséget az engedélyeztetés során? (több válasz lehetséges)

「 Nem kértem, mert nem volt olyan nehézség, amelyet nem tudtam volna megoldani

$\ulcorner\quad$ Nem kértem, mert nem tudtam, hogy honnan lehetett volna kérni

$\Gamma$ képzőhelytől (ahova tanfolyamra jártam)

$\Gamma$ képzőhelytől (de nem attól, ahova tanfolyamra jártam)

országos egyesülettől (Macske)

$\Gamma \quad$ önkormányzattól

「 ÁNTSZ-től

$\ulcorner$ egyéb hatóságtól

Г Államkincstártól

$\lceil$ Egyéb

8. Kapott-e megfelő segítséget onnan, ahonnan kért?

$\Gamma$ igen, segítettek

$\ulcorner$ nem, egyedül maradtam a gondjaimmal

Г Egyéb

9. Csana nyitásnál a közreműködő hatóság segítőkészsége, hozzáállása:

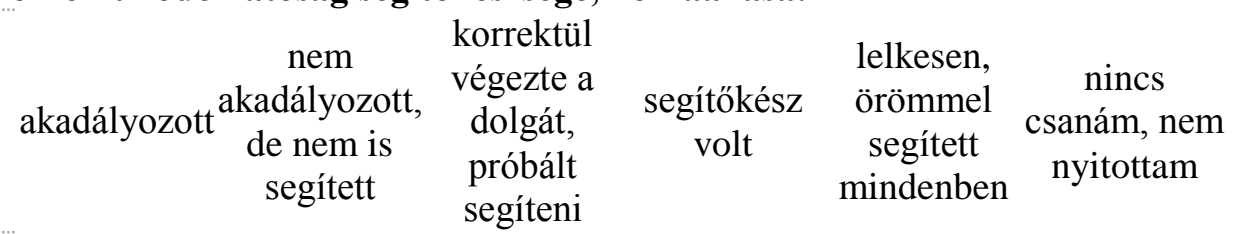

önkormányzat

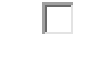

ÁNTSZ

Tüzoltóság

Építésügy

10. Kérem, írja le, hogy milyen KELLEMES meglepetések érték a csana engedélyeztetése során (szülők, önkormányzat, ÁNTSZ, Tủzoltóság, Építésügyi hatóság, képzőhely, országos egyesület, minisztérium részéről - bármit, amit fontosnak tart)

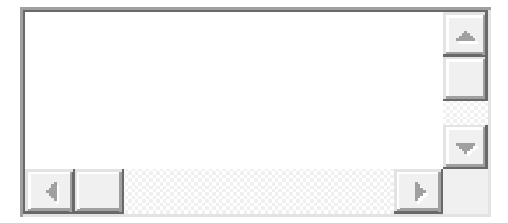

11. Kérem, írja le, hogy milyen KELLEMETLEN meglepetések érték a csana engedélyeztetése során (szülők, önkormányzat, ÁNTSZ, Tüzoltóság, Építésügyi hatóság, képzőhely, országos egyesület, minisztérium részéről - bármit, amit fontosnak tart) 


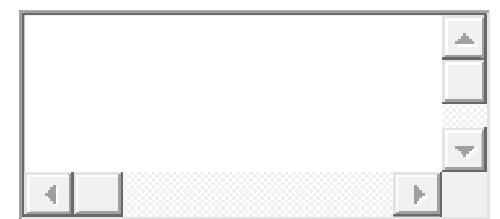

\section{Ha nem nyitott csanát, annak mi volt az oka?}

Nem is akartam nyitni, csak tájékozódtam a tanfolyammal

$\ulcorner\quad$ Nem is akartam nyitni, munkahelyet keresek, gondoltam, ez egy lehetőség, így könnyebben kapok munkát

A tanfolyamon olyan információkhoz jutottam, mely alapján úgy gondoltam, hogy inkább nem indítok önálló vállalkozást

「 A tanfolyam után úgy gondoltam, hogy ez mégsem nekem való munka

$\ulcorner$ Olyan nehézségekbe ütköztem, melyek meghaladták az anyagi lehetőségeimet, és / vagy lehetetlenné tették a nyitást (szakhatósági elvárások)

「A cégalapítás során olyan nehézségekbe ütköztem, hogy vállakozó sem lettem

$\ulcorner$ Nyitottam csanát (csanában dolgozom)

$\ulcorner\quad$ Kérem, fejtse ki a válaszát részletesen:

\section{Most mivel foglalkozik?}

a saját csanámban dolgozom (önálló vállalkozóként)

alkalmazott vagyok egy csanában

$\Gamma \quad$ csana hálózatot vezetek

máshol dolgozom (nem csanában, és nem is akarok csanában dolgozni)

$\ulcorner$ máshol dolgozom (nem csanában, de szeretnék önálló csanát nyitni)

$\Gamma \quad$ máshol dolgozom (nem csanában, de szeretnék csanában dolgozni)

$\ulcorner$ munkanélküli vagyok, és szeretnék csanában dolgozni

「 munkanélküli vagyok, de nem szeretnék csanában dolgozni

「 gyeden/gyesen vagyok, és szeretnék csanát nyitni (önállóan)

$\ulcorner$ gyeden/gyesen vagyok, és szeretnék majd csanában dolgozni (alkalmazottként)

「állalkozó vagyok, de nem csanás, és nem is akarok csanát nyitni

「 vállalkozó vagyok, de nem csanás, és csanát kívánok nyitni

14. Azon a településen (kerületben), ahol az Ön családi napközije múködik (vagy ahol Ön szeretett volna, vagy szeretne családi napközit nyitni), van-e...

van, van, van, de nem
mindenkit mindenkit vesznek fel
felvesznek, felvesznek, nem tudom
így is kevés túlzsúfoltság mindenkit, nárólista van
a gyermek van

bölcsőde?

gyermek van




\begin{tabular}{|c|c|c|c|c|}
\hline óvoda? & $\Gamma$ & $\Gamma$ & \ulcorner & $\Gamma$ \\
\hline alsó tagozatos napközi? & $\Gamma$ & $\Gamma$ & $\Gamma$ & $\Gamma$ \\
\hline $\begin{array}{l}\text { felsö tagozatos } \\
\text { napközi? }\end{array}$ & $\Gamma$ & $\Gamma$ & $\Gamma$ & Г \\
\hline családi napközi? & $\Gamma$ & $\Gamma$ & $\Gamma$ & $\Gamma$ \\
\hline játszóház? & $\Gamma$ & $\Gamma$ & $\Gamma$ & $\Gamma$ \\
\hline $\begin{array}{l}\text { más gyermekellátó } \\
\text { lehetőség? }\end{array}$ & $\Gamma$ & $\Gamma$ & $\Gamma$ & $\Gamma$ \\
\hline
\end{tabular}

\section{Van-e ellátási szerződése az önkormányzattal?}

igen

nem

nincs csana

16. Kap-e támogatást az önkormányzattól az ellátott gyermekek után?

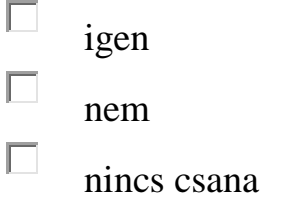

\section{Kap-e máshonnan támogatást?}

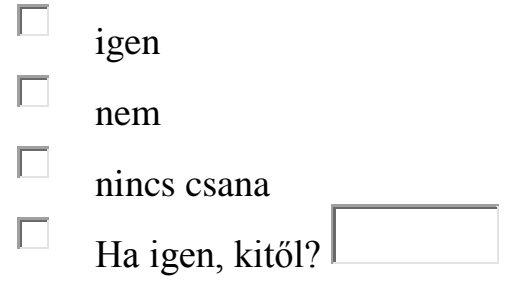

18. Mennyi az egész havi gondozási díjj, étkezés nékül?
$\ulcorner$ nincs (ingyenes)
ए 1-5.000
「 5.001-10.000
Г 10.001-20.000
Г 20.001-30.000
Г 30.001-40.000
Г 40.001-50.000
Г 50.001-60.000
Г 60.001-70.000
「 70.001-nél több
$\ulcorner$ nincs csana 


\section{2. melléklet - 0-3 éves korú gyermeket nevelök közötti felmérés}

Mindenkinek nagy öröm, amikor gyermek érkezik a családba. Ám a kezdeti boldogság mellett hamarosan megfogalmazódik a kérdés is: hogyan tovább?

- Vannak szerencsések, akik, ha szeretnének, otthon maradhatnak gyermekükkel akár 3 évig (vagy még tovább), segítve ezzel a családot.

- Vannak szerencsések, akik, ha szeretnének, vissza tudnak térni a munkahelyükre, és eközben gyermekük megnyugtató felügyeletét is megoldottnak tudhatják.

- Ám vannak, akiknek ezek a dolgok problémát jelentenek:

o vagy a gyermek születése elött sem dolgoztak,

o vagy volt ugyan munkahelyük, de most nem tudnak oda visszatérni.

o Vagy el tudnának helyezkedni, de nincs hova tenni ez idő alatt a gyermeküket.

Jelen kérdőívünkkel ezt szeretnénk felmérni: vajon Ön hova tartozik, Önnek mire lenne szüksége, tudunk-e Önnek a most létrejövő szolgáltatásunkkal segíteni?

Köszönjük, ha rászán néhány percet a kérdőív kitöltésére!

A kitöltött kérdővet a 0-3 éves korú gyermeket nevelőktől, vagy a gyermekvállalás előtt álló szülőktől szeretnénk visszakapni. A kérdésekben feltételezzük, hogy az édesanya marad otthon a gyermekkel a születés után - természetesen amennyiben nem így van, vagy nem az édesanya neveli a gyermeket, akkor kérjük, hogy értelemszerün jelezze ezt nekünk a megjegyzések között!

A kérdőívvel egy tudományos kutatáshoz nyújt segítséget. Kitöltése anonym és önkéntes. Köszönjük, ha válaszait visszaküldi nekünk, segítve ezzel a munkánkat!

Ha fontosnak tartja a témát, kérjük, küldje el kérdőívünket a témában érintett ismerőseinek is! Köszönjük!

Információk a kitöltőkröl:

Nem

Életkor

Lakóhely

Iskolai végzettség

Foglalkozás

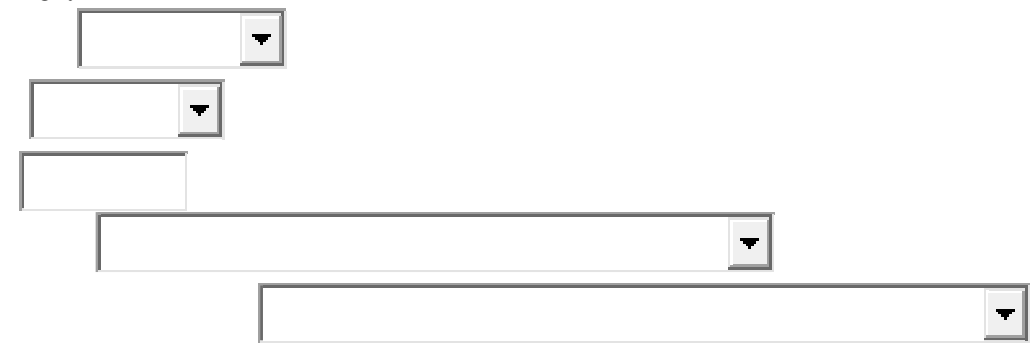

\section{Van Önnek gyermeke?}

igen

nem

\section{Hány gyermeke van?}

$$
\begin{array}{ll}
\Gamma & 1 \\
\Gamma & 2 \\
\Gamma \quad & 3 \\
\Gamma \quad & 4 \text { vagy több } \\
\Gamma \quad \text { nincs gyermekem }
\end{array}
$$

3. Volt munkája, mielőttt gyermeke megszületett? 
nem

4. A gyermekének az elhelyezése megoldott volt akkor, amikor Ön vissza szeretett volna térni dolgozni? Kérjük, olvassa figyelmesen végig az összes válaszlehetőséget, és csak egy választ adjon meg, azt, ami leginkább igaz Önre!

「 Nem akarok/akartam elmenni/visszamenni dolgozni, a gyermekemmel otthon akartam maradni, és ezt meg is tehettem (volt a családban másik jövedelem)

$\ulcorner\quad$ Nem akarok/akartam elmenni/visszamenni dolgozni, a gyermekemmel otthon akartam maradni, így is tettem, bár ez komoly anyagi áldozatokkal járt

「 Nem akarok/akartam elmenni/visszamenni dolgozni, de anyagi okok miatt rákényszerülnék. A gyermekem felügyeletét azonban nem tudom megoldani, erre megoldást keresek.

「 Nem akarok/akartam elmenni/visszamenni dolgozni, de anyagi okok miatt rákényszerültem. A gyermekemmel a férjem maradt otthon

「 Nem akarok/akartam elmenni/visszamenni dolgozni, de anyagi okok miatt rákényszerültem. A gyermekemmel a nagyszülő maradt otthon

Г Nem volt munkahelyem, amikor a gyermekem született

Nem volt hova visszamennem, mert megszünt a munkahelyem

$\lceil\quad$ Nem vettek vissza a kisgyermekem születése után - mást vettek föl a helyemre, és nem tudtak / nem akartak nekem munkát biztosítani

Г Vissza tudtam volna menni dolgozni, de nem tudtam hova tenni a gyermekem, így a munkavállalás meghíúsult a tervezett időpontban,

Vissza tudtam volna menni dolgozni, de nem tudtam hova tenni a gyermekem, csak később tudtam visszamenni, nem akkor, amikor amikor akartam

Г Vissza tudtam volna menni dolgozni, visszahívtak, de nem vállaltam, mert otthon akartam maradni a gyermekemmel

Г Vissza tudtam volna menni dolgozni, visszahívtak, de nem vállaltam, mert nem tudtam megoldani a gyermekem felügyeletét

$\lceil\quad$ Vissza tudtam menni dolgozni, amikor akartam, mert a gyermekemmel a férjem maradt otthon

$\ulcorner$ Vissza tudtam menni dolgozni, amikor akartam, mert a gyermekemmel a nagyszülő maradt otthon

「 Vissza tudtam menni dolgozni, amikor akartam, mert a gyermekem mellé bébiszittert fogadtunk

$\Gamma$ Vissza tudtam menni dolgozni, amikor akartam, mert a gyermekemet fölvették bölcsődébe

$\lceil\quad$ Vissza tudtam menni dolgozni, amikor akartam, mert a gyermekemet fölvették családi napközibe

$\ulcorner$ Egyéb

5. Milyen ellátóhelyet keres gyermekének? (több válasz lehetséges)

Nem keresek, mert én akarok vele lenni

nagyszülő vigyáz rá

$\ulcorner$ bölcsőde (állami) 
bölcsőde (magán)

családi napközi (állami)

családi napközi (magán)

bébiszitter (aki a saját lakásunkban vigyáz a gyermekre)

szomszéd, ismerős

Egyéb

6. Kérjük írja le véleményét az alábbi ellátási módokról, az alábbi szempontok alapján: mi az előnye, mi a hátránya - BÖLCSÖDE

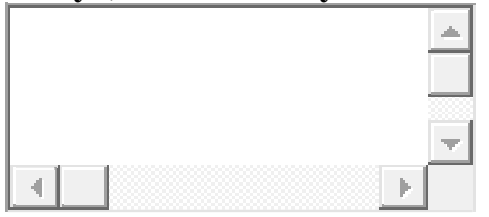

7. Kérjük írja le véleményét az alábbi ellátási módokról, az alábbi szempontok alapján: mi az előnye, mi a hátránya - CSALÁDI NAPKÖZI

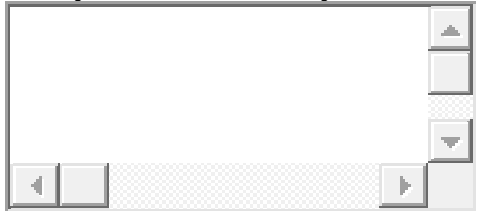

8. Kérjük írja le véleményét az alábbi ellátási módokról, az alábbi szempontok alapján: mi az előnye, mi a hátránya - BÉBISZITTER

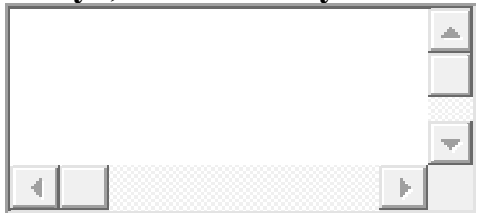

9. Kérjük írja le véleményét az alábbi ellátási módokról, az alábbi szempontok alapján: mi az előnye, mi a hátránya - HA CSAK A SZÜLŐ VAN A GYERMEKKEL AZ ELSŐ 3 ÉVBEN

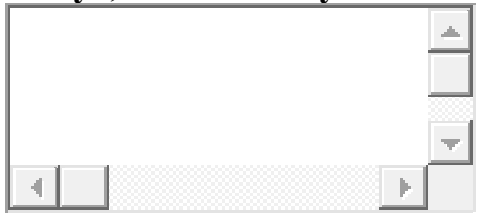

10. Kérjük írja le véleményét az alábbi ellátási módokról, az alábbi szempontok alapján: mi az előnye, mi a hátránya - NAGYSZÜLŐ VIGYÁZ MINDEN NAP A GYERMEKRE

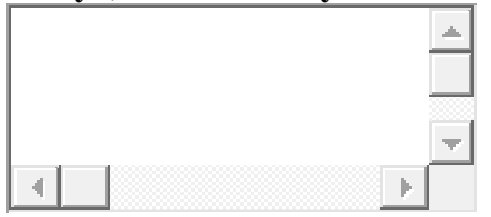

11. Mennyire tartja fontosnak az alábbiakat?

Egyáltalán
nem fontos Kicsit fontos Fontos $\begin{gathered}\text { Nagyon } \\ \text { fontos }\end{gathered}$ Elengedhetlen

Gondozók

szakképzettsége

Г Г

fontos 


\begin{tabular}{|c|c|c|c|c|}
\hline $\begin{array}{l}\text { Minden nap szabadban } \\
\text { játék, mozgás (udvar, } \\
\text { játszótér, stb) }\end{array}$ & Г & Г & $\Gamma$ & Г \\
\hline $\begin{array}{l}\text { Egészséges ételek } \\
\text { biztosítása }\end{array}$ & $\Gamma$ & г & \ulcorner & $\Gamma$ \\
\hline $\begin{array}{l}\text { Könnyü } \\
\text { megközelíthetőség } \\
\text { tömegközlekedéssel }\end{array}$ & $\Gamma$ & Г & $\Gamma$ & Г \\
\hline $\begin{array}{l}\text { Könnyú parkolás } \\
\text { autóval }\end{array}$ & $\Gamma$ & ᄃ & \ulcorner & $\Gamma$ \\
\hline Rugalmas nyitva tartás & $\Gamma$ & Г & $\Gamma$ & $\Gamma$ \\
\hline $\begin{array}{l}\text { Minőségi felszereltség } \\
\text { (játékok, eszközök, } \\
\text { berendezés) }\end{array}$ & $\Gamma$ & $\Gamma$ & $\Gamma$ & Г \\
\hline Kis létszámú csoportok & $\Gamma$ & Г & $\Gamma$ & $\Gamma$ \\
\hline $\begin{array}{l}\text { Munkahelyhez } \\
\text { közelség }\end{array}$ & $\Gamma$ & Г & $\Gamma$ & Г \\
\hline Lakóhelyhez közelség & $\Gamma$ & $\Gamma$ & $\Gamma$ & $\Gamma$ \\
\hline $\begin{array}{l}\text { Kevés gyermek jusson } \\
\text { egy gondozóra }\end{array}$ & Г & Г & $\Gamma$ & Г \\
\hline Családias jelleg & $\Gamma$ & $\Gamma$ & $\Gamma$ & $\Gamma$ \\
\hline Intézményi jelleg & $\Gamma$ & ᄃ & \ulcorner & $\Gamma$ \\
\hline $\begin{array}{l}\text { Gondozókkal } \\
\text { személyes kapcsolat } \\
\text { (napi kontaktus, a } \\
\text { gyermekkel } \\
\text { kapcsolatos dolgok } \\
\text { megbeszélése } \\
\text { érkezéskor és } \\
\text { távozáskor) }\end{array}$ & $\Gamma$ & Г & $\Gamma$ & $\Gamma$ \\
\hline $\begin{array}{l}\text { Kapjak írásos } \\
\text { visszajelzést a } \\
\text { gyermekem fejlődéről, } \\
\text { a napi történésekről } \\
\text { (üzenőfüzetben, } \\
\text { eseménynaplóban pl.) }\end{array}$ & Г & Г & $\Gamma$ & Г \\
\hline $\begin{array}{l}\text { Hivatalos ellátóhely } \\
\text { legyen, müködési } \\
\text { engedéllyel }\end{array}$ & $\Gamma$ & $\Gamma$ & $\Gamma$ & Г \\
\hline
\end{tabular}

12. Ha egy szóban vagy mondatban kellene megfogalmazni, hogy mitől jó egy kisgyermekellátás, mit mondana?

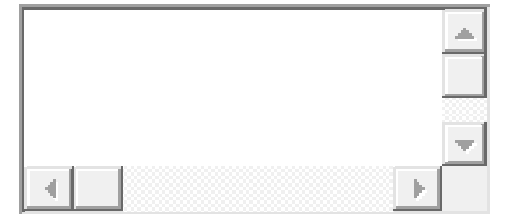

13. Milyen egyéb szolgáltatást venne igénybe szívesen? (több válasz lehetséges)

nyelv (angol német, egyéb) 
sport (úszás, torna lovaglás, népitánc, egyéb)

zenei foglalkozás (zenebölcsi, hangmasszázs, egyéb)

Г gyerekzsúr, születésnap

「 szülőknek rendezvény, program, közben a gyermekeknek felügyelet (pl. aerobik édesanyának)

Г bébitaxi („háztól házig” szolgáltatás)

$\Gamma$ bébihotel (éjszakai gyermekfelügyelet, ottalvás)

$\ulcorner\quad$ játszóház (időszakos gyermekfelügyelet)

$\Gamma$ sóbarlang

「 szülőkkel közös foglalkozások (játszóház, ringató, kézműves foglalkozás)

14. Egyéb véleménye, kérdése a témával kapcsolatban:

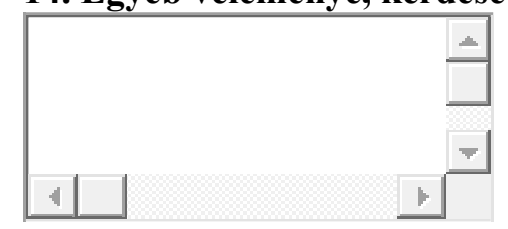




\section{3. melléklet - Céges gyermekfelügyelet munkavállalói oldalról}

Ön hova tette gyermekét, amikor visszament dolgozni? A szünetekben, gyermeke betegsége idején hogyan oldja meg a gyermeke felügyeletét? Tudta, hogy egyre több munkahely támogatja a családbarát gyermekellátást? Ön mit gondol erröl? Szeretné, ha a munkahelye is bekapcsolódna egy ilyen programba?

Nem

Életkor

Lakóhely

Iskolai végzettség

Foglalkozás

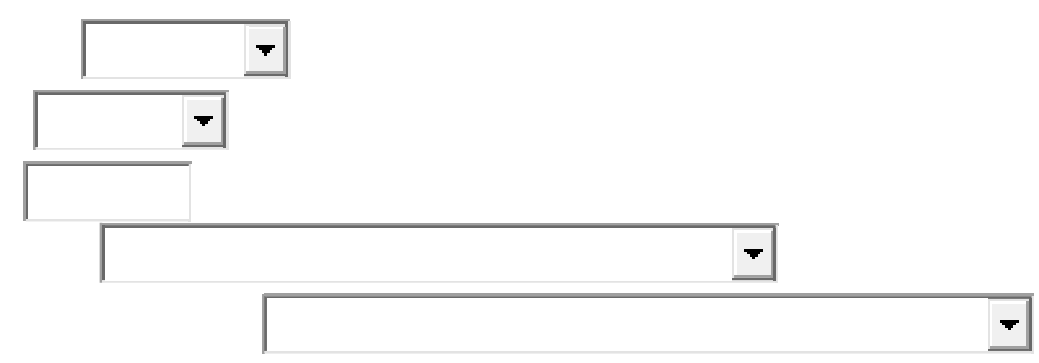

\section{Van Önnek gyermeke?}

igen

nem

\section{Hány gyermeke van?}

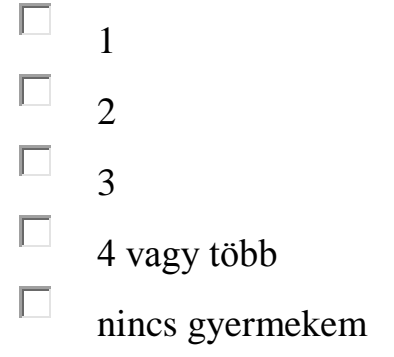

3. Hogyan oldja meg gyermeke felügyeletét, amíg Ön dolgozik? (több válasz lehetséges)

\ulcorner Nem dolgozom, mert én akarok vele lenni

$\Gamma \quad$ nagyszülő vigyáz rá

「ölcsőde, óvoda, iskolai napközi (állami)

$\ulcorner$ bölcsőde, óvoda, tanulószoba (magán)

$\Gamma \quad$ családi napközi (állami)

$\ulcorner$ családi napközi (magán)

$\lceil\quad$ bébiszitter (aki a saját lakásunkban vigyáz a gyermekre)

szomszéd, ismerős

$\Gamma$ céges (munkahelyen lévő) gyermekfelügyelet

$\ulcorner$ Egyéb

4. Ha egy szóban vagy mondatban kellene megfogalmazni, hogy mitől jó egy kisgyermekellátás, mit mondana? 


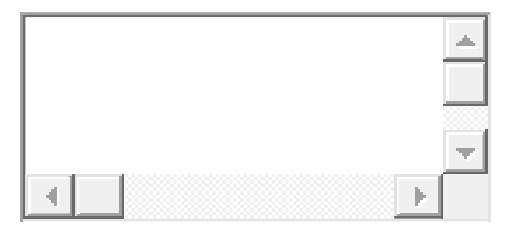

5. Van-e az Ön munkahelyén céges gyermekfelügyelet? (több válasz lehetséges)

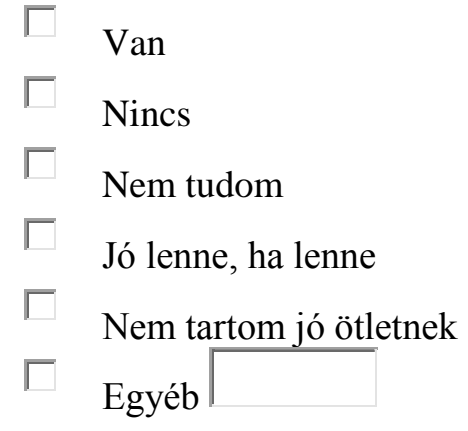

\section{Ha lenne, és igénybe venné, mennyit tudna/akarna fizetni érte?}

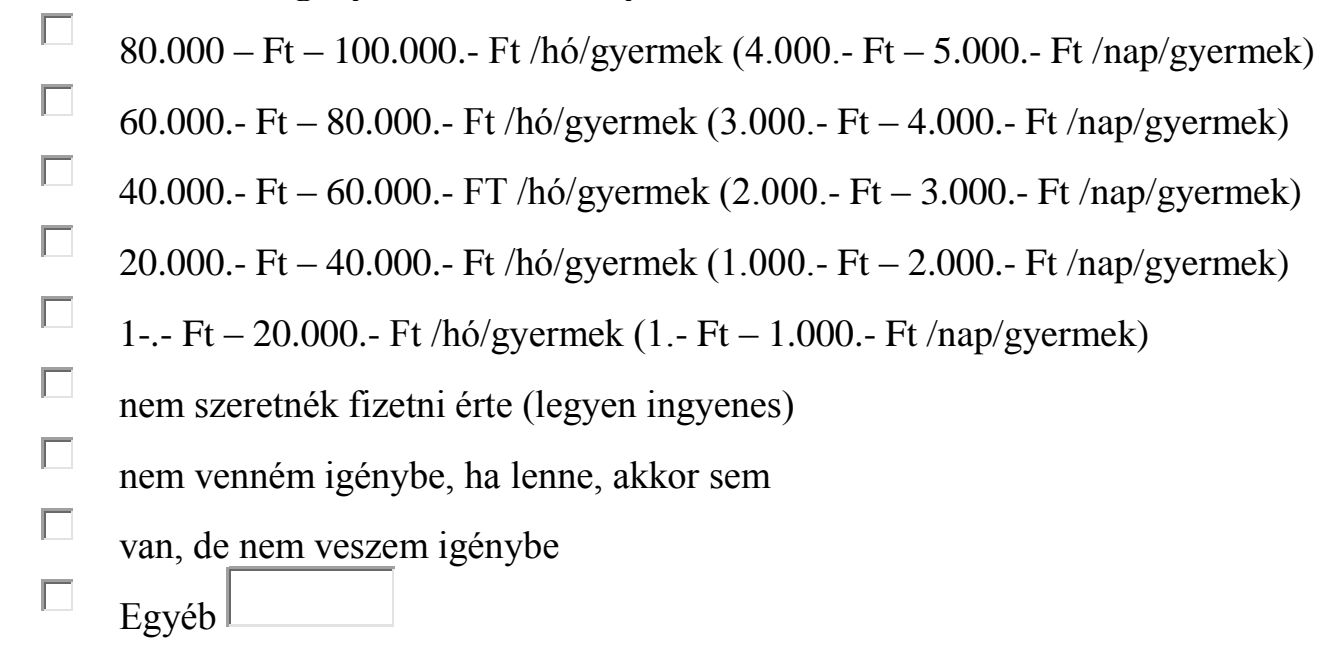

7. Milyen egyéb szolgáltatást venne igénybe szívesen? (több válasz lehetséges)

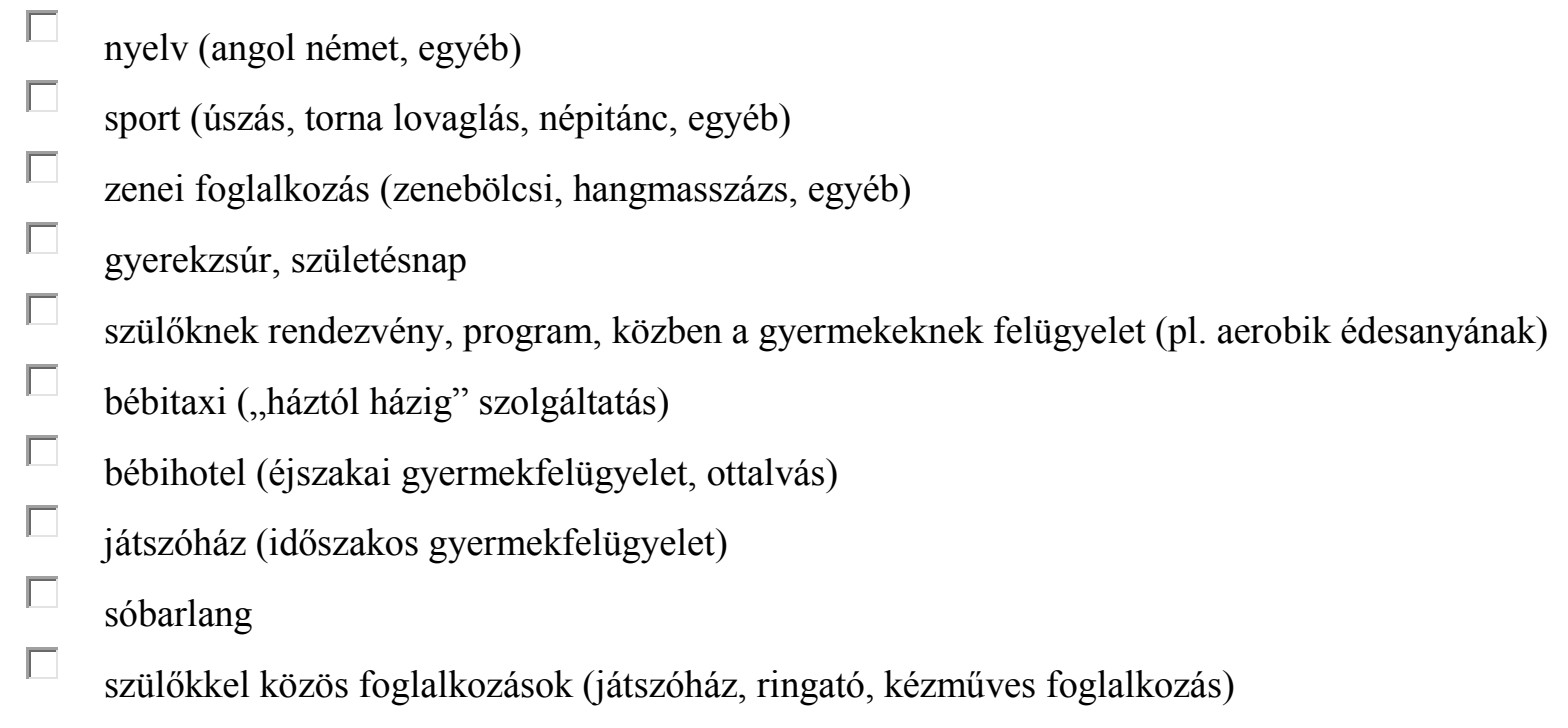

\section{Egyéb véleménye, kérdése a témával kapcsolatban:}




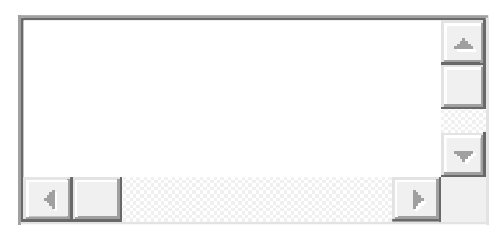




\section{4. melléklet - Napközbeni kisgyermekellátás a munkáltató szemszögéből}

A társadalmi felelösségvállalás (CSR) kötelezettsége napi kihívások elé állítja a vállalatot. Hisszük, hogy ez a kötelezettségvállalás túlmutathat a környezetvédelem és a fenntarthatóság egyébként igen fontos szempontjain. Célunk, hogy általánosan elfogadott legyen: a családos munkavállalóért érzett és tanúsított felelős magatartás is része a vállalat társadalmi felelősségvállalásának.

Ahhoz, hogy valódi segítséget nyújthassunk, meg kell ismernünk a munkáltatók témához kapcsolódó valódi gondolatait, érveit és ellenérveit. 2013.02.25-én tartottunk egy Kerekasztal megbeszélést („Céges családi napközi - közös gondolkodás” címmel), melyen körüljárva a témát továbbgondolandó kérdéseket fogalmaztunk meg. Ezen megbeszélés folytatásaként kérjük, hogy vegyen részt a felmérésünkben, melynek célja a munkáltatói igények felmérése, a meglévő problémák feltárása. A felmérés eredményeit tudományos publikációkban tesszük közzé. A kérdőív kitöltése önkéntes és anonym. A téma érzékenysége és aktualitása miatt nagyon fontos, hogy valós adatokat kapjunk. Attitúdökre, valós problémákra szeretnénk rávilágítani, mert az igazi megoldás javaslatait csak így tudjuk prezentálni. Külön köszönjük a bizalmat, mellyel megtisztelnek bennünket az őszinte válaszadással!

Kérjük, jelezze emailen, ha szeretné megismerni a kutatás eredményeit: cegescsana@csodacsalad.hu ! Köszönjük a kérdőív kitöltésére szánt időt és figyelmet, dr. Nagy Ágnes

www.cegescsana.hu

Nem

Életkor

Munkahely mérete (alkalmazottak száma)

Munkahely helye (település)

Kitöltő státusza

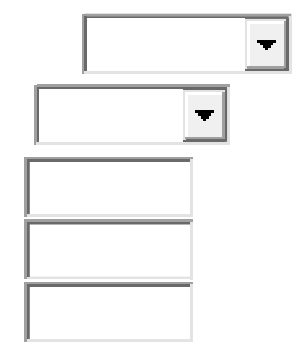

1. Bár régen általános volt a vállalati bölcsőde/óvoda, manapság alig találhatunk olyan munkahelyet, ahol a munkáltató valamilyen módon támogatja a dolgozó szülő gyermekének az ellátását. Ön szerint mi ennek az oka?

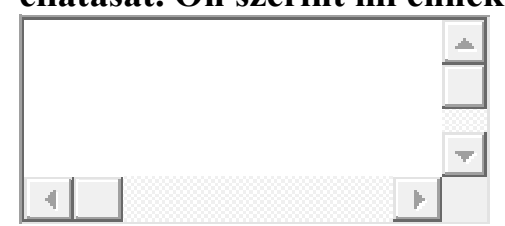

2. Mi úgy gondoljuk, hogy megéri a munkáltatónak támogatni a munkavállaló gyermekének a megnyugtató ellátását. Ön mit gondol erről?

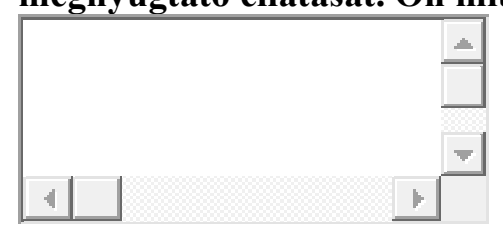

3. Előzetes felmérések alapján úgy találtuk, hogy a munkáltatók hajlandóak lennének áldozni a munkavállalóik gyermekeinek napközbeni ellátására, ha ehhez az államtól támogatást kapnának. Önnek erről mi a véleménye? 


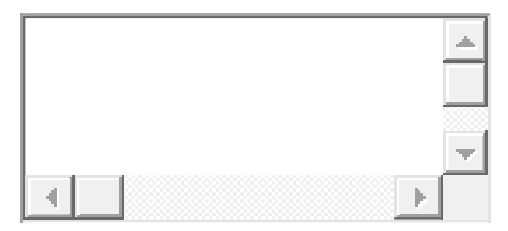

4. 2 fố úton lehet a vállalti gyermekfelügyeletet megoldani: munkahely által létrehozott vagy kiszervezett formában. Ön melyik megoldást tartja jobbnak, és miért?

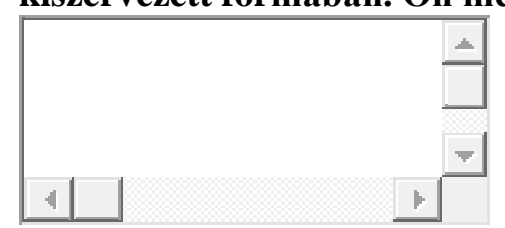

5. Mivel foglalkozik a cég (ha nem kívánja pontosan megnevezni, szektor is elég)

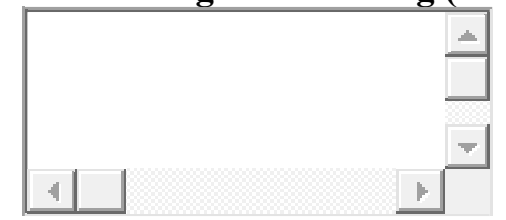

6. Kinek a feladata a cégnél a munkavállalók személyes ügyeinek intézése?
Г az ügyvezetőé
$\Gamma$ a HR vezetőé
$\ulcorner\quad$ nincs erre külön kijelölt ember

7. Az alkalmazottak közül hány főnek van 14 évnél fiatalabb gyermeke?

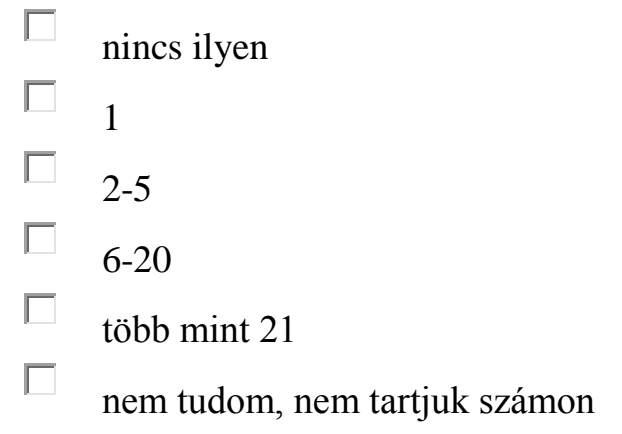

8. Átlagosan mikor térnek vissza a munkába gyermekvállalás után az édesanyák?

azonnal (1-2 hónap múlva)

「él év múlva

Г 1 év múlva

「 1-2 év között

「 2 év múlva (amikor lejár a GYED)

「 3 év múlva (amikor lejár a GYES)

Г 5-6 év múlva (több gyermeket vállalnak)

$\ulcorner$ nem tudom

Г Egyéb (megjegyzés) 
9. Hogyan kommunikálnak a témáról a munkavállalókkal? Hogyan zajlik a várandósság bejelentésétől a munkába visszatérésig a folyamat? Kérjük, pár mondatban írjon le egy ÁLTALÁNOS ÉS/VAGY EGY EXTRÉM esetet!

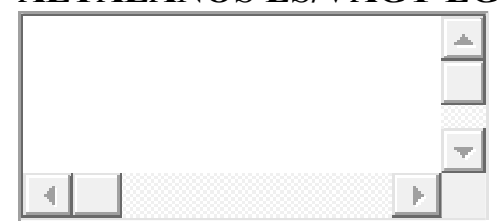

10. Segíti-e a vállalat a munkavállalót a gyermek elhelyezésének megoldásában? (több válasz lehetséges)

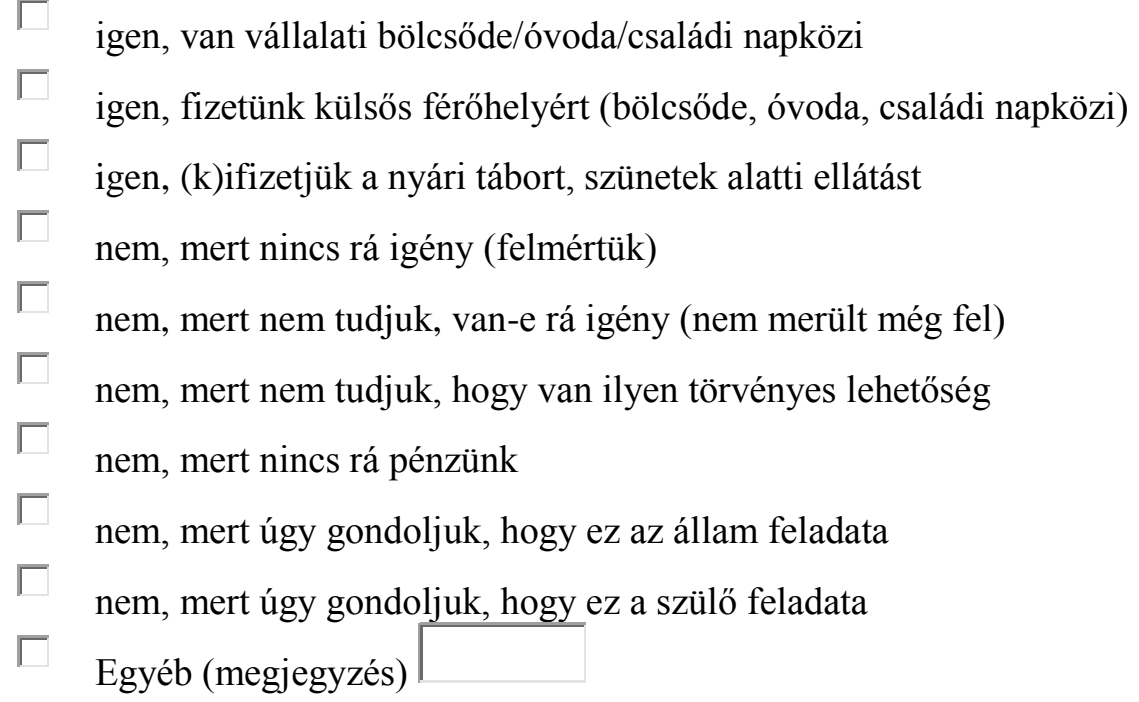

11. Kérjük, rangsorolja, az alábbi szempontok közül mit tart valódi segítségnek a kisgyermekes munkavállaló foglalkoztatása szempontjából?

lehessen egy éves kor $\begin{array}{ccc}\begin{array}{c}\text { egyáltalán } \\ \text { nem fontos }\end{array} & \text { semleges } & \begin{array}{c}\text { nagyon } \\ \text { fontos }\end{array}\end{array}$

elött hivatalosan, akár a GYED/GYES mellett dolgozni

legyen rugalmas és átjárható a családtámogatás (GYED, GYES, családi pótlék), a normatív támogatás és a béren kívüli juttatások rendszere (igazodjon a család és a munkáltató igényeihez) lehessen adó-és járulékmentesen adni a napközbeni kisgyermekellátás díját (magánbölcsőde, magánóvoda, családi napközi, tábor, stb.) 
kapjon állami

támogatást

(adómentesség, stb.) az

a munkahely, aki

napközbeni gyermek -

ellátóhelyet hoz létre és

müködtet

12. Pályázott-e a 2012-es TÁMOP 2.4.5 pályázaton (Vállalati és intézményi napközbeni kisgyermek-ellátási szolgáltatások létrehozása)

$\ulcorner\quad$ igen, nyertünk

$\Gamma \quad$ igen, nem nyertünk

$\Gamma$ nem, mert nem tudtunk róla

「 nem, mert nem tartottuk eléggé vonzónak a konstrukciót

ए Egyéb

13. Hozna-e létre, támogatna-e céges gyermekfelügyelet? Ha igen, hogyan tenné? ha nem, miért nem?

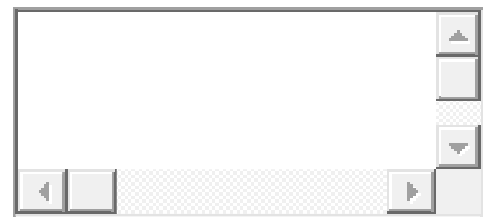

年 


\title{
1. függelék - A családi napközi létrehozását és működtetését befolyásoló fontosabb jogszabályok (felsorolás, kivonatolás)
}

\author{
lezárva: 2012. január 1.
}

\section{Törvények:}

- 1993. évi XCIII. törvény a munkavédelemröl

- 1995. évi XXVIII. törvény a nemzeti szabványosításról

- $\quad$ 1997. évi XXXI. törvény a gyermekek védelméről és a gyámügyi igazgatásról

- 1999. évi XLII. törvény a nemdohányzók védelméröl és a dohánytermékek fogyasztásának és forgalmazásának szabályairól

- 2000. évi XXV. törvény a Kémia biztonságról

- 2011. évi CXC. törvény a nemzeti köznevelésröl

- 2011. évi CXCV. törvény az államháztartásról

- 2011. évi CCXI. törvény a családok védelméről

- 1998. évi LXXXIV. törvény a családok támogatásáról

- 2004. évi CXL törvény a közigazgatási hatósági eljárás és szolgáltatás általános szabályairól

- mindenkori költségvetési törvény

\section{Kormányrendeletek:}

- 235/1997. (XII. 17) Kormányrendelet a gyámhatóságok, a területi gyermekvédelmi szakszolgálatok, a gyermekjóléti szolgálatok és a személyes gondoskodást nyújtó szervek és személyek által kezelt személyes adatokról

- 253/1997. (XII. 20.) Kormányrendelet az országos településrendezési és építési követelményekröl

- 257/2000. (XII. 26)) Kormányrendelet a közalkalmazottak jogállásáról szóló 1992. évi XXXIII. törvénynek a szociális, valamint a gyermekjóléti és gyermekvédelmi ágazatban történő végrehajtásáról

- 259/2002 (XII. 18) Kormányrendelet a gyermekjóléti és gyermekvédelmi szolgáltatótevékenység engedélyezéséről, valamint a gyermekjóléti és gyermekvédelmi vállalkozás engedélyezéséről

- 226/2006. (XI. 20.) Kormányrendelet a szociális, gyermekjóléti és gyermekvédelmi szolgáltatók, intézmények ágazati azonosítójáról és országos nyilvántartásáról

- 213/2009. (IX. 29) Kormányrendelet az egyházi és nem állami fenntartású szociális, gyermekjóléti és gyermekvédelmi szolgáltatók normatív állami fenntartásáról

- 328/2011. (XII. 29.) Kormányrendelet a személyes gondoskodást nyújtó gyermekjóléti alapellátások és gyermekvédelmi szakellátások térítési díjáról és az igénylésükhöz felhasználható bizonyítékokról

- 331/2010. (XII. 27.) Korm. rendelet a Nemzeti Rehabilitációs és Szociális Hivatalról, valamint eljárásának részletes szabályairól

\section{Miniszteri rendeletek:}

- 15/1998. (IV. 30) NM rendelet a személyes gondoskodást nyújtó gyermekjóléti, gyermekvédelmi intézmények, valamint személyek szakmai feladatairól és müködésük feltételeiröl

- 29/2003. (V. 20.) ESzCsM rendelet a helyettes szülők, a nevelőszülők, a családi napközit müködtetők képzésének szakmai és vizsgakövetelményeiről, valamint az örökbefogadás előtti tanácsadásról és felkészítő tanfolyamról

- 78/2003. (XI. 27.) GKM rendelet a játszótéri eszközök biztonságosságáról

- 28/2011.(IX.6) BM rendelet az Országos Tüzvédelmi Szabályzatról (478.§ (2) bekezdés)

- 33/1998. (VI. 24.) NM rendelet a munkaköri, szakmai, illetve személyi higiénés alkalmasság orvosi vizsgálatáról és véleményezéséről 
- 3/2002. (II. 8.) SzCsM-EüM együttes rendelet a munkahelyek munkavédelmi követelményeinek minimális szintjéről

- 25/2000. (IX. 30.) EüM-SzCsM együttes rendelet a munkahelyek kémiai biztonságáról

- 44/2000. (XII. 27.) EüM rendelet a veszélyes anyagokkal és a veszélyes készítményekkel kapcsolatos egyes eljárások, illetve tevékenységek részletes szabályairól

- 8/1981. (XII. 27.) IpM rendelet a Kommunális- és Lakóépületek Érintésvédelmi Szabályzatáról 


\section{7. évi XXXI. törvény a gyermekek védelméről és a gyámügyi igazgatásról}

Az Országgyülés a jövő nemzedékért érzett felelősségtől vezérelve a Gyermek jogairól szóló, New Yorkban, 1989. november 20-án kelt Egyezmény kihirdetéséről szóló 1991. évi LXIV. törvényben, továbbá az Alaptörvényben meghatározott gyermeki jogok érvényre juttatása érdekében, a házasságról, a családról és a gyámságról szóló 1952. évi IV. törvénnyel, valamint a szociális igazgatásról és szociális ellátásokról szóló 1993. évi III. törvénnyel összhangban a -következö törvényt alkotja:

\section{ELSÖ RÉSZ}

\section{ALAPVETÖ RENDELKEZÉSEK \\ I. Fejezet \\ Általános rendelkezések \\ A törvény célja és alapelvei}

1. § (1) E törvény célja, hogy megállapítsa azokat az alapvető szabályokat, amelyek szerint az állam, a helyi önkormányzatok és a gyermekek védelmét ellátó természetes és jogi személyek, továbbá jogi személyiséggel nem rendelkező más szervezetek meghatározott ellátásokkal és intézkedésekkel segítséget nyújtsanak a gyermekek törvényben foglalt jogainak és érdekeinek érvényesítéséhez, a szülői kötelességek teljesítéséhez, illetve gondoskodjanak a gyermekek veszélyeztetettségének megelőzéséről és megszüntetéséröl, a hiányzó szülői gondoskodás pótlásáról, valamint a gyermekvédelmi gondoskodásból kikerült fiatal felnőttek társadalmi beilleszkedéséről.

(2) A törvény meghatározza az (1) bekezdésben megjelölt célok elérése érdekében a gyermekek alapvető jogait és e jogok érvényesítésének garanciáit, a gyermekek védelmének rendszerét, alapvető szabályait.

2. § (1) A gyermekek védelmét ellátó helyi önkormányzatok, gyámhivatalok, bíróságok, rendőrség, ügyészség, pártfogó felügyelői szolgálat, más szervezetek és személyek e törvény alkalmazása során a gyermek mindenek felett álló érdekét figyelembe véve, törvényben elismert jogait biztosítva járnak el.

(2) Az (1) bekezdésben foglaltak szerint eljáró szervezetek és személyek tevékenységük során együttmüködnek a családdal és - jogszabályban meghatározottak szerint - elősegítik a gyermek családban történő nevelkedését.

(3) A gyermek családban történő nevelkedését segítő ellátást a gyermek és családja helyzetéhez, szükségleteihez igazodóan kell nyújtani.

(4) A családjából bármely okból kikerült gyermek biztonságát, korához és szükségleteihez igazodó gondozását, nevelését, egészséges személyiségfejlődését biztosítani kell.

3. § (1) A jogszabályban meghatározott ellátások igénybevétele általában önkéntes. A gyermek szülője vagy más törvényes képviselője csak törvényben meghatározott esetekben kötelezhető valamely ellátás igénybevételére.

(2) A gyermekek védelme során az egyenlő bánásmód követelményét meg kell tartani.

4. § (1) A törvény hatálya kiterjed

\section{A törvény hatálya}

a) a (2) és (3) bekezdésben foglalt eltéréssel Magyarország területén tartózkodó magyar állampolgárságú, valamint - ha nemzetközi szerződés másként nem rendelkezik - a letelepedett, bevándorolt, illetve befogadott jogállású, továbbá a magyar hatóságok által menekültként, oltalmazottként, illetve hontalanként elismert gyermekre, fiatal felnőttre és szüleire;

b) a szabad mozgás és tartózkodás jogával rendelkező személyek beutazásáról és tartózkodásáról szóló törvény (a továbbiakban: Szmtv.) szerint a szabad mozgás és tartózkodás jogával rendelkező személyre, amennyiben az ellátás igénylésének időpontjában az Szmtv.-ben meghatározottak szerint a szabad mozgás és a három hónapot meghaladó tartózkodási jogát Magyarország területén gyakorolja, és a polgárok személyi adatainak és lakcímének nyilvántartásáról szóló törvény szerint bejelentett lakóhellyel rendelkezik;

c) a menedékjogról szóló törvény szerint, arra a tizennyolcadik életévét be nem töltött menedékjogi kérelmet benyújtó külföldi gyermekre, aki jogszabály vagy szokás alapján felügyeletéért felelős nagykorú személy kísérete nélkül lépett Magyarország területére, vagy a belépést követően maradt felügyelet nélkül, mindaddig amíg ilyen személy felügyelete alá kerül - feltéve, hogy az illető gyermek kiskorúságát a menekültügyi hatóság megállapította.

(2) A törvény hatálya a rendkívüli gyermekvédelmi támogatás tekintetében az (1) bekezdésben foglaltakon túlmenően kiterjed az Európai Szociális Kartát megerösítő országok állampolgárainak Magyarország területén jogszerüen tartózkodó gyermekeire is.

(3) E törvény szerint kell eljárni az (1) és (2) bekezdésben meghatározott személyeken kívül a Magyarország területén tartózkodó nem magyar állampolgárságú gyermek védelmében is, ha az ideiglenes hatályú elhelyezésnek, a nevelési felügyelet elrendelésének vagy az eseti gondnok kirendelésének az elmulasztása a gyermek veszélyeztetettségével vagy elháríthatatlan kárral járna. Magyarország területén a szabad mozgás és tartózkodás jogával rendelkező és szokásos tartózkodási helyet létesítő gyermek védelmét 
szolgáló eljárás során e törvény rendelkezéseit kell alkalmazni, feltéve, hogy a házassági ügyekben és a szülői felelősségre vonatkozó eljárásokban a joghatóságról, valamint a határozatok elismeréséről és végrehajtásáról, illetve az 1347/2000/EK rendelet hatályon kívül helyezéséről szóló 2201/2003/EK tanácsi rendelet vagy nemzetközi szerződés eltérően nem rendelkezik.

(4) A Magyar Köztársaság területén kívül tartózkodó magyar állampolgárságú gyermek és fiatal felnőtt, valamint szülei gyámügyében e törvényt akkor kell alkalmazni, ha nemzetközi szerződés vagy más jogszabály szerint a személyes joguk az irányadó.

\section{5. § E törvény alkalmazásában}

\section{Értelmező rendelkezések}

a) gyermek: a Polgári Törvénykönyvről szóló 1959. évi IV. törvény (a továbbiakban: Ptk.) 12. §-a szerinti kiskorú,

b) fiatalkorú: az a személy, aki a szabálysértés vagy a büncselekmény elkövetésekor 14. évét betöltötte, de 18. évét még nem,

c) fiatal felnött: az a nagykorú személy, aki a 24. évét nem töltötte be,

d) a gyermek hozzátartozói: a vér szerinti és az örökbe fogadó szülők (a továbbiakban együtt: szülő), a szülő házastársa, a szülő testvére, a nagyszülő, a nagyszülő házastársa, a nagyszülő testvére, a dédszülő, a testvér, a testvér házastársa, a saját gyermek,

e) a gyermek közeli hozzátartozói: ha e törvény másképp nem rendelkezik, a szülö, a szülő házastársa, a szülő testvére, a nagyszülő, testvér, a saját gyermek,

f) a gyermek tartására köteles személy: a házasságról, a családról és a gyámságról szóló 1952. évi IV. törvény (a továbbiakban: Csjt.) 61. §-a (4) bekezdésében és 62. §-a (1) bekezdésében, a Csjt. 69/A. §-ában, valamint a 69/D. § (2) bekezdésében meghatározott személy,

g) gyermekjóléti és gyermekvédelmi szolgáltató tevékenység: a gyermekjóléti alapellátás, illetve a gyermekvédelmi szakellátás keretében - működési engedéllyel - végzett tevékenység, függetlenül a feladatellátás e törvényben nevesített formájától és módjától; a szolgáltató tevékenység célja a gyermekjólétnek, azaz a gyermek testi, értelmi, érzelmi és erkölcsi fejlődésének, személyi, vagyoni és egyéb jogainak biztosítása,

h) gyermeki jogok: az Alaptörvényben, a Gyermek jogairól szóló, New Yorkban, 1989. november 20-án kelt Egyezmény kihirdetéséről szóló 1991. évi LXIV. törvényben és más törvényekben megfogalmazott, a gyermeket megillető jogok összessége,

i) ellátás: jogszabályban meghatározott pénzbeli, természetbeni, illetve személyes gondoskodást nyújtó alapellátás és szakellátás,

j) természetbeni ellátás: olyan támogatás, amellyel a gyermeket alapvető szükségleteinek kielégítésében az állam (önkormányzat) anyagi javak biztosításával, szolgáltatások kifizetésével és nyújtásával segíti,

k) gyámhatóság: a települési önkormányzat jegyzője és a gyámhivatal,

l) gyámügy: a jogszabály által a gyámhatóság feladat- és hatáskörébe utalt ügyek köre,

m) gyermekvédelmi gondoskodás: az e törvényben meghatározottak szerint elrendelt hatósági intézkedésen alapuló ellátás és védelem,

n) veszélyeztetettség: olyan - a gyermek vagy más személy által tanúsított - magatartás, mulasztás vagy körülmény következtében kialakult állapot, amely a gyermek testi, értelmi, érzelmi vagy erkölcsi fejlődését gátolja vagy akadályozza,

o) várandós anya válsághelyzete: olyan családi, környezeti, szociális, társadalmi helyzet vagy ezek következtében kialakult állapot, amely a várandós anya testi vagy lelki megrendülését, társadalmi ellehetetlenülését okozza, és ezáltal veszélyezteti a gyermek egészséges megszületését,

p) tartós betegség: azon kórforma, amely a külön jogszabályban meghatározott magasabb összegű családi pótlékra jogosít,

q) fogyatékos gyermek, fiatal felnött:

qa) a gyermekvédelmi pénzbeli és természetbeni ellátások tekintetében a külön jogszabályban meghatározott magasabb összegü családi pótlékra jogosító fogyatékosságban szenvedő gyermek, fiatal felnőtt,

$q b)$ a személyes gondoskodás keretébe tartozó gyermekjóléti alapellátások és gyermekvédelmi szakellátások, valamint a gyermekétkeztetés normatív kedvezménye tekintetében a közoktatásról szóló 1993. évi LXXIX. törvény (a továbbiakban: Kt.) 121. §-a (1) bekezdésének 29. a) pontjában foglaltaknak megfelelő gyermek, fiatal felnőtt,

r) jövedelem: a szociális igazgatásról és szociális ellátásokról szóló 1993. évi III. törvény (a továbbiakban: Szt.) 4. §-a (1) bekezdésének $a$ ) pontjában meghatározottak,

s) fenntartó:

sa) a központi költségvetési szerv, a megyei intézményeket fenntartó, Kormány által rendeletben kijelölt szerv (a továbbiakban: megyei fenntartó), a helyi önkormányzat, a helyi önkormányzatok társulásairól és együttműködéséről szóló 1997. évi CXXXV. törvény 8-9. §-a, illetve 16. §-a szerinti intézményi társulás, a 
települési önkormányzatok többcélú kistérségi társulása, a nemzetiségi önkormányzat (a továbbiakban együtt: állami fenntartó),

$s b)$ a lelkiismereti és vallásszabadság jogáról, valamint az egyházak, vallásfelekezetek és vallási közösségek jogállásáról szóló törvény szerinti nyilvántartásba vett egyház, illetve annak belső egyházi jogi személy (a továbbiakban együtt: egyházi fenntartó), nem minősül egyházi fenntartónak az a jogi személy, amely más típusú szervezetként jogalanyisággal rendelkezik, így különösen a civil szervezet, annak alapszabályban jogi személlyé nyilvánított szervezeti egysége, az alapítvány, annak alapító okiratban jogi személlyé nyilvánított szervezeti egysége, a gazdasági társaság,

sc) az egyéni vállalkozó,

$s d)$ az $s a$ )-sb) alpontokban nem említett, magyarországi székhelyű jogi személy, jogi személyiség nélküli gazdasági társaság és egyéni cég,

se) az Európai Gazdasági Térségről szóló megállapodásban részes valamely államban (a továbbiakban: EGT-állam), valamint - ha az Európai Közösséggel és tagállamaival létrejött nemzetközi szerződés alapján az adott állam szolgáltatói a letelepedés szabadsága tekintetében az EGT-államok szolgáltatóival azonos jogállást élveznek - az EGT-államoktól eltérő más államban honos vállalkozás belföldön bejegyzett fióktelepe [az $s c$ )-se) pontokban foglaltak a továbbiakban együtt: nem állami fenntartó],

ha az e törvényben és más jogszabályban meghatározott feltételek szerint, müködési engedély alapján gondoskodik a gyermekjóléti és gyermekvédelmi szolgáltató tevékenység biztosításához szükséges feltételekről. Ha jogszabály másképp nem rendelkezik, az egyházi fenntartóra a nem állami fenntartóra vonatkozó rendelkezéseket kell megfelelően alkalmazni,

t) személyazonosító adat: az érintett személy természetes személyazonosító adatai, neme, állampolgársága, bevándorolt, letelepedett, oltalmazott vagy menekült jogállása, lakó- és tartózkodási helye,

u) intézmény: az e törvényben meghatározott gyermekjóléti és gyermekvédelmi szolgáltató tevékenységet végző szervezet vagy annak szakmailag önálló szervezeti egysége, amely a rá vonatkozó külön jogszabályban foglaltak alapján jön létre, legalább három föt foglalkoztat teljes munkaidőben, és tevékenysége müködési engedélyköteles. Ha e törvény másképp nem rendelkezik, az intézmény fogalmát kell megfelelően alkalmazni a helyettes szülői, illetve nevelőszülői hálózatra is,

v) müködtető: az a természetes személy, jogi személy, illetve ezek jogi személyiség nélküli szervezete, aki, illetve amely a fenntartó által biztosított müködési feltételek között a gyermekjóléti és gyermekvédelmi szolgáltató tevékenységet szervezi,

x) államilag támogatott lakás-elötakarékossági programban való részvétel: a lakástakarékpénztárakról szóló 1996. évi CXIII. törvény szerinti lakás-előtakarékossági szerződés megkötése és teljesítése,

y) családi pótlék: a családok támogatásáról szóló 1998. évi LXXXIV. törvény (a továbbiakban: Cst.) 5. §ának $a$ ) pontja szerinti nevelési ellátás és iskoláztatási támogatás,

z) rendszeres jövedelem: a legalább három egymást követő hónapban keletkezett jövedelem.

\section{Fejezet \\ Alapvető jogok és kötelességek \\ Gyermeki jogok}

6. § (1) A gyermeknek joga van a testi, értelmi, érzelmi és erkölcsi fejlődését, egészséges felnevelkedését és jólétét biztosító saját családi környezetében történő nevelkedéshez.

(2) A gyermeknek joga van ahhoz, hogy segítséget kapjon a saját családjában történő nevelkedéséhez, személyiségének kibontakoztatásához, a fejlődését veszélyeztető helyzet elhárításához, a társadalomba való beilleszkedéséhez, valamint önálló életvitelének megteremtéséhez.

(3) A fogyatékos, tartósan beteg gyermeknek joga van a fejlődését és személyisége kibontakozását segítő különleges ellátáshoz.

(4) A gyermeknek joga van ahhoz, hogy a fejlődésére ártalmas környezeti és társadalmi hatások, valamint az egészségére káros szerek ellen védelemben részesüljön.

(5) A gyermeknek joga van emberi méltósága tiszteletben tartásához, a bántalmazással - fizikai, szexuális vagy lelki erőszakkal -, az elhanyagolással és az információs ártalommal szembeni védelemhez. A gyermek nem vethető alá kínzásnak, testi fenyítésnek és más kegyetlen, embertelen vagy megalázó büntetésnek, illetve bánásmódnak.

(6) A gyermeknek joga van ahhoz, hogy a médiában fejlettségének megfelelő, ismeretei bővítését segítő, a magyar nyelv és kultúra értékeit őrző müsorokhoz hozzáférjen, továbbá hogy védelmet élvezzen az olyan káros hatásokkal szemben, mint a gyülöletkeltés, az erőszak és a pornográfia.

7. § (1) A gyermek szüleitől vagy más hozzátartozóitól csak saját érdekében, törvényben meghatározott esetekben és módon választható el. A gyermeket kizárólag anyagi okból fennálló veszélyeztetettség miatt nem szabad családjától elválasztani.

(2) A gyermeknek joga van - örökbefogadó családban vagy más, családot pótló ellátás formájában - a szülői vagy más hozzátartozói gondoskodást helyettesítő védelemhez. 
(3) A gyermek helyettesítő védelme során tiszteletben kell tartani lelkiismereti és vallásszabadságát, továbbá figyelemmel kell lenni nemzetiségi, etnikai és kulturális hovatartozására.

(4) Ha törvény másként nem rendelkezik, a gyermeknek a szülő felügyeleti joga megszünése esetén is joga van származása, vér szerinti családja megismeréséhez és - a vér szerinti család beleegyezése mellett - a kapcsolattartáshoz.

(5) A gyermeknek joga van ahhoz, hogy mindkét szülöjével kapcsolatot tartson abban az esetben is, ha a szülők különböző államokban élnek.

8. § (1) A gyermeknek joga van a szabad véleménynyilvánításhoz, és ahhoz, hogy tájékoztatást kapjon jogairól, jogai érvényesítésének lehetőségeiről, továbbá ahhoz, hogy a személyét és vagyonát érintő minden kérdésben közvetlenül vagy más módon meghallgassák, és véleményét korára, egészségi állapotára és fejlettségi szintjére tekintettel figyelembe vegyék.

(2) A gyermeknek joga van ahhoz, hogy az öt érintő ügyekben az e törvényben meghatározott fórumoknál panasszal éljen.

(3) A gyermeknek joga van ahhoz, hogy alapvető jogai megsértése esetén bíróságnál és törvényben meghatározott más szerveknél eljárást kezdeményezzen.

9. § (1) Az átmeneti vagy tartós nevelésbe vett gyermek joga különösen, hogy életkorához, egészségi állapotához, fejlettségéhez, valamint egyéb szükségleteihez igazodóan

a) állandóságot, érzelmi biztonságot nyújtó teljes körü ellátásban, gondozásban, - nemzetiségi, etnikai és vallási hovatartozását figyelembe vevő - megfelelő nevelésben, oktatásban részesüljön,

b) gondozási helyének megváltoztatását, gyermekével vagy testvéreivel való együttes elhelyezését kezdeményezze,

c) felzárkóztató, tehetségfejlesztő programokon és érdeklődésének megfelelő szabadidős foglalkozásokon vegyen részt,

d) vallási vagy lelkiismereti meggyőződését szabadon megválassza, kinyilvánítsa és gyakorolja, valamint hit- és vallásoktatásban vegyen részt,

e) véleményt nyilvánítson a részére biztosított nevelésről, oktatásról, ellátásról, a személyét érintő kérdésekben meghallgassák, tájékoztassák,

f) érdekei képviseletére gyermekönkormányzat létrehozását kezdeményezze,

g) támogatást kapjon gondozójától, törvényes képviselőjétől családi környezetébe való visszatéréséhez,

h) családi környezetébe való visszatérését kezdeményezze,

i) személyes kapcsolatait ápolhassa,

j) a személyes tulajdon szokásos tárgyaihoz füződő jogait gyakorolhassa,

$k$ ) utógondozásban részesüljön.

(2) Ha az (1) bekezdés $i$ ) pontja szerinti jog gyakorlása a gyermek személyiségfejlődését hátrányosan befolyásolja, a szülő vagy más kapcsolattartásra jogosult közeli hozzátartozó kapcsolattartási joga az e törvényben foglaltak szerint korlátozható, megvonható vagy szüneteltethetö.

(3) A speciális gyermekotthonban vagy gyermekotthon speciális csoportjában elhelyezett gyermeket helyzetére való tekintettel - fokozott védelemben kell részesíteni.

(4) A speciális gyermekotthonban elhelyezett gyermek

a) egészségügyi ellátására, személyisége korrekciójához szükséges terápiára az állapotának megfelelő és a többi gyermek biztonságát védő módon, továbbá

b) gondozása és nevelése során jogait, személyes szabadságát korlátozó intézkedés alkalmazására csak feltétlenül indokolt esetben önmaga vagy mások veszélyeztetése esetén kerülhet sor.

10. § (1) A gyermek kötelessége különösen, hogy

a) gondozása és nevelése érdekében szülőjével vagy más törvényes képviselőjével, gondozójával együttmüködjön,

b) képességeinek megfelelően tegyen eleget tanulmányi kötelezettségének,

c) tartózkodjék az egészségét károsító életmód gyakorlásától és az egészségét károsító szerek használatától.

(2) A gyermekjóléti és gyermekvédelmi ellátást biztosító intézmények házirendje - e törvényben meghatározott keretek között - a gyermek életkorához, egészségi állapotához, fejlettségi szintjéhez igazodva állapítja meg a gyermekek jogai gyakorlásának és kötelességei teljesítésének szabályait.

(3) Az intézmény - a külön jogszabályban meghatározottak szerint elkészített - házirendjét az intézményben mindenki által jól látható helyen ki kell függeszteni, és gondoskodni kell annak megismertetéséről.

(4) Helyettes szülöi és nevelőszülői hálózat esetében a jogok gyakorlásának és a kötelességek teljesítésének alapvető szabályait a szervezeti és müködési szabályzat tartalmazza.

\section{Gyermeki jogok védelme}


11. § (1) A gyermeki jogok védelme minden olyan természetes és jogi személy kötelessége, aki a gyermek nevelésével, oktatásával, ellátásával, ügyeinek intézésével foglalkozik.

(2)

11/A. § (1) A gyermekjogi képviselő ellátja a gyermekvédelmi gondoskodásban részesülő gyermek e törvényben meghatározott jogainak védelmét, és segíti a gyermeket jogai megismerésében és érvényesítésében, valamint kötelességei megismerésében és teljesítésében. A gyermekjogi képviselő kiemelt figyelmet fordít a különleges vagy speciális ellátást igénylő gyermek védelmére.

(2) A gyermekjogi képviselő

a) segít a gyermeknek panasza megfogalmazásában, kezdeményezheti annak kivizsgálását,

b) segíti a gyermeket az állapotának megfelelő ellátáshoz való hozzájutásban, a gyermekjóléti szolgálat esetmegbeszélésén, illetve a területi gyermekvédelmi szakszolgálat elhelyezési értekezletén az ezzel kapcsolatos megjegyzések, kérdések megfogalmazásában,

c) a 36. § (2) bekezdése szerinti esetben eljár a gyermek szülöje vagy más törvényes képviselöje, a gyermek, illetve fiatal felnőtt, valamint a gyermek-önkormányzat felkérése alapján,

d) eljár az érdek-képviseleti fórum 35. § (4) bekezdése szerint tett megkeresése alapján,

e) a gyámhivatal kirendelése alapján képviseli a gyermeket a nevelési felügyelettel kapcsolatos eljárásban,

f) a 100/A. § (1) bekezdése szerinti jogsértések észlelése esetén javaslatot tehet

fa) gyermekvédelmi igazgatási bírság kiszabására az arra a 100/A. § (1) bekezdése szerint jogosult szervnek,

$f b)$ a jogsértés jövőbeni előfordulásának megelözése érdekében a jogsértéssel érintettek között, szükség szerint szakértők bevonásával, egyeztető megbeszélés tartására a gyámhivatalnak,

fc) a jogsértő személy továbbképzésére a fenntartónak, müködtetőnek.

(3) A gyermekjogi képviselő jogosult a gyermekjóléti, illetve gyermekvédelmi szolgáltató tevékenységet végzö müködési területén tájékoztatást, iratokat, információkat kérni és a helyszínen tájékozódni. A gyermekjogi képviselő köteles a gyermek személyes adatait az adatvédelmi jogszabályoknak megfelelően kezelni.

(4) A gyermekjogi képviselő e célra létrehozott szervezet keretében müködik. A gyermekjogi képviselő jogállására és eljárására vonatkozó részletes szabályokat külön jogszabály rendezi.

(5) A gyermekjóléti és gyermekvédelmi szolgáltató tevékenységet végző biztosítja, hogy a gyermek és hozzátartozói a gyermekjogi képviselő személyét és a vele való kapcsolat felvételének módját megismerhessék.

(6) A gyermekjóléti és gyermekvédelmi intézmények, illetve szolgálatok vezetöi tizenöt napon belül, a fenntartó harminc napon belül, illetve a képviselö-testület vagy a közgyülés a következő testületi ülésén érdemben megtárgyalja a gyermekjogi képviselő észrevételeit, és az ezzel kapcsolatos állásfoglalásáról, intézkedéséről tájékoztatja őt.

(7) A gyermekjogi képviselő figyelemmel kíséri az óvoda, az iskola, a kollégium és a pedagógiai szakszolgálat intézményeiben folyó gyermekvédelemmel kapcsolatos tevékenységet, segíti a gyermeki jogok érvényesülését. A gyermekjogi képviselő indokolt esetben megkeresi az említett intézmények fenntartóját, illetve szükség szerint a gyermek érdekében a gyámhatóságnál eljárást kezdeményez.

(8) Nem lehet gyermekjogi képviselő az a személy,

a) aki büntetett elö́letü,

b) aki büntetlen előéletü, de a bíróság büntetőjogi felelősségét jogerős ítéletben megállapította a Büntető Törvénykönyvről szóló 1978. évi IV. törvény XII. fejezet I. címében meghatározott élet, testi épség és egészség elleni büncselekmény, II. címében meghatározott egészségügyi beavatkozás, orvostudományi kutatás rendje és az egészségügyi önrendelkezés elleni büncselekmény, kényszerítés, a lelkiismeret és vallásszabadság megsértése, közösség tagja elleni erőszak, személyi szabadság megsértése, emberrablás, emberkereskedelem, zaklatás, magántitok megsértése, visszaélés személyes adattal, visszaélés közérdekü adattal, XIV. fejezetében meghatározott házasság, család, ifjúság és nemi erkölcs elleni büncselekmény, embercsempészet, XV. fejezet V. címében meghatározott hivatalos személy elleni büncselekmény és VI. címében meghatározott igazságszolgáltatás elleni büncselekmény, XVI. fejezet II-IV. címében meghatározott köznyugalom, közbizalom és közegészség elleni büncselekmény, lopás, sikkasztás, csalás, hütlen kezelés, hanyag kezelés, rablás, kifosztás, zsarolás, orgazdaság vagy olyan büntett miatt, amelyet bünszervezet keretében követett el

$b a)$ ötévi vagy azt meghaladó végrehajtandó szabadságvesztés büntetés esetén a mentesítés beálltától számított tizenkét évig,

$b b)$ öt évet el nem érő végrehajtandó szabadságvesztés esetén a mentesítés beálltától számított tíz évig,

$b c$ ) végrehajtásában felfuiggesztett szabadságvesztés esetén a mentesítés beálltától számított nyolc évig,

$b d$ ) közérdekü munka vagy pénzbüntetés kiszabása esetén a mentesítés beálltától számított öt évig,

be) végrehajtásában felfüggesztett pénzbüntetés esetén a mentesítés beálltától számított három évig,

c) aki a $b$ ) pontban meghatározott büncselekmény miatt büntetőeljárás hatálya alatt áll, 
d) aki a szakmai gyakorlata meglétének vizsgálata során figyelembe veendő foglalkozás tekintetében foglalkoztatástól eltiltás hatálya alatt áll, valamint

$e$ ) akinek szülői felügyeleti jogát a bíróság jogerős ítéletével megszüntette, valamint - ha külön jogszabály másképp rendelkezik - akinek szülői felügyeleti joga a gyermek átmeneti nevelésbe vétele miatt szünetel.

(9) Megszünik a gyermekjogi képviselő megbízatása, ha vele szemben a (8) bekezdésben meghatározott kizáró okok valamelyike fennáll, vagy ha a gyermekjogi képviselö a 11/B. § (3) bekezdésben meghatározott igazolási kötelezettségének ismételt szabályszerü felhívásra sem tesz eleget, és nem bizonyítja, hogy a kötelezettség elmulasztása rajta kívülálló ok következménye.

11/B. § (1) A gyermekjogi képviselői feladatok ellátására pályázó személy a jelentkezéskor a gyermekjogi képviselet céljából létrehozott szervezett vezetője (a továbbiakban: vezető) részére

a) hatósági bizonyítvánnyal igazolja azt a tényt, hogy a 11/A. § (8) bekezdés $a$ )-d) pontjában meghatározott kizáró ok vele szemben nem áll fenn, valamint

b) igazolja, hogy a 11/A. $\S(8)$ bekezdés $e$ ) pontjában meghatározott kizáró ok vele szemben nem áll fenn.

(2) Ha a pályázó az (1) bekezdésben meghatározott tényeket nem igazolja, gyermekjogi képviselő nem lehet.

(3) A vezető a gyermekjogi képviselöt - a képviselet ellátásának időtartama alatt - írásban, a mulasztás jogkövetkezményeinek ismertetésével felhívhatja annak hatósági bizonyítvánnyal való igazolására, hogy a gyermekjogi képviselővel szemben nem állnak fenn a 11/A. § (8) bekezdés $a$ )-d) pontjában meghatározott kizáró okok.

(4) Ha az (3) bekezdésben meghatározott felhívásra a gyermekjogi képviselő igazolja, hogy vele szemben a 11/A. $\S(8)$ bekezdés $a$ )- $d$ ) pontjában meghatározott kizáró okok nem állnak fenn, a vezető az igazolásra szolgáló hatósági bizonyítvány kiadása iránti eljárásért megfizetett igazgatási szolgáltatási díjat a gyermekjogi képviselö részére megtéríti.

(5) A vezető a 11/A. § (8) bekezdés $a$ )-d) pontjában meghatározott körülmények igazolása céljából kezeli

a) gyermekjogi képviselői feladatok ellátására pályázó személy,

b) a gyermekjogi képviselő

azon személyes adatait, amelyeket az e célból a bünügyi nyilvántartó szerv által kiállított hatósági bizonyítvány tartalmaz.

(6) Az (5) bekezdésben meghatározott személyes adatokat a vezető az ellenőrzés lefolytatásáig vagy ha az ellenőrzés következtében a gyermekjogi képviselő megbízatása megszűnik, a megbízatás megszünésének időpontjáig kezeli.

\section{Szülöi jogok és kötelességek}

12. § (1) A gyermek szülője jogosult és köteles arra, hogy gyermekét családban gondozza, nevelje és a gyermeke testi, értelmi, érzelmi és erkölcsi fejlödéséhez szükséges feltételeket - különösen a lakhatást, étkezést, ruházattal való ellátást -, valamint az oktatásához és az egészségügyi ellátásához való hozzájutást biztosítsa.

(2) A gyermek szülője jogosult arra, hogy a gyermeke nevelkedését segítő ellátásokról tájékoztatást, neveléséhez segítséget kapjon.

(3) A gyermek szülöje - ha törvény másként nem rendelkezik - jogosult és köteles gyermekét annak személyi és vagyoni ügyeiben képviselni.

(4) A gyermek szülöje köteles

a) gyermekével együttműködni, és emberi méltóságát a 6. § (5) bekezdése szerint tiszteletben tartani,

b) gyermekét az öt érintő kérdésekről tájékoztatni, véleményét figyelembe venni,

c) gyermekének jogai gyakorlásához iránymutatást, tanácsot és segítséget adni,

d) gyermeke jogainak érvényesítése érdekében a szükséges intézkedéseket megtenni,

e) a gyermeke ellátásában közremúködő személyekkel és szervekkel, továbbá a hatóságokkal együttmüködni.

13. § (1) Az átmeneti nevelésbe vett gyermek szülöje jogosult arra, hogy

a) a gyermeke gondozójától, gyámjától, hivatásos gyámjától a gyermeke elhelyezéséről, neveléséről, fejlődéséről rendszeres tájékoztatást kapjon,

b) a gyámhivataltól gyermeke gondozási helyének megváltoztatását kérje,

c) a gyermeke családba történő visszahelyezése érdekében a települési önkormányzattól - a nevelésbe vétel okának elháritásához, a körülmények rendezéséhez, a gyermeke családba való visszailleszkedéséhez segítséget kapjon,

d) a Csjt.-nek megfelelően a gyermeke sorsát érintő lényeges kérdésekben - a gyermeke nevének meghatározásáról, illetve megváltoztatásáról, tartózkodási helyének kijelöléséröl, iskolájának, valamint életpályájának megválasztásáról - meghallgassák.

(2) Az átmeneti nevelésbe vett gyermek szülöje jogosult és köteles

a) a gyermeke gondozását ellátó személyekkel, intézményekkel - a nevelés érdekében - együttmüködni,

b) gyermekével - törvényben meghatározott módon - kapcsolatot tartani. 
(3) Az átmeneti nevelésbe vett gyermek szülöje köteles

a) minden tőle elvárhatót megtenni gyermeke családba történő visszahelyezéseért,

b) tiszteletben tartani a nevelőszülö családját és otthonát, az intézményben dolgozó személyeket, valamint köteles betartani az intézmény rendjét,

c) gyermeke ellátásáért gondozási díjat fizetni.

\section{Fejezet}

\section{A gyermekek védelmének rendszere}

14. §(1) A gyermekek védelme a gyermek családban történő nevelkedésének elősegítésére, veszélyeztetettségének megelőzésére és megszüntetésére, valamint a szülöi vagy más hozzátartozói gondoskodásból kikerülő gyermek helyettesítő védelmének biztosítására irányuló tevékenység.

(2) A gyermekek védelmét pénzbeli, természetbeni és személyes gondoskodást nyújtó gyermekjóléti alapellátások, illetve gyermekvédelmi szakellátások, valamint e törvényben meghatározott hatósági intézkedések biztosítják.

(3) A gyermekvédelmi rendszer múködtetése állami és önkormányzati feladat.

15. § (1) Pénzbeli és természetbeni ellátások:

a) a rendszeres gyermekvédelmi kedvezmény,

b) a rendkívüli gyermekvédelmi támogatás,

c) a gyermektartásdíj megelőlegezése,

d) az otthonteremtési támogatás,

e) a kiegészítő gyermekvédelmi támogatás.

(2) A személyes gondoskodás keretébe tartozó gyermekjóléti alapellátások:

a) a gyermekjóléti szolgáltatás,

b) a gyermekek napközbeni ellátása,

c) a gyermekek átmeneti gondozása.

(3) A személyes gondoskodás keretébe tartozó gyermekvédelmi szakellátások:

a) az otthont nyújtó ellátás

b) az utógondozói ellátás,

c) a területi gyermekvédelmi szakszolgáltatás.

(4) A gyermekvédelmi gondoskodás keretébe tartozó hatósági intézkedések:

a) a védelembe vétel,

b) a családbafogadás,

c) az ideiglenes hatályú elhelyezés,

d) az átmeneti nevelésbe vétel,

e) a tartós nevelésbe vétel,

f) a nevelési felügyelet elrendelése,

g) az utógondozás elrendelése,

h) az utógondozói ellátás elrendelése.

(5) A gyermekvédelmi rendszer része a bíróság által javítóintézeti nevelésre utalt, illetve elözetes letartóztatásba helyezett fiatalkorúak intézeti ellátása. A fiatalkorúak javítóintézeti neveléséröl külön törvény rendelkezik.

(6) A gyermekjóléti és gyermekvédelmi rendszerben foglalkoztatottakat - a külön jogszabályban meghatározott munkakörükkel összefüggésben - megilleti az a jog, hogy személyüket megbecsüljék, emberi méltóságukat és személyiségi jogaikat tiszteletben tartsák, tevékenységüket értékeljék és elismerjék.

(7) A gyermekvédelmi rendszerben foglalkoztatott

a) nevelö, gyermekfelügyelö, gondozó, csecsemő- és gyermekgondozó, helyettes szülő vagy nevelőszülő, családgondozó, utógondozó, gyermekjóléti és gyermekvédelmi intézmény vezetöje, a gyermek, illetve a fiatal felnőtt közvetlen gondozása, családgondozása és utógondozása során,

b) nevelőszülői tanácsadó, gyám, gyámi tanácsadó a gyermek közvetlen gondozásának ellenőrzése, illetve törvényes képviseletének ellátása során

hivatalból jár el, és e tevékenységével kapcsolatban a büntetőjogi védelem szempontjából közfeladatot ellátó személynek minősül.

(8) A gyermekvédelmi rendszerben a külön jogszabályban meghatározott munkakörben, valamint önkéntes jogviszonyban nem foglalkoztatható az a személy, akivel szemben a 11/A. § (8) bekezdésben meghatározott kizáró okok valamelyike fennáll, vagy aki e törvényben meghatározott igazolási kötelezettségének ismételt szabályszerú felhívásra sem tesz eleget, és nem bizonyítja, hogy a kötelezettség elmulasztása rajta kívülálló ok következménye.

(9) Gyermekjóléti, gyermekvédelmi intézményben történő foglalkoztatás esetén a Kjt. 41. § (2) bekezdésének $a$ ) pontja nem alkalmazható.

16. § (1) Az e törvényben meghatározott, a gyermekek védelmét biztosító hatósági feladat- és hatásköröket 
a) a helyi önkormányzat képviselö-testülete,

b) a települési önkormányzat jegyzöje,

c) a gyámhivatal

gyakorolja.

(2) Ha jogszabály eltérően nem rendelkezik, a helyi önkormányzat képviselö-testületének feladat- és hatáskörébe tartozó eljárásoknál az illetékességet a gyermek szülői felügyeletet gyakorló szülőjének, gyámjának lakóhelye határozza meg.

17. § (1) Az e törvényben szabályozott gyermekvédelmi rendszerhez kapcsolódó feladatot látnak el - a gyermek családban történő nevelkedésének elösegítése, a gyermek veszélyeztetettségének megelőzése és megszüntetése érdekében - a törvényben meghatározott alaptevékenység keretében

a) az egészségügyi szolgáltatást nyújtók, így különösen a védőnői szolgálat, a háziorvos, a házi gyermekorvos,

b) a személyes gondoskodást nyújtó szolgáltatók, így különösen a családsegítő szolgálat, a családsegítő központ,

c) a közoktatási intézmények, így különösen a nevelési-oktatási intézmény, a nevelési tanácsadó,

d) a rendörség,

e) az ügyészség,

f) a bíróság,

g) a pártfogó felügyelői szolgálat,

h) az áldozatsegítés és a kárenyhítés feladatait ellátó szervezetek,

i) a menekülteket befogadó állomás, a menekültek átmeneti szállása,

j) a társadalmi szervezetek, egyházak, alapítványok,

k) a munkaügyi hatóság.

(2) Az (1) bekezdésben meghatározott intézmények és személyek kötelesek

a) jelzéssel élni a gyermek veszélyeztetettsége esetén a gyermekjóléti szolgálatnál,

b) hatósági eljárást kezdeményezni a gyermek bántalmazása, illetve súlyos elhanyagolása vagy egyéb más, súlyos veszélyeztető ok fennálása, továbbá a gyermek önmaga által előidézett súlyos veszélyeztető magatartása esetén.

Ilyen jelzéssel és kezdeményezéssel bármely állampolgár és a gyermekek érdekeit képviselő társadalmi szervezet is élhet.

(3) Az (1) és (2) bekezdésben meghatározott személyek, szolgáltatók, intézmények és hatóságok a gyermek családban történő nevelkedésének elösegítése, a veszélyeztetettség megelözése és megszüntetése érdekében kötelesek egymással együttmüködni és egymást kölcsönösen tájékoztatni.

(4) Ha az (1) bekezdés $a$ )-i) és $k$ ) pontjában meghatározott személy vagy az (1) bekezdés $a$ )-i) és $k$ ) pontja szerinti szerv alkalmazottja a (2) vagy (3) bekezdésben foglalt jelzési vagy együttmüködési kötelezettségének nem tesz eleget, a gyámhivatal - jelzésre vagy hivatalból - értesíti a fegyelmi jogkör gyakorlóját és javaslatot tesz az érintett személlyel szembeni fegyelmi felelősségre vonás megindítására. A gyermek sérelmére elkövetett büncselekmény gyanúja esetén a gyámhivatal büntetőeljárást kezdeményez.

(5) A gyámhivatal a (4) bekezdésben foglaltakkal egyidejüleg egyeztető megbeszélést tart és a gyermekjóléti szolgálatnál kezdeményezi a külön jogszabály szerinti esetmegbeszélés megtartását.

\section{(...) \\ V. Fejezet \\ A személyes gondoskodást nyújtó ellátások \\ A személyes gondoskodást nyújtó ellátások általános szabályai}

29. §(1) A fenntartó önkormányzat a személyes gondoskodást nyújtó ellátások (a továbbiakban: személyes gondoskodás) formáiról, azok igénybevételéről, valamint a fizetendő térítési díjról rendeletet alkot.

(2) Ha törvény másként nem rendelkezik, a fenntartó önkormányzat rendeletben szabályozza

a) az önkormányzat által biztosított személyes gondoskodás formáit,

b) az önkormányzat által biztosított ellátás igénybevételére irányuló kérelem benyújtásának módját és a kérelem elbírálásának szempontjait,

c) az intézményvezető hatáskörében - külön eljárás nélkül - biztosítható ellátásokat,

d) az ellátás megszünésének eseteit és módjait,

e) a fizetendő térítési díjak mértékét, csökkentésének és elengedésének eseteit, módjait.

(3) Ha önkormányzati társulás vagy többcélú kistérségi társulás gyermekjóléti, gyermekvédelmi ellátást nyújt, akkor a társulási megállapodásban erre kijelölt települési önkormányzat - a társulási megállapodásban meghatározottak szerint - a nyújtott ellátásokról, azok igénybevételéről és a fizetendő térítési díjakról rendeletet alkot.

30. $§(1)$

(2) Szociális szövetkezet nem nyújthat gyermekvédelmi szakellátást. 


\section{Az ellátás igénybevételének módja}

31. § (1) A személyes gondoskodás igénybevétele - ha e törvény másként nem rendelkezik - önkéntes, az ellátást igénylő (a továbbiakban: kérelmező) kérelmére történik. Cselekvőképtelen személy kérelmét törvényes képviselője terjeszti elö, korlátozottan cselekvőképes személy a kérelmét törvényes képviselöjének beleegyezésével terjesztheti elö. A korlátozottan cselekvőképes személy és a törvényes képviselője között az ellátás igénybevételével kapcsolatban felmerült vitában - a tényállás tisztázása mellett - a települési önkormányzat jegyzője dönt.

(2) Ha a gyermek védelme az ellátás önkéntes igénybevételével nem biztosított, e törvény az ellátás kötelező igénybevételét elrendeli.

(3)

32. § (1) A személyes gondoskodást nyújtó ellátásra irányuló jogviszony keletkezését

a) a helyi önkormányzat képviselö-testületének határozata,

b) a települési önkormányzat jegyzőjének vagy a gyámhivatalnak a határozata,

c) a települési önkormányzat által fenntartott átmeneti gondozást nyújtó intézmény esetében az intézményvezető intézkedése,

d) a c) pontban foglaltakon túl a fenntartó önkormányzat rendeletében vagy az állami fenntartó által meghatározott körben az intézményvezetö intézkedése,

e) a személyes gondoskodás iránti kérelemről dönteni jogosult személy intézkedése alapozza meg.

(2) Ha az ellátás igénybevételére az (1) bekezdés $a$ ) vagy b) pontja alapján kerül sor, a határozatot közölni kell a müködtetővel és az ellátást nyújtó intézmény vezetőjével is.

(3) Állami fenntartású intézmény esetén az (1) bekezdés c) és d) pontja szerinti döntésről az intézményvezető értesíti a kérelmezőt, illetve törvényes képviselőjét. Az ellátás igénybevételének elutasítása esetén a kérelmezőt, illetve törvényes képviselőjét írásban kell értesíteni.

(4) Ha a kérelmező, illetve törvényes képviselője az intézmény vezetőjének (3) bekezdés szerinti döntését vitatja, az arról szóló értesítés kézhezvételétől számított nyolc napon belül a fenntartóhoz fordulhat. Ha az intézményvezető az ellátás igénybevételéről nem intézkedik, a kérelmező, illetve törvényes képviselője az arról való tudomásszerzéstől számított nyolc napon belül a fenntartóhoz fordulhat. Ezekben az esetekben a fenntartó határozattal dönt.

(5) A gyermekjóléti alapellátások igénybevételének megkezdése előtt és az utógondozói ellátás igénybevételének megkezdésekor

a) állami fenntartású szolgáltató, intézmény esetén a szolgáltató vezetője, illetve az intézményvezető,

b) egyházi és nem állami fenntartású szolgáltató, intézmény esetén a fenntartó vagy az általa megbízott személy

a kérelmezővel, illetve törvényes képviselőjével írásban megállapodást köt.

(6) Nem kell az (5) bekezdés szerint megállapodást kötni

a) gyermekjóléti szolgáltatás esetén,

b) - ha a fenntartó döntése alapján a szolgáltatás jellegére tekintettel az nem indokolt - alternatív napközbeni ellátás esetén.

(7) Az (5) bekezdés szerinti megállapodás tartalmazza

a) az ellátás kezdetének időpontját,

b) az intézményi ellátás időtartamát (a határozott vagy határozatlan időtartam megjelölését),

c) a gyermek, fiatal felnőtt számára nyújtott szolgáltatások és ellátások tartalmát, módját,

d) a személyi térítési díj megállapítására és megfizetésére vonatkozó szabályokat, ha az ellátás térítésidíjfizetési kötelezettséggel jár,

e) az ellátás megszüntetésének módjait,

f) a gyermek és törvényes képviselője, valamint a fiatal felnőtt személyazonosító adatait.

(8) Az intézményvezetőnek az ellátásra jogosult gyermek, fiatal felnőtt azonnali elhelyezéséről kell gondoskodnia

a) az elhelyezés fellebbezésre tekintet nélküli végrehajtását elrendelő határozat alapján,

b) soron kívüli elhelyezésre vonatkozó indokolt kérelem alapján,

c) az 57. $\S(2)$ bekezdése szerinti esetben.

(9) Ha az egyházi, nem állami fenntartó a helyi önkormányzattal vagy állami szervvel kötött ellátási szerződés hatálya alá tartozó esetben az ellátásra irányuló kérelmet elutasítja, a kérelmezőt, illetve törvényes képviselőjét írásban értesíti. Ha a kérelmező, illetve törvényes képviselője a döntést vitatja, az arról szóló értesítés kézhezvételétől számított nyolc napon belül az ellátási szerződést megkötő helyi önkormányzathoz vagy állami szervhez fordulhat. A helyi önkormányzat vagy állami szerv a kérelemről határozattal dönt. 
(10) Ha a helyi önkormányzattal vagy állami szervvel ellátási szerződést kötött egyházi, nem állami fenntartó az elhelyezést elrendelö döntés ellen fellebbezést nyújt be, a helyi önkormányzatot vagy állami szervet írásban értesíti.

\section{Tájékoztatási kötelezettség}

33. § (1) A személyes gondoskodás feltételeiről a kérelem benyújtásakor a kérelmezőt tájékoztatni kell.

(2) A személyes gondoskodást nyújtó ellátás esetén az ellátás megkezdésekor az ellátásra jogosult gyermeket és törvényes képviselöjét, illetve a fiatal felnőttet tájékoztatni kell

a) az ellátás tartamáról és feltételeiről,

b) az intézmény által vezetett, reá vonatkozó nyilvántartásokról,

c) az ellátásra jogosult gyermek, fiatal felnőtt és hozzátartozói közötti kapcsolattartásról, különösen a látogatás, a távozás és a visszatérés rendjéröl

ca) a gyermekek átmeneti otthonában biztosított személyes gondoskodást nyújtó gyermekjóléti alapellátásnál, ha a gyermek kapcsolattartásra jogosult hozzátartozói külön élnek,

cb) a családok átmeneti otthonában biztosított személyes gondoskodást nyújtó gyermekjóléti alapellátásnál, ha a gyermeknek van különélő, kapcsolattartásra jogosult hozzátartozója,

$c c$ ) a gyermekotthonban biztosított személyes gondoskodást nyújtó gyermekvédelmi szakellátásnál (a $c a$ )cc) alpontokban szereplö intézmények a továbbiakban együtt: bentlakásos gyermekintézmény),

$c d)$ a helyettes szülőnél biztosított személyes gondoskodást nyújtó gyermekjóléti alapellátásnál és

ce) a nevelőszülőnél biztosított személyes gondoskodást nyújtó gyermekvédelmi szakellátásnál,

d) az érték- és vagyonmegőrzés módjáról,

e) az intézmény házirendjéről,

f) panaszjoga gyakorlásának módjáról,

g) a fizetendő térítési, illetve gondozási díjról,

h) a jogosult jogait és érdekeit képviselő érdek-képviseleti fórumról.

(3) Az ellátásra jogosult gyermek törvényes képviselője, illetve a fiatal felnőtt köteles

a) a (2) bekezdésben meghatározott tájékoztatás megtörténtéröl nyilatkozni,

b) az e törvény alapján vezetett intézményi nyilvántartásokhoz adatokat szolgáltatni,

c) nyilatkozni a jogosultsági feltételekben, valamint a személyazonosító adatokban beállott változásokról.

\section{( ...) \\ Érdekvédelem}

35. § (1) Az intézmény fenntartója meghatározza - a (6) bekezdésben meghatározott ellátások kivételével - az ellátásban részesülők érdekvédelmét szolgáló érdek-képviseleti fórum megalakításának és müködésének szabályait.

(2) Az érdekképviseleti fórum szavazati jogú választott tagjai

a) a gyermekönkormányzat képviselői,

b) az ellátásban részesülö gyermek szülei vagy más törvényes képviselői, illetve a fiatal felnőttek képviselöi,

c) az intézmény dolgozóinak képviselői,

d) az intézményt fenntartó képviselői.

(3) A (2) bekezdés $a$ ) és b) pontjában meghatározott személyek száma nem lehet kevesebb a (2) bekezdés $c$ )-d) pont szerinti személyek összlétszámánál.

(4) Az érdek-képviseleti fórum megvizsgálja a hozzá benyújtott panaszokat és a hatáskörébe tartozó ügyekben dönt, továbbá intézkedéseket kezdeményezhet a fenntartónál, a gyermekjogi képviselőnél, illetve más hatáskörrel rendelkező szervnél.

(5) Az érdekképviseleti fórum az intézmény vezetőjénél véleményt nyilváníthat a gyermeket, fiatal felnőttet érintő ügyekben, valamint javaslatot tehet az intézmény alaptevékenységével összhangban végzett szolgáltatások tervezéséről, müködtetéséről, valamint az ebből származó bevételek felhasználásáról. Az érdekképviseleti fórum egyetértési jogot gyakorol a házirend jóváhagyásánál.

(6) A gyermekjóléti szolgálatban és a házi gyermekfelügyelet formájában biztosított napközbeni ellátásban részesülők érdekvédelmére a fenntartónak érdek-képviseleti fórumot nem kell müködtetnie. Panaszjoguk gyakorlására a 36. §-ban foglaltak az irányadók.

36. §(1) A gyermek, a gyermek szülője vagy más törvényes képviselöje, valamint a gyermekönkormányzat és a fiatal felnőtt, továbbá a gyermekek érdekeinek védelmét ellátó érdek-képviseleti és szakmai szervek a házirendben foglaltak szerint panasszal élhetnek az intézmény vezetőjénél vagy érdekképviseleti fórumánál

a) az ellátást érintő kifogások orvoslása érdekében,

b) a gyermeki jogok sérelme, továbbá az intézmény dolgozói kötelezettségszegése esetén,

c) a 136/A. § szerinti iratbetekintés megtagadása esetén.

(2) Az intézmény vezetője, illetve az érdekképviseleti fórum a panaszt kivizsgálja, és tájékoztatást ad a panasz orvoslásának más lehetséges módjáról. A gyermek szülője vagy más törvényes képviselője, valamint 
a gyermekönkormányzat és a gyermek, illetve fiatal felnőtt az intézmény fenntartójához vagy a gyermekjogi képviselöhöz fordulhat, ha az intézmény vezetője vagy az érdekképviseleti fórum 15 napon belül nem küld értesítést a vizsgálat eredményéröl, vagy ha a megtett intézkedéssel nem ért egyet.

37. §(1) A bentlakásos gyermekintézményben elhelyezett gyermekek érdekeik képviseletére gyermekönkormányzatot hozhatnak létre.

(2) A bentlakásos gyermekintézmény valamennyi gyermekének képviseletében az a gyermekönkormányzat járhat el, amelyiket a gyermekek több mint 50\%-a választott meg.

(3) A gyermekönkormányzat - az intézményvezető véleményének kikérésével - dönt saját müködéséről. Szervezeti és müködési szabályzatát a választó gyermekközösség fogadja el, és az intézményvezető hagyja jóvá. A jóváhagyás csak akkor tagadható meg, ha a szabályzat jogszabálysértő vagy ellentétes az intézmény szervezeti és müködési szabályzatával, illetve házirendjével.

(4) A gyermekönkormányzat véleményt nyilváníthat az intézmény vezetőjénél a bentlakásos gyermekintézmény müködésével és a gyermekekkel kapcsolatos valamennyi kérdésben, amit az intézmény vezetőjének figyelembe kell venni.

\section{Az ellátás megszüntetésének módja}

37/A. § (1) Ha e törvény másképp nem rendelkezik, a személyes gondoskodást nyújtó ellátás megszűnik

a) a határozott idejü elhelyezés esetén a megjelölt időtartam - illetve a meghosszabbított időtartam leteltével,

b) a jogosultsági feltételek megszünésével.

(2) Az önkéntesen igénybe vett gyermekjóléti és gyermekvédelmi ellátás megszüntetését a jogosult, illetve törvényes képviselője kérelmezheti, melynek alapján az intézményvezető az ellátást megszünteti. Az ellátás a megegyezés időpontjában, illetve ennek hiányában a megállapodásban foglaltak szerint szünik meg.

(3) Az intézményvezető az önkéntesen igénybe vett gyermekjóléti és gyermekvédelmi ellátást megszünteti, ha a jogosult a házirendet ismételten súlyosan megsérti, vagy az ellátás feltételei, okai már nem állnak fenn.

(4) Az intézményvezető az önkéntesen igénybe vett gyermekjóléti és gyermekvédelmi ellátás megszüntetéséről, illetve az ellene tehető panaszról írásban értesíti a jogosultat, illetve törvényes képviselőjét. Egyet nem értés esetén a jogosult, illetve törvényes képviselője az értesítés kézhezvételétől számított nyolc napon belül a fenntartóhoz fordulhat. A fenntartó végrehajtható határozatáig az ellátást biztosítani kell.

(5) Ha az ellátást a 32. § (1) bekezdésének a) vagy b) pontja alapozza meg, az ellátást csak határozat szüntetheti meg.

\section{Fejezet \\ Gyermekjóléti alapellátások \\ A gyermekjóléti alapellátások célja}

38. § (1) Az alapellátásnak hozzá kell járulnia a gyermek testi, értelmi, érzelmi és erkölcsi fejlődésének, jólétének, a családban történő nevelésének elősegítéséhez, a veszélyeztetettség megelözéséhez és a kialakult veszélyeztetettség megszüntetéséhez, valamint a gyermek családjából történő kiemelésének a megelözéséhez.

(2) Az alapellátás keretében nyújtott személyes gondoskodást - lehetőség szerint - a jogosult lakóhelyéhez, tartózkodási helyéhez legközelebb eső ellátást nyújtó személynél vagy intézményben kell biztosítani.

$$
\text { ( ...) }
$$

\section{Gyermekek napközbeni ellátása}

41. § (1) A gyermekek napközbeni ellátásaként a családban élő gyermekek életkorának megfelelő nappali felügyeletét, gondozását, nevelését, foglalkoztatását és étkeztetését kell megszervezni azon gyermekek számára, akiknek szülei, nevelői, gondozói munkavégzésük, munkaerőpiaci részvételt elösegítő programban, képzésben való részvételük, betegségük vagy egyéb ok miatt napközbeni ellátásukról nem tudnak gondoskodni. A napközbeni ellátás keretében biztosított szolgáltatások időtartama lehetőleg a szülő munkarendjéhez igazodik.

(2) A gyermekek napközbeni ellátását különösen az olyan gyermek számára kell biztosítani,

a) akinek fejlödése érdekében állandó napközbeni ellátásra van szüksége,

b) akit egyedülálló vagy időskorú személy nevel, vagy akivel együtt a családban három vagy több gyermeket nevelnek, kivéve azt, akire nézve eltartója gyermekgondozási díjban részesül,

c) akinek a szülője, gondozója szociális helyzete miatt az ellátásról nem tud gondoskodni.

(3) A gyermekjóléti alapellátás keretében biztosított gyermekek napközbeni ellátásának formái - a gyermekek életkorának megfelelöen -

a) a bölcsőde, a hetes bölcsőde,

b) a családi napközi,

c) a családi gyermekfelügyelet, 
d) a házi gyermekfelügyelet,

e) az alternatív napközbeni elláás.

(4)

\section{Bölcsőde}

42. § (1) A bölcsőde a családban nevelkedő 3 éven aluli gyermekek napközbeni ellátását, szakszerü gondozását és nevelését biztositó intézmény. Ha a gyermek a 3. évét betöltötte, de testi vagy szellemi fejlettségi szintje alapján még nem érett az óvodai nevelésre, a 4. évének betöltését követő augusztus 31-ig nevelhető és gondozható a bölcsődében.

(2) A bölcsőde az (1) bekezdésben foglaltakon túl végezheti a fogyatékos gyermekek korai habilitációs és rehabilitációs célú nevelését és gondozását is. A bölcsődei ellátás keretében a Kt. szerinti szakértői és rehabilitációs bizottság szakvéleménye alapján a fogyatékos gyermek legfeljebb hatéves koráig fejlődését biztosító korai fejlesztésben és gondozásban, vagy fejlesztő felkészítésben vehet részt.

(3) A bölcsőde az alapellátáson túl szolgáltatásként speciális tanácsadással, időszakos gyermekfelügyelettel, gyermekhotel müködtetésével, vagy más gyermeknevelést segítő szolgáltatásokkal segítheti a családokat.

(4) A bölcsődei ellátás megszünik

a) a bölcsődei nevelési év végén, ha a gyermek a 3. évét betöltötte,

b) ha a gyermek az (1), illetve (2) bekezdés szerinti életkort elérte.

(5) A bölcsőde nyári nyitvatartási rendjét a fenntartó hagyja jóvá. A fenntartó a bölcsődei szünet idejére a szülő kérésére gondoskodhat a gyermek intézményi gondozásának megszervezéséröl.

42/A. § A bölcsődei felvétel során előnyben kell részesíteni azt a rendszeres gyermekvédelmi kedvezményre jogosult gyermeket, akinek szülöje vagy más törvényes képviselöje igazolja, hogy munkaviszonyban vagy munkavégzésre irányuló egyéb jogviszonyban áll.

\section{Családi napközi}

43. § (1) A gyermekek napközbeni ellátásának minősül a bölcsődei és óvodai ellátásban nem részesülő, továbbá az iskolai oktatásban részesülő gyermeknek az iskola nyitvatartási idején kívüli, valamint az iskolai napközit vagy tanulószobai ellátást igénybe nem vevő gyermek családi napköziben történő, nem közoktatási célú ellátása.

(2) A családi napközi a családban nevelkedő gyermekek számára nyújt életkoruknak megfelelő nappali felügyeletet, gondozást, nevelést, étkeztetést és foglalkoztatást. A fogyatékos gyermekek számára sajátos szükségleteikhez igazodó ellátást kell nyújtani.

(3) A családi napközi - az alapellátáson túli szolgáltatásként - speciális tanácsadással, időszakos gyermekfelügyelettel vagy más gyermeknevelést segítő szolgáltatással segítheti a családokat.

(4) Családi napköziben ellátást az a nagykorú, cselekvőképes, büntetlen eloóletű személy biztosíthat, aki

a) személyisége és - a külön jogszabályban meghatározott - körülményei alapján alkalmas a gyermek napközbeni ellátására, és

b) a külön jogszabályban meghatározott tanfolyamon eredménnyel részt vett, feltéve, hogy nem áll fenn vele szemben a 15. § (8) bekezdésében meghatározott kizáró ok.

(5) A családi napközi mủködhet az ellátást nyújtó saját otthonában vagy más e célra kialakított helyiségben.

(6) A családi napköziben húszhetestől tizennégy éves korig gondozható gyermek.

(7) A családi napköziben - a saját, napközbeni ellátást máshol igénybe nem vevő gyermeket is beszámítva - legfeljebb öt gyermek gondozható. Ha a családi napköziben egy fogyatékos gyermeket is gondoznak, akkor a gondozható gyermekek száma legfeljebb négy fö. Ha a családi napköziben gondozott valamennyi gyermek fogyatékos, akkor a gondozható gyermekek száma legfeljebb három fő.

(8) A (7) bekezdésben meghatározott létszámon túl még két gyermek, ha fogyatékos gyermekről van szó, még egy gyermek gondozható a családi napköziben, feltéve, hogy az ellátást nyújtónak állandó segítője van.

(9) A családi napköziben gondozott saját gyermek után normatív állami hozzájárulást nem lehet igénybe venni.

(10) A családi napközi feladatait önálló szolgáltató vagy legalább három - telephelyként müködő - családi napközit magába foglaló családi napközi hálózat biztosítja. Öt, vagy annál több családi napközi fenntartását hálózatba kell szervezni. A hálózatban biztosítani kell a szolgáltatást nyújtók részére a folyamatos szakmai tanácsadást, valamint az ellátottak igényeihez rugalmasan igazodó szolgáltatások összehangolását.

(11) A családi napközi esetében a 32. § (5) bekezdése szerint megkötött megállapodások száma - a szolgáltatás eltérő időpontokban történő igénybevétele esetén - túllépheti a családi napközi müködési engedélyében meghatározott férőhelyek számát. A szolgáltatást azonos időben igénybe vevő gyermekek száma ebben az esetben sem haladhatja meg a müködési engedélyben meghatározott férőhelyszámot.

\section{Családi gyermekfelügyelet}

43/A. § (1) A gyermekek napközbeni ellátásaként családi gyermekfelügyelet biztosítható az ellátást nyújtó saját otthonában. 
(2) A családi gyermekfelügyelet a családban nevelkedő gyermekek számára nyújt életkoruknak megfelelő nappali felügyeletet, gondozást, nevelést és étkeztetést.

(3) A családi gyermekfelügyelet keretében két évestől négy éves korig gondozható gyermek.

(4) A családi gyermekfelügyelet ellátása során - a saját, napközbeni ellátást máshol igénybe nem vevő gyermeket is beszámítva - legfeljebb három gyermek gondozható.

(5) A családi gyermekfelügyelet keretében gondozott saját gyermek után normatív állami hozzájárulást nem lehet igénybe venni.

(6) Családi gyermekfelügyeletet az a személy biztosíthat, aki megfelel a 43. § (4) bekezdésében foglaltaknak.

(7) A családi gyermekfelügyelet esetében a 32. § (5) bekezdése szerint megkötött megállapodások száma a szolgáltatás eltérő időpontokban történő igénybevétele esetén - túllépheti a családi gyermekfelügyelet müködési engedélyében meghatározott férőhelyek számát. A szolgáltatást azonos időben igénybe vevő gyermekek száma ebben az esetben sem haladhatja meg a müködési engedélyben meghatározott féröhelyszámot.

\section{Házi gyermekfelügyelet}

44. § (1) A házi gyermekfelügyelet keretében a gyermekek napközbeni ellátását a szülő vagy más törvényes képviselö otthonában gondozó biztosíthatja, ha a gyermek állandó vagy időszakos ellátása nappali intézményben nem biztosítható (pl. betegség miatt) és a szülö a gyermek napközbeni ellátását nem vagy csak részben tudja megoldani.

(2) A házi gyermekfelügyelet keretében végzett napközbeni ellátás időtartama a szülő munkarendjéhez igazodik.

(3) A házi gyermekfelügyelet során a gyermek életkorához, egészségi állapotához igazodó gondozást, felügyeletet kell biztosítani.

(4) Házi gyermekfelügyeletet az a személy biztosithat, aki megfelel a 43. § (4) bekezdésében foglaltaknak.

(5) A házi gyermekfelügyelet keretében segítséget kell nyújtani az iskolai tanulmányok folytatásához, amennyiben a gyermek tanulmányait a Kt. rendelkezései szerint fogyatékossága vagy súlyos betegsége miatt magántanulóként folytatja.

\section{Alternatív napközbeni ellátás}

44/A. § Alternatív napközbeni ellátás a játszótéri program, játszóház, klubfoglalkozás keretében nyújtott,

a) a szülő és a gyermek kapcsolatát erősítő, a gyermek szocializációját támogató, valamint egyéb szabadidős és prevenciós szolgáltatás,

b) a csellengő vagy egyéb okból veszélyeztetett iskoláskorú gyermekek számára biztosított nappali felügyelet, sport-, illetve egyéb foglalkozás és étkeztetés,

feltéve, ha a müködtető rendelkezik az ehhez szükséges - külön jogszabályban meghatározott - személyi és tárgyi feltételekkel.

\section{( ...) \\ NEGYEDIK RÉSZ \\ A GYERMEKVÉDELMI FELADATOK ELLÁTÁSA ÉS IRÁNYÍTÁSA \\ XIV. Fejezet \\ A helyi önkormányzat feladatai \\ A települési önkormányzat feladatai}

94. § (1) A települési önkormányzat, fővárosban a fővárosi kerületi önkormányzat feladata a gyermekek védelme helyi ellátó rendszerének kiépítése és múködtetése, a területén lakó gyermekek ellátásának megszervezése.

(2) A települési önkormányzat az e törvényben foglaltak szerint biztosítja a rendkívüli gyermekvédelmi támogatást, a személyes gondoskodást nyújtó alapellátások keretében - a (3)-(4) bekezdésben meghatározottak figyelembevételével - a gyermekjóléti szolgáltatást, a gyermekek napközbeni ellátását, a gyermekek átmeneti gondozását, szervezi és közvetíti a máshol igénybe vehető ellátásokhoz való hozzájutást.

(3) Az a települési önkormányzat, fơvárosban a kerületi önkormányzat, amelynek területén

a) tízezernél több állandó lakos él, bölcsődét,

b) húszezernél több állandó lakos él, az a) pontban meghatározottak mellett gyermekek átmeneti otthonát,

c) harmincezernél több állandó lakos él, az $a$ ) és $b$ ) pontokban meghatározottak mellett családok átmeneti otthonát,

d) negyvenezernél több állandó lakos él, az a)-c) pontokban meghatározottak mellett gyermekjóléti központot [40. § (3) bek.]

köteles müködtetni.

(4) A megyei jogú város lakosságszámtól függetlenül köteles gyermekjóléti központot működtetni. 
(5) A települési önkormányzat által fenntartott intézmények ellátási területe a település lakosságára terjed ki, kivéve, ha az intézményt társulás keretében közösen tartják fenn, vagy ha az ellátást szerződésben vállalta más önkormányzat lakosságára is kiterjedően.

(6) Ha az intézmény ellátási területe a fenntartó önkormányzat illetékességi területét meghaladja, - eltérő megállapodás hiányában - az ellátást valamennyi jogosult számára azonos feltételek szerint kell biztosítani. E rendelkezést kell alkalmazni az ellátás megszüntetése esetén is.

(7) Az intézményt fenntartó önkormányzat az intézménnyel nem rendelkező önkormányzat kérésére az ellátást nem tagadhatja meg, ha e törvény hatálybalépésekor vagy külön megállapodásuk alapján már biztosított ellátást.

(8) A települési önkormányzat a bölcsődés korú gyermekek napközbeni ellátásának biztosítására irányuló, a (2) bekezdésben és a (3) bekezdés $a$ ) pontjában foglalt kötelezettségének a bölcsőde müködtetése mellett családi napközi formájában is eleget tehet.

94/A. § A települési önkormányzatok a személyes gondoskodás keretébe tartozó gyermekjóléti alapellátásokat, különösen a bölcsőde, a gyermekek átmeneti otthona, a családok átmeneti otthona és a gyermekjóléti központ müködtetését a külön jogszabályban meghatározott többcélú kistérségi társulás útján is biztosíthatják.

Az állam megyei szintü feladatai, valamint a fóvárosi és megyei jogú városi önkormányzat feladatai

95. § (1) Az állam a megyei fenntartó útján, valamint a fővárosi és - a 94. § (2) bekezdésében meghatározott feladatain túl - a megyei jogú városi önkormányzat az e törvényben foglaltak szerint biztosítja az otthont nyújtó ellátást és az utógondozói ellátást. Az állam a megyei fenntartó útján és a fővárosi önkormányzat biztosítja a területi gyermekvédelmi szakszolgáltatást.

(2) A megyei fenntartó, illetve a fövárosi önkormányzat által fenntartott otthont nyújtó, valamint utógondozói ellátást biztosító intézmények ellátási területe - a megyei jogú város területének kivételével - a megyére, illetve a fóvárosra terjed ki.

(3) A fövárosi önkormányzat és a fövárosi kerületi önkormányzat között létrejött megállapodás arról is rendelkezhet, hogy a fővárosi önkormányzat gondoskodik a gyermekek átmeneti gondozásának e törvényben meghatározott formájáról.

\section{A feladatok ellátásának módja}

96. § (1) A helyi önkormányzat az e törvényben meghatározott személyes gondoskodást nyújtó ellátást a helyi önkormányzatokról szóló 1990. évi LXV. törvény (a továbbiakban: Ötv.) 81. § (1) bekezdése szerint, valamint a több önkormányzat illetékességi területére kiterjedő intézményi ellátási kötelezettségnek és a 94/A. §-nak a figyelembevételével más szervvel, személlyel kötött ellátási szerződés útján, illetve társulásban biztosítja.

(2) Az intézmények ellátási területének meghatározásánál tekintettel kell lenni arra is, hogy az intézmény és az ellátottak lakóhelye közötti távolság lehetőleg ne haladja meg az ötven km-t.

(3) Többcélú intézmény akkor létesíthetö, ha a létesítés és müködés anyagi, személyi és tárgyi feltételei valamennyi feladat ellátásához külön-külön biztosítva vannak.

(4) A közös igazgatású gyermekjóléti és/vagy gyermekvédelmi intézmény szervezeti és szakmai tekintetben önálló intézményegységek keretében különböző típusú intézmények feladatát látja el.

(5) A (4) bekezdés szerinti intézményben a gyermek ellátásához és neveléséhez kapcsolódó nem gyermekjóléti és nem gyermekvédelmi tevékenységet ellátó intézményegység is müködhet, különösen családsegítő szolgálat, illetve családvédelmi szolgálat, védőnői szolgálat, házi gyermekorvosi szolgálat, továbbá óvodai vagy általános iskolai nevelést, oktatást, kollégiumi ellátást, nevelési tanácsadást végző intézményegység.

(6) A települési önkormányzat és a megyei fenntartó a gyermekjóléti és gyermekvédelmi feladatainak ellátásáról minden év május 31-éig - a külön jogszabályban meghatározott tartalommal - átfogó értékelést készít. Az értékelést - települési önkormányzat esetén a képviselő-testület általi megtárgyalást követően meg kell küldeni a gyámhivatalnak. A gyámhivatal az értékelés kézhezvételétől számított harminc napon belül javaslattal élhet a települési önkormányzat, illetve a megyei fenntartó felé, amely hatvan napon belül érdemben megvizsgálja a gyámhivatal javaslatait és állásfoglalásáról, intézkedéséről tájékoztatja.

(7) A fenntartó kezdeményezi a gyámhivatalnál a gyermekjóléti és gyermekvédelmi személyes gondoskodást nyújtó müködési engedéllyel rendelkező gyermekjóléti szolgálatok és lakásotthonok közül a módszertani feladatokat ellátó intézmény kijelölését, azzal, hogy ellátási típusonként a megyében egy, a fővárosban két módszertani intézet müködhet. A kijelölés ötévi időtartamra szól, amelynek elteltét követően az intézmény ismételten kijelölhetö.

(8) A miniszter pályázat útján, a fenntartó egyetértésével

a) a bölcsődék, illetve a gyermekotthonok közül regionális módszertani feladatokat ellátó intézményt,

b) a családok átmeneti otthona, a nevelőszülői hálózatok, a területi gyermekvédelmi szakszolgálatok közül országos hatáskörrel módszertani feladatokat ellátó intézményt

jelöl ki. A kijelölés ötévi időtartamra szól, amelynek elteltét követően az intézmény ismételten kijelölhető. 
(8a) A Kormány által kijelölt szerv látja el országos hatáskörrel

a) a családi napközi szolgáltatással,

b) a házi gyermekfelügyelet szolgáltatással,

c) a családi gyermekfelügyelet szolgáltatással,

d) a 41. § (4) bekezdése szerinti ellátásokkal,

e) a helyettes szülöi ellátással,

f) a gyermekek átmeneti otthonával,

g) a különleges gyermekotthoni ellátással,

h) a speciális gyermekotthoni ellátással

kapcsolatos módszertani feladatokat.

(9) A kijelölt módszertani intézmény feladatkörében

a) részt vesz a minőségfejlesztési elvek kidolgozásában,

b) a kijelölt feladatok tekintetében ajánlásokat készít a hatékonyabb szolgáltatási módszerek alkalmazására,

c) szakmai tanácsadással segíti a kijelölt feladatok tekintetében a területén levő gyermekjóléti és gyermekvédelmi szolgáltató tevékenységet végzők szakmai munkáját,

d) szakértőként közremüködik a gyermekjóléti és gyermekvédelmi szolgáltató tevékenységet végzők szakmai ellenőrzésében, a szakmai programok értékelésében,

e) kezdeményezi a gyermekvédelmi rendszerben dolgozók továbbképzését és tapasztalatcseréjét.

(10) A miniszter a módszertani feladatok ellátásához a módszertani intézmények kijelöléséről és feladatairól szóló miniszteri rendeletben meghatározottak szerint egyedi támogatást nyújt.

\section{Ellátási szerződés}

97. § (1) Az e törvényben meghatározott személyes gondoskodást nyújtó ellátást vagy egyes körülhatárolható és elkülöníthető feladatok ellátását a helyi önkormányzat, az állam, valamint az állami szerv nem állami szervvel kötött ellátási szerződés útján is biztosíthatja.

(2) Ha az ellátási szerződés alapján a feladat ellátásában vallási vagy világnézeti elkötelezettségủ nem állami szerv müködik közre, a megállapodás megkötése nem mentesíti a helyi önkormányzatot, valamint az állami szervet a feladatellátási kötelezettség alól azon gyermek tekintetében, akinek szülöje nem kívánja a nem állami szerv szolgáltatását igénybe venni.

(3) Az ellátási szerződés tartalmát a felek szabadon állapítják meg azzal, hogy a szerződés az Szt. 121. §ában meghatározottakon túl tartalmazza

a) azt az időszakot, amelyre a szerződést kötötték, amely időszak a bentlakásos gyermekintézmény esetén nem lehet kevesebb 5 évnél,

b) a szolgáltatást végző nem állami szerv nyilatkozatát a nyilvántartási kötelezettség, az adatkezelés és az adatvédelem szabályainak ismeretére és betartására.

(4) Az ellátási szerződés létrejöttét a helyben szokásos módon közzé kell tenni.

(5) A helyi önkormányzat képviselö-testülete az ellátási szerződés megkötésének, a szerződés módosításának, illetve megszüntetésének jogát nem ruházhatja át.

A gyermekjóléti és gyermekvédelmi szolgáltató tevékenységet végzők müködésének engedélyezése

98. § (1) Az e törvényben és a külön jogszabályban meghatározott személyi és tárgyi feltétellel rendelkező bármely, az 5 . §s) pontja szerinti személy vagy szervezet folytathat gyermekjóléti és gyermekvédelmi szolgáltató tevékenységet, illetve ennek érdekében intézményt létesíthet, helyettes szülőt foglalkoztathat, illetve helyettes szülői vagy nevelőszülöi hálózatot működtethet.

(2) A gyermekvédelmi szolgáltatás keretében nem végezhető olyan szolgáltató tevékenység, amelyet jogszabály kizárólagosan állami szerv hatáskörébe utal.

99. §(1) A gyermekjóléti és gyermekvédelmi szolgáltató tevékenységnek meg kell felelnie az e törvényben és a szakmai szabályokban foglalt követelményeknek.

(2) A gyermekjóléti és gyermekvédelmi szolgáltató tevékenység keretében szolgáltatást csak a külön jogszabályban meghatározott képesítésű személy végezhet.

100. § (1) A gyermekjóléti és gyermekvédelmi szolgáltató tevékenység müködési engedélyhez kötött. A müködési engedélyezés részletes szabályait külön jogszabály határozza meg.

(2) A működési engedély kiadásáról a fenntartó kérelmére a működést engedélyező szerv - első fokon a Kormány általános hatáskörü területi államigazgatási szervének szakigazgatási szerveként müködö gyámhivatal - dönt. A működési engedély kiadásával, módosításával és visszavonásával kapcsolatos eljárás illetékmentes.

(3) A müködést engedélyező szerv ellenőrzi, hogy a szolgáltató tevékenységet a müködési engedélyben és a jogszabályokban foglaltaknak megfelelően végzik-e.

(4) A müködést engedélyező szerv - külön jogszabályban foglaltak szerint - a működési engedélyt visszavonja, ha a szolgáltató tevékenység nem felel meg a jogszabályokban, illetve a müködési engedélyben foglaltaknak. 
(5) Az otthont nyújtó ellátás nevelöszülö, illetve gyermekotthon által történő biztosítása esetén az ellátottak száma éves átlagban nem haladhatja meg a fenntartó által müködtetett - a müködési engedélyben meghatározott - nevelőszülői, illetve gyermekotthoni összféröhelyszám 100\%-át. A helyettes szülőnél, a gyermekek átmeneti otthonában, illetve a családok átmeneti otthonában ellátottak száma éves átlagban nem haladhatja meg a müködési engedélyben meghatározott féröhelyszám 100\%-át.

\section{A gyermekvédelmi igazgatási bírság}

100/A. § (1) A müködést engedélyező szerv vagy a gyámhivatal ellenőrzési jogkörében jogsértésenként legfeljebb 200 ezer forint összegű gyermekvédelmi igazgatási bírságot szabhat ki

a) a müködtetővel, az intézményvezetővel, illetve a fenntartóval szemben, ha a müködtető, a szolgáltató, az intézmény, illetve a fenntartó a gyermeknek az e törvényben biztosított jogait megsérti,

b) a müködtetővel, az intézményvezetővel, illetve a fenntartóval szemben, ha a működtető, a szolgáltató, az intézmény, illetve a fenntartó a tájékoztatási kötelezettséget megszegi, vagy a gyermeket, a szülőt vagy más törvényes képviselőt, az érdek-képviseleti szervet akadályozzák jogai gyakorlásában, illetve abban, hogy a működést engedélyező szervhez, a gyermekjogi képviselőhöz vagy más hatósághoz forduljon, vagy az intézményvezető, illetve a fenntartó a panaszt határidőben nem vizsgálja ki,

c) a fenntartóval és a fenntartó nevében eljárni jogosult személlyel szemben, ha a fenntartó a külön jogszabály szerinti esetekben nem kéri a müködési engedély módosítását, ismételt kiadását, vagy nem teljesíti a működést engedélyező szerv felé fennálló, külön jogszabályban meghatározott bejelentési kötelezettségét,

d) a fenntartóval és a fenntartó nevében eljárni jogosult személlyel szemben, ha a fenntartó a gyermekjóléti, gyermekvédelmi szolgáltatás biztosításával jogellenesen hagy fel.

(2) A bírság összegét az eset összes körülményeire, így különösen a jogsértéssel érintett gyermekek számára, a jogsértés súlyára, a jogsértéssel okozott érdeksérelem nagyságára, a jogsértő állapot időtartamára, a jogsértő magatartás ismételt tanúsítására és - fenntartóra kiszabott bírság esetén - a bírság megfizetésének az ellátás színvonalára gyakorolt hatására tekintettel kell meghatározni.

(3) A bírság - a jogsértés jellegétől, a jogsértők számától, illetve a felelősség mértékétől függően - több személlyel, illetve szervezettel szemben is kiszabható.

(4) Ha a bírsággal sújtott személy vagy szervezet a müködést engedélyező szerv vagy az ellenőrzési jogkörében eljáró gyámhivatal által megállapított határidőn belül nem intézkedik a jogellenesség megszüntetése érdekében, a bírság ismételten kiszabható.

(5) A bírság más jogkövetkezményekkel, illetve a feljelentési kötelezettség teljesítésével egyidejüleg is alkalmazható.

(6) Az intézményvezetőre vonatkozó rendelkezéseket a gyermekjóléti, gyermekvédelmi szolgáltató, intézmény vezetőjén kívül arra a személyre is alkalmazni kell, aki az intézményvezető jogszabályban meghatározott azon feladatát ellátja, amelyből származó jog gyakorlásával, illetve kötelesség megszegésével a jogsértést elkövették.

(7)

(8)-(9)

100/B. § A müködést engedélyező szerv vagy a gyámhivatal ellenőrzési jogkörében a gyermekvédelmi igazgatási bírság kiszabása helyett vagy mellett

a) a gyermekjóléti, gyermekvédelmi szolgáltatás engedélyezésével, müködtetésével kapcsolatos rendelkezések megsértése esetén a külön jogszabályban meghatározott jogkövetkezményeket alkalmazhatja,

b) a fenntartót, működtetőt kötelezheti, hogy a jogsértő személyt küldje az Országos Szociális és Gyermekvédelmi Továbbképzési és Szakvizsga Bizottság által minősített továbbképzésre, illetve

c) a jogsértéssel érintettek között egyeztető megbeszélés tartása iránt intézkedhet.

\section{(...) \\ XVI. Fejezet}

\section{A fenntartó feladat- és jogköre}

104. § (1) A gyermekjóléti és gyermekvédelmi szolgáltató tevékenységet ellátó állami és nem állami intézmény fenntartója

a) dönt az intézmény alapító okiratáról, gazdálkodási köréről, átszervezéséről, megszüntetéséről, tevékenységi körének módosításáról, nevének megállapításáról,

b) meghatározza az intézmény költségvetését, valamint az intézményi térítési díjat,

c) ellenőrzi az intézmény gazdálkodását és működésének törvényességét,

d) jóváhagyja az intézmény szervezeti és müködési szabályzatát, szakmai programját,

e) ellenőrzi és évente egy alkalommal értékeli a szakmai munka eredményességét, a szakmai program végrehajtását, valamint a gazdálkodás szabályszerüségét és hatékonyságát,

f) gondoskodik a szakemberek képzéséről, továbbképzéséről,

g) gyakorolja az intézmény vezetője tekintetében a munkáltatói jogokat,

h) gondoskodik az érdek-képviseleti fórum megalakításának feltételeiről, 
i) kikéri a gyámhivatal véleményét az intézmény müködését érintő lényeges döntés meghozatala előtt, így különösen az intézmény fenntartását érintő változások, az intézmény átszervezésének, megszüntetésének, feladatkörének megváltoztatása esetén,

j) kivizsgálja a 36. § (2) bekezdése alapján hozzá érkező panaszokat és szükség esetén intézkedik a panaszt kiváltó okok megszüntetése iránt, és a megtett intézkedéséről tájékoztatja a müködést engedélyező szervet,

k) kijelöli és működteti az ideiglenes hatállyal elhelyezett gyermekek befogadására szolgáló nevelőszülőt és gyermekotthont,

l) müködteti az utógondozói ellátást igénylö fiatal felnőttek lakhatását biztosító külső férőhelyeket.

(2) Az állami és nem állami intézmény fenntartója a szervezeti és múködési szabályzat jóváhagyását akkor tagadhatja meg, ha az jogszabályt sért. A szakmai program jóváhagyását akkor tagadhatja meg, ha az nem felel meg az e törvényben, valamint a szakmai jogszabályokban elöírt követelményeknek.

(3) A fenntartó a törvényesség biztosítása érdekében ellenőrzi a házirend, valamint más belső szabályzatok jogszerűségét. Az ellenőrzés eredményeképpen az állami és nem állami fenntartó felhívja az intézmény vezetőjét a jogszabálysértés orvoslására, illetve annak eredménytelensége esetén a jogsértő házirendet vagy más belső szabályzatot megsemmisíti.

(4) Az állami és nem állami intézmény fenntartója a szakmai munka eredményességét különösen a Névjegyzékben szereplő szakértő által készített szakértői vélemény, a gyámhivatal szakmai ellenőrzése, illetve az intézmény által készített beszámoló alapján értékeli.

(5) Az állami és nem állami intézmény évenként egy alkalommal kötelezhető arra, hogy tevékenységéről átfogó, szakmai és pénzügyi beszámolót adjon.

(6) A gyermekjóléti és gyermekvédelmi szolgáltató tevékenységet ellátó intézmény egyházi fenntartója az (1) bekezdés $a), b), f), g), i$ ) pontjában meghatározott feladatokon túl gondoskodik az intézmény

a) szervezeti és múködési szabályzatának, szakmai programjának elkészítéséről,

b) gazdálkodásának és müködésének törvényességéről.

(7) A fenntartónak a (3) és (5) bekezdésben megfogalmazott jogköre nem sértheti az intézmény szakmai programjában meghatározott önállóságát.

(8) A gyermekjóléti és gyermekvédelmi szolgáltató tevékenységet ellátó állami és nem állami intézmény fenntartója a gyámhivatal számára hozzáférhetővé teszi azokat az információkat, amelyek az intézmény működését érintő lényeges fenntartói döntés meghozatalához rendelkezésére állnak. A gyermekjóléti és gyermekvédelmi szolgáltató tevékenységet ellátó állami és nem állami intézmény fenntartójának az intézmény müködését érintő lényeges döntés meghozatala előtt úgy kell a gyámhivatal véleményét kikérnie, hogy a gyámhivatalnak - a szükséges információk hozzáférhetővé tételének napjától számítva - legalább tizenöt nap álljon rendelkezésre véleménye kialakításához.

\section{ÖTÖDIK RÉSZ}

A GYERMEKVÉDELMI ÉS GYAMÜGYI IGAZGATÁS SZERVEZETE ÉS EGYES ELJÁRÁSI SZABALYAI

XVII. Fejezet

A gyermekvédelmi és gyámügyi igazgatás szervei

105. § (1) Az e törvényben meghatározott gyámügyi feladatok, továbbá a gyermekek védelmét biztosító ellátórendszer müködésének ellenőrzése állami feladat.

(2) Az állam az (1) bekezdésben meghatározott feladatokat a települési önkormányzat jegyzője és a gyámhivatal útján látja el.

(3) Az (1) bekezdésben meghatározott feladatok felügyeletét a miniszter gyakorolja.

121. $\S(1)$

$$
\text { ( ...) }
$$

(2) A helyi önkormányzat köteles előzetesen kikérni a gyámhivatal véleményét, ha

a) személyes gondoskodást nyújtó intézményt kíván megszüntetni, illetőleg annak ellátási területét vagy az ellátási kötelezettség terjedelmét változtatja meg,

b) az ellátórendszer működését szolgáló vagyont más célra kívánja felhasználni,

c) az e törvényben vagy külön jogszabályban nem szabályozott új ellátást kíván bevezetni.

122. § (1) A megyei fenntartó a 95. § (1) bekezdés szerinti állami ellátási kötelezettségnek intézmény fenntartásával, vagy - a területi gyermekvédelmi szakszolgáltatás kivételével - az intézményt müködtető fenntartóval létrejött ellátási szerződés megkötésével tehet eleget.

(2) Az (1) bekezdés szerinti intézmény létrehozásához, átszervezéséhez és megszüntetéséhez, valamint az (1) bekezdés szerinti ellátási szerződés megkötéséhez, módosításához és megszüntetéséhez a miniszter jóváhagyása szükséges. A miniszter ezen jogkörében a 96 . § (6) bekezdése szerinti értékelésben foglaltak figyelembevételével, a személyes gondoskodást nyújtó ellátás iránti helyi szükségletek alapján dönt.

\section{Fejezet}

A gyermekvédelmi és gyámügyi igazgatás főbb szabályai 
123. $\S$

124. $\S$

125. § (1) Bármely települési önkormányzat képviselő-testülete az arra rászoruló gyermek részére rendkívüli gyermekvédelmi támogatást biztosít, ha ennek hiányában a késedelem a gyermek életét, testi épségét veszélyeztetné. Az ellátást biztosító települési önkormányzat haladéktalanul értesíti az illetékes települési önkormányzatot, amelytől követelheti a kifizetett támogatás megtérítését.

(2)-(14)

126. §

\section{Egyéb eljárási szabályok}

127. §(1) A települési önkormányzat jegyzője vagy a gyámhivatal - ha jogszabály másképp nem rendelkezik - a hatáskörébe tartozó ügyekben az eljárást hivatalból is megindíthatja.

(2) A gyámhatósági eljárásban a 128. § (2)-(3) bekezdése szerinti esetekben kizárt elektronikus úton a kapcsolattartás.

(3) A 15. § (1)-(4) bekezdése szerinti ellátásokkal és intézkedésekkel kapcsolatos eljárásokban hirdetményi úton történő közlésnek nincs helye. A 15. § (1)-(4) bekezdése szerinti ellátásokkal és intézkedésekkel kapcsolatos eljárásokban azokban az esetekben, amikor a közigazgatási hatósági eljárás általános szabályairól szóló törvény szerint hirdetményi közlésnek lenne helye, kézbesítési ügygondnokot kell kirendelni.

(4) A gyámügyi és gyermekvédelmi eljárásban hozott döntés - a gyermekjóléti és gyermekvédelmi szolgáltatótevékenység müködésének engedélyezésével és ellenőrzésével kapcsolatos döntés kivételével nem nyilvános.

128. § (1) A gyámügyi eljárásban meg kell hallgatni a szülőt és más törvényes képviselöt, a gondozót, a korlátozottan cselekvőképes személyt és az ítélőképessége birtokában levő cselekvőképtelen gyermeket, továbbá minden esetben azt, akivel szemben kötelezettséget kívánnak megállapítani, valamint - szükség szerint - a gyermek más közeli hozzátartozóit. A meghallgatást mellőzni lehet, ha a meghallgatás miatti késedelem elháríthatatlan kárral vagy veszéllyel járna.

(2) Ha jogszabály a gyermek személyi ügyeiben a törvényes képviselő eljárását vagy nyilatkozatát írja elő, a szülői felügyeletet együttesen gyakorló mindkét szülőnek személyesen kell eljárnia, illetőleg személyesen kell nyilatkoznia.

(3) A kapcsolattartással, a kiskorú házasságkötésének engedélyezésével, az örökbefogadással, a családi jogállással, a szülői ház elhagyásával, a családbafogadással és a gyámsággal, gondnoksággal kapcsolatos jognyilatkozatokat csak személyesen lehet megtenni, valamint, ha a tényállás tisztázása érdekében a gyámhatóság tárgyalást tart, azon személyesen kell megjelenni.

(4)-(5)

128/A. $\S$

129. § (1) A települési önkormányzat képviselő-testülete, jegyzője és a gyámhivatal (a továbbiakban együtt: eljáró szerv) az eljárásban mindenkor vizsgálja a kérelmező állampolgárságát, jogállását, valamint személyes jogát.

(2) Az eljáró szerv az ellátásra való jogosultság elbírálásához a kérelmezőt kötelezheti arra, hogy családja vagyoni, jövedelmi viszonyairól nyilatkozzék, illetve azokat igazolja.

(3) A gyermek szülője és más törvényes képviselője, gondozója kötelezhető arra, hogy saját vagy gyermeke egészségi állapotáról, munkavégzéséről, tanulói, hallgatói jogviszonyáról nyilatkozzék, azokat igazolja.

(4) A gyámhivatal eljárása során kezdeményezheti az illetékes háziorvosnál - súlyos veszélyeztetés esetén bármely orvosnál - betegsége, illetve szenvedélybetegsége következtében állandóan vagy időszakosan kóros elmeállapotú szülő vagy más törvényes képviselő, illetve a gyermekkel együtt élő más hozzátartozó orvosi vizsgálatát.

130. § (1) Ha az eljáró szerv a kérelmező vagyoni, szociális, egészségügyi, kulturális, lakás- vagy egyéb körülményeinek tisztázására helyszíni szemlét tart, az ügyre vonatkozó lényeges nyilatkozatokat és a megállapításokat jegyzőkönyvben (a továbbiakban: környezettanulmány) rögzíti.

(2) Az eljáró szerv az eljárásban felhasználhat más hatóság, illetőleg családvédelemmel foglalkozó más szerv vagy személy által készített környezettanulmányt is, feltéve, hogy annak elkészítése óta 6 hónap még nem telt el.

(3) A gyámhivatal megkeresheti a települési önkormányzat jegyzőjét, hogy a kérelmezőnek az (1) bekezdésben megjelölt körülményeiről készítsen környezettanulmányt.

(4) Az eljáró szerv a bíróság és az ügyészség megkeresésére környezettanulmányt készít.

(5) Az ellátásban részesülő az ellátásra való jogosultság feltételeit érintő lényeges tények, körülmények megváltozásáról 15 napon belül értesíti az eljáró szervet.

(6) 
130/A. § A gyermek bántalmazása, illetve súlyos elhanyagolása vagy egyéb más, súlyos veszélyeztető ok fennállása, továbbá a gyermek önmaga által előidézett súlyos veszélyeztető magatartása esetén

a) a hatóság és az ügyfél bármilyen módon tarthat kapcsolatot,

b) ha környezettanulmányra van szükség, azt haladéktalanul el kell készíteni,

c) a helyszíni szemle a lezárt terület, épület, helyiség felnyitásával, az ott tartózkodó személyek akarata ellenére is megtartható.

131. § (1) A helyi önkormányzat hatáskörébe tartozó ellátásoknál az igazolás és a nyilatkozat tartalmát, benyújtásának részletes szabályait, az elbírálás részletes szempontjait, a jövedelemszámításnál irányadó időszakot a helyi önkormányzat rendeletben szabályozza.

(2) A jövedelemszámításnál irányadó időszak - ha a törvény másképpen nem rendelkezik - az Szt. 10. §ának (2)-(5) bekezdése szerint kerül megállapításra.

(3) A pénzbeli és természetbeni ellátás - jogerős megállapítása esetén - a kérelem benyújtásától esedékes.

(4) Ha a helyi önkormányzat vagy annak jegyzője hivatalos tudomása vagy környezettanulmány

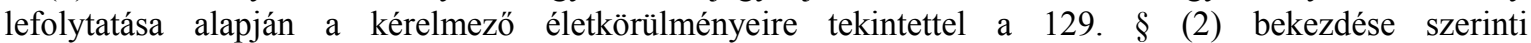
jövedelemnyilatkozatban foglaltakat vitatja, felhívhatja a kérelmezőt az általa lakott lakás, illetve saját és vele közös háztartásban élő közeli hozzátartozója tulajdonában álló vagyon fenntartási költségeit igazoló dokumentumok benyújtására. Abban az esetben, ha a fenntartási költségek meghaladják a jövedelemnyilatkozatban szereplő jövedelem 70\%-át, a valós jövedelem az igazolt fenntartási költségek figyelembevételével kerül megállapításra.

(5) A települési önkormányzat képviselö-testülete, jegyzője, illetve a gyámhivatal megkeresésére az állami adóhatóság tizenöt napon belül köteles közölni a pénzbeli ellátást igénylö szülö vagy más törvényes képviselö, valamint - írásbeli felhatalmazás alapján - az egy före jutó havi jövedelem kiszámításánál figyelembe veendő, a 19. § (4) bekezdése szerinti közeli hozzátartozó személyi jövedelemadójának alapját.

132. §(1) Ha az ügyben a gyermek személyiségével kapcsolatos jelentős tény vagy körülmény megítéléséhez különleges szakértelem szükséges, szakértőként elsősorban nevelési tanácsadót, szakértő- és rehabilitációs bizottságot, pszichiátriai szakellátó intézményt vagy családvédelemmel foglalkozó szervet, illetve szakértői névjegyzékbe felvett személyt kell megkeresni.

(2) Az (1) bekezdésben meghatározott esetben a települési önkormányzat jegyzője, a gyámhivatal arra kötelezi a szülöt, a törvényes képviselőt vagy az egyéb ügyfelet, hogy a gyermekkel keresse fel a szakértőként kirendelt szervet vagy személyt, és közremüködésével, szakértői vizsgálaton való részvételével járuljon hozzá a szakértői vizsgálat eredményességéhez.

(3) Abban a kérdésben, hogy a gyermek testi, érzékszervi, értelmi, beszéd vagy más fogyatékosságban szenved, továbbá, hogy a gyermek beilleszkedési, tanulási, magatartási rendellenességgel küzd, a Kt. 35. §-a szerinti szakértői és rehabilitációs bizottság, illetve nevelési tanácsadó ad véleményt.

(4) Az átmeneti vagy tartós nevelésbe vett és súlyos pszichés vagy disszociális tüneteket mutató, illetve pszichoaktív szerekkel küzdő gyermek ellátására, az ellátás módjára, formájára a megyei, fővárosi, valamint az országos gyermekvédelmi szakértői bizottság tesz javaslatot. A szakértői bizottság eljárásának részletes szabályait külön jogszabály határozza meg.

(5) Az Szt. hatálya alá tartozó fogyatékosok és pszichiátriai betegek otthonában az Szt.-ben meghatározott feltételek szerint helyezhetők el gyermekek.

(6) A gyermek és hozzátartozói közötti kapcsolattartás szabályozása vagy annak végrehajtása iránti eljárásban felmerülő konfliktus megoldására a gyámhivatal kezdeményezheti a konfliktusnak közvetítői (mediációs) eljárás keretében történő rendezését. A közvetítő eljárás rendjét külön jogszabály szabályozza.

133. § (1) Az e törvényben meghatározott feltételek hiányában vagy az e törvény rendelkezéseinek megsértésével nyújtott ellátást meg kell szüntetni.

(2) Az ellátást jogosulatlanul és rosszhiszemüen igénybe vevőt kötelezni kell a pénzbeli ellátás visszafizetésére, természetbeni ellátás esetén a pénzegyenérték megfizetésére, személyes gondoskodást nyújtó ellátás esetén az intézményi térítési díj összegének megfizetésére (a továbbiakban: megtérítés).

(3) A folyamatosan nyújtott ellátás megtérítését legfeljebb egy évre visszamenőlegesen lehet elrendelni.

(4) Az ellátás megtérítését az eljáró szerv az igénybevétel jogosulatlanságáról való tudomásszerzéstől számított 3 hónapon belül rendelheti el. Nem lehet a megtérítést elrendelni, ha az igénybevételtől, illetve az ellátás megszünésétől egy év már eltelt.

(5) Az eljáró szerv a megtérítést méltányosságból elengedheti, csökkentheti, illetve részletfizetést engedélyezhet, ha a visszafizetésre kötelezett személy családjában az egy före jutó havi jövedelem összege nem haladja meg az öregségi nyugdíj mindenkori legkisebb összegének kétszeresét.

133/A. § (1) A gyámhatósági eljárás költségeit - a (2)-(5) bekezdésben foglaltak kivételével - az eljáró szerv viseli. A gyermekvédelmi gondoskodással kapcsolatos hatósági ügyekben az eljárás költségeit minden esetben az eljáró szerv viseli.

(2) Ha az eljárást azért kellett megindítani, mert jogsértés történt, az eljárás költségeit az viseli, akinek a jogsértés felróható. 
(3) Az eljárás költségeit az ügyfél viseli

a) az örökbefogadási ügyekben,

b) az öregségi nyugdíj mindenkori legkisebb összegének százszorosát meghaladó értékhatárú, kérelemre induló vagyoni ügyekben,

c) a kapcsolattartási ügyekben.

(4) A (3) bekezdés szerinti ügyekben szakértő kirendelése esetén a gyámhatóság az ügyfelet a szakértői díj megelölegezésére kötelezheti.

(5) Ha az eljárásban közremüködők hibájából merültek fel költségek, azokat az viseli, akinek a költségek felmerülése felróható.

(6) A más szerv eljárásában történő képviseletre kirendelt ügygondnok, eseti gondnok munkadíját és költségeit - a (11) bekezdésben foglaltak kivételével - a kirendelést kérelmező szerv fizeti meg.

(7) A gyámhivatal által kiszabott, illetve megállapított eljárási költség és a kapcsolattartás meghiúsítása folytán keletkezett igazolt költségek meg nem térült összegét adók módjára kell behajtani az adózás rendjéről szóló törvény rendelkezései szerint.

(11) Az eseti gondnok munkadíját és költségeit a gyámhivatal fizeti meg, ha az

a) hagyatéki eljárásban vagy

b) bírósági végrehajtási eljárásban

merült fel és e költség másra át nem hárítható.

133/B. § A kapcsolattartásra vonatkozó határozat végrehajtására irányuló eljárásban hozott valamennyi döntés ellen fellebbezésnek van helye. A kapcsolattartásra vonatkozó határozat végrehajtására irányuló eljárásban elöterjesztett fellebbezésnek halasztó hatálya van.

\section{HATODIK RÉSZ \\ EGYÉB RENDELKEZÉSEK \\ XXI. Fejezet \\ Adatkezelés \\ Általános szabályok}

134. § (1) A gyermekek védelmét biztosító feladat- és hatáskört gyakorló állami és nem állami szerv (a továbbiakban: adatkezelő szerv) az e törvényben szabályozott feladatai ellátásához a 135-136. §-ban felsorolt adatkörben, az ott meghatározott célok teljesüléséhez elengedhetetlenül szükséges személyes adatokat kezelheti.

(2) Az adatkezelő szerv gondoskodik arról, hogy a személyes adatok védelmének biztosítása érdekében

a) az érintett - ha törvény kivételt nem tesz - az adataihoz hozzáférhessen, illetve gyakorolhassa a helyesbítéshez vagy a törléshez való jogát,

b) a tárolt adatokat töröljék, ha azok oka e törvény rendelkezése szerint megszünt.

(3) Az adatkezelő szerv biztosítja az adatok védelmét a véletlen vagy szándékos megsemmisítéssel, megsemmisüléssel, megváltoztatással, nyilvánosságra kerüléssel szemben, és azt, hogy azokhoz arra jogosulatlan szerv vagy személy ne férjen hozzá.

(4) E törvény felhatalmazása alapján az adatkezelésre jogosult szerv a kezelt adatokat személyes azonosító adatok nélkül statisztikai célra felhasználhatja, azokból statisztikai célra adatot szolgáltathat.

(5) A hatáskört gyakorló szerv

a) a gyermekvédelmi és gyámügyi igazgatási eljárás során az eljárása alá vont ügyfélre ismert természetes személyazonosító adatainak közlésével, az ügyfélre vonatkozó a polgárok személyi adatainak és lakcímének nyilvántartásáról szóló 1992. évi LXVI. törvény 11. §-a (1) bekezdésének $a$ )-e), $g$ )- $h$ ), $k$ ) és $m$ ) pontja szerinti adatai tekintetében egyedi adatszolgáltatást kérhet a jogosultság megállapításához, illetve a hatósági intézkedések megtételéhez a polgárok személyi adatait és lakcímét nyilvántartó szervtől, amely adatokat a hatáskört gyakorló szerv az eljárása jogerős befejezéséig kezelhet azzal, hogy az átvett adatokat a hatáskört gyakorló szerv nem továbbíthatja,

b) a gyámsággal és a gondnoksággal kapcsolatos ügyekben, valamint a kiskorúak vagyoni ügyeiben vagyoni érdekei védelmében - a gyámság, gondnokság alatt álló, illetve a kiskorú személy valamennyi ingatlanára vonatkozóan a tulajdoni lapon szereplő adatokról adatszolgáltatást kérhet az ingatlanügyi hatóságtól.

(6) A személyes adatok felhasználására a miniszter, a helyi önkormányzat, a gyermekvédelmi és gyámügyi igazgatási hatáskört, illetve szociális hatáskört gyakorló szerv, a személyes gondoskodást nyújtó személy és intézmény, közoktatási és felsőoktatási intézmény, az ügyészség, a nyomozó hatóság, az ingatlannyilvántartási szerv, valamint pénzintézet, külföldi hatóság és bíróság jogosult e törvényben meghatározott módon és mértékben.

(7)

135. § (1) A 15. § (1)-(4) bekezdéseiben meghatározott ellátások és intézkedések nyújtása és megtétele, azok ellenőrzése, valamint biztosítása során az e törvényben meghatározott jogok érvényesülésének 
elösegítése céljából a (2) bekezdésben meghatározott adatok kezelésére az alábbi szervek és személyek jogosultak: $\S)$,

a) a gyermekek védelmét biztosító hatósági feladat- és hatásköröket gyakorló szervek és személyek (16.

b) a fövárosi föjegyző,

c) a gyermekjóléti alapellátást és gyermekvédelmi szakellátást nyújtó szolgáltatás, intézmény fenntartója, vezetöje,

d) a helyettes szülö, nevelöszülö,

e) a gyermekjogi képviselö, illetve amennyiben a gyermek panaszának orvoslása érdekében feltétlenül szükséges a betegjogi képviselő, illetve az ellátottjogi képviselő,

f) az áldozatsegítés és a kárenyhítés feladatait ellátó szervezetek,

g) a gyermekvédelmi szakértői bizottság.

(2) Az (1) bekezdés szerinti szervek jogosultak

a) a gyermek

aa) személyazonosító adatainak és társadalombiztosítási azonosító jelére vonatkozó,

$a b)$ anyanyelvére vonatkozó,

ac) családi jogállására vonatkozó,

ad) veszélyeztetettségének megállapításához szükséges és elégséges adatainak, így különösen vagyoni helyzetére, környezetére, élelmezésére, ruházatára, lakhatási viszonyaira vonatkozó,

ae) megfelelő ellátásához, gondozásához szükséges és elégséges adatainak, így különösen a személyiségére, magatartására, személyes kapcsolataira, szokásaira, tanulmányi eredményeire, neveltségi állapotára vonatkozó,

af) egészségi állapotára vonatkozó,

ag) büntetlen előéletére, illetve a vele kapcsolatos hatósági, bírósági eljárásokra, határozatokra vonatkozó, ah) kóros szenvedélyére vonatkozó,

ai) áldozattá válásának körülményeire vonatkozó, a bűncselekmények áldozatainak segítéséről és az állami kárenyhítésről szóló 2005. évi CXXXV. törvény (a továbbiakban: Ást.) 16. § (2) bekezdés $a$ )c) pontjában meghatározott;

b) a szülö, törvényes képviselö, helyettes szülö, nevelőszülő

ba) személyazonosító,

bb) vagyoni helyzetére, munkahelyére, iskolai végzettségére, kapcsolataira vonatkozó,

bc) gyermekneveléssel összefüggő, így különösen életvezetésére, nevelési magatartására vonatkozó,

bd) egészségi állapotára vonatkozó,

be) büntetlen elöéletére vonatkozó,

bf) áldozattá válásának körülményeire vonatkozó, az Ást. 16. § (2) bekezdés $a$ )-c) pontjában meghatározott;

c) a gyermek

ca) testvéreinek személyazonosító,

cb) saját gyermekének személyazonosító,

cc) kapcsolattartásra jogosult hozzátartozójának személyazonosító,

$c d$ ) lakóhelyén életvitelszerüen tartózkodó személyek személyazonosító és személyes körülményeire vonatkozó,

ce) sorsának megtervezése szempontjából jelentőséggel bíró személyek, így különösen a korábbi gondozók, szomszédok elérhetőségére vonatkozó,

cf) háziorvosának, védőnőjének, amennyiben óvodai, iskolai nevelésben részesül, a közoktatási intézmény vezetőjének elérhetőségére vonatkozó

adatainak a kezelésére.

(3) A személyes gondoskodást nyújtó (1) bekezdésben meghatározott szervek és személyek a gyermek nevelkedésének megtervezését az (1) és (2) bekezdésben meghatározott adattartalmú - külön jogszabályban meghatározott - környezettanulmány, elhelyezési javaslat, egyéni elhelyezési terv, egyéni gondozási-nevelési terv alapján végzik. A (2) bekezdésben meghatározott adatkörök pontos tartalmát a külön jogszabály szerinti gyermekvédelmi nyilvántartás rögzíti.

(4) A gyermekjóléti szolgálat, és a települési önkormányzat jegyzője, illetve a gyámhivatal a 15. § (2)-(4) bekezdésben meghatározott ellátások nyújtása, illetve intézkedések alkalmazása során a (2) bekezdésben meghatározott adatokon túl

a) a gyermek, illetve a fiatalkorú által elkövetett büncselekményre,

b) a szülő vagy más törvényes képviselő által a gyermek sérelmére elkövetett büncselekményre,

c) a Polgári Törvénykönyv szerinti hozzátartozó, vagy a közös háztartásban rendszeresen vagy időszakonként együtt élő más személy által a gyermek sérelmére elkövetett hozzátartozók közötti erőszak miatt alkalmazható ideiglenes megelőző távoltartó határozatra vagy megelőző távoltartó határozatra 
vonatkozó adatokat kezelhet.

(5) A gyermekvédelmi gondoskodás biztosítása, a gyermek örökbefogadásának elősegítése és a származás megismeréséhez való jog érvényesülésének biztosítása céljából a területi gyermekvédelmi szakszolgálat és a gyámhivatal kezeli

a) a családba fogadó személy személyazonosító adatait, valamint az egészségi állapotára és a vagyoni helyzetére vonatkozó adatokat,

b) az örökbe fogadni szándékozó személy családi állapotára, fennálló házasságára, élettársi, bejegyzett élettársi kapcsolatának tényére, gyermekei számára és az arra vonatkozó adatokat, hogy kivel él egy háztartásban és gyermekei kinek a gondozásában nevelkednek (a továbbiakban együtt: családi helyzetre vonatkozó adatok), személyazonosító adatait, vagyoni helyzetére, az egészségi állapotára, Csjt. 47. §-a szerinti alkalmasságára és az örökbe fogadandó gyermekkel kapcsolatos elvárásaira vonatkozó adatokat,

c) az örökbe fogadó szülő személyazonosító adatait, családi helyzetére, egészségi állapotára, vagyoni helyzetére vonatkozó adatokat,

d) a válsághelyzetben lévő várandós anya, a vér szerinti szülő személyazonosító adatait, az egészségi állapotára vonatkozó adatokat és - önkéntes adatszolgáltatása alapján - a vagyoni helyzetére, a családi helyzetére és a terhesség eltitkolásának tényére, okára vonatkozó adatokat,

e) az örökbe adható gyermek személyazonosító adatait és az egészségi állapotára vonatkozó adatokat.

(6) Az (1) bekezdésben felsorolt szervek, illetve személyek az érintett személyazonosító adatait, valamint a gyermek (2) bekezdésben meghatározott adatait a 15. § (1)-(4) bekezdései szerinti célból egymásnak átadhatják.

(7) A települési önkormányzat jegyzője, a gyámhivatal, a gyermekjóléti szolgálat vezetője és a területi gyermekvédelmi szakszolgálat vezetője kezelheti a 135. § (2) bekezdés ai) ésbf) alpontjában meghatározott adatokat. Ezeket a felsorolt szervek és személyek a 15. § (1)-(4) bekezdésében meghatározott szolgáltatások nyújtása és intézkedések megtétele vagy azok ellenőrzése, illetve az áldozatsegitő szolgálat tevékenységének elősegítése céljából egymásnak, illetve az áldozatsegítő szolgálatnak átadhatják.

(8) Az országos örökbefogadási nyilvántartást vezető szerv a gyermek belföldön történő örökbefogadásának elősegítése, az átmeneti vagy tartós nevelésbe vett gyermek belföldi örökbefogadására tett intézkedések eredménytelenségének megállapítása és a származás megismeréséhez való jog érvényesülésének biztosítása céljából kezeli

a) az örökbe adható gyermek személyazonosító adatait és az egészségi állapotára vonatkozó adatokat,

b) az örökbe fogadni szándékozó személy személyazonosító adatait, családi helyzetére, egészségi állapotára, vagyoni helyzetére, Csjt. 47. §-a szerinti alkalmasságára és az örökbe fogadandó gyermekkel kapcsolatos elvárásaira vonatkozó adatokat,

c) a válsághelyzetben lévő várandós anya, a vér szerinti szülő személyazonosító adatait, az egészségi állapotára vonatkozó adatokat és - önkéntes adatszolgáltatása alapján - a vagyoni helyzetére, családi helyzetére és a terhesség eltitkolásának tényére, okára vonatkozó adatokat.

(9) A központi hatóság az átmeneti vagy tartós nevelésbe vett gyermek külföldre történő örökbefogadásának elősegítése, a külföldi örökbefogadások utánkövetése és a származás megismeréséhez való jog érvényesülésének biztosítása céljából kezeli

a) a Csjt. 49. § (3) bekezdése alapján külföldre örökbe adható gyermek személyazonosító adatait és az egészségi állapotára vonatkozó adatokat, valamint a külföldre örökbe adott gyermek személyazonosító adatait,

b) a külföldön élő örökbe fogadni szándékozó személy személyazonosító adatait, családi helyzetére, egészségi állapotára, vagyoni helyzetére, Csjt. 47. §-a szerinti alkalmasságára és az örökbe fogadandó gyermekkel kapcsolatos elvárásaira vonatkozó adatokat,

c) a külföldön élő örökbe fogadó szülő személyazonosító adatait, családi helyzetére, egészségi állapotára, vagyoni helyzetére vonatkozó adatokat,

d) a külföldre örökbe adott gyermek helyzetéről, beilleszkedéséről szóló jelentésben foglalt adatokat.

(10) A területi gyermekvédelmi szakszolgálat, az országos örökbefogadási nyilvántartást vezető szerv és a központi hatóság a gyermek örökbefogadásának elősegítése céljából az (5) bekezdés $b$ ) és $e$ ) pontjában, a (8) bekezdés $a$ ) és $b$ ) pontjában, valamint a (9) bekezdés $a$ ) és $b$ ) pontjában meghatározott adatokat egymásnak átadhatják.

(11) A területi gyermekvédelmi szakszolgálat és az országos örökbefogadási nyilvántartást vezető szerv a gyermek örökbefogadásának elösegítése céljából az (5) bekezdés $d$ )pontjában és a (8) bekezdés $c$ ) pontjában meghatározott adatokat egymásnak átadhatják. Az önkéntes adatszolgáltatás alapján kezelhető adatok az érintett hozzájárulásával adhatók át.

135/A. § (1) Az örökbefogadást elősegítő közhasznú szervezet a válsághelyzetben lévő várandós anya segítése, a nyílt örökbefogadások előmozdítása, az örökbefogadást elösegítő tevékenységének nyújtása, az örökbefogadás engedélyezését követően az örökbe fogadó szülőnek, az örökbe fogadott gyermeknek, a vér 
szerinti szülőnek segítséget nyújtó szolgáltatások és tanácsadás biztosítása, valamint az örökbe fogadott gyermek (személy) vér szerinti szülőjével való kapcsolatfelvételének elősegítése céljából kezeli

a) $a$ válsághelyzetben lévő várandós anya, a vér szerinti szülő

aa) személyazonosító adatait,

$a b)$ egészségi állapotára vonatkozó adatokat,

$a c)$ - önkéntes adatszolgáltatása alapján - a vagyoni helyzetére vonatkozó adatokat,

$a d)$ - önkéntes adatszolgáltatása alapján - a családi helyzetére vonatkozó adatokat,

$a e$ ) - önkéntes adatszolgáltatása alapján - a terhesség eltitkolásának tényére, okára vonatkozó adatokat;

b) a gyermek

ba) személyazonosító adatait,

$b b$ ) egészségi állapotára vonatkozó adatokat;

c) az örökbe fogadni szándékozó személy

ca) személyazonosító adatait,

$c b)$ családi helyzetére vonatkozó adatokat,

$c c$ ) egészségi állapotára vonatkozó adatokat,

$c d)$ vagyoni helyzetére vonatkozó adatokat,

ce) Csjt. 47. §-a szerinti alkalmasságára vonatkozó adatokat,

$c f)$ örökbe fogadandó gyermekkel kapcsolatos elvárásaira vonatkozó adatokat;

d) az örökbe fogadó szülő

da) személyazonosító adatait,

$d b)$ családi helyzetére vonatkozó adatokat,

$d c$ ) egészségi állapotára vonatkozó adatokat,

dd) vagyoni helyzetére vonatkozó adatokat;

e) a gyermek törvényes képviselőjének, a válsághelyzetben lévő várandós anya törvényes képviselőjének, a vér szerinti szülő törvényes képviselőjének személyazonosító adatait.

(2) Ha az örökbefogadást elősegítő közhasznú szervezet szolgáltatása megszűnik, e tényről 8 napon belül tájékoztatja a szolgáltatást igénybe vevőt. A tájékoztatásban 30 napos határidő megjelölésével felhívja a szolgáltatást igénybe vevőt a hozzá benyújtott dokumentumok átvételére. Ha a szolgáltatást igénybe vevő a dokumentumokat nem veszi át, úgy ezeket és a tevékenysége során keletkezett iratokat megküldi a müködést engedélyezö szervnek.

(3) A működést engedélyező szerv az örökbefogadást elösegítő közhasznú szervezet szolgáltatásának további szervezése céljából kezelheti az (1) bekezdés szerinti adatokat. A müködést engedélyező szerv az adatkezelés céljának megszünését követően adatkezelését haladéktalanul megszünteti.

(4) Az örökbefogadást elösegítő közhasznú szervezet az örökbefogadást elősegítő magánszervezetek tevékenységéről és müködésük engedélyezéséről szóló kormányrendeletben meghatározott formában évente adatot szolgáltat a müködést engedélyező szervnek - az örökbefogadást elösegítő közhasznú szervezet tevékenységének ellenörzése céljából -

a) személyazonosításra alkalmatlan módon az (1) bekezdés a) pontjában foglaltakról,

b) az (1) bekezdés $b$ ) pontjában foglaltakról.

(5) Az örökbefogadást elösegítő közhasznú szervezet az örökbefogadást elősegítő magánszervezetek tevékenységéről és működésük engedélyezéséről szóló kormányrendeletben meghatározott formában - a gyermek belföldön történő örökbefogadásának elösegítése, az átmeneti vagy tartós nevelésbe vett gyermek belföldi örökbefogadására tett intézkedések eredménytelenségének megállapítása és a származás megismeréséhez való jog érvényesülésének biztosítása céljából - folyamatosan továbbítja az országos örökbefogadási nyilvántartást vezető szerv számára

a) $a z$ (1) bekezdés $a$ ) pontja szerinti adatokat,

$b)$ az (1) bekezdés $b$ ) pontja szerinti adatokat.

(6) A 69/D. § (1) bekezdésében foglalt megállapodás megszünése esetén a benyújtott dokumentumokat a szolgáltatást igénybe vevőnek vissza kell adni.

(7) A közhasznú szervezet adatvédelmi szabályzatot készít, amely nyilvános.

136. § (1) A gyermek személyazonosító adatai, továbbá

a) az ingatlanra vonatkozó adatok az ingatlan-nyilvántartás szerveinek az ingatlantulajdonnal kapcsolatos jogot érintő változás esetén,

b) a készpénzvagyonára vonatkozó adatok a pénzintézetnek a gyámhatósági fenntartásos betétkönyv vagy folyószámla kezelése, illetve egyéb szerződések megkötése céljából

továbbíthatók.

(2) A gyermek személyazonosító adatai, továbbá az egészségi állapotára és vagyoni viszonyaira vonatkozó adatok továbbíthatók

a) a szociális hatáskört gyakorló szervnek a szociális ellátás megállapítása, 
b) a rendőrségnek, az ügyészségnek, a bíróságnak, az igazságügyi szakértőnek bünüldözés és bünmegelőzés, illetve bírósági eljárás lefolytatása,

c) a külföldi hatóságnak, illetve bíróságnak családi jogállás, gyermektartás, kapcsolattartás, gyámság, örökbefogadás, a gyermek érdekében tett ideiglenes intézkedés, valamint a gyermek jogellenes külföldre vitelének megszüntetése,

d) a minisztériumnak, a gyermekvédelmi ágazati irányítási tevékenység és a külön jogszabályban meghatározott központi hatósági feladatok ellátása

céljából.

(3) A gyermek személyazonosító adatai és

a) az egészségbiztosítási szervnek a gyermek társadalombiztosítási azonosító jele az egészségügyi szolgáltatásra való jogosultság kezdetére és megszünésére vonatkozó bejelentéssel összefüggésben,

b) egészségügyi intézménynek az egészségi állapotra vonatkozó adatok gyógykezelés céljából,

c) a közoktatási és felsőoktatási intézménynek a tanulmányi eredményre vonatkozó adatok,

d) a közoktatási és felsőoktatási intézménynek a rendszeres gyermekvédelmi kedvezményre való jogosultságra vonatkozó adatok a gyermeknek, fiatal felnőttnek járó természetbeni ellátások és kedvezmények igénybevétele céljából továbbíthatók.

(4) A szülő és más törvényes képviselő személyazonosító adatai, továbbá az egészségi állapotára és vagyoni viszonyaira vonatkozó adatai az (1)-(3) bekezdések szerinti szerveknek átadhatók.

(5) A gyámhatóság és a személyes gondoskodást nyújtó gyermekjóléti, gyermekvédelmi szolgáltató tevékenységet végző szervezet alkalmazottja és vezetője, a gyermek és az őt nevelő szülő, vagy más törvényes képviselő tartózkodási helyére vonatkozóan megtagadhatja a szülő tájékoztatását, illetve korlátozhatja a szülő iratbetekintési jogát, ha

a) a szülő ellen gyermeke vagy a gyermeket nevelő másik szülő sérelmére elkövetett büncselekmény miatt büntetőeljárás van folyamatban, annak jogerös befejezéséig,

b) a szülő ellen gyermeke vagy a gyermeket nevelő másik szülő sérelmére elkövetett külön törvényben meghatározott hozzátartozók közötti erőszak miatt alkalmazható ideiglenes megelőző távoltartó határozat vagy megelőző távoltartó határozat iránti eljárás van folyamatban, a távoltartás időtartamáig.

(6) Az (5) bekezdés szerinti korlátozást a büntetőeljárás befejezésekor felül kell vizsgálni.

136/A. § (1) A gyermek szülője vagy más törvényes képviselője a szolgáltató (intézmény) vezetőjénél kérelmezheti, hogy betekinthessen a külön jogszabály szerinti gyermekvédelmi nyilvántartásnak a gyermek vonatkozásában kitöltött adatlapjaiba, valamint - a (2) bekezdésben foglalt kivétellel - a gyermekjóléti, gyermekvédelmi szolgáltatónál, intézménynél keletkezett, illetve részére megküldött, a gyermekkel kapcsolatos iratba. Az iratokról kivonat vagy másolat kérhető.

(2) A közigazgatási hatósági eljárás általános szabályairól szóló törvényben meghatározottakon túl az érintett írásbeli hozzájárulása hiányában nem lehet betekinteni a másik szülőre vonatkozó, különleges adatot tartalmazó iratba, kivéve, ha az a gyermek érdekében kezdeményezett, a gyermek védelembe vételére vagy átmeneti nevelésbe vételére irányuló gyámhatósági eljárás, illetve a gyermek elhelyezésének megváltoztatására irányuló bírósági eljárás megindításához elengedhetetlenül szükséges.

\section{Nyilvántartások vezetése}

137. § (1) Az ellátást nyújtó intézmény és személy az e törvényben elöírt nyilvántartást köteles vezetni, a Országos Statisztikai Adatgyüjtési Programban, valamint a helyi önkormányzati rendeletben meghatározott adatokat köteles szolgáltatni.

(2) A Kormány által kijelölt szerv gondoskodik a személyes gondoskodást nyújtó gyermekjóléti és gyermekvédelmi tevékenységet végző és a külön jogszabályban meghatározott szakképesítéssel rendelkező személy adatai müködési nyilvántartásának az Szt.-ben meghatározottak szerinti vezetéséről.

(3) A Kormány által kijelölt szerv - külön jogszabályban meghatározottak szerint - országos nyilvántartást vezet a szolgáltató tevékenységet végző szolgáltatókról, intézményekről, helyettes szülői és nevelőszülői hálózatokról. A nyilvántartás adattartalma nyilvános.

(4) A nyilvántartás eszköze lehet minden olyan adattároló eszköz vagy módszer, amely biztosítja a 134. § (3) bekezdése szerinti védelmet.

138. §(1) A jegyző az ellátásra való jogosultság megállapításához, megváltoztatásához és megszüntetéséhez nyilvántartást vezet. A nyilvántartás tartalmazza

a) a gyermek, a szülő vagy más törvényes képviselő, illetve tartásra köteles személy személyazonosító adatait és a gyermek társadalombiztosítási azonosító jelét,

b) a 4 . $\S(1)$ bekezdésének $b$ ) pontja szerinti személy esetében a Magyarországon tartózkodás jogcímét, hozzátartozó esetén a rokoni kapcsolatot,

c) a jogosultsági feltételekre és az azokban bekövetkezett változásokra vonatkozó adatokat,

d) az ellátással kapcsolatos döntéseket,

e) a jogosultság és a térítési díj megállapításához szükséges jövedelmi adatokat. 
(2) A jegyző nyilvántartást vezet a hatósági intézkedéssel védelembe vett gyermekekről. A nyilvántartás tartalmazza

a) az (1) bekezdés $a$ ) pontjában meghatározott adatokat,

b) a gyermek egészségi és neveltségi állapotára vonatkozó adatokat,

c) a hatósági intézkedésre vonatkozó döntést, annak időpontját,

d) a hatósági intézkedés felülvizsgálatának időpontját és eredményét.

(3) A jegyző nyilvántartást vezet a szülő adatai nélkül anyakönyvezett gyermekekröl az (1) bekezdés $a$ ) pontjában meghatározott adatok mellett a hatósági eljárásra vonatkozó döntésről.

(4) A települési önkormányzat jegyzője nyilvántartást vezet az általa engedélyezett gyermekjóléti szolgáltató tevékenységről és az ellenőrzéssel kapcsolatos döntésről.

139. § (1) A személyes gondoskodásban részesülő személyekről az ellátó személy vagy az intézmény vezetője nyilvántartást vezet. A nyilvántartás tartalmazza

a) a 138. § (1) és (2) bekezdésében meghatározott adatokat,

b) az ellátás igénybevételének és megszünésének időpontját,

c) a térítési vagy gondozási díj fizetési kötelezettség teljesítésére, elmaradására, behajtására, illetve elévülésére vonatkozó adatokat.

(2) A Kormány által kijelölt szerv a személyes gondoskodást nyújtó gyermekjóléti alapellátások és gyermekvédelmi szakellátások finanszírozásának ellenőrzése céljából nyilvántartást vezet. A nyilvántartás tartalmazza

a) a személyes gondoskodásban részesülő személy

aa) személyazonosító adatait,

$a b)$ hontalan jogállására, a szabad mozgás és tartózkodás jogára vonatkozó adatot,

ac) társadalombiztosítási azonosító jelét,

b) a személyes gondoskodást nyújtó gyermekjóléti alapellátás vagy gyermekvédelmi szakellátás formáját, igénybevételének és megszünésének időpontját,

c) az intézmény, szolgáltató, hálózat ágazati azonosító jelét,

d) a finanszírozás, támogatás költségvetési törvény szerinti jogcímét és feladatmutatóját,

e) hatósági döntéssel elhelyezett gyermek, illetve fiatal felnőtt esetén

ea) a határozatot hozó szerv nevét, a határozat számát, keltét, jogerőre emelkedésének napját,

$e b)$ a hatósági döntés jellegét (ideiglenes hatályú elhelyezés, átmeneti nevelésbe vétel, tartós nevelésbe vétel, utógondozói ellátás elrendelése),

ec) a gyermek ellátási szükségletét,

ed) a gyermek gondozási helyét, a fiatal felnőtt ellátásának helyét, a gyermek hatósági döntéssel elrendelt nevelőszülői elhelyezése, illetve a fiatal felnőtt nevelőszülőnél nyújtott utógondozói ellátása esetén a nevelöszülö nevét és címét.

(3) Nem kell a (2) bekezdés szerinti nyilvántartásba venni az adatokat

a) alternatív napközbeni ellátás esetén,

b) házi gyermekfelügyelet esetén,

c) gyermekjóléti szolgáltatás esetén, ha a gyermekjóléti szolgáltatás nyújtása az első találkozást követően tett intézkedéssel lezárható,

d) a gyermekjóléti központ speciális szolgáltatásai közül az utcai és lakótelepi szociális munka, a kórházi szociális munka és a készenléti szolgálat esetén.

(4) A (2) bekezdés szerinti nyilvántartásból a személyes gondoskodást nyújtó gyermekjóléti alapellátás és gyermekvédelmi szakellátás igénybevételének megszűnésétől számított öt év elteltével törölni kell az adott személyre vonatkozó adatokat. A nyilvántartásból - ha törvény eltéröen nem rendelkezik - adat nem továbbítható.

(5) A (2) bekezdés szerinti nyilvántartás vezetése céljából a Kormány által kijelölt szerv a (2) bekezdés $a$ )-d) pontjaiban meghatározott adatok szolgáltatását kérheti a személyes gondoskodást nyújtó gyermekjóléti alapellátást, gyermekvédelmi szakellátást nyújtó személyektől vagy intézményektől.

(6) A (2) bekezdés szerinti nyilvántartás adatait a személyes gondoskodást nyújtó gyermekjóléti alapellátások és gyermekvédelmi szakellátások finanszírozásának ellenőrzése céljából elektronikus úton továbbítani kell a kincstárnak.

(7) A (2) bekezdés szerinti nyilvántartásból adatot kérhet a müködést engedélyező szerv a működési engedélyezésre és a hatósági ellenőrzésre vonatkozó eljárása lefolytatása céljából.

140. § (1) A gyámhivatal nyilvántartást vezet

a) az általa megállapított és folyósított pénzbeli ellátásokról,

b) az ideiglenes hatállyal elhelyezett, valamint az átmeneti és a tartós nevelésbe vett gyermekekröl, a gyámság és gondnokság alatt állókról a 139. § (1) bekezdésében meghatározott adattartalommal, 
c) az $a$ ) és $b$ ) pontban megjelölt személyek, valamint a gyermekek minden olyan vagyonáról, amely nem tartozik a szülő kezelésébe, amelyet a gyámhivatal rendszeres felügyelete alá vont, vagy amelyet a gyámhivatalhoz beszolgáltattak,

d) a vagyonnal rendelkező gyermekről a bekövetkező nagykorúsága szerint.

(2) A Kormány által kijelölt gyámhivatal az ideiglenes hatállyal elhelyezett külföldi állampolgárságú gyermekekről - ide nem értve a 4. § (1) bekezdésének $b$ ) pontja szerinti személyt - nyilvántartást vezet és az abban szereplő adatokról, valamint az azokban bekövetkezett változásokról rendszeresen tájékoztatja a minisztert. A nyilvántartás tartalmazza a 139. § (1) bekezdésében meghatározott adatokat.

(3) A gyámhivatal egységes nyilvántartást vezet az általa engedélyezett gyermekvédelmi szolgáltatásokról és az ellenőrzéssel kapcsolatos döntésekről. A nyilvántartás adattartalma nyilvános.

(4)

141. § (1) A területi gyermekvédelmi szakszolgálat vezetője nyilvántartást vezet

a) a nevelöszülőnél, gyermekotthonban vagy fogyatékosok és pszichiátriai betegek otthonában elhelyezett gyermekekről és az üres férőhelyekről,

b) az ideiglenes hatállyal elhelyezett gyermek ellátását biztosító nevelőszülőkröl, gyermekotthonokról,

c) az örökbefogadhatónak nyilvánított, illetve örökbefogadható gyermekekröl, valamint az örökbefogadásra váró szülökröl a 135 . $§(5)$ bekezdés $b$ ) és $e$ ) pontjában meghatározott adattartalommal,

d) az általa kijelölt, eseti gondnoki és hivatásos gyámi feladatokra kirendelhető személyekröl,

$e)$ az állami és nem állami fenntartó által müködtetett intézményben, illetve nevelőszülőnél ideiglenes hatállyal elhelyezett, átmeneti vagy tartós nevelésbe vett gyermek, továbbá az utógondozói ellátásban, illetve utógondozásban részesülö fiatal felnőtt gondozási napjairól.

(2) Az (1) bekezdés $c$ ) pontjában meghatározott nyilvántartásokról - a titkos örökbefogadás kivételével - a területi gyermekvédelmi szakszolgálat kérelemre tájékoztatja a szülőket, valamint az örökbefogadásra váró szülőket.

(3) A területi gyermekvédelmi szakszolgálat negyedévente tájékoztatja a gyámhivatalt az (1) bekezdés $a$ )$b$ ) és $d$ ) pontjaiban meghatározott nyilvántartásokról és az abban bekövetkező változásokról.

(4) A területi gyermekvédelmi szakszolgálat folyamatosan továbbítja az (1) bekezdés $c$ ) pontjában meghatározott nyilvántartásokban szereplő adatokat és az azokban bekövetkező változásokat az országos örökbefogadási nyilvántartás számára.

141/A. § A Kormány által kijelölt szerv országos jelentési rendszert müködtet. A fenntartó az országos jelentési rendszer számára köteles bejelenteni a külön jogszabályban meghatározott adatokat.

141/B. §(1) Az örökbefogadást elősegítő közhasznú szervezet az örökbe fogadni szándékozó személyekről és az örökbe fogadandó gyermekekröl - a nyílt örökbefogadások elömozdítása és az örökbefogadást elősegítő tevékenysége nyújtása céljából - nyilvántartást vezet.

(2) A nyilvántartás tartalmazza

a) az örökbe fogadni szándékozó személy

aa) személyazonosító adatait,

ab) Csjt. 47. §-a szerinti alkalmasságára vonatkozó adatokat,

ac) örökbe fogadandó gyermekkel kapcsolatos elvárásaira vonatkozó adatokat,

b) az örökbe fogadandó gyermek

ba) személyazonosító adatait,

bb) egészségi állapotára vonatkozó adatokat.

(3) A (2) bekezdés szerinti adatok a szolgáltatást igénybe vevővel való megállapodás megkötését követően haladéktalanul bekerülnek a nyilvántartásba.

(4) Az örökbefogadást elősegítő közhasznú szervezet az adatkezelés céljának megszünését követően haladéktalanul törli a nyilvántartásból az érintettre vonatkozó adatokat.

141/C. §(1) Az országos örökbefogadási nyilvántartást vezető szerv a gyermek belföldön történő örökbefogadásának elősegítése, az átmeneti vagy tartós nevelésbe vett gyermek belföldi örökbefogadására tett intézkedések eredménytelenségének megállapítása és a származás megismeréséhez való jog érvényesülésének biztosítása céljából országos örökbefogadási nyilvántartást vezet.

(2) Az országos örökbefogadási nyilvántartás a gyermek, az örökbe fogadni szándékozó személy és a válsághelyzetben lévő várandós anya, a vér szerinti szülő 135 . § (8) bekezdésében meghatározott adatait tartalmazza.

(3) Az országos örökbefogadási nyilvántartásból

a) $a z$ országos örökbefogadási nyilvántartást vezető szerv közremüködésével létrejött örökbefogadások esetén az örökbe fogadott gyermek nagykorúságától számított 50 év elteltével,

b) az a) pont alá nem tartozó esetekben az adatkezelés céljának megszünését követően haladéktalanul törölni kell az adatokat.

141/D. §(1) A központi hatóság az átmeneti vagy tartós nevelésbe vett gyermek külföldre történő örökbefogadásának elősegítése, a külföldi örökbefogadások utánkövetése és a származás megismeréséhez 
való jog érvényesülésének biztosítása céljából nyilvántartást vezet a Csjt. 49. § (3) bekezdése alapján külföldre örökbe adható gyermekröl és a külföldre örökbe adott gyermekről, a külföldön élö örökbe fogadni szándékozó személyröl és a külföldön élö örökbe fogadó szülőröl a 135. § (9) bekezdés $a$ )-c) pontjában meghatározott adattartalommal.

(2) Az (1) bekezdés szerinti nyilvántartásból

a) a központi hatóság közremüködésével létrejött örökbefogadások esetén az örökbe fogadott gyermek nagykorúságától számított 50 év elteltével,

b) az a) pont alá nem tartozó esetekben az adatkezelés céljának megszűnését követően haladéktalanul törölni kell az adatokat.

142. § (1) Ha törvény másképp nem rendelkezik, a 138. §, a 139. § (1) bekezdése, a 140. § és a 141. § szerint vezetett nyilvántartásból - a jogosultság megszünésétől, illetve a gyermek nagykorúságától számított 25 év elteltével - törölni kell az adott személyre vonatkozó adatokat.

(2) Az adatkezelésre és a nyilvántartások vezetésére vonatkozó rendelkezések az irányadóak a személyes gondoskodás megszervezésének a nem állami szerv által az önkormányzattól történő átvállalása, illetve a törvény által nem szabályozott, az önkormányzat képviselö-testülete vagy a jegyzője feladat- és hatáskörébe tartozó ellátásokról vezetett nyilvántartás esetén is.

(3) Az adatkezelésre törvényben feljogosított szerveken kívül a 137. § (2) bekezdése, a 138. §, a 139. §, a 140. § (1) és (2) bekezdése, a 141. § és a 141/B-141/D. §-ok szerinti nyilvántartások adatainak megismerésére jogosult

a) a rá vonatkozó adatok tekintetében az érintett személy és törvényes képviselője,

b) - az adatok megismeréséhez füződő jogos érdek igazolásával - az egymásra vonatkozó adatok tekintetében a gyermek és a szülö,

c) - $a z$ adatok megismeréséhez füződő jogos érdek igazolásával - a szülőre vonatkozó adatok tekintetében a másik szülő.

\section{Fejezet}

\section{A gyermekek védelmének főbb finanszírozási szabályai}

143. §(1) A gyermekvédelmi rendszer múködéséhez szükséges pénzügyi fedezetet a központi költségvetés és az önkormányzat hozzájárulása biztosítja, amit az igénylő által fizetendő térítési és gondozási díj egészít ki.

(2) Az állam hozzájárul az önkormányzat által megállapított és folyósított pénzbeli és természetbeni ellátások kiadásaihoz, valamint a helyi önkormányzat által fenntartott, a személyes gondoskodás keretébe tartozó ellátási formák müködési és fejlesztési költségeihez.

(3) Az állam a helyi önkormányzatok feladatainak ellátásához

a) az állandó lakos után járó differenciált szociális és gyermekjóléti normatív állami hozzájárulással (a továbbiakban: szociális és gyermekjóléti normatíva),

b) a fenntartott intézményben ellátott gyermekek után járó normatív állami hozzájárulással,

c) a települési önkormányzat jegyzője, illetve a gyámhivatal határozata alapján ideiglenes hatállyal elhelyezett, valamint átmeneti és tartós nevelésbe vett gyermek után, továbbá a korábban gondozás alatt álló fiatal felnőtt után járó normatív állami hozzájárulással,

d) kötött felhasználású támogatásokkal járul hozzá.

(4) A szociális és gyermekjóléti normatíva összege a települési önkormányzat területén élő lakosság szociális helyzete, valamint az állandó lakosú gyermek száma szerint eltérő. A differenciálás alapjául szolgáló mutatókat évente a költségvetési törvény rögzíti.

(5) A normatív állami hozzájárulással történő támogatás szakmai céloknak megfelelő módját és mértékét a költségvetési törvény határozza meg.

144. § (1) A gyermektartásdíj megelőlegezésének, valamint az otthonteremtési támogatásnak a teljes fedezetét a központi költségvetés elöleg nyújtásával biztosítja.

(2) Szakmai programok meghirdetésével kell elösegíteni a helyi önkormányzat részére meghatározott ellátási formák létrehozásának, valamint olyan mértékü fejlesztésének és korszerüsítésének támogatását, amely lehetővé teszi az önkormányzat az e törvényben elöírt kötelezettségének teljesítését.

145. §(1) A külön törvényben meghatározottak szerint normatív hozzájárulásra, illetve feladatfinanszírozásra jogosult a jogerős müködési engedéllyel gyermekjóléti vagy gyermekvédelmi szolgáltató tevékenységet végző, közfeladatot ellátó egyházi és - külön törvényben meghatározott - nem állami fenntartó.

(2) Az állami, egyházi és nem állami fenntartó normatív állami hozzájárulásra való jogosultságának feltétele a

a) személyes gondoskodást nyújtó gyermekjóléti alapellátást nyújtó új szolgáltatónak, intézménynek, hálózatnak,

b) gyermekek napközbeni ellátása és gyermekek átmeneti gondozása esetében az új férőhelyeknek 
a gyermekjóléti szolgáltatások területi lefedettségét figyelembe vevő, külön jogszabály szerinti finanszírozási rendszerbe történő befogadása.

(2a) A (2) bekezdés alkalmazásában új szolgáltatónak, intézménynek, hálózatnak, illetve férőhelyszámnak az minősül, amelyre a fenntartó 2011. december 31-én nem rendelkezett jogerős müködési engedéllyel és a gyermekjóléti szolgáltatások területi lefedettségét figyelembe vevő finanszírozási rendszerbe nem nyert még befogadást.

(2b) A (2a) bekezdés szerinti esetben a normatív hozzájárulás a külön jogszabály szerinti finanszírozási rendszerbe történő befogadás nélkül is jár, ha a változás a müködési engedély módosítását nem teszi szükségessé.

(3) A normatív hozzájárulásban és támogatásban részesülő egyházi és nem állami fenntartású gyermekjóléti, gyermekvédelmi intézmény a munkavállalók számára legalább a közalkalmazottak jogállásáról szóló 1992. évi XXXIII. törvény 55-80. §-aiban megállapított, a munkaidőre, pihenőidőre, előmeneteli és illetményrendszerre vonatkozó feltételeket köteles biztosítani.

(4) A nem állami, illetve egyházi fenntartónak a külön jogszabályban meghatározott, és az általa fenntartott gyermekjóléti, gyermekvédelmi intézmény müködéséhez biztosított normatív állami hozzájárulás - kivéve a kiegészítő támogatást - teljes összegét át kell adnia azon intézmény részére, amelyre tekintettel a támogatás megállapítására sor került.

145/A. § (1) Ha a helyi önkormányzat vagy a társulás a fenntartásában müködő szolgáltatót, intézményt egyházi jogi személy fenntartásába adja át, az egyházi kiegészítő támogatást a helyi önkormányzat, illetve a társulás köteles a központi költségvetésnek öt éven keresztül folyamatosan, a nettó finanszírozás keretében megtéríteni.

(2) Ha a helyi önkormányzat vagy a társulás fenntartásában müködő szolgáltató, intézmény megszünésétől számított tizenkét hónapon belül egyházi jogi személy új szolgáltatót, intézményt hoz létre, a megszünt intézményben is végzett gyermekjóléti, gyermekvédelmi szolgáltató tevékenység után kifizetett egyházi kiegészítő támogatást a helyi önkormányzat, illetve a társulás köteles a központi költségvetésnek öt éven keresztül folyamatosan, a nettó finanszírozás keretében megtéríteni, feltéve, hogy

a) a megszünt és a létrehozott szolgáltatónál, intézményben ellátott gyermekeknek legalább ötven százaléka azonos, valamint

b) a megszünt és a létrehozott intézmény - részben vagy egészben - ugyanabban az ingatlanban müködik.

(3) A megtérítendő összeg megállapítása során nem vehető figyelembe a korábbi fenntartó mủködési engedélyében nem szereplő szolgáltató tevékenység - ide nem értve azt az esetet, ha az új szolgáltató tevékenységet a korábbi férőhelyek átminősítésével hozták létre - és féröhelyszám.

(4) Az egyházi kiegészítő támogatás megtérítéséről a kincstár külön kormányrendeletben meghatározott eljárás szerint határozatban dönt.

(5)

146. $§(1)$ Térítési díj alapellátás keretében biztosított gyermekek napközbeni ellátásáért és gyermekek átmeneti gondozásáért, valamint a személyes gondoskodást nyújtó gyermekvédelmi szakellátás keretében biztosított utógondozói ellátásért térítési díjat kell fizetni.

(2) Az e törvényben meghatározottak szerint a térítési díjat

a) az ellátást igénybe vevő nagykorú jogosult,

b) az ellátást igénybe vevő gyermek esetén a szülői felügyeletet gyakorló szülő vagy más törvényes képviselö,

c) az ellátást igénybe vevő gondnokolt esetében a törvényes képviselő

$(\mathrm{az} a)$-c) pont alattiak a továbbiakban együtt: kötelezett) az intézménynek fizeti meg.

147. § (1) A fenntartó megállapítja a 146. § (1) bekezdése szerinti ellátások intézményi térítési díját, ami a szolgáltatási önköltség és a normatív állami hozzájárulás különbözete. Az intézményi térítési díjat több szolgáltatás és ellátás nyújtása esetében is szolgáltatásonként (ellátásonként) kell meghatározni, a közös költségelemek szolgáltatásonkénti (ellátásonkénti) közvetlen költségeinek arányában történő megosztásával.

(2) A bölcsőde esetében az intézményi térítési díjat külön meg kell határozni a gyermek gondozására, nevelésére, nappali felügyeletére és a vele történő foglalkozásra (a továbbiakban együtt: gondozására), valamint a 151. § (3) bekezdésében foglaltak szerint a gyermekétkeztetésre vonatkozóan.

(3) A szolgáltatási önköltséget a tárgyévre tervezett adatok alapján a tárgyév április elsejéig kell megállapítani. A szolgáltatási önköltség év közben egy alkalommal korrigálható, ha azt a tárgyidőszaki folyamatok indokolják.

(4) A fenntartó az intézményi térítési díjat az (1) bekezdés szerint kiszámított és külön jogszabály szerint dokumentált térítési díjnál alacsonyabb összegben is meghatározhatja. 
148. § (1) A kötelezett által fizetendö térítési díj összegét (a továbbiakban: személyi térítési díj) az intézményvezető, a szolgáltatást vezető vagy a müködtető (a továbbiakban együtt: intézményvezető) konkrét összegben állapítja meg.

(2) A bölcsődei ellátás esetében az intézményvezető a 151. § (4) bekezdés alapján megállapítja a bölcsődei ellátás keretében biztosított gyermekétkeztetésre vonatkozó személyi térítési díjat, valamint emellett - a fenntartó döntésétől függően - a bölcsődei ellátás keretében nyújtott gondozásra is megállapíthat személyi térítési díjat.

(3) Az intézményvezető a kötelezettet írásban értesíti a személyi térítési díj összegéről

a) a gyermekek napközbeni ellátása esetén a szolgáltatás, ellátás igénybevételét megelőzően,

b) a gyermekek átmeneti gondozása és utógondozói ellátás esetén legkésőbb az ellátás igénybevételétől számított harminc napon belül.

(4) A személyi térítési díj - a gyermekétkeztetés kivételével - nem haladhatja meg az intézményi térítési díj összegét. Ha az intézményi térítési díj számítása nem eredményez pozitív számot, a személyi térítési díj összege nulla.

(5) A személyi térítési díj összege - önkormányzati intézmény esetén - a fenntartó rendeletében foglaltak szerint csökkenthető, illetve elengedhetö, ha a kötelezett jövedelmi és vagyoni viszonyai ezt indokolttá teszik.

(6) Ha a kötelezett a személyi térítési díjat vitatja, illetve annak csökkentését vagy elengedését kéri, a (3) bekezdés szerinti értesítés kézhezvételétől számított nyolc napon belül a fenntartóhoz fordulhat.

(7) Ha a kötelezett a személyi térítési díj egyházi vagy nem állami fenntartó által megállapított összegét vitatja, a bíróságtól kérheti a személyi térítési díj megállapítását. A bíróság jogerős határozatáig a korábban megállapított személyi térítési díjat kell megfizetni.

(8) A személyi térítési díj összege évente két alkalommal vizsgálható felül és változtatható meg, kivéve, ha a kötelezett jövedelme olyan mértékben csökken, hogy az e törvényben szabályozott díjfizetési kötelezettségének nem tud eleget tenni. A kötelezett nem kötelezhető a felülvizsgálatot megelőző időszakra vonatkozóan az új térítési díj megfizetésére.

(9) A térítési díj meg nem fizetése esetén késedelmi pótlék nem állapítható meg.

(10) A kötelezett írásban vállalhatja a mindenkori intézményi térítési díjjal azonos személyi térítési díj megfizetését, vagy a mindenkori intézményi térítési díj és a számára megállapítható személyi térítési díj különbözete egy részének megfizetését. Ebben az esetben nem kell a 150. $§(1)-(3)$ bekezdésében foglaltakat alkalmazni, ugyanakkor biztosítani kell, hogy az ellátást ilyen módon igénylő ne kerüljön előnyösebb helyzetbe, mint ha a vállalást a kötelezett nem tenné meg.

(11) A normatív állami hozzájárulásban nem részesülő fenntartó esetén a 147. §-t, a 148. § (4) bekezdését és a 150. \$-t nem kell alkalmazni.

149. § Térítésmentesen kell biztosítani a 40. § (1)-(3) bekezdés szerinti gyermekjóléti szolgáltatást, amely esetben intézményi térítési díjat sem kell megállapítani.

150. § (1) A személyi térítési díj megállapításánál

a) utógondozói ellátás esetében az igénybe vevő fiatal felnőtt rendszeres havi jövedelmét,

b) a gyermekek napközbeni ellátása és a gyermekek átmeneti gondozása esetében a gyermek családjában az egy före jutó rendszeres havi jövedelmet

kell figyelembe venni.

(2) Az (1) bekezdés $b$ ) pontjában meghatározott egy före jutó jövedelem megállapításánál a 19. § (4) bekezdés $a$ )-e) pontjában felsorolt személyek jövedelmét kell figyelembe venni.

(3) A személyi térítési díj összege igénybe vevőnként nem haladhatja meg az (1) bekezdésben meghatározott jövedelem

a) 50\%-át családi napközi és családi gyermekfelügyelet esetén,

b) 20\%-át az a) pont alá nem tartozó egyéb gyermekek napközbeni ellátása esetén,

c) $25 \%$-át az a) pont alá nem tartozó egyéb gyermekek napközbeni ellátása esetén, ha annak keretében étkezést is biztosítanak,

d) 50\%-át átmeneti gondozás esetén,

e) $30 \%$-át a fiatal felnőtt utógondozói ellátása esetén.

(4) A családok átmeneti otthona esetében a szolgáltatást a gyermekkel együtt igénybe vevő szülő és nagykorú testvér számára is személyi térítési díjat kell megállapítani a (3) bekezdés $d$ ) pontjának figyelembevételével.

(5) Ingyenes ellátásban kell részesíteni a jogosultat, ha a térítési díj fizetésére kötelezett jövedelemmel nem rendelkezik.

(6) Bölcsőde esetében

a) a rendszeres gyermekvédelmi kedvezményben részesülő gyermek,

b) a tartósan beteg vagy fogyatékos gyermek,

c) a három- vagy többgyermekes család gyermekének, 
d) az átmeneti gondozásban lévő, az ideiglenes hatállyal nevelőszülőnél vagy gyermekotthonban elhelyezett, az átmeneti vagy tartós nevelésbe vett gyermek

gondozását térítésmentesen kell biztosítani. Ezekben az esetekben személyi térítési díj - a 151. § (5) bekezdésében foglaltak figyelembevételével - csak az étkezésért kérhető. A $c$ )pont szerinti gyermekszámot a 151. $\S(10)$ bekezdésében foglaltak szerint kell meghatározni.

151. § (1) A gyermekétkeztetés szabályait kell alkalmazni

a) a bölcsődében, hetes bölcsődében,

b) az óvodában,

c) a nyári napközis otthonban,

d) az általános és középiskolai diákotthonban, kollégiumban, illetve az itt szervezett externátusi ellátásban,

e) az általános iskolai, továbbá - ha külön jogszabály másképpen nem rendelkezik - középfokú iskolai menzai ellátás keretében,

f) a fogyatékos gyermekek, tanulók nevelését, oktatását ellátó intézményben és a fogyatékos gyermekek számára nappali ellátást nyújtó, az Szt. hatálya alá tartozó fogyatékosok nappali intézményében,

g) a szociális nyári gyermekétkeztetés keretében

nyújtott étkeztetésre.

(2) Iskolai étkeztetésben részesülhet az a tanuló is, aki a napközit nem veszi igénybe. Az étkezések közül az ebéd külön is igényelhető.

(3) A gyermekétkeztetés intézményi térítési díjának alapja az élelmezés nyersanyagköltségének egy ellátottra jutó napi összege.

(4) A gyermekétkeztetés személyi térítési díját az intézményvezető a (3) bekezdés szerinti napi összeg általános forgalmi adóval növelt összegének és az igénybe vett étkezések számának, valamint az (5) bekezdésben megjelölt normatív kedvezményeknek a figyelembevételével állapítja meg.

(5) Gyermekétkeztetés esetén

a) a rendszeres gyermekvédelmi kedvezményben részesülő

aa) bölcsődés,

$a b)$ óvodás,

ac) 1-8. évfolyamon nappali rendszerü iskolai oktatásban részt vevő,

ad) fogyatékos gyermekek számára nappali ellátást nyújtó, az Szt. hatálya alá tartozó intézményben elhelyezett, $a a$ )-ac) alpont szerinti életkorú

gyermek után az intézményi térítési díj 100\%-át,

b) az a) pont alá nem tartozó, rendszeres gyermekvédelmi kedvezményben részesülő gyermek és tanuló után az intézményi térítési díj 50\%-át,

c) három- vagy többgyermekes családoknál gyermekenként az intézményi térítési díj 50\%-át,

d) az ad) alpont alá nem tartozó, tartósan beteg vagy fogyatékos gyermek, tanuló után az intézményi térítési díj 50\%-át,

kedvezményként kell biztosítani [az $a$ )-e) pont a továbbiakban együtt: normatív kedvezmény].

(6) A normatív kedvezmény csak egy jogcímen vehető igénybe.

(7) Nem jár a tanulónak kedvezmény azon étkeztetésére, amely kedvezményre - a szakképzésre vonatkozó rendelkezések szerint létrejött - tanulószerződése alapján már jogosult.

(8) A gyermekvédelmi gondoskodásban részesülő - nevelőszülőnél, gyermekotthonban vagy más bentlakásos intézményben nevelkedő - ideiglenes hatállyal elhelyezett, átmeneti vagy tartós nevelésbe vett gyermek után nem vehető igénybe a normatív kedvezmény.

(9) A gyermek lakóhelye szerint illetékes önkormányzat, illetve - ha a gyermek közoktatási intézményben részesül étkezésben - a nevelési-oktatási intézmény vezetője - a fenntartó által megállapított szabályok keretei között - a gyermek egyéni rászorultsága alapján további gyermekenkénti kedvezményt állapíthat meg.

(10) Az (5) bekezdés szerinti normatív kedvezmény megállapításához közös háztartásban élőként kell figyelembe venni

a) a tizennyolc éven aluli,

b) a huszonöt évesnél fiatalabb, közoktatásban nappali rendszerü oktatásban részt vevő, illetve felsőoktatásban nappali tagozaton tanuló, valamint

c) életkortól függetlenül a tartósan beteg vagy súlyos fogyatékos gyermekeket.

(11) A normatív kedvezményt a tanuló után a nappali rendszerü oktatásban való részvétele befejezéséig kell biztosítani.

$(\ldots)$ 


\section{5/1998. (IV. 30.) NM rendelet a személyes gondoskodást nyújtó gyermekjóléti, gyermekvédelmi intézmények, valamint személyek szakmai feladatairól és múködésük feltételeiről}

A gyermekek védelméröl és a gyámügyi igazgatásról szóló 1997. évi XXXI. törvény (a továbbiakban: Gyvt.) 162. §-a (2) bekezdésének $a$ )-b) pontjában kapott felhatalmazás alapján az alábbiakat rendelem el:

\section{Fejezet}

\section{ÁLTALÁNOS RENDELKEZÉSEK}

1. § (1) A rendelet hatálya kiterjed valamennyi személyes gondoskodást nyújtó ellátásra, az ellátásban részesülő gyermekre és szülőjére, törvényes képviselőjére, a fiatal felnőttre, továbbá a fenntartóra, az ellátást nyújtó személyre és intézményre.

(2) E rendelet alkalmazásában személyes gondoskodáson a Gyvt. 15. § (2) bekezdésében meghatározott gyermekjóléti alapellátást (a továbbiakban: alapellátás), valamint a Gyvt. 15. § (3) bekezdésében meghatározott gyermekvédelmi szakellátást (a továbbiakban: szakellátás) kell érteni ${ }^{98}$.

(3) E rendeletben foglaltakat kell alkalmazni az egyházi és nem állami szerv által nyújtott személyes gondoskodásra is.

(4) A Gyvt. 5. §-ában foglalt értelmező rendelkezések e rendelet vonatkozásában is irányadóak.

(5) E rendelet alkalmazásában ellátást nyújtó: a gyermek gondozását, nevelését, felügyeletét közvetlenül végző személy, illetve intézmény.

2. §(1) A személyes gondoskodás során a gyermeki és szülői jogok tiszteletben tartásával, azok érvényesülését biztosítva kell eljárni.

(2) A gyermeki jogok minél szélesebb körü érvényesülése érdekében a gyermekjóléti, illetve gyermekvédelmi szolgáltató tevékenységet végzők (a továbbiakban: szolgáltatók) gondoskodnak arról, hogy a gyermekek számára megismerhető legyen a gyermekjogi képviselő neve, telefonszáma, valamint fogadóóráinak helye és időpontja.

(3) A szolgáltatók a gyermekjogi képviselő részére biztosítják

a) annak odalátogatása során az intézmény területén belül a gyermekek számára könnyen hozzáférhető és négyszemközti beszélgetés lefolytatására alkalmas megfelelő helyiséget;

b) a helyszínen való tájékozódás és az iratokba való betekintés lehetőségét

c) az érdek-képviseleti fórum ülésének időpontjáról való tudomásszerzést.

(4) A gyermekjogi képviselő által írásban tett észrevételekre, megkeresésekre a szolgáltatók 15 napon belül kötelesek válaszolni, illetőleg megtett intézkedéseikről a gyermekjogi képviselőt értesíteni.

(5) A személyes gondoskodást nyújtó személy, illetve intézmény az önkéntesen vagy hatósági intézkedés alapján igénybe vett ellátás megkezdésekor gondoskodik a gyermeknek és szülöjének (törvényes képviselőjének), illetve a fiatal felnőttnek a Gyvt. 33. § (2) bekezdésében ${ }^{99}$ és 34. §-ában foglaltakról való

98 (2) A személyes gondoskodás keretébe tartozó gyermekjóléti alapellátások:

a) a gyermekjóléti szolgáltatás,

b) a gyermekek napközbeni ellátása,

c) a gyermekek átmeneti gondozása.

(3) A személyes gondoskodás keretébe tartozó gyermekvédelmi szakellátások:

a) az otthont nyújtó ellátás,

b) az utógondozói ellátás,

c) a területi gyermekvédelmi szakszolgáltatás.

99 33. § (1) A személyes gondoskodás feltételeiről a kérelem benyújtásakor a kérelmezőt tájékoztatni kell.

(2) A személyes gondoskodást nyújtó ellátás esetén az ellátás megkezdésekor az ellátásra jogosult gyermeket és törvényes képviselőjét, illetve a fiatal felnőttet tájékoztatni kell

a) az ellátás tartamáról és feltételeiről,

b) az intézmény által vezetett, reá vonatkozó nyilvántartásokról,

c) az ellátásra jogosult gyermek, fiatal felnőtt és hozzátartozói közötti kapcsolattartásról, különösen a látogatás, a távozás és a visszatérés rendjéről

ca) a gyermekek átmeneti otthonában biztosított személyes gondoskodást nyújtó gyermekjóléti alapellátásnál, ha a gyermek kapcsolattartásra jogosult hozzátartozói külön élnek,

cb) a családok átmeneti otthonában biztosított személyes gondoskodást nyújtó gyermekjóléti alapellátásnál, ha a gyermeknek van különélő, kapcsolattartásra jogosult hozzátartozója, 
tájékoztatásáról. A gyermek szülője (törvényes képviselője), illetve a fiatal felnőtt írásban nyilatkozik a tájékoztatás megtörténtéröl.

(6) Az ellátás megkezdésekor az ellátást nyújtó felhívja a gyermek törvényes képviselőjét, illetve a fiatal felnőttet az intézményi nyilvántartásokhoz szükséges adatok szolgáltatására, továbbá a jogosultsági feltételekben, illetve a nyilvántartásban szereplö adatokban beállott változások bejelentésére.

2/A. § (1) A gyermekjóléti alapellátás - kivéve a gyermekek napközbeni ellátása - és a gyermekvédelmi szakellátás során a gyermekek élethelyzetének feltárására, sorsának megtervezésére és végigkísérésére a gyámhatóságok, a területi gyermekvédelmi szakszolgálatok, a gyermekjóléti szolgálatok és a személyes gondoskodást nyújtó szervek és személyek által kezelt személyes adatokról szóló 235/1997. (XII. 17.) Korm. rendelet (a továbbiakban: Ar.) alapján létrejövő „Gyermekeink védelmében” elnevezésű adatlaprendszer (a továbbiakban: gyermekvédelmi nyilvántartás) szolgál.

(2) A gyermekvédelmi nyilvántartás célja, hogy biztosítsa a különböző gyermekvédelmi szolgáltatások, intézmények, valamint a hatóságok között a Gyvt. adatkezelésre vonatkozó rendelkezéseinek figyelembevételével a kölcsönös tájékoztatást és az együttmüködést, továbbá megjelölje az elvégzendő gondozási-nevelési feladatokat, illetőleg lehetővé tegye a gyermek sorsának alakításában részt vevő intézmények és hatóságok tevékenységének ellenőrzését.

3. § (1) A gyermekjóléti szolgáltatás és az átmeneti gondozás formáinak szakmai létszám irányszámait, továbbá a bölcsődei ellátásnak, valamint a szakellátás formáinak szakmai létszámminimum követelményeit az 1. számú melléklet tartalmazza. A feladatellátás érdekében további munkakörök is létesíthetők.

(2) Magasabb vezetői, vezetői beosztást

a) a három vagy annál több szakmai munkát végző személyt foglalkoztató gyermekjóléti szolgálatnál,

b) a tizenkét férőhely feletti átmeneti ellátást nyújtó intézménynél,

c) a tíz vagy ennél több nevelőszülő munkáját irányító gyermekvédelmi szolgáltatónál,

d) a tizenkét férőhely feletti gyermekotthonnál, illetve speciális gyermekotthonnál,

e) a területi gyermekvédelmi szakszolgálatnál

betöltő személyek - a (3) bekezdésben foglaltak figyelembevételével - szociális szakvizsga letételére kötelezettek. Ezek a követelmények a bölcsődei igazgatóságoknál és bölcsődék egyesített intézményeinél csak a magasabb vezetőre vonatkoznak.

(3) A (2) bekezdésben felsorolt személyes gondoskodást nyújtó gyermekjóléti, gyermekvédelmi intézményekben magasabb vezetői, vezetői beosztást betöltő személy a megbízást követő két éven belül köteles a szociális szakvizsgát letenni. E határidőt követően szociális szakvizsgával nem rendelkező személy magasabb vezetői, vezetői beosztásban nem foglalkoztatható.

(4) Mentesül a szakvizsga letételének kötelezettsége alól az, aki a gyermekjóléti, gyermekvédelmi szakképesítéshez kapcsolódó szakterületen tudományos fokozatot szerzett, ideértve - az egyetemi végzettséget igazoló doktori címek kivételével - a felsőoktatásról szóló 2005. évi CXXXIX. törvény 149. §-a szerinti doktori címeket, továbbá akinek 2001. január 1-jét követően öt vagy öt évnél kevesebb időtartam van hátra a reá irányadó nyugdíjkorhatár betöltéséig.

(5) Az egyes munkakörökben foglalkoztatott személyek képesítési elöírásait a 2. számú melléklet tartalmazza.

(6) A munkáltató a személyes gondoskodás körébe tartozó feladatokat ellátó személyek részére - a közalkalmazottak jogállásáról szóló 1992. évi XXXIII. törvény 79. §-ának (1)-(2) bekezdésében foglaltak szerint - munkaruhát biztosít.

cc) a gyermekotthonban biztosított személyes gondoskodást nyújtó gyermekvédelmi szakellátásnál (a $c a$ )cc) alpontokban szereplö intézmények a továbbiakban együtt: bentlakásos gyermekintézmény),

cd) a helyettes szülőnél biztosított személyes gondoskodást nyújtó gyermekjóléti alapellátásnál és

ce) a nevelőszülőnél biztosított személyes gondoskodást nyújtó gyermekvédelmi szakellátásnál,

d) az érték- és vagyonmegőrzés módjáról,

e) az intézmény házirendjéről,

f) panaszjoga gyakorlásának módjáról,

g) a fizetendő térítési, illetve gondozási díjról,

h) a jogosult jogait és érdekeit képviselő érdek-képviseleti fórumról.

(3) Az ellátásra jogosult gyermek törvényes képviselője, illetve a fiatal felnőtt köteles

a) a (2) bekezdésben meghatározott tájékoztatás megtörténtéröl nyilatkozni,

b) az e törvény alapján vezetett intézményi nyilvántartásokhoz adatokat szolgáltatni,

c) nyilatkozni a jogosultsági feltételekben, valamint a személyazonosító adatokban beállott változásokról. 
(7) A munkáltató beszerzi az 1. számú mellékletben meghatározott munkakörben foglalkoztatni kívánt személy nyilatkozatát arról, hogy nem áll fenn vele szemben a Gyvt. 15. §-ának (8) bekezdésében ${ }^{100}$ meghatározott kizáró ok.

(8) Többcélú intézményben vezetői megbízást az kaphat, illetve vezetői munkakörbe az nevezhető ki, aki bármely, az intézmény által biztosított szolgáltatás, illetve ellátás vezetőjére meghatározott, felsőfokú végzettség körébe tartozó képesítési elöírásoknak megfelel.

4. § (1) A szociális és gyámhivatal (a továbbiakban: megyei gyámhivatal), illetve a gyermekek és az ifjúság védelméért felelős miniszter (a továbbiakban: miniszter) által kijelölt módszertani és továbbképzési feladatokat ellátó intézmény (a továbbiakban: módszertani intézmény) a Gyvt. 96. §-ának (9) bekezdésében foglaltak szerint segíti illetékességi területén a szolgáltatók munkáját. Tevékenysége során együttmüködik a Nemzeti Család- és Szociálpolitikai Intézettel (a továbbiakban: Intézet).

(2) Módszertani intézményi feladatok ellátására az a gyermekjóléti, gyermekvédelmi intézmény jelölhető ki, amely

a) a gyermekjóléti és gyermekvédelmi szolgáltató tevékenység engedélyezését szabályozó jogszabályban meghatározott müködési engedéllyel rendelkezik,

b) legalább öt éve müködik,

c) vezetője legalább ötéves szakmai és kétéves vezetői gyakorlattal rendelkezik,

d) a módszertani munkára vonatkozó szakmai programmal rendelkezik.

(3) A módszertani intézmény, valamint módszertani feladatai ellátása körében az Intézet

a) figyelemmel kíséri az alap- és szakellátásokat érintő tudományos kutatásokat, publikációkat, a modellértékủ új kezdeményezéseket, továbbá elősegíti ezek mind szélesebb körü megismerését, gyakorlati alkalmazását,

b) szervezi a gyermekjóléti, gyermekvédelmi területen dolgozók tapasztalatcseréjét és továbbképzését,

c) elemzi és értékeli a szolgáltatók müködését, valamint javaslatot tesz a hiányzó ellátások megszervezésére, a müködés lehetőség szerinti javítására,

d) információkat gyüjt az illetékességi területén az ellátórendszer sajátosságairól, problémáiról,

$10015 \S$ (8) A gyermekvédelmi rendszerben a külön jogszabályban meghatározott munkakörben, valamint önkéntes jogviszonyban nem foglalkoztatható az a személy, akivel szemben a 11/A. § (8) bekezdésben meghatározott kizáró okok valamelyike fennáll, vagy aki e törvényben meghatározott igazolási kötelezettségének ismételt szabályszerü felhívásra sem tesz eleget, és nem bizonyítja, hogy a kötelezettség elmulasztása rajta kívülálló ok következménye.

11/A§ (8) a) aki büntetett elöéletü,

b) aki büntetlen elöéletü, de a bíróság büntetőjogi felelősségét jogerős ítéletben megállapította a Büntető Törvénykönyvről szóló 1978. évi IV. törvény XII. fejezet I. címében meghatározott élet, testi épség és egészség elleni büncselekmény, II. címében meghatározott egészségügyi beavatkozás, orvostudományi kutatás rendje és az egészségügyi önrendelkezés elleni büncselekmény, kényszerítés, a lelkiismeret és vallásszabadság megsértése, közösség tagja elleni erőszak, személyi szabadság megsértése, emberrablás, emberkereskedelem, zaklatás, magántitok megsértése, visszaélés személyes adattal, visszaélés közérdekü adattal, XIV. fejezetében meghatározott házasság, család, ifjúság és nemi erkölcs elleni bűncselekmény, embercsempészet, XV. fejezet V. címében meghatározott hivatalos személy elleni büncselekmény és VI. címében meghatározott igazságszolgáltatás elleni büncselekmény, XVI. fejezet II-IV. címében meghatározott köznyugalom, közbizalom és közegészség elleni büncselekmény, lopás, sikkasztás, csalás, hütlen kezelés, hanyag kezelés, rablás, kifosztás, zsarolás, orgazdaság vagy olyan bủntett miatt, amelyet bủnszervezet keretében követett el

ba) ötévi vagy azt meghaladó végrehajtandó szabadságvesztés büntetés esetén a mentesítés beálltától számított tizenkét évig,

bb) öt évet el nem érő végrehajtandó szabadságvesztés esetén a mentesítés beálltától számított tíz évig,

bc) végrehajtásában felfüggesztett szabadságvesztés esetén a mentesítés beálltától számított nyolc évig,

bd) közérdekü munka vagy pénzbüntetés kiszabása esetén a mentesítés beálltától számított öt évig,

be) végrehajtásában felfüggesztett pénzbüntetés esetén a mentesítés beálltától számított három évig,

c) aki a b) pontban meghatározott büncselekmény miatt büntetőeljárás hatálya alatt áll,

d) aki a szakmai gyakorlata meglétének vizsgálata során figyelembe veendő foglalkozás tekintetében foglalkoztatástól eltiltás hatálya alatt áll, valamint

e) akinek szülői felügyeleti jogát a bíróság jogerős ítéletével megszüntette, valamint - ha külön jogszabály másképp rendelkezik - akinek szülöi felügyeleti joga a gyermek átmeneti nevelésbe vétele miatt szünetel. 
e) szaktanácsadás keretében szakmai módszertani segítséget nyújt a gyermekjóléti, gyermekvédelmi területen dolgozók szakmai problémáinak megoldásához,

f) szervezi az egyetemi, főiskolai képzésben és a szakképzésben részt vevő hallgatók, tanulók terepgyakorlatát.

(3a) A módszertani intézmény a (3) bekezdésben foglaltakon túl

a) az Intézet irányításával részt vesz a minőségfejlesztési elvek kidolgozásában, és segítséget nyújt azok gyakorlati alkalmazásához,

b) részt vesz a gyermekek és az ifjúság védelméért felelös miniszter által vezetett minisztérium (a továbbiakban: Minisztérium), valamint az Intézet által szervezett szakmai programok lebonyolításában, megszervezésében, valamint az e szervektől származó anyagoknak, információknak a szolgáltatókhoz való eljuttatásában.

(3b) A fenntartó a Gyvt. 96. § (7)-(8a) bekezdés ${ }^{101}$ szerinti módszertani intézménynek a gyermekjóléti szolgáltatók, intézmények és a gyermekvédelmi intézmények szakmai programjának - külön jogszabály alapján, szakértőként végzett - véleményezéséért szakértői díjat fizet, amelynek összege müködési engedélyenként

a) gyermekjóléti szolgáltató esetén 16000 forint,

b) gyermekjóléti, gyermekvédelmi intézmény esetén 24000 forint,

c) gyermekjóléti szolgáltató és gyermekjóléti, gyermekvédelmi intézmény egy telephelyen történő múködése esetén a $b$ ) pont szerinti összeg.

(4) A módszertani intézmény a múködést engedélyező szerv, valamint a fenntartója felkérésére térítésmentesen, más fenntartó felkérésére eseti megbízás alapján, térítés ellenében részt vesz a szolgáltató ellenőrzésében.

(5) A módszertani intézmény, valamint az Intézet a módszertani feladatok ellátásába, egyes új módszerek modellkísérletének elvégzésébe állandó vagy eseti jelleggel más szolgáltatót is bevonhat. Az állandó jellegü munkakapcsolathoz a módszertani intézmény fenntartójának hozzájárulása szükséges.

101 (7) A fenntartó kezdeményezi a gyámhivatalnál a gyermekjóléti és gyermekvédelmi személyes gondoskodást nyújtó müködési engedéllyel rendelkező gyermekjóléti szolgálatok és lakásotthonok közül a módszertani feladatokat ellátó intézmény kijelölését, azzal, hogy ellátási típusonként a megyében egy, a fơvvárosban két módszertani intézet müködhet. A kijelölés ötévi időtartamra szól, amelynek elteltét követően az intézmény ismételten kijelölhető.

(8) A miniszter pályázat útján, a fenntartó egyetértésével

a) a bölcsődék, illetve a gyermekotthonok közül regionális módszertani feladatokat ellátó intézményt,

b) a családok átmeneti otthona, a nevelőszülői hálózatok, a területi gyermekvédelmi szakszolgálatok közül országos hatáskörrel módszertani feladatokat ellátó intézményt

jelöl ki. A kijelölés ötévi időtartamra szól, amelynek elteltét követően az intézmény ismételten kijelölhetö.

(8a) A Kormány által kijelölt szerv látja el országos hatáskörrel

a) a családi napközi szolgáltatással,

b) a házi gyermekfelügyelet szolgáltatással,

c) a családi gyermekfelügyelet szolgáltatással,

d) a 41. § (4) bekezdése szerinti ellátásokkal,

e) a helyettes szülői ellátással,

f) a gyermekek átmeneti otthonával,

g) a különleges gyermekotthoni ellátással,

h) a speciális gyermekotthoni ellátással

kapcsolatos módszertani feladatokat.

(9) A kijelölt módszertani intézmény feladatkörében

a) részt vesz a minőségfejlesztési elvek kidolgozásában,

b) a kijelölt feladatok tekintetében ajánlásokat készít a hatékonyabb szolgáltatási módszerek alkalmazására,

c) szakmai tanácsadással segíti a kijelölt feladatok tekintetében a területén levő gyermekjóléti és gyermekvédelmi szolgáltató tevékenységet végzők szakmai munkáját,

d) szakértőként közremüködik a gyermekjóléti és gyermekvédelmi szolgáltató tevékenységet végzök szakmai ellenőrzésében, a szakmai programok értékelésében,

e) kezdeményezi a gyermekvédelmi rendszerben dolgozók továbbképzését és tapasztalatcseréjét.

(10) A miniszter a módszertani feladatok ellátásához a módszertani intézmények kijelöléséröl és feladatairól szóló miniszteri rendeletben meghatározottak szerint egyedi támogatást nyújt. 
(6) A módszertani intézmény éves munkatervet, valamint módszertani feladatai ellátásáról szakmai beszámolót készít, melyet minden év február 15-éig megküld a fenntartónak, a Minisztériumnak, az Intézetnek és a megyei gyámhivatalnak. Az Intézet éves munkatervet, valamint módszertani feladatainak ellátásáról szakmai beszámolót készít, melyet minden év február 15-éig megküld a Minisztériumnak.

4/A. §(1) A gyermekjóléti, gyermekvédelmi szolgáltató, intézmény szakmai programjának tartalmaznia kell

a) a szolgáltató, intézmény nevét, székhelyét, telephelyét;

b) az ellátandó célcsoport és az ellátandó terület jellemzőit;

c) a szolgáltatás célját, feladatát, alapelveit, így különösen

ca) a megvalósítani kívánt program konkrét bemutatását, a létrejövő kapacitások, a nyújtott szolgáltatáselemek, tevékenységek leírását,

cb) az intézményen belüli és más intézményekkel történő együttmüködés módját,

d) a feladatellátás szakmai tartalmát, módját, a biztosított szolgáltatások formáit, körét, rendszerességét, valamint a szolgáltatási típusnak megfelelően a gondozási, nevelési, fejlesztési feladatok jellegét, tartalmát, módját;

e) az ellátás igénybevételének módját;

f) a gyermekjóléti szolgáltató, intézmény szolgáltatásáról szóló tájékoztatás helyi módját;

g) az igénybe vevők és a személyes gondoskodást végző személyek jogainak védelmével kapcsolatos szabályokat;

h) a szolgáltatást nyújtók folyamatos szakmai felkészültsége biztosításának módját, formáit.

(2) A szakmai programhoz mellékelni kell

a) a Gyvt. 32. § (4) és (6) bekezdése szerinti megállapodások tervezetét,

b) nevelőszülői hálózat müködtetése esetén a Gyvt. 66/A. § (1) bekezdése szerinti, utógondozói ellátás nyújtása esetén a Gyvt. 53/A. § (3) bekezdése szerinti megállapodás ${ }^{102}$ tervezetét,

31. § (1) A személyes gondoskodás igénybevétele - ha e törvény másként nem rendelkezik - önkéntes, az ellátást igénylő (a továbbiakban: kérelmező) kérelmére történik. Cselekvőképtelen személy kérelmét törvényes képviselője terjeszti elő, korlátozottan cselekvőképes személy a kérelmét törvényes képviselőjének beleegyezésével terjesztheti elö. A korlátozottan cselekvőképes személy és a törvényes képviselöje között az ellátás igénybevételével kapcsolatban felmerült vitában - a tényállás tisztázása mellett - a települési önkormányzat jegyzője dönt.

(2) Ha a gyermek védelme az ellátás önkéntes igénybevételével nem biztosított, e törvény az ellátás kötelező igénybevételét elrendeli.

(3)

32. § (1) A személyes gondoskodást nyújtó ellátásra irányuló jogviszony keletkezését

a) a helyi önkormányzat képviselö-testületének határozata,

b) a települési önkormányzat jegyzőjének vagy a gyámhivatalnak a határozata,

c) a települési önkormányzat által fenntartott átmeneti gondozást nyújtó intézmény esetében az intézményvezető intézkedése,

d) a c) pontban foglaltakon túl a fenntartó önkormányzat rendeletében vagy az állami fenntartó által meghatározott körben az intézményvezető intézkedése,

e) a személyes gondoskodás iránti kérelemről dönteni jogosult személy intézkedése alapozza meg.

(2) Ha az ellátás igénybevételére az (1) bekezdés a) vagy b) pontja alapján kerül sor, a határozatot közölni kell a müködtetővel és az ellátást nyújtó intézmény vezetőjével is.

(3) Állami fenntartású intézmény esetén az (1) bekezdés c) és d) pontja szerinti döntésröl az intézményvezető értesíti a kérelmezőt, illetve törvényes képviselőjét. Az ellátás igénybevételének elutasítása esetén a kérelmezőt, illetve törvényes képviselöjét írásban kell értesíteni.

(4) Ha a kérelmező, illetve törvényes képviselője az intézmény vezetőjének (3) bekezdés szerinti döntését vitatja, az arról szóló értesítés kézhezvételétől számított nyolc napon belül a fenntartóhoz fordulhat. Ha az intézményvezető az ellátás igénybevételéről nem intézkedik, a kérelmező, illetve törvényes képviselője az arról való tudomásszerzéstöl számított nyolc napon belül a fenntartóhoz fordulhat. Ezekben az esetekben a fenntartó határozattal dönt.

(5) A gyermekjóléti alapellátások igénybevételének megkezdése előtt és az utógondozói ellátás igénybevételének megkezdésekor

a) állami fenntartású szolgáltató, intézmény esetén a szolgáltató vezetője, illetve az intézményvezető,

b) egyházi és nem állami fenntartású szolgáltató, intézmény esetén a fenntartó vagy az általa megbízott személy

a kérelmezővel, illetve törvényes képviselőjével írásban megállapodást köt. 
c) átmeneti elhelyezést biztosító gyermekjóléti intézmény, befogadó gyermekotthon, otthont nyújtó ellátást biztosító gyermekotthon, lakásotthon, utógondozói ellátást biztosító utógondozó otthon esetében a házirendet vagy annak tervezetét,

d) a - (2a) bekezdésben foglalt kivétellel - a szervezeti és müködési szabályzatot vagy annak tervezetét.

(2a) A nem hálózatban múködtetett családi napközi és családi gyermekfelügyelet, valamint egyszemélyes gyermekjóléti szolgáltatás és alternatív napközbeni ellátás esetén nem kötelező szervezeti és müködési szabályzatot készíteni.

(3) A szakmai programot az (1) bekezdés szerinti elemeinek változása esetén módos-ítani kell.

\section{Fejezet \\ A GYERMEKJÓLÉTI ALAPELLÁTÁSOK \\ 1. Cím \\ ÁLTALÁNOS SZABÁLYOK}

5. § (1) Az alapellátásnak a gyermek szükségleteit figyelembe véve kell szolgálnia a Gyvt. 38. § (1) bekezdésében ${ }^{103}$ meghatározott célokat.

(2) A települési önkormányzatnak az igénybe vehető alapellátásokról tájékoztatnia kell a városi gyámhivatalt, valamint a lakosságot a helyben szokásos módon.

(3) Az alapellátást a jogosult lakóhelyéhez vagy tartózkodási helyéhez legközelebb eső szolgáltatást nyújtó személynél vagy intézménynél kell biztosítani, kivéve, ha ez nem áll a gyermek érdekében.

$(\ldots)$

\section{A GYERMEKEK NAPKÖZBENI ELLÁTÁSA}

(6) Nem kell az (5) bekezdés szerint megállapodást kötni

a) gyermekjóléti szolgáltatás esetén,

b) - ha a fenntartó döntése alapján a szolgáltatás jellegére tekintettel az nem indokolt - alternatív napközbeni ellátás

esetén.

(7) Az (5) bekezdés szerinti megállapodás tartalmazza

a) az ellátás kezdetének időpontját,

b) az intézményi ellátás időtartamát (a határozott vagy határozatlan időtartam megjelölését),

c) a gyermek, fiatal felnőtt számára nyújtott szolgáltatások és ellátások tartalmát, módját,

d) a személyi térítési díj megállapítására és megfizetésére vonatkozó szabályokat, ha az ellátás térítésidíjfizetési kötelezettséggel jár,

e) az ellátás megszüntetésének módjait,

f) a gyermek és törvényes képviselője, valamint a fiatal felnőtt személyazonosító adatait.

(8) Az intézményvezetőnek az ellátásra jogosult gyermek, fiatal felnőtt azonnali elhelyezéséről kell gondoskodnia

a) az elhelyezés fellebbezésre tekintet nélküli végrehajtását elrendelő határozat alapján,

b) soron kívüli elhelyezésre vonatkozó indokolt kérelem alapján,

c) az 57. § (2) bekezdése szerinti esetben.

(9) Ha az egyházi, nem állami fenntartó a helyi önkormányzattal vagy állami szervvel kötött ellátási szerződés hatálya alá tartozó esetben az ellátásra irányuló kérelmet elutasítja, a kérelmezőt, illetve törvényes képviselőjét írásban értesíti. Ha a kérelmező, illetve törvényes képviselője a döntést vitatja, az arról szóló értesítés kézhezvételétől számított nyolc napon belül az ellátási szerződést megkötő helyi önkormányzathoz vagy állami szervhez fordulhat. A helyi önkormányzat vagy állami szerv a kérelemröl határozattal dönt.

(10) Ha a helyi önkormányzattal vagy állami szervvel ellátási szerződést kötött egyházi, nem állami fenntartó az elhelyezést elrendelő döntés ellen fellebbezést nyújt be, a helyi önkormányzatot vagy állami szervet írásban értesíti.

103 38. § (1) Az alapellátásnak hozzá kell járulnia a gyermek testi, értelmi, érzelmi és erkölcsi fejlődésének, jólétének, a családban történő nevelésének elősegítéséhez, a veszélyeztetettség megelőzéséhez és a kialakult veszélyeztetettség megszüntetéséhez, valamint a gyermek családjából történő kiemelésének a megelőzéséhez.

(2) Az alapellátás keretében nyújtott személyes gondoskodást - lehetőség szerint - a jogosult lakóhelyéhez, tartózkodási helyéhez legközelebb eső ellátást nyújtó személynél vagy intézményben kell biztosítani. 
34. § A családban nevelkedö, a szülök munkavégzése, betegsége vagy egyéb ok miatt ellátatlan gyermek nappali felügyeletét, gondozását, nevelését napközbeni ellátás keretében kell biztosítani.

\section{Bölcsőde}

35. § (1) A bölcsőde olyan szolgáltató intézmény, amely az alapellátás keretében alaptevékenységként napközbeni ellátást nyújt a gyermek számára.

(2) A bölcsőde feladata a három éven aluli gyermekek gondozása-nevelése, harmonikus testi-szellemi fejlődésének segítése az életkori és egyéni sajátosságok figyelembevételével.

(3) A bölcsőde vállalhatja a hat éven aluli fogyatékos gyermek korai fejlesztését, gondozását, fejlesztő felkészítését, amennyiben ennek tárgyi és személyi feltételeivel rendelkezik.

(4) A bölcsőde szervezetileg müködhet

a) önálló bölcsődeként,

b) Bölcsődei Igazgatóság, illetve Egyesített Bölcsőde szervezeti formában, annak tagintézményeként,

c) többcélú, közös igazgatású intézmény önálló szervezeti és szakmai egységeként.

(5) A bölcsöde a feladat jellegétöl függően

a) napos bölcsőde,

lehet.

b) hetes (5 napos) bölcsőde

(6) Ha a bölcsőde más intézménnyel összevontan müködik, biztosítani kell a bölcsőde önálló szakmai egységként történő müködtetését.

36. § (1) Bölcsődébe a gyermek húszhetes korától harmadik életévének, fogyatékos gyermek az ötödik életévének betöltéséig, illetve annak az évnek a december 31-éig vehető fel, amelyben a gyermek a harmadik életévét, a fogyatékos gyermek az ötödik életévét betölti.

(2) Ha a gyermek a harmadik életévét betöltötte, de testi vagy szellemi fejlettségi szintje alapján még nem érett az óvodai nevelésre és óvodai jelentkezését a bölcsőde orvosa nem javasolja, bölcsődében gondozható negyedik életévének betöltését követő augusztus 31 -ig.

(3) A gyermek bölcsődébe történő felvételét a szülő hozzájárulásával

a) a körzeti védőnő,

b) a házi gyermekorvos vagy a háziorvos,

c) a szociális, illetve családgondozó,

d) a gyermekjóléti szolgálat,

e) a gyámhatóság

is kezdeményezheti.

(4) A bölcsődébe történő felvételt fogyatékos gyermek esetén a (3) bekezdésben foglaltakon túl a gyermek habilitációját segítő szakember és a közoktatásról szóló 1993. évi LXXIX. törvény (a továbbiakban: Kt.) 30. §-ának (3) bekezdésében, valamint 34. §-ának $a$ ) pontjában szabályozott szerv (a továbbiakban: szakértői bizottság) is kezdeményezheti, ha a bölcsődében a gyermek korai fejlesztése megszervezhető.

37. § (1) A napos bölcsőde a fenntartó által meghatározott napi nyitvatartási időn belül biztosítja a gyermek ellátását. Alapfeladatként nyújtott ellátás esetén egy gyermek napi gondozási ideje a tizenkét órát nem haladhatja meg.

(2) A hetes bölcsőde naptári hetenként legalább százhúsz óra időtartamban bentlakásos formában folyamatos ellátást biztosít.

38. § (1) Hetes bölcsődébe azt a gyermeket lehet felvenni, akinek egészsége, testi vagy szellemi fejlődése a család szociális helyzete, illetve otthoni körülményei miatt otthonában hétközben nem biztosítható.

(2) Ha a gyermek hetes bölcsődei elhelyezésére okot adó körülmények megváltoztak, a hetes bölcsődei ellátást meg kell szüntetni.

39. § (1) A szülőnek (törvényes képviselőnek) a gyermek bölcsődei jelentkezéséhez csatolnia kell a házi gyermekorvos vagy a háziorvos igazolását arról, hogy a gyermek egészségi állapota alapján bölcsődében gondozható.

(2) Nem gondozható bölcsődében a fertőző beteg gyermek mindaddig, amíg a házi gyermekorvos vagy a háziorvos igazolása szerint ez az állapota fennáll.

40. § (1) A bölcsődei ellátás keretében a gyermek életkorának és egészségi állapotának megfelelően biztosítani kell

a) a gondozás-nevelés feltételeit, így különösen

aa) a törvényes képviselő közreműködésével történő fokozatos beilleszkedés lehetőségét,

$a b)$ megfelelő textíliát és bútorzatot,

ac) a játéktevékenység feltételeit,

$a d)$ a szabadban való tartózkodás feltételeit,

ae) a fogyatékos gyermek egyéni fejlesztésének feltételeit,

b) az egészséges táplálkozás követelményének megfelelő étkeztetést az energia- és tápanyagbeviteli, illetve élelmiszer-felhasználási ajánlásokat tartalmazó jogszabályban meghatározottak szerint. 
(2) Egy bölcsődei csoportban - a (3)-(4) bekezdésben meghatározott kivétellel - legfeljebb 12 gyermek nevelhetö, gondozható.

(3) A bölcsődei csoportban, ha valamennyi gyermek betöltötte a második életévét - a (4) bekezdésben meghatározott kivétellel -, legfeljebb 14 gyermek nevelhetö, gondozható.

(4) A fogyatékos gyermeket is ellátó bölcsődei csoportban legfeljebb 10, a kizárólag fogyatékos gyermeket ellátó bölcsődei csoportban legfeljebb 6 gyermek fejleszthető, gondozható.

(5) A bölcsődei nevelés-gondozás az Intézet által kidolgozott Bölcsődei nevelés-gondozás országos alapprogramja és a Bölcsődei nevelés-gondozás szakmai szabályai alapján folyik.

(6) A Bölcsődei nevelés-gondozás országos alapprogramjának kidolgozásába be kell vonni a bölcsődei ellátás területén müködő társadalmi-érdekképviseleti szervezeteket és a Kt. 98. § (1) bekezdése szerinti bizottságot.

(7) Az (5) bekezdés szerinti dokumentumok alapján a bölcsőde helyi szakmai programot készít. A sajátos nevelési igényü gyermekek nevelését-gondozását biztosító bölcsőde helyi szakmai programja kidolgozásánál figyelembe veszi a sajátos nevelési igényü gyermekek nevelésére, gondozására és fejlesztésére vonatkozó szakmai szabályokat.

(8) A bölcsődei csoportszoba hasznos alapterülete gyermekenként legalább 3 négyzetméter.

41. § (1) A fogyatékos gyermek habilitációs céllal a korai fejlesztés feltételeivel rendelkezö bölcsődébe abban az esetben vehető fel és gondozható, ha

a) a Kt. szerinti szakértői és rehabilitációs bizottság szakvéleményében erre javaslatot tesz, és

b) a bölcsődei gondozás során nem veszélyezteti sem maga, sem társai testi épségét.

(2) A fogyatékos gyermek a bölcsődei korai fejlesztésben, gondozásban vagy fejlesztő felkészítésben legfeljebb a hatodik életévének betöltését követő augusztus 31-éig vehet részt. A gyermek képességeiröl ötödik életévének betöltésekor a szakértői bizottságnak szakvéleményben kell ismételten nyilatkoznia.

(3) Fogyatékos gyermeket bölcsődébe próbaidővel lehet felvenni, melynek legrövidebb időtartama egy hónap.

(4) A próbaidő letelte után a gyermekkel közvetlenül foglalkozó szakmai csoport (orvos, gyógypedagógus, gondozónő) együttes véleménye figyelembevételével kell dönteni a gyermek további gondozásáról. Elutasítás esetén a gyermeket további korai fejlesztése érdekében a 36. § (4) bekezdése szerinti szakértői bizottsághoz kell irányítani.

42. § (1) A fogyatékos gyermek bölcsődei elhelyezése történhet

a) egészséges gyermekekkel közös csoportban,

b) speciális bölcsődei csoportban.

(2) A speciális csoportban elhelyezett gyermekek állapotától függően kell meghatározni az egy gondozó által ellátható gyermeklétszámot, ez azonban gondozónként három gyermeknél több nem lehet.

43. § (1) A bölcsődei ellátás megszünik

a) a bölcsődei nevelési év végén (augusztus 31.), ha a gyermek a harmadik életévét betöltötte, illetve

b) ha a 36. $\S(2)$ bekezdése, illetve a 41. $\S(2)$ bekezdése szerinti életkort elérte.

(2) Meg kell szüntetni annak a gyermeknek az ellátását, aki a bölcsőde orvosának szakvéleménye szerint egészségi állapota miatt bölcsődében nem gondozható, illetőleg magatartászavara veszélyezteti a többi gyermek fejlödését.

(3) A bölcsőde orvosa a (2) bekezdés szerinti szakvélemény kialakítása előtt más szakember (gyógypedagógus, pszichológus, gondozónő stb.) véleményét is kikéri.

44. §(1) Ha a bölcsőde alapfeladatát nem veszélyezteti, a bölcsőde térítési díj ellenében külön szolgáltatásként

a) játszócsoportot,

b) időszakos gyermekfelügyeletet,

c) gyermekhotelt,

d) egyéb, gyermeknevelést segítő szolgáltatást (pl. gyermeknevelési tanácsadást, játék-, eszközkölcsönzést)

müködtethet, illetve otthoni gyermekgondozást biztosíthat. A bölcsőde által biztosított külön szolgáltatásokat a gyermek 6. életévének betöltéséig lehet igénybe venni.

(2) A játszócsoportban szakképzett gondozónő segítségével gyermekfelügyelet vagy a gyermek és a szülő (gondozó) együttes játéklehetősége biztosítható.

(3) Az időszakos gyermekfelügyelet keretében a gyermek számára a szülő (gondozó) által igényelt alkalommal és időtartamban bölcsődei ellátás nyújtható az e célra létrehozott játszócsoportban vagy a normál bölcsődei csoport üres féröhelyein.

(4) A gyermekhotel olyan gyermek részére nyújt 24 órás folyamatos ellátást, akiről szülője (gondozója) elfoglaltsága miatt átmeneti ideig nem tud gondoskodni. Az ellátás hétvégén és ünnepnapon is biztosítható, időtartama azonban egy alkalommal a tizenöt napot nem haladhatja meg.

45. § (1) A bölcsődék szakmai ellenőrzése a Gyvt. 118. §-ának (3) bekezdése szerint történik. 
(2) A bölcsődék egészségügyi tevékenysége feletti szakfelügyeletet a fövárosi és megyei kormányhivatal népegészségügyi szakigazgatási szervének tisztifőorvosa (a továbbiakban: tisztifőorvos) gyakorolja. A tisztifőorvos feladata ellátása érdekében közremüködésre felkérheti a regionális módszertani bölcsődét vagy az Országos Gyermekvédelmi Szakértői Névjegyzékben szereplő szakértőt.

(3) A módszertani bölcsőde felkérésre szakvéleményt ad a müködési engedélyt kiadó, az ellenörzést végzö, illetve a felügyeletet gyakorló szervnek, valamint a fenntartónak, hogy a bölcsőde tárgyi és személyi feltételei, szakmai programja és müködése megfelel-e a jogszabályokban elöírt szakmai követelményeknek.

(4) A regionális módszertani bölcsőde együttmüködik az egységes óvoda-bölcsődével. Az egységes óvoda-bölcsőde fenntartójának felkérésére a regionális módszertani bölcsőde

a) szakmai véleményt ad arról, hogy az egységes óvoda-bölcsőde rendelkezik-e a 3 évesnél fiatalabb gyermekek neveléséhez, gondozásához szükséges feltételekkel,

b) véleményezi az egységes óvoda-bölcsőde nevelési programját, minőségirányítási programját, házirendjét, valamint szervezeti és müködési szabályzatát a 3 évesnél fiatalabb gyermekek nevelésével, gondozásával összefüggésben,

c) részt vesz az egységes óvoda-bölcsőde ellenőrzésében, amelynek során a 3 évesnél fiatalabb gyermekek nevelésével, gondozásával összefüggő szakmai kérdéseket ellenörzi.

\section{Családi napközi}

46. § (1) A Gyvt. 43. $\S^{104}$-a (5) bekezdésének alkalmazásában saját otthon alatt a családi napközi szolgáltatást nyújtó személy életvitelszerü tartózkodására szolgáló lakást, illetve más lakást kell érteni.

(2) A Gyvt. 43. §-ának (10) bekezdése szerinti családi napközi hálózat fenntartója a telephelyeken müködő családi napközi szolgáltatást nyújtó személyek munkáját folyamatosan figyelemmel kíséri, biztosítja számukra a szakmai tanácsadást, valamint kapcsolatot tart az ellátást igénybe vevőkkel és igényeiket figyelembe véve segíti a családi napközi szolgáltatást nyújtó személyeket a szolgáltatások szervezésében, összehangolásában, illetve a helyettesítés megszervezésében.

1997. évi XXXI. Törvény 43. § (1) A gyermekek napközbeni ellátásának minősül a bölcsődei és óvodai ellátásban nem részesülö, továbbá az iskolai oktatásban részesülő gyermeknek az iskola nyitvatartási idején kívüli, valamint az iskolai napközit vagy tanulószobai ellátást igénybe nem vevő gyermek családi napköziben történő, nem közoktatási célú ellátása.

(2) A családi napközi a családban nevelkedő gyermekek számára nyújt életkoruknak megfelelő nappali felügyeletet, gondozást, nevelést, étkeztetést és foglalkoztatást. A fogyatékos gyermekek számára sajátos szükségleteikhez igazodó ellátást kell nyújtani.

(3) A családi napközi - az alapellátáson túli szolgáltatásként - speciális tanácsadással, időszakos gyermekfelügyelettel vagy más gyermeknevelést segítő szolgáltatással segítheti a családokat.

(4) Családi napköziben ellátást az a nagykorú, cselekvőképes, büntetlen eloóletű személy biztosíthat, aki

a) személyisége és - a külön jogszabályban meghatározott - körülményei alapján alkalmas a gyermek napközbeni ellátására, és

b) a külön jogszabályban meghatározott tanfolyamon eredménnyel részt vett, feltéve, hogy nem áll fenn vele szemben a 15. § (8) bekezdésében meghatározott kizáró ok.

(5) A családi napközi müködhet az ellátást nyújtó saját otthonában vagy más e célra kialakított helyiségben.

(6) A családi napköziben húszhetestől tizennégy éves korig gondozható gyermek.

(7) A családi napköziben - a saját, napközbeni ellátást máshol igénybe nem vevő gyermeket is beszámítva - legfeljebb öt gyermek gondozható. Ha a családi napköziben egy fogyatékos gyermeket is gondoznak, akkor a gondozható gyermekek száma legfeljebb négy fö. Ha a családi napköziben gondozott valamennyi gyermek fogyatékos, akkor a gondozható gyermekek száma legfeljebb három fö.

(8) A (7) bekezdésben meghatározott létszámon túl még két gyermek, ha fogyatékos gyermekről van szó, még egy gyermek gondozható a családi napköziben, feltéve, hogy az ellátást nyújtónak állandó segítője van.

(9) A családi napköziben gondozott saját gyermek után normatív állami hozzájárulást nem lehet igénybe venni.

(10) A családi napközi feladatait önálló szolgáltató vagy legalább három - telephelyként müködő - családi napközit magába foglaló családi napközi hálózat biztosítja. Öt, vagy annál több családi napközi fenntartását hálózatba kell szervezni. A hálózatban biztosítani kell a szolgáltatást nyújtók részére a folyamatos szakmai tanácsadást, valamint az ellátottak igényeihez rugalmasan igazodó szolgáltatások összehangolását.

(11) A családi napközi esetében a 32. § (5) bekezdése szerint megkötött megállapodások száma - a szolgáltatás eltérő időpontokban történő igénybevétele esetén - túllépheti a családi napközi müködési engedélyében meghatározott férőhelyek számát. A szolgáltatást azonos időben igénybe vevő gyermekek száma ebben az esetben sem haladhatja meg a müködési engedélyben meghatározott férőhelyszámot. 
(3) A családi napközi hálózat fenntartója a (2) bekezdésben foglalt feladatok ellátására családi napközis koordinátort alkalmaz.

(4) A családi napközis koordinátornak

a) eredményesen el kell végeznie a helyettes szülök, a nevelöszülök, a családi napközit müködtetők képzésének szakmai és vizsgakövetelményeiröl, valamint az örökbefogadás elötti tanácsadásról és felkészítő tanfolyamról szóló 29/2003. (V. 20.) ESzCsM rendelet 9-12. §-a szerinti tanfolyamot (a továbbiakban: családi napközit működtetők felkészítő tanfolyama) és

b) rendelkeznie kell a 2. számú melléklet II. Része I. Alapellátások 3. Családi napközi pontjában elöírt képesítéssel.

47. § (1) Családi napköziben szolgáltatást az biztosíthat, aki - a Gyvt. 43. §-ában meghatározott feltételeknek való megfelelésen túl - a munkaköri, szakmai, illetve személyi higiénés alkalmasság orvosi vizsgálatáról és véleményezéséről szóló 33/1998. (VI. 24.) NM rendelet 2. számú melléklete szerinti érvényes Egészségügyi Nyilatkozattal (a továbbiakban: Egészségügyi Nyilatkozat) rendelkezik.

(2) A fenntartó döntése alapján a családi napköziben a családi napközi szolgáltatást nyújtó személy foglalkoztatására a 2. számú melléklet II. Része I. Alapellátások 3. Családi napközi pontja alatt meghatározott munkakörök létesíthetők. A munkakört betöltő személynek

a) eredményesen el kell végeznie a családi napközit müködtetők felkészítő tanfolyamát, és

b) rendelkeznie kell a 2. számú melléklet II. Része I. Alapellátások 3. Családi napközi pontjában elöírt képesítéssel.

(3) Ha a fenntartó nem létesít a 2. számú melléklet II. Része I. Alapellátások 3. Családi napközi pontja alatt meghatározott munkakört, a családi napközi szolgáltatást nyújtó személynek elegendő a családi napközit müködtetők felkészítő tanfolyamát elvégezni.

(4) A családi napközi szolgáltatást nyújtó személynek igazolnia kell, hogy betegsége vagy egyéb váratlan esemény bekövetkezése esetén helyettesítése megoldott olyan személlyel, aki megfelel az (1) bekezdésben megjelölt alkalmassági feltételeknek. A helyettesítésre szociális gondozói díjban részesíthető személy is alkalmazható.

(5) Ha a családi napközi szolgáltatást nyújtó személy az életvitelszerü tartózkodására szolgáló lakásban nyújtja az ellátást, az ellátás megkezdésekor, azt követően pedig évente háziorvosi igazolással tanúsítja, hogy a vele közös háztartásban élő személy egészségi állapota nem veszélyezteti az ellátandó gyermeket.

48. § (1) A családi napközi feladatainak ellátására csak száraz, világos, jól szellőztethető és füthető épület vagy lakás alkalmas. A gyermekek által napközben használt szobát, illetve foglalkoztatót úgy kell kialakítani, hogy az adott életkorú gyermekek igényeit, szükségleteit kielégítse. A szolgáltatás nyújtásával azonos időben a helyiség más célra nem használható. A szoba, illetve foglalkoztató hasznos alapterülete legalább 2 négyzetméter/gyermek, de összességében legalább 12 négyzetméter.

(2) A családi napköziben a gondozás-nevelés részletes szakmai szempontjait úgy kell meghatározni, illetve az esetleges balesetek megelőzése érdekében a gyermekek tartózkodására szolgáló helyiségeket úgy kell kialakítani, hogy az megfeleljen az Intézet módszertani levelében foglaltaknak.

(3) A saját otthonban nyújtott családi napközi szolgáltatás keretében biztosított étkeztetés családi étkeztetésnek minősül, amelyet az Intézet módszertani levelében foglaltak szerint kell biztosítani.

(4) A családi napköziben a 44. §-ban foglaltak szerint nyújtható az alapellátáson túli külön szolgáltatás.

(5) Az egy épületben müködő családi napközik közül legfeljebb három használhatja közös helyiségként a konyhát és a fürdőszobát, feltéve, hogy azok tárgyi feltételei megfelelnek az Intézet módszertani útmutatójában foglaltaknak.

(6) A Gyvt. 43. § (9) bekezdésének alkalmazásában saját gyermek alatt annak a szolgáltatást közvetlenül nyújtó személynek a gyermekét kell érteni, aki a Gyvt. 5. $\S s$ ) pont $s c$ )alpontjában foglaltak alapján egyben a szolgáltatás fenntartója is.

49. §(1) Az állandó segítő közreműködik a családi napközi szolgáltatást nyújtó személy irányítása alapján a naponta rendszeresen előforduló tevékenységekben. Ha a családi napközi nyitvatartási ideje a napi 5 órát

a) meghaladja, legalább heti 30 órában,

b) nem haladja meg, legalább heti 15 órában

kell az állandó segítőnek rendelkezésre állnia.

(2) Az állandó segítőnek abban az esetben kell elvégeznie a családi napközit müködtetők felkészítő tanfolyamát, ha a családi napközi szolgáltatást nyújtó személy helyettesítését is ellátja.

50. § Ha a családi napköziben 3 évesnél fiatalabb és 3-14 éves kor közötti gyermekeket is elhelyeznek, az 1 éves kor alattiak részére elkülönített játszó- és öltözőhelyet kell kialakítani.

\section{Családi gyermekfelügyelet}

50/A. § (1) A Gyvt. 43/A. §-a (1) bekezdésének alkalmazásában saját otthon alatt a szolgáltatást nyújtó személy életvitelszerü tartózkodására szolgáló lakást kell érteni. 
(2) Családi gyermekfelügyelet szolgáltatást az biztosíthat, aki - a Gyvt. 43/A. §-ában meghatározott feltételeknek való megfelelésen túl - érvényes Egészségügyi Nyilatkozattal rendelkezik.

(3) A 47. § (5) bekezdésében és a 48. § (1)-(3) bekezdésében foglalt rendelkezéseket a családi gyermekfelügyeletre is alkalmazni kell.

(4) Családi gyermekfelügyeletet elsősorban olyan gyermek számára kell biztosítani, akinek a szülője vagy más törvényes képviselője igazolja, hogy munkaviszonya, munkavégzésre irányuló egyéb jogviszonya, munkaerő-piaci részvételt elősegítő programban, képzésben való részvétele vagy betegsége miatt nem tud gyermeke napközbeni ellátásáról gondoskodni.

(5) A Gyvt. 43/A. § (5) bekezdésének alkalmazásában saját gyermek alatt annak a szolgáltatást közvetlenül nyújtó személynek a gyermekét kell érteni, aki a Gyvt. 5. §s) pontsc) alpontjában foglaltak alapján egyben a szolgáltatás fenntartója is.

\section{Házi gyermekfelügyelet}

51. § (1) Az alapellátás keretében gyermekek napközbeni ellátásaként házi gyermekfelügyelet biztosítható a 20 hetes kortól az általános iskolai tanulmányokat folytató, tanköteles korú gyermek ellátásában akadályozott szülő kérelmére

a) a fogyatékossága vagy súlyos betegsége miatt egyéb napközbeni ellátásban nem részesíthetö,

b) a nappali intézményben elhelyezett, de a nappali intézmény nyitvatartási idején túl felügyelet nélkül maradó,

c) napközbeni ellátást igénybe vevő, de átmeneti kóros állapota miatt hosszabb ideig otthoni gondozásra szoruló

gyermek számára.

(2) Különösen indokolt a házi gyermekfelügyelet biztosítása

a) az egyedülálló szülő gyermeknevelésben való átmeneti akadályoztatása esetén,

b) többes ikrek születésekor, valamint az ikergyermekek gondozásának, nevelésének segítésére,

c) a váltott müszakban dolgozó, egyedülálló szülő gyermekének a kora reggeli, illetve késő esti órákban,

d) az egyik szülő betegsége esetén, ha emiatt akadályoztatva van a gyermek gondozásában, nevelésében,

e) az egyik szülő halála esetén.

(2a) Többes ikrek születésekor, valamint a (2) bekezdés $d$ ) és $e$ ) pontja szerinti esetekben a házi gyermekfelügyelet a gyermek születésétől kezdve nyújtható.

(3) A tankötelezettségét - szakorvosi javaslat, vagy az illetékes tanulási képességet vizsgáló szakértői és rehabilitációs bizottság szakvéleménye alapján - magántanulóként teljesítő, továbbá a súlyos fogyatékossága miatt képzési kötelezettséget teljesítő, tanköteles korú gyermek számára a szülő kérésének megfelelő időszakra házi gyermekfelügyeletet kell biztosítani.

(4) A házi gyermekfelügyelet során a gyermek életkorához, egészségi állapotához igazodó gondozást, felügyeletet kell biztosítani.

(5) A házi gyermekfelügyelet keretében gondozó tevékenységet csak olyan személy láthat el, aki megfelel a 47. $\S(1)$ bekezdésében foglaltaknak.

(6) A házi segítségnyújtás körébe tartozó gondozói tevékenységet hivatásos és társadalmi gondozó végzi. A gondozó napi gondozási tevékenységéről a személyes gondoskodást nyújtó gyermekjóléti alapellátások és gyermekvédelmi szakellátások térítési díjáról, és az igénylésükhöz felhasználható bizonyítékokról szóló 133/1997. (VII. 29.) Korm. rendelet 4. számú melléklete szerinti gondozási naplót vezeti.

(7) A házi gyermekfelügyeletet végző gondozó csak a gyermek gondozására vehető igénybe.

\section{Alternatív napközbeni ellátás}

51/A. § (1) A gyermekek napközbeni ellátása körébe tartozó, a Gyvt. 44/A. §-ában szabályozott tevékenységek (a továbbiakban: alternatív napközbeni ellátás) a helyi adottságoktól és lehetőségektől függően, a helyi igényekhez igazodóan, az ellátott célcsoport életkori sajátosságainak megfelelően megszervezhetőek minden, a gyermekek csoportos foglalkoztatására alkalmas épületben, így különösen közösségi, müvelődési vagy ifjúsági házban, családsegítő és gyermekjóléti szolgálatnál, iskolában, óvodában, illetve ezek önálló helyiségében, továbbá játszótereken.

(2) Az alternatív napközbeni ellátás valamely gyermekekből álló célcsoport életkori sajátosságaihoz, illetve a szülők speciális élethelyzetéhez igazodó, a gyermekek társadalmi beilleszkedését és közösségi tevékenységét elősegítő, a helyi szükségleteknek és igényeknek megfelelően változó módon, vagy rendszeres időközönként tematikus program szerint, meghatározott időtartamokra megszervezett, önálló szakmai programban rögzített tevékenység, amelynek biztosítása során kiemelt figyelmet kell tulajdonítani a szocializációnak, a korai, egyéni és csoportos fejlesztésnek, a prevenciónak.

(3) Az alternatív napközbeni ellátás a (4)-(10) bekezdés szerinti formákban és tartalommal szervezhető meg.

(4) A játszótéri program szakemberek közreműködésével, folyamatos nyitva tartással szabadidős, egyéni, csoportos, közösség-, érték- és normateremtő tevékenységeket biztosít a gyermekeknek és a szülőknek. 
(5) A játszóház elsősorban a játéktevékenységhez kötődő, egyéni készségeket és képességeket fejlesztő, családi nevelést segítő, illetve a szülö-gyermek kapcsolatot erősítő szolgáltatás, amelyben a szülő és a gyermek közösen vesz részt.

(6) A játszóház integratív családi játéktár szolgáltatása segíti a családokat a családi kapcsolatok harmonizálásával, a gyermekek fejlődésével, a neveléssel és életvezetéssel kapcsolatos problémák megoldásában, valamint a családi konfliktusok és a pszichés fejlődési zavarok megelőzésében.

(7) A játszóház keretében nem rendszeres jelleggel, esetenként nem az egész napos nyitva tartás teljes időtartama alatt időszakos gyermekfelügyelet biztosítható.

(8) A klubfoglalkozás az óvodán és az iskolán kívüli nevelést támogató, elsősorban sport- és szabadidős tevékenységekhez kötődő, a gyermekek, illetve szüleik hasznos időtöltését célzó szolgáltatás.

(9) A klubfoglalkozás keretében gyermekfelügyelet biztosítható azokban az időszakokban, amikor a szülő nem tudja megoldani a gyermek napközbeni felügyeletét, így különösen az óvoda és az iskola nyitvatartási idején túli időszakban, valamint az óvodai, iskolai szünet időtartama alatt.

(10) Az azonos, illetve hasonló problémákkal küzdő, nehéz vagy szociálisan hátrányos élethelyzetü, különösen a csellengő vagy egyéb okból veszélyeztetett gyermekek számára szervezett személyiségfejlesztő, valamint önsegítő vagy kortárssegítő közösségépítő tematikus csoportfoglalkozások a (4)-(9) bekezdésben meghatározott bármelyik formában megszervezhetők.

51/B. § (1) Alternatív napközbeni ellátás szervezése különösen azokban az időszakokban indokolt, amikor az óvodai, iskolai napközi nem müködik, vagy azok nyitvatartási idejében, illetőleg azon túl igény jelentkezik a gyermekek felügyeletének és együttes foglalkoztatásának, fejlesztésének biztosítására, továbbá amikor nincs tanítás az iskolákban.

(2) Az alternatív napközbeni ellátást nyújtó személyek és szervezetek együttmüködnek az általuk ellátott gyermekek családjával, valamint szükség szerint az illetékes oktatási-nevelési intézménnyel, gyermekjóléti szolgálattal, egyéb segítő, illetőleg egészségügyi vagy más szolgáltatást nyújtó személlyel, szervezettel, különösen, ha az együttmüködés a gyermeket veszélyeztető körülmények, illetve helyzet felszámolására és a gyermek érdekében szükséges intézkedés megtételére vagy tevékenység megvalósítására irányul.

51/C. § (1) Az 51/A. § (10) bekezdés szerinti foglalkozások vezetését felsőfokú végzettségű szociális vagy mentálhigiénés szakember, valamint a fejleszteni kívánt képesség tekintetében tréning-, illetve csoportvezetésre jogosultságot szerzett személy láthatja el.

(2) Az önkéntes segítők, kortárssegítők közremüködésével vagy együttes részvételével működtetett ellátásokban az önkéntesek felkészítéséről, folyamatos szakmai segítéséről és szupervíziójáról a programot működtető felsőfokú szociális alapvégzettséggel vagy mentálhigiénés végzettséggel rendelkező szakember, illetve szupervízió esetén szupervízor útján gondoskodik.

(3) Az alternatív napközbeni ellátások közegészségügyi követelményei tekintetében a 48. § (2) bekezdés szerinti módszertani levélben foglaltakat kell alkalmazni.

(4) Nem tartoznak az alternatív napközbeni ellátások közé

a) azon intézmények által biztosított ellátások, amelyeknek kötelező alapfeladata szabadidős programok szervezése,

b) elnevezésétől függetlenül az az időszakos gyermekfelügyelet, amelyet a kereskedelmi, vendéglátóipari üzletben vagy kulturális intézményben a szülő tehermentesítése érdekében biztosítanak és amelyhez nem kapcsolódik gyermekjóléti, gyermekvédelmi tevékenység.

( ... )

1. számú melléklet a 15/1998. (IV. 30.) NM rendelethez

A gyermekjóléti és gyermekvédelmi személyes gondoskodás formáinak szakmai létszám irányszámai és létszámminimum normái

I. Alapellátások

\begin{tabular}{|c|c|c|}
\hline Ellátás & Munkakör/fö & \\
\hline \multirow[t]{3}{*}{$\begin{array}{l}2 . \quad \text { Bölcsődei } \\
\text { Gyermekcsoportonként } \\
\text { (max. } 12 \\
\text { fö, } 2 \text { évesnél idősebb gyermekek } \\
\text { csoportjában max. } 14 \text { fó, integrált } \\
\text { csoportban max. } 10 \text { fó, kizárólag } \\
\text { fogyatékosokat ellátó csoportban } \\
\text { max. } \\
\text { Bölcsődénként }\end{array}$} & $\begin{array}{l}\text { kisgyermeknevelö } \\
\text { orvos }\end{array}$ & $\begin{array}{l}2 \\
\text { havi } 4 \text { óra }\end{array}$ \\
\hline & intézményvezető/vezető & $1 \mathrm{fö}$ \\
\hline & $\begin{array}{l}\text { gazdasági vezető, élelmezésvezető, tejkonyhavezető } \\
\text { (létszámuk fenntartói döntés alapján kerül } \\
\text { meghatározásra) }\end{array}$ & 1 fö \\
\hline
\end{tabular}




\begin{tabular}{|c|c|c|}
\hline & $\begin{array}{|lccc|}5 & \text { vagy több gyermekcsoport } & \text { esetén } & \text { további } \\
\text { kisgyermeknevelö }\end{array}$ & $2 \mathrm{f}$ \\
\hline & $\begin{array}{|lcr|}\begin{array}{l}\text { hetes bölcsődében éjszakai szolgálatot teljesítö } \\
\text { kisgyermeknevelö }\end{array} & & \\
\end{array}$ & $2 \mathrm{f}$ \\
\hline $\begin{array}{l}\text { fogyatékos gyermekeket is ellátó } \\
\text { bölcsődében }\end{array}$ & $\begin{array}{l}\text { gyógypedagógus, gyógytornász, } \\
\text { gyógypedagógiai asszisztens (létszámuk } \\
\text { döntés alapján kerül megállapításra) }\end{array}$ & \\
\hline $\begin{array}{l}\text { egyesített bölcsődei intézményben, } \\
\text { bölcsődei igazgatóságon, } \\
\text { módszertani felletve } \\
\text { bölcsődében }\end{array}$ & szaktanácsadó & $1 \mathrm{f}$ \\
\hline $\begin{array}{ll}\text { regionális } & \text { módszertani } \\
\text { bölcsödében } & \end{array}$ & szaktanácsadó & $3 \mathrm{f}$ \\
\hline $\begin{array}{l}\text { 3. Családi napközi az ellátható } \\
\text { gyermekek száma a jogszabályban } \\
\text { meghatározottak szerint }\end{array}$ & 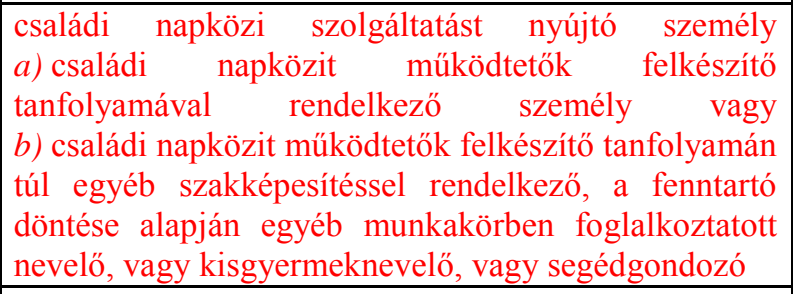 & \\
\hline Családi napközi hálózat & $\begin{array}{l}\text { családi napközis koordinátor (létszáma fenntartói } \\
\text { döntés alapján kerül megállapításra) }\end{array}$ & \\
\hline 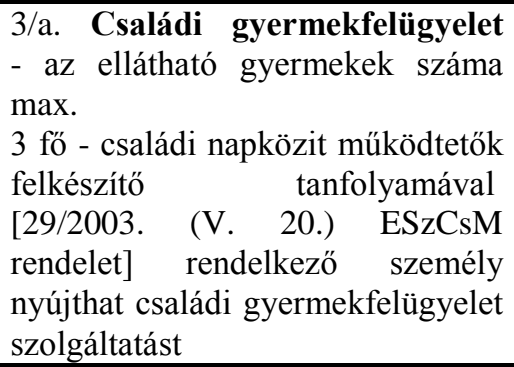 & & \\
\hline 4. Házi gyermekfelügyelet & $\begin{array}{l}\text { nevelő, vagy szakgondozó (hivatásos, társadalmi), vagy } \\
\text { gondozó, vagy segédgondozó }\end{array}$ & \\
\hline
\end{tabular}

2. számú melléklet a 15/1998. (IV.30.) NM rendelethez

I. Rész

Képesitési elöírások a gyermekjóléti és gyermekvédelmi személyes gondoskodás egyes formáiban vezetöi beosztásban dolgozók részére

(...)

II. Rész

Képesitési elöirások a gyermekjóléti és gyermekvédelmi személyes gondoskodás egyes formáiban dolgozók részére

I. Alapellátások

\begin{tabular}{|c|c|c|}
\hline Ellátási forma & Intézményi munkakör & Képesítés \\
\hline 2. Bölcsőde & kisgyermeknevelő & 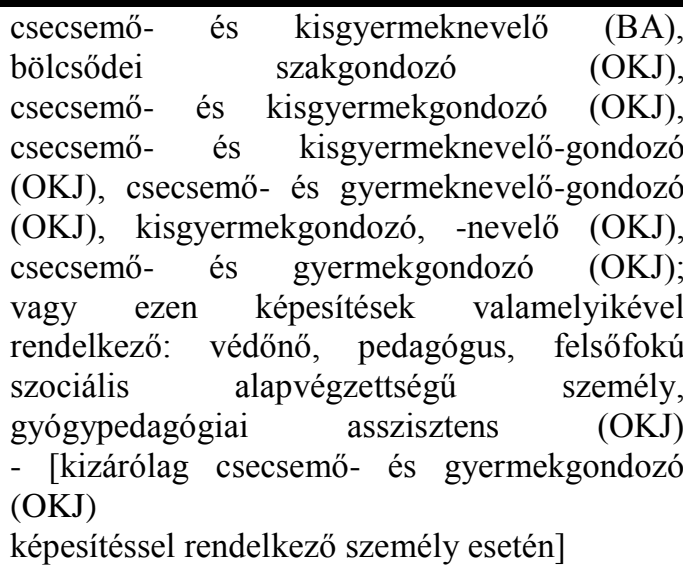 \\
\hline
\end{tabular}




\begin{tabular}{|c|c|c|}
\hline & orvos & orvos \\
\hline & gyógypedagógus & gyógypedagógus \\
\hline & gyógytornász & gyógytornász \\
\hline & konduktor & konduktor \\
\hline & gyógypedagógiai asszisztens & gyógypedagógiai asszisztens $(\mathrm{OKJ})$ \\
\hline & szaktanácsadó & $\begin{array}{l}\text { csecsemő- és kisgyermeknevelő }(\mathrm{BA}), \\
\text { orvos, pszichológus, pedagógus, felsőfokú } \\
\text { szociális alapvégzettség, védőnő, intézetvezető, } \\
\text { szakoktató; vagy bölcsődei szakgondozó }(\mathrm{OKJ}) \text {, } \\
\text { csecsemő- és kisgyermekgondozó (OKJ), } \\
\text { csecsemő- és kisgyermeknevelő-gondozó } \\
(\mathrm{OKJ}) \text {, } \\
\text { csecsemő- és gyermeknevelö-gondozó (OKJ) }\end{array}$ \\
\hline Családi napközi & 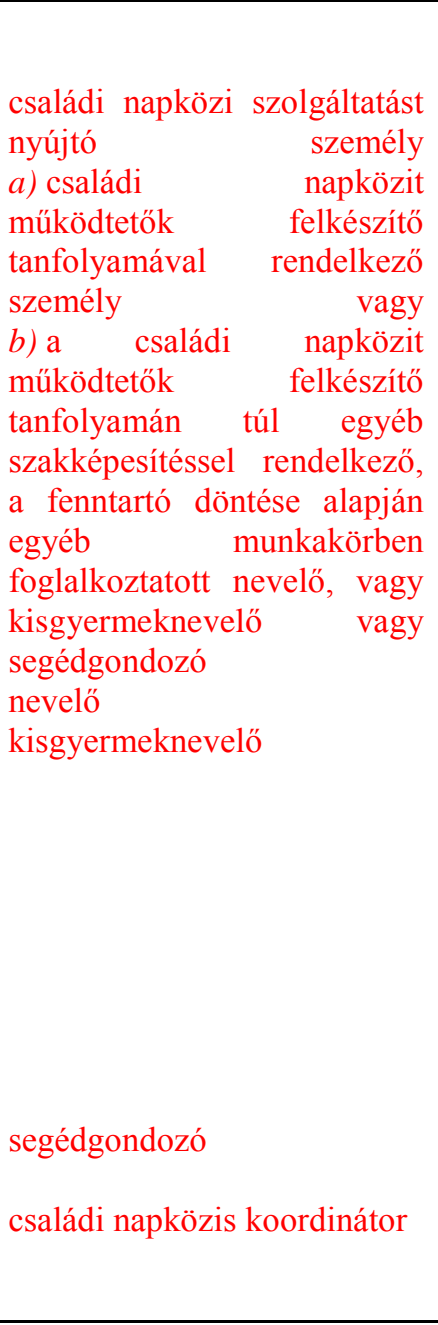 & 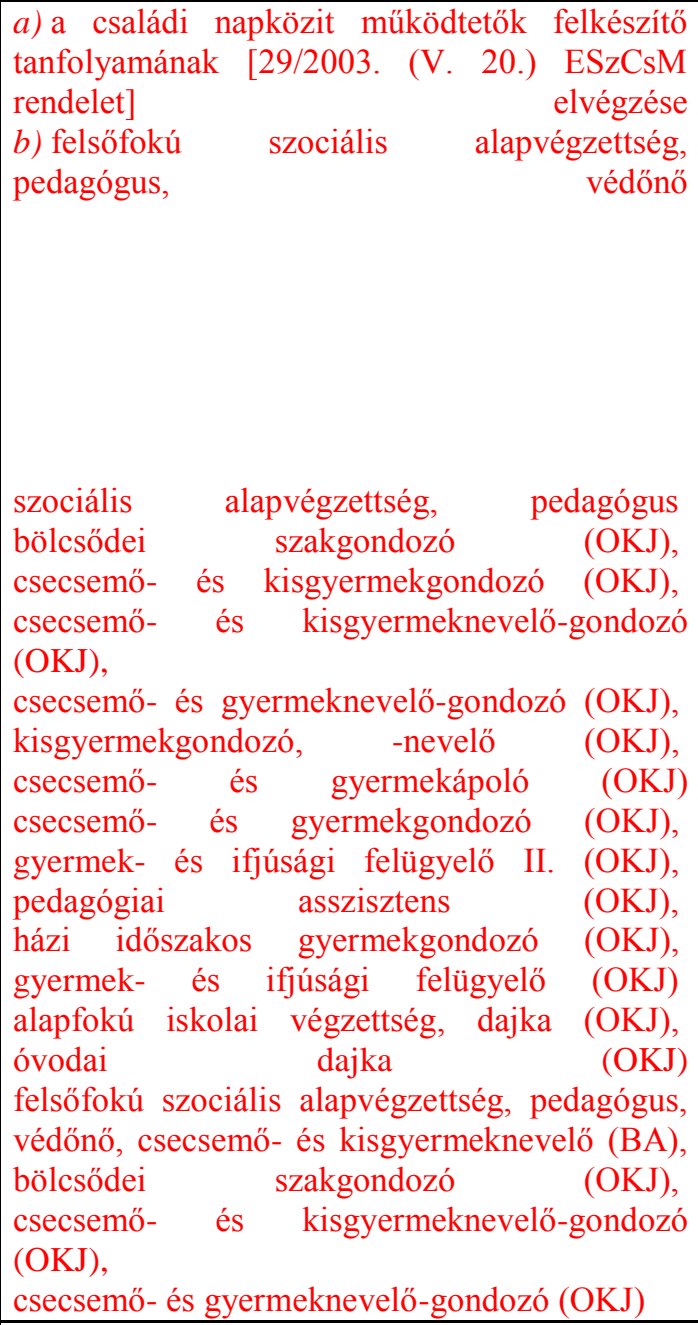 \\
\hline $\begin{array}{ll}\text { 3/a. } & \text { Családi } \\
\text { gyermekfelügyelet } & \end{array}$ & & $\begin{array}{l}\text { a családi napközit müködtetők } \text { felkészítő } \\
\text { tanfolyamának [29/2003. (V. 20.) } \\
\text { reszCsM } \\
\end{array}$ \\
\hline 4. Házi gyermekfelügyelet & nevelö & felsőfokú szociális alapvégzettség, pedagógus \\
\hline & szakgondozó (hivatásos) & 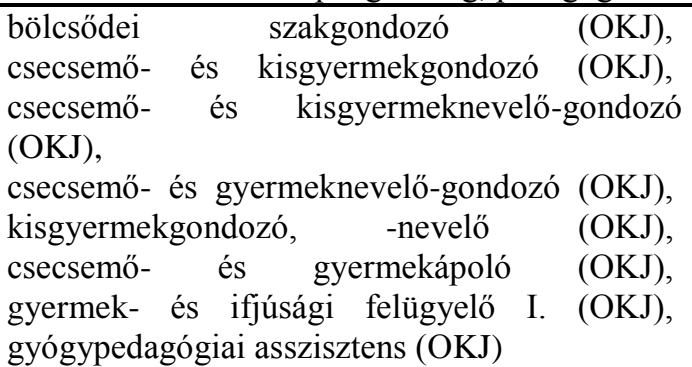 \\
\hline
\end{tabular}




\begin{tabular}{|c|c|c|}
\hline & gondozó & 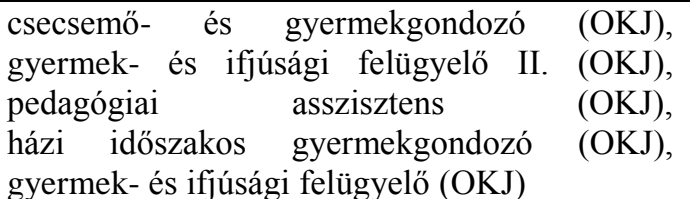 \\
\hline & segédgondozó & $\begin{array}{l}\text { alapfokú iskolai végzettség, dajka (OKJ), } \\
\text { óvodai dajka (OKJ) }\end{array}$ \\
\hline \multirow[t]{6}{*}{$\begin{array}{l}\text { 4/a. Alternatív napközbeni } \\
\text { ellátás }\end{array}$} & & 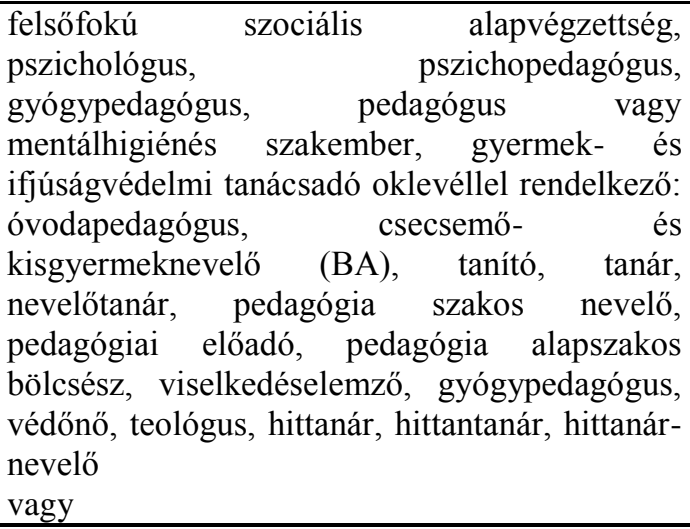 \\
\hline & & $\begin{array}{l}\text { gyermekotthoni asszisztens (OKJ), gyermek- és } \\
\text { ifjúsági felügyelö I. (OKJ), gyógypedagógiai } \\
\text { asszisztens (OKJ), mentálhigiénés asszisztens } \\
\text { (OKJ), pedagógiai asszisztens (OKJ), szociális } \\
\text { asszisztens } \\
\text { vagy } \\
\text { (OKJ) }\end{array}$ \\
\hline & & $\begin{array}{l}\text { gyermek- és ifjúsági felügyelö II. (OKJ), dajka } \\
\text { (OKJ), házi időszakos gyermekgondozó (OKJ), } \\
\text { gyermek- és ifjúsági felügyelö (OKJ), óvodai } \\
\text { dajka } \\
\text { vagy } \\
\text { (OKJ) }\end{array}$ \\
\hline & & 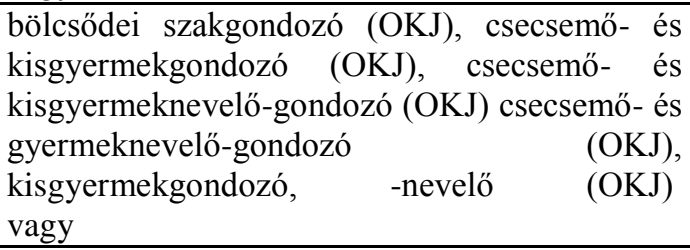 \\
\hline & & $\begin{array}{l}\text { csecsemő- és gyermekgondozó } \\
\text { gyermek- és ifjúsági felügyelö II. (OKJ), } \\
\text { pedagógiai asszisztens (OKJ), házi időszakos } \\
\text { gyermekgondozó (OKJ), gyermek- és ifjúsági } \\
\text { felügyelö } \\
\text { vagy } \\
\text { (OKJ) }\end{array}$ \\
\hline & & $\begin{array}{l}\text { szociális asszisztens (OKJ), pedagógiai } \\
\text { asszisztens (OKJ), gyógypedagógus asszisztens } \\
(\mathrm{OKJ}), \quad \text { mentálhigiénés asszisztens (OKJ), } \\
\text { szociális, gyermek- és ifjúságvédelmi ügyintéző } \\
(\mathrm{OKJ}) \text { vagy népmüvelö-múvelődésszervező }\end{array}$ \\
\hline
\end{tabular}




\section{9/2002. (XII. 18.) Korm. rendelet a gyermekjóléti és gyermekvédelmi szolgáltatótevékenység engedélyezéséről, valamint a gyermekjóléti és gyermekvédelmi vállalkozói engedélyről}

A Kormány a gyermekek védelméről és a gyámügyi igazgatásról szóló 1997. évi XXXI. törvény (a továbbiakban: Gyvt.) 162. §-a (1) bekezdésének $i$ ) és $l$ ) pontjában, valamint az egyéni vállalkozásról szóló 1990. évi V. törvény 2. §-ának (2) bekezdésében foglalt felhatalmazás alapján a következöket rendeli el:

Általános rendelkezések

1. $\S$

2. § E rendelet alkalmazásában

a) székhely: a központi ügyintézés helye, függetlenül attól, hogy a székhelyen ellátást nyújtanak-e;

b) telephely: a bölcsőde, a hetes bölcsőde, a családi napközi, az alternatív napközbeni ellátás (Gyvt. 44/A. §), a gyermekek átmeneti otthona, a családok átmeneti otthona, a gyermekotthon, az utógondozó otthon esetén az a székhelytöl különböző, a szolgáltató (intézmény) használatában lévő hely, ahol az ellátást nyújtják, a félutas ház kivételével;

c) a szolgáltatótevékenység típusai ${ }^{105}$ :

ca) a gyermekjóléti szolgáltatás (Gyvt. 39-40. §),

$c b)$ a gyermekek napközbeni ellátása (Gyvt. 41-44/A. §),

$c c$ ) a gyermekek átmeneti gondozása (Gyvt. 45-51. §),

$c d)$ az otthont nyújtó ellátás (Gyvt. 53. §, 54-59. §),

ce) az utógondozói ellátás (Gyvt. 53/A-59. §),

$c f)$ a területi gyermekvédelmi szakszolgáltatás (Gyvt. 60-66. §);

d) a szolgáltatótevékenység formái:

da) gyermekjóléti szolgáltatás esetén az egy vagy kettő, a képesítési előírásoknak megfelelő személy foglalkoztatásával biztosított (a továbbiakban: önálló gyermekjóléti szolgáltató), a három vagy több, a képesítési elörrásoknak megfelelő személy foglalkoztatásával biztosított (a továbbiakban: gyermekjóléti szolgálat) gyermekjóléti szolgáltatás, továbbá a gyermekjóléti központ,

$d b)$ gyermekek napközbeni ellátása esetén a bölcsőde, a hetes bölcsőde (Gyvt. 42. §), az önálló családi napközi és a hálózatban mủködtetett családi napközi (Gyvt. 43. §, a továbbiakban együtt: családi napközi), a családi gyermekfelügyelet (Gyvt. 43/A. §), a házi gyermekfelügyelet (Gyvt. 44. §), továbbá az alternatív napközbeni ellátás (Gyvt. 44/A. §),

dc) gyermekek átmeneti gondozása esetén a gyermekek átmeneti házi gondozása [Gyvt. 48. § (2) bekezdés], az önálló helyettes szülöi ellátás és a helyettes szülöi hálózat (a továbbiakban együtt: helyettes szülöi ellátás) (Gyvt. 49. §) a gyermekek átmeneti otthona (Gyvt. 50. §) és a családok átmeneti otthona (Gyvt. 51. §),

dd) otthont nyújtó ellátás esetén a nevelöszülői hálózat (Gyvt. 54-56. §) és a gyermekotthon (Gyvt. 57-59. $\S)$,

de) utógondozói ellátás esetén a nevelőszülöi hálózat (Gyvt. 54-56. §), a gyermekotthon (Gyvt. 57-59. §), az utógondozó otthon és a külső férőhelyen biztosított utógondozói ellátás [Gyvt. 53/A. § (2) bekezdés],

$d f)$ területi gyermekvédelmi szakszolgáltatás esetén a területi gyermekvédelmi szakszolgálat;

e) ellátási terület: az az egy vagy több település, kistérség, megye vagy régió, illetve az ország teljes területe, ahonnan a szolgáltató (intézmény, hálózat) gyermekeket vagy más ellátottakat fogad;

f) intézmény: a gyermekjóléti szolgálat, a gyermekjóléti központ, a bölcsőde, a hetes bölcsőde, a gyermekek átmeneti otthona, a családok átmeneti otthona, a gyermekotthon, az utógondozó otthon és a területi gyermekvédelmi szakszolgálat;

g) szolgáltató: a szolgáltató tevékenységet olyan formában végző személy vagy szervezet, amely nem minősül intézménynek, helyettes szülöi hálózatnak vagy nevelőszülöi hálózatnak;

10541 § (3) A gyermekjóléti alapellátás keretében biztosított gyermekek napközbeni ellátásának formái - a gyermekek életkorának megfelelően -

a) a bölcsőde, a hetes bölcsőde,

b) a családi napközi,

c) a családi gyermekfelügyelet,

d) a házi gyermekfelügyelet,

e) az alternatív napközbeni ellátás. 
h) területi iroda: önálló gyermekjóléti szolgáltató, gyermekjóléti szolgálat, gyermekjóléti központ és területi gyermekvédelmi szakszolgálat esetén a szolgáltató (intézmény) székhelyétől, telephelyétől különböző helyen található, a szolgáltató (intézmény) használatában álló és a szolgáltató tevékenység végzésére használt helyiség;

i) ellátási kötelezettséget teljesitő állami fenntartó: a központi költségvetési szerv, a megyei intézményfenntartó központ (a továbbiakban: megyei fenntartó), a helyi önkormányzat, illetve a helyi önkormányzatok társulásairól és együttműködéséről szóló 1997. évi CXXXV. törvény 8-9. §-a, illetve 16. §a szerinti intézményi társulás és a települési önkormányzatok többcélú kistérségi társulása az általa fenntartott szolgáltató (intézmény, hálózat) által végzett olyan szolgáltató tevékenység tekintetében, amelyet a helyi önkormányzat, illetve a társulás valamelyik tagja a Gyvt. alapján biztosítani köteles;

j) müködtető: az a személy vagy szervezet, amely a fenntartó által biztosított működési feltételek között a helyettes szülői hálózatot, a nevelőszülői hálózatot, illetve a külső férőhelyen biztosított utógondozói ellátást szervezi.

2/A. $\S$

A gyermekjóléti és gyermekvédelmi szolgáltatótevékenység engedélyezése

3. $§(1)$

(2) A múködési engedélyezéssel és az ellenőrzéssel kapcsolatos ügyekben első fokon

a) - a $b$ )-d) pontban foglalt kivétellel - a szolgáltató (intézmény) székhelye, telephely engedélyezése esetén a telephelye szerint illetékes szociális és gyámhivatal;

b) helyettes szülői hálózat, nevelöszülői hálózat, külső férőhelyen biztosított utógondozói ellátás esetén a $c$ ) és $d$ ) pontban foglalt kivétellel - a müködtető székhelye szerint illetékes szociális és gyámhivatal;

c) egyházi, nem állami fenntartású, ellátási szerződés alapján müködtetett nevelőszülői hálózat, külső féröhelyen biztosított utógondozói ellátás esetén

$c a)$ a $c b$ ) alpontban nem említett esetben az ellátásra kötelezett települési önkormányzat, illetve megyei fenntartó székhelye szerint illetékes szociális és gyámhivatal,

cb) Pest megyei fenntartó esetén a Pest Megyei Szociális és Gyámhivatal,

ha a fenntartó a nevelöszülöi hálózat müködtetésére, külső férőhelyen biztosított utógondozói ellátásra egy ellátásra kötelezett települési önkormányzattal, megyei fenntartóval kötött ellátási szerződést, vagy több ellátásra kötelezett települési önkormányzattal, megyei fenntartóval kötött ellátási szerződést, de azok egy szociális és gyámhivatal illetékességi területén vannak;

d) Pest megyei fenntartó nevelőszülői hálózata, külső férőhelyen biztosított utógondozói ellátása, területi gyermekvédelmi szakszolgáltatása és a fövárosban vagy Pest megyében található gyermekotthona, utógondozó otthona (telephelye) esetén a Pest Megyei Szociális és Gyámhivatal jár el.

(3) Helyettes szülői hálózatra, nevelőszülői hálózatra és külső férőhelyen biztosított utógondozói ellátásra külön müködési engedélyt kell kiadni.

(4) Többféle gyermekjóléti és a (3) bekezdésben nem említett gyermekvédelmi szolgáltató tevékenységet végző szolgáltató (intézmény) számára egy müködési engedélyt kell kiadni.

(4a) Telephellyel rendelkező szolgáltató (intézmény) esetén az ellátást nyújtó székhelyre és az egyes telephelyekre - a (3) és (4) bekezdésben foglaltak figyelembevételével - külön kell müködési engedélyt kiadni, és e rendeletnek a szolgáltatóra (intézményre) vonatkozó szabályait mind az ellátást nyújtó székhelyre, mind a telephelyekre megfelelően alkalmazni kell.

(5) A különböző formájú, típusú szolgáltatótevékenység engedélyezése esetén a jogszabályi feltételek teljesítését külön kell vizsgálni.

(6) A fenntartó a múködési engedély kiadása, módosítása és visszavonása iránti kérelmet a gyermekek és az ifjúság védelméért felelős miniszter (a továbbiakban: miniszter) által e célra rendszeresített és a gyermekek és az ifjúság védelméért felelős miniszter által vezetett minisztérium (a továbbiakban: minisztérium) és a működést engedélyező szervek honlapján, valamint a kormányzati portálon közzétett adatlapon vagy elektronikus ürlapon nyújthatja be. Az adatlap és az elektronikus ürlap adattartalmát az 1. számú melléklet határozza meg. ${ }^{106}$

(7) A müködést engedélyező szerv a müködési engedély kiadásáról, módosításáról és visszavonásáról

a) a határozat jogeröre emelkedésétől, a fellebbezésre való tekintet nélkül végrehajthatóvá nyilvánított határozat meghozatalától, illetve a 14/B. § (6) bekezdése szerinti végzés meghozatalától számított nyolc napon belül értesíti

aa) az ellátásra köteles helyi önkormányzat jegyzőjét, főjegyzőjét, a megyei fenntartó vezetőjét,

$a b)$ az illetékes gyermekjogi képviselöt,

ac) az illetékes módszertani intézményt,

\footnotetext{
${ }^{106}$ http://www.kormanyhivatal.hu/hu
} 
ad) a szolgáltató (intézmény, müködtetö) székhelye, telephelye szerint illetékes települési jegyzöt,

$a e$ ) helyettes szülői, nevelöszülői hálózat esetén az ellátás helye szerint illetékes szociális és gyámhivatalt,

af)

b) szóló jogerős vagy a fellebbezésre való tekintet nélkül végrehajthatóvá nyilvánított határozatát és a 14/B. § (6) bekezdése szerinti végzését közli a Magyar Államkincstár - a normatív állami támogatás ügyében illetékes - területi szervével (a továbbiakban: Igazgatóság).

(8) Az e rendelet szerinti eljárásokban a Veszprém Megyei Népegészségügyi Szakigazgatási Szerv Fejér megyére, Komárom-Esztergom megyére és Veszprém megyére kiterjedő illetékességgel jár el.

4. § (1) Intézményi formában végzett szolgáltatótevékenység engedélyezése esetén a müködési engedély kiadása iránti kérelemhez a fenntartónak csatolnia kell

a) az intézményvezető - többcélú intézmény esetén a szakmai vezető - szakképesítését bizonyító irat másolatát, és a vezető (szakmai vezetö) nyilatkozatát arra vonatkozóan, hogy vele szemben nem állnak fenn a Gyvt. 15. §-ának (8) bekezdésében meghatározott kizáró okok,

b) az intézmény fenntartójának és az intézményvezető együttes nyilatkozatát arra vonatkozóan, hogy a feladat ellátását biztosító, külön jogszabályban meghatározott munkakört betöltő személyek (a továbbiakban: szakalkalmazottak) rendelkeznek a szükséges szakképesítéssel, és nem állnak fenn velük szemben a Gyvt. 15. §-ának (8) bekezdésében meghatározott kizáró okok,

c) a szolgáltatótevékenység célját, alapelveit, módszereit tartalmazó szakmai programot,

d) az intézmény elhelyezésére szolgáló épület (épületrész) használati jogcímét bizonyító okirat másolatát,

$e)$ - ha beszerezte - az előzetes szakhatósági hozzájárulást, illetve ha a kérelem szerinti ingatlanra vonatkozóan, azonos rendeltetésre, a kérelem benyújtását megelözö hat hónapon belül használatbavételi engedélyt vagy fennmaradási engedélyt adtak ki, a használatbavételi engedély, illetve a fennmaradási engedély másolatát.

(2) Helyettes szülői hálózat, nevelőszülői hálózat, illetőleg külső férőhelyeken biztosított utógondozói ellátás esetén a múködési engedély kiadása iránti kérelemhez a fenntartónak csatolnia kell

a) a működtető vezetőjének - többcélú intézmény keretében végzett szolgáltató tevékenység esetén a szakmai vezető - szakképesítését bizonyító irat másolatát, és a vezető (szakmai vezető) nyilatkozatát arra vonatkozóan, hogy vele szemben nem állnak fenn a Gyvt. 15. §-ának (8) bekezdésében meghatározott kizáró okok,

b) a fenntartónak és a müködtető vezetőjének az együttes nyilatkozatát arra vonatkozóan, hogy

ba) a feladat ellátását biztosító helyettes szülők, nevelöszülők, illetve a feladat ellátását biztosító szakalkalmazottak rendelkeznek a szükséges szakképesítéssel, illetőleg elvégezték a szükséges felkészítő tanfolyamot, és nem állnak fenn velük szemben a Gyvt. 15. §-ának (8) bekezdésében meghatározott kizáró okok, valamint

$b b)$ a helyettes szülők, illetőleg a nevelöszülök büntetlen elöéletüek,

$b c$ ) a helyettes szülők, nevelöszülők, illetve a helyettes szülőkkel, nevelőszülőkkel egy háztartásban élő személyek egészségi állapota nem veszélyezteti az ellátandó kiskorúakat,

c) a szolgáltatótevékenység célját, alapelveit, módszereit tartalmazó szakmai programot,

d) a szolgáltatótevékenység folytatására szolgáló épület (épületrész) használati jogcímét bizonyító okirat másolatát,

e) a helyettes szülö háztartásáról, a nevelöszülő háztartásáról, illetőleg a külső férőhelyet biztosító lakásról (lakrészről) készített környezettanulmányt.

(3) Az (1)-(2) bekezdésekben nem szabályozott szolgáltatótevékenység engedélyezése esetén a müködési engedély kiadása iránti kérelemhez a fenntartónak csatolnia kell

a) - ha a szolgáltatás nyújtása, illetve a munkakör betöltése külön jogszabály szerint szakképesítéshez vagy tanfolyam elvégzéséhez kötött - a szakképesítést, illetve a tanfolyam elvégzését bizonyító okirat másolatát,

b) családi napközi és családi gyermekfelügyelet esetén a szolgáltatást nyújtó személynek és helyettesének, illetve az önálló helyettes szülőnek a három hónapnál nem régebbi erkölcsi bizonyítványát,

c) családi napközi és családi gyermekfelügyelet esetén a szolgáltatást nyújtó személynek és helyettesének, az önálló helyettes szülőnek, valamint a szolgáltatónál külön jogszabályban meghatározott munkakörben, illetve önkéntes jogviszonyban foglalkoztatott személynek a nyilatkozatát arra vonatkozóan, hogy vele szemben nem állnak fenn a Gyvt. 15. §-ának (8) bekezdésében meghatározott kizáró okok,

d) családi napközi és családi gyermekfelügyelet esetén a szolgáltatást nyújtó személynek és helyettesének a külön jogszabály szerinti Egészségügyi Nyilatkozatát, illetve a háziorvos igazolását arra vonatkozóan, hogy a gondozás helyén élő más személyek egészségi állapota nem veszélyezteti az ellátandó gyermekeket, 
e) az önálló helyettes szülő háztartásáról készített környezettanulmányt, valamint a háziorvos igazolását arra vonatkozóan, hogy az önálló helyettes szülő és a gondozás helyén élő más személyek egészségi állapota nem veszélyezteti az ellátandó gyermekeket,

f) a szolgáltatótevékenység célját, alapelveit, módszereit tartalmazó szakmai programot,

g) a házi gyermekfelügyelet és a gyermekek átmeneti házi gondozása kivételével a szolgáltatótevékenység folytatására szolgáló épület (épületrész) használati jogcímét bizonyító okirat másolatát,

h) családi napközi és alternatív napközbeni ellátás esetén - ha beszerezte - az előzetes szakhatósági hozzájárulást.

(4)

(5) Állami fenntartó esetén a kérelemhez - az (1)-(3) bekezdésben foglaltakon túl - csatolni kell

a) a fenntartó és - ha a fenntartóétól különböző adószámmal rendelkezik - a szolgáltató (intézmény, müködtetö) adószámát igazoló közokirat másolatát,

b) - ha a szolgáltató (intézmény, müködtetö) költségvetési szerv - a szolgáltató (intézmény, müködtetö) alapító okiratának másolatát,

c) - ha a fenntartó a helyi önkormányzatok társulásairól és együttmüködéséröl szóló 1997. évi CXXXV. törvény $8 . \S$-a, $9 . \S$-a, illetve 16 . §-a szerinti intézményi társulás vagy települési önkormányzatok többcélú kistérségi társulása - a társulási szerződés másolatát,

d) a fenntartó nyilatkozatát arról, hogy a Gyvt. 145. § (2) bekezdés szerinti szolgáltatót, intézményt, hálózatot, illetve férőhelyszámot normatív állami hozzájárulással kívánja-e müködtetni.

(6) Egyházi és nem állami fenntartó esetén a kérelemhez - az (1)-(3) bekezdésben foglaltakon túl csatolni kell

a) a fenntartó által megkötött, a szolgáltató tevékenység körében okozott kár megtérítésére kötött felelősségbiztosítási szerződés másolatát, ha jogszabály kivételt nem tesz;

b) az ellátási szerződést, ha a fenntartó a szolgáltató tevékenységre ellátási szerződést kötött;

c) annak harminc napnál nem régebbi közokirati igazolását, hogy a fenntartó köztartozásmentes adózónak minősül;

d) egyéni vállalkozó fenntartó esetén az egyéni vállalkozók nyilvántartásában szereplő hatályos adatait igazoló, három hónapnál nem régebbi hatósági bizonyítványt, vagy a működést engedélyező szervnek be kell mutatni az egyéni vállalkozói igazolványt vagy az egyéni vállalkozók nyilvántartásába történő bejelentkezésről, illetve a változás-bejelentésről kiadott, a fenntartó hatályos adatait tartalmazó igazolást (igazolásokat);

e) a fenntartó három hónapnál nem régebbi cégkivonatát, ha a fenntartó cég;

f) a fenntartó bírósági nyilvántartásba bejegyzett hatályos adatairól kiadott, három hónapnál nem régebbi kivonatot, ha a fenntartó társadalmi szervezet, alapítvány vagy közalapítvány;

g) egyházi fenntartó esetén

ga) az egyházat nyilvántartásba vevő bírósági végzés másolatát, kivéve, ha az egyházat a lelkiismereti és vallásszabadságról, valamint az egyházakról szóló 1990. évi IV. törvény 22. §-a alapján vették nyilvántartásba, és

$g b)$ az egyház bírósági nyilvántartásba bejegyzett hatályos adatairól kiadott, három hónapnál nem régebbi kivonatot, továbbá

$g c$ ) - ha a fenntartó az egyház bírósági nyilvántartásba nem vett szervezeti egysége - a nyilvántartásba vett egyház, egyházi jogi személy képviselőjének a nyilatkozatát a fenntartó nevéről, székhelyéről és képviselőjének személyéről, valamint arról, hogy a fenntartó az általa képviselt egyház, egyházi jogi személy szervezeti egysége és az egyház alapszabálya alapján jogi személyiséggel rendelkezik;

h) a fenntartó és - ha a fenntartóétól különbözö adószámmal rendelkezik - a szolgáltató (intézmény, működtető) adószámát igazoló közokirat másolatát, kivéve, ha a fenntartó egyéni vállalkozó vagy cég;

i) a fenntartó nyilatkozatát arról, hogy a Gyvt. 145. § (2) bekezdés szerinti szolgáltatót, intézményt, hálózatot, illetve férőhelyszámot normatív állami hozzájárulással kívánja-e működtetni. ${ }^{107}$

107 145. § (1) A külön törvényben meghatározottak szerint normatív hozzájárulásra, illetve feladatfinanszírozásra jogosult a jogerős müködési engedéllyel gyermekjóléti vagy gyermekvédelmi szolgáltató tevékenységet végzö, közfeladatot ellátó egyházi és - külön törvényben meghatározott - nem állami fenntartó.

(2) Az állami, egyházi és nem állami fenntartó normatív állami hozzájárulásra való jogosultságának feltétele a

a) személyes gondoskodást nyújtó gyermekjóléti alapellátást nyújtó új szolgáltatónak, intézménynek, hálózatnak,

b) gyermekek napközbeni ellátása és gyermekek átmeneti gondozása esetében az új féröhelyeknek 
(6a) Ha a fenntartó a Gyvt. 145. § (2) bekezdése szerinti, a gyermekjóléti szolgáltatások területi lefedettségét figyelembe vevő finanszírozási rendszerbe történő befogadását (a továbbiakban: befogadás) kéri, és a Nemzeti Rehabilitációs és Szociális Hivatal előzetes szakhatósági hozzájárulását nem csatolja, azon szolgáltató, intézmény, hálózat, illetve féröhelyszám esetében, amellyel az ellátásra köteles helyi önkormányzat feladatellátási kötelezettségének tesz eleget, illetve amelyre nézve a fenntartó európai uniós vagy hazai fejlesztési támogatásban részesül, a kérelemhez csatolni kell a jegyző feladatellátást igazoló nyilatkozatát, illetve a pályázat elnyerését igazoló dokumentumot.

(7) Ha a fenntartó a kérelemhez nem csatolta

a) az (1) bekezdés $d$ ) pontja, a (2) bekezdés $d$ ) pontja, illetve a (3) bekezdés $g$ ) pontja szerinti esetben a tulajdoni lap másolatát, a szolgáltató tevékenység folytatására szolgáló ingatlan tulajdoni lapján található adatokat a müködést engedélyező szerv az ingatlan-nyilvántartásból szerzi be,

b) az (5) bekezdés $a$ ) pontja, illetve a (6) bekezdés $h$ ) pontja szerinti iratot, az adószámot a müködést engedélyező szerv az adózók nyilvántartásából ellenőrzi,

c) az (5) bekezdés $b$ ) pontja szerinti iratot, a költségvetési szerv szolgáltató (intézmény, múködtető) alapító okiratának másolatát a müködést engedélyező szerv a Magyar Államkincstártól szerzi be,

d) a (6) bekezdés $c$ ) pontja szerinti iratot, a müködést engedélyező szerv ellenőrzi, hogy az egyházi, nem állami fenntartó szerepel-e a köztartozásmentes adózói adatbázisban,

e) az (1) bekezdés $e$ ) pontja, illetve a (3) bekezdés $h$ ) pontja szerinti iratot - ideértve azt az esetet, ha a fenntartó az (5) bekezdés $d$ ) pontja vagy a (6) bekezdés $d$ ) pontja szerinti nyilatkozata alapján normatív állami hozzájárulást kíván igényelni -, vagy nem igazolta, hogy az előzetes szakhatósági hozzájárulásban a hozzájárulás megadásához megkövetelt feltételt teljesítette, a müködést engedélyező szerv megkeresi a (9) bekezdés szerinti szakhatóságokat, hogy szakhatósági állásfoglalást adjanak ki, illetve - ha intézményi formában végzett szolgáltatótevékenység engedélyezése esetén a kérelem szerinti ingatlanra vonatkozóan, azonos rendeltetésre, a kérelem benyújtását megelőző hat hónapon belül használatbavételi engedélyt vagy fennmaradási engedélyt adtak ki - megkeresi az építésügyi hatóságot, hogy a használatbavételi engedélyröl, illetve a fennmaradási engedélyről szolgáltasson adatot,

f) illetve mutatta be a (6) bekezdés $d$ ) pontja szerinti iratot, vagy az nem tartalmazza az egyéni vállalkozó fenntartónak az egyéni vállalkozók nyilvános nyilvántartásában feltüntetett valamennyi hatályos adatát, az adatokat a müködést engedélyező szerv az egyéni vállalkozók nyilvántartásából szerzi be, illetve ellenörzi,

$g$ ) a (6) bekezdés $e$ )-f) pontja vagy $g a$ )-gb) alpontja szerinti iratot, a működést engedélyező szerv a bíróság nyilvántartásából szerzi be, illetve ellenőrzi az egyházi, nem állami fenntartó nyilvántartásba vett adatait, vagy - ha a fenntartó az egyház bírósági nyilvántartásba nem vett, egyházi fenntartónak minősülő szervezeti egysége - annak a nyilvántartásba vett egyházi jogi személynek a nyilvántartásba vett adatait, amelynek az egyházi fenntartó a szervezeti egysége.

(8) A müködést engedélyező szerv a bölcsőde, a hetes bölcsőde, a családi napközi, a családi gyermekfelügyelet, az alternatív napközbeni ellátás, a gyermekek átmeneti otthona, a családok átmeneti otthona, a gyermekotthon és az utógondozó otthon székhelyén, illetve telephelyén, valamint az önálló gyermekjóléti szolgáltató, a gyermekjóléti szolgálat, a gyermekjóléti központ és a területi gyermekvédelmi

a gyermekjóléti szolgáltatások területi lefedettségét figyelembe vevő, külön jogszabály szerinti finanszírozási rendszerbe történő befogadása.

(2a) A (2) bekezdés alkalmazásában új szolgáltatónak, intézménynek, hálózatnak, illetve féröhelyszámnak az minősül, amelyre a fenntartó 2011. december 31-én nem rendelkezett jogerös müködési engedéllyel és a gyermekjóléti szolgáltatások területi lefedettségét figyelembe vevő finanszírozási rendszerbe nem nyert még befogadást.

(2b) A (2a) bekezdés szerinti esetben a normatív hozzájárulás a külön jogszabály szerinti finanszírozási rendszerbe történő befogadás nélkül is jár, ha a változás a müködési engedély módosítását nem teszi szükségessé.

(3) A normatív hozzájárulásban és támogatásban részesülő egyházi és nem állami fenntartású gyermekjóléti, gyermekvédelmi intézmény a munkavállalók számára legalább a közalkalmazottak jogállásáról szóló 1992. évi XXXIII. törvény 55-80. §-aiban megállapított, a munkaidőre, pihenőidőre, előmeneteli és illetményrendszerre vonatkozó feltételeket köteles biztosítani.

(4) A nem állami, illetve egyházi fenntartónak a külön jogszabályban meghatározott, és az általa fenntartott gyermekjóléti, gyermekvédelmi intézmény müködéséhez biztosított normatív állami hozzájárulás - kivéve a kiegészítő támogatást - teljes összegét át kell adnia azon intézmény részére, amelyre tekintettel a támogatás megállapítására sor került. 
szakszolgálat székhelyén és területi irodájában helyszíni szemlét tart. Nem kell a székhelyen helyszíni szemlét tartani, ha ott ellátást nem nyújtanak.

(9) A Kormány

a) családi napközi múködési engedélyének kiadására irányuló eljárásban, ha egy lakásban egy családi napközi kerül kialakításra, és a gondozott gyermekek száma a saját, napközbeni ellátást máshol igénybe nem vevő gyermekeket és az időszakos gyermekfelügyelet keretében ellátott gyermekeket is beleszámítva sem haladja meg a hét főt, - az ellátás helyére vonatkozó közegészségügyi és az ivóvízminőségi követelményeknek való megfelelés jogszabályi elöírásainak teljesülése kérdésében - első fokú eljárásban a fővárosi és megyei kormányhivatalnak a szolgáltató székhelye, telephelye szerint illetékes kistérségi (fővárosi kerületi) népegészségügyi intézetét (a továbbiakban: kistérségi népegészségügyi intézet), másodfokú eljárásban a fóvárosi és megyei kormányhivatal megyei népegészségügyi szakigazgatási szervét (a továbbiakban: megyei népegészségügyi szakigazgatási szerv);

b) az a) pontban nem említett családi napközi, valamint az alternatív napközbeni ellátás múködési engedélyének kiadására irányuló eljárásban

ba) - az ellátás helyére vonatkozó közegészségügyi, az ivóvíz-minőségi, a települési szilárd és folyékony hulladékkal kapcsolatos közegészségügyi, járványügyi vonatkozású követelmények, valamint a kémiai biztonságra és a dohányzóhelyek kijelölésére vonatkozó jogszabályi elöírások teljesülése kérdésében - első fokú eljárásban a szolgáltató székhelye, telephelye szerint illetékes kistérségi népegészségügyi intézetet, másodfokú eljárásban a megyei népegészségügyi szakigazgatási szervet,

$b b)$ - az ellátás helyére vonatkozó létesítési, használati és üzemeltetési tüzvédelmi elöírások érvényesítése kérdésében - első fokú eljárásban a szolgáltató székhelye, telephelye szerint illetékes, első fokon eljáró tüzvédelmi szakhatóságot, másodfokú eljárásban a másodfokon eljáró tüzvédelmi szakhatóságot,

bc)

c) bölcsőde, hetes bölcsőde, gyermekek átmeneti otthona, családok átmeneti otthona, gyermekotthon és utógondozó otthon müködési engedélyének kiadására irányuló eljárásban

ca) - az intézményre vonatkozó közegészségügyi, az ivóvíz-minőségi, a települési szilárd és folyékony hulladékkal kapcsolatos közegészségügyi, járványügyi vonatkozású követelmények, valamint a kémiai biztonságra és a dohányzóhelyek kijelölésére vonatkozó jogszabályi elöírások teljesülése kérdésében - első fokú eljárásban az intézmény székhelye, telephelye szerint illetékes kistérségi népegészségügyi intézetet, másodfokú eljárásban a megyei népegészségügyi szakigazgatási szervet,

$c b)$ - az intézményre vonatkozó létesítési, használati és üzemeltetési tűzvédelmi elöírások érvényesítése kérdésében - első fokú eljárásban az intézmény székhelye, telephelye szerint illetékes, első fokon eljáró tüzvédelmi szakhatóságot, másodfokú eljárásban a másodfokon eljáró tüzvédelmi szakhatóságot,

cc) ha a kérelem szerinti ingatlanra vonatkozóan, azonos rendeltetésre, a kérelem benyújtását megelőző hat hónapon belül használatbavételi engedélyt vagy fennmaradási engedélyt nem adtak ki, - a településrendezési és általános építésügyi követelményeknek való megfelelés kérdésében - első fokú eljárásban az intézmény székhelye, telephelye szerint illetékes építésügyi hatóságot, másodfokú eljárásban a Kormány általános hatáskörű területi államigazgatási szervét,

$c d)$ - családok átmeneti otthona és utógondozó otthon esetén csak abban az esetben, ha az intézmény meleg étkeztetést nyújt - az élelmiszer-higiéniai és élelmiszer-biztonsági követelményeknek való megfelelés kérdésében - első fokú eljárásban a megyei kormányhivatal Élelmiszerlánc-biztonsági és Állategészségügyi Igazgatóságának kerületi hivatalát, másodfokú eljárásban a megyei kormányhivatal Élelmiszer-biztonsági és Állategészségügyi Igazgatóságát;

d) egyházi vagy nem állami fenntartású, korai fejlesztést és gondozást, illetve fejlesztő felkészítést végző bölcsőde, hetes bölcsőde és gyermekotthon esetén - a korai fejlesztéshez és gondozáshoz, illetve a fejlesztő felkészítéshez szükséges személyi és tárgyi feltételek teljesítése kérdésében - első fokú eljárásban az intézmény székhelye, telephelye szerint illetékes megyei, fővárosi föjegyzőt, másodfokú eljárásban a Kormány általános hatáskörü területi államigazgatási szervét;

e) abban az esetben, ha a fenntartó a szolgáltatót, intézményt, hálózatot, féröhelyet normatív állami hozzájárulással kívánja múködtetni, a befogadás kérdésében az első fokú eljárásban a Nemzeti Rehabilitációs és Szociális Hivatalt, a másodfokú eljárásban a minisztert

szakhatóságként jelöli ki. A szakhatóságok ügyintézési határideje harminc nap. A szakhatóság a fenntartó kérelmére előzetes szakhatósági állásfoglalást ad ki, amely a müködési engedélyezési eljárásban akkor használható fel, ha a fenntartó a müködési engedély iránti kérelmét az előzetes szakhatósági állásfoglalás kiadását követő hat hónapon belül benyújtja.

(10) Családi gyermekfelügyelet engedélyezése esetén ki kell kérni a kistérségi népegészségügyi intézet - a szolgáltató székhelye, telephelye szerint illetékes - vezető védőnőjének (a továbbiakban: védőnő) véleményét. A védőnő - a megkereséstől számított tizenöt napon belül - helyszíni vizsgálat alapján azt véleményezi, hogy a családi gyermekfelügyelet körülményei alkalmasak-e a 2-4 éves gyermekek ellátására. 
(11) A szakmai programot a módszertani intézmény - a kirendeléstől számított harminc napon belül valamennyi szolgáltató tevékenység engedélyezése esetén szakértőként véleményezi. A müködést engedélyező szerv a határidőt - a módszertani intézménynek a határidő letelte előtt benyújtott indokolt kérelmére - egy alkalommal, legfeljebb tizenöt nappal meghosszabbíthatja.

5. § (1) A müködést engedélyező szerv a szolgáltató tevékenységet engedélyezi, ha

a) a fenntartó a 4. § (1)-(3) és (5)-(6) bekezdése szerinti mellékleteket csatolta, illetve a müködést engedélyező szerv a 4 . § (7) bekezdése alapján a szükséges adatokat, iratokat beszerezte,

b) a szolgáltatótevékenység tárgyi és személyi feltételei megfelelnek a külön jogszabályban meghatározott követelményeknek,

c) az egyházi, nem állami fenntartó a kérelme benyújtásának időpontjában köztartozásmentes adózónak minősül.

(2) Az (1) bekezdésben foglaltakon túl a müködési engedély kiadásának további feltétele, hogy a külön jogszabályban foglaltak szerint

a) az önálló gyermekjóléti szolgáltató, a gyermekjóléti szolgálat, a gyermekjóléti központ, a bölcsőde, a hetes bölcsőde, a családi napközi, a családi gyermekfelügyelet, az alternatív napközbeni ellátás, a gyermekek átmeneti otthona, a családok átmeneti otthona, a gyermekotthon, illetőleg az utógondozó otthon, a területi gyermekvédelmi szakszolgálat esetében a szolgáltatótevékenység folytatására, illetőleg az intézmény elhelyezésére szolgáló ingatlan (ingatlanrész) alkalmas a gyermekek, illetőleg a fiatal felnőttek ellátására,

b) a helyettes szülő, illetőleg a nevelőszülő körülményei alkalmasak a gyermek ellátására,

c) a külső férőhely megfelelő lakhatást biztosít,

d)

6. § (1) A mülködési engedélyben fel kell tüntetni

a) a fenntartó nevét, székhelyét és adószámát,

b) a szolgáltatótevékenység típusát és formáját,

c) az ellátási területet,

d) a szolgáltató tevékenység megkezdésének - az engedélyező határozat jogerőre emelkedésének időpontjánál nem korábbi - időpontját,

e) egyházi, nem állami fenntartó esetén - ha a fenntartó a szolgáltató (intézmény, hálózat) által végzett szolgáltató tevékenységekre ellátási szerződést kötött - az ellátási szerződést megkötő helyi önkormányzat, társulás, illetve állami szerv nevét, székhelyét, valamint azokat a szolgáltató tevékenységeket és férőhelyszámot, amelyekre az ellátási szerződés kiterjed,

f) a szolgáltató (intézmény, hálózat), illetve a telephely ágazati azonosítóját.

(2) Intézmény esetén - az (1) bekezdésben foglaltakon túl - a müködési engedélyben fel kell tüntetni

a) az intézmény nevét és - ha a fenntartóétól különböző adószámmal rendelkezik - az adószámát,

b) az intézmény székhelyét, valamint telephelyen végzett szolgáltatótevékenység engedélyezése esetén a telephelyét,

c)

d) a gyermekjóléti szolgálat, a gyermekjóléti központ, illetve a területi gyermekvédelmi szakszolgálat területi irodájának címét,

e) a bölcsőde, hetes bölcsőde, gyermekek átmeneti otthona, családok átmeneti otthona, a gyermekotthon, az utógondozó otthon engedélyezett féröhelyszámát.

(3) Helyettes szülői, illetve nevelőszülői hálózat, illetőleg külső férőhelyeken biztosított utógondozói ellátás esetén - az (1) bekezdésben foglaltakon túl - a müködési engedélyben fel kell tüntetni

a) a működtető nevét, székhelyét és - ha a fenntartóétól különböző adószámmal rendelkezik - az adószámát,

b)

c) a helyettes szülők, illetőleg a nevelőszülők nevét, az ellátás helyét, a hálózat engedélyezett férőhelyszámát, az egyes helyettes szülőknél, illetve nevelőszülőknél elhelyezhető gyermekek és fiatal felnőttek számát, illetőleg

d) a külső férőhelyek számát és címét.

(4) A (2)-(3) bekezdésekben nem szabályozott szolgáltatótevékenység esetén - az (1) bekezdésben foglaltakon túl - a múködési engedélyben fel kell tüntetni

a) a szolgáltató székhelyét és - ha a fenntartóétól különböző adószámmal rendelkezik - az adószámát, valamint telephelyen végzett szolgáltatótevékenység engedélyezése esetén a telephelyét, továbbá önálló helyettes szülöi ellátás esetén azt a helyet, ahol az ellátást nyújtják,

b) a szolgáltató nevét, amely hálózatban müködtetett családi napközi esetén a hálózat és az adott telephely, ellátást nyújtó székhely neve, valamint az önálló helyettes szülö nevét,

c) az önálló gyermekjóléti szolgáltató területi irodájának címét,

d) a családi napközi férőhelyszámát, illetve az önálló helyettes szülőnél elhelyezhető gyermekek számát.

(5) A müködési engedélyben meg kell határozni azt az ellátotti létszámot, amelynek erejéig 
a) a gyermekek átmeneti gondozását végző szolgáltató (intézmény, hálózat) befogadhatja gyermek otthontalanná vált szülőjét,

b) a gyermekotthon elláthatja várandós anyák átmeneti gondozását,

c) a gyermekotthon és a nevelőszülő befogadhatja a gondozásában lévő kiskorú szülö, valamint utógondozói ellátásban részesülő fiatal felnőtt gyermekét,

ha a szolgáltató (intézmény, hálózat) az ellátást biztosítani kívánja.

(6) A müködési engedélyben fel kell tüntetni, ha

a) a gyermekotthon speciális gyermekotthonként kizárólag speciális ellátást igénylő gyermekeket lát el,

b) a gyermekotthon különleges gyermekotthonként kizárólag különleges ellátást igénylö gyermekeket lát

c) a gyermekotthon rendelkezik olyan csoporttal, amelyben kizárólag speciális vagy különleges ellátást igénylő gyermekeket lát el,

d) a nevelöszülői hálózat speciális hivatásos nevelőszülőt foglalkoztat,

e) a gyermekotthon, illetve a nevelőszülöi hálózat az $a$ )-d) pontban nem említett esetben a szakmai programja alapján alkalmas speciális vagy különleges ellátást igénylő gyermekek integrált ellátására,

f) a bölcsőde, a hetes bölcsőde, illetve a gyermekotthon korai fejlesztést és gondozást, illetve fejlesztő felkészítést végez.

(7) A müködési engedélyben fel kell tüntetni, hogy az engedélyt határozott időre vagy határozatlan időre adták ki. A határozott idejü múködési engedélynek tartalmaznia kell az engedély lejártának idejét és a határozatlan idejű engedély kiadásához szükséges feltételeket.

(8) A múködési engedélyben fel kell tüntetni a Gyvt. 145. § (2) bekezdés $a$ ) pontja szerinti új szolgáltatónak, intézménynek, hálózatnak a befogadására, valamint a Gyvt. 145. § (2) bekezdés b) pontja szerinti ellátások esetén a férőhelyszámon belül a befogadott féröhelyek számára vonatkozó adatot.

7. § (1) A müködést engedélyező szerv legfeljebb három év időtartamra ideiglenes müködési engedélyt adhat ki, ha

a) a szakalkalmazottként foglalkoztatott és nem a gyermekek közvetlen gondozását végző személyek száma nem éri el a jogszabályban meghatározott létszámot, de eléri annak háromnegyedét, vagy

b) a szakképesítéssel nem rendelkezö, szakalkalmazottként foglalkoztatott személyeknek a szükséges szakképesítés megszerzése folyamatban van.

(2) Az (1) bekezdés alapján kiadott ideiglenes müködési engedély egyszer, legfeljebb újabb három év időtartamra meghosszabbítható.

(3) Ha a bölcsőde, a hetes bölcsőde, a családi napközi, a családi gyermekfelügyelet, az alternatív napközbeni ellátás, a gyermekek átmeneti otthona, a családok átmeneti otthona, a gyermekotthon, illetve az utógondozó otthon elhelyezésére szolgáló ingatlan használatának joga határozott időre szól, a müködést engedélyező szerv határozott idejü működési engedélyt ad ki legfeljebb arra az időre, ameddig az épület a szolgáltató (intézmény) használatában van.

(4) Ha a szakhatóság a hozzájárulását határozott időre adta meg, a szakhatósági állásfoglalásban meghatározott időre ideiglenes múködési engedélyt kell kiadni. Ha a szakhatóság a hozzájárulását ismét határozott időre adta meg, az ideiglenes működési engedély hatálya meghosszabbítható.

(5) Ha az (1)-(4) bekezdés alapján az adott szolgáltató tevékenységre a müködési engedély több különböző hatállyal is kiadható lenne, a müködési engedélyt a legrövidebb hatállyal kell kiadni. A fennmaradt időre - ha a feltételei egyébként fennállnak - az ideiglenes müködési engedély hatálya is meghosszabbítható.

7/A. $\S$

A müködési engedély módosítása

8. §(1) A fenntartó köteles kérelmezni a müködési engedély módosítását, ha a működési engedélyben feltüntetett adatok megváltoznak.

(2) A müködési engedély módosítását

a) az ok bekövetkeztétől számított egy hónapon belül kell kérelmezni

$a a)$ a fenntartó adataiban bekövetkező változás miatt,

$a b)$ a szolgáltató (intézmény, múködtető) nevének, adószámának megváltozása, illetve telephely múködési engedélyében a székhely megváltozása miatt,

ac) közterület átnevezéséből, átszámozásából adódó címváltozás miatt,

ad) az ellátási szerződés adataiban bekövetkező változás miatt,

$a e)$ be nem töltött férőhelyek megszüntetése miatt a $b$ ) pontban foglalt kivétellel,

af) fenntartóváltozás miatt, ha az új fenntartó a korábbi fenntartó jogutódlással történő megszűnése révén jött létre, vagy a fenntartó egyéni vállalkozó halála esetén a vállalkozói tevékenységet özvegye vagy örököse folytatja, vagy a fenntartó egyéni vállalkozó egyéni céget alapított, illetve átruházással megszerezte az egyéni cég vagyoni betétjét, és a szolgáltatót (intézményt, hálózatot) az egyéni cég veszi át; 
b) a nevelőszülőnek, helyettes szülőnek a nevelőszülöi, helyettes szülői hálózat müködési engedélyéböl történő törlése, illetve a nevelöszülöi, helyettes szülői hálózat féröhelyszámának csökkentése miatt a működési engedély módosítását - ha a működési engedély módosítására más okból nincs szükség - abban a naptári negyedévben kell kérelmezni, amelyben a változás bekövetkezett;

c) az $a$ )-b) pontban nem említett esetben azt megelőzően kell kérelmezni, hogy a szolgáltatót (intézményt, hálózatot) elkezdenék a módosítás iránti kérelemben foglaltaknak megfelelően müködtetni.

(3) A müködési engedély módosítása

a) a (2) bekezdés $b$ ) pontja szerinti esetben naptári negyedévenként egyszer kérelmezhetö,

b) fenntartóváltozás miatt - a (2) bekezdés af) alpontjában foglaltak kivételével - naptári évenként egyszer kérelmezhető, a kérelmet a korábbi és az új fenntartónak együttesen kell benyújtania.

(3a) A fenntartóváltozások (3) bekezdés $b$ ) pontja szerinti éves számának meghatározásánál a jogszabály erejénél fogva történő fenntartóváltozást figyelmen kívül kell hagyni.

(4) A múködési engedély módosítására a müködési engedély kiadására vonatkozó szabályokat kell megfelelően alkalmazni azzal, hogy

a) a kérelemhez csak a változással összefüggő körülményekkel kapcsolatos iratokat kell csatolni;

b) - ha jogszabály másként nem rendelkezik - csak a változással összefüggő körülményeket kell vizsgálni, és ezekkel kapcsolatban kell bizonyítási eljárást lefolytatni;

c) csak az (5) bekezdés szerinti szakhatóságokat kell az eljárásba bevonni;

d) családi gyermekfelügyelet esetén ki kell kérni a védőnő véleményét, ha a 4 . § (10) bekezdése szerint körülmények megváltoznak;

e) helyszíni szemlét kell tartani

ea) bölcsőde, hetes bölcsőde, családi napközi, családi gyermekfelügyelet, alternatív napközbeni ellátás, gyermekek átmeneti otthona, családok átmeneti otthona, gyermekotthon és utógondozó otthon esetén, ha az ellátást nyújtó székhely, telephely megváltozik, a férőhelyszám emelkedik, az ellátásba a szolgáltató (intézmény) elhelyezésére korábban nem szolgáló épületet (épületrészt) kívánnak bevonni, vagy az ellátásból korábban erre a célra szolgáló épületet (épületrészt) kívánnak kivonni,

$e b)$ önálló gyermekjóléti szolgáltató, gyermekjóléti szolgálat, gyermekjóléti központ és területi gyermekvédelmi szakszolgálat esetén, ha az ellátást nyújtó székhely megváltozik, vagy a módosítás célja területi irodának a müködési engedélyben történő feltüntetése,

ec) az ea)-eb) alpontban nem említett esetben, ha a helyszíni szemle tartása egyéb okból indokolt;

f) csak fenntartóváltozás esetén - ide nem értve a (2) bekezdés af) alpontjában foglaltakat - feltétele a múködési engedély módosításának, hogy a kérelem benyújtásakor a szolgáltatót (intézményt, hálózatot) átvevő egyházi, nem állami fenntartó köztartozásmentes adózónak minősüljön;

g) a szakmai program véleményezésére a módszertani intézményt akkor kell szakértőként kirendelni, ha a módosítás új szolgáltató tevékenység engedélyeztetésére irányul.

(5) A működési engedély módosítására irányuló eljárásban szakhatóságként járnak el:

a) családi napközi és alternatív napközbeni ellátás esetén a változással összefüggésben a 4. § (9) bekezdésének $a$ ), illetve $b$ ) pontja szerinti szakhatóságok, ha a szolgáltató ellátást nyújtó székhelye, telephelye megváltozik, az ellátásba a szolgáltató elhelyezésére korábban nem szolgáló épületet (épületrészt) kívánnak bevonni, vagy a müködési engedély módosításának célja családi napközi ellátás vagy alternatív napközbeni ellátás engedélyezése, és az ehhez kapcsolódó követelményeket a hatáskörrel rendelkezö szakhatóság korábban nem vizsgálta meg;

b) bölcsőde, hetes bölcsőde, gyermekek átmeneti otthona, családok átmeneti otthona, gyermekotthon és utógondozó otthon esetén

ba) a 4. $\S$ (9) bekezdésének $c a$ )-cc) alpontja, továbbá - ha a hatáskörüket érinti - a 4. $\S$ (9) bekezdésének $c d$ ) alpontja, illetve $d$ ) pontja szerinti szakhatóságok a változással összefüggésben, ha az intézmény ellátást nyújtó székhelye, telephelye megváltozik, vagy az ellátásba az intézmény elhelyezésére korábban nem szolgáló épületet (épületrészt) kívánnak bevonni, vagy ha a müködési engedély módosításának célja valamely e pont szerinti szolgáltató tevékenység engedélyezése, és az ehhez kapcsolódó követelményeket a hatáskörrel rendelkező szakhatóság korábban nem vizsgálta meg,

$b b)$ a kistérségi népegészségügyi intézet - a közegészségügyi követelmények teljesülésének szakkérdésében -, valamint az elsőfokú tüzvédelmi szakhatóság - a változással összefüggő létesítési, használati és üzemeltetési tüzvédelmi elöírások teljesülése kérdésében -, ha a férőhelyek száma emelkedik;

c) a 4 . $\S(9)$ bekezdésének $d$ ) pontja szerinti szakhatóság, ha egyházi vagy nem állami fenntartású bölcsőde, hetes bölcsőde vagy gyermekotthon korai fejlesztést és gondozást, illetve fejlesztő felkészítést kíván nyújtani;

d) gyermekotthon esetén a változással összefüggésben a kistérségi népegészségügyi intézet - a közegészségügyi követelmények teljesülésének szakkérdésében -, ha a továbbiakban speciális vagy különleges gyermekotthonként kívánják működtetni; 
e) az a szakhatóság, amely a hozzájárulását a korábbiakban határozott időre adta meg, ha a fenntartó az ideiglenes müködési engedély határozatlan vagy határozott idejüre történő módosítását, illetve hatályának meghosszabbítását kéri;

f) a 4. $\S(9)$ bekezdés $e$ ) pontja szerinti szakhatóság, ha a müködési engedély módosításának célja befogadás.

(6) Ha a működési engedély módosítása következtében ellátás megszüntetésére kerül sor, a múlködési engedély módosításának

a) ellátási kötelezettséget teljesítő állami fenntartó esetén feltétele, hogy az ellátott gyermekekről és más ellátottakról (a továbbiakban együtt: ellátott gyermekek) megfelelően gondoskodott,

b) az a) pontban nem említett fenntartó esetén feltétele, hogy a 8/A. § (4) bekezdése szerinti bejelentési kötelezettségének határidőben eleget tett, vagy a gyermekekről megfelelően gondoskodott.

(7) A működési engedélyt módosító határozatban fel kell tüintetni

a) azt az időpontot, amelytől kezdődően a szolgáltató (intézmény, hálózat) a módosításnak megfelelően müködtethető, és amely a (2) bekezdés $a$ )- $b$ ) pontjában nem említett esetben nem lehet korábbi, mint a müködési engedélyt módosító határozat jogerőre emelkedésének időpontja, valamint

b) a müködési engedélynek a módosítást követően hatályos valamennyi adatát.

(8) A határozott idejü müködési engedély hatálya meghosszabbítható vagy határozatlan idejüre módosítható, ha a 7. § (3) bekezdése szerinti szolgáltató (intézmény) elhelyezésére szolgáló ingatlan használatának joga meghosszabbodik, illetve határozatlan idejüre módosul.

(9) Ha jogszabály másként nem rendelkezik, az ideiglenes müködési engedély a hatályának megváltoztatása nélkül módosítható, feltéve, hogy az ellátás színvonala nem romlik. Ha a fenntartó azelött igazolja, hogy a szolgáltató (intézmény, hálózat) megfelel a jogszabályokban meghatározott feltételeknek, mielőtt az ideiglenes müködési engedély hatályát vesztené, a müködés engedélyt határozatlan, illetve a 7. § (3) bekezdése szerinti esetben határozott idejüre kell módosítani. Az ideiglenes müködési engedély hatálya csak akkor hosszabbítható meg, ha azt jogszabály lehetővé teszi.

(10) Ha a fenntartó azelőtt kérelmezi a határozott idejü, illetve az ideiglenes múködési engedély hatályának módosítását, mielőtt az hatályát vesztené, a kérelem elbírálásáig a működési engedély hatálya meghosszabbodik. A müködési engedély hatályának meghosszabbítása során a 7 . § (5) bekezdésében foglaltakat megfelelöen alkalmazni kell.

(11) Ha a müködést engedélyező szerv tudomására jutott tény vagy adat alapján kétséges, hogy a szolgáltató (intézmény, hálózat) a kérelemmel nem érintett, jogszabályokban meghatározott feltételeket teljesíti, a működést engedélyező szerv egyéb működési feltételeket is megvizsgálhat, azokkal kapcsolatban bizonyítási eljárást folytathat le, szükség esetén a 4. § (9) bekezdése szerinti hatóságokat is bevonhatja, továbbá - ha jogsértést állapít meg, a kérelemmel érintett változások és a jogsértés jellegétől függően - erre hivatkozva a kérelmet elutasíthatja, illetve alkalmazhatja a 14/B. § szerinti jogkövetkezményeket.

\section{Bejelentési kötelezettség}

8/A. § (1) A fenntartó köteles az első fokú múködést engedélyező szervnek a változást követő tizenöt napon belül bejelenteni, ha

a) bölcsőde, hetes bölcsőde, családi napközi, családi gyermekfelügyelet, alternatív napközbeni ellátás, gyermekek átmeneti otthona, családok átmeneti otthona, gyermekotthon és utógondozó otthon esetén

aa) az ellátásba a szolgáltató (intézmény) elhelyezésére korábban nem szolgáló épületet (épületrészt) vont be, vagy az ellátásból korábban erre a célra szolgáló épületet (épületrészt) vont ki,

$a b)$ a szolgáltató (intézmény) épületén építésiengedély-köteles építést, bővítést vagy átalakítást végeztetett,

b) az engedélyezés alapjául szolgáló egyéb lényeges körülményben bekövetkező változást, így különösen, ha a szolgáltató (intézmény, hálózat, telephely) vezetője megváltozik, vagy a szakmai program, illetve ellátási szerződés lényeges eleme megváltozik,

feltéve, hogy a változások a müködési engedély módosítását nem teszik szükségessé.

(2) Az (1) bekezdés $a b$ ) alpontja szerinti bejelentéshez csatolni kell a jogerős használatbavételi engedély vagy fennmaradási engedély másolatát. Ha a fenntartó a használatbavételi engedélyt, illetve a fennmaradási engedélyt nem csatolja, annak adatait a működést engedélyező szerv az építésügyi hatóságtól szerzi be.

(3) Az (1) bekezdés $b$ ) pontja szerinti bejelentési kötelezettség nem teljesítése esetén gyermekvédelmi igazgatási bírság (a továbbiakban: bírság) nem szabható ki.

(4) Az egyházi, a nem állami és az ellátási kötelezettséget teljesítőnek nem minősülő állami fenntartó gyermekek napközbeni ellátása esetén legalább két hónappal, gyermekek átmeneti gondozása, otthont nyújtó ellátás és utógondozói ellátás esetén legalább hat hónappal korábban köteles bejelenteni

a) az érintett gyermekek törvényes képviselőinek és az érintett nagykorú ellátottaknak, valamint

b) az első fokú müködést engedélyező szervnek,

hogy kérelmezni fogja a müködési engedély visszavonását, vagy olyan módosítását, amelynek következtében gyermekek vagy más személyek ellátásának megszüntetésére kerül sor, kivéve, ha ellátásukról megfelelően 
gondoskodik. Ellátási szerződés a bejelentési kötelezettség teljesítésére eltérö, de legalább egy hónapos határidőt is megállapíthat.

(5) A fenntartó köteles az ok bekövetkeztétől számított öt napon belül bejelenteni a (4) bekezdés $a$ )b) pontja szerinti személyeknek és szervnek, ha

a) az egyéni vállalkozói tevékenységre való jogosultsága a (6) bekezdésben nem említett esetben megszünt vagy szünetel,

b) az egyéni vállalkozói tevékenysége folytatásának megtiltása iránt eljárás indult, és ha az eljárás befejeződött,

c) a jogutód nélküli megszünése iránt eljárás indult, és ha az eljárás befejeződött.

(6) Ha a fenntartó egyéni vállalkozó meghal vagy cselekvőképességet kizáró vagy korlátozó gondnokság alá helyezik, az özvegy, az örökös, illetve a gondnok köteles ezt az első fokú müködést engedélyező szervnek az ok bekövetkeztétől számított tíz napon belül bejelenteni.

(7) $\mathrm{Az}$ (5)-(6) bekezdés alapján teljesített bejelentéshez mellékelni kell a bejelentésben foglaltakat alátámasztó okirat másolatát. Ha a bejelentésre kötelezett az (5) bekezdés $a$ )-b)pontja vagy a (6) bekezdés, illetve bírósági nyilvántartásba vett fenntartó esetén a (5) bekezdés $c$ ) pontja alapján teljesített bejelentésben foglaltakat nem igazolja, és az adat az egyéni vállalkozók nyilvántartásában, illetve bírósági nyilvántartásban rendelkezésre áll, a bejelentésben foglaltakat a müködést engedélyező szerv a nyilvántartásból ellenőrzi.

(8) A müködést engedélyező szerv a (4)-(6) bekezdés szerinti bejelentésről nyolc napon belül értesíti az ellátásra köteles helyi önkormányzatot, megyei fenntartót, az igazgatóságot és a gyermekjogi képviselőt.

\section{Engedély nélkül végzett szolgáltató tevékenység}

9. § (1) Ha az engedélyező szerv engedély nélkül végzett szolgáltató tevékenységről szerez tudomást,

a) kötelezi a fenntartót a szolgáltató tevékenység abbahagyására, ha a gyermekek elhelyezésére szolgáló épület állaga vagy a szolgáltató (intézmény, hálózat) müködése a gyermekek életét, testi épségét vagy egészségét súlyosan veszélyezteti, illetve a gyermekek más alkotmányos jogait súlyosan sérti,

b) az a) pontban nem említett esetben felszólítja a fenntartót, hogy harminc napon belül kérelmezze a működési engedély kiadását,

c)

(2) Amennyiben a fenntartó az (1) bekezdésben meghatározott határidő lejártáig a müködési engedély iránti kérelmét nem nyújtja be, vagy a kérelmet elutasítják, a müködést engedélyező szerv

a) kötelezi a fenntartót a szolgáltató tevékenység abbahagyására,

b) értesíti a szolgáltató (intézmény, müködtető) székhelye, telephelye szerint illetékes városi, fővárosi kerületi gyámhivatalt és az ellátásra köteles helyi önkormányzat jegyzőjét, főjegyzőjét, a megyei fenntartó vezetöjét,

c) a Gyvt. alapján ellátásra jogosult személyek ellátása érdekében a 12. §-ban foglaltak szerint $^{108}$ intézkedik.

10. § (1) A müködést engedélyező szerv a müködési engedélyt visszavonja

a) a fenntartó - jogszabályoknak és az ellátási szerződésben foglaltaknak megfelelő - kérelmére,

b) a fenntartó egyéni vállalkozói tevékenységre való jogosultságának megszünése, e tevékenység folytatásának megtiltása vagy szüneteltetése esetén az (5) bekezdésben foglaltak kivételével,

c) a fenntartó jogutód nélküli megszünése esetén,

108 12. § (1) A gyermek szülője jogosult és köteles arra, hogy gyermekét családban gondozza, nevelje és a gyermeke testi, értelmi, érzelmi és erkölcsi fejlödéséhez szükséges feltételeket - különösen a lakhatást, étkezést, ruházattal való ellátást -, valamint az oktatásához és az egészségügyi ellátásához való hozzájutást biztosítsa.

(2) A gyermek szülője jogosult arra, hogy a gyermeke nevelkedését segítő ellátásokról tájékoztatást, neveléséhez segítséget kapjon.

(3) A gyermek szülöje - ha törvény másként nem rendelkezik - jogosult és köteles gyermekét annak személyi és vagyoni ügyeiben képviselni.

(4) A gyermek szülője köteles

a) gyermekével együttmüködni, és emberi méltóságát a 6 . $§(5)$ bekezdése szerint tiszteletben tartani,

b) gyermekét az őt érintő kérdésekről tájékoztatni, véleményét figyelembe venni,

c) gyermekének jogai gyakorlásához iránymutatást, tanácsot és segítséget adni,

d) gyermeke jogainak érvényesítése érdekében a szükséges intézkedéseket megtenni,

e) a gyermeke ellátásában közreműködő személyekkel és szervekkel, továbbá a hatóságokkal együttmüködni. 
d) törvényben vagy kormányrendeletben meghatározott egyéb esetben.

(2) A fenntartó köteles a müködési engedély visszavonását a (3)-(4) bekezdésben foglaltak szerint kérelmezni, vagy - az a)-b) pont szerinti esetben - a szolgáltatót (intézményt, hálózatot) a 8. §-ban foglaltak szerint más fenntartónak átadni, mielött

a) az egyéni vállalkozói tevékenység megszüntetését vagy szüneteltetését az egyéni vállalkozói tevékenységgel kapcsolatos ügyekben eljáró, országos illetékességủ hatóságnak bejelentené, illetve a jogutód nélkül megszünését kérné,

b) a szolgáltatót (intézményt, hálózatot) megszüntetné, vagy fenntartásával felhagyna,

c) a szolgáltató (intézmény, hálózat) a szolgáltató tevékenységek végzésével felhagyna.

(3) Az ellátási kötelezettséget teljesítő állami fenntartó kérelmére a müködési engedély akkor vonható vissza, ha az ellátott gyermekekröl megfelelően gondoskodott.

(4) Az egyházi, a nem állami és az ellátási kötelezettséget teljesítőnek nem minősülő állami fenntartó kérelmére a múködési engedély akkor vonható vissza, ha

a) a 8/A. § (4) bekezdése szerinti bejelentési kötelezettségének határidőben eleget tett, vagy

b) az ellátott gyermekekről megfelelően gondoskodott.

(5) A múködési engedély nem vonható vissza

a) a fenntartó egyéni vállalkozó halála esetén, ha az özvegy, illetve az örökös határidöben benyújtott kérelmére a fenntartóváltozást engedélyezik,

b) a fenntartó egyéni vállalkozó cselekvőképességet kizáró vagy korlátozó gondnokság alá helyezése esetén, ha a gondnok az ok bekövetkeztétöl számított egy hónapon belül bejelenti, hogy az egyéni vállalkozói tevékenységet az egyéni vállalkozó nevében és javára folytatja,

c) ha a fenntartó egyéni vállalkozó egyéni céget alapított, vagy átruházással megszerezte az egyéni cég vagyoni betétjét, és határidőben benyújtott kérelmére a fenntartóváltozást engedélyezik.

11. $\S$

12. § (1) A müködést engedélyező szerv értesíti a gyermek ellátására a Gyvt. értelmében köteles települési, fővárosi kerületi önkormányzat jegyzőjét, a fővárosi önkormányzat föjegyzőjét, illetve a megyei fenntartót, ha

a)

b)

c) az engedély nélkül végzett szolgáltatótevékenység működési engedélye iránti kérelmet a fenntartó - a 9. § (1) bekezdésében meghatározott határidőn belül - nem nyújtja be.

(2) Amennyiben a szociális és gyámhivatal gyermekek átmeneti gondozásának, otthont nyújtó ellátásnak, illetve utógondozói ellátásnak a müködési engedélyét vonja vissza, vagy ilyen szolgáltató tevékenységet végeznek működési engedély nélkül, az ellátás ideiglenes megszervezése érdekében - a szociális és gyámhivatal megkeresése alapján - a gondozási hely szerint illetékes megyei fenntartó, fövárosi föjegyző haladéktalanul intézkedik. A gyermek további ellátásáról a Gyvt. értelmében arra köteles települési önkormányzat, megyei fenntartó hatvan napon belül gondoskodik.

(3) A (2) bekezdésben megjelölt ellátási kötelezettség teljesítéséhez az arra kötelezett szolgáltató (intézmény, hálózat) fenntartója a külön jogszabályban meghatározottak szerint normatív állami támogatásra jogosult.

\section{Tanúsítvány}

12/A. § (1) A müködési engedélyt kiadó határozat jogerőre emelkedését követő tizenöt napon belül az első fokú múködést engedélyező szerv a fenntartó részére a miniszter által erre a célra rendszeresített formában, a 2. számú melléklet szerinti adattartalommal, a szükséges számú példányban tanúsítványt állít ki.

(2) A tanúsítványt a szolgáltató (intézmény, müködtető) székhelyén, telephelyén és területi irodáiban jól látható módon ki kell függeszteni.

(3) A müködési engedélynek a tanúsítványban foglalt adatokat érintő módosítása és visszavonása esetén az első fokú müködést engedélyező szerv a tanúsítványt bevonja, és módosítás esetén új tanúsítványt állít ki.

\section{A szolgáltatás igénybevételéröl szóló megállapodás}

13. § (1) Ha a szolgáltatás igénybevétele nem hatósági határozat alapján történik, a gyermek törvényes képviselője és a szolgáltató (intézmény, müködtető) vezetője - az ellátás kezdetétől számított 15 napon belül - megállapodást köt, amely tartalmazza különösen

a) az ellátás kezdetének időpontját,

b) az ellátás időtartamát, amely nem lehet hosszabb külön jogszabályban meghatározott mértéknél,

c) az intézmény által nyújtott szolgáltatásokat,

d) a térítési díj fizetésére kötelezett személy nevét, lakcímét,

e) a személyi térítési díj összegét,

f) az ellátás megszünésére vonatkozó szabályokat.

(2) Családok átmeneti otthona esetén a megállapodás - a (2) bekezdésben foglaltakon túl - tartalmazza 
a) a gyermekkel együtt ellátásban részesülö személy gyermekgondozással kapcsolatos feladatait, a gondozás módját, mértékét,

b) a szülő nyilatkozatát arról, hogy a gyermekjóléti szolgáltatást nyújtó szolgáltatóval, illetve intézménnyel együttmüködik.

(3) A gyámhivatal határozatával elrendelt utógondozói ellátás esetén az utógondozói ellátásra jogosult fiatal felnőtt és a szolgáltató (intézmény, müködtető) vezetője - az ellátás kezdetétől számított tizenöt napon belül - megállapodást köt, amely tartalmazza különösen

a) az ellátás kezdetének időpontját,

b) az intézmény által nyújtott szolgáltatásokat,

c) a személyi térítési díj összegét,

d) az ellátás megszünésére vonatkozó szabályokat.

\section{A gyermekjóléti és gyermekvédelmi szolgáltatótevékenység ellenörzése}

14. § (1) A müködést engedélyező szerv gyermekjóléti szolgáltatás, gyermekek napközbeni ellátása és gyermekek átmeneti gondozása esetén legalább kétévente, otthont nyújtó ellátás, utógondozói ellátás és területi gyermekvédelmi szakszolgáltatás esetén pedig legalább évente ellenőrzi, hogy a szolgáltató (intézmény, hálózat) a jogszabályokban és a múködési engedélyben foglaltaknak megfelelően múködik-e.

(2) A müködést engedélyező szerv éves ellenőrzési tervet készít, amelyet minden év január 31-éig megküld a felügyeleti szervének és annak a hatóságnak, amelyet a 14/A. § (2) bekezdése alapján meg kell keresnie.

(3) A múködést engedélyező szerv helyszíni ellenőrzést tart

a) az (1) bekezdésben meghatározott esetben,

b) ha tudomására jut, hogy a szolgáltató (intézmény, hálózat) személyi, tárgyi feltételei vagy müködése az ellátott gyermekek életét, testi épségét, egészségét vagy fejlődését veszélyezteti, vagy más jogát sérti, illetve a szolgáltató (intézmény, hálózat) müködésére vonatkozó jogszabályokat vagy a müködési engedélyben foglaltakat súlyosan megsértették,

c) a 8/A. § (1) bekezdés $a a$ ) alpontja szerinti bejelentést követő harminc napon belül.

(4) Ha a szolgáltató (intézmény, hálózat) múködésével kapcsolatban más hatóság észlel hiányosságot, köteles azt nyolc napon belül jelezni az első fokú müködést engedélyező szervnek.

(5) Családi gyermekfelügyelet ellenőrzése során a 4. § (10) bekezdése szerint körülményekkel kapcsolatban ki kell kérni a védőnő véleményét.

(6) A müködést engedélyező szerv az ellenőrzésről készült jegyzőkönyvet, illetve hivatalos feljegyzést megküldi a fenntartónak és a szolgáltatónak (intézménynek, hálózatnak), továbbá azok másolatát normatív állami hozzájárulásban részesülö egyházi és nem állami fenntartású szolgáltató (intézmény, hálózat) esetén az Igazgatóságnak.

(7) Ha jogszabály másként nem rendelkezik, az eljárás során a fenntartó és a szolgáltató (intézmény, működtető, helyettes, illetve nevelőszülők) köteles átadni, illetve megküldeni az ellenőrzéshez szükséges adatokat és iratokat a müködést engedélyező szervnek.

14/A. § (1) Ha a müködést engedélyező szerv a 4. § (9) bekezdése szerinti hatóságot ellenőrzés lefolytatása céljából megkeresi, az a feladat- és hatáskörébe tartozó kérdésekben - ideértve a meleg étkeztetést nyújtó családi napközinek és az alternatív napközbeni ellátásnak, valamint a 4. § (9) bekezdésének $c d$ ) alpontja szerinti szolgáltató tevékenységnek a kistérségi népegészségügyi intézet által történő ellenőrzése során a táplálkozás-egészségügyi és dietetikai feltételek teljesítését is - a szolgáltatónál (intézménynél, hálózatnál), a működést engedélyező szervvel együttműködve, harminc napon belül ellenőrzést folytat le.

(2) A működést engedélyező szerv a 14. § (1) bekezdése szerinti ellenőrzést megelőzően legalább tizenöt nappal ellenőrzés lefolytatása céljából megkeresi

a) családi napközi, alternatív napközbeni ellátás, bölcsőde, hetes bölcsőde, gyermekek átmeneti otthona, családok átmeneti otthona, gyermekotthon és utógondozó otthon esetén a kistérségi népegészségügyi intézetet,

b) egyházi vagy nem állami fenntartású, korai fejlesztést és gondozást, illetve fejlesztő felkészítést végző bölcsőde, hetes bölcsőde és gyermekotthon esetén a megyei, fővárosi föjegyzőt.

(4) A 4. § (9) bekezdése szerinti hatóság a szolgáltatónál (intézménynél, hálózatnál) lefolytatandó ellenőrzésről előzetesen értesíti az első fokú müködést engedélyező szervet, ha az ellenőrzés lefolytatása céljából nem a müködést engedélyező szerv kereste meg.

(5) Ha a 4. § (9) bekezdése szerinti vagy más hatóság szolgáltatót (intézményt, hálózatot) ellenőriz,

a) az ellenőrzésröl készült jegyzőkönyv, illetve hivatalos feljegyzés másolatát megküldi az első fokú müködést engedélyező szervnek,

b) az ügyben hozott döntését közli az első fokú múködést engedélyező szervvel.

14/B. § (1) A müködést engedélyező szerv 
a) a müködési engedélyt visszavonja, ha a szolgáltató (intézmény, hálózat) megszünt vagy szolgáltató tevékenységet nem végez;

b) a területi irodát, illetve a külső féröhelyet - szükség szerint a szolgáltató férőhelyszámának egyidejü csökkentésével - törli a müködési engedélyből, ha az elhelyezésére szolgáló épület (épületrész) állaga az ellátott gyermekek életét, testi épségét vagy egészségét súlyosan veszélyezteti;

c) a nevelőszülöt, helyettes szülöt - szükség szerint a hálózat férőhelyszámának egyidejü csökkentésével törli a hálózat müködési engedélyéből, ha az ellátott gyermekek életét, testi épségét, egészzégét vagy fejlődését súlyosan veszélyezteti, illetve más alapvető jogát súlyosan sérti, vagy jogszabály a nevelőszülöként, helyettes szülöként történő müködését kizárja;

d) az intézmény épületének egy részét lezáratja, ha az az intézmény müködőképességének fenntartása mellett megfelelően lezárható, és állaga az ellátott gyermekek életét, testi épségét vagy egészségét súlyosan veszélyezteti;

e) a $b$ )-d pontban nem említett esetben a múködési engedélyt visszavonja, és kötelezi a fenntartót, hogy a szolgáltató tevékenységgel hagyjon fel, ha a szolgáltató (intézmény, hálózat) személyi, tárgyi feltételei vagy müködése az ellátott gyermekek életét, testi épségét, egészségét vagy fejlődését súlyosan veszélyezteti, illetve más alapvető jogát súlyosan sérti;

$f)$ az $a$ )-c) és $e$ ) pontban nem említett jogsértés esetén a jogsértés jellegétől és súlyától függően, az ellátott gyermekek érdekeinek figyelembevételével

fa) legalább tizenöt napos, de legfeljebb négy hónapos határidő megjelölésével szólíthatja fel a fenntartót a hiányosság vagy más jogsértés megszüntetésére, illetve a jogszerü müködés helyreállítására,

$f b)$ az $f a$ ) alpont szerinti felszólítással egyidejüleg - ha az ellátott gyermekek Gyvt. szerinti jogainak megóvása érdekében szükséges - legfeljebb a hiányosság vagy más jogsértés megszüntetéséig, illetve a jogszerủ müködés helyreállításáig megtilthatja újabb gyermekek, illetve más ellátottak felvételét,

fc) az ügynek az ellátott gyermekek, az ellátási érdek és a fenntartó szempontjából is előnyös rendezése érdekében a hiányosság - legfeljebb három éven belül történő - megszüntetéséről a fenntartóval hatósági szerződést köthet,

$f d$ a müködési engedélyt az ellenőrzés során megállapított tényeknek és a jogszabályoknak megfelelően a b)-c) pontban foglaltakon túl hivatalból módosíthatja, ha a fenntartó elmulasztotta kérni a müködési engedély módosítását;

g) a Gyvt.-ben meghatározott esetben bírságot szabhat ki.

(2) A közigazgatási hatósági eljárás és szolgáltatás általános szabályairól szóló 2004. évi CXL. törvény 94. § (2) bekezdés $b$ ) pontja alkalmazásának van helye

a) az (1) bekezdés $b$ )-e) pontjában és $f b$ ) alpontjában foglalt jogkövetkezmények esetén;

b) bírság kiszabása esetén

$b a$ a a Gyvt. 100/A. §-a (1) bekezdésének $a$ )-b) pontja szerinti esetben,

$b b)$ a 8/A. § (1) bekezdésének a) pontja és (4)-(6) bekezdése szerinti bejelentési kötelezettség elmulasztása miatt.

(3) A fenntartó kérelmére az (1) bekezdés $f a$ ) alpontja szerinti határidő indokolt esetben egyszer, legfeljebb két hónappal meghosszabbítható. Ha a fenntartó a megjelölt határidőben nem igazolja, hogy a felszólításban foglaltaknak eleget tett, vagy a felszólításban foglaltak teljesítésének megállapítása érdekében egyébként szükséges, a müködést engedélyező szerv utóellenőrzést tart. Ha a fenntartó a megjelölt határidőben nem intézkedik a szabályszerü müködés megteremtése érdekében, a müködést engedélyező szerv a jogsértés jellegétől és súlyától függően, az ellátott gyermekek érdekeinek figyelembevételével

a) a határozatlan vagy határozott idejü müködési engedélyt feltételek elöírása mellett - legfeljebb két évig hatályos - ideiglenes müködési engedélyre módosíthatja,

b) az ügynek az ellátott gyermekek, az ellátási érdek és a fenntartó szempontjából is előnyös rendezése érdekében a hiányosság - legfeljebb három éven belül történő - megszüntetéséről a fenntartóval hatósági szerződést köthet,

c) a hiányosság vagy más jogsértés megszüntetéséig, illetve a jogszerü müködés helyreállításáig megtilthatja újabb gyermekek, illetve más ellátottak felvételét,

d) csökkentheti a féröhelyek számát,

e) az intézmény épületének egy részét lezárathatja,

f) a nevelőszülöt, helyettes szülőt - szükség szerint a hálózat férőhelyszámának egyidejü csökkentésével törölheti a müködési engedélyböl,

$g$ ) a területi irodát, illetve a külső férőhelyet - szükség szerint a szolgáltató férőhelyszámának egyidejü csökkentésével - törölheti a müködési engedélyböl,

h) a müködési engedélyt visszavonhatja, és kötelezheti a fenntartót, hogy a szolgáltató tevékenységgel hagyjon fel, 
i) a müködési engedélyt az ellenőrzés során megállapított tényeknek és a jogszabályoknak megfelelöen az $a$ ), d) és $f$ )-g) pontban foglaltakon túl hivatalból módosíthatja, ha a fenntartó elmulasztotta kérni a müködési engedély módosítását,

j) a Gyvt.-ben meghatározott esetben bírságot szabhat ki,

k) alkalmazhatja a Gyvt.-ben meghatározott egyéb jogkövetkezményeket.

(4) A jogsértés jellegének, súlyának megfelelően egyidejüleg több jogkövetkezmény is megállapítható.

(5) Az intézmény épületének lezárt része szolgáltató tevékenységhez akkor használható, ha a müködést engedélyező szerv a lezárást - az arra okot adó körülmény megszünése esetén - a fenntartó kérelmére megszünteti.

(6) A hatósági szerződésben meg kell határozni azt az egy vagy több - (3) bekezdés szerinti jogkövetkezményt, amelyik jogerőssé válik, ha a fenntartó a hatósági szerződésben foglaltakat megszegi. A jogkövetkezmény jogerőssé válását - ha ezzel a müködési engedély módosításra vagy visszavonásra kerül - a működést engedélyező szerv végzéssel állapítja meg, amelyben a müködési engedély módosítása esetén fel kell tüntetni a módosítás időpontját és a müködési engedélynek a módosítást követően hatályos valamennyi adatát.

(7) A (3) bekezdés $a$ ) pontja alapján kiadott ideiglenes müködési engedély hatálya egy alkalommal, legfeljebb egy évvel meghosszabbítható.

(8) Az újabb gyermekek, illetve más ellátottak felvétele a (3) bekezdés $c$ ) pontjában foglaltaktól eltérő időpontig is megtiltható, ha az egyidejüleg alkalmazott más jogkövetkezmény azt indokolja. Ha a tilalmat megszegik, a müködést engedélyezö szerv a (3) bekezdésben meghatározott más jogkövetkezményt alkalmazhat.

15. § (1) A szociális és gyámhivatal, a gyermekvédelmi és gyámügyi feladat- és hatáskörök ellátásáról, valamint a gyámhatóság szervezetéről és illetékességéről szóló 331/2006. (XII. 23.) Korm. rendelet 14. § (1) bekezdés $b$ ) pontjában meghatározott intézmények, illetve személyek bevonásával, legalább négyévente, az adott évben esedékes 14. § (1) bekezdése szerinti ellenőrzés keretében ellenőrzi a szolgáltatók (intézmények, hálózatok) szakmai munkáját. A kijelölt módszertani feladatokat ellátó intézmény módszertani és szolgáltató tevékenységének ellenőrzését a szociális és gyámhivatal a Nemzeti Család és Szociálpolitikai Intézet bevonásával ellenőrzi.

(2) Ha a szociális és gyámhivatal jogszabálysértést észlel, a 14/B. §-ban foglaltak szerint intézkedik a jogszerü müködés helyreállítása érdekében.

16. § (1) A bírságot az első fokon eljárt működést engedélyező szervnek - ha fizetési kedvezményt nem engedélyeztek - a kiszabó határozat jogeröre emelkedését követő harminc napon belül kell megfizetni.

(2)

(3) A bírságból befolyt összeget a működést engedélyező szerv negyedévente, a negyedévet követő hónap 20-áig a minisztérium fejezeti kezelésű előirányzat-felhasználási keretszámlájára utalja át. A működést engedélyező szerv az átutalással egyidejűleg a bírságot kiszabó jogerős határozat másolatát megküldi a minisztériumnak.

\section{7. $\$$}

\section{7/A-17/B. $\S$}

18. § (1) E rendelet 2003. január 1-jén lép hatályba.

\section{Záró rendelkezések}

(2)

19. § (1) A szolgáltatótevékenység engedélyezésére vonatkozó rendelkezéseket csak az e rendelet hatálybalépését követően beadott kérelmek elbírálása során kell alkalmazni.

(2) A megyei önkormányzatok által 2011. december 31-én fenntartott intézmények működési engedélyének hivatalból történő módosítására irányuló eljárás során a megyei fenntartó 2012. január 15-éig bejelenti a nevét, székhelyét és adószámát, valamint bejelentheti a szolgáltató (intézmény, müködtető) nevének és adószámának megváltozását. A szolgáltató (intézmény, működtető) alapító okiratának másolatát a szolgáltató nevének módosítása esetén nem kell benyújtani, és azt a müködést engedélyező szervnek sem kell az eljárás során beszereznie.

(3) A müködést engedélyező szerv a megyei önkormányzatok által 2011. december 31-én fenntartott intézmények működési engedélyének hivatalból történő módosítására irányuló eljárás során kizárólag a fenntartó adatait és a fenntartó erre irányuló bejelentése esetén a szolgáltató (intézmény, müködtető) nevét és adószámát módosíthatja. A $8 . \S$ (11) bekezdése ebben az esetben nem alkalmazható.

(4) Az ellátási szerződés megyei fenntartóra való átszállása miatt az egyházi, nem állami fenntartású intézmény müködési engedélyét nem kell módosítani, a változás átvezetésére a müködési engedély egyéb okból történő soron következő módosítása vagy a soron következő ellenőrzés alkalmával kerül sor.

(5) E rendeletnek az egyes kormányrendeletek szociális és gyermekjóléti, gyermekvédelmi szolgáltatásokkal összefüggő módosításáról szóló 330/2011. (XII. 29.) Korm. rendelettel történő módosítása alapján 
a) a 2012. január 1-jén folyamatban levő müködési engedélyezési eljárásokban a normatív állami hozzájárulással történő müködtetésre vonatkozó, finanszírozási rendszerbe történő befogadással kapcsolatos nyilatkozatot - amennyiben szükséges - 2012. január 31-éig, illetve azt követően a hiánypótlási szabályok szerint kell benyújtani,

b) azon szolgáltatás, intézmény, hálózat, féröhelyszám esetében, amely a Gyvt. 145. § (2a) bekezdése szerint nem minősül új szolgáltatásnak, intézménynek, hálózatnak, férőhelyszámnak, a jogszabály erejénél fogva történő befogadottság tényét a müködési engedélyben a müködési engedély soron következő módosítása során kell hivatalból bejegyezni.

(6) E rendeletnek az egyes kormányrendeletek szociális és gyermekjóléti, gyermekvédelmi szolgáltatásokkal összefüggő módosításáról szóló 330/2011. (XII. 29.) Korm. rendelettel megállapított 3. § (2) bekezdésében foglalt illetékességi szabályokat a 2012. január 1-jén folyamatban lévő eljárásokban is alkalmazni kell.

(7) E rendeletnek az egyes kormányrendeletek szociális és gyermekjóléti, gyermekvédelmi szolgáltatásokkal összefüggő módosításáról szóló 330/2011. (XII. 29.) Korm. rendelettel megállapított 3. § (3), (4) és (4a) bekezdésében foglaltakat a müködési engedély egyéb okból történő soron következő módosítása vagy a soron következő ellenőrzés alkalmával kell alkalmazni.

(8) A 7. § (2) bekezdése alapján meghosszabbított ideiglenes müködési engedély hatálya a fenntartó kérelmére - kizárólag ellátási érdekből - legfeljebb 2014. december 31-éig meghosszabbítható. A fenntartó a kérelmet akkor is benyújthatja, ha az ideiglenes müködési engedély hatálya 2012. január 1-jét megelőzően járt le. A fenntartó a kérelméhez csatolja a határozatlan idejü müködési engedély kiadásához szükséges feltételek megteremtésére vonatkozó szakmai tervét vagy az európai uniós forrás (TIOP 3.4.1/B-11/1., TIOP 3.4.2.-11/1.) felhasználására vonatkozó megkötött támogatási szerződés másolatát.

19/A. § A gondozó, a családgondozó, valamint családi napközi és családi gyermekfelügyelet esetén a szolgáltatást nyújtó személy nevének a müködési engedélyből történő törléséről határozatban nem kell intézkedni. A nevet a müködési engedély módosítása során a müködési engedély hatályos adatai között nem kell feltüntetni.

19/B. § A jegyző a 2011. június 30-án a hatáskörébe és illetékességébe tartozó szolgáltatók, intézmények működési engedélyezésével és ellenőrzésével kapcsolatos iratokat 2011. augusztus 31-éig megküldi az illetékes szociális és gyámhivatalnak. A szociális és gyámhivatal - a jegyzői ellenőrzés időpontjától függetlenül - a müködési engedély módosítására irányuló soron következő eljárással egyidejüleg, de legkésőbb 2012. december 31-éig - a 14. § (5)-(7) bekezdésének, valamint a 14/A. § (1), (2) és (5) bekezdésének alkalmazásával - az iratok alapján és a helyszínen ellenőrzi azokat a szolgáltatókat, intézményeket, amelyek 2011. július 1-jén kerültek a hatáskörébe és illetékességébe, és

a) szükség esetén alkalmazza a 14/B. § szerinti jogkövetkezményeket, továbbá

b) - ha a jegyző által kiadott működési engedély nem felel meg a hatályos jogszabályoknak - a hatályos jogszabályoknak megfelelö müködési engedélyt ad ki, és a jegyző által korábban kiadott müködési engedélyt visszavonja.

\section{Az Európai Unió jogának való megfelelés}

20. § Ez a rendelet az Unió polgárainak és családtagjaiknak a tagállamok területén történő szabad mozgáshoz és tartózkodáshoz való jogáról, valamint az 1612/68/EGK rendelet módosításáról, továbbá a 64/221/EGK, a 68/360/EGK, a 72/194/EGK, a 73/148/EGK, a 75/34/EGK, a 75/35/EGK, a 90/364/EGK, a 90/365/EGK és a 93/96/EGK irányelv hatályon kívül helyezéséről szóló, 2004. április 29-i 2004/38/EK európai parlamenti és tanácsi irányelv 24. cikkének, valamint a belső piaci szolgáltatásokról szóló, 2006. december 12-i 2006/123/EK európai parlamenti és tanácsi irányelv 9. és 16. cikkének való megfelelést szolgálja.

\section{1. számú melléklet a 259/2002. (XII. 18.) Korm. rendelethez}

\section{A müködési engedély kiadása, módosítása és visszavonása iránti kérelem benyújtására szolgáló adatlapok} és elektronikus ürlapok adattartalma

1. a fenntartó neve, székhelye, szervezeti formája, adószáma és elérhetősége;

2. a fenntartó képviselőjének és kapcsolattartójának neve, beosztása és elérhetősége;

3. a szolgáltató (intézmény, hálózat, telephely) vezetőjének neve és elérhetősége;

4. a szolgáltató (intézmény, hálózat) székhelyének és valamennyi telephelyének ágazati azonosítója, továbbá családi napközi esetén annak megjelölése, hogy más családi napközire nyújtott-e be müködési engedély iránti kérelmet;

5. müködési engedély kiadása iránti kérelem esetén azok az adatok, amelyekkel a fenntartó a szolgáltató (intézmény, hálózat, ellátást nyújtó székhely, telephely) engedélyeztetését kéri, valamint az annak megállapításához szükséges adatok, hogy a jogszabályban meghatározott személyi, tárgyi és egyéb feltételeket teljesítik;

6. müködési engedély módosítása iránti kérelem esetén a változások, valamint az annak megállapításához szükséges adatok, hogy a jogszabályban meghatározott személyi, tárgyi és egyéb feltételeket teljesítik; 
7. müködési engedély visszavonása iránti kérelem esetén a visszavonás feltételeinek teljesítésére vonatkozó adatok;

8. a kérelem elbírálásához jogszabály alapján szükséges egyéb adatok;

9. a fenntartó nyilatkozata arról, hogy a Gyvt. 145. § (2) bekezdés szerinti szolgáltatót, intézményt, hálózatot, illetve férőhelyszámot normatív állami hozzájárulással kívánja-e működtetni.

\section{2. számú melléklet a 259/2002. (XII. 18.) Korm. rendelethez}

\section{A tanúsítvány tartalma}

1. A tanúsítványt kiállító szerv neve, székhelye és elérhetősége.

2. A fenntartó neve, székhelye és elérhetősége.

3. A szolgáltató (intézmény, müködtető) neve.

4. A szolgáltató (intézmény, müködtető) székhelye.

5. Telephely részére kiállított tanúsítvány esetén a szolgáltató (intézmény) telephelye.

6. Területi irodával rendelkező szolgáltató (intézmény, ellátást nyújtó székhely, telephely) esetén a területi iroda címe.

7. A szolgáltató (intézmény, hálózat) ágazati azonosítója.

8. Az engedélyezett gyermekjóléti, gyermekvédelmi szolgáltató tevékenységek és az engedélyezett férőhelyek száma a müködési engedélyben feltüntetett módon. Nevelőszülői hálózat, helyettes szülői hálózat vagy külső férőhelyen biztosított utógondozói ellátás esetén csak a hálózat engedélyezett összes féröhelyszámát kell feltüntetni.

9. Határozott idejü és ideiglenes müködési engedély esetén a müködési engedély hatálya, egyéb esetben az arra való utalás, hogy a müködési engedély határozatlan idöre szól.

10. A tanúsítvány kiállításának helye és ideje.

11. A kiadmányozási joggal rendelkező személy aláírása és a tanúsítványt kiállító szerv bélyegzőlenyomata.

\section{3. számú melléklet a 259/2002. (XII. 18.) Korm. rendelethez}

\section{A D A T L A P}

„A"

gyermekjóléti, gyermekvédelmi szolgáltató, intézmény, hálózat müködési engedélyének kiadása iránti kérelemhez

(a gyermekjóléti és gyermekvédelmi szolgáltató tevékenység engedélyezéséről, valamint a gyermekjóléti és gyermekvédelmi vállalkozói engedélyről szóló 259/2002. (XII. 18.) Korm. rendelet [Gymr.] 3. § (6) bekezdése alapján a fenntartó tölti ki)

\section{A fenntartó adatai}

neve:

székhelye:

település

közterület neve

jellege szám

.....emelet........ajtó.

típusa: $\square$ állami, $\square$ nem állami, $\square$ egyházi

adószáma:

ágazati azonosítója ${ }^{109}$ :

elérhetöségei: telefonszám:

fax szám:

e-mail cím:

honlap cím:

képviselőjének neve:

beosztása:

elérhetőségei:

telefonszám:

e-mail cím:

kapcsolattartójának neve:

beosztása:

elérhetőségei:

${ }^{109}$ Csak akkor kell kitölteni, ha a kérelmezőnek van. 
telefonszám:

e-mail cím:

\section{Gyermekjóléti és gyermekvédelmi szolgáltató, intézmény, müködtető ${ }^{110}$ adatai}

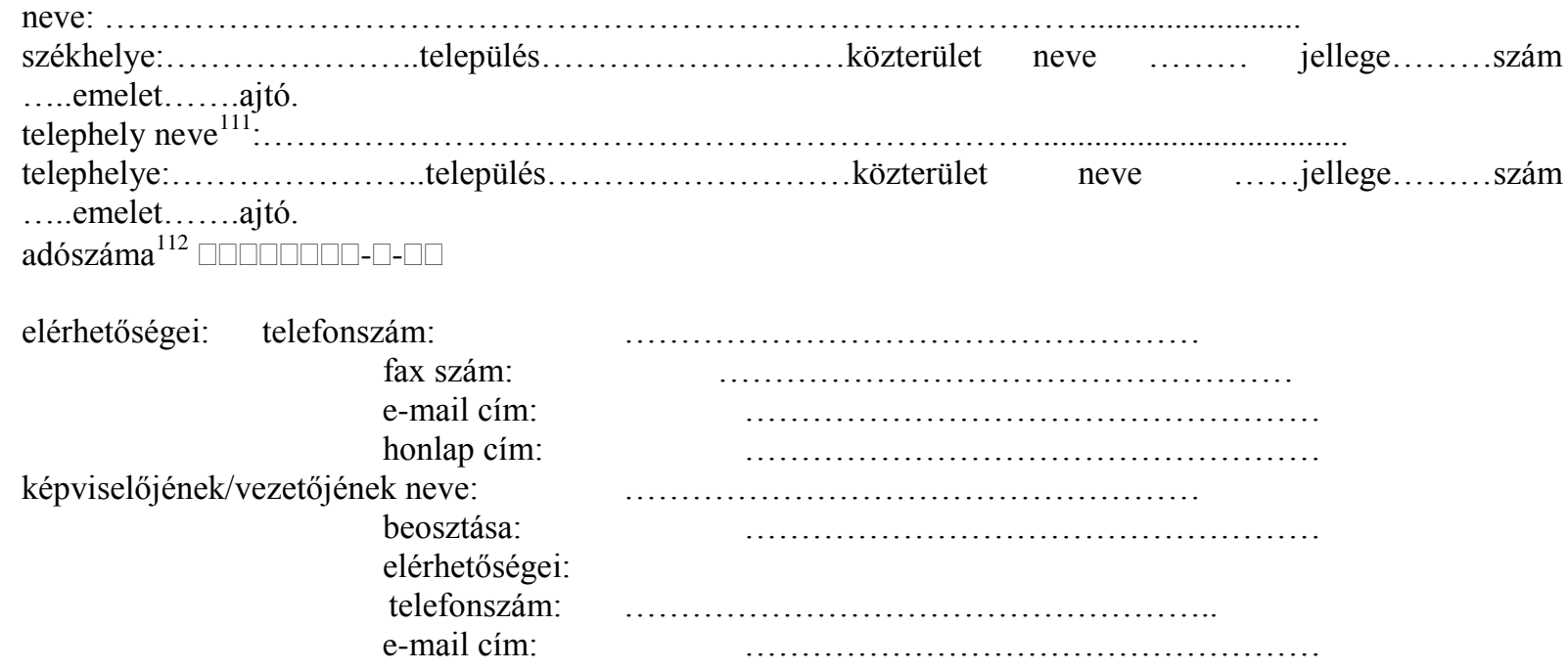

A működési engedély kiadását az alábbi időponttól kérem ${ }^{113}$ :

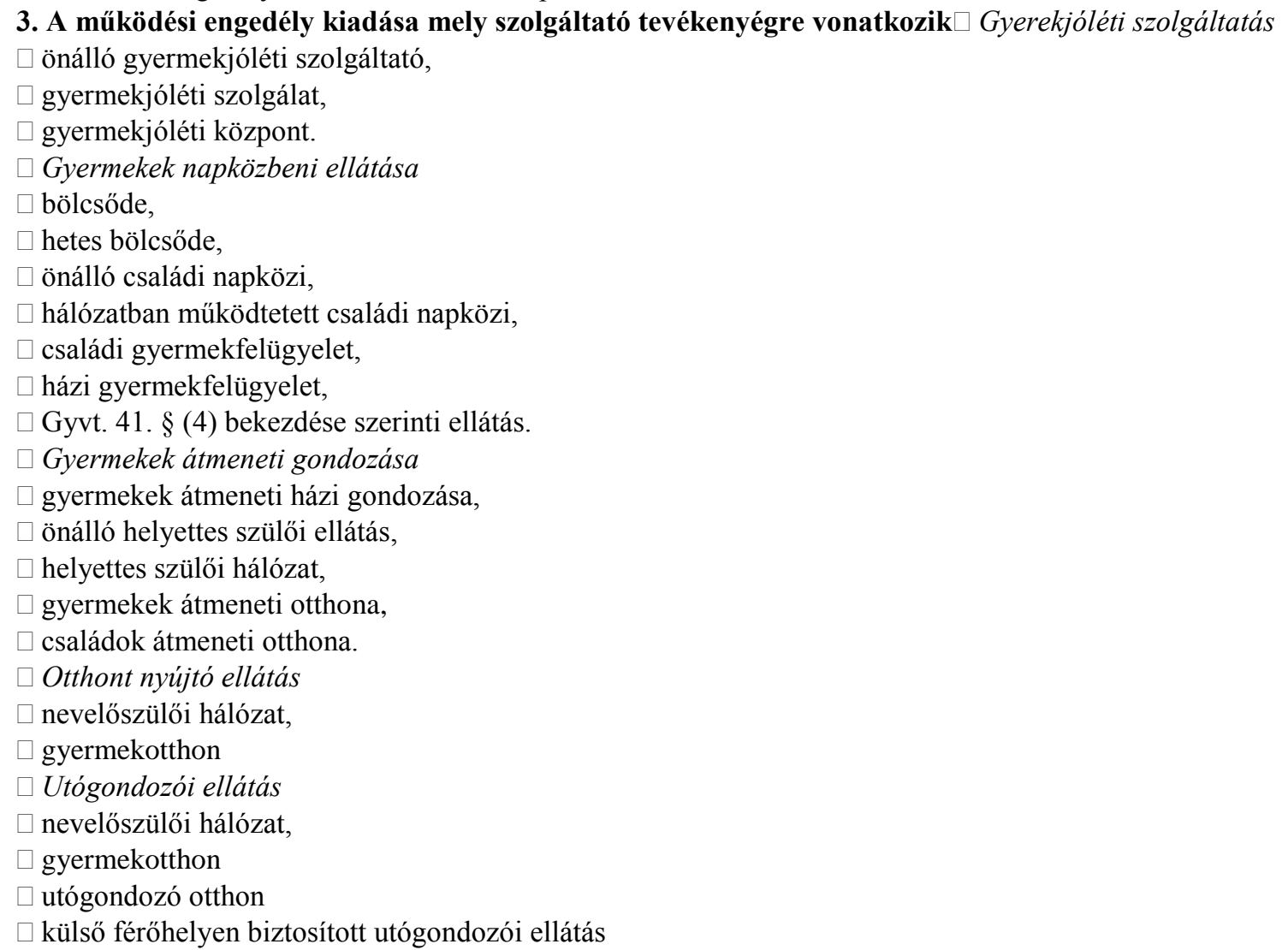

\footnotetext{
${ }^{110}$ Helyettes szülői hálózat, nevelőszülői hálózat, külső férőhelyen biztosított utógondozói ellátás esetén.

${ }^{111}$ Csak telephely engedélyezése esetén kell kitölteni (neve, címe).

112 Akkor kell kitölteni, ha a szolgáltató, intézmény, müködtető adószáma a fenntartóétól különbözik.

${ }^{113} \mathrm{Ez}$ az időpont legkorábban a müködési engedélyt kiadó határozat jogerőre emelkedésének időpontja lehet. Az időpont meghatározása egy tervezhető időpont, ugyanakkor ez az időpont nem kötelezi a müködési engedélyt kiadó szervet.
} 
$\square$ Területi gyermekvédelmi szakszolgáltatás

$\square$ területi gyermekvédelmi szakszolgálat

4. Az ellátási terület meghatározása ${ }^{114}$ :

5. A szolgáltató, intézmény más telephelyeinek ágazati azonosítói:

1. $\begin{aligned} & 0 \\ & \text { 2. }\end{aligned}$

2. $\quad$ (b)

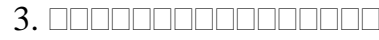

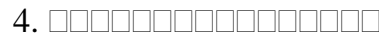

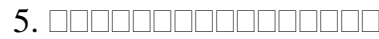

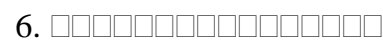

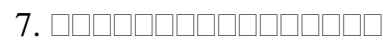

8. $\quad$ (a)

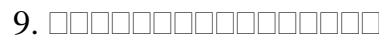

10. $\square\left[\begin{array}{ll}11 . \\ \text {. }\end{array}\right.$

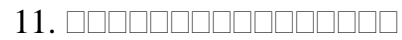

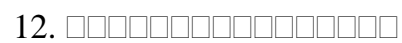

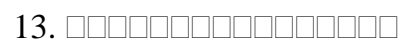

14. $\quad$ (1)

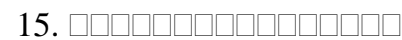

16. $\quad\left[\begin{array}{ll}\text { 15. } \\ \text { 17. }\end{array}\right.$

17. $\quad\left[\begin{array}{ll}\text { 16. } \\ \text { 18. }\end{array}\right.$

18. $\quad\left[\begin{array}{ll}\text { 19. } \\ \text { 19. }\end{array}\right.$

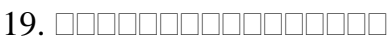

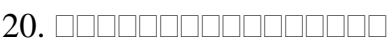

${ }^{114}$ Egy, vagy több település, kistérség, megye vagy régió, illetve az ország teljes területe, ahonnan a szolgáltató (intézmény, hálózat) gyermekeket, vagy más ellátottakat fogad. 
A hatáskör megállapítása érdekében kijelentem, hogy a müködési engedélyben érintett szolgáltatónak, intézménynek $^{115}$

$\square$ Nincs olyan telephelye, amely gyermekek átmeneti gondozását, gyermekvédelmi szakellátást vagy bentlakásos szociális intézményi ellátást is nyújt - ideértve azt az esetet is, ha helyettes szülöi hálózat, nevelőszülői hálózat vagy külső férőhelyen biztosított utógondozói ellátás müködtetője.

$\square$ Van olyan telephelye, amely gyermekek átmeneti gondozását, gyermekvédelmi szakellátást vagy bentlakásos szociális intézményi ellátást is nyújt - ideértve azt az esetet is, ha helyettes szülői hálózat, nevelőszülői hálózat vagy külső férőhelyen biztosított utógondozói ellátás müködtetője.

Családi napközi esetén jelölje be, ha más családi napközire is nyújtott be müködési engedély iránti kérelmet.

A kérelem benyújtásával kifejezetten hozzájárulok, hogy a müködést engedélyező szerv eljárása során a kérelemben és mellékleteiben megjelölt adatokat, valamint a fenntartó, szolgáltató, intézmény, hálózatnak a kérelem elbírálásához kezelje, ellenőrizze, illetve beszerezze.

Kérelmemmel megegyező határozathozatal esetén fellebbezési jogomról lemondok ${ }^{116}$.

Kelt: 20 év hó nap

Fenntartó képviselőjének aláírása

\footnotetext{
${ }^{115}$ Kérjük, a megfelelő négyzetet „X” jellel bejelölni.

${ }^{116}$ Csak abban az esetben szükséges megjelölni, ha ezt kéri a fenntartó.
} 


\section{SZOLGÁLTATÁSI ADATLAP}

A müködési engedély kiadása, illetve módosítása iránti kérelemhez csatolt, illetve bemutatott mellékletek

(a gyermekjóléti és gyermekvédelmi szolgáltató tevékenység engedélyezéséről, valamint a gyermekjóléti és gyermekvédelmi vállalkozói engedélyröl szóló 259/2002. (XII. 18.) Kormány rend. 4. § alapján a fenntartó tölti ki és csatolja a szükséges dokumentumokat, nyilatkozatokat)

\section{Családi napközi ${ }^{117}$ \\ "CSANA"}

\section{I. Állami fenntartó esetén ${ }^{118}$}

a) csatolt dokumentumok:

1. $\square$ a fenntartó adószámát igazoló közokirat másolata,

2. $\square$ a helyi önkormányzatok társulásairól és együttmüködéséröl szóló 1997. évi CXXXV. törvény 8. §-a, 9. $\S$-a, illetve 16. §-a szerinti intézményi társulás vagy települési önkormányzatok többcélú kistérségi társulása - társulási szerződés másolata,

3. $\square$ költségvetési szerv esetén alapító okirat másolat,

4. $\square$ a szolgáltatást nyújtó személynek, ha munkakörbe sorolta a fenntartó a szakképesítését, illetve a jogszabály szerint előírt tanfolyam elvégzését bizonyító okirat másolatát,

5. $\square$ a szolgáltatást nyújtó személynek, illetve helyettesének a külön jogszabály szerinti Egészségügyi Nyilatkozatát, illetve háziorvos igazolását arra vonatkozóan, hogy a gondozás helyén élő más személyek egészségi állapota nem veszélyezteti az ellátandó gyermekeket,

6. $\square$ előzetes szakhatósági hozzájárulást, - ha beszerezte - valamint ha a kérelem szerinti ingatlanra vonatkozóan, azonos rendeltetésre, a kérelem benyújtását megelőző hat hónapon belül használatbavételi engedélyt vagy fennmaradási engedélyt adtak ki, a használatbavételi engedély, illetve a fennmaradási engedély másolata,

7. $\square$ a szolgáltatást nyújtó három hónapnál nem régebbi erkölcsi bizonyítványát,

8. $\square$ a szolgáltatótevékenység folytatására szolgáló épület (épületrész) használati jogcímét bizonyító okirat másolatát,

9. $\square$ a szolgáltatótevékenység céljait, alapelveit, módszereit tartalmazó szakmai program.

\section{b) csatolt nyilatkozat(ok):}

1. $\square$ a szolgáltatást nyújtó nyilatkozatát arra vonatkozóan, hogy vele szemben nem állnak fenn a Gyvt. 15 . §-ának (8) bekezdésében meghatározott kizáró okok,

\section{Nem állami, egyházi fenntartó esetén ${ }^{119}$}

a) csatolt dokumentumok:

1. $\square$ a fenntartó adószámát igazoló közokirat másolata,

2. $\square$ fenntartó által megkötött, a szolgáltató tevékenység körében okozott kár megtérítésére kötött felelősségbiztosítási szerződés másolata,

3. $\square$ az ellátási szerződést, ha a fenntartó a szolgáltató tevékenységre ellátási szerződést kötött,

4. $\square$ annak harminc napnál nem régebbi közokirati igazolást, hogy a fenntartó köztartozásmentes adózónak minősül,

5. $\square$ egyéni vállalkozói igazolványt vagy a fenntartó hatályos adatait tartalmazó igazolást (igazolásokat), vagy csatolni kell a fenntartónak az egyéni vállalkozók nyilvántartásában szereplő hatályos adatait igazoló, három hónapnál nem régebbi hatósági bizonyítványt,

6. $\square$ a fenntartó három hónapnál nem régebbi cégkivonatát, ha a fenntartó cég,

7. $\square$ ha a fenntartó társadalmi szervezet, alapítvány vagy közalapítvány, csatolni kell a fenntartó bírósági nyilvántartásba bejegyzett hatályos adatairól kiadott, három hónapnál nem régebbi kivonata,

8. $\square$ egyházi fenntartó esetén az egyházat nyilvántartásba vevő bírósági végzés másolatát, kivéve, ha az egyházat a lelkiismereti és vallásszabadságról, valamint az egyházakról szóló 1990. évi IV. törvény 22. §a alapján vették nyilvántartásba, és

9. $\square$ az egyház bírósági nyilvántartásba bejegyzett hatályos adatairól kiadott, három hónapnál nem régebbi kivonatot, továbbá

\footnotetext{
${ }^{117} \mathrm{Ha}$ a csatolandó dokumentumokat a fenntartó nem csatolta, azt a müködést engedélyező szerv szerzi be.

${ }^{118}$ Kérem a csatolt dokumentumokat „X”-szel jelölje meg!

${ }^{119}$ Kérem a csatolt dokumentumokat „X”-szel jelölje meg!
} 
10. $\square$ ha a fenntartó az egyház bírósági nyilvántartásba nem vett szervezeti egysége - a nyilvántartásba vett egyház, egyházi jogi személy képviselőjének a nyilatkozatát a fenntartó nevéről, székhelyéről és képviselőjének személyéről, valamint arról, hogy a fenntartó az általa képviselt egyház, egyházi jogi személy szervezeti egysége és az egyház alapszabálya alapján jogi személyiséggel rendelkezik;

11. $\square$ a szolgáltatást nyújtó személynek a jogszabály szerint elöírt tanfolyam elvégzését bizonyító okirat másolatát,

12. $\square$ a szolgáltatást nyújtó személynek, illetve helyettesének a külön jogszabály szerinti Egészségügyi Nyilatkozatát, illetve háziorvos igazolását arra vonatkozóan, hogy a gondozás helyén élő más személyek egészségi állapota nem veszélyezteti az ellátandó gyermekeket,

13. $\square$ előzetes szakhatósági hozzájárulást, - ha beszerezte - valamint ha a kérelem szerinti ingatlanra vonatkozóan, azonos rendeltetésre, a kérelem benyújtását megelőző hat hónapon belül használatbavételi engedélyt vagy fennmaradási engedélyt adtak ki, a használatbavételi engedély, illetve a fennmaradási engedély másolata,

14. $\square$ a szolgáltatást nyújtó három hónapnál nem régebbi erkölcsi bizonyítványát,

15. $\square$ a szolgáltatótevékenység céljait, alapelveit, módszereit tartalmazó szakmai program.

b) csatolt nyilatkozat $(\mathrm{ok})$ :

1. $\square$ a szolgáltatást nyújtó nyilatkozatát arra vonatkozóan, hogy vele szemben nem állnak fenn a Gyvt. 15 . §-ának (8) bekezdésében meghatározott kizáró okok.

A müködési engedély iránti kérelemben a szolgáltató tevékenység folytatásához... fö ellátására kérem a müködési engedély kiadását.

Csatolandó dokumentumok ${ }^{120}$ darab.

Felhívjuk figyelmét, hogy a kérelemhez a Gymr. alapján több iratot is csatolni kell, illetve az eljárás folyamán be kell mutatni a müködést engedélyező szervnek. Mivel ezekre az iratokra, illetve az általuk tanúsított adatok igazolására a müködési engedély kiadásához szükség van, feltétlenül csatolja őket. Abban az esetben, ha egyes iratokat nem csatol, a müködést engedélyező szerv szerzi be, amely az eljárás elhúzódásához vezethet.

Dátum: $20 \ldots$ év hó nap

${ }^{120}$ Kérjük, számozza meg a csatolandó dokumentumokat. 


\section{6/2006. (XI. 20.) Korm. rendelet a szociális, gyermekjóléti és gyermekvédelmi szolgáltatók, intézmények ágazati azonosítójáról és országos nyilvántartásáról}

A Kormány a szociális igazgatásról és szociális ellátásokról szóló 1993. évi III. törvény (a továbbiakban: Szt.) 132. §-a (1) bekezdésének $f$ ), $j$ ), illetve $m$ ) pontjában, továbbá a gyermekek védelméről és a gyámügyi igazgatásról szóló 1997. évi XXXI. törvény (a továbbiakban: Gyvt.) 162. §-a (1) bekezdésének $i$ ) pontjában kapott felhatalmazás alapján a következőket rendeli el:

1. $§$ E rendelet alkalmazása során

Értelmezö rendelkezések

a) engedélyes: az Szt. 57. §-a (1) bekezdésének $a$ ) és $c$ )-j) pontja, illetve (2) bekezdése szerinti szociális szolgáltatásokat működési engedéllyel, illetve a Gyvt. 15. §-ának (2)-(3) bekezdése ${ }^{121}$ szerinti szolgáltató tevékenységet működési engedéllyel végző szolgáltató, intézmény, illetve hálózat; telephellyel rendelkező szolgáltató, intézmény esetén önálló engedélyesnek minősül az ellátást nyújtó székhely és a telephely,

b) telephely: a szociális szolgáltatók és intézmények müködésének engedélyezéséről és ellenőrzéséről szóló 321/2009. (XII. 29.) Korm. rendelet (a továbbiakban: Szmr.) 1. § b)pontjában, illetve a gyermekjóléti és gyermekvédelmi szolgáltató tevékenység engedélyezéséröl, valamint a gyermekjóléti és gyermekvédelmi vállalkozói engedélyről szóló 259/2002. (XII. 18.) Korm. rendelet (a továbbiakban: Gymr.) 2. §ának b) pontjában ${ }^{122}$ meghatározott hely,

c) fenntartó: az Szt. 4. $\S$-a (1) bekezdésének $m$ ) pontja, illetve a Gyvt. 5. §-ának $s$ ) pontja ${ }^{123}$ szerinti személy vagy szervezet,

$12115 \S$ (2) A személyes gondoskodás keretébe tartozó gyermekjóléti alapellátások:

a) a gyermekjóléti szolgáltatás,

b) a gyermekek napközbeni ellátása,

c) a gyermekek átmeneti gondozása.

(3) A személyes gondoskodás keretébe tartozó gyermekvédelmi szakellátások:

a) az otthont nyújtó ellátás,

b) az utógondozói ellátás,

c) a területi gyermekvédelmi szakszolgáltatás.

$1222 \S$ b) telephely: a bölcsőde, a hetes bölcsőde, a családi napközi, az alternatív napközbeni ellátás (Gyvt. 44/A. §), a gyermekek átmeneti otthona, a családok átmeneti otthona, a gyermekotthon, az utógondozó otthon esetén az a székhelytől különbözö, a szolgáltató (intézmény) használatában lévő hely, ahol az ellátást nyújtják, a félutas ház kivételével;

\section{$1235 \S s)$ fenntartó:}

sa) a központi költségvetési szerv, a megyei intézményeket fenntartó, Kormány által rendeletben kijelölt szerv (a továbbiakban: megyei fenntartó), a helyi önkormányzat, a helyi önkormányzatok társulásairól és együttműködéséről szóló 1997. évi CXXXV. törvény 8-9. §-a, illetve 16. §-a szerinti intézményi társulás, a települési önkormányzatok többcélú kistérségi társulása, a nemzetiségi önkormányzat (a továbbiakban együtt: állami fenntartó),

sb) a lelkiismereti és vallásszabadság jogáról, valamint az egyházak, vallásfelekezetek és vallási közösségek jogállásáról szóló törvény szerinti nyilvántartásba vett egyház, illetve annak belső egyházi jogi személy (a továbbiakban együtt: egyházi fenntartó), nem minősül egyházi fenntartónak az a jogi személy, amely más típusú szervezetként jogalanyisággal rendelkezik, így különösen a civil szervezet, annak alapszabályban jogi személlyé nyilvánított szervezeti egysége, az alapítvány, annak alapító okiratban jogi személlyé nyilvánított szervezeti egysége, a gazdasági társaság,

sc) az egyéni vállalkozó,

$s d)$ az $s a$ )-sb) alpontokban nem említett, magyarországi székhelyü jogi személy, jogi személyiség nélküli gazdasági társaság és egyéni cég,

se) az Európai Gazdasági Térségről szóló megállapodásban részes valamely államban (a továbbiakban: EGT-állam), valamint - ha az Európai Közösséggel és tagállamaival létrejött nemzetközi szerződés alapján az adott állam szolgáltatói a letelepedés szabadsága tekintetében az EGT-államok szolgáltatóival azonos jogállást élveznek - az EGT-államoktól eltérő más államban honos vállalkozás belföldön bejegyzett fióktelepe [az sc)-se) pontokban foglaltak a továbbiakban együtt: nem állami fenntartó],

ha az e törvényben és más jogszabályban meghatározott feltételek szerint, müködési engedély alapján gondoskodik a gyermekjóléti és gyermekvédelmi szolgáltató tevékenység biztosításához szükséges 
d) müködést engedélyező szerv: az Szt. 92/K. §-ának (2) bekezdésében, illetve a Gyvt. 100. §-ának (2) bekezdésben ${ }^{124}$ meghatározott szervek,

e) szociális foglalkoztatás: az Szt. 99/B-99/E. §-a szerinti foglalkoztatás,

f) jelentési időpont: azon - a 11. § (1) bekezdése és (2) bekezdésének $a$ ) pontja szerinti - időpont, amelyre tekintettel az adatot szolgáltatni kell,

g) jelentési idöszak: azon - a 11. § (1) bekezdése, (2) bekezdésének b) pontja, illetve (3) bekezdésének $b$ ) pontja szerinti - időszak, amelyre tekintettel az adatot szolgáltatni kell,

h) feladatmutató: a támogató szolgáltatás és a közösségi ellátások finanszírozásának rendjéről szóló 191/2008. (VII. 30.) Korm. rendelet 1 . $\S$-a (2) bekezdésének $f$ ) pontja ${ }^{125}$, illetve a szociális foglalkoztatás engedélyezéséről és a szociális foglalkoztatási támogatásról szóló 112/2006. (V. 12.) Korm. rendelet 1. §-a (2) bekezdésének $e$ ) pontja szerinti feladatmutató,

i) szolgáltatás: a szociális szolgáltatás és a gyermekjóléti, gyermekvédelmi szolgáltató tevékenység. Ágazati azonositó

2. § (1) Az ágazati azonosító az engedélyes egységes azonosítójele.

(2) Az ágazati azonosítót a müködést engedélyező szerv a müködési engedélyben történő feltüntetéssel adja ki.

(3) Az ágazati azonosítót engedélyesenként kell kiadni. A telephely számára önálló ágazati azonosítót kell kiadni. Szociális és gyermekjóléti, gyermekvédelmi szolgáltatást egyaránt nyújtó engedélyesnek egy ágazati azonosítót kell kiadni.

(4) Ha az engedélyes székhelyén ellátást nem nyújtanak, a székhely részére a telephely müködési engedélyének kiadása során önálló ágazati azonosítót kell kiadni, és azt az engedélyes valamennyi telephelyének múködési engedélyében fel kell tüntetni.

3. § (1) A működést engedélyező szerv az ágazati azonosítót a Nemzeti Rehabilitációs és Szociális Hivataltól (a továbbiakban: Hivatal) a 2. § (2) bekezdése szerinti eljárás során, az 1. számú melléklet szerinti adatok továbbításával kéri meg.

(2) A Hivatal az ágazati azonosítót a müködést engedélyező szerv megkeresését követő három munkanapon belül - a 2. számú melléklet szerint - képzi és küldi meg a müködést engedélyezö szervnek.

(3) Az ágazati azonosító megkérése és megküldése elektronikus úton, az engedélyesek országos nyilvántartásának (a továbbiakban: országos nyilvántartás) elektronikus rendszerén keresztül történik.

(4) Az ágazati azonosító a működési engedély módosítása esetén - ideértve a fenntartóváltozást, további szolgáltatás engedélyezését, a székhely, illetve a telephely elköltöztetését, valamint a telephely önálló szolgáltatóvá, intézménnyé szervezését, illetve önálló szolgáltató, intézmény telephellyé szervezését - sem módosítható. A megszünt engedélyes ágazati azonosítója másik engedélyesnek nem adható ki.

4. § (1) Amennyiben az engedélyes már rendelkezik ágazati azonosítóval, azt valamennyi,

a) a müködési engedélyezéssel, a szociális foglalkoztatási engedélyezéssel és a normatív állami hozzájárulással kapcsolatos hatósági ügyben a kérelmen és a hatósági döntésben, továbbá a müködést engedélyező szervnek, illetve a szociális foglalkoztatást engedélyező szervnek tett bejelentésben,

b) az e rendelet szerinti, illetve más, statisztikai célú adatszolgáltatáson

fel kell tüntetni.

(2) A telephely ágazati azonosítóját megelőzően a székhely ágazati azonosítóját is fel kell tüntetni.

Az országos nyilvántartás általános szabályai

5. § (1) Az országos nyilvántartás része

a) az Szt. 88/A. § (5) bekezdése, illetve a Gyvt. 137. § (3) bekezdése ${ }^{126}$ szerinti nyilvántartás (a továbbiakban együtt: intézményi nyilvántartás),

b) az Szt. 20/B. §-a szerinti országos jelentési rendszer, valamint

feltételekröl. Ha jogszabály másképp nem rendelkezik, az egyházi fenntartóra a nem állami fenntartóra vonatkozó rendelkezéseket kell megfelelően alkalmazni,

${ }^{124} 100 \S$ (2) A müködési engedély kiadásáról a fenntartó kérelmére a működést engedélyező szerv - első fokon a Kormány általános hatáskörủ területi államigazgatási szervének szakigazgatási szerveként müködő gyámhivatal - dönt. A működési engedély kiadásával, módosításával és visszavonásával kapcsolatos eljárás illetékmentes.

${ }^{125} 1 \S(2)$ f) feladatmutató: a vállalt, illetve teljesített feladategységek száma

${ }^{126} 137 \S$ (3) A Kormány által kijelölt szerv - külön jogszabályban meghatározottak szerint - országos nyilvántartást vezet a szolgáltató tevékenységet végző szolgáltatókról, intézményekről, helyettes szülői és nevelőszülői hálózatokról. A nyilvántartás adattartalma nyilvános. 
c) a szolgáltatások igénybe vevőinek az Szt. 20/C. §-ában, illetve a Gyvt. 139. § (2) bekezdésében ${ }^{127}$ meghatározott adatairól vezetett központi elektronikus nyilvántartási rendszer (a továbbiakban együtt: igénybevevői nyilvántartás).

(2) Az országos nyilvántartás adatait a Hivatal egységes adatbázisban kezeli.

(3) Az országos nyilvántartás nem minősül hatósági nyilvántartásnak.

(4) Az országos nyilvántartás a fenntartó, illetve az engedélyes önkéntes adatszolgáltatása alapján további közérdekü, illetve közérdekből nyilvános adatokat is tartalmazhat.

(5) Az országos nyilvántartás adatainak módosítását a rendszer naplózza.

6. § (1) Az engedélyes az országos nyilvántartásba a müködés engedélyezésekor a 9 . § szerint történö adatrögzítéssel kerül felvételre.

(2) Az országos nyilvántartásból az engedélyest törölni kell, ha

a) ideiglenes vagy határozott idejü múködési engedélye valamennyi általa nyújtott szolgáltatásra lejárt és új múködési engedélyt a részére nem adtak ki,

b) müködési engedélyét valamennyi általa nyújtott szolgáltatásra vonatkozóan visszavonták [Szmr. 9. § (1) bekezdés, illetve Gymr. 10. § (1) bekezdés].

(3) A törölt engedélyes természetes személy fenntartójának nevét, székhelyét, valamint adószámát törölni, az egyéb adatokat archiválni kell. A törlést és az archiválást a Hivatal hajtja végre a müködési engedély lejártát, illetve a müködési engedély visszavonására vonatkozó adatok rögzítését követő harminc munkanapon belül.

7. §(1) Az országos nyilvántartás adatai - az igénybevevői nyilvántartás adatainak kivételével elektronikus úton bárki számára hozzáférhetőek.

(2) Ha a fenntartó kéri, a családok, illetve a gyermekek átmeneti otthona székhelyének, telephelyének címét nem lehet közzétenni.

(3) A Hivatal

a) az intézményi nyilvántartás és az országos jelentési rendszer adatait egyedi azonosításra alkalmas módon,

b) az igénybevevői nyilvántartás adatait egyedi azonosításra alkalmatlan módon, statisztikai célra átadja a Központi Statisztikai Hivatalnak.

Intézményi nyilvántartás

8. § Az intézményi nyilvántartás engedélyesenként tartalmazza

a) szociális szolgáltatások esetén a 3. számú melléklet,

${ }^{127} 139$ (2) A Kormány által kijelölt szerv a személyes gondoskodást nyújtó gyermekjóléti alapellátások és gyermekvédelmi szakellátások finanszírozásának ellenőrzése céljából nyilvántartást vezet. A nyilvántartás tartalmazza

a) a személyes gondoskodásban részesülő személy

aa) személyazonosító adatait,

$a b)$ hontalan jogállására, a szabad mozgás és tartózkodás jogára vonatkozó adatot,

ac) társadalombiztosítási azonosító jelét,

b) a személyes gondoskodást nyújtó gyermekjóléti alapellátás vagy gyermekvédelmi szakellátás formáját, igénybevételének és megszünésének időpontját,

c) az intézmény, szolgáltató, hálózat ágazati azonosító jelét,

d) a finanszírozás, támogatás költségvetési törvény szerinti jogcímét és feladatmutatóját,

e) hatósági döntéssel elhelyezett gyermek, illetve fiatal felnőtt esetén

ea) a határozatot hozó szerv nevét, a határozat számát, keltét, jogerőre emelkedésének napját,

$e b)$ a hatósági döntés jellegét (ideiglenes hatályú elhelyezés, átmeneti nevelésbe vétel, tartós nevelésbe vétel, utógondozói ellátás elrendelése),

ec) a gyermek ellátási szükségletét,

ed) a gyermek gondozási helyét, a fiatal felnőtt ellátásának helyét, a gyermek hatósági döntéssel elrendelt nevelőszülői elhelyezése, illetve a fiatal felnőtt nevelőszülőnél nyújtott utógondozói ellátása esetén a nevelőszülő nevét és címét.

(3) Nem kell a (2) bekezdés szerinti nyilvántartásba venni az adatokat

a) alternatív napközbeni ellátás esetén,

b) házi gyermekfelügyelet esetén,

c) gyermekjóléti szolgáltatás esetén, ha a gyermekjóléti szolgáltatás nyújtása az első találkozást követően tett intézkedéssel lezárható,

d) a gyermekjóléti központ speciális szolgáltatásai közül az utcai és lakótelepi szociális munka, a kórházi szociális munka és a készenléti szolgálat esetén. 
b) gyermekjóléti, gyermekvédelmi szolgáltató tevékenység esetén a 4. számú melléklet szerinti adatokat.

9. § (1) Az első fokon eljáró müködést engedélyező szerv, illetve az első fokú ellenőrzési jogkörében eljáró Hivatal a 3. számú melléklet 1-4. pontja szerinti adatokat az általa közvetlenül elérhető nyilvántartásban

a) a müködési engedélyt kiadó, módosító vagy visszavonó határozat jogerőre emelkedését követő öt munkanapon belül rögzíti, ha a határozat első fokon jogerőre emelkedett,

b) az iratok hozzá történő visszaérkezését követő öt munkanapon belül rögzíti, ha az $a$ ) pont szerinti határozat másodfokon emelkedett jogerőre, vagy ha a határozatot a bíróság hatályon kívül helyezte, illetve a felügyeleti szerv megváltoztatta, megsemmisítette.

(2) A 3. számú melléklet 5. pontja szerinti adatokat a szociális foglalkoztatást első fokon engedélyező szerv, illetve az ellenőrzést végző Hivatal az általa közvetlenül elérhető nyilvántartásban az (1) bekezdésben foglaltak megfelelő alkalmazásával rögzíti.

(3) Ha a Hivatal, vagy a 3. számú melléklet 1-4. pontja szerinti adatok tekintetében az első fokú működést engedélyező szerv, illetve a 3. számú melléklet 5. pontja szerinti adatok tekintetében a szociális foglalkoztatást első fokon engedélyező szerv az intézményi nyilvántartásban hibás vagy hiányos adatot észlel, azt soron kívül kijavítja, kiegészíti, illetve törli. A Hivatal az adat kijavításáról, kiegészítéséről, illetve törléséről egyidejüleg értesíti az első fokú működést engedélyező szervet, illetve a szociális foglalkoztatást első fokon engedélyező szervet.

(4) Ha a fenntartó vagy az engedélyes hibás vagy hiányos adatot észlel, nyolc napon belül értesíti

a) a 3. számú melléklet 1-4. pontja szerinti adatok tekintetében az első fokú müködést engedélyező szervet,

b) a 3. számú melléklet 5. pontja szerinti adatok tekintetében a szociális foglalkoztatást első fokon engedélyező szervet.

\section{Országos jelentési rendszer}

10. $§ A z$ országos jelentési rendszer a szociális szolgáltatásokat nyújtó engedélyesekre terjed ki, és engedélyesenként tartalmazza az 5. számú melléklet szerinti adatokat.

11. § (1) Az országos jelentési rendszer számára az 5. számú mellékletben meghatározott adatokat a fenntartó - a (2) bekezdés szerinti kivétellel - évente két alkalommal,

a) január 15-éig a december 31-ei jelentési időpontra, valamint a július 1-je és december 31-e közötti jelentési időszakra,

b) július 15-éig a június 30-ai jelentési időpontra, valamint a január 1-je és június 30-a közötti jelentési időszakra szolgáltatja.

(2) Támogató szolgáltatás, közösségi ellátások, jelzőrendszeres házi segítségnyújtás, utcai szociális munka, szociális foglalkoztatás, valamint idősek otthona esetén a fenntartó minden naptári negyedév első hónapjának 10. napjáig

a) az azt megelőző naptári negyedév utolsó napjára, mint jelentési időpontra,

b) az azt megelőző naptári negyedévre, mint jelentési időszakra

szolgáltatja az 5. számú mellékletben meghatározott adatokat.

(3) Új engedélyes, illetve új szociális szolgáltatás esetén az országos jelentési rendszer számára először

a) a szolgáltatás megkezdésének - a jogerős müködési engedélyben meghatározott - időpontját követő első jelentési időpontra, valamint

b) a szolgáltatás megkezdésének múködési engedélyben feltüntetett időpontja és az első jelentési időpont közötti időszakra

kell adatot szolgáltatni.

12. §(1) Az országos jelentési rendszer számára az adatokat - a (4) bekezdésben meghatározott kivétellel - a Hivatal internetes honlapján közzétett elektronikus ürlapon kell szolgáltatni.

(2) Az elektronikus ürlap kitöltése során a fenntartó a Hivatal által kiadott jelszóval azonosítja magát.

(3) Az adatszolgáltatás - a fenntartó kérelmére - úgy is történhet, hogy az elektronikus ürlapot az engedélyes tölti ki, és a fenntartó hagyja jóvá. Ebben az esetben az engedélyes a Hivatal által a számára külön kiadott jelszóval, a fenntartó pedig a (2) bekezdés szerinti jelszóval azonosítja magát.

(4) Azon egyházi, nem állami fenntartó, amely csak egy,

a) legfeljebb három szociális alapszolgáltatást, vagy

b) legfeljebb két szociális alapszolgáltatást és gyermekjóléti szolgáltatást

nyújtó engedélyest tart fenn, adatszolgáltatási kötelezettségét a Hivataltól igényelt nyomtatványon is teljesítheti.

13. § (1) Ha a fenntartó vagy az engedélyes az országos jelentési rendszerben hibás vagy hiányos adatot észlel, köteles arról soron kívül - az adatszolgáltatással megegyező módon - értesíteni a Hivatalt.

(2) Ha a müködést engedélyező szerv az országos jelentési rendszerben olyan adatot észlel, amely a működési engedélyben foglaltakkal vagy a hatósági ellenörzés megállapításaival ellentétes, köteles arról 
soron kívül értesíteni a Hivatalt. Ha az adatok hatósági ellenőrzés során váltak ismertté, az értesítéshez mellékelni kell az ellenőrzésröl készített jegyzőkönyv, illetve az ellenőrzés eredményeképpen hozott határozat másolatát.

(3) Ha a normatív állami támogatást folyósító és ellenőrző szerv az országos jelentési rendszerben olyan adatot észlel, amely a normatív állami hozzájárulás igénylésében, az arról történő lemondásban vagy az elszámolásban foglaltakkal, illetve az ellenörzés megállapításaival ellentétes, köteles arról soron kívül értesíteni a Hivatalt. Az értesítéshez mellékelni kell az adatot alátámasztó irat másolatát.

(4) A Hivatal az értesítés kézhezvételét követő 8 munkanapon belül a hibás vagy hiányos adatot - a (2)-(3) bekezdés szerinti esetben a fenntartó egyidejü tájékoztatása mellett - az értesítésben foglaltaknak megfelelően kijavítja, kiegészíti, illetve törli.

13/A. § (1) Az Szt. 92/L. § (3) bekezdése alapján kiszabott szociális igazgatási bírságot a Hivatalnak kell megfizetni - ha fizetési kedvezményt nem engedélyeztek - a bírságot kiszabó határozat jogerőre emelkedését követö harminc napon belül.

(2) A bírságból befolyt összeget a Hivatal negyedévente, a negyedévet követő hónap 20-áig a szociál- és nyugdíjpolitikáért felelős miniszter által vezetett minisztérium (a továbbiakban: minisztérium) fejezeti kezelésű előirányzat-felhasználási keretszámlájára utalja át. A Hivatal az átutalással egyidejüleg a bírságot kiszabó jogerős határozat másolatát megküldi a minisztériumnak.

\section{Igénybevevöi nyilvántartás}

13/B. §(1) Az igénybevevői nyilvántartásba történő adatszolgáltatási kötelezettség - a (2) bekezdésben foglalt kivételekkel - arra az engedélyesre terjed ki, amely bármely általa nyújtott szolgáltatás után az adott időpontban normatív állami hozzájárulásban vagy a támogató szolgáltatás és a közösségi ellátások finanszírozásának rendjéről szóló 191/2008. (VII. 30.) Korm. rendelet szerinti finanszírozásban részesüll.

(2) Nem terjed ki az igénybevevői nyilvántartásba történő adatszolgáltatási kötelezettség arra az engedélyesre, amely kizárólag az Szt. 20/C. § (2) bekezdése vagy a Gyvt. 139. § (3) bekezdése szerinti szolgáltatást nyújt, vagy kizárólag ilyen szolgáltatás után részesül normatív állami hozzájárulásban, illetve a támogató szolgáltatás és a közösségi ellátások finanszírozásának rendjéről szóló 191/2008. (VII. 30.) Korm. rendelet szerinti finanszírozásban.

(3) Az adatszolgáltatási kötelezettség az (1) bekezdés szerinti engedélyesek által nyújtott valamennyi szolgáltatásra kiterjed az Szt. 20/C. § (2) bekezdésében és a Gyvt. 139. § (3) bekezdésében foglaltak kivételével.

13/C. § (1) Az igénybevevői nyilvántartásba történő adatszolgáltatásért a fenntartó felel.

(2) Az adatszolgáltatást a (3) és (5) bekezdés szerinti személyek (a továbbiakban együtt: adatszolgáltatásra jogosult) teljesítik.

(3) A fenntartó az adatszolgáltatás teljesítésére - a Hivatal honlapján közzétett formanyomtatványon ügyfélkapu belépési jogosultsággal rendelkező személyt jelöl ki (a továbbiakban: e-képviselö). Az egyéni vállalkozó fenntartó és a fenntartó szervezet képviselöje saját magát is kijelölheti e-képviselőnek.

(4) Az e-képviselő a Hivatalnál vagy megyei kirendeltségénél - nyilvántartásba vétel céljából személyesen mutatja be a (3) bekezdés szerinti kijelölő okiratot és igazolja az ügyfélkapu felé megadott személyazonosító adatait. A fenntartó köteles a Hivatalnak bejelenteni, ha az e-képviselö nyilvántartásba vett adatai megváltoztak vagy megbízása megszünt.

(5) Az adatszolgáltatás teljesítésére az e-képviselő a (4) bekezdés szerinti nyilvántartásba vételét követően - az engedélyes vagy a fenntartó munkatársai közül - ügyfélkapu belépési jogosultsággal rendelkező személyt vagy személyeket jelölhet ki (a továbbiakban: adatszolgáltató munkatárs). Az adatszolgáltató munkatárs megfelelő felkészítéséről az e-képviselő gondoskodik.

(6) Az adatszolgáltató munkatárs az igénybevevői nyilvántartás rendszerében jelölhető ki. A kijelöléshez meg kell adni az adatszolgáltató munkatárs ügyfélkapu használatára jogosító személyazonosító adatait, és meg kell jelölni azokat az engedélyeseket, amelyek tekintetében az adatszolgáltató munkatárs adatszolgáltatásra jogosult. Az e-képviselö köteles az igénybevevői nyilvántartás rendszerében bejelenteni, ha az adatszolgáltató munkatárs nyilvántartásba vett adatai megváltoztak. Az adatszolgáltató munkatárs kijelölése az igénybevevői nyilvántartás rendszerében vonható vissza.

13/D. § Az adatszolgáltatás az igénybe vevők Szt., illetve Gyvt. szerinti adatainak a 13/E. § szerinti rögzítéséből és a 13/F. § szerinti napi jelentésből áll.

13/E. § (1) Az adatszolgáltatásra jogosult az Szt.-ben, illetve a Gyvt.-ben meghatározott adatokat

a) szociális szolgáltatás és gyermekjóléti alapellátás esetén legkésőbb az igénybevétel első napját követő munkanap 24 óráig,

b) gyermekvédelmi szakellátás esetén az ideiglenes hatályú elhelyezés, az átmeneti vagy tartós nevelésbe vétel, illetve az utógondozói ellátás elrendeléséről szóló hatósági határozatban az ellátás kezdő időpontjaként megjelölt napot, ennek hiányában a határozat keltének napját követő munkanap 24 óráig, de legkésőbb a határozat engedélyessel való közlését követő munkanap 24 óráig 
rögzíti az igénybevevői nyilvántartásban.

(2) Szociális szolgáltatás és gyermekjóléti alapellátás esetén az adatok már az Szt. 94/C. §-a, illetve a Gyvt. 32. § szerinti ${ }^{128}$ megállapodás megkötésétől kezdődően rögzíthetők.

(3) Ha az igénybe vevő Társadalombiztosítási Azonosító Jellel (a továbbiakban: TAJ) nem rendelkezik vagy a TAJ nem ismert, az igénybevevői nyilvántartás az igénybe vevőnek - a TAJ rögzítéséig - ideiglenes azonosítót képez.

(4) Ha az adott engedélyes által az igénybe vevőnek nyújtott szolgáltatás formája, a szolgáltatás igénybevételének kezdő időpontja vagy a szolgáltatás megszünésének várható időpontja megváltozik, azt az adatszolgáltatásra jogosult

a) szociális szolgáltatás és gyermekjóléti alapellátás esetén legkésőbb a módosított feltételek szerinti igénybevétel első napját követő munkanap 24 óráig,

b) gyermekvédelmi szakellátás esetén a tudomásszerzést követő munkanap 24 óráig módosítja.

(5) A szolgáltatás igénybevételének kezdő időpontja visszamenőlegesen csak későbbi időpontra módosítható. A (4) bekezdés szerinti egyéb adatok visszamenőlegesen nem módosíthatók.

(6) Ha az igénybevevői nyilvántartásban rögzített adat - a TAJ és a (4) bekezdés szerinti adatok kivételével - megváltozik, azt az adatszolgáltatásra jogosult a tudomásszerzést követő munkanap 24 óráig módosítja. Az e bekezdés szerinti adatok visszamenőlegesen akkor módosíthatók, ha a módosítás ideiglenes hatályú elhelyezéssel, átmeneti vagy tartós nevelésbe vétellel, illetve utógondozói ellátással kapcsolatos hatósági döntés miatt szükséges.

(7) Ha a szolgáltatás igénybevétele megszünik, azt az adatszolgáltatásra jogosult a megszünést követő munkanap 24 óráig rögzíti. Ha a gyermekvédelmi szakellátás igénybevétele hatósági határozat alapján szűnik meg, a határozatban megállapított időpontot kell megjelölni a megszünés időpontjaként.

(8) Ha az igénybe vevőnek szolgáltatást nyújtó engedélyes az Szt. szerinti áthelyezés vagy a Gyvt. szerinti gondozási hely, utógondozói ellátási hely módosítása miatt megváltozik,

a) a korábbi engedélyes az áthelyezés, illetve a gondozási hely, utógondozói ellátási hely megváltozását megelőző nappal a (7) bekezdésben foglaltak szerint rögzíti az igénybevétel megszűnését,

b) az új engedélyes az áthelyezés, illetve a gondozási hely, utógondozói ellátási hely megváltozásának napjával az (1) bekezdésben foglaltak szerint rögzíti az igénybe vevő Szt., illetve Gyvt. szerinti adatait.

(9) A (8) bekezdés alkalmazása során

a) az áthelyezés időpontjának az Szt. 94/C. §-a szerinti megállapodás módosításában meghatározott időpontot,

b) a gondozási hely, utógondozói ellátási hely megváltozása időpontjának az erről szóló határozatban megállapított időpontot, ennek hiányában a határozat keltének napját kell tekinteni.

13/F. § (1) Az adatszolgáltatásra jogosult az igénybevevői nyilvántartásban naponta nyilatkozik arról, hogy a 13/E. § szerint rögzített személy a szolgáltatást az adott napon igénybe vette-e (napi jelentés).

$12832 \S$ (5) A gyermekjóléti alapellátások igénybevételének megkezdése előtt és az utógondozói ellátás igénybevételének megkezdésekor

a) állami fenntartású szolgáltató, intézmény esetén a szolgáltató vezetője, illetve az intézményvezető,

b) egyházi és nem állami fenntartású szolgáltató, intézmény esetén a fenntartó vagy az általa megbízott személy

a kérelmezövel, illetve törvényes képviselöjével írásban megállapodást köt.

(6) Nem kell az (5) bekezdés szerint megállapodást kötni

a) gyermekjóléti szolgáltatás esetén,

b) - ha a fenntartó döntése alapján a szolgáltatás jellegére tekintettel az nem indokolt - alternatív napközbeni ellátás

esetén.

(7) Az (5) bekezdés szerinti megállapodás tartalmazza

a) az ellátás kezdetének időpontját,

b) az intézményi ellátás időtartamát (a határozott vagy határozatlan időtartam megjelölését),

c) a gyermek, fiatal felnőtt számára nyújtott szolgáltatások és ellátások tartalmát, módját,

d) a személyi térítési díj megállapítására és megfizetésére vonatkozó szabályokat, ha az ellátás térítésidíj-

fizetési kötelezettséggel jár,

e) az ellátás megszüntetésének módjait,

f) a gyermek és törvényes képviselője, valamint a fiatal felnőtt személyazonosító adatait. 
(2) A napi jelentési kötelezettséget az adott napot követő munkanap 24 óráig kell teljesíteni.

(3) Ha az igénybe vevő nem rendelkezik TAJ-jal, és a TAJ igénylésére jogosult

a) szociális szolgáltatás és gyermekjóléti alapellátás esetén a TAJ-t hatvan napon belül nem szerzi be,

b) gyermekvédelmi szakellátás esetén hatvan napon belül nem igazolja, hogy a TAJ kiadását kérelmezte, az érintett a napi jelentésben nem tüntethető fel igénybe vevőként.

(4) Az ideiglenesen elhelyezett, átmeneti vagy tartós nevelésbe vett, de javítóintézetben vagy büntetésvégrehajtási intézetben ellátott a napi jelentésben nem tüntethető fel.

(5) A napi jelentésben az igénybevételről szolgáltatott adat egyszer, a napi jelentés szerinti igénybevétel hónapját követő hónap tizenötödik napjáig módosítható (a továbbiakban: önellenőrzés). Önellenőrzés keretében új ellátott rögzítésére nincs lehetőség, a napi igénybevétel tényén túl adatot módosítani csak a 13/E. §-ban foglaltak szerint lehet. Az önellenörzés során meg kell jelölni

a) az igénybevételi napot,

b) a hibás adatot,

c) a helyes adatot és

d) a hiba okát.

13/G. § (1) A Hivatal az igénybevevői nyilvántartásban rögzített

a) természetes személyazonosító és lakcímadatokat a Közigazgatási és Elektronikus Közszolgáltatások Központi Hivatalának nyilvántartásából,

b) TAJ-t az Országos Egészségbiztosítási Pénztár nyilvántartásából

való adatigénylés útján ellenörzi, illetve - ha az adat nem vagy hibásan áll a Hivatal rendelkezésére - kéri meg.

(2) Ha a szociális és gyámhivatal vagy a Magyar Államkincstár valamely szerve az igénybevevői nyilvántartásban olyan adatot észlel, amely a müködési engedélyben foglaltakkal vagy a hatósági ellenőrzés megállapításaival ellentétes, soron kívül értesíti a Hivatalt. Ha az adatok hatósági ellenőrzés során váltak ismertté, az értesítéshez mellékelni kell az ellenőrzésröl készített jegyzőkönyv, illetve az ellenőrzés eredményeképpen hozott határozat másolatát.

(3) A Hivatal a tudomására jutott hibás adatot a tudomására jutástól számított három munkanapon belül az adatszolgáltatásra jogosultnak az igénybevevői nyilvántartás rendszerén keresztül történő egyidejü tájékoztatása mellett - kijavítja vagy törli. A javítás nem terjedhet ki a napi jelentésben igénybe vevőként fel nem tüntetett személy igénybe vevőként történő feltüntetésére.

13/H. § (1) A Hivatal folyamatosan ellenőrzi, hogy az igénybe vevő adott napon nem kerül-e egyidejüleg több olyan szolgáltatással kapcsolatos napi jelentésben is feltüntetésre, amelyek

a) esetében a normatív állami hozzájárulás egyidejủ igénybevételét a központi költségvetésről szóló törvény kizárja, vagy

b) egyidejű nyújtása a jogszabályok alapján kizárt. ${ }^{129}$

(2) Ha az (1) bekezdés $a$ ) vagy $b$ ) pontja szerinti jogosulatlan adatrögzítést a Hivatal megállapítja, a Hivatal - az ügyben érintett ügyintézője nevének és elérhetőségének egyidejü közlése mellett - az

129 1998. évi LVXXXIV. törvény 21. § (1) A gyermekgondozási segélyben részesülő személy - ide nem értve a nagyszülöt, az örökbefogadó szülöt a 20/B. § szerinti esetben, továbbá a kiskorú szülő gyermekének gyámját - kereső tevékenységet

a) a gyermek egyéves koráig nem folytathat,

b) a gyermek egyéves kora után heti harminc órát meg nem haladó időtartamban folytathat, vagy időkorlátozás nélkül, ha a munkavégzés az otthonában történik,

c) a tartósan beteg vagy súlyosan fogyatékos gyermek egyéves kora után időkorlátozás nélkül folytathat,

d) ikergyermekek esetében a gyermekek egyéves kora után a $b$ ) pont szerinti korlátozás nélkül folytathat, azzal, hogy az e pont szerinti feltételekkel keresőtevékenységet folytató személy az ikergyermekek számától függetlenül az egy gyermek után járó összegü gyermekgondozási segélyre jogosult.

(2) A kiskorú szülő gyermekének gyermekgondozási segélyben részesülő gyámja időkorlátozás nélkül folytathat kereső tevékenységet.

21/A. §(1) A gyermekgondozási segélyben részesülő nagyszülő kereső tevékenységet a gyermek hároméves kora után, a 21. § (1) bekezdés b) pontjában meghatározottak szerint folytathat.

(2) A 27. § (1) bekezdésében foglaltakon túl nem jár gyermekgondozási segély a nagyszülőnek, ha kormányrendeletben meghatározott kivétellel - a gyermeket napközbeni ellátást biztosító intézményben [Gyvt. 41. § (3) bek.] helyezik el. 
igénybevevői nyilvántartás rendszerén keresztül felhívja az érintett adatszolgáltatásra jogosultakat a napi jelentés adatainak módosítására, szükség esetén a szolgáltatás megszüntetésére.

(3) Ha az adatszolgáltatásra jogosultak önellenörzéssel, valamint szükség esetén a jogosulatlanul nyújtott szolgáltatás megszüntetésével a jogosulatlan adatrögzítést a felhívást követő három munkanapon belül nem szüntetik meg, a Hivatal a később rögzített napi jelentésböl az érintett igénybe vevőt hivatalból törli. A törlésről a Hivatal értesíti a Magyar Államkincstár illetékes igazgatóságát és az igénybevevői nyilvántartás rendszerén keresztül az adatszolgáltatásra jogosultakat.

\section{Hatályba léptetö és átmeneti rendelkezések}

14. § (1) Ez a rendelet - a (2) bekezdés szerinti kivétellel - 2007. június 1-jén lép hatályba.

(2) E rendelet 28. §-ának (1) és (4)-(5) bekezdése, valamint 29. §-ának (3) bekezdése a kihirdetését követő harmadik napon lép hatályba.

(3) E rendelet rendelkezéseit - a (4)-(5) bekezdésben foglaltak kivételével - az e rendelet hatálybalépésekor folyamatban lévő müködési engedélyezési eljárásokban is alkalmazni kell.

(4) Ahol jogszabály adatszolgáltatás, illetve nyilvántartás adattartalmának meghatározása során az engedélyes működési engedélyének számát említi, azon az ágazati azonosítót kell érteni. E rendelet hatálybalépésekor müködési engedéllyel rendelkező engedélyesek esetén akkor kell a müködési engedély számaként az ágazati azonosítót feltüntetni, ha a müködést engedélyező szerv az ágazati azonosítót - a 15. § (5) bekezdésének $b$ ) pontja vagy (6) bekezdésének $d$ ) pontja szerint - már jogerős határozatba foglalta.

(5)

15. § (1) A 2012. január 1-jén múködési engedéllyel rendelkező fenntartók e-képviselöje 2012. január 31éig köteles kérni - szükség esetén ügyfélkapu-regisztrációt követően - a 13/C. § (4) bekezdése szerinti nyilvántartásba vételt.

(2) Az adatszolgáltatásra jogosult 2012. február 29-éig rögzíti a nyilvántartásában szereplő igénybe vevők Szt., illetve Gyvt. szerinti adatait az igénybevevői nyilvántartásban.

(3) A napi jelentési kötelezettség 2012. március 1-jétől minden engedélyes számára kötelező azzal, hogy a napi jelentés során tett adatszolgáltatásnak 2012. június 30-áig jogkövetkezménye nincs. Az adatszolgáltatást érintő hibás, hiányos adatokat azok javítása, pótlása érdekében az engedélyes 2012. június 15-éig jelzi a Hivatalnak.

16-29. $\S$

\section{1. számú melléklet a 226/2006. (XI. 20.) Korm. rendelethez Az ágazati azonosító kiadásához szü̈kséges adatok}

\section{A fenntartó adatai:}

1.1. a fenntartó neve,

1.2. a fenntartó székhelye,

1.3. a fenntartó adószáma.

2. A szolgáltató (intézmény, hálózat) adatai:

2.1. a szolgáltató (intézmény, hálózat) neve,

2.2. a szolgáltató (intézmény, müködtető) székhelye,

2.3. a szolgáltató (intézmény) székhelyének ágazati azonosítója,

2.4. a szolgáltató (intézmény) székhelyén ellátást nyújtanak-e,

2.5. a szolgáltató (intézmény) telephelye,

2.6. a szolgáltató (intézmény, müködtető) adószáma,

2.7. ha a szolgáltató (intézmény, hálózat) részben önállóan gazdálkodó költségvetési szerv, annak az önállóan gazdálkodó költségvetési szervnek a neve, székhelye és adószáma, amely a külön jogszabály szerinti pénzügyi-gazdasági feladatokat ellátja,

2.8. a nyújtani kívánt szolgáltatás típusa és formája,

2.9. a kérelemben megjelölt ellátási terület,

2.10. a szolgáltató (intézmény, hálózat) férőhelyeinek száma.

3. Az eljáró hatóság adatai:

3.1. az eljáró hatóság megnevezése,

3.2 .

\section{2. számú melléklet a 226/2006. (XI. 20.) Korm. rendelethez}

1. Az ágazati azonosító nyolcjegyủ. Az ágazati azonositó képzése

2. Az ágazati azonosító összetétele:

1. jegye: konstans , ,S” betü,

2-7. jegye: a szolgáltató (intézmény, hálózat, telephely) sorszáma,

8. jegye: a 2-7. számjegyek felhasználásával, a 3. pont szerinti matematikai módszerekkel képzett ellenőrző szám. 
3. Az ágazati azonosító 8. számjegyét úgy kell képezni, hogy a 2-7. jegyek mindegyikét szorozni kell azzal a sorszámmal, ahányadik helyet foglalja el az azonosítón belül (a konstans „, $\mathrm{S}$ " betü utáni első számjegy szorozva kettővel, második számjegy szorozva hárommal stb.). (...)

Az így kapott szorzatok összegét el kell osztani 10-zel, és a 8. jegy az osztás maradéka lesz.

\section{4. számú melléklet a 226/2006. (XI. 20.) Korm. rendelethez}

\section{A gyermekjóléti, gyermekvédelmi szolgáltatókról, intézményekröl nyilvántartott adatok}

1. A fenntartó adatai:

1.1. a fenntartó neve,

1.2. a fenntartó székhelye,

1.3. a fenntartó típusa,

1.4. a költségvetési szerv fenntartó gazdálkodási formája,

1.5. a fenntartó adószáma.

2. A szolgáltató (intézmény, hálózat) adatai:

2.1. a szolgáltató (intézmény, hálózat) ágazati azonosítója,

2.2. a szolgáltató (intézmény, müködtető) neve,

2.3. a szolgáltató (intézmény, müködtető) székhelye,

2.4. a szolgáltató (intézmény) telephelye,

2.5. a telephely ágazati azonosítója,

2.6. területi irodák címe,

2.7. a szolgáltató (intézmény, müködtető) adószáma,

2.8. ha a szolgáltató (intézmény, hálózat) részben önállóan gazdálkodó költségvetési szerv, annak az önállóan gazdálkodó költségvetési szervnek a neve, székhelye és adószáma, amely a külön jogszabály szerinti pénzügyi-gazdasági feladatokat ellátja.

3. A gyermekjóléti és gyermekvédelmi szolgáltató tevékenység adatai.

3.1. a szolgáltató tevékenység típusa és formája,

3.2. az ellátási terület,

3.3. férőhelyek, külső férőhelyek, önálló helyettes szülőnél ellátható gyermekek száma,

3.4. helyettes szülői, illetve nevelőszülői hálózat esetén a helyettes szülők, nevelőszülők, speciális hivatásos nevelőszülők száma,

3.5. annak megjelölését, hogy a gyermekotthon

3.5.1. speciális gyermekotthon,

3.5.2. különleges gyermekotthon,

3.5.3. rendelkezik speciális csoporttal,

3.5.4. rendelkezik különleges csoporttal,

3.5.5. integráltan ellát speciális szükségletü gyermekeket,

3.5.6. integráltan ellát különleges szükségletủ gyermekeket,

3.6. a szolgáltató tevékenység megkezdésének időpontja,

3.7. a határozott idejü, illetve az ideiglenes müködési engedély lejártának ideje,

3.8. egyházi és nem állami fenntartó esetén az ellátási szerződést megkötő helyi önkormányzat, társulás, illetve állami szerv neve, székhelye, az ellátási szerződés hatálya alá tartozó szolgáltató tevékenységek és férőhelyszám, továbbá az ellátási szerződés megszünésének időpontja, ha az ellátási szerződést határozott időre kötötték,

3.9. a szolgáltató (intézmény, hálózat) megszűnésének időpontja.

4. A müködést engedélyezö (módositó, visszavonó) határozat adatai:

4.1. a határozatot hozó hatóság megnevezése,

4.2. a határozat kelte, száma és jogerőre emelkedésének napja.

5. számú melléklet a 226/2006. (XI. 20.) Korm. rendelethez

Az országos jelentési és féröhelyfigyelö rendszerben nyilvántartott adatok

1. Alapszolgáltatások

1.1. Étkeztetés:

1.1.1-1.1.3.

1.1.4. a jelentési időpontban az intézményi térítési díj összege,

1.1.5. a jelentési időpontban a szolgáltatásra várakozók száma,

1.1.6. népkonyhai étkeztetés esetén a jelentési időszakban az igénybe vevők száma.

(...)

3. Szociális foglalkoztatás

3.1. Munka-rehabilitáció: 
3.1.1. a jelentési időpontban azon ellátottak száma a foglalkoztatás időtartama szerinti megbontásban, akikkel vagy akik törvényes képviselőjével munka-rehabilitációban részvételről megállapodást kötöttek,

3.1.2. a jelentési időpontban a munka-rehabilitációs díj átlagos összege a foglalkoztatás időtartama szerinti megbontásban,

3.1.3. a jelentési időszak alatt a munka-rehabilitációban részt vevők közül fejlesztő-felkészítő foglalkoztatásba került személyek száma.

3.2. Fejlesztő-felkészítő foglalkoztatás:

3.2.1. a jelentési időpontban azon ellátottak száma munkaidő szerinti megbontásban, akikkel fejlesztőfelkészítő foglalkoztatás céljából munkaszerződést kötöttek,

3.2.2. a jelentési időpontban a munkadíj átlagos összege munkaidő szerinti megbontásban,

3.2.3. a jelentési időszakban a foglalkoztatottak közül védett foglalkoztatásba került személyek száma,

3.2.4. a jelentési időszakban a foglalkoztatottak közül a nyílt munkaerőpiacra került személyek száma.

3.3. Feladatmutató:

3.3.1. a jelentési időpontig az adott évben teljesített feladatmutató,

3.3.2. a jelentési időszakban munka-rehabilitációs foglalkoztatásban teljesített feladatmutató,

3.3.3. a jelentési időszakban fejlesztő-felkészítő foglalkoztatásban teljesített feladatmutató. 
NeMzeti ReHABILITÁCiós És Szociális Hivatal

Főigazgató

1071 Budapest, Damjanich u. 48.

Telefon: (1) 462-6410 Fax: (1) 462-6421

E-mail: foigazgato@nrszh.hu

\section{Tájékoztatás a Központi Elektronikus Nyilvántartási Rendszert érintő változásokról}

Tisztelt Fenntartók! ${ }^{130}$

A szociális igazgatásról és szociális ellátásokról szóló 1993. évi III. törvény 20/C. § (1) bekezdése alapján a szociális hatóság a személyes gondoskodást nyújtó szociális ellátások, szolgáltatások finanszírozásának ellenőrzése céljából nyilvántartást vezet. A szociális, gyermekjóléti és gyermekvédelmi szolgáltatók, intézmények ágazati azonosítójáról és országos nyilvántartásáról szóló 226/2006. (XI. 20.) Korm. rendelet (továbbiakban rendelet) 13/B. §-a írja elő a fenntartók igénybevevői nyilvántartásba történő adatszolgáltatási kötelezettségét, melyhez az alábbi tájékoztató formájában szeretnénk segítséget nyújtani:

Az igénybevevői nyilvántartásba történő adatszolgáltatási kötelezettség arra az engedélyesre terjed ki, amely bármely általa nyújtott szolgáltatás után az adott időpontban normatív állami hozzájárulásban vagy a támogató szolgáltatás és a közösségi ellátások finanszírozásának rendjéről szóló 191/2008. (VII. 30.) Kormányrendelet szerinti finanszírozásban részsül.

Nem terjed ki az igénybevevői nyilvántartásba történő adatszolgáltatási kötelezettség az alábbi fenntartókra:

- Családsegítés esetében, amennyiben a külön jogszabályban meghatározott szakmai tevékenység az első interjú kapcsán tett intézkedéssel lezárható

- falugondnoki és tanyagondnoki szolgáltatás,

- népkonyha,

- $\quad$ szenvedélybetegek alacsonyküszöbü ellátása,

- utcai szociális munka esetén

- $\quad$ a gyermekek védelméről és a gyámügyi igazgatásról szóló 1997. évi XXXI Tv. 139 §-a alapján

- a) alternatív napközbeni ellátás esetén,

- b) házi gyermekfelügyelet esetén,

- c) gyermekjóléti szolgáltatás esetén, ha a gyermekjóléti szolgáltatás nyújtása az első találkozást követően tett intézkedéssel lezárható,

- d) a gyermekjóléti központ speciális szolgáltatásai közül az utcai és lakótelepi szociális munka, a kórházi szociális munka és a készenléti szolgálat esetén.

A rendelet 13/C. $§(1)$ bekezdése alapján az igénybevevői nyilvántartásba történő adatszolgáltatásért a fenntartó felel.

A Fenntartónak az adatszolgáltatási kötelezettség teljesítése érdekében az alábbi lépéseket szükséges megtennie:

\section{FENNTARTÓ FELADATAI}

1. A 2012. január 1-jén müködési engedéllyel rendelkező fenntartónak minimum egy személyt ki kell jelölnie, akinek - amennyiben még nem rendelkezik vele - 2012. január hónapban a területileg illetékes Okmányirodán kell személyi hozzáférést kérnie az ügyfélkapun történő belépéshez.

2. Ezt követően a fenntartónak a Hivatal honlapján közzétett MEGHATALMAZÁS formanyomtatványon (1. számú melléklet) kell a már ügyfélkapu belépési jogosultsággal rendelkező személyt (a továbbiakban: eképviselö) meghatalmaznia az adatszolgáltatás teljesítése érdekében. A fenntartó szervezet képviselője saját magát is kijelölheti e-képviselőnek.

A fenntartó köteles a Hivatalnak bejelenteni, ha az e-képviselő nyilvántartásba vett adatai megváltoztak vagy megbízása megszünt.

\section{E-KÉPVISELŐ FELADATAI}

1. Az e-képviselő a 2. sz. mellékletében foglalt Regionális Igazgatóságok Kirendeltségeinél nyilvántartásba vétel céljából - személyesen mutatja be az alábbi dokumentumokat:

- Meghatalmazás,

- Személyazonosító okmány,

${ }^{130}$ Forrás: http://www.nrszh.hu/ 
- Ügyfélkapus regisztrációkor kapott igazolás (nem kötelező, de a pontos beazonosithatóság érdekében kérjük bemutatni)

- Olyan müködési engedély, amelyben a fenntartó adatai szerepelnek (nem kötelezö, de a pontos beazonosíthatóság érdekében kérjük bemutatni)

A Hivatal Kirendeltségeinél az e-képviselő adatait a fenti iratok alapján berögzítik az elektronikus rendszerbe, majd ezt követően a Kirendeltség ügyintézője a Szociális Regiszterben szereplő fenntartóhoz hozzárendeli. A fenntartók adatai a müködési engedély alapján szerepelnek a Szociális Regiszterben, melyen az e-képviselök megadásakor módosítani nem lehet. Ha a fenntartó adatai hibásak vagy adatai nem szerepelnek a Szociális Regiszterben, akkor a fenntartó a székhelye szerint illetékes müködést engedélyező szervnél (megyei kormányhivatal szociális és gyámhivatala) kezdeményezhet adategyeztetést.

2. A nyilvántartásba vételt követően az e-képviselő az általa megadott elektronikus elérhetőségre kapni fog egy aktivációs kódot, majd a saját munkaállomásán be kell lépnie a tevadmin.nrszh.hu weboldalra.

3. Az aktivációs kódot megadva a rendszer felveszi a kapcsolatot az ügyfélkapuval és úgynevezett visszaazonosítást végez a következőek szerint:

- A aktivációs kód megadása után a rendszer automatikusan átirányítja az elektronikus felületet az ügyfélkapu oldalára, ahol az azonosítás érdekében az e-képviselőnek be kell lépni az ügyfélkapuba a létesítéskor megadott felhasználói névvel és jelszóval.

- Az ügyfélkapu ez után leellenörzi, hogy a kirendeltségen történő nyilvántartásba vételkor valamint az ügyfélkapu létesítésekor megadott személyi adatok egyeznek-e és amennyiben igen az e- képviselő beléphet az igénybevevői nyilvántartás felületére.

- Az ezt követő alkalmakkor már kizárólag csak az ügyfélkapuhoz használatos belépési nevet és jelszót szükséges megadni az igénybevevői nyilvántartásba történő felületre történő belépéshez.

Amennyiben a természetes személyazonosító adatai nem egyeznek az ügyfélkapus regisztrációnál rögzítettekkel, akkor az e-képviselő nem tud a rendszerbe belépni. Ebben az esetben az ügyfélkapus regisztráció igazoló lapján szereplő adatokra kell módosítani az e-képviselő adatait.

Egy személy lehet több fenntartó e-képviselője, de erről a rendszer a fenntartókat értesíti valamint ugyanazon fenntartó több e-képviselőt is meghatalmazhat egyidejüleg.

4. Adatszolgáltató munkatárs berögzítése

Az adatszolgáltatás teljesítésére az e-képviselő a nyilvántartásba vételét követően - az engedélyes vagy a fenntartó munkatársai közül - ügyfélkapu belépési jogosultsággal rendelkező személyt vagy személyeket jelölhet ki (a továbbiakban: adatszolgáltató munkatárs). Az adatszolgáltató munkatárs megfelelő felkészítéséről az eképviselő gondoskodik. Az e-képviselő az adatszolgáltató munkatársak berögzítése során megadja, hogy adott munkatársnak mely ellátás nyújtási hely (székhely, telephely) és mely szolgáltatási típus vonatkozásában van jogosultsága a napi adatrögzítést elvégezni.

$\mathrm{Az}$ adatszolgáltató munkatársak felrögzítése során szintén ügyelni kell arra, hogy adatai egyezzenek az ügyfélkapu létesítése során megadott személyes adatokkal. Az adatszolgáltató munkatárs tekintetében a Hivatal kirendelései felé nem kell adatokat szolgáltatni, igazolásokat bemutatni. Az ügyintézők szintén az ügyfélkapu létesítése során megadott felhasználói névvel és jelszóval tudnak belépni a rendszerbe az adatrögzítés céljából.

5. Amennyiben az e-képviselő maga is szeretne adatrögzítési jogosultsággal rendelkezni, abban az esetben a saját jogosultságát is meg kell adnia, tekintettel arra, hogy automatikusan nem jogosult egyetlen szolgáltató adatainak kezelésére sem.

6. Az e-képviselő feladatát képezi továbbiakban, hogy amennyiben szükséges módosítja vagy megszünteti az adatszolgáltató munkatársak jogosultságait. Az adatszolgáltató munkatárs kijelölése az igénybevevöi nyilvántartás rendszerében vonható vissza.

\section{Az adatszolgáltató munkatárs feladata:}

1. Az adatszolgáltatás az igénybe vevők Szt., illetve Gyvt. szerinti adatainak a 13/E. § szerinti rögzítéséböl és a 13/F. § szerinti napi jelentésből áll.

Az adatszolgáltatásra jogosult az Szt.-ben, illetve a Gyvt.-ben meghatározott adatokat

a) szociális szolgáltatás és gyermekjóléti alapellátás esetén legkésőbb az igénybevétel első napját követő munkanap 24 óráig,

b) gyermekvédelmi szakellátás esetén az ideiglenes hatályú elhelyezés, az átmeneti vagy tartós nevelésbe vétel, illetve az utógondozói ellátás elrendeléséről szóló hatósági határozatban az ellátás kezdő időpontjaként megjelölt napot, ennek hiányában a határozat keltének napját követő munkanap 24 óráig, de legkésőbb a határozat engedélyessel való közlését követő munkanap 24 óráig rögzíti az igénybevevői nyilvántartásban.

\footnotetext{
IV. Az Igénybevevői nyilvántartási rendszer kiépülése kapcsán az alábbi fontos dátumokat és határidőket kell betartani:
} 


\begin{tabular}{|l|l|}
\hline 2012. január 1-től 2012. január 31-ig & $\begin{array}{l}\text { müködési engedéllyel rendelkező fenntartók e- képviselője } \\
\text { 2012. január 31-ig köteles kérni a nyilvántartásba vételét. }\end{array}$ \\
\hline 2012. február 1-től 2012. február 29-ig & $\begin{array}{l}\text { nyilvántartásba vett e- képviselő 2012. február 29-ig rögzíti a } \\
\text { törzsadatokat. }\end{array}$ \\
\hline 2012. március 1-től 2012. június 30-ig & $\begin{array}{l}\text { napi jelentési kötelezettség teljesítése elindulása } \\
\text { jogkövetkezmény nélkül }\end{array}$ \\
\hline 2012. június 30-tól & $\begin{array}{l}\text { jogkövetkezmény alkalmazása a napi jelentési kötelezettség } \\
\text { teljesítésének elmaradása miatt }\end{array}$ \\
\hline
\end{tabular}

A jogszabályban foglalt adatszolgáltatási kötelezettség teljesítése érdekében a továbbiakban folyamatos tájékoztatókat fog a Hivatal megjelentetni a nyilvántartáshoz kapcsolódó feladatokról.

Budapest, 2012. január 6.

Dr. Pósfai Gábor

föigazgató 


\section{3/2009. (IX. 29.) Korm. rendelet az egyházi és nem állami fenntartású szociális, gyermekjóléti és gyermekvédelmi szolgáltatók normatív állami támogatásáról}

A Kormány a szociális igazgatásról és szociális ellátásokról szóló 1993. évi III. törvény 132. § (1) bekezdés $g$ ) pontjában kapott felhatalmazás, a gyermekek védelméről és a gyámügyi igazgatásról 1997. évi XXXI. törvény 162 . § (1) bekezdés $s$ ) és $t$ ) pontjában kapott felhatalmazás, valamint az államháztartásról szóló 1992. évi XXXVIII. törvény 124. § (2) bekezdés $c$ ) pontjában kapott felhatalmazás alapján, az Alkotmány 35 . § (1) bekezdés $b$ ) pontjában foglalt feladatkörében a következöket rendeli:

1. § E rendelet alkalmazásában

\section{Altalános rendelkezések}

a) normatíva: a feladatnormatíva és a képzési támogatás,

b) feladatnormativa: az ellátotti létszám, a férőhelyszám vagy a fenntartott szolgálatok, központok száma alapján járó normatív állami hozzájárulás és az egyházi kiegészitő támogatás,

c) képzési támogatás: a szociális továbbképzés és szakvizsga támogatása jogcímen igénybe vehető normatív, kötött felhasználású állami támogatás,

d) igazgatóság: a Magyar Államkincstár területi szerve,

e) fenntartó: a szociális igazgatásról és szociális ellátásokról szóló 1993. évi III. törvény (a továbbiakban: Szt.) 4. § (1) bekezdés $m b$ ) alpontja, illetve a gyermekek védelméről és a gyámügyi igazgatásról szóló 1997. évi XXXI. törvény (a továbbiakban: Gyvt.) 5. § sb) alpontja szerinti egyházi fenntartó, valamint az Szt. 4. § (1) bekezdés $m c$ )-me) alpontja, illetve a Gyvt. 5. § sc)-se) alpontja szerinti nem állami fenntartók közül a társadalmi szervezet, az alapítvány, a közalapítvány, az országos kisebbségi önkormányzat, a nonprofit gazdasági társaság, a gazdasági társaság és a humánszolgáltatást alaptevékenységként végző, a személyi jövedelemadóról szóló törvény hatálya alá tartozó egyéni vállalkozó,

f) szolgáltatás: az Szt. szerinti szociális szolgáltatás, valamint a Gyvt. szerinti gyermekjóléti, gyermekvédelmi szolgáltató tevékenység,

g) szolgáltató: az Szt. szerinti szociális szolgáltatást müködési engedéllyel nyújtó szociális szolgáltató, intézmény, valamint a Gyvt. szerinti gyermekjóléti, gyermekvédelmi szolgáltató tevékenységet müködési engedéllyel végző szolgáltató, intézmény, hálózat,

h) tárgyév: az a naptári év, amelyre tekintettel a normatívát megállapítják, illetve folyósítják,

i) új fenntartó: az a fenntartó, amely a tárgyévet megelőző évben egy szolgáltatóra sem rendelkezett jogerös múködési engedéllyel,

j) megszünt fenntartó: az a fenntartó, amely valamennyi szolgáltatóját más személy vagy szervezet fenntartásába adta, illetve valamennyi szolgáltatójának müködési engedélyét visszavonták,

k) jegybanki alapkamat: a tárgyév átlagos jegybanki alapkamata, a tárgyévben megszünt fenntartó esetén a megszünés napjáig érvényes átlagos jegybanki alapkamat,

l) korrekció: a tárgyévi központi költségvetés végrehajtásáról szóló törvény alapján az egyházi fenntartót megillető vagy az egyházi fenntartó által visszafizetendő egyházi kiegészítő támogatás összege,

$m$ ) befogadás: az Szt. 58/A. § (2) és (2a) bekezdése, valamint a gyermekek védelméröl és a gyámügyi igazgatásról szóló 1997. évi XXXI. törvény 145. § (2) és (2a) bekezdése szerinti, a szociális és a gyermekjóléti szolgáltatások területi lefedettségét figyelembe vevő finanszírozási rendszerbe történő befogadás.

2. § (1) Az e rendelet szerinti eljárásokban a közigazgatási hatósági eljárás általános szabályairól szóló törvény rendelkezéseit kell alkalmazni.

(2) Ha e rendelet másként nem rendelkezik, az egyházi és nem állami fenntartású szociális, gyermekjóléti és gyermekvédelmi szolgáltatók normatív állami támogatásával kapcsolatos, e rendelet szerinti hatósági ügyekben első fokon a fenntartó székhelye szerint illetékes igazgatóság, magyarországi székhellyel nem rendelkező fenntartó esetén a Magyar Államkincstár Budapesti és Pest Megyei Igazgatósága jár el. Ha a fenntartó székhelye a tárgyévi normatíva megállapítását követően megváltozik, továbbra is a korábbi székhely szerint illetékes igazgatóság jár el a tárgyévi normatívával kapcsolatos ügyekben, és folyósítja a tárgyévi normatívát.

(3) A fenntartó a normatíva iránti kérelmet - ide értve a kérelem 5. § (1) bekezdés szerinti módosítását, a pótigényt és a lemondást -, valamint az elszámolást a szociál- és nyugdíjpolitikáért felelős miniszter által e célra rendszeresített

a) és a szociál- és nyugdíjpolitikáért felelös miniszter által vezetett minisztérium (a továbbiakban: minisztérium), valamint a Magyar Államkincstár honlapján közzétett adatlapon vagy

b) elektronikus formanyomtatványon

nyújthatja be. Az adatlap és az elektronikus formanyomtatvány adattartalmát a melléklet határozza meg. A tárgyévi normatívára vonatkozó adatlapokat és elektronikus formanyomtatványokat a tárgyévi központi költségvetésről szóló törvényjavaslat benyújtását követő tizenöt napon belül kell elérhetővé tenni. 
(4) Az igazgatóság a normatíva ügyében hozott jogerős határozat és a lefolytatott ellenőrzésről készített jegyzőkönyv másolatát elektronikus levélben megküldi az első fokú múködést engedélyező szervnek, valamint szociális szolgáltató, intézmény esetén a Nemzeti Rehabilitációs és Szociális Hivatalnak.

(5) Ha a fenntartó év közben új szolgáltatóra vagy szolgáltatásra kap jogerős müködési engedélyt, illetve valamely szolgáltatójának vagy szolgáltatásának múködési engedélyét év közben visszavonják, e szolgáltatók, illetve szolgáltatások után a normatíva időarányosan illeti meg, amennyiben az igénybevétel egyéb feltételeinek - ideértve a befogadást - megfelel.

(6)

(7) Az e rendelet szerinti eljárásokban a fenntartó számára hiánypótlásra nyitva álló határidő a felhívás közlését követő nyolc nap.

(8) Ha a fenntartó a normatíva iránti kérelmet - ide értve a kérelem 5. § (1) bekezdés szerinti módosítását, a pótigényt és a lemondást -, illetve az elszámolást hibásan nyújtja be, az igazgatóság a felhívás közlését követő nyolc napos határidővel nyilatkozattételre hívja fel.

(9) Ha jogszabály másként nem rendelkezik, az e rendelet szerinti, hivatalból indult eljárásokban a fenntartó és a szolgáltató köteles átadni, illetve megküldeni az érdemi döntéshez szükséges adatokat és iratokat az igazgatóságnak.

\section{Igénylés}

3. § (1) A fenntartó a normatíva iránti kérelmet - a (2) bekezdésben foglaltak kivételével - a 2. § (3) bekezdése szerinti adatlap, illetve elektronikus formanyomtatvány elérhetővé tételét követően, a tárgyévet megelőzó év november 30-áig nyújthatja be.

(2) A tárgyévet megelőző év november 15-ét megelözően jogerős müködési engedéllyel nem rendelkező fenntartó a normatíva iránti kérelmet a múködési engedély jogerőre emelkedését követő egy hónapon belül nyújthatja be.

(3)

(4) Normatíva iránti kérelem a tárgyév végéig az igénylési határidő elmulasztása esetén is benyújtható.

(5) A fenntartó

a) feladatnormatívát olyan szolgáltató, illetve szolgáltatás után igényelhet, amelyre a tárgyévben jogerős müködési engedéllyel rendelkezik és az Szt. 58/A. § (2)-(2a) bekezdése, illetve a Gyvt. 145. § (2)-(2a) bekezdése alapján új szociális, gyermekjóléti szolgáltató, intézmény, hálózat, új ellátotti létszám, illetve új férőhely esetén - külön jogszabályban meghatározott kivételekkel - befogadást nyert;

b) képzési támogatást olyan szolgáltató után igényelhet, amelyre

ba) a tárgyévben jogerös múködési engedéllyel rendelkezik, és

$b b)$ a tárgyévet megelőző év szeptember 1-jén - maga vagy fenntartóváltozás esetén a korábbi fenntartó jogerős müködési engedéllyel rendelkezett, amennyiben az igénybevétel egyéb feltételeinek megfelel.

(6) A tárgyévet megelőzó évben normatívában nem részesülő fenntartónak a normatíva iránti kérelemhez csatolnia kell

a) az egyéni vállalkozók nyilvántartásában szereplő adatait igazoló közokiratot, ha a nem állami fenntartó egyéni vállalkozó;

b) a fenntartó három hónapnál nem régebbi cégkivonatát, ha a nem állami fenntartó cég;

c) a fenntartó bírósági nyilvántartásba bejegyzett hatályos adatairól kiadott, három hónapnál nem régebbi kivonatot, ha a nem állami fenntartó társadalmi szervezet, alapítvány vagy közalapítvány;

d) egyházi fenntartó esetén

da) az egyházat nyilvántartásba vevő bírósági végzés hiteles másolatát a lelkiismereti és vallásszabadságról, valamint az egyházakról szóló 1990. évi IV. törvény 22. §-a szerint nyilvántartásba vett egyházak kivételével, és

$d b$ ) az egyház bírósági nyilvántartásba bejegyzett hatályos adatairól kiadott, három hónapnál nem régebbi kivonatot, valamint

dc) - ha a fenntartó az egyház bírósági nyilvántartásba nem vett szervezeti egysége, a $d a$ )-db) alpontban foglaltakon túl - a nyilvántartásba vett egyház, egyházi jogi személy képviselőjének a nyilatkozatát a fenntartó nevéről, székhelyéről és képviselőjének személyéről, valamint arról, hogy a fenntartó az általa képviselt egyház, egyházi jogi személy szervezeti egysége, és az egyház alapszabálya alapján jogi személyiséggel rendelkezik;

e) - ha a fenntartó gazdasági társaság - a fenntartó képviselőjének közjegyzői aláírás-hitelesítéssel ellátott címpéldányát vagy az ügyvéd által cégbejegyzési (változásbejegyzési) eljárásban való közremüködés során ellenjegyzett aláírás-mintáját;

f) az e) pontban nem említett fenntartó esetén a fenntartó írásbeli képviseletére jogosult személy, illetve az egyéni vállalkozó közjegyző által hitelesített aláírás-mintáját; 
g) a magyarországi vagy az Európai Gazdasági Térségről szóló megállapodásban részes más államban székhellyel rendelkező pénzforgalmi szolgáltató igazolását a fenntartó nevére szóló azon fizetési számla számáról, amelyre a fenntartó a normatíva folyósítását kéri.

(7) Ha a fenntartó a (6) bekezdés $a$ )-c) pontja vagy $d a$ )-db) alpontja szerinti iratokat nem csatolja, azokat az egyéni vállalkozók nyilvántartását vezető szervtől, illetve a bíróságtól az igazgatóság szerzi be.

(8) Az adatváltozást - a változást követő tizenöt napon belül - az adatváltozással érintett, (6) bekezdés szerinti iratokat mellékelve be kell jelenteni az igazgatóságnak. Ha a fenntartó az adatváltozás bejelentése során a (6) bekezdés $a$ )-c) pontja vagy $d b$ ) alpontja szerinti iratokat nem csatolja, azokat az igazgatóság a (7) bekezdésben foglaltak szerint szerzi be.

4. § (1) Az igazgatóság a normatíva iránti kérelemről

a) a tárgyévet megelőző évben benyújtott kérelem esetén tárgyév január 16-áig, belül,

b) tárgyévben benyújtott kérelem esetén a kérelem megérkezését követő naptól számított harminc napon

c) az igénylési határidő elmulasztása esetén a kérelem megérkezését követő naptól számított két hónapon belül

határoz.

(2) Az igazgatóság a normatívát - ha jogszabály másként nem rendelkezik vagy a kérelemben más nem szerepel - nem új fenntartó esetén tárgyév január 1-jétől, új fenntartó esetén a befogadás müködési engedélybe történő bejegyzése jogerőre emelkedésének időpontjától állapítja meg.

(3) A normatívát megállapító határozat tartalmazza

a) a fenntartó nevét, székhelyét és adószámát,

b) a szolgáltató nevét, székhelyét, telephelyét és ágazati azonosítóját,

c) a normatíva jogcímét,

d) a jogosultság alapját,

e) a fenntartónak megállapított normatíva teljes, valamint az egyes jogcímekre meghatározott összegét,

f) a folyósítás ütemét,

g) a normatíva elszámolásának határidejét és módját,

h) a normatíva felhasználásáról való elszámolás és ellenőrzés rendjéröl, a köztartozás esetén követendő eljárásról, valamint a visszafizetésről és a kamatfizetésről szóló tájékoztatást.

5. §(1) Ha az elfogadott központi költségvetésröl szóló törvény az igényelt normatíva jogosultsági feltételében eltér a benyújtott központi költségvetésről szóló törvényjavaslattól, vagy a fenntartó a normatíva iránti kérelem benyújtását követően új szolgáltatóra, illetve új szolgáltatásra kap jogerős működési engedélyt, vagy valamely szolgáltatójának müködési engedélyében más, a normatíva igénylését befolyásoló változás következik be, a fenntartó erre hivatkozva a normatíva iránti kérelmét tárgyév január 6-áig módosíthatja, ezt követöen a változást a (2)-(3) bekezdésben foglaltak szerint érvényesítheti.

(2) A fenntartó a támogatási igény évközi változását - ideértve azt az esetet is, ha év közben új szolgáltatót hoz létre vagy egyes szolgáltatóit megszünteti - pótigény vagy lemondás benyújtásával érvényesítheti. Pótigény vagy lemondás naptári negyedévenként egyszer nyújtható be. A pótigényről és a lemondásról az igazgatóság határoz.

(3) A működési engedély kiadása, visszavonása, fenntartóváltozás vagy az engedélyezett szolgáltatások, illetve férőhelyszám (az ellátható személyek engedélyezett száma, a kihelyezhető jelzőkészülékek engedélyezett száma, az önálló helyettes szülőnél elhelyezhető gyermekek száma) megváltozása esetén pótigény vagy lemondás - a múködési engedélyt kiadó, módosító vagy visszavonó határozat jogerőre emelkedésétől, a fellebbezésre való tekintet nélkül végrehajthatóvá nyilvánított határozat meghozatalától, illetve a hatósági szerződésben foglalt jogkövetkezmény jogerőssé válását megállapító végzés meghozatalától számított - tizenöt napon belül akkor is benyújtható, ha az adott naptári negyedévben a fenntartó már nyújtott be pótigényt vagy lemondást.

\section{Folyósítás}

6. §(1) Az igazgatóságok az összesített igényeket a minisztérium által meghatározott módon a tárgyhónapot megelőző hónap 23-áig, januárban 12-éig küldik meg a minisztériumnak. A minisztérium az igényelt normatívát minden hónap 5-éig, januárban 16-áig utalja át az igazgatóságoknak.

(2) A normatíva megállapítására illetékes igazgatóság a normatívát a fenntartónak havi ütemezésben, a tárgyhó 10-éig, januárban 20-áig, a kérelemben megjelölt, a fenntartó nevére szóló magyarországi vagy az Európai Gazdasági Térségről szóló megállapodásban részes más államban székhellyel rendelkező pénzforgalmi szolgáltatónál vezetett fizetési számlára folyósítja.

(3) Pótigény, illetve lemondás esetén a módosított összeg folyósítására a kérelem benyújtását követő hónaptól akkor kerülhet sor, ha a fenntartó a pótigényt, illetve a lemondást a megelőző hónap 10-éig benyújtja. A korábban folyósított és a módosított normatíva különbségének - a módosítás alapján történő folyósítás idejét megelőző hónapokra számított - összegét egy összegben kell folyósítani, illetve levonni. A fenntartó a lemondással egyidejüleg a fizetési kedvezményre vonatkozó szabályok megfelelő 
alkalmazásával kérheti a tartozás több részletben történő levonását azzal, hogy a levonásnak a tárgyévben meg kell történnie. Ha a levonásra a tárgyévben folyósítandó normatíva nem nyújt fedezetet, a fenntartó köteles a különbözetet a lemondás ügyében hozott határozat jogeröre emelkedését követő húsz napon belül visszafizetni. A visszafizetésről a lemondás ügyében hozott határozatban rendelkezni kell.

(4) Az elszámolás, illetve az ellenörzés során megállapított többlettámogatást a forrás - (1) bekezdésben meghatározottak szerint történő - biztosítását követő tíz napon belül kell átutalni a fenntartónak. Ha az elszámolás, illetve az ellenőrzés során megállapított többlettámogatás nem éri el az ezer forintot, azt nem kell folyósítani.

(5) A fenntartó a normatíva felhasználását, nem önállóan gazdálkodó szolgáltatók esetén a fenntartó és az egyes szolgáltatók gazdálkodását, továbbá a szolgáltató a normatíva és a térítési díj felhasználását a számviteli rendjében feladatonkénti bontásban elkülönítetten köteles kezelni. Az egyházi kiegészítő támogatást a számviteli rendben a többi normatívától elkülönítetten kell kezelni.

(6) Az igazgatóságok a fel nem használt vagy a fenntartók által visszafizetett normatívát, valamint a megfizetett kamatot és késedelmi pótlékot - a felfüggesztés alapján visszatartott normatíva kivételével december 31-éig utalják át a minisztériumnak.

\section{7. $\S$}

Elszámolás

8. § (1) A fenntartó az igénybe vett normatíváról a szolgáltató beszámolója és dokumentációja segítségével, a teljesített feladatmutatók alapján - a (2) bekezdésben foglalt kivétellel - a tárgyévet követő év január 31-éig számol el.

(2) A megszünt fenntartó a fenntartóváltozásról, illetve a müködési engedély visszavonásáról szóló határozat jogeröre emelkedését követő tizenöt napon belül számol el. Ha az egyéni vállalkozó fenntartó meghal, az elszámolást az örökös köteles - legkésőbb a hagyaték jogerős átadását követő tizenöt napon belül - benyújtani, az elszámolás és az ellenőrzés során az örökösre a fenntartóra vonatkozó rendelkezéseket kell megfelelően alkalmazni. Ha eljárás indul a fenntartó jogutód nélküli megszünése iránt, az elszámolást az eljárás megindítását követő öt napon belül be kell nyújtani. Ha az özvegy vagy az örökös az elhunyt egyéni vállalkozó fenntartó helyébe lépett, illetve az új fenntartó a korábbi fenntartó jogutódlással történő megszünése révén jött létre, évközi elszámolást nem kell benyújtani.

(3)

(4) Ha a fenntartó az elszámolást határidőben nem nyújtja be, vagy a hiánypótlási felhívásban foglaltaknak határidőben nem tesz eleget, illetve az elszámolás hibás benyújtása esetén határidőben nem tesz nyilatkozatot, és a hiánypótlás, illetve a nyilatkozat hiányában a rendelkezésre álló adatok alapján az elszámolásról nem lehet dönteni, az igazgatóság

a) a normatíva folyósítását - a kötelezettség teljesítéséig, illetve az elszámolási kötelezettséggel érintett időszakban igénybe vett normatívának a 11. § (2) bekezdése alapján történő visszafizetésére kötelező határozat jogerőre emelkedéséig - felfüggeszti, és

b) írásban felhívja a fenntartót, hogy kötelezettségének a felhívás közlését követő húsz napon belül tegyen eleget.

(5) A fenntartó a határidőben benyújtott elszámolásában többlettámogatási igényt olyan jogcím vagy szolgáltató (székhely, telephely) után is érvényesíthet, amely után normatívát a tárgyévben nem igényelt, feltéve, hogy a normatívára a tárgyévben jogosult volt.

(6) Az elszámolás elfogadásáról, a többlettámogatási igényről, a normatíva visszavonásáról, a visszafizetésről és a kamatfizetésről az igazgatóság a tárgyévet követő év március 31 -éig, megszünt fenntartó esetén az elszámolás megérkezését követő naptól számított harminc napon belül határoz.

(7) Az igazgatóság az elszámolásokat a minisztérium által meghatározott módon összesíti, és a tárgyévet követő év április 15-éig megküldi a minisztériumnak.

\section{Ellenörzés}

9. § (1) A normatíva igénylésének jogszerüségét és elszámolásának szabályszerűségét az igazgatóságok ellenőrzik. Az ellenőrzés kiterjed a normatívára való jogosultság jogszabályi feltételei teljesítésének, a normatívaigénylés alapját jelentő feladatmutatók - ideértve a képzési támogatás igénybevételének alapját jelentő létszámot is - teljesítésének, megalapozottságának, továbbá a normatívafelhasználás jogszerüségének, a vizsgálatára, valamint a közérdek védelme érdekében felmerült egyéb megállapításokra.

(2) Az adott évben ellenőrizendő fenntartókat és az ellenőrizendő időszakot az előző évi normatíva ügyében illetékes igazgatóság (a továbbiakban: ellenőrzést elrendelő igazgatóság) kockázatelemzéssel választja ki. Az ellenőrzést elrendelő igazgatóság soron kívüli ellenőrzés lefolytatását is elrendelheti.

(3) Minden fenntartót kétévente legalább egyszer ellenőrizni kell. A 8. § (2) bekezdése alapján benyújtott elszámolás esetén az ellenőrzést az elszámolás megérkezését követő naptól számított harminc napon belül kell lefolytatni.

(4) A fenntartó szolgáltatóinak székhelye, telephelye szerint illetékes igazgatóságok a kiválasztott fenntartó valamennyi szolgáltatójának székhelyén, telephelyén, valamint szükség szerint a fenntartó 
székhelye szerint illetékes igazgatóság a fenntartó székhelyén helyszíni ellenőrzést folytat le (a helyszíni ellenőrzést lefolytató igazgatóságok a továbbiakban együtt: ellenőrző igazgatóság).

(5) Ha a fenntartó vagy a szolgáltató az ellenőrzést akadályozza, az igazgatóság a normatíva folyósítását az arra okot adó körülmény fennállásáig felfüggeszti, vagy a rendelkezésre álló adatok alapján dönt.

(6) Az igazgatóság a lefolytatott ellenőrzés során tett megállapításokra figyelemmel, a közérdek védelmében a normatíva folyósítását felfüggesztheti, ha

a) a fenntartóval,

b) a szolgáltatóval, vagy

c) a fenntartó, illetve a szolgáltató tisztségviselöjével, vezető tisztségviselőjével, ügyintéző és képviseleti szervének tagjával vagy vezetőjével, kezelő szervével, kezelő szervezetének tagjával vagy vezetőjével, vezető állású munkavállalójával, a fenntartó tevékenységét egyéb módon meghatározó munkavállalójával szemben,

a fenntartó jogszabályszerü tevékenységével, valamint a szolgáltató müködésével összefüggő ügyben büntetőeljárás folyik.

(7) Az ellenőrző igazgatóság az ellenőrzésről készített jegyzőkönyvet az általa ellenőrzött - a fenntartóhoz tartozó - valamennyi szolgáltató ellenörzésének lezárását követő húsz napon belül megküldi a fenntartónak. A fenntartó a jegyzőkönyvben foglaltakra a kézhezvételtől számított húsz napon belül észrevételeket tehet. Ha az ellenőrző igazgatóság a fenntartó észrevételeivel egyetért, a jegyzőkönyvet tíz napon belül módosítja és megküldi a fenntartó részére. Az ellenőrző igazgatóság a végleges jegyzőkönyvet a fenntartó észrevételeivel és - el nem fogadott észrevételek esetén - az elutasítás indokaival együtt öt napon belül megküldi az ellenőrzést elrendelö igazgatóságnak.

(8) Az ellenőrizendő időszak az ellenőrzés során tapasztaltak alapján kiterjeszthető. Az ellenőrizendő időszakot az ellenőrző igazgatóság értesítése alapján az ellenőrzést elrendelő igazgatóság terjeszti ki, és erről értesíti az ellenőrző igazgatóságokat.

(9) A fenntartónak az ellenőrzés során többlettámogatás olyan jogcím után is megállapítható, amely után normatívát a tárgyévben nem igényelt, feltéve, hogy a normatívára a tárgyévben jogosult volt.

(10) Az ellenőrzés során megállapított többlettámogatásról, a visszafizetésről és a kamatfizetésről az ellenőrzést elrendelő igazgatóság határoz.

\section{Visszafizetés és kamatfizetés}

10. § (1) Ha a fenntartó a normatívát vagy annak egy részét jogtalanul vette igénybe, köteles azt visszafizetni.

(2) Jogtalan igénybevételnek minősül

a)

b) a falugondnoki, tanyagondnoki szolgáltatás után igénybe vehető normatíva arányos része, ha az igazolt munkaórák száma nem éri el a kétezret, illetve törtévi működés esetén annak időarányos részét,

c) ha a normatívára való jogosultság jogszabályi feltételei a $b$ ) pontban foglalt eseteken túl nem teljesülnek, vagy azok teljesülése a jogszabályban meghatározott módon nem igazolható.

(3) Ha az igényelt tárgyévi normatíva teljes összege legalább három százalékkal meghaladja a fenntartót a tárgyévben ténylegesen megillető normatíva összegét, a fenntartó a jogtalanul igénybe vett normatíva teljes összege után igénybevételi kamatot is köteles fizetni.

(4) Az igénybevételi kamatot az elszámolás során, illetve - ha a kamatfizetési kötelezettség az ellenőrzés során keletkezik - az ellenőrzés során kell felszámítani.

(5) Az igénybevételi kamat mértéke, ha a fenntartó az igényelt normatíváról tárgyév

a) április 30-áig lemond, a jegybanki alapkamat huszonöt százaléka,

b) július 31-éig lemond, a jegybanki alapkamat ötven százaléka,

c) október 15-éig lemond, a jegybanki alapkamat.

(6) Az igénybevételi kamat mértéke a jegybanki alapkamat kétszerese, ha

a) a fenntartó a normatíváról tárgyév október 15-ét követően mond le,

b) a visszafizetési kötelezettség az elszámolás során keletkezik,

c) a jogtalan igénybevételt az igazgatóság ellenőrzés során állapítja meg.

(7) Új fenntartó esetén az igénybevételi kamat mértéke az (5)-(6) bekezdésben meghatározott kamatmértéknek a tárgyévi finanszírozás időtartamának figyelembevételével számított időarányos része. Megszünt fenntartó esetén az igénybevételi kamat mértéke a jegybanki alapkamat kétszeresének a tárgyévi finanszírozás időtartamának figyelembevételével számított időarányos része, ha a visszafizetési kötelezettség az elszámolás során keletkezik, vagy a jogtalan igénybevételt az igazgatóság ellenőrzés során állapítja meg.

(8) Ha a jogtalanul igénybe vett normatíva összege nem haladja meg az ötszázezer forintot, az igénybevételi kamat mértéke az (5)-(7) bekezdésben meghatározott kamatmérték ötven százaléka.

11. § (1) Ha a fenntartó a normatíva teljes összegét vagy annak egy részét nem alapfeladatának ellátására vagy nem múködési, fenntartási kiadásaira fordította, illetve az egyházi kiegészítő 
támogatás vagy a képzési támogatás teljes összegét vagy annak egy részét nem a központi költségvetésről szóló törvényben meghatározottak szerint használta fel, köteles ennek az összegnek a jegybanki alapkamat kétszeresével növelt összegét visszafizetni.

(2) Ha a fenntartó a 8 . § (4) bekezdésének b) pontja szerinti felhívásban foglaltaknak határidőben nem tesz eleget, köteles a tárgyévi normatívának a jegybanki alapkamat kétszeresével növelt összegét visszafizetni.

12. § (1) A fenntartó az elszámolás, illetve az ellenőrzés során keletkezett visszafizetési kötelezettségének és a kamatfizetési kötelezettségének - ha az igazgatóság fizetési kedvezményt nem engedélyezett - az azt elöíró határozat jogerőre emelkedését követő húsz napon belül köteles eleget tenni.

(2) Ha a fenntartó a visszafizetési és kamatfizetési kötelezettségének határidőben nem tesz eleget, a visszafizetendő összeg után késedelmi pótlékot kell fizetnie, és tartozását a késedelmi pótlékkal együtt a fizetési határidő lejártát követően folyósítandó normatívából le kell vonni.

(3) Ha a visszafizetendő normatíva és a fizetendő kamat együttes összege nem éri el az ezer forintot, vagy a fenntartónak kizárólag ezer forintot el nem érő összegű késedelmipótlék-tartozása áll fenn, a tartozást nem kell nyilvántartani és megfizetni.

(4) Fizetési kedvezmény úgy engedélyezhető, hogy a visszafizetés és a kamatfizetés az engedélyezés évében megtörténjen. Fizetési kedvezmény engedélyezése esetén annak időtartamára a tartozás után késedelmi pótlékot nem kell fizetni. Amennyiben a fenntartó a fizetési kedvezményben engedélyezett feltételeknek nem tesz eleget, a fennmaradó tartozást - a visszafizetendő összeg után az eredeti esedékességtől felszámított késedelmi pótlékkal együtt - a folyósítandó normatívából le kell vonni.

(5) Fenntartóváltozás esetén a korábbi fenntartó által visszafizetendő normatíva megfizetésére a szolgáltatót átvevő fenntartó is kötelezhető, ha a korábbi fenntartót megillető, pénzforgalmi szolgáltatónál kezelt pénzösszegre vezetett végrehajtás részben vagy egészben eredménytelen volt. A szolgáltatót átvevő fenntartó fizetési kötelezettségének teljesítésére az (1)-(4) bekezdésben foglaltakat kell megfelelően alkalmazni.

\section{Az egyházi kiegészítő támogatás korrekciója}

13. § (1) A korrekcióra, illetve - ha a korrekció mértéke negatív - a korrekció megfizetésére a tárgyévben egyházi kiegészítő támogatásban részesült egyházi fenntartó jogosult, illetve köteles. Ha a szolgáltató fenntartását másik egyházi fenntartó vette át, a korrekcióra, illetve a korrekció megfizetésére a szolgáltatót átvevő egyházi fenntartó jogosult, illetve köteles. Amennyiben a szolgáltató müködési engedélyét visszavonták vagy a szolgáltató fenntartását nem egyházi fenntartó vette át, a korrekció nem utalható ki, de ha a korrekció mértéke negatív - a korábbi egyházi fenntartó köteles a korrekció megfizetésére.

(2) A korrekciónak az egyházi fenntartót megillető, illetve terhelö összegét az igazgatóság a tárgyévi feladatmutató alapján járó egyházi kiegészítő támogatás arányában hivatalból állapítja meg.

(3) Negatív mértékü korrekció esetén az egyházi fenntartó fizetési kötelezettségének teljesítésére a 12. § (1)-(4) bekezdésében foglaltakat kell megfelelően alkalmazni.

(4) A korrekcióról elszámolást nem kell benyújtani, a korrekció felhasználásának jogszerüségét az igazgatóság a 9 . § szerinti ellenőrzés során ellenőrzi.

\section{Az egyházi kiegészitő támogatás megtérítése}

14. § (1) A Gyvt. 145/A. § (2) bekezdés $a$ )-b) pontja, illetve - ha a korábbi fenntartó helyi önkormányzat vagy társulás volt - az Szt. 127/A. §-a (2) bekezdésének $a$ )-b) pontja szerinti feltételek fennállását a működést engedélyező szerv a működési engedélynek az egyházi fenntartó részére történő kiadása során hivatalból állapítja meg ${ }^{131}$.

131 145/A. § (1) Ha a helyi önkormányzat vagy a társulás a fenntartásában működő szolgáltatót, intézményt egyházi jogi személy fenntartásába adja át, az egyházi kiegészítő támogatást a helyi önkormányzat, illetve a társulás köteles a központi költségvetésnek öt éven keresztül folyamatosan, a nettó finanszírozás keretében megtéríteni.

(2) Ha a helyi önkormányzat vagy a társulás fenntartásában müködő szolgáltató, intézmény megszünésétől számított tizenkét hónapon belül egyházi jogi személy új szolgáltatót, intézményt hoz létre, a megszünt intézményben is végzett gyermekjóléti, gyermekvédelmi szolgáltató tevékenység után kifizetett egyházi kiegészítő támogatást a helyi önkormányzat, illetve a társulás köteles a központi költségvetésnek öt éven keresztül folyamatosan, a nettó finanszírozás keretében megtéríteni, feltéve, hogy

a) a megszünt és a létrehozott szolgáltatónál, intézményben ellátott gyermekeknek legalább ötven százaléka azonos, valamint

b) a megszünt és a létrehozott intézmény - részben vagy egészben - ugyanabban az ingatlanban müködik. 
(2) Ha az ellátottak azonossága a müködési engedélynek az egyházi fenntartó részére történő kiadása során nem állapítható meg, de legalább részben azonos ellátási területen hasonló szolgáltatásokat nyújtó, helyi önkormányzat vagy társulás által fenntartott - nappali szociális ellátás, bentlakásos szociális intézményi ellátás, valamint gyermekjóléti, gyermekvédelmi intézmény esetén részben vagy egészben ugyanabban az ingatlanban müködő - szolgáltató tizenkét hónapnál nem régebben szünt meg, a müködést engedélyezö szerv a működési engedély kiadását követő két hónapon belül ellenőrzést tart, és amennyiben az Szt. 127/A. §-a (2) bekezdésének $a$ )- $b$ ) pontja, illetve a Gyvt. 145/A. § (2) bekezdés $a$ )- $b$ ) pontja szerinti feltételek fennállnak, azt határozatban állapítja meg.

(3) A müködést engedélyező szerv az (1)-(2) bekezdés szerinti határozatot közli a korábbi állami és a szolgáltatót átvevő egyházi fenntartóval, a normatívájuk ügyében illetékes igazgatóságokkal, valamint a helyi önkormányzatokért felelős és a szociál- és nyugdíjpolitikáért felelős miniszterrel.

(4) A megtérítendő egyházi kiegészítő támogatás összegéről, és annak esetleges változásáról a szolgáltatót átvevő egyházi fenntartó normatívája ügyében illetékes igazgatóság dönt, amely az üggyel kapcsolatos döntését közli a korábbi állami fenntartóval, a müködést engedélyező szervvel, a korábbi állami fenntartó normatívája ügyében illetékes igazgatósággal, valamint a helyi önkormányzatokért felelős és a szociál- és nyugdíjpolitikáért felelős miniszterrel.

(5) A megtérített egyházi kiegészítő támogatást a minisztérium - egyházi kiegészítő támogatás folyósítására szolgáló - előirányzata javára kell átutalni.

(6)-(9)

14/A. § (1) Ha a korábbi fenntartó nem állami fenntartó volt, és az Szt. 127/A. §-ának (4) bekezdése szerinti feltételek fennállnak, a müködést engedélyezö szerv a fenntartóváltozás, illetve a szolgáltató működésének engedélyezésére irányuló eljárását felfüggeszti, a feltételek fennállását az eljárást felfüggesztő végzésben állapítja meg, és megkeresi a korábbi nem állami fenntartó normatívája ügyében eljárt igazgatóságot.

(2) A megtérítendő egyházi kiegészítő támogatás összegét a korábbi nem állami fenntartó normatívája ügyében eljárt igazgatóság állapítja meg. A korábbi nem állami fenntartó a megtérítendő egyházi kiegészítő támogatást - ha fizetési kedvezményt nem engedélyeztek - az azt megállapító határozat jogerőre emelkedését követő egy hónapon belül köteles megfizetni. Az igazgatóság a megtérítendő egyházi kiegészítő támogatás összegének megfizetéséről értesíti a müködést engedélyező szervet, amely az eljárását folytatja.

(3) Ha a korábbi nem állami fenntartó a megtérítendő egyházi kiegészítő támogatást határidőben nem fizeti meg, vagy a fizetési kedvezményben engedélyezett feltételeknek nem tesz eleget, az igazgatóság felhívja, hogy a fennmaradó tartozását fizesse meg. Ha a korábbi nem állami fenntartó megszünt, vagy a fennmaradó tartozását a felhívás közlését követő húsz napon belül nem fizeti meg, az igazgatóság értesíti a működést engedélyező szervet, amely a fenntartóváltozás, illetve a szolgáltató müködésének engedélyezésére irányuló kérelmet elutasítja.

(4) Az (1)-(3) bekezdés szerinti ügyekben

a) müködést engedélyező szerv a döntését közli a korábbi nem állami és a szolgáltatót átvevő egyházi fenntartóval, a normatívájuk ügyében illetékes igazgatóságokkal, valamint a szociál- és nyugdíjpolitikáért felelös miniszterrel,

b) az igazgatóság a döntését közli a korábbi nem állami és a szolgáltatót átvevő egyházi fenntartóval, a müködést engedélyező szervvel, valamint a szociál- és nyugdíjpolitikáért felelős miniszterrel.

(5) Az (1)-(3) bekezdés szerint megtérítendő egyházi kiegészítő támogatást a korábbi nem állami fenntartó normatívája ügyében eljárt igazgatóságnak kell megfizetni, amely az összeget a minisztérium egyházi kiegészítő támogatás folyósítására szolgáló - előirányzata javára utalja át.

\section{Záró rendelkezések}

15. $\$$ (1) Ez a rendelet 2009. október 1-jén lép hatályba.

(2) E rendelet szabályait - a (3)-(6) bekezdésben foglaltak kivételével - elöször a 2010. évi normatíva igénylésére, folyósítására és elszámolására, a 2009. évi normatíva ellenőrzésére, továbbá a 2008. évi egyházi kiegészítő támogatás korrekciójára kell alkalmazni. A 2010. évi normatívára vonatkozó adatlapokat és elektronikus formanyomtatványokat 2009. október 10-éig kell elérhetővé tenni. A 2009. évi normatíva igénylésére, folyósítására és elszámolására a személyes gondoskodást nyújtó szociális intézmény és a falugondnoki szolgálat működésének engedélyezéséről, továbbá a szociális vállalkozás engedélyezéséről

(3) A megtérítendő összeg megállapítása során nem vehető figyelembe a korábbi fenntartó működési engedélyében nem szereplö szolgáltató tevékenység - ide nem értve azt az esetet, ha az új szolgáltató tevékenységet a korábbi férőhelyek átminősítésével hozták létre - és féröhelyszám.

(4) Az egyházi kiegészítő támogatás megtérítéséről a kincstár külön kormányrendeletben meghatározott eljárás szerint határozatban dönt. 
szóló 188/1999. (XII. 16.) Korm. rendelet (a továbbiakban: Szmr.) 2009. szeptember 30-án hatályos szabályait kell alkalmazni.

(3) E rendelet 14. §-át a folyamatban lévő ügyekben is alkalmazni kell.

(4) Az egyházi és nem állami fenntartású szociális, gyermekjóléti és gyermekvédelmi szolgáltatók normatív állami támogatása ügyében a fellebbezés elbírálására jogosult hatóság a Magyar Államkincstár központi szerve, ha az első fokú döntést 2009. október 31-ét követően hozzák.

(5) A személyes gondoskodást nyújtó szociális ellátások térítési díjáról szóló 29/1993. (II. 17.) Korm. rendelet 1. számú melléklete szerinti gondozási napló vezetése a támogató szolgáltatást nyújtó szociális szolgáltatóktól, intézményektől a folyamatban lévő ellenőrzések során sem követelhető meg.

(6)-(10)

15/A. $\S$

16. § (1) A 2011. január 1-jét megelőzően müködtetett bázis-szállás után a Magyar Köztársaság 2010. évi költségvetéséröl szóló 2009. évi CXXX. törvény (a továbbiakban: Kvt.) alapján járó normatíva e rendelet 2010. december 31-én hatályos rendelkezései alapján 2010. december 31 -ét követően is igénybe vehető.

(2) A Kvt. alapján könyvvizsgálatra köteles fenntartó a Kvt. alapján igénybe vett normatíva elszámolásához köteles csatolni a független könyvvizsgálónak az elszámolás jogszerüségéről szóló nyilatkozatát.

17. § Az utcai szociális munka után 2011. évre járó normatíva elszámolására, valamint a 2009-2011. évre járó normatíva ellenőrzésére e rendelet 2011. december 31-én hatályos rendelkezéseit kell alkalmazni.

\section{Melléklet a 213/2009. (IX. 29.) Korm. rendelethez}

A normatíva iránti kérelem és az elszámolás benyújtására szolgáló adatlapok és elektronikus

$$
\text { formanyomtatványok adattartalma }
$$

1. A fenntartóval és a szolgáltatóval kapcsolatos adatok:

1.1. a fenntartó neve, székhelye, szervezeti formája, adószáma és elérhetősége;

1.2. a fenntartó képviselőjének és kapcsolattartójának neve, beosztása és elérhetősége;

1.3. a fenntartó és - ha a szolgáltató saját fizetési számlával rendelkezik - a szolgáltató magyarországi vagy az Európai Gazdasági Térségről szóló megállapodásban részes más államban székhellyel rendelkező pénzforgalmi szolgáltatónál vezetett fizetési számláinak száma és a pénzforgalmi szolgáltatók neve;

1.4. a szolgáltatók neve, székhelye, telephelye, ágazati azonosítója és - ha a fenntartóétól különböző adószámmal rendelkezik - adószáma;

1.5. a szolgáltatók vezetőinek neve és elérhetősége;

1.6. az első fokú müködést engedélyező szervek megnevezése.

2. A normatívával kapcsolatos adatok:

2.1. igénylés esetén a jogcímekre és az igényelt normatívákra vonatkozó adatok, a tervezett feladatmutatókra vonatkozó adatok, illetve képzési támogatás esetén a létszámadatok, továbbá a kérelem 5. § (1) bekezdés szerinti módosítása, pótigény és lemondás esetén a változások, valamint a jogosultság elbírálásához jogszabály alapján szükséges egyéb adatok;

2.2. elszámolás esetén a 2.1. pontban foglaltakon túl azokra a normatívaösszegekre vonatkozó adatok, amelyekre a fenntartó az elszámolás alapján jogosult, a visszafizetendö, illetve maradványösszeg, a teljesített feladatmutatókra, falugondnoki, tanyagondnoki szolgáltatás esetén az igazolt munkaórák számára vonatkozó adatok, illetve képzési támogatás esetén a létszámadatok, az elvégzett továbbképzésekkel és a letett szakvizsgákkal kapcsolatos adatok, valamint a képzési támogatás felhasználására vonatkozó adatok, továbbá az elszámolás elbírálásához jogszabály alapján szükséges egyéb adatok. 


\section{8/2011. (XII. 29.) Korm. rendelet a személyes gondoskodást nyújtó gyermekjóléti alapellátások és gyermekvédelmi szakellátások térítési díjáról és az igénylésükhöz felhasználható bizonyítékokról}

A Kormány a gyermekek védelméröl és a gyámügyi igazgatásról szóló 1997. évi XXXI. törvény 162. § (1) bekezdés c) pontjában, a 17. és 18 . § tekintetében a gyermekek védelméről és a gyámügyi igazgatásról szóló 1997. évi XXXI. törvény 162 . $§(1)$ bekezdés b) pontjában

kapott felhatalmazás alapján, az Alaptörvény 15. cikk (3) bekezdésében meghatározott feladatkörében eljárva a következőket rendeli el:

1. $\S$

\section{A rendelet hatálya}

(1) E rendeletet

a) a gyermekek védelméről és a gyámügyi igazgatásról szóló 1997. évi XXXI. törvény (a továbbiakban: Gyvt.) 5. § s) pont sa) alpontja szerinti állami fenntartó,

b) ha az ellátást normatív állami hozzájárulás, illetve külön jogszabályban meghatározott költségvetési támogatás igénybevételével biztosítja

ba) a Gyvt. 5. § s) pont sb) alpontja szerinti egyházi fenntartó,

bb) a Gyvt. 5 . § s) pont sc)-se) alpontja szerinti nem állami fenntartó

által fenntartott intézményben a gyermekjóléti alapellátás keretében biztosított gyermekek napközbeni ellátásáért, átmeneti gondozásáért, a gyermekvédelmi szakellátás keretében biztosított utógondozói ellátásért, valamint a Gyvt. 151. § szerinti gyermekétkeztetésért fizetendő téritési díjak megállapítására kell alkalmazni.

(2) E rendelet hatálya nem terjed ki

a) a gyermekek és az ifjúság védelméért felelös miniszter (a továbbiakban: miniszter) által vezetett minisztérium (a továbbiakban: minisztérium) fenntartásában müködő javítóintézetek által nyújtott utógondozói ellátásért fizetendő térítési díjra,

b) a gyermekétkeztetés kivételével az óvodai nevelés, az iskolai nevelés-oktatás, a kollégiumi nevelés keretében biztosított szolgáltatásokra.

2. $\S$

2. Általános szabályok

(1) A Gyvt. 147. §-ában foglaltak szerinti, szolgáltatási önköltség és normatív állami hozzájárulás különbözeteként számított intézményi térítési díjat akkor is dokumentálni kell, ha az ellátáshoz nyújtott saját hozzájárulás révén a fenntartó alacsonyabb intézményi térítési díjat határoz meg.

(2) A minisztérium fenntartásában müködő intézmény esetében az intézményi térítési díjat a miniszter állapítja meg.

(3) A megyei intézményfenntartó központ (a továbbiakban: megyei fenntartó) fenntartásában müködő intézmény esetében az intézményi térítési díjat a megyei fenntartó állapítja meg.

(4) Az egyházi vagy nem állami fenntartó fenntartásában múködő intézmény esetében az intézményi térítési díjat a fenntartó vezető testülete vagy a képviseletre jogosult személy állapítja meg.

(5) Az intézményi térítési díj szolgáltatónként, intézményenként, telephellyel rendelkező szolgáltató, intézmény esetén - ha ott ellátás nyújtására is sor kerül - székhelyenként, valamint telephelyenként külön-külön is meghatározható.

3. $\S$

(1) A települési, fövárosi kerületi és fővárosi önkormányzat, valamint ellátási szerződést kötött egyházi és nem állami fenntartó által fenntartott intézmény intézményi térítési díjának összegéről a jegyzö, a fövárosi kerületi jegyző és a föjegyző az intézmény ellátási területén élö lakosságot a helyben szokásos módon tájékoztatja.

(2) Ha az (1) bekezdés szerinti intézmény ellátási területe több települési (fövárosi kerületi) önkormányzat működési területére terjed ki, az intézmény fenntartója az intézményi téritési díjról értesíti a megyei, fövárosi önkormányzat föjegyzöjét, aki gondoskodik a lakosság, valamint az érintett önkormányzatok tájékoztatásáról.

(3) Ha az (1) bekezdés szerinti intézmény ellátási területe több megyére vagy az ország egész területére kiterjed, az intézmény fenntartója gondoskodik az intézményi térítési díj összegének a minisztérium hivatalos lapjában való közzétételéről. Intézményi társulás és többcélú kistérségi társulás által fenntartott intézmény, szolgáltató esetében a tájékoztatási kötelezettséget a társulás székhelye szerinti jegyző teljesíti.

(4) A minisztérium által fenntartott intézmények intézményi téritési díját a miniszter a minisztérium hivatalos lapjában közleményként közzéteszi.

(5) A megyei fenntartó által fenntartott intézmények intézményi térítési díát a minisztérium hivatalos lapjában közzé kell tenni, valamint arról értesíteni kell a megyei önkormányzat 
főjegyzőjét, aki gondoskodik a lakosság, valamint az ellátási terület szerint érintett önkormányzatok tájékoztatásáról.

(1) A Gyvt. 146. § (2) bekezdése szerinti kötelezett az ellátásért a Gyvt.-ben, az e rendeletben, valamint a helyi önkormányzat rendeletében foglaltak vagy a megyei fenntartó által meghatározottak szerint köteles a személyi térítési díjat megfizetni.

(2) A Gyvt. 148. § (10) bekezdése szerinti esetben a kötelezett az intézményi térítési díjjal azonos személyi térítési díj vagy a mindenkori intézményi térítési díj és a számára megállapítható személyi térítési díj különbözete egy részének megfizetését egy év időtartamra vállalhatja, amely időtartam meghosszabbítható.

(3) Ha a (2) bekezdés szerinti időtartam meghosszabbítására nem kerül sor, a személyi térítési díj megállapítására vonatkozó általános szabályokat kell alkalmazni.

5. $\S$

(1) Az intézményi térítési díjat és a személyi térítési díjat - a bölcsőde és a családi napközi alapellátáson túli szolgáltatásai kivételével -

a) házi gyermekfelügyelet esetében gondozási órára,

b) az a) pontban nem említett napközbeni ellátások esetében ellátási napra,

c) az átmeneti gondozás és az utógondozói ellátás esetében ellátási napra és hónapra vetítve kell megállapítani.

(2) A intézményi térítési díjat és a személyi térítési díjat az 1 és 2 forintos címletű érmék bevonása következtében szükséges kerekítés szabályairól szóló 2008. évi III. törvény 2. §-ának megfelelö módon kerekítve kell meghatározni.

6. $\S$

(1) Ha a személyi térítési díj az intézményi elhelyezést követő 30 napon belül nem állapítható meg, az intézményvezető térítésidíj-előleg fizetését kérheti.

(2) A személyi térítési díj megállapításakor intézkedni kell arról, hogy az (1) bekezdés szerinti előleg, illetve az előleg fizetésének időszakára jutó személyi térítési díj közötti különbözet kiegyenlítése megtörténjék.

7. $\S$

(1) Ha a fenntartó eltérően nem rendelkezik, a személyi térítési díjat

a) gyermekétkeztetésnél legfeljebb egy havi időtartamra elöre,

b) a gyermekek napközbeni ellátásának igénybevétele esetén legfeljebb egy havi időtartamra elöre,

c) az átmeneti gondozást nyújtó intézmény, valamint az utógondozói ellátás igénybevétele esetén havonta utólag

kell megfizetni.

(2) Ha a bölcsődei gondozás, a családi napközi, a családi gyermekfelügyelet, a gyermekek átmeneti gondozása vagy az utógondozói ellátás igénybevétele nem a hónap első napján kezdődik (tört havi ellátás), akkor az adott hónapra fizetendő személyi térítési díj a napi személyi térítési díj és az ellátási napok szorzata.

8. $\S$

(1) A Gyvt. 148. § (1) bekezdése szerinti intézményvezető az ellátást igénybe vevő személy térítésidíj-fizetési kötelezettségét - a gyermekétkeztetés és a Gyvt. 148. § (10) bekezdése szerinti eset kivételével - az 1. melléklet szerint dokumentálja.

(2) A bölcsőde, a családi napközi, a családi gyermekfelügyelet, a gyermekek átmeneti gondozása és az utógondozói ellátás esetében az ellátási napokon az ellátást igénybe vevők jelen- vagy távollétét az intézményvezető a 2. melléklet szerint dokumentálja. Az igénybe vevő azon az ellátási napon minősül távollévőnek, amelyen nem tartózkodik az intézményben, illetve nem veszi igénybe a szolgáltatást (ellátást).

\section{Gyermekek napközbeni ellátása}

\section{9. $§$}

(1) Bölcsőde esetében a gyermek Gyvt. 147. § (2) bekezdés szerinti gondozására számított intézményi térítési díj az élelmezés nyersanyagköltségével csökkentett szolgáltatási önköltség és a normatív állami hozzájárulás összegének különbözete. Az élelmezés nyersanyagköltségének meghatározásakor az általános forgalmi adóval növelt összeget kell figyelembe venni.

(2) Ha a bölcsődében a gondozásért külön nem kívánnak személyi térítési díjat megállapítani, az intézményi térítési díj összegét nullában kell meghatározni és írásban dokumentálni.

(3) A bölcsődei gondozás személyi térítési díját - a fenntartó eltérő döntése hiányában - akkor is teljes hónapra kell megállapítani, ha a gyermek az ellátást a hónap nem minden napján veszi igénybe. 
(4) A bölcsőde alapellátáson túli szolgáltatásaiért legfeljebb a szolgáltatás önköltségét meg nem haladó mértékü térítés kérhető.

10. $\S$

(1) A családi napközi és a családi gyermekfelügyelet intézményi térítési díja nem haladhatja meg az egy ellátottra jutó szolgáltatási önköltség és a tárgyévi normatív állami hozzájárulás különbségének az egy napra jutó összegét.

(2) A családi napközi és a családi gyermekfelügyelet személyi térítési díját a 9. § (3) bekezdés szerint kell megállapítani.

(3) A családi napközi alapellátáson túli szolgáltatásaiért a 9. § (4) bekezdésben foglalt mértékủ térítés kérhető.

(4) Ha a családi napközit a szolgáltatás igénybevételére vonatkozó megállapodásban foglaltak szerint a gyermek a csak a hét bizonyos napjain veszi igénybe, jelen- vagy távollétét a 2 . mellékletben kizárólag ezeken a napokon kell dokumentálni.

11. § Ha a fenntartó az alternatív napközbeni ellátás igénybevételét térítési díj fizetéséhez köti, az adott hónapra fizetendő személyi térítési díja napi személyi téritési díj és az ellátási napok szorzata.

12. $\S$

(1) A házi gyermekfelügyelet keretében biztosított személyes szolgáltatás intézményi térítési díja az ellátásra tervezett költségek alapján megállapított óradíj. Az óradíj nem haladhatja meg az adott évben a házi gyermekfelügyeletre tervezett éves kiadásoknak egy munkaórára és egy gondozóra jutó összegét. Az évi munkaórák száma a munkanapok és a napi teljes munkaidő szorzata.

(2) Az óradíj meghatározásánál csak a hivatásos és a díjazásban részesülő társadalmi gondozók száma vehető figyelembe.

(3) A házi gyermekfelügyelet keretében végzett tevékenységet a 3. melléklet szerinti gondozási naplóban kell dokumentálni.

(4) A gondozási naplóban ellátásra fordított időként kell feltüntetni a lakásban töltött időn kívül a gyermekkel egyéb helyen eltöltött, illetve a gyermek érdekében végzett tevékenységre fordított időt is.

13. $\S$

(1) Ha a gyermekétkeztetést betegség vagy más ok miatt a jogosult nem kívánja igénybe venni, a távolmaradást az intézmény vezetőjénél be kell jelenteni. Ha az intézmény házirendje vagy az étkeztetésre vonatkozó szabályzata kedvezőbben nem rendelkezik, a bejelentést követő naptól a kötelezett a távolmaradás idejére mentesül a gyermekétkeztetésért fizetendő térítési díj fizetésének kötelezettsége alól.

(2) A gyermekétkeztetés személyi térítési díjának elöre történő megfizetése esetén, ha az adott hónapra fizetendő térítési díj összege kevesebb, mint a már befizetett összeg, úgy a többletet a következő fizetés alkalmával be kell számítani, vagy vissza kell fizetni. Ha a fizetendő személyi téritési díj összege növekszik, a befizetett és a ténylegesen fizetendő összeg különbözetét visszamenőleg kell megfizetni.

(3) Helyettes szülőnél, nevelöszülőnél, gyermekek átmeneti otthonában vagy gyermekotthonban elhelyezett gyermek esetében a gyermekek napközbeni ellátása keretében biztosított gyermekétkeztetésért a személyi térítési díjat a helyettes szülö, a nevelőszülő, a gyermekek átmeneti otthona vagy a gyermekotthon fizeti meg.

(4) Családok átmeneti otthonában elhelyezett gyermek esetében a gyermekek napközbeni ellátása keretében biztosított gyermekétkeztetésért a személyi térítési díjat, ha a családok átmeneti otthona

a) teljes körü ellátást biztosít, a családok átmeneti otthona,

b) szükség szerinti ellátást biztosít, a szülő

fizeti meg.

(5) Az intézményvezető a gyermekétkeztetés igénybevételét a 4. melléklet szerint dokumentálja.

16. $\S$

\section{A térítési díj befizetése és ellenőrzése}

(1) A személyi térítési dijat az igénybevétel napjától havonként - ha a települési önkormányzat, a megyei fenntartó vagy a megállapodás másként nem rendelkezik -

a) bölcsőde, családi napközi, családi gyermekfelügyelet és gyermekétkeztetés esetén a tárgyhónap 10. napjáig,

b) házi gyermekfelügyelet, átmeneti gondozás és utógondozói ellátás esetén a tárgyhónapot követő hónap 10. napjáig

kell befizetni az ellátást nyújtó intézmény elszámolási számlájára.

(2) Az intézmény vezetöje ellenőrzi, hogy a megállapított térítési díj befizetése havonként megtörténik-e. Ha a kötelezett a befizetést elmulasztotta, az intézményvezetö 15 napos határidő 
megjelölésével a fizetésre kötelezett személyt írásban felhívja az elmaradt térítési díj befizetésére. Ha a határidő eredménytelenül telt el, az intézmény vezetője a kötelezett nevét, lakcímét és a fennálló díjhátralékot nyilvántartásba veszi.

(3) A (2) bekezdés szerint nyilvántartott díjhátralékról az intézmény vezetöje negyedévenként tájékoztatja a fenntartót a térítésidíj-hátralék behajtása vagy a behajthatatlan hátralék törlése érdekében.

7. Az ellátások igényléséhez és a térítési díjak megállapításához felhasználható bizonyítékok köre

17. § A személyi térítési díj megállapításához a kötelezett 30 napnál nem régebbi, az 5. melléklet szerinti jövedelemnyilatkozatot nyújt be az intézményvezetőnek.

18. $\S$

(1) Bölcsődei gondozás esetében a Gyvt. 150. § (6) bekezdés c) pontja szerinti téritésidij-fizetési mentesség és gyermekétkeztetés esetében a Gyvt. 151. § (5) bekezdés c) pontja szerinti normatív kedvezmény megállapításához be kell szerezni a térítési díj fizetésére kötelezett nyilatkozatát. A nyilatkozatnak tartalmaznia kell a Gyvt. 151. § (10) bekezdésben meghatározott gyermekek számát.

(2) Az (1) bekezdés szerinti gyermekek számában történt változást az intézmény vezetőjének a változást követő 15 napon belül írásban be kell jelenteni.

(3) Az eltartott gyermekek számának megváltozása esetén az új téritési díjat a (2) bekezdés szerinti bejelentést követő hónap első napjától kell megfizetni.

(4) Ha a bölcsődei gondozás esetében a Gyvt. 150. § (6) bekezdés a) és d) pontjában, valamint gyermekétkeztetés esetében a Gyvt. 151. § (5) bekezdés a) pontjában foglaltak fennállását hatósági döntés alapozza meg, azt be kell mutatni az intézménynek.

(5) Bölcsődei gondozásnál a Gyvt. 150. § (6) bekezdés b) pontjában, valamint gyermekétkeztetésnél a Gyvt. 151. § (5) bekezdés d) pontjában foglaltak fennállását tartós betegség esetén szakorvosi igazolással, fogyatékosság esetén a családok támogatásáról szóló 1998. évi LXXXIV. törvény végrehajtásáról szóló 223/1998. (XII. 30.) Korm. rendelet 7/A. § (1) bekezdése szerinti szakértői

\section{Záró rendelkezések} és rehabilitációs bizottság szakvéleményével kell igazolni.

19. § Hatályát veszti a személyes gondoskodást nyújtó gyermekjóléti alapellátások és gyermekvédelmi szakellátások térítési díjáról és az igénylésükhöz felhasználható bizonyítékokról szóló 133/1997. (VII. 29.) Korm. rendelet.

20. $§$ Ez a rendelet a kihirdetését követö tizenötödik napon lép hatályba.

Orbán Viktor s. k.,

miniszterelnök 


\section{1. melléklet a 328/2011. (XII. 29.) Korm. rendelethez A TÉRÍTÉSIDÍJ-FIZETÉS DOKUMENTÁLÁSA A ... ÉVBEN}

Az ellátásra jogosult neve: ...

Beutaló határozat száma, kelte: ... Az ellátás kezdete: ...

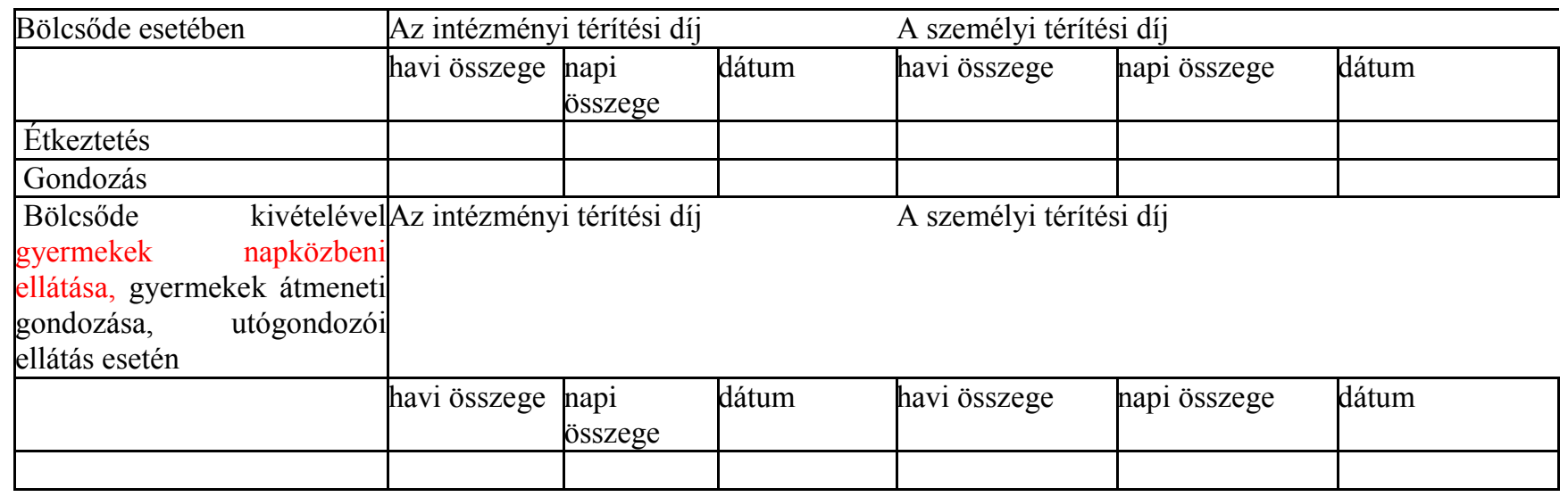

\begin{tabular}{|l|l|l|}
\hline A fizetésre kötelezett neve & Címe & Összeg \\
\hline & & \\
\hline & & \\
\hline
\end{tabular}

\begin{tabular}{|c|c|c|c|c|c|c|c|}
\hline \multirow[t]{2}{*}{ Hónap } & \multirow{2}{*}{$\begin{array}{l}\text { Havi } \\
\text { jövedelme }\end{array}$} & \multirow{2}{*}{$\begin{array}{l}\text { Havi } \\
\text { díj }\end{array}$} & \multicolumn{3}{|c|}{ térítési|A befizetés } & \multirow{2}{*}{$\begin{array}{l}\text { Túlfizetés } \\
\text { vagy hátralék }\end{array}$} & \multirow[t]{2}{*}{ Megjegyzés } \\
\hline & & & Kelte & naplószáma & összege & & \\
\hline \multicolumn{8}{|c|}{ Hátralék } \\
\hline \multicolumn{8}{|l|}{01.} \\
\hline \multicolumn{8}{|l|}{02.} \\
\hline \multicolumn{8}{|l|}{03.} \\
\hline \multicolumn{8}{|l|}{04.} \\
\hline \multicolumn{8}{|l|}{05.} \\
\hline \multicolumn{8}{|l|}{06.} \\
\hline \multicolumn{8}{|l|}{07.} \\
\hline \multicolumn{8}{|l|}{08.} \\
\hline \multicolumn{8}{|l|}{09.} \\
\hline \multicolumn{8}{|l|}{10.} \\
\hline \multicolumn{8}{|l|}{11.} \\
\hline \multicolumn{8}{|l|}{12.} \\
\hline Hátrale & & & & & & & \\
\hline
\end{tabular}

Ellenőrizte: 
2. melléklet a 328/2011. (XII. 29.) Korm. rendelethez AZ ELLÁTÁSI NAPOKON AZ ELLÁTÁST IGÉNYBE VEVÖK JELEN-VAGY TÁVOLLÉTÉNEK DOKUMENTÁLÁSA

Az intézmény neve, címe: ... Év, hónap: ... Ellenőrizte: . .

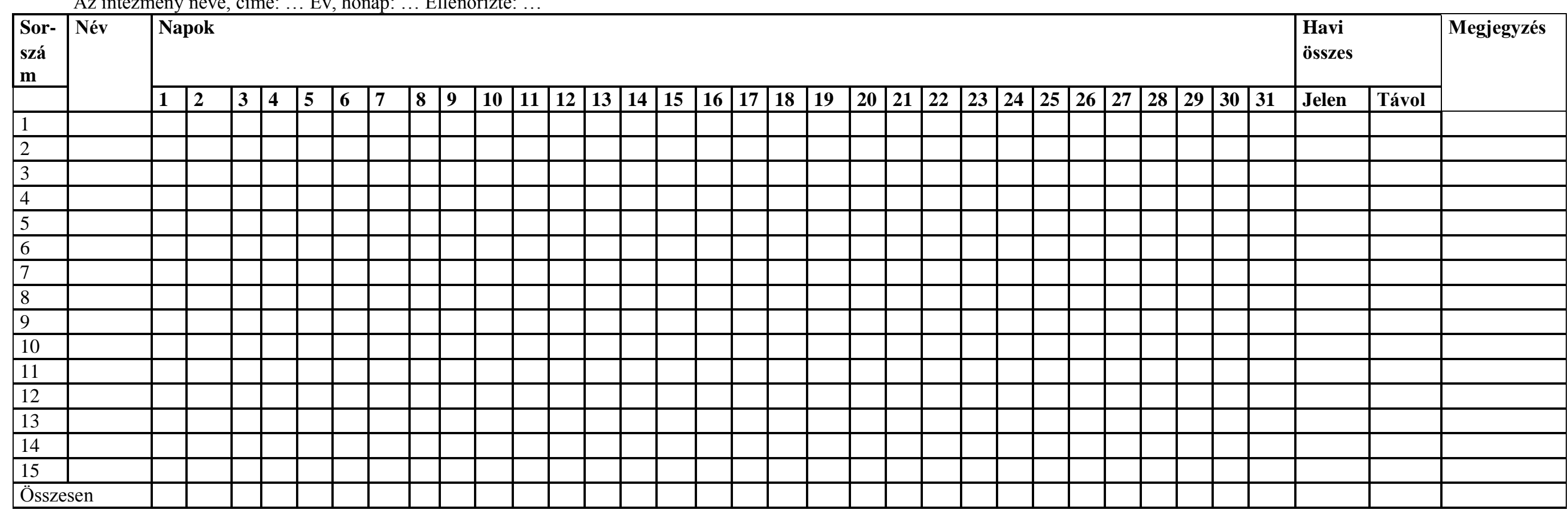


3. melléklet a 328/2011. (XII. 29.) Korm. rendelethez GONDOZÁSI NAPLÓ

\begin{tabular}{|c|c|c|c|c|c|}
\hline \multirow[t]{2}{*}{ Sorszám } & \multirow[t]{2}{*}{ Dátum } & \multirow[t]{2}{*}{ Az ellátott neve } & \multicolumn{3}{|c|}{ Az ellátás } \\
\hline & & & \begin{tabular}{|l} 
A \\
leírása \\
\end{tabular} & tevékenység Ráfordított idő & \begin{tabular}{|l|} 
A törvényes \\
képviselő aláírása \\
\end{tabular} \\
\hline & & & & & \\
\hline & & & & & \\
\hline
\end{tabular}

HAVI ZÁRÁS

Az ellátásra jogosultak száma a hónap folyamán

Az ellátással kapcsolatos látogatások száma

Az ellátásra fordított összes idő fél órára kerekítve

a gondozó aláírása

...

az ellátást nyújtó szervezet

vezetőjének aláírása

Dátum: 
4. melléklet a 328/2011. (XII. 29.) Korm. rendelethez A GYERMEKÉTKEZTETÉS IGÉNYBEVÉTELÉNEK DOKUMENTALÁSA

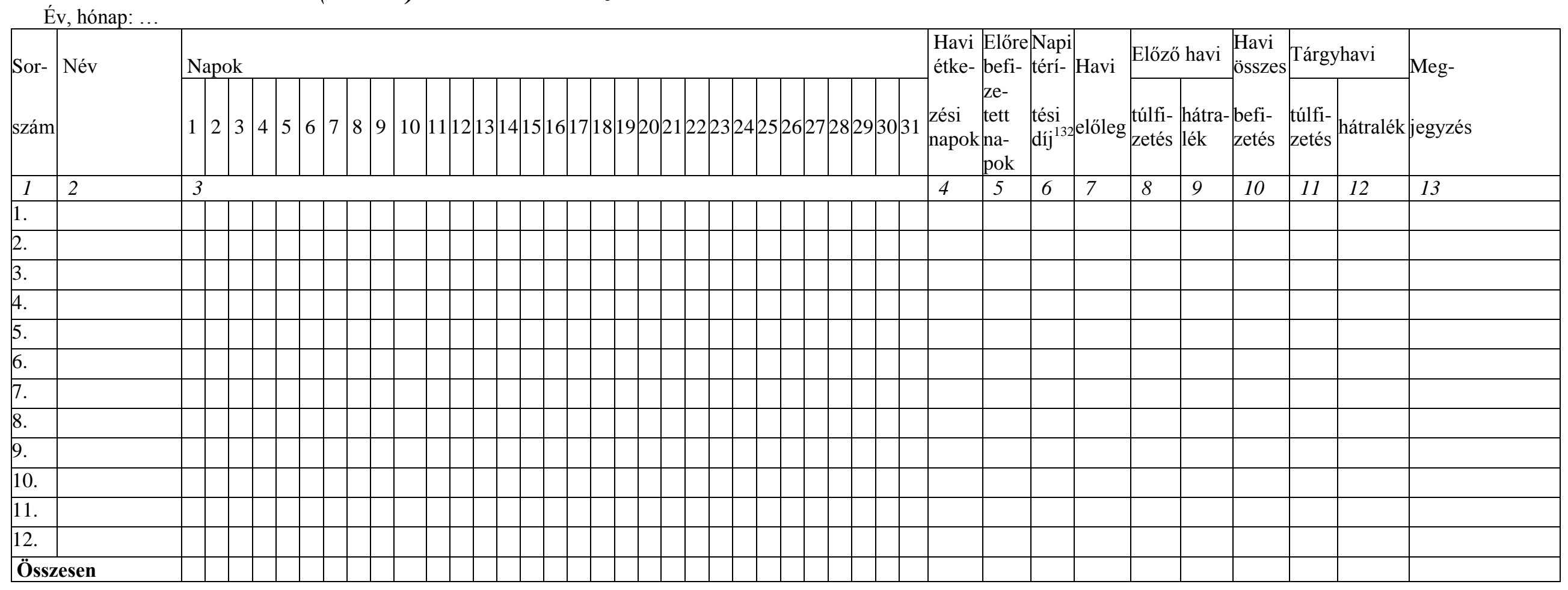

${ }^{132}$ A személyi térítési díj étkezésre befizetett összege 
5. melléklet a 328/2011. (XII. 29.) Korm. rendelethez JÖVEDELEMNYILATKOZATA

SZEMÉLYI TÉRÍTÉSI DÍJ MEGÁLLAPÍTÁSÁHOZ

\begin{tabular}{|l|}
\hline Az ellátást igénybe vevőre vonatkozó személyes adatok*: \\
\hline Név: ... \\
\hline Születési név: ... \\
\hline Születési hely, idö: ... \\
\hline Anyja neve: ... \\
\hline Apja neve: ... \\
\hline Lakóhelye: ... \\
\hline Tartózkodási helye: ... \\
\hline $\begin{array}{l}\text { Az 1997. évi XXXI. törvény 148. § (10) bekezdése szerint a mindenkori intézményi térítési díjjal azonos } \\
\text { személyi térítési díj megfizetését vagy a mindenkori intézményi térítési díj és a számára megállapítható } \\
\text { személyi térítési díj különbözete egy részének megfizetését a kötelezett vállalja-e (a rovat kitöltése nem } \\
\text { minősül tényleges vállalásnak): }\end{array}$ \\
\hline [] igen - ebben az esetben a jövedelemnyilatkozat további részét nem kell kitölteni, \\
\hline [] nem \\
\hline
\end{tabular}

Az elláást kérelmező fiatal felnőttre és családok átmeneti otthona esetén a szolgáltatást igénybe vevő szülöre, nagykorú testvérre vonatkozó jövedelmi adatok:

\begin{tabular}{|l|l|}
\hline A jövedelem típusa & Nettó összege \\
\hline $\begin{array}{l}\text { Munkaviszonyból és más foglalkoztatási jogviszonyból } \\
\text { származó }\end{array}$ & \\
\hline $\begin{array}{l}\text { Társas és egyéni vállalkozásból, östermelöi, szellemi és más } \\
\text { önálló tevékenységböl származó }\end{array}$ & \\
\hline Táppénz, gyermekgondozási támogatások & \\
\hline $\begin{array}{l}\text { Nyugellátás és egyéb nyugdíjszerú rendszeres szociális } \\
\text { ellátások }\end{array}$ & \\
\hline $\begin{array}{l}\text { Önkormányzat és munkaügyi szervek által folyósított } \\
\text { ellátások }\end{array}$ & \\
\hline Egyéb jövedelem (pl. ösztöndíj, bérbeadás) & \\
\hline Összes jövedelem & \\
\hline
\end{tabular}


Kiskorú igénybe vevő esetén a családban élőkre vonatkozó (nettó) jövedelmi adatok:

\begin{tabular}{|c|c|c|c|}
\hline A család létszáma: ... fó $* *$ & 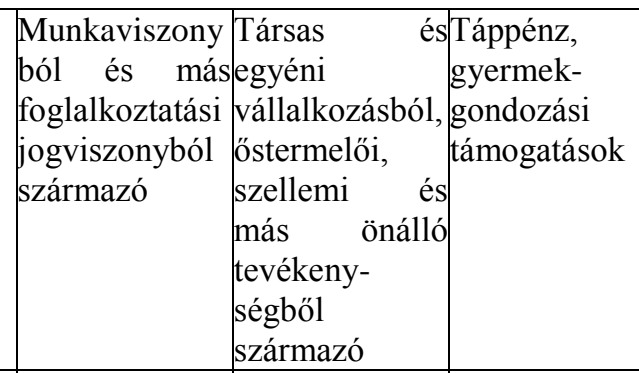 & \begin{tabular}{l|l} 
Önkormányzat & Nyugellátás és \\
és munkaügyi & egyéb \\
szervek által & nyugdíjszerü \\
folyósított & rendszeres \\
ellátások & szociális \\
& ellátások
\end{tabular} & $\begin{array}{l}\text { Egyéb } \\
\text { jövedelem }\end{array}$ \\
\hline \multicolumn{4}{|c|}{$\begin{array}{l}\begin{array}{l}\text { Az ellátást igénybe vevő } \\
\text { kiskorú }\end{array} \\
\end{array}$} \\
\hline \multicolumn{4}{|l|}{\begin{tabular}{|l|l|l|} 
A & közeli & Rokoni \\
hozzátartozók & kapcsolat \\
neve, születési & \\
ideje & & \\
\end{tabular}} \\
\hline \multicolumn{4}{|l|}{ 1) } \\
\hline \multicolumn{4}{|l|}{ 2) } \\
\hline \multicolumn{4}{|l|}{ 3) } \\
\hline \multicolumn{4}{|l|}{ 4) } \\
\hline \multicolumn{4}{|l|}{ 5) } \\
\hline \multirow{2}{*}{\multicolumn{4}{|c|}{\begin{tabular}{|l|l|l|l|l|} 
ÖSSZESEN: & & & & \\
(szïkség esetén a táblázat sorai bővíthetők)
\end{tabular}}} \\
\hline & & & \\
\hline \multicolumn{4}{|c|}{$\begin{array}{l}\text { (szükség esetén a táblázat sorai bővíthetök) } \\
\text { * Családok átmeneti otthona esetén, ha a szolgáltatást a gyermek a szülöjével (szüleivel), nagykorú testvérével együtt veszi } \\
\text { igénybe, a szülö, nagykorú testvér személyi adatai - a sorok számának értelemszerü növelésével - ugyanazon az adatlapon } \\
\text { felvehetők. } \\
\text { ** A családba fogadott vagy harmadik személynél elhelyezett gyámság alatt álló gyermek tekintetében a reá nézve igényelt } \\
\text { ellátás személyi térítési díjának megállapításánál csak a gyermek megélhetését szolgáló juttatásokat (pl. gyermektartásdíj, } \\
\text { árvaellátás, családi pótlék) kell a jövedelemszámítás szempontjából figyelembe venni [Csjt. 104. § (1) bek.], kivéve ha a } \\
\text { bíróság a gyámot kötelezte a gyermek eltartására. }\end{array}$} \\
\hline
\end{tabular}

Büntetőjogi felelősségem tudatában kijelentem, hogy a közölt adatok a valóságnak megfelelnek. A térítési díj megállapításához szükséges jövedelmet igazoló bizonylatokat egyidejüleg csatoltam. Hozzájárulok a kérelemben szereplő adatoknak az eljárás során történő felhasználásához.

Dátum: ...

...

az ellátást igénybe vevő

(törvényes képviselö) aláírása 


\section{Tájékoztató a jövedelemnyilatkozat kitöltéséhez}

\section{Személyi adatok}

A jövedelemvizsgálat vonatkozásában közös háztartásban élő közeli hozzátartozóként a szülöt, a szülö házastársát vagy élettársat, a húszévesnél fiatalabb, önálló keresettel nem rendelkezö, a huszonhárom évesnél fiatalabb, önálló keresettel nem rendelkező, a nappali oktatás munkarendje szerint tanulmányokat folytató, a huszonöt évesnél fiatalabb, önálló keresettel nem rendelkező, felsőoktatási intézmény nappali tagozatán tanulmányokat folytató gyermeket, valamint korhatárra tekintet nélkül a tartós beteg, illetőleg a fogyatékos gyermeket kell figyelembe venni.

II. Jövedelmi adatok

Jövedelem: a személyi jövedelemadóról szóló törvény szerint meghatározott, belföldröl vagy külföldröl származó - megszerzett - vagyoni érték (bevétel), ideértve a jövedelemként figyelembe nem vett bevételt és az adómentes jövedelmet is, továbbá az a bevétel, amely után az egyszerüsített vállalkozói adóról, illetve az egyszerüsített közteherviselési hozzájárulásról szóló törvény szerint adót, illetve hozzájárulást kell fizetni.

A jövedelmi adatok alatt havi nettó jövedelmet kell érteni. Elismert költségnek minősül a személyi jövedelemadóról szóló törvényben elismert költség, valamint a fizetett tartásdíj.

Befizetési kötelezettségnek minősül a személyi jövedelemadó, az egyszerüsített vállalkozási adó, a magánszemélyt terhelő egyszerüsített közteherviselési hozzájárulás, egészségbiztosítási hozzájárulás és járulék, egészségügyi szolgáltatási járulék, nyugdíjjárulék, nyugdíjbiztosítási járulék, magánnyugdíjpénztári tagdíj és munkavállalói járulék.

Ha a magánszemély az egyszerüsített vállalkozói adó vagy egyszerüsített közteherviselési hozzájárulás alapjául szolgáló bevételt szerez, a bevétel csökkenthető a személyi jövedelemadóról szóló törvény szerint elismert költségnek minősülő igazolt kiadásokkal, ennek hiányában a bevétel $40 \%$-ával. Ha a mezőgazdasági őstermelő adóévi őstermelésből származó bevétele nem több a kistermelés értékhatáránál (illetve ha részére támogatást folyósítottak, annak a folyósított támogatással növelt összegénél), akkor a bevétel csökkenthető az igazolt költségekkel, továbbá a bevétel 40\%-ának megfelelő összeggel, vagy a bevétel 85\%-ának, illetőleg állattenyésztés esetén 94\%-ának megfelelő összeggel.

A nettó jövedelem kiszámításánál a bevételt az elismert költségekkel és a befizetési kötelezettséggel csökkentett összegben kell feltüntetni.

Nem minősül jövedelemnek, így a jövedelembe sem kell beszámítani a temetési segélyt, az alkalmanként adott átmeneti segélyt, a lakásfenntartási támogatást, az adósságcsökkentési támogatást, a rendkívüli gyermekvédelmi támogatást, a rendszeres gyermekvédelmi kedvezmény keretében nyújtott pénzbeli támogatást, a kiegészítő gyermekvédelmi támogatás melletti pótlékot, a nevelőszülök számára fizetett nevelési díjat és külön ellátmányt, az anyasági támogatást, a szépkorúak jubileumi juttatását, a személyes gondoskodásért fizetendő személyi térítési díj megállapítása kivételével a súlyos mozgáskorlátozott személyek pénzbeli közlekedési kedvezményeit, a vakok személyi járadékát és a fogyatékossági támogatást, a fogadó szervezet által az önkéntesnek külön törvény alapján biztosított juttatást, a házi segítségnyújtás keretében társadalmi gondozásért kapott tiszteletdíjat, az energiafelhasználáshoz nyújtott támogatást.

Nem minősül jövedelemnek az alkalmi munkavállalói könyvvel történő foglalkoztatás, az egyszerüsített foglalkoztatásról szóló törvény alapján történő munkavégzés révén szerzett bevétel, továbbá a természetes személyek között az adórendszeren kívüli keresettel járó foglalkoztatásra vonatkozó rendelkezések alapján háztartási munkára létesített munkavégzésre irányuló jogviszony keretében történő munkavégzésnek (háztartási munka) a havi ellenértéke.

A családtagok jövedelmét kizárólag kiskorú igénybe vevő esetén kell feltüntetni, külön-külön. A családi pótlékot, az árvaellátást és a tartásdíj címén kapott összeget annak a személynek a jövedelmeként kell figyelembe venni, akire tekintettel azt folyósítják.

A jövedelemszámításnál irányadó időszakot a gyermekek védelméröl és a gyámügyi igazgatásról szóló 1997. évi XXXI. törvény 131. § (1)-(2) bekezdése alapján kell meghatározni.

- rendszeres jövedelem esetén a kérelem benyújtását megelőző hónap,

- nem rendszeres jövedelem, illetve vállalkozásból, östermelésből származó jövedelem esetén a kérelem benyújtását megelöző tizenkét hónap alatt kapott összeg egy havi átlagát kell együttesen figyelembe venni.

\section{Jövedelem típusai}

1. Munkaviszonyból és más foglalkoztatási viszonyból származó jövedelem: különösen a munkaviszonyban, közalkalmazotti, köztisztviselői jogviszonyban, kormánytisztviselői jogviszonyban, bírósági, ügyészségi, igazságügyi szolgálati jogviszonyban, honvédség, rendvédelmi szervek, polgári nemzetbiztonsági szolgálatok hivatásos és szerződéses szolgálati jogviszonyában folytatott 
munkavégzésre irányuló tevékenységböl, továbbá szövetkezet tagjaként folytatott - személyes közremüködést igénylő - tevékenységből származó jövedelem.

2. Társas és egyéni vállalkozásból, őstermelői, illetve szellemi és más önálló tevékenységből származó jövedelem: itt kell feltüntetni továbbá a jogdíjat, a bérbeadó, a választott könyvvizsgáló tevékenységéből származó jövedelmet, valamint a gazdasági társaság magánszemély tagja által külön szerződés szerint teljesített mellékszolgáltatást.

3. Táppénz, gyermekgondozási támogatások: táppénz, terhességi-gyermekágyi segély, gyermekgondozási díj, gyermekgondozási segély, gyermeknevelési támogatás, családi pótlék, gyermektartásdíj.

4. Önkormányzat és munkaügyi szervek által folyósított ellátások: különösen az időskorúak járadéka, a rendszeres szociális segély, az ápolási díj, az adósságcsökkentési támogatás; munkanélküli járadék, álláskeresési járadék, álláskeresési segély, képzési támogatásként folyósított keresetpótló juttatás.

5. Nyugellátás és egyéb nyugdíjszerü rendszeres szociális ellátások: öregségi, rokkantsági, baleseti rokkantsági nyugdíj, özvegyi és szülői nyugdíj, árvaellátás és baleseti hozzátartozói nyugellátások; rendszeres szociális járadék, átmeneti járadék, bányász dolgozók egészségkárosodási járadéka, rokkantsági járadék, rehabilitációs járadék, politikai rehabilitációs ellátások, házastársi pótlék, házastárs után járó jövedelempótlék.

6. Egyéb jövedelem: például az ösztöndíj, szakképzéssel összefüggő pénzbeli juttatások, nevelőszülői díj, szociális gondozói díj, végkielégítés és állampapírból származó jövedelem, ingatlan és ingó tárgyak értékesítéséből, vagyoni értékü jog átruházásából származó jövedelem, életjáradékból, föld és más ingatlan bérbeadásából származó jövedelem, illetve minden olyan jövedelem, amely az előző sorokban nem került feltüntetésre.

Szükség esetén a nyilatkozatok rovatai bővíthetők, valamint kitöltésük mellékletben folytatható. A cselekvőképességet kizáró gondnokság alatt állók esetében a gondnok aláíása, a cselekvőképességet korlátozó gondnokság alatt állók esetében a gondnok és a gondnokolt együttes aláirása szükséges. 


\section{2. függelék - Céges Csana Kerekasztal összefoglaló}

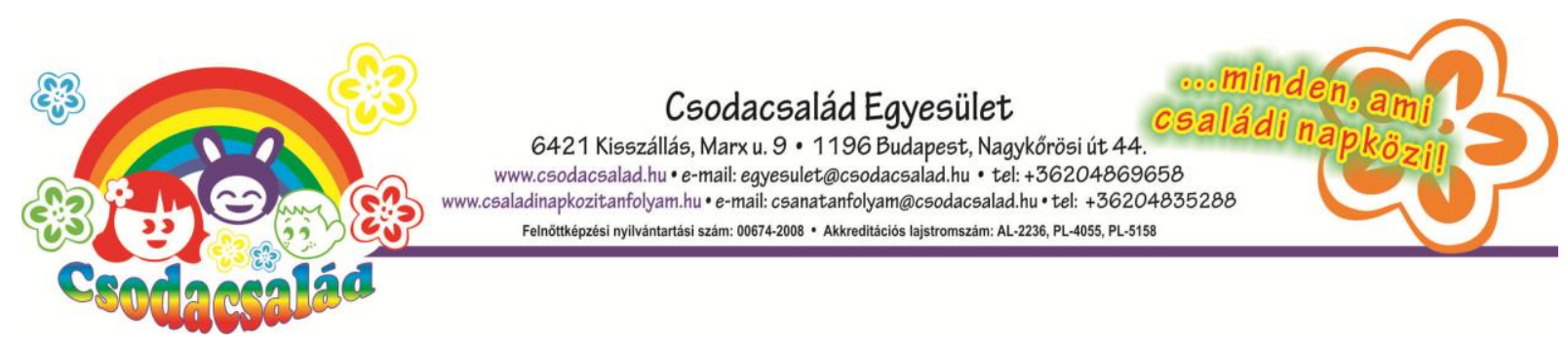

Budapest, 2013. március 3.

\section{ÖSSZEFOGLALÓ}

\section{Céges csana kerekasztal - közös gondolkodás}

2013.02.25

\section{Kedves Résztvevő Kollégák, Kolléganők!}

Ezúton is köszönjük az aktív részvételt, mellyel hozzájárultatok a céges családi napközik ügyének előrelépéséhez.

A rendezvényt a Csodacsalád Egyesület és a Céges Csana Kft közösen szervezte, a Céges Csana Kft fenntartásában müködő Goli Csana és Rendezvényházban. A rendezvény moderátora Beck György volt (Beckground Kft).

A rendezvényről részletes beszámolót (videó, fotók, újságcikkek, riportok, TV Híradó, Kossuth Rádió, stb) olvashattok - hallgathattok - nézhettek a weboldalunkon.

A „fordított kávészünetben” és az azt követő pezsgő megbeszélésen az alábbi eredményekre jutottunk ${ }^{133}$ :

4. Van valós igény a munkáltatók részéről egy béren kívül adható munkavállalói támogatásra, mellyel a munkavállaló gyermekének a megnyugtató, munkáltató és munkavállaló igényeihez egyaránt alkalmazkodó, rugalmas, magas színvonalú ellátása biztosítható. Ezt egy olyan béren kívüli juttatásként tartják a munkáltatók megvalósíthatónak, mely kívül esik a jelenlegi cafeteria rendszeren („,bébi cafeteria”). A kivitelezéshez információra van szükség (létrehozás, müködtetés költségei, megvalósítás részletei). A fenntartói feladatok elől a munkáltatók elzárkóznak, külső müködtetők

\footnotetext{
${ }^{133}$ Az elkészült táblákat csatoljuk
} 
bevonása célszerü. A gyermekek napközbeni ellátását azonban a munkáltatók határozottan állami feladatnak látják, melynek teljes költségét és felelősségét átvállalni nem kívánják, azonban hozzájárulnak, amennyiben az állam részéröl ehhez ösztönzést kapnak.

5. Van valódi szándék az államigazgatás részéről a családok ez irányú támogatására. A résztvevők üdvözlik a munkáltatók családbarát törekvéseit. A cafeteria rendszerbe való beemeléshez konkrét javaslatokat várnak.

6. Van létező kapacitás a családi napközi müködtetők között a rendszer kiépítésére, múködtetésére. Ehhez állami és munkáltató forrásokat várnak. A TÁMOP 2.4.5 pályázat hatalmas túlpályázása mutatja a valós igényeket. Sajnos a pályázati rendszer nem képes kezelni a probléma akutságát: közel egy ilyen pályázat elbírálása. Mivel a probléma most áll fenn, így azonnali megoldást kérnek a szereplők.

A fenti eredményekre hivatkozva az alábbi javaslatokat tesszük:

1. A további munkavégzéshez szükséges további kommunikáció. Ehhez - kérésetekre csatoljuk a résztvevők listáját, email-elérhetőségét. Javasoljuk egy Facebook zárt csoport és/vagy egy gmail levelező csoport létrehozását a gyors és hatékony kommunikáció érdekében.

2. Elkészítettünk egy „,bébi-cafeteria” javaslatot, mellyel kapcsolatban folyik az egyeztetés a Nemzetgazdasági Minisztériummal. Szerintetek milyen szabályozási környezet kellene ahhoz, hogy ez a munkáltatók számára szívesen fogadott legyen? Szövegszerü javaslatokat kérünk, köszönjük.

Kérjük, legkésőbb március 8-ig jelezzetek vissza a kommunikációs csatornát illetően (Facebook csoport és/vagy gmail levelező csoport), a bébi-cafeteria javaslattal kapcsolatos szövegszerü javaslataitokat is ugyaneddig köszönettel fogadjuk!

Köszönjük szépen!

Várva a visszajelzéseteket és a további közös munkát, minden jót kívánunk, üdvözlettel és barátsággal, 


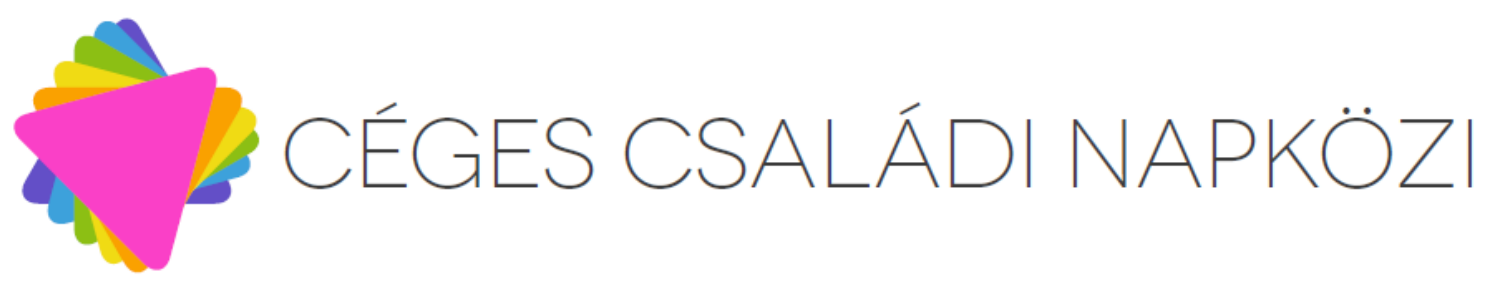

\section{Résztvevők listája, elérhetősége ${ }^{134}$}

\begin{tabular}{|l|l|l|l|}
\hline 1 & Beck György & Beckground Kft & \\
\hline 2 & dr. Farkas Zsuzsanna & Tudatos Életért Egyesület & \\
\hline 3 & Dr. Kiss Ágnes & Szász és Kiss Ügyvédi Iroda & \\
\hline 4 & Dr. Nagy Ágnes & Csodacsalád Egyesület & \\
\hline 5 & Dr. Prohászka-Rád Imre & Csodacsalád Egyesület & \\
\hline 6 & Dr. Szász Csilla & Szász és Kiss Ügyvédi Iroda & \\
\hline 7 & Györi Zsófia & Raiffeisen Bank & \\
\hline 8 & Hadházy Tímea & MOL & \\
\hline 9 & Karácsony Ildikó & csana vezető & \\
\hline 10 & Kiss Katalin & Magyar Telekom & \\
\hline 11 & Kovács Márta & British Telecom & \\
\hline 12 & Kurucz Erzsébet & Három Királyfi, Három & \\
& & Királylány Mozgalom & \\
\hline 13 & Losonczi Ildikó & csana vezetót & \\
\hline 14 & Máthé Judit & SZTMK & \\
\hline 15 & Némethné Tolvaj Diána & babamama.info & \\
\hline 16 & Ónody Csilla & Révész Máriusz képviseletében & \\
\hline 17 & Perlaki Anikó & babamama.info & \\
\hline 18 & Szalai Éva & Csodacsalád Egyesület & \\
\hline 19 & Szalai Piroska & NGM & \\
\hline 20 & Tóth Szilvia & csana vezetö & \\
\hline 21 & Trubjanszky Csilla & Céges Csana Kft & \\
\hline 22 & Vígh József & Három Királyfi, Három & \\
& & Királylány Mozgalom & \\
\hline
\end{tabular}

A program az Emberi Erőforrások Minisztériuma támogatásával és a Nemzeti Család-és Szociálpolitikai Intézet közremüködésével valósult meg.

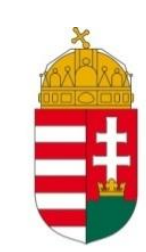

EMBERI ERŐFORRÁSOK MINISZTÉRIUMA

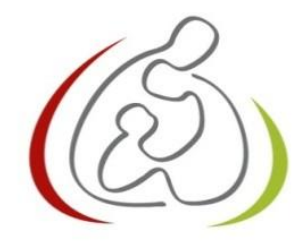

NEMZETI CSALÁD- ÉS SZOCIÁLPOLITIKAI INTÉZET

${ }^{134}$ az elérhetőségeket a dolgozat publicitása miatt töröltem 



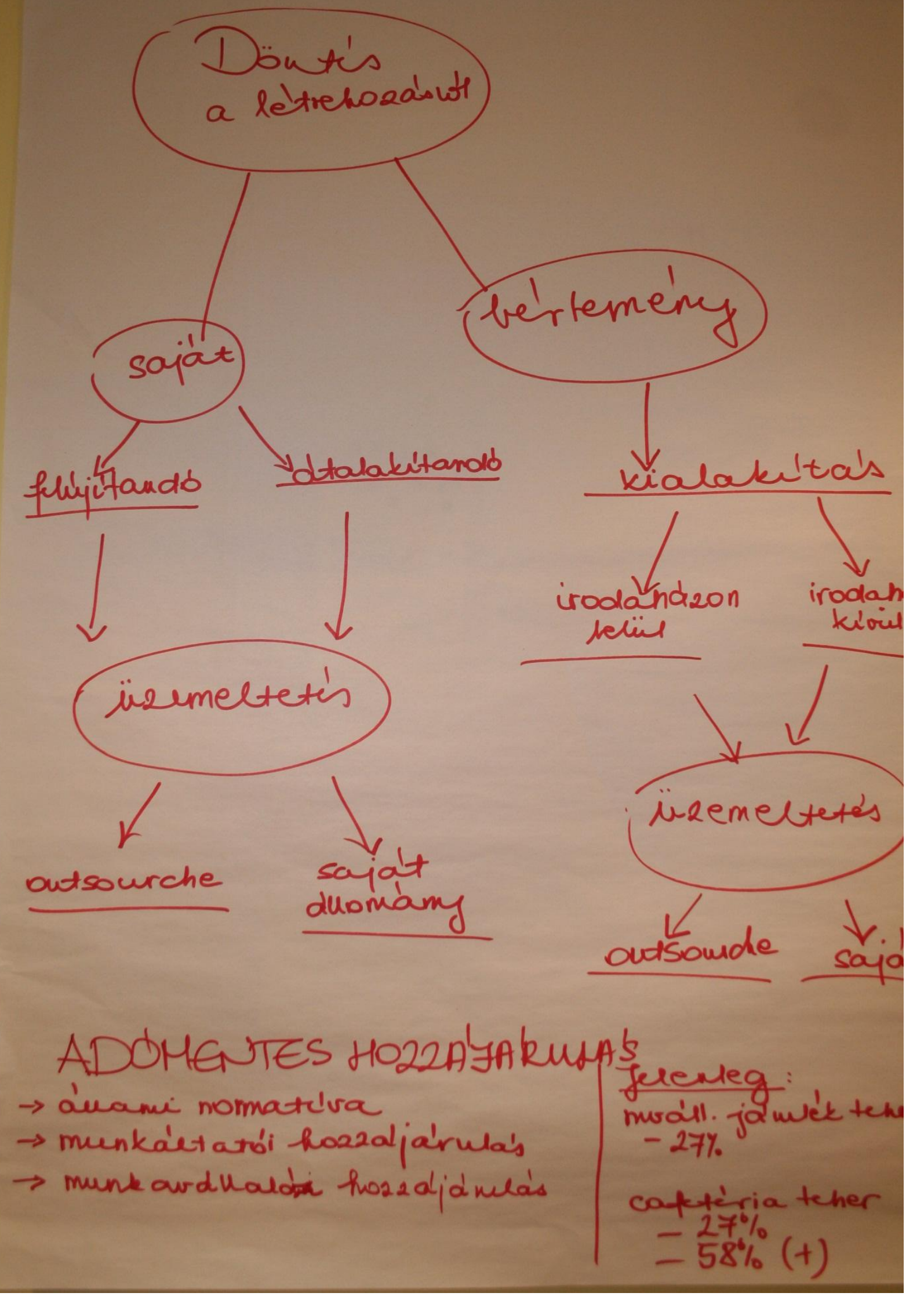




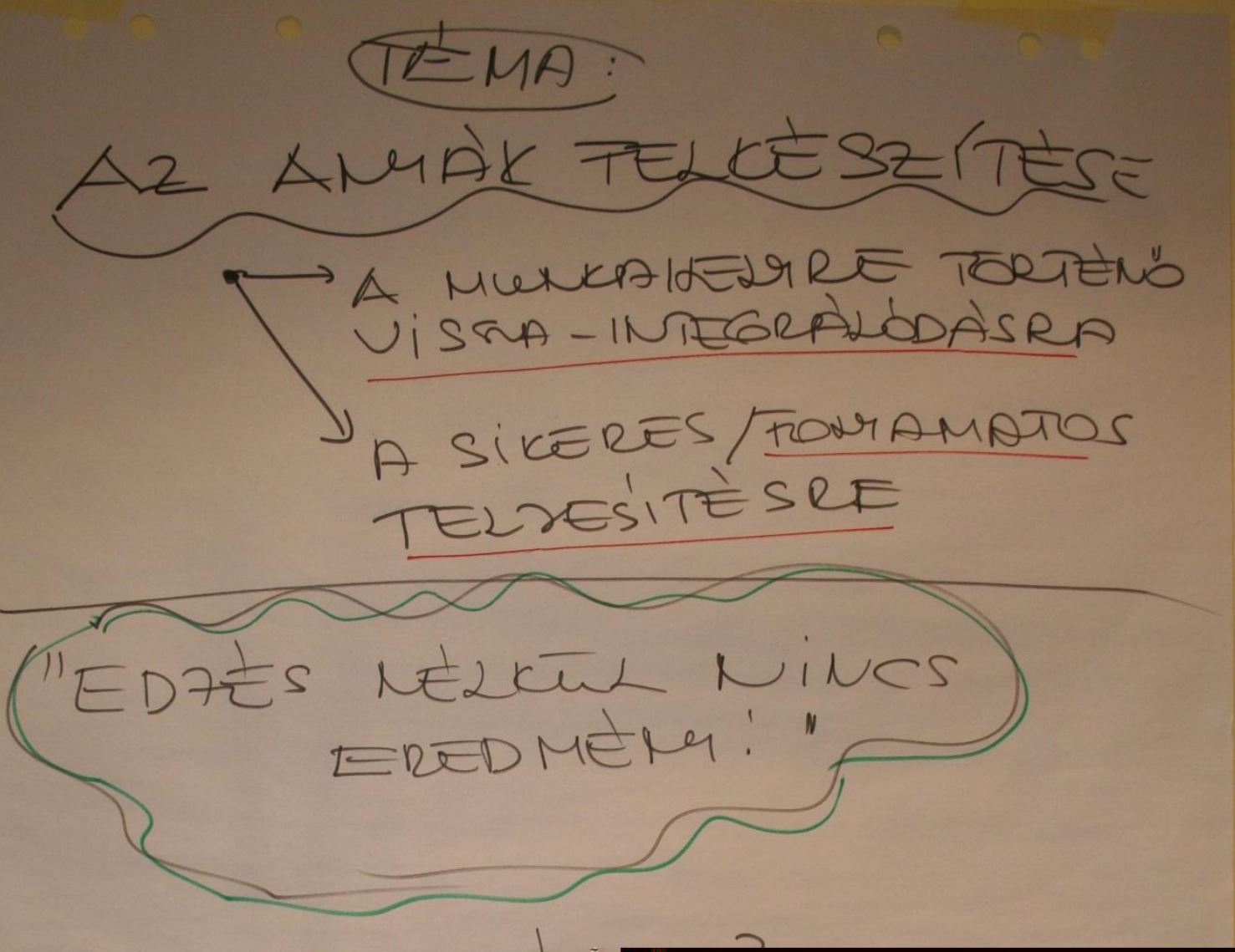




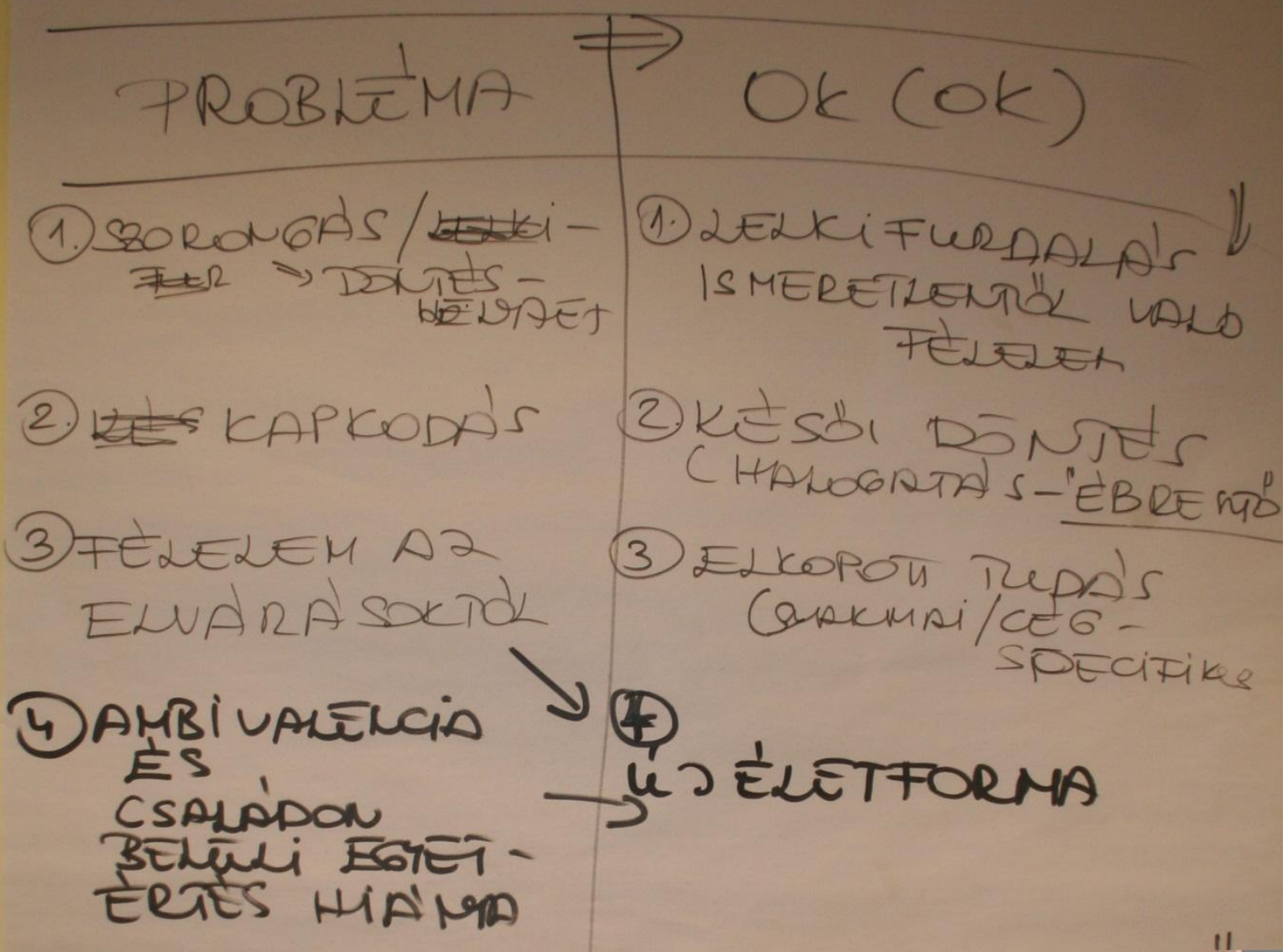




\section{3. függelék - NAV állásfoglalás ${ }^{135}$}

2013.04.15.

Nem pénzben juttatott bölcsődei szolgáltatás, családi napközi ellátás adómentessége

A személyi jövedelemadóról szóló 1995. évi CXVII. törvény (a továbbiakban: Szja tv.) 1. számú mellékletének 8.6. pontja a) és c) alpontjaiban foglaltak alapján a nem pénzben kapott juttatások közül adómentes az ingyenesen vagy

kedvezményesen juttatott

„a) a gyermeknek vagy rá tekintettel más magánszemélynek a közoktatásról szóló törvény, a gyermekek védelméröl és a gyámügyi igazgatásról szóló törvény vagy a tankönyvpiac rendjéröl szóló törvény alapján, a hallgatónak a felsőoktatásról szóló törvény alapján nem pénzben biztositott ellátás; ...

c) bölcsödei szolgáltatás;"”

Ezekben az esetekben az adómentesség a juttatott bevétel nem pénzbeli formájára vonatkozik. Az Szja tv. 4. § (2) bekezdés c) pontjában foglaltak szerint nem pénzben megszerzett bevételnek minősül különösen az elengedett, átvállalt tartozás; a magánszemély helyett teljesített kiadás, befizetés.

Így adómentes juttatásnak tekinthető az, ha a juttató (munkáltató) a szolgáltatás vásárlásáról a nevére szóló számla ellenében téríti meg a magánszemély által megelőlegezett összeget vagy pedig egy meghatározott összeget átad a magánszemélynek azzal, hogy a szolgáltatás vásárlásáról a nevére szóló számlával egy meghatározott időpontig számoljon el. Nem felel meg azonban az adómentesség feltételeinek az, ha a számla a magánszemély, és nem a munkáltató nevére szól, ugyanakkor a munkáltató nem csak a munkavállalóját részesítheti ilyen juttatásban, hanem a gyermek másik szülőjét, vagyis a munkavállaló házastársát, élettársát is, mert a törvény nem tartalmaz korlátozó rendelkezést arra nézve, hogy ilyen juttatásra csak a felek közötti munkaviszony esetében kerülhetne sor.

Az Szja tv. nem határozza meg azt, hogy mit kell érteni bölcsőde alatt, ezért a bölcsődei szolgáltatás jellemzőinek megállapítása során a gyermekek védelméröl és a gyámügyi igazgatásról szóló 1997. évi XXXI. törvény (a továbbiakban: Gyvt.) és a személyes gondoskodást nyújtó gyermekjóléti, gyermekvédelmi intézmények, valamint személyek szakmai feladatairól és müködésük feltételeiről szóló 15/1998. (IV. 30.) NM rendelet (a továbbiakban: R.) rendelkezéseit kell figyelembe venni.

A Gyvt. 5. § s) pontjának rendelkezései tartalmazzák azt, hogy kik lehetnek ezen személyes gondoskodást nyújtó, a gyermekek napközbeni ellátását biztosító intézmények fenntartói (például állami fenntartóként a Kormány rendeletében kijelölt szerv, a helyi önkormányzat, egyház, egyéni vállalkozó, magyarországi székhelyü jogi személy, jogi személyiség nélküli gazdasági társaság és egyéni cég). Ennek megfelelően állami és nem állami szerv által (például egy munkáltató által a munkavállalók gyermekeinek ellátása céljából) fenntartott bölcsőde, családi napközi szolgáltatásainak esetében is alkalmazhatók az adómentességre vonatkozó szabályok.

A Gyvt. 42. § (1)-(2) bekezdései alapján a bölcsőde a családban nevelkedő 3 éven aluli gyermekek napközbeni ellátását biztosító intézmény, ahol a gyermek a 4 . életévének betöltését követő augusztus 31-éig nevelhető, ha testi vagy szellemi fejlettségi szintje alapján még nem érett az óvodai nevelésre.

A R. 44. § (1) bekezdése úgy rendelkezik, hogy a bölcsőde alapfeladatán túlmenően, térítési díj ellenében külön szolgáltatásokat (például játszócsoportot, időszakos gyermekfelügyeletet, gyermekhotelt, egyéb, gyermeknevelést segítő szolgáltatást) müködtethet, amelyeket a gyermek 6. életévének betöltéséig lehet igénybe venni.

Ha tehát a gyermek betöltötte a 3. életévét, akkor a bölcsőde az alapellátásokat a gyermek 4. életévének betöltését követő augusztus 31-éig nyújthatja számára, a fent felsorolt további szolgáltatásokat pedig a gyermek 6. életévének betöltéséig, így az ezen életkorig ingyenesen vagy kedvezményesen nyújtott bölcsődei szolgáltatások minősülhetnek adómentesnek.

Az Szja tv. 8.6. pontjában a) alpontja az adómentes juttatások között említi a gyermeknek vagy rá tekintettel más magánszemélynek a gyermekek védelméröl és a gyámügyi igazgatásról szóló törvény alapján nem pénzben biztosított ellátást is.

135 eredeti link: http://www.nav.gov.hu/nav/ado/szja/bolcsodei_szolgaltatas_csaladi_napkozi.html 
A családi napközi keretében nyújtott ellátás a Gyvt. hatálya alá tartozik, így a Gyvt.-ben meghatározott fenntartók 43. §-a szerinti, családi napköziben nyújtott alapellátása, illetőleg a R. 44. §-ában foglalt speciális szolgáltatások ingyenes vagy kedvezményes formában történő nyújtása is adómentesnek tekinthető.

A természetben adott juttatások a számvitelről szóló 2000. évi C. törvény 3. § (7) bekezdés 3. pontjában foglaltak értelmében személyi jellegü egyéb kifizetésnek tekinthetők, és a társasági adóról és az osztalékadóról szóló 1996. évi LXXXI. törvény 3. számú melléklet B) pontjának 3. alpontja alapján, az ott írt feltételek szerint a vállalkozási tevékenység érdekében felmerülő költségként, ráfordításként vehetők figyelembe 